Caracterización paleomagnética de procesos deformacionales en cuencas intraplaca (Alto Atlas Central): diapirismo, compresión e intrusiones ígneas

Paleomagnetic characterization of deformational processes in intraplate basins (Central High Atlas): diapirism, compression and igneous intrusions

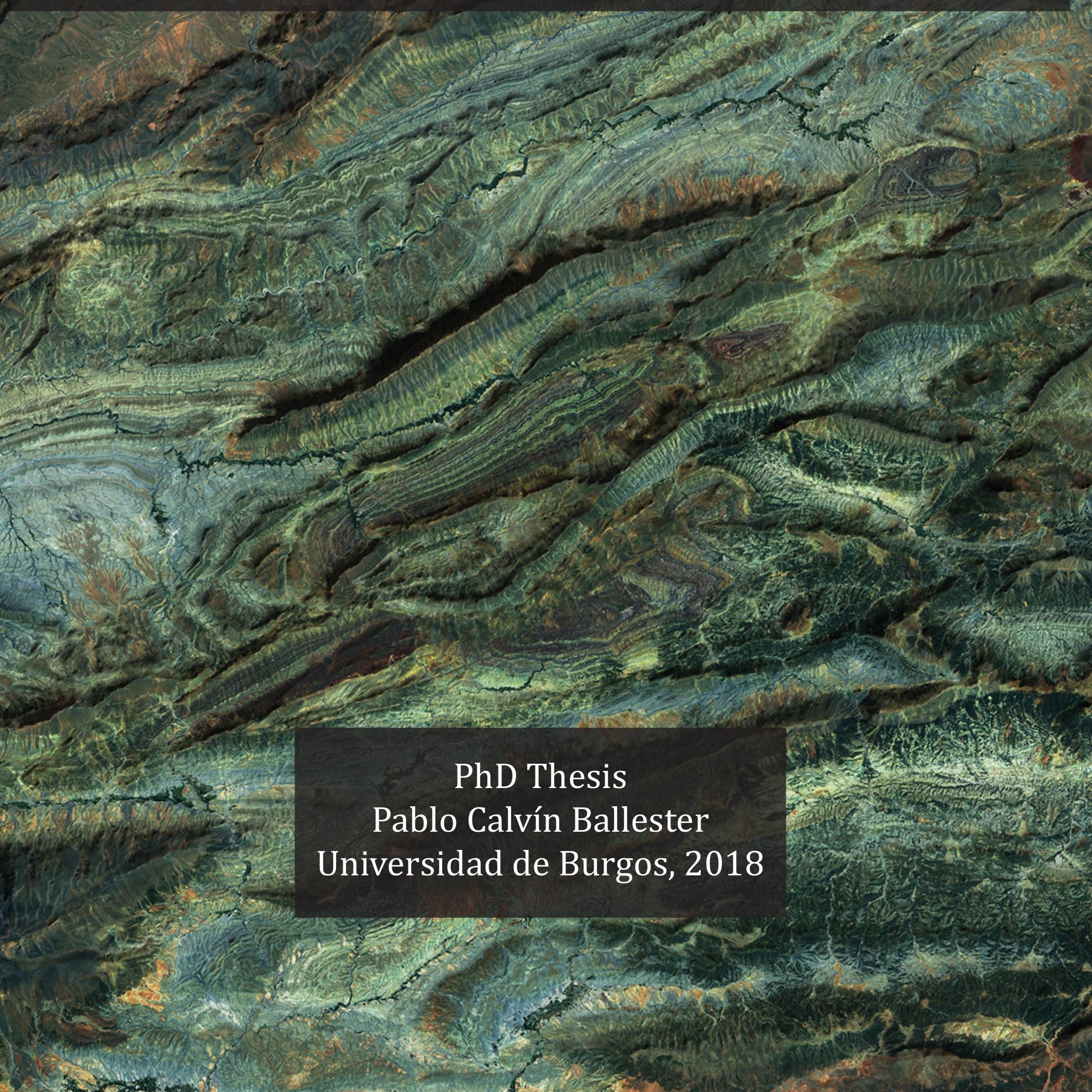



Juan José Villalaín, profesor titular de la Universidad de Burgos adscrito al Departamento de Física, y Antonio M. Casas Sainz, profesor titular de la Universidad de Zaragoza adscrito al departamento de Ciencias de la Tierra

\section{HACEN CONSTAR}

que la presente memoria titulada 'Caracterización paleomagnética de procesos deformacionales en cuencas intraplaca (Alto Atlas Central): diapirismo, compresión e intrusiones ígneas', ha sido realizada bajo nuestra dirección y supervisión, se ajusta al proyecto presentado al inicio de la tesis, y cumple las condiciones necesarias para que Pablo Calvín Ballester pueda optar al grado de Doctor, dentro del programa de doctorado 'Evolución humana, Paleoecología del Cuaternario y Técnicas Geofísicas Aplicadas en la Investigación' de la Universidad de Burgos, y autorizamos su presentación como 'compendio de publicaciones.

En Burgos, a 30 de julio de 2018

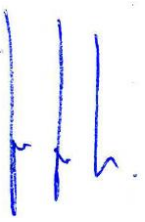

$\mathrm{V}^{\mathrm{o}} \mathrm{B}^{\mathrm{o}}$ Juan José Villalaín

DNI: $13112609 \mathrm{X}$

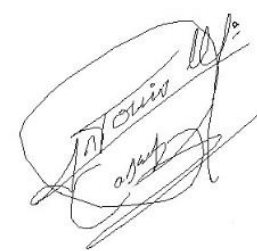

$\mathrm{V}^{\circ} \mathrm{B}^{\circ}$ Antonio M. Casas Sainz

DNI: $16525287 \mathrm{~V}$ 



\title{
Caracterización paleomagnética de procesos deformacionales en cuencas intraplaca (Alto Atlas Central): diapirismo, compresión e intrusiones ígneas
}

\author{
Pablo Calvín Ballester
}

\section{Memoria presentada para la obtención del título de Doctor a través de la modalidad de Compendio de Publicaciones}

Calvín, P., Ruiz-Martínez, V.C., Villalaín, J.J., Moussaid, B., El Ouardi, H., 2015. Restitución estructural por medio de direcciones paleomagnéticas en un cuerpo de gabro (Macizo de Tirrhist , Alto Atlas central , Marruecos). Geogaceta 58, 75-78.

Calvín, P., Strehlau, J., Jackson, M., Villalaín, J.J., 2016. Extractos magnéticos y observaciones mediante microscopía electrónica en carbonatos remagnetizados jurásicos, Geo-temas 16, 801-804.

Calvín, P., Casas-Sainz, A.M., Villalaín, J.J., Moussaid, B., 2017. Diachronous folding and cleavage in an intraplate setting (Central High Atlas, Morocco) determined through the study of remagnetizations. J. Struct. Geol. 97, 144-160. doi:10.1016/j.jsg.2017.02.009

Calvín, P., Ruiz-Martínez, V.C., Villalaín, J.J., Casas-Sainz, A.M., Moussaid, B., 2017. Emplacement and Deformation of Mesozoic Gabbros of the High Atlas (Morocco): Paleomagnetism and Magnetic Fabrics. Tectonics 36, 3012-3037. doi:10.1002/2017TC004578

Calvín, P., Villalaín, J.J., Casas-Sainz, A.M., Tauxe, L., Torres-López, S., 2017. pySCu: A new python code for analyzing remagnetizations directions by means of small circle utilities. Comput. Geosci. 109, 32-42. doi:10.1016/j.cageo.2017.07.002

Calvín, P., Casas-Sainz, A.M., Villalaín, J.J., Moussaid, B., 2018. Extensional vs. compressional deformation in the Central High Atlas salt province: A paleomagnetic approach. Tectonophysics 734-735, 130-147. doi:10.1016/j.tecto.2018.04.007

Calvín, P., Villalaín, J.J., Casas-Sainz, A.M., 2018. Anisotropic magnetite growth in remagnetized limestones: Tectonic constraints and implications for basin history. Geology. doi:10.1130/G45158.1

Calvín, P., Villalaín, J.J., Casas-Sainz, A.M., 2018. The carriers of AMS in remagnetized carbonates. Insights for remagnetization mechanism and basin evolution. Phys. Earth Planet. Inter. 282, 1-20. doi:10.1016/j.pepi.2018.06.003 



\section{Agradecimientos}

Esta tesis doctoral se ha realizado en la Universidad de Burgos, en el Departamento de Física. Ha sido financiado con la ayuda BES-2013-062988 para Formación de Personal Investigador, enmarcado en el proyecto CGL2012-38481 del Ministerio de Economía y Competitividad (MINECO) de España, cofinanciado con fondos FEDER (Unión Europea). Así mismo se ha contado con financiación del proyecto CGL2016-77560 del MINECO y del Grupo de Investigación Consolidado Geotransfer E27 del Gobierno de Aragón.

Las medidas de paleomagnetismo, parte de los experimentos de magnetismo de rocas y las medidas de anisotropía magnética se han realizado en el Laboratorio de Paleomagnetismo de la Universidad de Burgos (UBU). Los extractos magnéticos, el resto de experimentos de magnetismo de rocas y las observaciones mediante microscopía electrónica se realizaron en la University of Minnesota Twin Cities (EEUU), en colaboración con la Dra. Jennifer Strehlau y el Dr. Mike Jackson. La programación en Python se realizó principalmente en la University of California San Diego (EEUU), en colaboración con la Dra. Lisa Tauxe. Las láminas delgadas fueron realizadas en el Servicio de Preparación de Rocas y Materiales Duros (Servicio General de apoyo a la Investigación-SAI, Universidad de Zaragoza -UNIZAR-) y la preparación de parte de las muestras paleomagnéticas fue realizada por Sylvia Gracia (Departamento de Ciencias de la Tierra, UNIZAR). Así mismo, la observación de láminas delgadas mediante microscopía óptica fue realizada en el Departamento de Ciencias de la Tierra de la UNIZAR. El trabajo de campo se realizó en colaboración con Bennacer Moussaid (Universidad de Casablanca, Marruecos), Antonio M. Casas Sainz (UNIZAR) y Juan José Villalaín (UBU).

I sincerely thank the help given by my supervisors in both stays during the $\mathrm{PhD}$, Mike Jackson (Institute for Rock Magnetism, University of Minnesota) and Lisa Tauxe (Scripps Institution of Oceanography, University of California San Diego). I am grateful for the chance to get different views of science.

Besides, I also want to thank the constructive comments and suggestion and the time spend by all the reviewers of the papers as well as the editors of the journals, which have helped to improve the different manuscripts and the ideas obtained for the work.

Finalmente, agradecer a Juan José Villalaín (UBU) y Antonio M. Casas Sainz (UNIZAR) la buena dirección realizada durante todo el transcurso de esta tesis doctoral, que me han permitido seguir aprendiendo a pensar e investigar de una manera agradable. 

A mis padres, $M^{o}$ Pilar y Víctor

A Jesús

A Vicky 



\section{INDICE DE CONTENIDOS}

Abstract........................................................................... 1

Resumen................................................................................ 5

1. Paleomagnetismo, remagnetizaciones y tectónica................................. 9

1.1 Paleomagnetismo y tectónica......................................... 13

1.2 Historia de las remagnetizaciones...................................... 14

1.3 Las remagnetizaciones regionales químicas en carbonatos..................... 15

1.4 Las remagnetizaciones cretácicas del Mediterráneo occidental.................. 17

1.5 Aplicaciones tectónicas de las remagnetizaciones............................ 21

1.6 Aportaciones de la tesis doctoral........................................ 25

2. Contexto geológico del Atlas y del área de estudio.............................. 29

2.1 Introducción............................................................ 33

2.2 La evolución Mesozoica................................................... 38

2.3 La inversión cenozoica.................................................. 45

2.4 El origen de la elevación del Atlas......................................... 48

2.5 Geología del área de estudio............................................... 49

3. Metodología I: Técnicas de muestreo y laboratorio.............................. 55

3.1 Trabajo de campo................................................. 57

3.2 Desmagnetización de la magnetización remanente natural...................... 58

3.3 Fábricas magnéticas.................................................. 60

3.4 Mineralogía magnética de calizas remagnetizadas........................... 63

3.5 Mineralogía magnética de rocas ígneas.................................. 69

4. Metodología II: Círculos menores y restitución................................ $\quad 71$

4.1. pySCu: a new python code for analyzing remagnetizations directions by means of Small Circle utilities..................................................... 75

4.2 Vertical axis rotations and non-coaxial horizontal axes rotations. To what extent do SC tools work when the initial assumptions are not fulfilled?................... 87

5. Extractos magnéticos en calizas remagnetizadas................................. 109

5.1. Extractos magnéticos y observaciones mediante microscoía electrónica en carbonatos magnetizados jurásicos / Magnetic extractions and electronic microscopy observations in Jurassic remagnetized carbonated ....................... 
6. Restoration of structures using the ca. 100 Ma remagnetization in the Central High Atlas.

6.1 Diachronous folding and cleavage in an intraplate setting (Central High Atlas, Morocco) determined through the study of remagnetizations.

6.2 Extensional vs. compressional deformation in the Central High Atlas salt province: A paleomagnetic approach

7. Paleomagnetic and magnetic fabric study of the Jurassic gabbros from the Central High Atlas.

7.1 Restitución estructural por medio de direcciones paleomagnéticas en un cuerpo de gabro (macizo de Tirrhist, Alto Atlas Central, Marruecos) / Structural restoration using paleomagnetic directions in a gabbro body (Tirrhist Massif, Central High Atlas, Morocco).

7.1 Emplacement and Deformation of Mesozoic Gabbros of the High Atlas (Morocco): Paleomagnetism and Magnetic Fabrics.

8. Magnetic fabrics in remagnetized carbonates.

8.1 Anisotropic magnetite growth in remagnetized limestones: Tectonic constrains and implications for basin history.

8.2 The carriers of AMS in remagnetized carbonates. Insights for remagnetization mechanism and basin evolution.

9. Discusión.

9.1 La remagnetización cretácica del Alto Atlas Central.

9.2 Aportaciones a la metodología basada en círculos menores

9.3 Aportaciones a la geología regional.

10. Conclusions 


\section{Abstract}

The Atlas System comprises a set of intraplate basins inverted during the Cenozoic as a consequence of the Africa-Iberia-Eurasia convergence. These basins were developed during the Mesozoic in two rifting stages (Triassic and Early Jurassic), influenced both by the opening of the Atlantic and the evolution of the Tethys. The study area is located in the middle of the Central High Atlas (Morocco) and is characterized by NE-SW to ENE-WSW tight anticlines separating open, gentle synclines. The Mesozoic sequence reaches big thickness (more than 6-7 km) in the depocenters. This sequence is mainly composed by Lower-Middle Jurassic marine carbonates that pass upwards into continental red beds (Middle Jurassic sediments). No younger sediments crop out in the study area but in the northern basins Upper Jurassic to Lower Cretaceous continental sediments can be observed.

Basalts linked with the CAMP event and emplaced in sub-aerean conditions at the end of the Triassic crop out in the core of the anticlines, together with Upper Jurassic plutonic rocks (mainly troctolites, gabbros and sienites) and Triassic shales and salts. Associated with the Jurassic volcanic event several dykes and, in the northern basins, two sets of basaltic lava flows that were emplaced during the Late Jurassic and the Early Cretaceous can be observed.

Several aspects (growth strata, angular unconformities in the limbs of the anticlines, etc.) evidence a major halokinetic activity during the Early-Middle Jurassic, which conditioned the sedimentation in the region defining areas with differential subsidence. Besides, this halokinetic activity deformed the Jurassic carbonates during the development of diapirs and salt-walls.

The Jurassic carbonates of the Central High Atlas record a widespread chemical remagnetization, carried by stable single domain (SSD) magnetite, which has been previously dated as Albian-Cenomanian (ca. $100 \mathrm{Ma}$ ). This is an interfolding remagnetization since it is temporally bracketed between two folding stages (Jurassic extension and Cenozoic compression). Working with this kind of remagnetizations, the small circle (SC) tools allow (i) to calculate the remagnetization direction and (ii) to restore the beds at the remagnetization time i.e., to calculate the paleodip of the beds. Once that the paleodips are know, they can be used to restore partially the structure and to show how was the structure during the remagnetization acquisition.

In regard with the methodological development of the SC tools, in this doctoral thesis is presented a new software (PySCu) allowing to perform the necessary SC calculations in a simple way. As PySCu is written in language Python, the application is open and cross-platform. Moreover, this incorporates an improvement in the calculation of the uncertainty associated to the calculated remagnetization direction: using bootstrap the program estimates the error propagation in the calculated direction resulting from the uncertainty of the mean paleomagnetic direction and the bedding.

Using the SC tools, three main starting hypotheses must be considered: (i) the remagnetization must be geologically synchronous, (ii) there is an absence of vertical axis rotation 
(VAR) and (iii) the pre- and post-remagnetization folding are coaxial. Through simulations of artificial data that consider both presence of VAR and non-coaxiality the effect in the results of the non fulfillment of the starting hypotheses was evaluated.

The presence of VAR affects strongly the calculation of the remagnetization direction and systematically higher inclinations than expected are obtained. On the other hand, VARs generate characteristic patterns in the calculation of the paleodip, over- and under estimating symmetrically the paleodip in opposite limbs. These features can help to detect the presence of VARs. On the other hand, the non-coaxiality affects in lesser degree both to the remagnetization direction and the paleodip calculations.

The comparison between simulations and real data shows that the study area fulfills the starting hypotheses necessary for the application of the SC tools. Moreover, the comparison of the bedding between sites affected mainly by the pre-remagnetization deformation with sites in which the post-remagnetization deformation dominates, indicates that both folding states are nearly coaxial.

Present-day and restored (at the remagnetization time, ca. $100 \mathrm{Ma}$ ) geologic cross-section have been compared and this practice has shown to be a useful tool to unravel and clarify some geological aspects present in the study area: (i) the region is affected by a regional cleavage considered alternatively as Jurassic and Cenozoic by different authors. The folds with axial-plane cleavage clearly post-date the remagnetization because they completely unfold after the partial restoration. This means that cleavage developed during the Cenozoic compression. (ii) On the other hand, the restoration of several anticlines shows a different degree of development of the structures at the remagnetization time. Some of them were already structured at ca. $100 \mathrm{Ma}$, with steep limbs that become progressively horizontal towards the synclines, whereas in other structures the pre-100 Ma structure is gentler and limited to the proximity of their cores (affecting only to the nearest $500 \mathrm{~m}$ ). This pre-remagnetization deformation is mainly the consequence of the halokinetic process that generated diapirs and salt-walls with different degrees of development. These structures seem to be related to basement normal faults that controlled the tectonic subsidence. Besides, the structure inherited from the extensional stage had a main role controlling the subsequent deformation during compression.

As well as the beds can be restored, other structural elements that can be related to bedding can also be restored using the paleodip, as for example the petrofabric or the magnetic fabrics. It is a common procedure to compare the in situ magnetic fabrics with the totally restored (rotating the bedding to the horizontal) ones; knowing the paleodip, they also can be compared with the partially restored (rotating the bedding to the paleobedding) magnetic fabrics.

The restoration of the anisotropy of the anhysteretic remanent magnetization (AARM) has allowed to put forward significant advances in the understanding of how the SSD magnetite grains that carry the remagnetization grow. The AARM has been measured in sites with different dips and paleodips, and the orientation of the principal axes of all sites has been compared before apply any 
bedding correction, after apply the total bedding correction (i.e., restoring the bedding to the horizontal) and after apply the partial bedding correction (i.e., restoring the bedding to their attitude at the remagnetization time). Comparing these three stages, the best clustering of the principal axes is reached after the partial bedding correction, when a prolate ellipsoid with horizontal magnetic foliation and horizontal NNW-SSE magnetic lineation, parallel to the general tectonic extension is defined. This has been interpreted because either: (i) the neoformed magnetite grains grew without following any preexisting structure or, conversely, (ii) the magnetite grains grew following the extensional tectonic constraints present in the Atlas at the remagnetization time, producing a weak but well-defined magnetic fabric. Furthermore, the absence of compressive fabrics in the AARM shows that the magnetite grains were not affected by the Cenozoic cleavage present in the study area. (iii) We interpret these facts as an indicator that the magnetite grains grew replacing pyrite crystals that, on one hand, offers an isotropic frame within which the grains can grow following the tectonic constraints and, on the other hand, the pyrite grains deflect the deformation directions associated with cleavage development.

The analysis of the anisotropy of the magnetic susceptibility measured at room temperature (RT-AMS) and its comparison with different subfabrics (LT-AMS and AARM) allow to unravel four different behaviors in RT-AMS. Type 1 RT-AMS shows the same behavior that the already described by AARM and RT-AMS is not coincident with LT-AMS. Conversely, type 3 and 4 RTAMS are coincident with the LT-AMS but not with AARM; in these cases the magnetic lineation is parallel to the intersection lineation defined between cleavage and bedding (it is a tectonic compressive fabric); the difference between the two fabrics is that the magnetic foliation in type 3 is parallel to bedding and in type 4 is parallel to cleavage. Finally, type 2 shows intermediate behavior between the previous ones. The comparison between the different subfabrics, as well as the interpretation of rock magnetic measurements, allow to explain the type 1 RT-AMS as carried by superparamagnetic magnetite neoformed during the remagnetization process; these grains have the same distribution than the SSD magnetites that carry the remagnetization. On the other hand, type 3 and 4 RT-AMS are carried by phyllosilicates, which at difference with ferrimagnetic grains are affected by the Cenozoic compression.

The Jurassic gabbros that crop out at the core of the anticlines have also been analyzed paleomagnetically. A stable paleomagnetic component with maximum unblocking temperatures around $580^{\circ} \mathrm{C}$ that is carried by magnetite has been isolated. The mean paleomagnetic directions show a strong scatter when all structures are analyzed together. This scattering has been interpreted as a consequence of tectonic movements. However, when the mean paleomagnetic directions are plotted for each structure separately, the directions are located over same small circles, with horizontal axes parallel to the main trend of each respective structure; this is evident in the western structures, where the scatter is lower and there are available more site-mean paleomagnetic directions. The dispersion of the paleomagnetic directions over small circles parallel to each structure is interpreted as the result of the Cenozoic folding. Besides, most of the sites record counter-clockwise rotation (looking towards the NE / ENE) that means that the structures present a dominant vergence towards the NW / NNW. 
The magnetic fabrics in the gabbros are coincident with the petrofabric defined by the plagioclase crystals. Before any correction, the orientation of the main axes show a strong scattering between sites. However, and using the information that come from the paleomagnetic analysis, when the magnetic fabrics are restored to the emplacement position, they show a better cluster and are coherent in each structure.

According to paleomagnetic results and magnetic fabrics two kind of structures have been differentiated: (i) in the western structures, where the ratio between ductile and igneous rocks is higher, the recorded rotations are bigger. The magnetic fabrics show mainly horizontal magnetic foliations and horizontal NW-SE magnetic lineations that we interpret as the reflect of the regional tectonic extension during the intrusion of the igneous rocks. (ii) On the other hand, in the eastern structures the ratio is lower and the cores of the anticlines are mainly composed by igneous rocks. In these cases the rotations are smaller and the magnetic fabrics show more complex patterns; the magnetic lineations are mainly horizontal and N-S to NE-SO, and the magnetic foliation presents different attitude. This is likewise consequence of the emplacement of the magma with limited space and the magnetic fabrics reflect the different flux controlled by the structural frame. 


\section{Resumen}

El sistema del Atlas está formado por un conjunto de cuencas mesozoicas intraplaca que fueron invertidas durante el Cenozoico, consecuencia de la convergencia entre la placa Africana con las placas Ibérica y Euroasiática. Dichas cuencas se generaron durante el Mesozoico ligadas a la apertura del Atlántico y a la evolución del Tethys, siendo afectadas por dos episodios de rift (Triásico y Jurásico Inferior) y los consiguientes periodos de post-rift. El área de estudio se encuentra en la zona central del Alto Atlas Central (Marruecos), caracterizado estructuralmente por la presencia de anticlinales apretados de dirección NE-SO a ENE-OSO que limitan sinclinales amplios y laxos. La serie mesozoica está caracterizada por la presencia de potentes series jurásicas con más de 6-7 km de espesor en los depocentros y formadas esencialmente por carbonatos marinos, si bien los materiales del Jurásico Medio registran una continentalización de los depósitos. En el área de estudio no se observan materiales más modernos al Jurásico Medio, aunque en varias cuencas situadas al norte afloran materiales continentales del Jurásico Superior y el Cretácico.

En el núcleo de los anticlinales afloran importantes series basálticas asociadas al CAMP emplazadas en condiciones subaéreas durante el Triásico Superior. Además, afloran materiales plutónicos de edad Jurásico Medio-Superior compuestos principalmente por troctolitas, gabros y sienitas. Asociado a la etapa de vulcanismo jurásico se observan numerosos diques y, en las cuencas situadas al norte dan lugar a dos conjuntos de coladas basálticas de edad Jurásico Superior y el Cretácico Inferior.

Existen evidencias (variaciones de espesor, discordancias en los flancos de los anticlinales, etc.) de una importante actividad halocinética durante el Jurásico Inferior-Medio, que condicionó la subsidencia en la cuenca del Atlas definiendo áreas con subsidencia diferencial. Esta actividad halocinética generó importantes estructuras diapíricas que deformaron los materiales jurásicos.

Los carbonatos jurásicos que afloran en el área de estudio están afectados por una remagnetización química regional portada por cristales monodominio estable (SSD) de magnetita , que ha sido previamente datada como Albiense-Cenomaniense (ca. $100 \mathrm{Ma}$ ). Esta remagnetización tiene un carácter inter-plegamiento, dado que se adquirió en un momento de no deformación que separa dos eventos de plegamiento diferentes (asociados a la extensión jurásica y la compresión cenozoica). Trabajando con este tipo de remagnetizaciones, el uso de las técnicas de círculos menores (SC) permite (i) calcular la dirección de la remagnetización para el área de estudio y (ii) restituir el paleobuzamiento de las capas, i.e., calcular el buzamiento que presentaban las capas en el momento de adquisición de la remagnetización. Una vez conocidos los paleobuzamientos, estos pueden ser usados para realizar restituciones parciales que permiten reconstruir cómo era la estructura en el momento de la adquisición de la remagnetización.

Respecto al desarrollo metodológico centrado en los métodos SC, en esta tesis doctoral se presenta un nuevo programa informático (PySCu) que permite realizar todos los cálculos asociados al método de manera rápida y sencilla. PySCu ha sido escrito en lenguaje Python, siendo una 
aplicación sencilla, de código libre y multiplataforma. Esta nueva aplicación incorpora una mejora sustancial en el cálculo de la incertidumbre de la dirección de la remagnetización: mediante el uso de la técnica de bootstrap se determina la propagación del error en la dirección calculada de la incertidumbres provenientes de las direcciones paleomagnéticas medias y de los datos de estratificación.

Cuando se usan las técnicas SC se asumen una serie de hipótesis de partida: (i) la remagnetización es sincrónica a escala geológica, (ii) las direcciones paleomagnéticas no registran rotaciones de eje vertical (VAR) y (iii) las etapas de deformación pre- y post-remagnetización son coaxiales. Utilizando simulaciones con datos artificiales y considerando tanto la presencia de VAR como la no coaxialidad entre las dos etapas de deformación, hemos podido observar y cuantificar la influencia del no cumplimiento de ambas hipótesis de partida en el cálculo tanto de la dirección de remagnetización como de los paleo-buzamientos.

La presencia de VAR afecta de manera importante al cálculo de la dirección de remagnetización, obteniéndose de manera sistemática inclinaciones más altas a las esperadas. Por otro lado, las VAR generan patrones característicos en el cálculo de paleobuzamientos, infra- y sobre-estimando los mismos de manera simétrica en flancos opuestos. Estas dos afecciones de la presencia de VAR en los resultados pueden ayudar a detectar la presencia de VAR cuando se trabaja con datos reales. La no coaxialidad afecta en menor grado a los resultados que se obtienen al aplicar los métodos SC, y ni la dirección de remagnetización calculada ni los paleo-buzamientos presentan grandes dispersiones respecto a los valores esperados en la mayoría de los modelos.

La comparación entre las simulaciones y los datos reales muestran que el área de estudio cumple las hipótesis de partida necesarias para la aplicación de las técnicas SC. Por otro lado, la comparación de la estratificación entre las estaciones en las que domina la deformación pre- y postremagnetización muestra un ajuste cilíndrico similar, indicando que ambas etapas de deformación son coaxiales.

A partir de los datos de paleo-buzamientos calculados con las técnicas SC se han elaborado cortes geológicos que representan la geometría del área en el momento de la adquisición de la remagnetización (ca. $100 \mathrm{Ma}$ ). La comparación de estos cortes geológicos con los que ilustran la estructura actual ha resultado ser una herramienta útil para resolver varios problemas geológicos presentes en el área de estudio. (i) El área está afectada por una foliación regional, cuya formación ha sido atribuida tanto al Jurásico como al Cenozoico por diferentes autores. La restitución de pliegues con foliación de plano axial asociada ha mostrado que estos post-datan la remagnetización, y por tanto, tanto los pliegues como la foliación asociada se generaron durante la compresión cenozoica. (ii) Por otro lado, la restitución de diferentes anticlinales muestra diferentes grados de estructuración durante el Jurásico. Algunas de las estructuras se encontraban ya prácticamente estructuradas antes de ca. $100 \mathrm{Ma}$, con flancos que presentaban buzamientos moderados a altos, disminuyendo progresivamente hacia los sinclinales. Por el contrario, en otras estructuras la deformación pre-100 Ma se limita a las áreas en contacto con el núcleo (a menos de $500 \mathrm{~m}$ de distancia). Esta deformación pre-remagnetización es consecuencia de procesos halocinéticos que generaron una serie de salt-walls, con distinto grado de desarrollo, que limitaban pequeños 
depocentros sedimentarios. Estas estructuras parecen estar relacionadas en profundidad con fallas normales de basamento que controlaban la subsidencia tectónica del área. Es importante destacar que el estilo de deformación durante la compresión cenozoica fue condicionada por la herencia de la etapa extensional mesozoica.

Del mismo modo que se pueden restituir las capas estratigráficas mediante el paleo-buzamiento, también pueden ser restituidos otros elementos presentes en las rocas, como por ejemplo su petrofábrica o las fábricas magnéticas. Cuando se trabaja con fábricas magnéticas, es usual comparar las mismas en su disposición in situ y tras realizar la restitución total de las mismas (restituyendo la estratificación a la horizontal). Dado que es posible conocer el paleobuzamiento de las capas, es posible realizar la restitución parcial de la fábrica magnética y compararla con las anteriores.

La restitución de la anisotropía de la magnetización remanente anhisterética (AARM) ha permitido obtener significativos avances en el conocimiento del crecimiento de los granos SSD de magnetita que portan la remagnetización. Se ha comparado la AARM de diferentes estaciones paleomagnéticas con diferente buzamiento y paleobuzamiento, antes de realizar la corrección de capa, tras abatir las capas a la horizontal, y abatiendo las mismas a su posición en el momento de la remagnetización. Tras realizar la restitución parcial se observa el mejor agrupamiento de los ejes magnéticos principales, definiéndose una foliación horizontal y una lineación horizontal NNO-SSE, paralela a la dirección de extensión regional. Esto ha sido interpretado como (i) un crecimiento de los cristales SSD que no sigue estructuras previas, (ii) sino que crecen orientados según el campo de esfuerzos presentes en el momento de la remagnetización. Así mismo, la ausencia de fábricas compresivas en la AARM indica que estos granos de magnetita no han sido afectados por la foliación cenozoica presente en el área de estudio. Este hecho lo interpretamos (iii) como un indicador de que los granos de magnetita crecen reemplazando cristales de pirita, que por una parte les proporcionan un medio isótropo en el que crecer siguiendo el campo de esfuerzos, y por otro dificultan una reorientación de los granos durante la compresión posterior.

El análisis de la anisotropía de la susceptibilidad magnética a temperatura ambiente (RTASM) y su comparación con diferentes subfábricas (LT-ASM y AARM) permite distinguir diferentes comportamientos de RT-AMS. El tipo 1 presenta el mismo comportamiento que el definido para la AARM, y presenta diferencias direccionales con la LT-ASM. Por el contrario, en los tipos de RT-ASM 3 y 4 ésta es coincidente con la LT-ASM pero no con la AARM, y la lineación magnética es paralela a la lineación de intersección entre estratificación y foliación, indicando que se trata de una fábrica tectónica compresiva. La diferencia entre los tipos 3 y 4 radica en que en el primero la foliación magnética es paralela a la estratificación y en el segundo es paralela a la foliación tectónica. Finalmente, el tipo 2 muestra características intermedias entre los anteriores. La comparación entre las diferentes subfábricas, así como el análisis de las propiedades magnéticas de muestras pertenecientes a los diferentes grupos, ha permitido conocer que los portadores de la RTASM del grupo 1 es magnetita superparamagnética generada durante el proceso de remagnetización y con la misma orientación que los granos SSD que portan la AARM. Por el contrario, la RT-ASM 
de los tipos 3 y 4 es portada por filosilicatos, que ha diferencia de los granos ferromagnéticos, registran la compresión cenozoica.

Los gabros jurásicos presentes en el núcleo de los anticlinales también han sido estudiados paleomagnéticamente. En ellos se ha observado una componente paleomagnética con temperaturas máximas de desbloqueo de $580^{\circ} \mathrm{C}$ portada por magnetita. Cuando las direcciones paleomagnéticas medias de las diferentes estructuras son analizadas de manera conjunta, se observa una gran dispersión de los datos atribuible a causas tectónicas. Al analizar las direcciones separadas por estructuras, se observa que las mismas se disponen sobre círculos menores cuyo eje es horizontal y paralelo a cada estructura; esto es claramente observable en las estructuras más orientales, donde la dispersión de las direcciones es menor y la disponibilidad de datos es mayor. Este agrupamiento de las direcciones sobre círculos menores es interpretada como que la dispersión de las direcciones es consecuencia de un plegamiento de eje horizontal consistente con el desarrollo cenozoico de los anticlinales. Además, la mayoría de las estaciones han registrado rotaciones antihorarias de eje horizontal (mirando hacia el NE / ENE), indicando una vergencia predominante de las estructuras hacia el NNO / NO.

Las fábricas magnéticas de los gabros son coincidentes con la petrofábrica definida por los cristales de plagioclasa. Antes de realizar ninguna corrección, la orientación de los ejes principales muestra gran dispersión entre las diferentes estaciones. Sin embargo, y usando la información proveniente del análisis paleomagnético, cuando las fábricas magnéticas son restituidas a su posición de emplazamiento, los ejes principales de las diferentes estaciones paleomagnéticas de cada estructura anticlinal son coherentes entre sí.

Se han podido diferenciar dos tipos de estructuras en base a la información proveniente del estudio paleomagnético y de fábricas magnéticas. (i) En las estructuras más occidentales, donde el ratio entre rocas dúctiles y rígidas en el núcleo de las mismas es mayor, las rotaciones registradas son mayores, y la fábrica magnética muestra una foliación horizontal y una lineación horizontal NO-SE, que ha sido interpretada como reflejo de la tectónica extensional presente durante la intrusión de las rocas ígneas. (ii) Por el contrario, en las estructuras orientales, cuyo núcleo está compuesto esencialmente por rocas ígneas, las rotaciones registradas son menores; las fábricas magnéticas presentan pautas más complejas, dominando lineaciones N-S a NE-SO y foliaciones con diferente inclinación, y que pueden ser interpretadas como consecuencia del emplazamiento del magma en áreas con poco espacio, y por tanto el flujo del mismo estaría condicionado por las estructuras NE-SO. 


\section{Paleomagnetismo, remagnetizaciones y tectónica}

1.1 Paleomagnetismo y tectónica........................................................ 13

1.2 Historia de las remagnetizaciones.................................................. 14

1.3 Las remagnetizaciones regionales químicas en carbonatos............................ 15

1.4 Las remagnetizaciones cretácicas del Mediterráneo occidental......................... 17

1.5 Aplicaciones tectónicas de las remagnetizaciones.................................. 21

1.6 Aportaciones de la tesis doctoral.......................................................... 25 

Una remagnetización o magnetización secundaria es aquella que se adquiere tiempo después de haberse formado una roca o depositado un sedimento. Las remagnetizaciones afectan de manera habitual a todo tipo de rocas y existen diferentes mecanismos por las que se adquieren. (i) El aumento de la temperatura por encima de la temperatura de Curie de los minerales ferromagnéticos s.l. presentes en la roca (y su posterior enfriamiento) origina la pérdida de la señal magnética previa y queda registrada la información magnética acorde con el momento del enfriamiento: remagnetización térmica. (ii) La estabilidad magnética de los granos ferromagnéticos depende de sus característica intrínsecas (forma y volumen) y la temperatura a la que se encuentran (Néel, 1950). La combinación de estos factores determina el tiempo de relajación de los granos (tiempo que tardan en perder la información magnética que portan). Cuando una roca es sometida a una temperatura determinada un tiempo superior a su tiempo de relajación, los granos ferromagnéticos pierden la información que registraban y sus momentos magnéticos quedan orientados con el campo magnético correspondiente al momento del proceso. Esta es la remagnetización termoviscosa. (iii) Por último, la remagnetización química es debida a la neoformación y crecimiento de cristales ferromagnéticos s.l. estables consecuencia de procesos geoquímicos, cuyos momentos magnéticos quedan orientados según el campo magnético presente durante su crecimiento. Estos tres procesos, dependiendo de la intensidad con la que actúan, los tipos y características de los minerales ferromagnéticos s.l. presentes en la roca, etc., pueden obliterar o no la información magnética previa que registraba la roca, de modo que una misma roca puede registrar la información adquirida en diferentes eventos de adquisición de la remagnetización.

Las rocas estudiadas en este trabajo son carbonatos (calizas y margas) jurásicos que no han sido expuestos a temperaturas mayores de $300^{\circ} \mathrm{C}$, i.e. zona de la diagénesis y anquizona. Estos han sido afectados por una remagnetización regional química portada por magnetita autigénica, cuyo crecimiento está relacionado con el aumento de la temperatura en un entorno diagenético. En este apartado, por tanto, nos vamos a centrar en las características más significativas de este tipo de remagnetizaciones, así como en la descripción de la remagnetización cretácica que afecta a las rocas jurásicas del Atlas. 



\subsection{Paleomagnetismo y tectónica}

El comportamiento principalmente dipolar del Campo Magnético Terrestre hace de éste un excepcional marco de referencia espacial (y también temporal) en el planeta Tierra, dado que es externo y absoluto. La utilidad de esta propiedad para resolver problemas tectónicos (a escalas muy variadas) ha favorecido la íntima relación entre tectónica y paleomagnetismo.

Los primeros trabajos del estudio de la magnetización remanente que portan las rocas se remontan a los años 20, aplicados al estudio de rocas ígneas (Chevallier, 1925; Mercaton, 1926; Matuyama, 1929). Por otro lado, podemos situar el nacimiento del paleomagnetismo sistemáticamente aplicado a rocas sedimentarias en el trabajo de Graham (1949), quien establece una serie de pautas sobre cómo proceder en el trabajo paleomagnético, tanto en el laboratorio como analizando las direcciones paleomagnéticas. En este trabajo Graham ya propuso el uso de los test de estabilidad (test del conglomerado, del pliegue y de inversión). Durante los años 40 y 50 los trabajos de paleomagnetismo eran ya numerosos, hecho que lleva a Cox y Doell (1960) a realizar la primera revisión sobre dicha metodología. Tras una lectura de dicha revisión, se obtiene la visión de que los pilares desarrollados durante los años 50 eran sólidos, y la metodología de trabajo sigue en gran parte vigente hasta nuestros días. Esto es especialmente patente en la aplicación de la estadística a las direcciones paleomagnéticas, basada en el desarrollo de la estadística esférica de Fisher (1953), o las aportaciones al estudio de la paleointensidad de Thellier y Thellier (1959).

Rápidamente, la aplicación del paleomagnetismo supuso una revolución para la Tectónica de Placas tras entender que las curvas de deriva polar obtenidas de los datos paleomagnéticos (Hospers, 1955; Irving; 1958; Creer et al., 1964), por comparación entre las curvas obtenidas para los distintos continentes, no implicaban un cambio de la situación de los polos magnéticos, sino el movimiento de los continentes a lo largo del tiempo; eran curvas de deriva polar aparente que permitían reconstruir los movimientos latitudinales y rotacionales de los continentes. Los trabajos para la definición de dichas curvas se han ido desarrollando hasta la actualidad, mejorando la cantidad y calidad de los datos que conforman las mismas (p. ej., Irving, 1959; Evans y McElhinny, 1966; Hospers y Van Andel, 1969; Van der Voo, 1969; McElhinny y Brock, 1975; Osete et al., 1997;Besse y Courtillot, 2002; Torsvik et al., 2012; Hinsbergen et al., 2018). Tradicionalmente, los datos paleomagnéticos usados para la obtención de polos paleomagnéticos virtuales provienen de magnetizaciones primarias, dado que la edad de la magnetización está constreñida por la edad de la roca. Sin embargo, algunos autores (Tohver et al., 2008; Fitz-Diaz et al., 2014; Nemkin et al., 2015) han propuesto la posibilidad de datación de remagnetizaciones a partir de la datación de los minerales autigénicos generados de manera coetánea a la adquisición de la remagnetización, en concreto la datación de illitas autigénicas, de modo que las remagnetizaciones también podrían ser utilizadas para la obtención de paleopolos. Quizá uno de los mayores inconvenientes sea que generalmente las remagnetizaciones suelen encontrarse en zonas poco estables de las placas tectónicas (cuencas sedimentarias y cinturones de pliegues y cabalgamientos), de modo que aunque pueda constreñirse la edad de la remagnetización, su dirección no pueda ser extrapolada al resto de la placa. 
El paleomagnetismo también ha supuesto ser una técnica relevante en el estudio de cadenas montañosas (ver la revisión de Pueyo et al., 2016). Si bien el análisis de rotaciones a lo largo de ejes horizontales es asequible y habitual en los trabajos de tectónica, las rotaciones de eje vertical son difíciles de observar y cuantificar, incluso una tarea imposible si no se dan unas condiciones idóneas. Y es precisamente aquí donde el paleomagnetismo ha tenido más relevancia, tanto en el estudio de la naturaleza primaria o secundaria de curvaturas observadas en numerosos orógenos (p. ej., Eldredge et al., 1985; Weil et al., 2001; Weil y Sussman, 2004), con en el estudio de rotaciones de eje vertical y desplazamientos diferenciales en sistemas de cabalgamientos (p. ej. Norris y Black, 1961; Villalaín et al., 1994; Pueyo et al., 2004; Muñoz et al., 2013; Izquierdo-Llavall et al., 2015). Combinar la información proveniente de los estudios tectónicos y paleomagnéticos permite, por tanto, obtener una visión mucho más amplia de la deformación sufrida por las rocas, que puede ser plasmada en modelos tridimensionales (Ramón et al., 2012; Ramón, 2013). Por otro lado, la datación de series syn-tectónicas mediante magnetoestratigrafía permite estimar, por ejemplo, velocidades de acortamiento o datar la actividad tectónica de estructuras concretas (Holl y Anastasio, 1993; Lu y Xiong, 2009; Gautam et al., 2012; Oliva-Urcia et al., 2016)

Pero el paleomagnetismo no sólo tiene su aplicación en contextos compresivos, valorando rotaciones de eje vertical. En cuencas extensionales, el estudio de remagnetizaciones interplegamiento (adquiridas entre dos fases de plegamiento diferentes) mediante métodos basados en círculos menores (Shipunov, 1997; Henry et al., 2004; Waldhör y Appel, 2006), permite realizar restituciones de las capas sedimentarias a su disposición en el momento de la remagnetización (ver revisión en Villalaín et al., 2016). Numerosos trabajos realizados en las cuencas invertidas de Iberia y el Norte de África han permitido poner en valor esta técnica, restituyendo la geometría previa a la compresión que es derivada de la etapa de cuenca (Villalaín et al., 2003; Casas et al., 2009; Moussaid et al., 2015), reconocer eventos de inversión temprana (Soto et al., 2008), o restituir estructuras concretas (Torres-López et al., 2016; García-Lasanta et al., 2017)

Finalmente, y a escala de deformación interna de las rocas, el paleomagnetismo ha permitido analizar y caracterizar procesos de cizalla y la consiguiente deformación y/o rotación de granos ferromagnéticos, que implica una rotación de las componentes paleomagnéticas (p. ej., Kligfield et al., 1983; Cogné y Perroud al., 1985; Hirt et al., 1986; Borradaile, 1997). Una de las implicaciones que pueden tener estos procesos es la caracterización de (re)magnetizaciones derivadas de la rotación de granos ferromagnéticos s.l. como falsas remagnetizaciones synplegamiento (p. ej., van der Pluijm, 1987; Kodama, 1988; Stamatakos y Kodama, 1991).

\subsection{Historia de las remagnetizaciones}

Si bien ya se conocía la posibilidad de que las rocas fuesen remagnetizadas (p. ej. Graham, 1949; Hospers, 1955), Creer (1968) formuló la llamada 'hipótesis de la remagnetización', con la que proponía que los materiales sedimentarios de edad Paleozoico Inferior de Europa y Estados Unidos (constituyentes del orógeno Varisco-Alleghaniense ) portaban una señal magnética más joven que las rocas, habiendo sido éstas afectadas por una remagnetización regional. Como en otras ocasiones 
ocurre en el ámbito de la ciencia, este nuevo paradigma no fue totalmente aceptado en un inicio, quizá debido a las implicaciones en los modelos y reconstrucciones paleogeográficas en el que se estaba trabajando en aquel momento (ver revisión de McCabe y Elmore, 1989). Otro aspecto que favoreció el rechazo de la hipótesis de la remagnetización fue el mecanismo de adquisición propuesto; Creer propuso que se trataba de una remagnetización de origen químico adquirida por procesos de meteorización cuando los continentes se encontraban en latitudes tropicales, de manera similar a la formación de las lateritas. La observación de direcciones similares portadas por magnetita (p. ej., McElhinny y Opdyke, 1973) parecía invalidar la oxidación propuesta por Creer y por tanto, la hipótesis de la remagnetización (o al menos su mecanismo de adquisición). Si bien algunas de las interpretaciones de Creer no eran correctas, pronto la evidencia de una remagnetización regional adquirida durante el Paleozoico Superior, que afectaba tanto a calizas como a capas rojas (portada por magnetita y hematites respectivamente), empezó a observarse en diferentes puntos de América del Norte (Steiner, 1973; Van der Voo, 1979; entre otros). Con estos nuevos estudios, en los que se observaban incluso varias componentes paleomagnéticas, se comenzó a aceptar de manera generalizada la presencia de remagnetizaciones químicas adquiridas por procesos geoquímicos generados lejos de la superficie, relacionados con la orogenia VariscoAlleghaniense (Van der Voo y French, 1977).

Durante los años 80 y 90 el estudio de las remagnetizaciones se hace más extenso, centrándose principalmente en los materiales paleozoicos de los Montes Apalaches, que como ya se ha indicado fueron remagnetizados durante el supercron Kiaman a consecuencia de la orogenia Varisco-Alleghaniense (p. ej., Jackson, 1990). Desde entonces hasta la actualidad los estudios de remagnetizaciones regionales, centrándose en diferentes materiales sedimentarios, se han extendido a lo largo del globo, y se ha observado que este proceso afecta a muchas cuencas y cadenas montañosas presentes en el planeta (Van der Voo y Torsvik, 2012; para revisión). Estos estudios presentan la combinación de diferentes aproximaciones, entre las que podemos destacar el propio análisis de las direcciones paleomagnéticas, propiedades magnéticas de las rocas, análisis geoquímicos, cálculo de paleotemperaturas y observaciones mediante microscopía electrónica. Quizá uno de los temas más discutidos es el mecanismo que desencadena las remagnetizaciones químicas, proponiéndose diferentes modelos que pueden separarse en dos grandes grupos según la revisión de Elmore et al. (2012): (i) los derivados de la presencia de fluidos externos (i.e., migración de fluidos orogénicos, meteóricos, hidrocarburos y mineralizaciones) o (ii) por procesos diagenéticos internos (i.e., illitización y maduración de materia orgánica).

\subsection{Las remagnetizaciones regionales químicas en carbonatos}

Cuando las rocas carbonatadas, así como las lutitas, son afectadas por procesos de enterramiento debido, por ejemplo, a la evolución de una cuenca sedimentaria o al apilamiento tectónico durante una orogenia, la mineralogía ferrimagnética evoluciona dependiendo de las paleotemperaturas alcanzadas por las rocas. Estos procesos han sido ampliamente estudiados (Aubourg et al., 2012; Kars et al. 2015), y se han propuesto como geotermómetros en rocas lutíticas. Concretamente, estos 
autores han observado la siguiente evolución de la mineralogía: hasta $50^{\circ} \mathrm{C}$, el mineral dominante es greigita, a partir de $50^{\circ} \mathrm{C}$ ésta comienza a desaparecer y se neoforma magnetita hasta los $200^{\circ} \mathrm{C}$. Entre 200 y $300^{\circ} \mathrm{C}$ disminuye la cantidad de magnetita a medida que se forma pirrotina, coexistiendo ambas mineralogías. A partir de $300^{\circ} \mathrm{C}$ la única fase es la pirrotina. Por tanto, las remagnetizaciones químicas portadas predominantemente por magnetita están restringidas a temperaturas entre 50 y $300^{\circ} \mathrm{C}$ (pudiendo estar limitadas a un máximo de $200^{\circ} \mathrm{C}$ si se prueba la ausencia de pirrotina). Estos cambios mineralógicos implican la neoformación de nuevos cristales ferrimagnéticos, y por tanto remagnetizaciones químicas.

Los carbonatos afectados por remagnetizaciones químicas portadas por magnetita presentan una serie de características magnéticas, que son comunes independientemente del contexto tectónico en el que se adquiera la remagnetización, la edad tanto del proceso en sí como de los materiales a los que afectan, los procesos que dan lugar al crecimiento autigénico de magnetita o los mecanismos que desencadenan dichos procesos. Las principales aportaciones al conocimiento de este tipo de remagnetizaciones deriva de los trabajos realizados en los Apalaches, principalmente durante los años 80 y 90 (Van der Voo y Torsvik, 2012; para revisión), y posteriormente el estudio de las mismas se ha extendido a todas las zonas del planeta, observando estas mismas propiedades magnéticas. Algunas de estas propiedades magnéticas (ver revisión de Jackson y Swanson-Hysell, 2012) son la presencia de curvas de histéresis en cintura de avispa (Tauxe et al., 1996) generadas como consecuencia de la presencia de dos fases de diferente coercitividad, que implica altos ratios de coercitividad remanente frente a coercitividad y que permite separar groseramente calizas
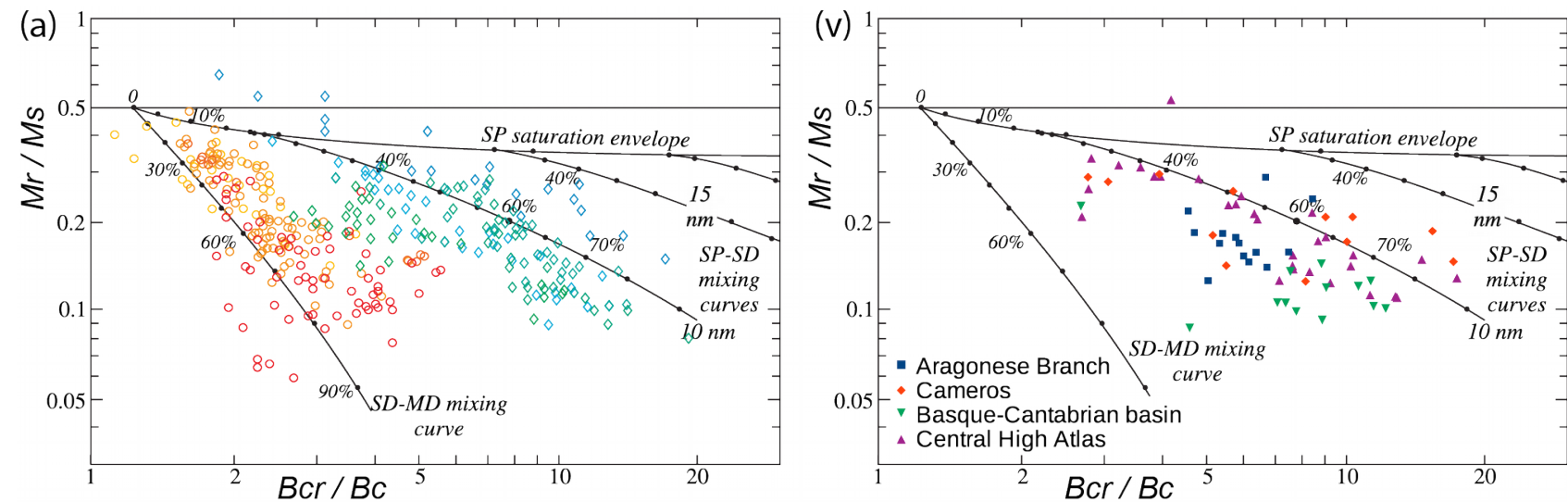

Figura 1.1. Gráficos mostrando los parámetros de la histéresis, así como las curvas de mezcla para diferentes tamaños de grano de magnetita (Dunlop, 2002a). (a) Comparación entre calizas remagnetizadas (colores fríos) y no remagnetizadas (colores cálidos). Compilación de datos proveniente de Jackson y Swanson-Hysell (2012). (b) Datos provenientes de las cuencas de Iberia y el Atlas. Rama Aragonesa (Cordillera Ibérica), Villalaín et al. (2008); Cameros (Cordillera Ibérica), Villalaín et al., (2006); cuenca Vasco-Cantábrica, Soto et al. (2008); Alto Atlas Central, TorresLópez et al. (2015)

Figure 1.1. Plots showing the hysteresis parameters and the mixing curves for different grain sizes of magnetite (Dunlop, 2002a). (a) Comparison between remagnetized (cold colors) and nonremagnetized (warm colors) limestones. Data compilation from Jackson and Jackson-Hysell (2012). (b) Data from the Iberian basins and the Atlas. Aragonese Branch (Iberian Range), Villalaín et al. (2008); Cameros (Iberian Range), Villalaín et al. (2006); Basque-Cantabrian basin, Soto et al. (2008); Central High Atlas, Torres-López et al. (2015). 
remagnetizadas y no remagnetizadas (Fig. 1.1) (Channel y McCabe, 1994; Jackson y SwansonHysell, 2012). Otra propiedad característica es que la componente paleomagnética asociada a la remagnetización usualmente presenta temperaturas de desbloqueo inferiores a la temperatura de Curie de la magnetita, constreñidas entre 300 y $500^{\circ} \mathrm{C}$. Las observaciones realizadas mediante los parámetros de la histéresis se interpretan como derivadas de la presencia de una importante población de granos de magnetita de tamaño de grano muy fino (monodominio), que se distribuye de manera progresiva entre el comportamiento superparamagnético (SP) y el monodominio estable (SSD) (Dunlop, 2002a; Jackson y Swanson-Hysell, 2012). En cuando a las temperaturas de desbloqueo, pueden explicarse (véase Jackson y Swanson-Hysell, 2012) (i) como consecuencia de que el portador de la remagnetización es magnetita con un alto grado de impurezas (titanio u otros elementos afines), (ii) como magnetita isótropa, cuyo comportamiento estaría dominado por la anisotropía magnetocristalina y/o (iii) debido al pequeño volumen de los granos de magnetita dominantes, indicando que no se alcanzan los valores máximos de tamaño para el comportamiento SSD (estos tamaños varían dependiendo de la mayor o menor anisotropía de los granos de magnetita, pero dentro del rango comprendido entre 30 y $80 \mathrm{~nm}$; Winklhofer et al., 1997). Uniendo ambas observaciones, las bajas temperaturas de desbloqueo observadas pueden deberse a que el grueso de la población de magnetita SSD presenta volúmenes intermedios; por otro lado, y dada la ausencia casi sistemática de la transición de Verwey, las temperaturas de desbloqueo también podrían estar condicionadas por la composición mineralógica de la magnetita neoformada (magnetita no estequiométrica). Por último, la descomposición de la IRM y la separación de componentes también permite distinguir entre materiales afectados y no afectados por remagnetizaciones químicas (Dekkers, 2012, y referencias allí presentes).

Si bien parece probado que este tipo de remagnetizaciones tiene origen químico, con la oxidación de sulfuros de hierro, y es portada por magnetita SSD, la naturaleza exacta de los granos portadores no se conoce. Se han realizado diferentes acercamientos mediante el uso de microscopía electrónica, observando cristales de sulfuro de hierro parcialmente oxidados a magnetita (Suk et al., 1990; 1993) indicando la presencia de este tipo de procesos diagenéticos. Sin embargo, la observación directa (y los consecuentes experimentos de análisis de composición química, o valoración de la anisotropía de los granos) de los cristales nanométricos que portan la remagnetización no se ha realizado hasta la hecha (Sun y Jackson, 1994; Van der Voo y Torsvik, 2012).

\subsection{Las remagnetizaciones cretácicas del Mediterráneo occidental}

Tanto en la Península Ibérica como el Norte de África se reconocen una serie de cuencas intracontinentales mesozoicas, relacionadas con la apertura del Atlántico y la evolución del Tethys, que presentan una serie de características evolutivas generales (Salas y Casas, 1993; Vera, 2004; Dias et al., 2006; Frizon de Lamotte et al., 2008): (i) en general presentan dos etapas de rift y subsecuentemente dos de post-rift; la primera etapa se produce durante el Pérmico Superior y el Triásico y la segunda durante el Jurásico Medio en el norte de África y durante el Jurásico Superior 
- Cretácico Inferior en Iberia. Consecuencia de estos episodios se depositan series sedimentarias potentes, constituidas por series principalmente detríticas pertenecientes al Triásico y al Jurásico Superior - Cretácico Inferior, y carbonatos pertenecientes principalmente al Jurásico y al Cretácico Superior.

En la práctica totalidad de las cuencas se ha observado la presencia de remagnetizaciones regionales, más o menos intensas y presuntamente adquiridas durante el Cretácico, afectando tanto a las capas rojas (portadas por hematites) como a los carbonatos (portadas por magnetita) (Schott y Peres, 1987; Galdeano et al., 1989; Moreau et al., 1992; Juárez et al., 1998; Dinarès-Turell y Garcia-Senz, 2000; Villalaín et al., 2003; Gong et al., 2008; Soto et al. 2008; Villalaín et al., 2014; Torres-López et al., 2015; Moussaid et al., 2015). Estas remagnetizaciones se caracterizan por presentar propiedades magnéticas similares (Fig. 1.1b) y polaridad sistemáticamente normal (Figs.

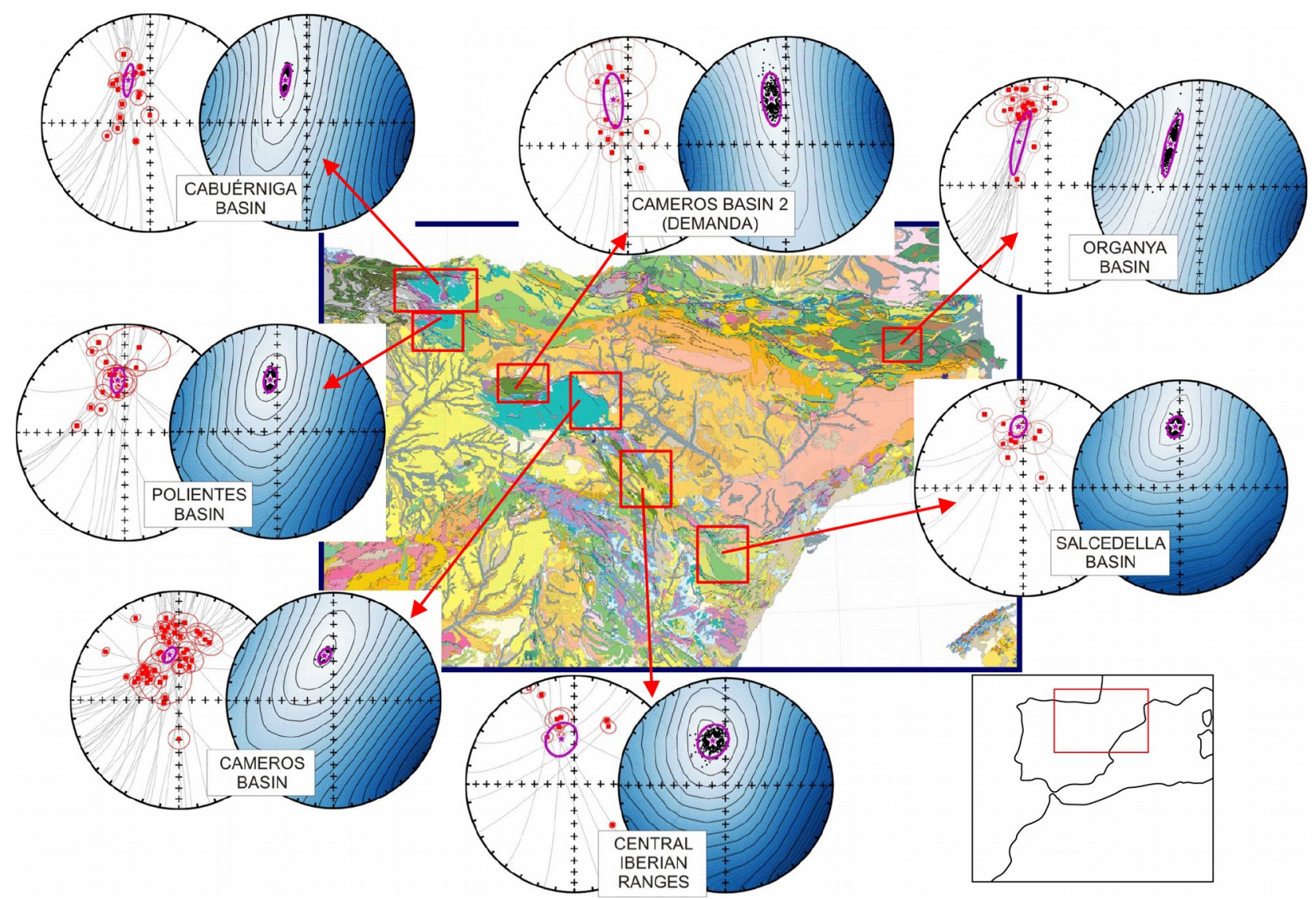

Figura 1.2 Círculos menores, direcciones paleomagnéticas in situ, y dirección calculada de remagnetización para diferentes cuencas del NE de la Península Ibérica. Datos provenientes de Soto et al. (2008 y 2011), cuencas de Cabuérniga y Polientes; Villalaín et al. (2006), Sierra de la Demanda; Villalaín et al. (2003), Cuenca de Cameros; Juárez et al. (1998), Cordillera Ibérica Central; Villalaín et al. (2014), cuenca de Salcedella; Gong et al. (2009), cuenca de Organya.

Figure 1.2. Small circles, in situ paleomagnetic directions and calculated remagnetization direction of different basin of the NE Iberian Peninsula. Data came from Soto et al. (2008 and 2011), Cabuérniga and Polientes basins; Villalaín (2006), Demanda Range; Villalaín et al. (2003), Cameros basin; Juárez et al. (1998), Central Iberian Range; Villalaín et al. (2014), Salcedella basin; Gong et al. (2009), Organya basin. 
1.2 y 1.3), y por tanto (así como por la extensión de edad de los materiales a los que afectan) se ha interpretado generalmente que fueron adquiridas durante el supercron cretácico de polaridad normal. Una consecuencia directa de estas remagnetizaciones es la falta de datos de magnetizaciones primarias mesozoicas (especialmente durante el Cretácico Inferior) que permitan definir la curva de deriva polar aparente con el grado de credibilidad necesario (Neres et al., 2012), si bien existen excepciones y en algunos casos la remagnetización no ha enmascarado totalmente la señal primaria (Juárez et al., 1994; García-Lasanta, 2016).

La falta de una curva bien definida para el Iberia durante el Cretácico, así como la posible presencia de rotaciones de eje vertical en algunas de las cuencas (que pudieron ser generadas durante la extensión mesozoica y/o la compresión cenozoica), y a pesar de los esfuerzos realizados por Gong et al. (2009), impide conocer con exactitud las relaciones temporales entre las remagnetizaciones observadas en las cuencas de Iberia. En cualquier caso, las remagnetizaciones

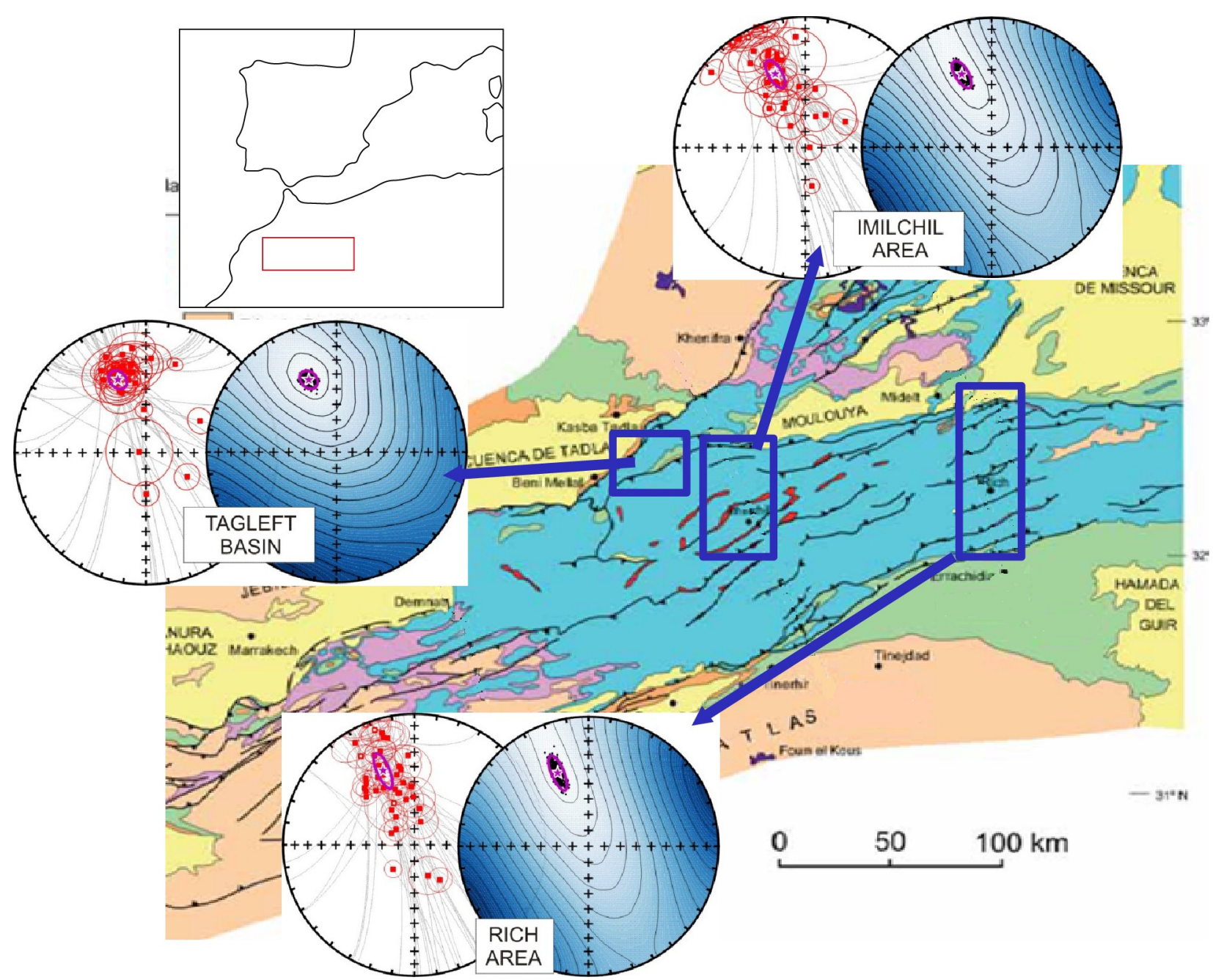

Figura 1.3 Círculos menores, direcciones paleomagnéticas in situ, y dirección calculada de remagnetización para diferentes cuencas del NE de la Península Ibérica. Datos provenientes de Torres-López et al. (2015), área de Imilchil; Moussaid et al. (2014), cuenca de Tagleft.

Figure 1.3. Small circles, in situ paleomagnetic directions and calculated remagnetization direction of different basin of the NE Iberian Peninsula. Data came from Torres-López et al. (2015), Imilchil area; Moussaid et al. (2014), Tagleft basin. 
parecen presentar direcciones bastante similares. Villalaín et al. (2003), a partir de un estudio paleomagnético en la cuenca de Cameros, consideran que la remagnetización en dicha cuenca fue adquirida después del Albiense, dado que afecta a materiales de esa edad, y antes del final del supercron (antes del Campaniense). Además, en la cuenca de Cameros se alcanzó un pico térmico de $350^{\circ} \mathrm{C}$ en las zonas más profundas de la cuenca (Mata et al. 2001), al que se le asigna una edad Albiense (95-100 Ma) mediante la datación con K-Ar y Ar-Ar en illitas autigénicas probablemente formadas durante el pico metamórfico (Goldberg et al., 1988; Casquet et al., 1992).

El caso de África difiere del de Iberia dado que su mayor tamaño (y por tanto la mayor disponibilidad de materiales geológicos a partir de los cuales obtener información para calcular paleopolos) permite una buena definición de su curva de deriva polar aparente (Torsvik et al., 2012). Es posible por tanto comparar la misma con las direcciones de remagnetización obtenidas de carbonatos (Torres-López et al., 2015) y capas rojas (Moussaid et al., 2014), obteniendo un solapamiento entre ellas en torno a 100-105 Ma.

La remagnetización del Atlas fue caracterizada por Torres-López et al. (2015), quienes observaron un comportamiento similar al observado en las cuencas ibéricas. Concretamente, en carbonatos la remagnetización es portada por magnetita, con temperaturas máximas de desbloqueo de $450-500^{\circ} \mathrm{C}$. En ocasiones es posible observar la misma componente a temperaturas inferiores $\left(275-325^{\circ} \mathrm{C}\right)$ que se relaciona con la presencia de pirrotina portando la misma remagnetización. Las propiedades magnéticas son similares a las observadas en otras calizas remagnetizadas, indicando la elevada presencia de granos SP y SSD. Respecto a la distribución areal, se ha observado dicha remagnetización regional, al menos, entre las transversales N-S de Demnate y Rich (Torres-López et al., 2015; y referencias allí incluidas), si bien posiblemente su extensión es mayor. En dichas transversales, se observa que la remagnetización queda limitada a las áreas subsidentes que presentaban un espesor mínimo de materiales suprayacentes, y por tanto no se observa en los márgenes de la cadena. En las capas rojas (Moussaid et al., 2015) la componente remagnetizada presenta alta coercitividad y temperaturas máximas de desbloqueo de $550-650^{\circ} \mathrm{C}$, portada por hematites. En ocasiones es posible observar una componente de más alta temperatura $\left(660-675^{\circ} \mathrm{C}\right)$ con polaridad inversa. La remagnetización en capas rojas parece presentar menos limitaciones respecto al enterramiento, pudiendo producirse a profundidades más someras; esto se deriva del hecho de que en la cuenca de Aït Attab se observa claramente la remagnetización en las capas rojas, pero no en los carbonatos. Un estudio realizado en el Atlas Medio, en el entorno de Boulemane, parece indicar lo mismo; Calvín et al. (2017) observan por medio de test del pliegue y del conglomerado que las capas rojas jurásicas están afectadas por la remagnetización cretácica, pero no así las calizas jurásicas. En todos los casos, las direcciones presentan polaridad normal de manera sistemática, con inclinaciones positivas hacia el NO. Del mismo modo, en ambos casos se observa un comportamiento interplegamiento generalizado.

Finalmente, hay que tener en cuenta que el mecanismo por el cual se adquirieron las remagnetizaciones, si fueron o no sincrónicas, si existe relación entre las observadas en Iberia y en el Norte de África, son todavía incógnitas por resolver y un campo de trabajo de gran interés en relación incluso con la dinámica planetaria a los 100 Ma (Matthews et al., 2012). En general, parece 
que las remagnetizaciones están limitadas a rocas que estuvieron afectadas por un mínimo de materiales suprayacentes, y la intensidad de la misma (para una misma litología) se relaciona con el grado de enterramiento (y previsiblemente con la temperatura máxima alcanzada). En Iberia, y como consecuencia de la rotación de la placa, se produjeron una serie de eventos térmicos y geoquímicos en torno al Albiense-Cenomaniense (p. ej. Mata et al., 2001; DeFelipe et al., 2017; Bodego et al., 2018; y referencias allí indicadas) que pudieron desencadenar un evento remagnetizador más o menos puntual. Sin embargo, relacionar la rotación de Iberia con la remagnetización del Atlas es más complicado, y en caso de que todas las remagnetizaciones respondan a un mismo evento, éste debería corresponderse con una anomalía térmica de gran amplitud y de una escala mucho mayor que la propia Placa Ibérica. Por otro lado, la similar evolución de todas las cuencas analizadas podría explicar la aparente 'sincronía' entre las remagnetizaciones; de hecho, la sincronía o no de la misma depende de la velocidad del propio mecanismo de remagnetización, hecho que también desconocemos.

\subsection{Aplicaciones tectónicas de las remagnetizaciones}

\subsubsection{Aplicación clásica en sistemas de pliegues y cabalgamientos}

Las remagnetizaciones, del mismo modo que las magnetizaciones primarias, pueden utilizarse para el estudio de sistemas de pliegues y cabalgamientos. El uso clásico de las mismas ha sido la valoración de rotaciones de eje vertical, tanto a nivel del orógeno como en el estudio de estructuras concretas, y la valoración de acortamientos diferenciales. Las diferencias que puede suponer trabajar con magnetizaciones primarias o remagnetizaciones son i) las relativas a la edad de la magnetización con respecto a los procesos de deformación y ii) en algunos casos la corrección por basculamiento que es necesario aplicar cuando las remagnetizaciones son syn- o post-plegamiento. Este último problema puede resolverse mediante el uso de test de pliegue incremental (Villalaín et al., 1994). En este sentido, y cuando se dan las circunstancias necesarias, es posible usar distintas remagnetizaciones adquiridas en momentos diferentes de la evolución de un orógeno o sistema de cabalgamientos, acotando temporalmente diferentes eventos de deformación. Este es el caso, por ejemplo, del trabajo realizado por Izquierdo-Llavall et al. (2015) en la Sierras Interiores del Pirineo Central; estos autores observan la presencia de dos remagnetizaciones que presentan diferente relación con el plegamiento. La componente B fue adquirida posteriormente al plegamiento principal pero posteriormente registró rotaciones de eje vertical diferenciales entre las diferentes láminas de cabalgamiento estudiadas. Por otro lado, la componente C presenta un comportamiento más complejo respecto al plegamiento, con relaciones temporales desde pre- hasta post-plegamiento en las distinta áreas, pero en todas ellas es previa al basculamiento generado por un cabalgamiento de basamento. Esto es un ejemplo de cómo el estudio de remagnetizaciones puede ayudarnos a entender la evolución de sistemas de cabalgamientos.

En el ejemplo anterior, una de las dificultades proviene de que la datación de las remagnetizaciones debe realizarse de manera relativa a la evolución del área. Esta dificultad puede resolverse con la propuesta de los nuevos métodos de datación de remagnetizaciones, consistentes 
en la datación absoluta (Ar-Ar) de illitas neoformadas (en caso de que estén relacionadas con el mecanismo de adquisición de la remagnetización) (Tohver et al., 2008). Una aplicación de este método es el realizado en el sistema de pliegues y cabalgamientos de Sierra Madre (México), donde Fitz-Diaz et al. (2014) estimaron la edad de diferentes pliegues mediante la datación Ar/Ar de illitas autigénicas. Estos datos de edad fueron utilizados por Nemkin et al. (2015) para datar la remagnetización coetánea al plegamiento observada en los mismos pliegues. Sin embargo, estos autores advierten que el proceso de illitización no siempre conlleva una remagnetización, y que pueden existir otros mecanismos (como por ejemplo la movilización de fluidos) que generen remagnetizaciones, presentando diferentes relaciones temporales con el plegamiento.

\subsubsection{Las aportaciones de los círculos menores}

El estudio de remagnetizaciones con comportamiento syn-plegamiento presenta ciertas limitaciones, en base a que el análisis clásico de las mismas mediante los test del pliegue (Graham, 1949; McCabe y Elmore, 1989; McFadden, 1990; Bazhenov y Shipunov, 1991; Watson y Enkin, 1993; Tauxe y Watson, 1994) asume un plegamiento proporcional en sendos flancos, algo que no ha de cumplirse siempre (Suppe, 1983; Cairanne et al., 2002; Delaunay et al., 2002; Villalaín et al., 2003), impidiendo el cálculo de la dirección de remagnetización (ésta no tiene que corresponder necesariamente con el máximo agrupamiento de las direcciones de ambos flancos en una restitución proporcional).

Esta problemática puede abordarse aplicando diferentes grados de despliegue a los diferentes flancos (McClelland-Brown, 1983; Surmont et al., 1990; Villalaín et al., 1994). Esta práctica, en la que se despliega progresivamente la estratificación y por tanto se rota la dirección paleomagnética, puede hacerse más extensiva si se consideran todos los grados de despliegue para cada estación paleomagnética. Esto puede realizarse mediante el uso de los círculos menores (Shipunov, 1997; Henry et al., 2004; Waldhör, 1999; Waldhör y Appel, 2006), que son las trayectorias seguidas por las direcciones paleomagnéticas cuando son rotadas alrededor del eje horizontal contenido en la estratificación. En base a una serie de asunciones (ver apartado 4. Metodología II), esta técnica permite el cálculo de la dirección de remagnetización local, coincidente con la intersección de los círculos menores de las diferentes estaciones paleomagnéticas.

Antolín et al. (2012) integran las aproximaciones expuestas en el apartado anterior (relaciones entre plegamiento, remagnetizaciones y dataciones Ar/Ar de illitas y moscovitas) con el análisis de las direcciones paleomagnéticas por medio de los círculos menores. Estos autores observaron en el Himalaya Oriental la presencia de una remagnetización térmica portada por pirrotina, adquirida en el pico metamórfico y por tanto correlacionables con las edades provenientes de la recristalización de los filosilicatos. Los test del pliegue realizados en estructuras de escala de afloramiento indican que la remagnetización fue adquirida tras el desarrollo de los mismos, pero la comparación de las direcciones entre las diferentes estaciones por medio de los círculos menores indica que fue adquirida de manera previa o sincrónica a un plegamiento de mayor longitud de onda. Además, la dirección calculada de la remagnetización no se solapa con la dirección esperada 
para su edad de adquisición, presentando igual inclinación pero distinta declinación. Esto indica que tras su adquisición fue afectada por una rotación de eje vertical.

Un ejemplo similar es el estudio de Rouvier et al. (2012), quienes estudian una remagnetización en el oroclinal de Corbières (NE Francia), y mediante las direcciones de remagnetización locales calculadas utilizando círculos menores calculan rotaciones de eje vertical diferenciales entre diferentes áreas. Para ello, es imprescindible acotar bloques que no hayan sufrido rotaciones de eje vertical diferenciales entre las diferentes estaciones, para poder calcular las direcciones de remagnetización para cada área y posteriormente comparar éstas entre los distintos bloques (Fig. 1.4).y la dirección esperada en caso de conocerse.

\subsubsection{Los círculos menores y la restitución de cuencas}

El uso de las remagnetizaciones en el estudio de la evolución de cuencas sedimentarias ha sido muy relevante, permitiendo obtener imágenes de las mismas de momentos previos a su inversión (generalmente, las cuencas sedimentarias afloran en superficie debido a su inversión tectónica). Esta

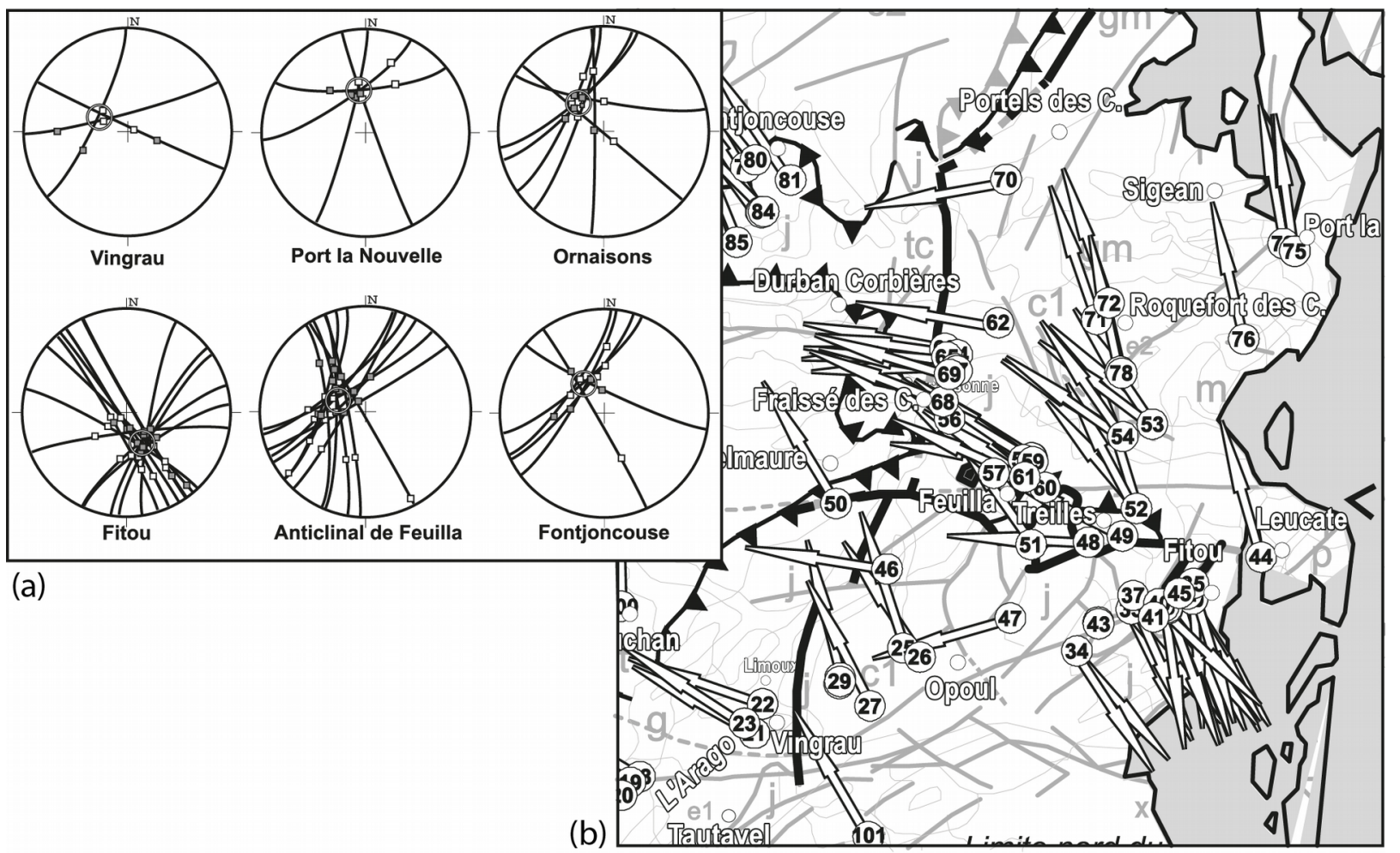

Figura 1.4 Aplicación de los círculos menores en el oroclinal de Corbières (SE de Francia) para (a) el cálculo de las direcciones locales de remagnetización en áreas homogéneas respecto a la rotación de eje vertical que registran, que es usada para (b) la estimación de rotaciones de eje vertical diferenciales entre las diferentes áreas de estudio. Modificado de Rouvier et al. (2012).

Figure 1.4. Small circles application in the Corbières orocline (SE of France) for (a) the local remagnetization directions calculation in sectors affected by homogeneous vertical axis rotations, which is used for (b) the estimation of vertical axis rotations recorded in the different areas. Modified from Rouvier et al. (2012). 
técnica ha sido ampliamente desarrollada por los grupos de investigación de las Universidades de Burgos y Zaragoza (en los que se integra esta tesis doctoral), con su aplicación en diferentes cuencas de la Península Ibérica y el Alto Atlas Central (Villalaín et al., 2003; Soto et al., 2008, 2011; Casas et al., 2009; Moussaid et al., 2015; Torres-López et al., 2016).

Estas cuencas están afectadas por una remagnetización cretácica interplegamiento, adquirida en un periodo en el que no se estaría produciendo ningún plegamiento, pero que separa las fases de plegamiento asociada al estado de cuenca (pre-remagnetización), y ligada a la inversión durante el Cenozoico (post-remagnetización). Este tipo de remagnetizaciones, cuando únicamente han sido rotadas alrededor de la dirección del plano de la estratificación, pueden ser usadas para restituir el paleobuzamiento que las capas presentaban en el momento de la adquisición de la remagnetización (ver revisión de Villalaín et al., 2016).

Soto et al. (2008, 2011) realizan la restitución de varias subcuencas presentes en la cuenca Vasco-Cantábrica haciendo uso de los círculos menores. La comparación de la geometría actual y la

(a) PRESENT-DAY GEOMETRY:

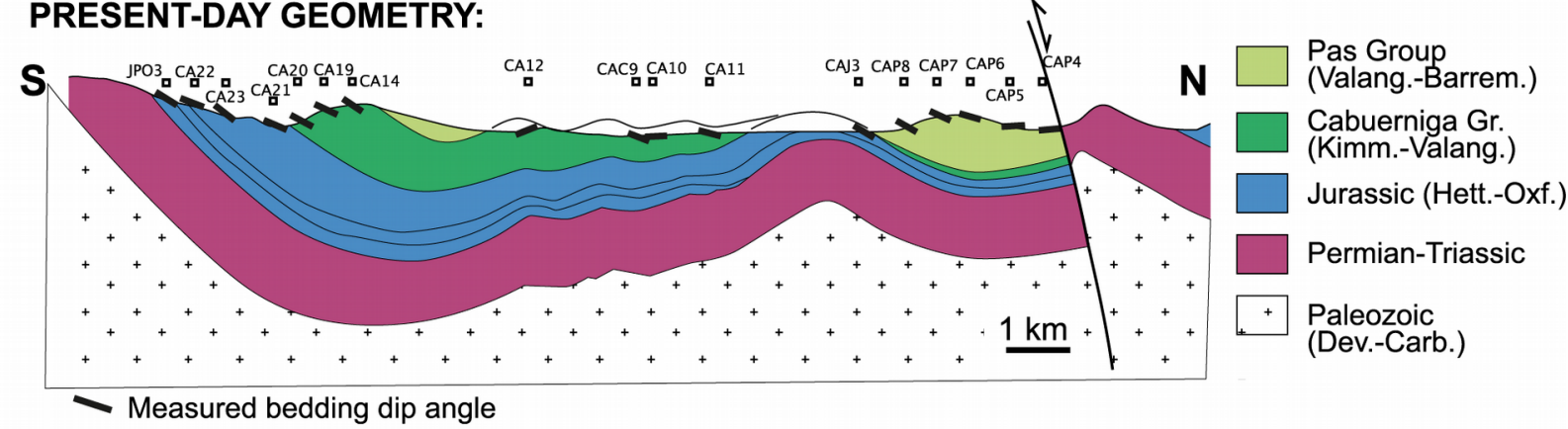

(b) BASIN GEOMETRY RECONSTRUCTION at the remagnetization acquisition time:

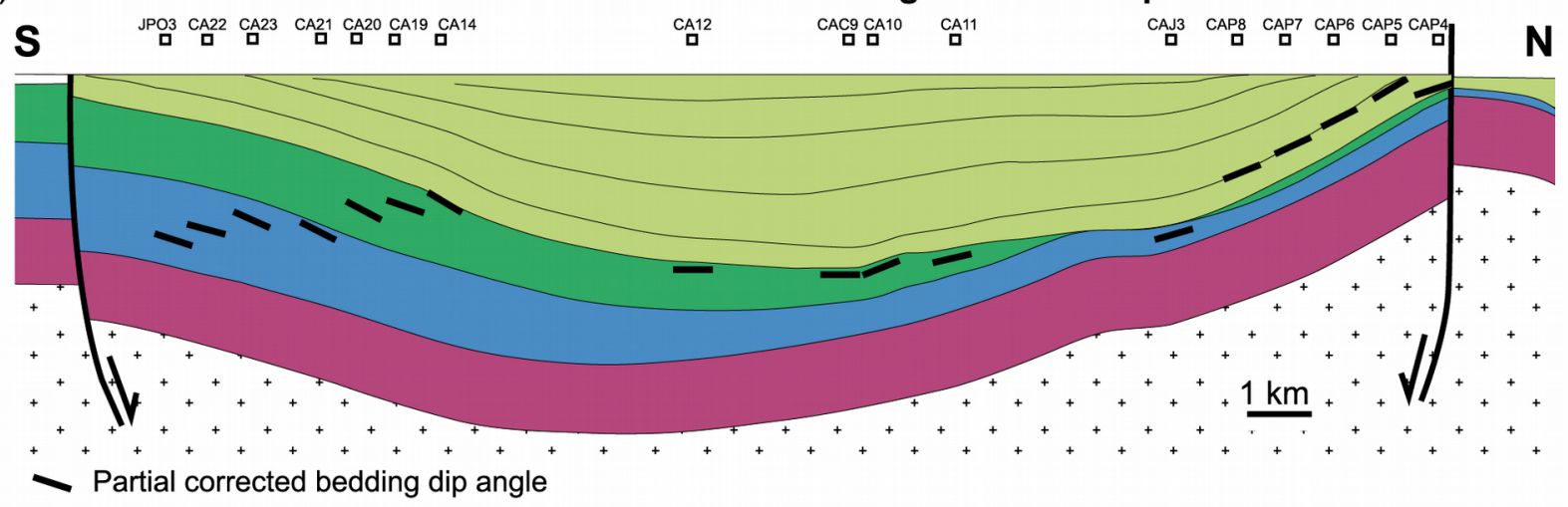

Figura 1.5 Aplicación de los círculos menores para la reconstrucción de cuencas (ejemplo de la cuenca de Cabuérniga, $\mathrm{N}$ de España), mostrando (a) su geometría actual y (b) la que presentaba en el momento de la adquisición de la remagnetización (Albiense-Cenomaniense). Modificado de Soto et al. (2008).

Figure 1.5. Small circles application to restorations of sedimentary basin (case of the Cabuérniga basin, $N$ of Spain), showing (a) its present day geometry and (b) the restored geometry at the remagnetization acquisition time (Albian-Cenomanian). Modified from Soto et al. (2008). 
que presentaban los materiales en el momento de la adquisición de la remagnetización (AlbienseCenomaniense) les permite realizar diferentes inferencias difícilmente abordables de otro modo. En la cuenca de Cabuérniga (Fig. 1.5) observan que la geometría previa a la compresión es acorde con una geometría de cuenca, cuya deformación está condicionada por la subsidencia, controlada por las fallas normales en sendos márgenes (Soto et al., 2008). Por el contrario, la restitución en la cuenca de Ponientes (al sur de la anterior) muestra una geometría Cretácica muy similar a la actual, más acorde a haber sido afectada por compresión que por extensión (Soto et al., 2011). A partir de estos resultados establecen una etapa de inversión previa a la adquisición de la remagnetización relacionada con movimientos direccionales siniestros, que puede afectar de manera diferente a las distintas cuencas dependiendo de su orientación y relación con las fallas transcurrentes que focalizan los movimientos direccionales.

Finalmente, los trabajos realizados por Torres-López et al. $(2014,2016)$ han permitido caracterizar la geometría Albiense-Cenomaniense en el Alto Atlas Central (Marruecos). Estos trabajos han evidenciado que un alto porcentaje de la estructuración actual es heredada de la etapa extensional, con el desarrollo de importantes estructuras anticlinales relacionadas con procesos halocinéticos e intrusión de materiales ígneos durante el Jurásico.

\subsection{Aportaciones de la tesis doctoral}

\subsubsection{Los portadores de la remagnetización del AAC}

Haciendo uso de experimentos clásicos de magnetismo de rocas, Torres-López et al. (2014) caracterizaron que el mineral portador de la remagnetización del AAC en carbonatos es magnetita SSD, con similares características a otras áreas afectadas por remagnetizaciones regionales químicas.

La realización de extractos magnéticos y su posterior observación mediante microscopía electrónica ha sido uno de los acercamientos utilizados para tratar de observar los portadores de este tipo de remagnetizaciones (Suk et al. 1990; 1993). Sin embargo, la comparación de las propiedades magnéticas entre la roca total y los derivados del proceso de extracción indican que los minerales observados mediante microscopía electrónica no son los portadores de la remagnetización (Sun y Jackson, 1994), de modo que los métodos de extracción utilizados no eran apropiados. Las nuevas técnicas para la realización de extractos magnéticos (Strehlau et al., 2013) probadas con éxito en espeleotemas (Strauss et al., 2013), hizo que nos propusiésemos aplicar esta técnica en calizas remagnetizadas para su posterior observación. Esta tarea se llevó a cabo en la Universidad de Minnesota, en colaboración con la Dra. Jennifer H. Strehlau, durante una estancia de investigación en el Institute for Rock Magnetism (Universidad de Minnesota) supervisada por el Dr. Mike Jackson. 


\subsubsection{Aportaciones a la metodología basada en los círculos menores}

Durante los últimos 25 años los grupos de investigación del IPGP de París (Francia), de la Universidad de Tübingen (Alemania) y de las universidades de Burgos y Zaragoza (España) han desarrollado ampliamente los métodos basados en los círculos menores, tanto para el cálculo de la dirección de remagnetización local, como para la obtención de paleo-buzamientos. Esto ha permitido que estas técnicas se encontrasen ampliamente desarrolladas al inicio de esta tesis doctoral, si bien su uso todavía no se ha extendido al resto de la comunidad científica que combina la geología estructural y el paleomagnetismo. Hasta la fecha existían dos programas informáticos no publicados, desarrollados por B. Henry (IPGP, París) y por M. Waldhör (UT, Tübingen), que permitían aplicar estos métodos de una manera relativamente sencilla (el grupo de investigación en el que me integro ha usado de manera exhaustiva el programa de M. Waldhör). Sin embargo, es posible que la falta de un programa informático automatizado y de uso sencillo acompañado de una revisión sobre esta metodología haya impedido la expansión de esta serie de técnicas útiles para el análisis de remagnetizaciones.

Uno de los objetivos de esta tesis ha consistido en el desarrollo de un nuevo programa informático multiplataforma, escrito en lenguaje Python, que presenta algunas mejoras respecto a los anteriores: (i) los cálculos son más rápidos, haciendo más operativo al programa, (ii) en las tablas de datos de salida se incluyen nuevos parámetros de interés para valorar la calidad de las estaciones paleomagnéticas tanto en el cálculo de la dirección de remagnetización, como en el cálculo de paleo-buzamientos, (iii) se ha desarrollado la salida gráfica de los resultados, facilitando su inclusión en artículos e informes científicos, (iv) el tratamiento estadístico en el cálculo de la dirección de remagnetización ha sido mejorado al incluir técnicas de bootstrap, ya propuestas por Henry et al (2004). Este trabajo se realizó parcialmente gracias a la estancia de investigación realizada en el instituto SCRIPPS (Universidad de California - San Diego, EEUU), supervisado por la Dra. Lisa Tauxe.

De manera paralela al desarrollo informático se ha realizado gran hincapié en los protocolos de trabajo que se deben seguir cuando se aplican estas técnicas. Se han discutido las incertidumbres y limitaciones del método, así como las asunciones de partida necesarias para el uso del mismo. Además, y en colaboración con el Dr. Emilio Pueyo y la Dra. María José Ramón (IGME-Zaragoza), se ha valorado el impacto en los resultados cuando no se cumplen las asunciones iniciales.

Los resultados derivados de esta sección se exponen en el apartado 4. Metodología II.

\subsubsection{Restitución de estructuras y resolución de problemas geológicos concretos}

Como se indicaba en los apartados anteriores, las técnicas de restitución por medio de círculos menores se han aplicado en numerosas cuencas de la Península Ibérica y la cuenca atlásica, demostrando su validez en dichos entornos. En esta tesis se aplican los métodos de restitución para resolver dos problemas geológicos concretos del Alto Atlas Central (AAC). 
- Datación relativa de la foliación tectónica del AAC. Algunos autores (p. ej., Laville y Piqué, 1992) han propuesto la posibilidad de que la foliación tectónica presente en el Alto Atlas Central se desarrollase en el Jurásico durante un periodo compresivo-transpresivo. Algunas de las observaciones en las que se basaba esta edad han sido desmentidas (p. ej., Charrière et al., 2009), poniendo en duda la edad jurásica de la foliación. Sin embargo, que se hayan desmentido algunas de las hipótesis en las que se basaba la adscripción del desarrollo de la foliación al periodo Jurásico, no implica que no pueda presentar dicha edad. El acercamiento científico desarrollado aquí para resolver este problema consiste en la datación relativa de los pliegues con desarrollo de foliación, con respecto a la remagnetización AlbienseCenomaniense.

- Análisis cuantitativo de la deformaciones generadas durante la extensión jurásica y la compresión cenozoica en el AAC. Los procesos halocinéticos jurásicos han sido propuestos como mecanismos de gran importancia en la estructuración de la cuenca del Atlas (p. ej., Ettaki et al., 2007; Michard et al., 2011; Saura et al., 2014; Teixell et al., 2017). Siguiendo la metodología empleada por Torres-López et al. (2016), quienes restituyen la geometría precompresiva de varios anticlinales del AAC, hemos realizado la restitución de cuatro estructuras anticlinales con la finalidad de valorar (i) la homogeneidad de la deformación pre-compresiva en estas estructuras y (ii) la importancia de la estructuración jurásica en el estilo de deformación durante la compresión cenozoica.

- Estudio paleomagnético de los gabros jurásicos. En el núcleo de los anticlinales del AAC aparecen bloques de gabro, de diferente tamaño y proporción con respecto a las rocas triásicas. Enlazando con el punto anterior, el estudio paleomagnético de estas rocas puede aportar importante información respecto a la evolución de las estructuras anticlinales tanto durante el periodo extensivo como durante la compresión. Para ello, y tras observar una importante dispersión de las direcciones paleomagnéticas (interpretadas como magnetizaciones primarias), se discuten cuatro hipótesis que podrían haber generado tal dispersión: (i) se ha generado como consecuencia de procesos transcurrentes, (ii) es consecuencia de la deformación cenozoica caracterizada por la generación de pliegues de eje horizontal, (iii) las direcciones paleomagnéticas han sido rotadas por procesos diapíricos o (iv) una combinación de los anteriores. Analizando las pautas de dispersión de las direcciones paleomagnéticas podemos interpretar los procesos generadores de la estructura actual.

Todos estos trabajos se han realizado en colaboración con el Dr. Bennacer Moussaid (Universidad de Casablanca), y en el trabajo de los gabros jurásicos también se ha colaborado con el Dr. Vicente Carlos Ruiz Martínez y el Dr. Carlos Rossi Nieto (Universidad Complutense de Madrid). Los resultados provenientes de estos puntos se exponen en los apartados 6 y 7. 


\subsubsection{Restitución de fábricas magnéticas}

Los métodos de restitución permiten caracterizar la geometría de la estratificación en el momento de la adquisición de la remagnetización. Del mismo modo que es restituida la estratificación, es posible restituir los elementos internos de las rocas, como su petrofábrica o su fábrica magnética.

Siguiendo los trabajos desarrollados en las cuencas ibéricas y atlásicas, en los que se infiere la evolución temporal de las direcciones de extensión por medio de las fábricas magnéticas (p. ej., Oliva-Urcía et al., 2011; Moussaid et al., 2013; García-Lasanta et al., 2015), tratamos de reconstruir las direcciones de extensión jurásicas en la cuenca del Atlas. Tras un estudio de las diferentes subfábricas magnéticas (AARM, RT-ASM y LT-ASM), y comparando las fábricas en su posición actual, tras la restitución total de la estratificación, y tras la restitución parcial de las mismas a su posición Albiense-Cenomaniense, hemos observado que la fábrica magnética está portada por magnetita autigénica, generada durante la remagnetización. Esto nos ha permitido (i) inferir el contexto tectónico en el que se produjo la remagnetización y (ii) aportar nueva información sobre los mecanismos de remagnetización en el AAC. Los resultados derivados de estos trabajos se presentan en el apartado 8.

Los estudios paleomagnéticos en los gabros nos han permitido restituir las rotaciones sufridas por los distintos cuerpos desde su enfriamiento y adquisición de la magnetización. Tras restituir las fábricas usando la información proveniente del análisis paleomagnético, observamos un mejor agrupamiento de las mismas con respecto a las que presentaban antes de la restitución. Por tanto, tras realizar su restitución podemos observar las mismas en la posición que presentaba cuando se fijaron, en el momento de emplazamiento de los cuerpos ígneos. Esto permite realizar inferencias sobre los mecanismos de emplazamiento de los mismos. Estos resultados se presentan en el apartado 7. 


\section{Contexto geológico del Atlas y del área de estudio}

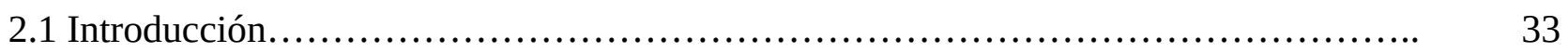

2.2 La evolución Mesozoica.................................................................. 38

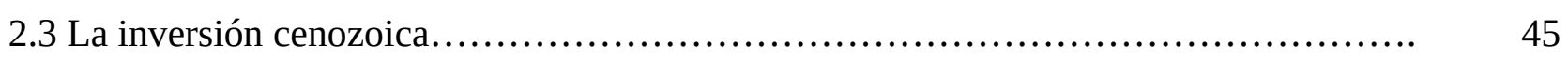

2.4 El origen de la elevación del Atlas............................................... 48

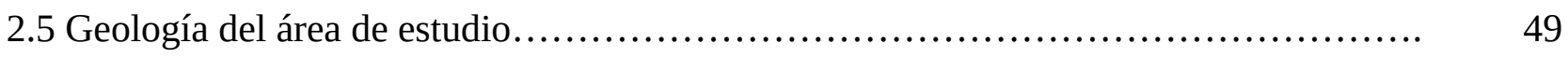



La evolución geológica de las cadenas atlásicas ha sido ampliamente discutida en la literatura científica, mostrando que a pesar de sus excepcionales afloramientos, las observaciones geológicas pueden ajustarse a diferentes modelos tectónicos. Las diferencias entre los diversos autores son importantes, y se centran en la mayor o menor oblicuidad de la extensión en relación a las estructuras (modelos extensionales versus transtensionales), la posible presencia de una fase compresiva durante el Jurásico Superior que generase una estructuración temprana de la cadena del Atlas, así como la importancia de los procesos halocinéticos y la intrusión de las rocas ígneas en la deformación de las rocas encajantes jurásicas.

A continuación se ofrece el modelo de evolución más generalizado y consensuado, que es acorde a los trabajos, por ejemplo, de Teixell et al. (2007) y Frizon de Lamotte et al. (2009), en el que se proponen dos etapas de rift, la primera durante el Permo-Triásico y la segunda durante la mitad del Jurásico Inferior, y una etapa de compresión (más o menos compleja) durante el Cenozoico.

Diferentes propuestas evolutivas que difieren de esta visión consensuada (p. ej., Laville et al., 2004), así como la importancia de los diferentes procesos que pudieron conllevar una estructuración temprana del Atlas durante el Jurásico, son discutidos en los diferentes apartados de resultados, así como en el apartado de discusión general de esta tesis doctoral. 



\subsection{Introducción}

El Atlas está constituido por un conjunto de cadenas intraplaca (Mattauer et al., 1977) situado en el antepaís del Sistema Alpino Mediterráneo (Fig. 2.1). Con dirección dominante ENE-OSO a NE-SO, se extiende desde la costa atlántica marroquí hasta la costa mediterránea tunecina, abarcando más de $2000 \mathrm{~km}$ en su dirección longitudinal y presentando una anchura en torno a $100 \mathrm{~km}$. En
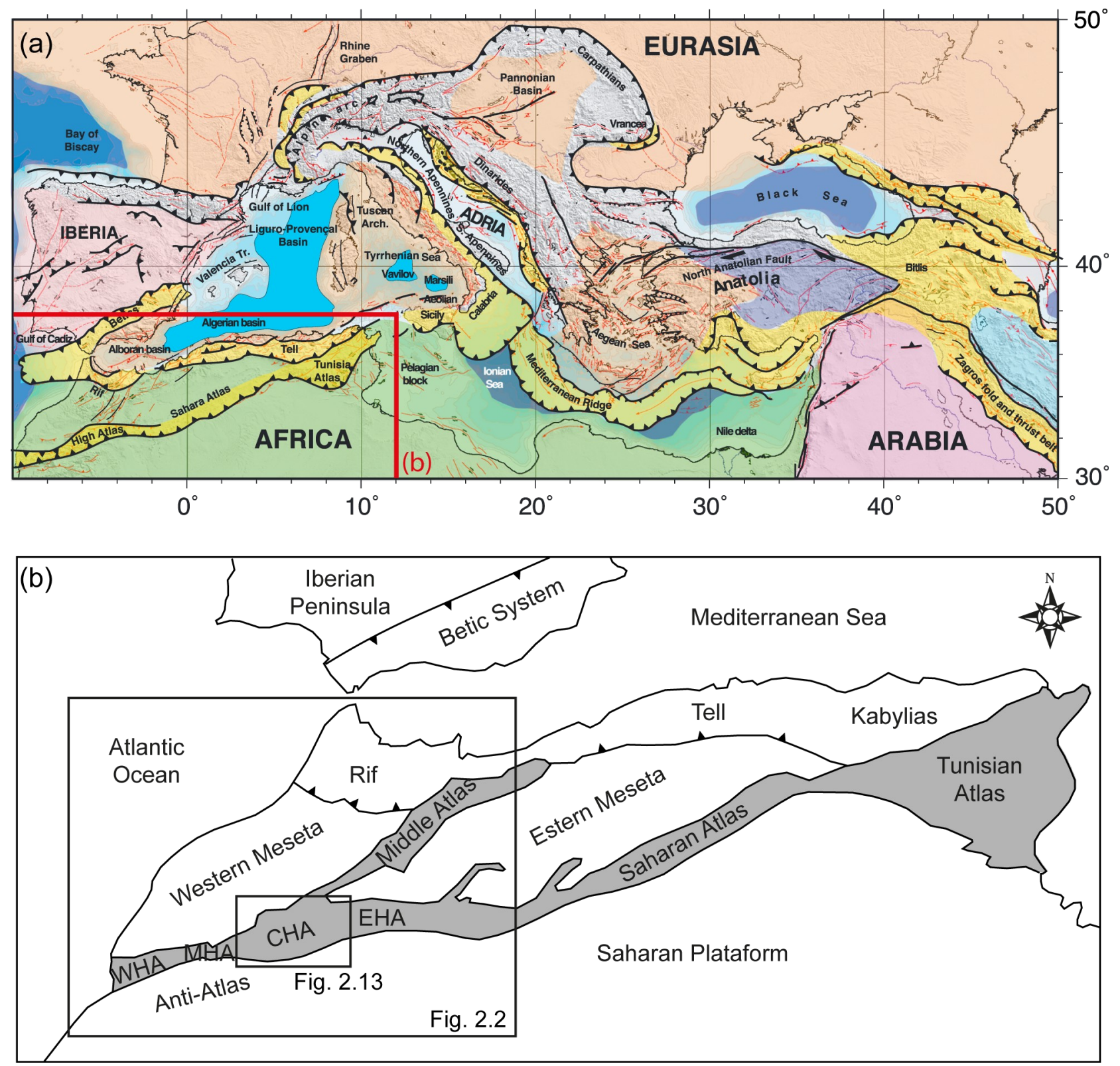

Figura 2.1. El Atlas se sitúa en el antepaís del Sistema Alpino Mediterráneo (a), formado en el Norte de África (b) por el sistema Rif-Tell-Kabilias. WHA: Alto Atlas Occidental; MHA: Alto Atlas de Marrakech; CHA: Alto Atlas Central; EHA: Alto Atlas Oriental. (a) Tomado de Faccenna et al. (2014).

Figure 2.1.The Atlas is placed in the southern foreland of the Mediterranean Alpine System (a), which is constituted in North of Africa (b) by the Rif-Tell-Kabylias system. WHA: Western High Atlas; MHA: Marrakech High Atlas; CHA: Central High Atlas; EHA: Eastern High Atlas. (a) From Faccenna et al. (2014). 
conjunto, el Atlas comprende una serie de cuencas mesozoicas asociadas a la apertura del Océano Atlántico y a la evolución del Tethys, que fueron invertidas durante el Cenozoico como consecuencia del acercamiento entre las placas de África y Eurasia y la microplaca de Iberia (Mattauer et al., 1977; Gomez et al., 2000). Las actuales directrices estructurales del Atlas son un reflejo de su estructuración extensional durante el Mesozoico, que a su vez presenta una fuerte herencia de las estructuras variscas (Charrière, 1990; Piqué y Laville, 1996). A grandes rasgos, las cuencas se formaron bajo una extensión NO-SE y fueron invertidas por una compresión NNO-SSE (Ait-Brahim et al., 2002 y referencias allí incluidas).

El Atlas ha sido subdividido en diferentes zonas (Fig. 2.1): Alto Atlas, Atlas Medio, Atlas Sahariano y Atlas Tunecino. A su vez, el Alto Atlas (Fig. 2.2) se divide en Alto Atlas Occidental, de Marrakech, Central y Oriental.

El Alto Atlas Occidental está asociado a la apertura del Atlántico y únicamente fue afectado por la etapa de rift triásica. Su evolución tectónica está controlada por estructuras NNE-SSO, paralelas a la costa atlántica marroquí. Destacan las importantes series triásicas compuestas por materiales detríticos y salinos, así como las importantes series basálticas asociadas al evento del CAMP (Central Atlantic Magmatic Province) emplazadas en el Triásico-Jurásico (ca. 200 Ma; p. ej. Knight et al., 2004; Verati et al., 2007). Las rocas jurásicas se apoyan discordantemente sobre los materiales triásicos y, a diferencia del resto de dominios, no registra la fase de rift jurásica.

El Alto Atlas de Marrakech constituye el sector más sur-occidental del Tethys. Actualmente, los afloramientos predominantes están constituidos por rocas del basamento sobre las que se apoyan de manera discordante sedimentos triásicos, describiendo geometrías tipo graben y semi-graben (p. ej., Domènech et al., 2015). Durante gran parte del Jurásico esta área estuvo emergida, formando parte del Arco Occidental Marroquí. Esta área fue definida mediante datos de huellas de fisión (Ghorbal et al., 2008; Saddiqi et al., 2009) por su escasa subsidencia en comparación con las áreas circundantes. De hecho, a partir del Jurásico dividió los dominios con influencia de los océanos Atlántico y Tethys. Durante el Cretácico se produjo nuevamente sedimentación en esta área, con el depósito de materiales carbonatados sobre los materiales subyacentes.

El Alto Atlas Central (AAC) y Oriental se caracterizan por la potente serie de sedimentos liásicos marinos (> $5 \mathrm{~km}$ de manera generalizada) que afloran extensamente a lo largo de todo el área. En el núcleo de los anticlinales afloran materiales triásicos (arcillas, basaltos y sales) junto con rocas ígneas que se emplazaron durante el Jurásico Medio-Superior; hacia el E, los materiales Paleozoicos afloran en el núcleo de los anticlinales. Durante el Jurásico, los procesos halocinéticos asociados a la extensión han condicionado tanto su evolución durante la etapa extensional, como su posterior inversión durante el Cenozoico (Michard et al., 2011; Vergés et al., 2017). 


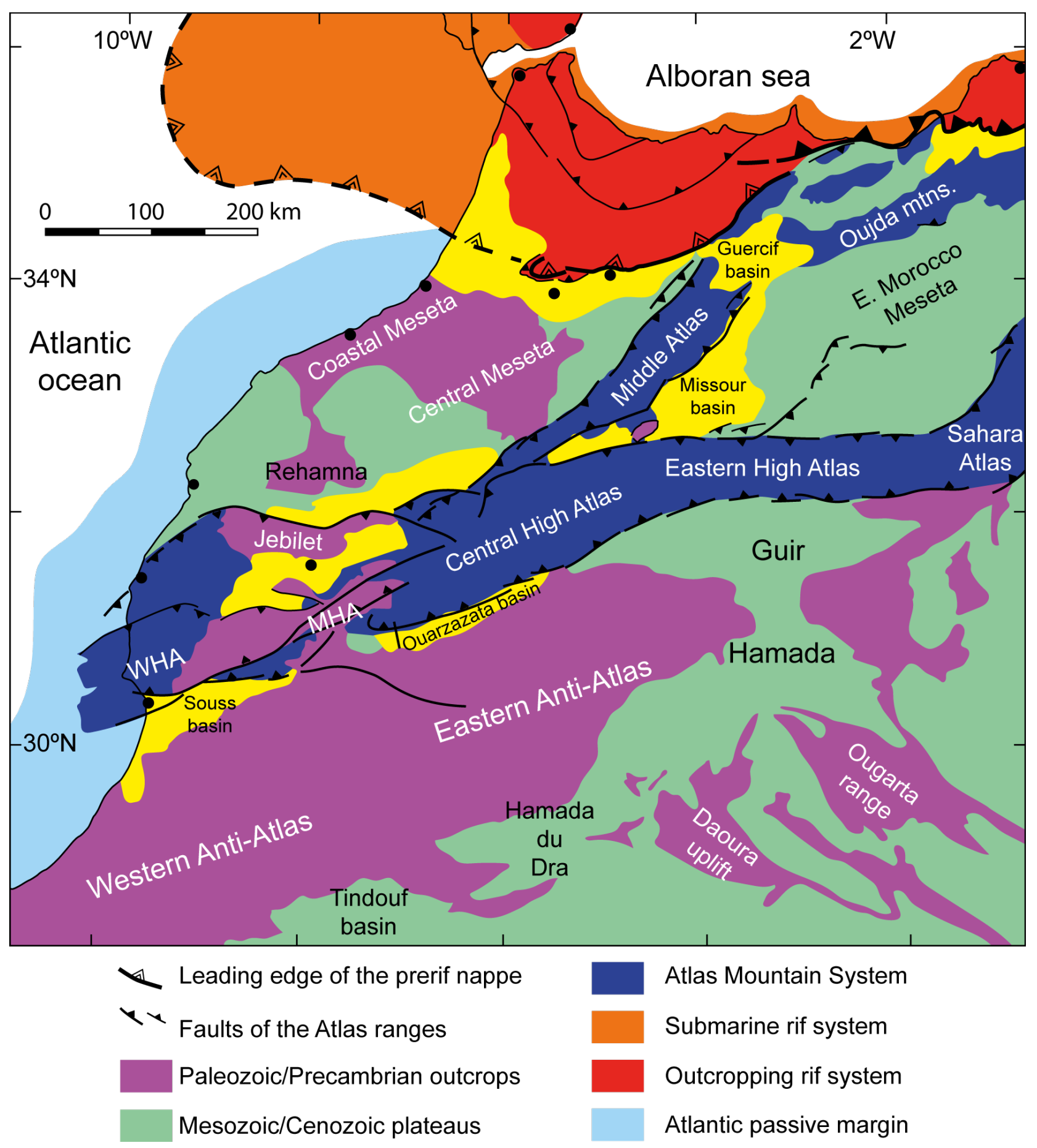

Figura 2.2. Diferentes dominios geológicos presentes en el NO de África. El Atlas está limitado al sur principalmente por las rocas pre-Mesozoicas del Anti-Atlas, mientras que al norte dominan los plateaus de rocas Mesozoicas y Cenozoicas. Las cuencas Cenozoicas asociadas a la compresión son escasas, y se limitan a los bordes de las cadenas. Tomado de de Frizon de Lamotte et al. (2008).

Figure 2.2.Different geologic domains of the NW of Africa. The Atlas is mainly limited towards the south by the pre-Mesozoic rocks of the Anti-Atlas, whereas in the north, the Mesozoic and Cenozoic plateaus are dominants. The Cenozoic basins associated to the compression are scarce and they are limited to the margins of the chains. From Frizon de Lamotte et al. (2008). 
Desde el AAC parte la rama NE-SO que constituye el Atlas Medio. Si bien la serie sedimentaria mesozoica está bien representada, los espesores son menores que en otras zonas del Atlas. El acortamiento cenozoico estimado calculado en la dirección perpendicular a la cadena está en torno al 10\% (Arboleya et al., 2004), si bien parte del acortamiento se ha podido acomodar mediante estructuras direccionales dada la oblicuidad entre el Atlas Medio y la compresión NNOSSE. Una particularidad es el importante volumen de basaltos asociados al vulcanismo cuaternario preservados en el sector.

Las tres zonas que conforman el Alto Atlas, así como el Atlas Medio, presentan una elevada topografía, con altitudes medias por encima de $2000 \mathrm{~m}$ y alturas máximas que sobrepasan los 4000 m. Como se comentará más adelante, dichas elevaciones no son coherentes con el espesor cortical de la cadena, mostrando un desequilibrio isostático relacionado con un levantamiento de origen mantélico (p. ej., Ayarza et al., 2005; Zeyen et al., 2005; Teixell et al., 2005; Missenard et al., 2006).

Finalmente, hacia el Este se extienden el Atlas Sahariano y el Atlas Tunecino, ambos con menores elevaciones que las zonas anteriores. Situadas en zonas más internas del Tethys, la sedimentación es relativamente continua a lo largo del Mesozoico, con desarrollo de importantes procesos halocinéticos (Kamoun et al., 2001, Masrouhi et al., 2013).

Los eventos más importantes en la evolución del Alto Atlas son resumidos en la figura 2.3. Se caracteriza por dos etapas de rift con las consiguientes etapas de post-rift (p. ej., Laville et al., 2004; Frizon de Lamotte et al., 2009), a las que se asocian episodios de vulcanismo básico (Knight et al., 2004). Durante el final de la primera etapa se depositan importantes volúmenes de sales que juegan un rol importante en la evolución de las cuencas durante la segunda etapa sedimentaria (Saura et al., 2014; Moragas et al., 2016). Durante el Cretácico la actividad tectónica es reducida y la sedimentación está controlada por la subsidencia térmica y los procesos eustáticos (Frizon de Lamotte et al., 2009). Durante el Albiense-Cenomaniense, las rocas mesozoicas se ven afectadas por un evento de remagnetización química de escala regional, afectando tanto a los materiales carbonatados como a las capas rojas jurásicas (Torres-López et al., 2014). Al final del Cretácico comienza la compresión asociada a la orogenia Alpina, si bien la edad de las etapas de deformación principales son discutidas por los diferentes autores; parece que se darían desde el Oligoceno hasta la actualidad (p. ej., Tesón y Teixell, 2006; Frizon de Lamotte et al., 2009). También durante el Cenozoico tiene lugar un adelgazamiento litosférico con vulcanismo asociado, que genera una elevación topográfica del Alto Atlas (Zeyen et al., 2005; Babault et al., 2008). 

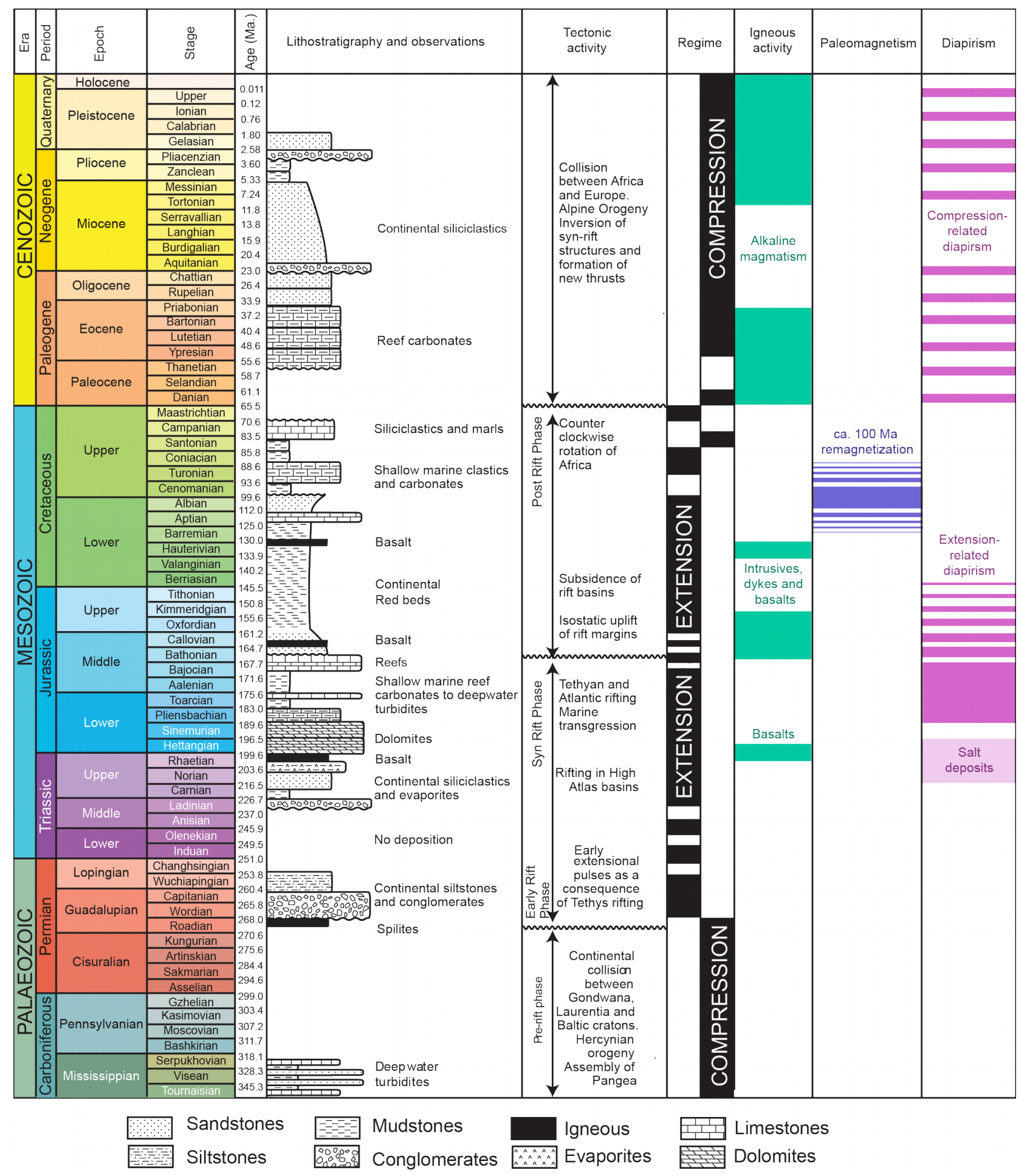

Figura 2.3. Marco cronoestratigráfico mostrando los principales eventos que han marcado la evolución del Alto Atlas Central. Modificado de Baudon et al. (2009); recopilación de datos de Hailwood y Mitchell (1971), Armando (1999), Beauchamp et al. (1996, 1999), Le Roy et al. (1998), Haddoumi et al. (2002), Gradstein et al. (2012), Teixell et al. (2007), Verati et al. (2007), Tesón y Teixell (2008), Michard et al. (2011), Torres-López et al. (2014), Moragas et al. (2016).

Figure 2.3. Chronostratigraphic frame with the main geological events that characterize the evolution of the Central High Atlas. Modified from Baudon et al. (2009); data compiled from Hailwood and Mitchell (1971), Armando (1999), Beauchamp et al. (1996, 1999), Le Roy et al. (1998), Haddoumi et al. (2003), Gradstein et al. (2003), Teixell et al. (2007), Verati et al. (2007), Tesón and Teixell (2008), Michard et al. (2011), Torres-López et al. (2014), Moragas et al. (2016). 


\subsection{La evolución Mesozoica}

\subsubsection{El rift permo-triásico}

Durante las últimas etapas de la formación del orógeno Varisco-Allengiense se generó un sistema de cizalla dextro como consecuencia del movimiento relativo entre África y Europa. Esto condujo a un colapso del orógeno Varisco, la formación de un sistema de cuencas de pull-apart y un intenso magmatismo (Ziegler y Stampfli, 2001; Stampfli et al., 2013). El final del Pérmico y el Triásico está

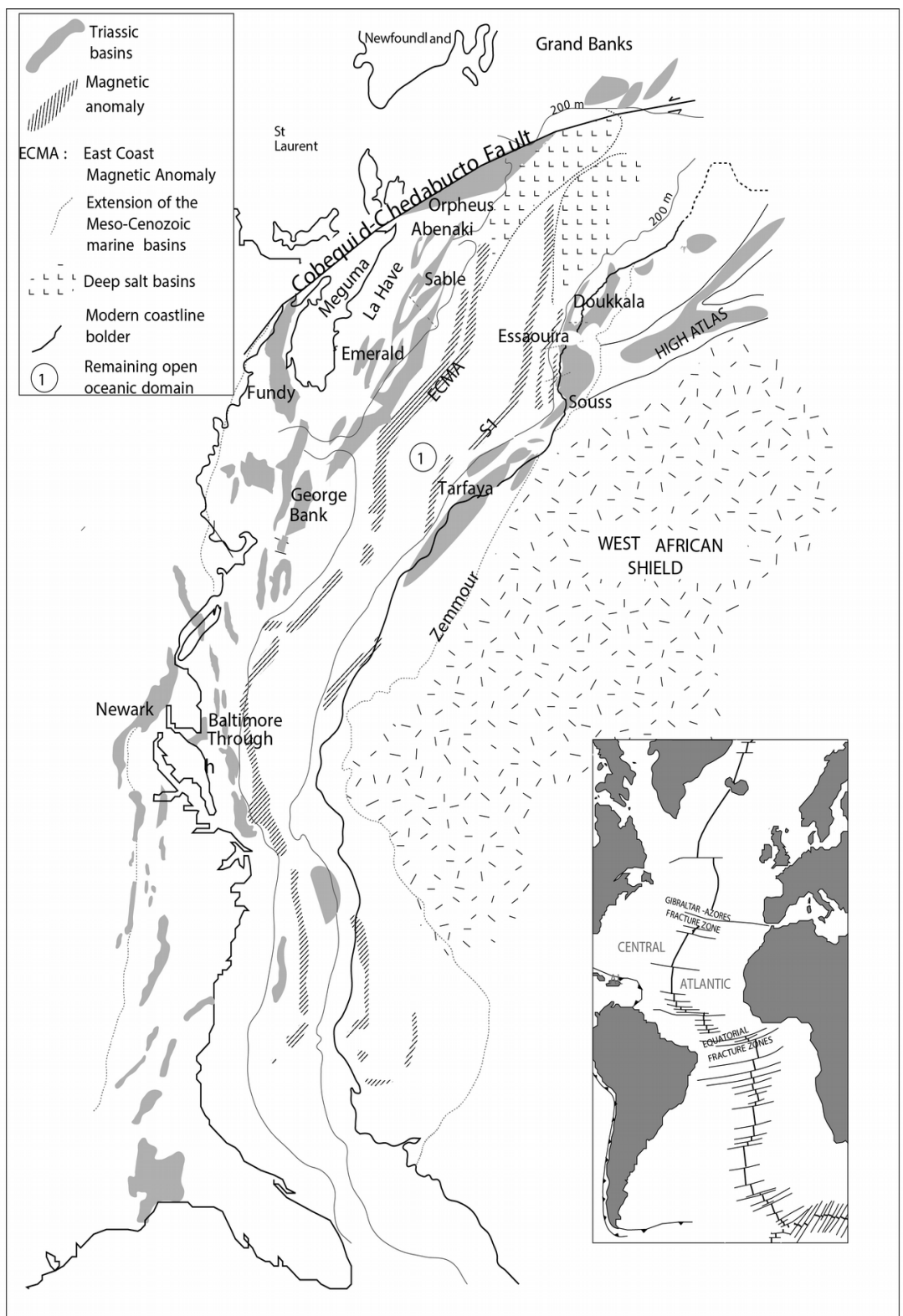

Figura 2.4. Contexto del dominio Atlántico Central y correlación entre las cuencas triásicas antes de la apertura del mismo. Tomado de Le Roy y Piqué (2001).

Figure 2.4.Setting of the Central Atlantic domain and correlation between the Triassic basins before the opening of the ocean. From Le Roy and Piqué (2001). caracterizado por subsidencia térmica y extensión del Atlántico Central y del Tethys, con la consiguiente generación de cuencas sedimentarias (Fig. 2.4).

La separación del Alto Atlas Occidental del resto del Atlas ya es patente durante el Triásico (Fig. 2.5). Ésta se da por la presencia del Arco Occidental Marroquí que limita ambos dominios. De hecho, puede observase una diferenciación entre las fallas que controlaban las cuencas triásicas, NNE-SSO en el Atlas Occidental y ENE-OSO a NESO hacia el E.

Las cuencas generadas presentaban un fuerte control tectónico, formando grabens y semi-grabens en un contexto extensional, sin que sean apreciables movimientos direccionales en las mismas (Domènech et al., 2015). Por otro lado, la posición y geometría de las cuencas presentan un fuerte control por las estructuras variscas y tardi- 
variscas (p. ej. Domènech et al., 2015). En la zona oriental, las estructuras dominantes son perpendiculares a la extensión NO-SE.

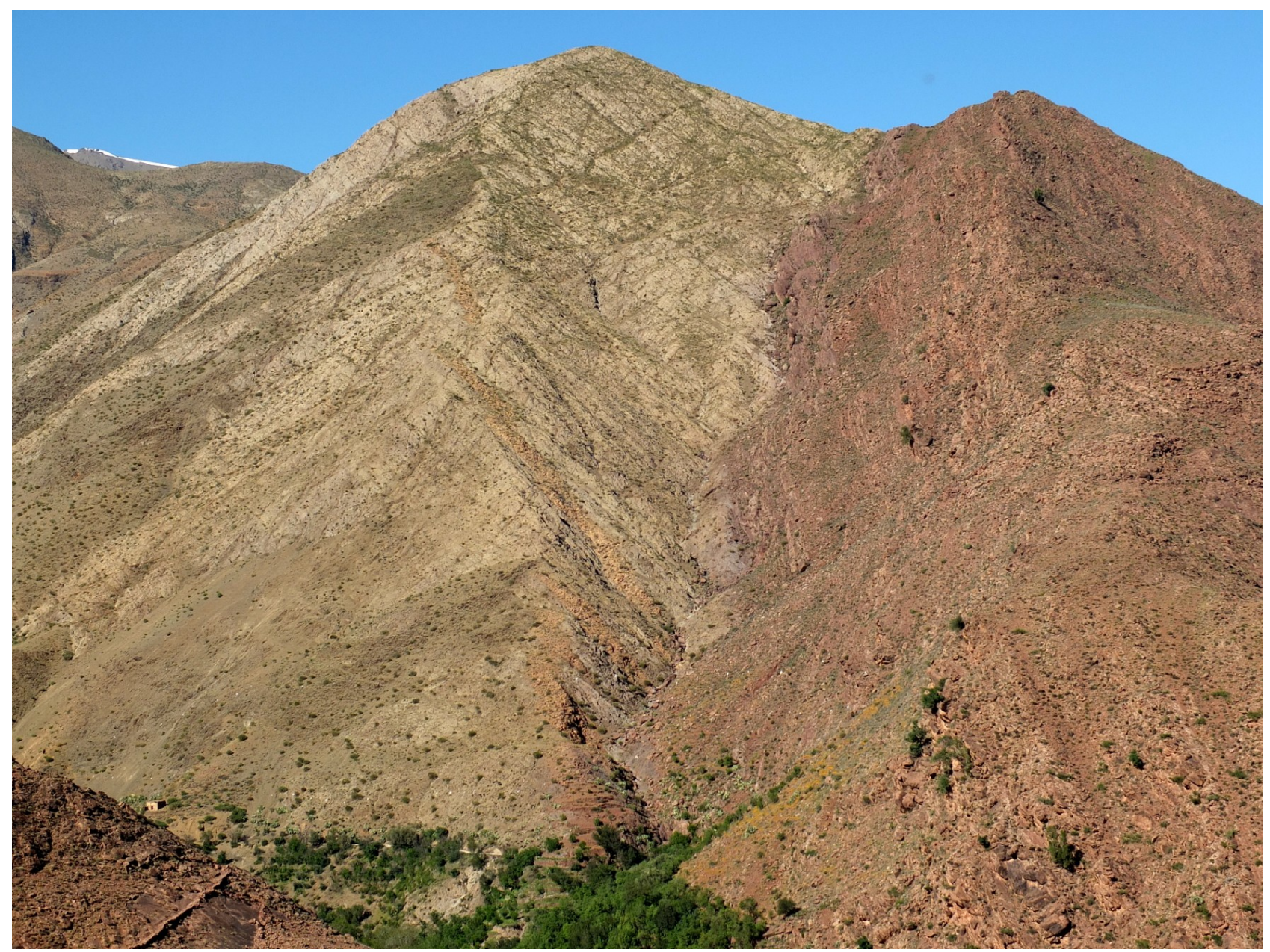

Figura 2.5. Contacto discordante entre los materiales paleozoicos (a la izquierda) y triásicos (derecha) en el Alto Atlas de Marrakech. Sur a la izquierda de la fotografía.

Figure 2.5. Paleozoic (left) - Triassic (right) unconformity in the Marrakech High Atlas. South towards the left of the picture.

La sedimentación se inicia con el depósito de conglomerados y areniscas discordantes sobre el basamento (Fig. 2.5), y hacia zonas más internas de las cuencas dominan los materiales detríticos finos y las sales (Fig. 2.6a). En un perfil realizado a lo largo del Alto Atlas de Marrakech (El Arabi, 2007) (Fig. 2.6b) se observa una migración de los depocentros hacia el SE. A partir del Noriense las series son totalmente expansivas a lo largo de la cuenca (Fig. 2.6b), y durante el NorienseHettangiense se depositan importantes volúmenes de arcillas y sales entre las que se intercalan potentes coladas basálticas pertenecientes al CAMP, datadas en 195-200 Ma (Knight et al., 2004, Nomade et al., 2007; Verati et al., 2007). Estos basaltos se observan en el núcleo de las estructuras a lo largo de todo el Alto Atlas, siendo los materiales dominantes de manera generalizada. Por el contrario, las sales están prácticamente ausentes, aflorando en algunas estructuras discretas como Toumliline. 

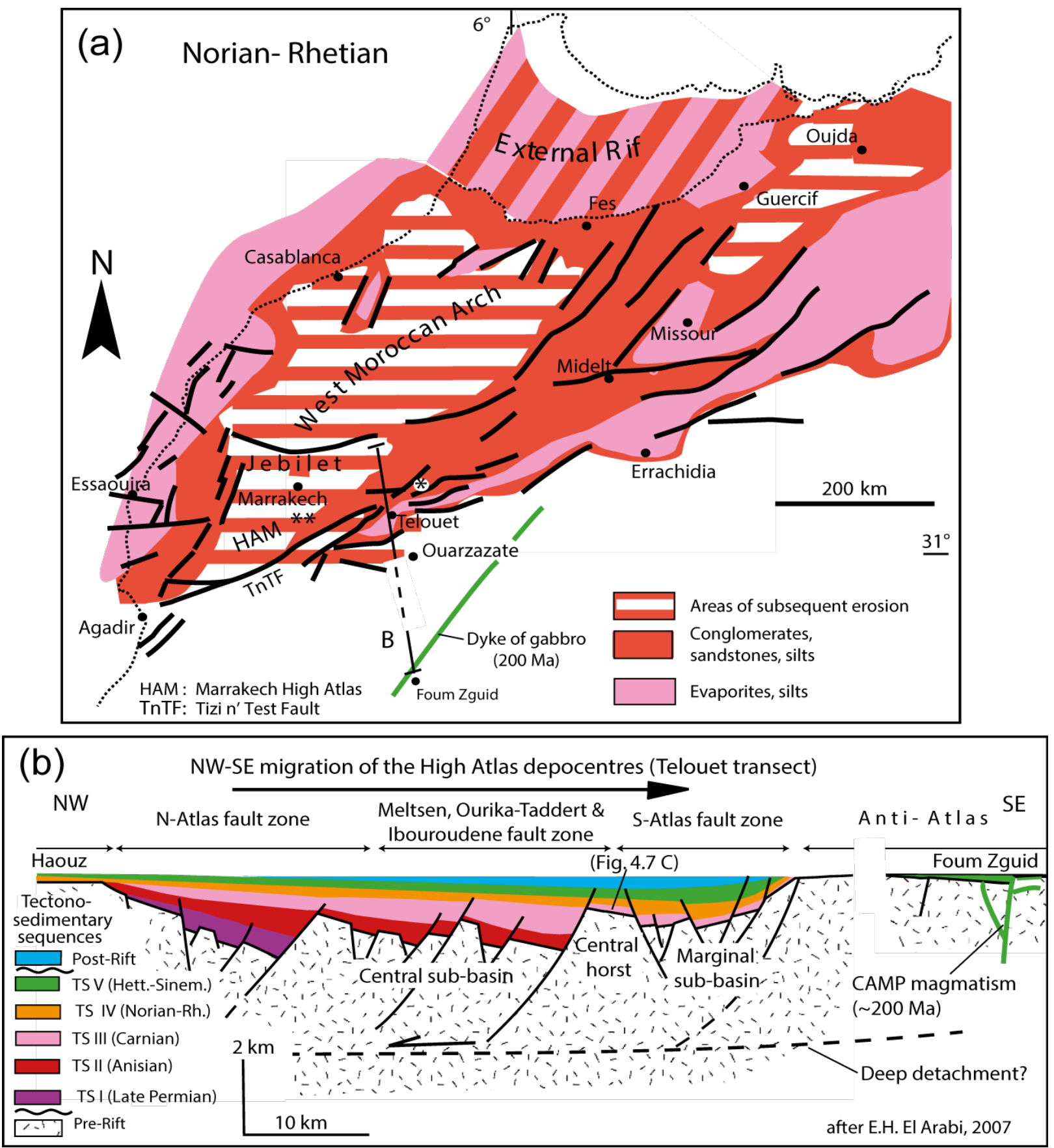

Figura 2.6. (a) Mapa paleogeográfico mostrando la distribución de facies depositadas durante el Triásico Superior, así como la posición del Arco Marroquí Occidental (West Moroccan Arch). (b) Restitución de los depocentros triásico a lo largo del perfil de Telouet (mostrado en a), en el que se observa una migración de los mismos hacia el SE. Modificado de Frizon de Lamotte (2008), quienes lo modifican a su vez de El Arabi (2007).

Figure 2.6. Paleogeographic map at Late Triassic times showing the facies distribution as well as the position of the West Moroccan Arch. (b) Restoration of the Triassic depocenters along the Telouet profile (this is located in a) showing a migration of the depocenters towards the SE. Modified from Frizon de Lamotte et al. (2008) after El Arabi (2007). 


\subsubsection{El rift jurásico}

A mediados del Jurásico Inferior aumenta la actividad tectónica extensional, fragmentando la plataforma carbonatada y generando una profundización de la cuenca (p. ej., Ait Addi y Chafiki, 2013; y referencias allí incluidas) (Fig. 2.7). Durante este momento las dos ramas del Atlas con influencia del Tethys estuvieron claramente individualizadas y controladas por estructuras tectónicas de distinta orientación, predominando las estructuras ENE-OSO en el Alto Atlas y NESO en el Atlas Medio; las respectivas directrices estructurales serán heredadas en las siguientes etapas evolutivas. Por otro lado el Arco Occidental Marroquí se encontraba emergido, y el Alto Atlas en conjunto constituyó un golfo del Tethys, siendo el Alto Atlas de Marrakech la zona costera (Fig. 2.7).

Durante este periodo de rift y el subsiguiente periodo de post-rift se sedimentaron potentes series de calizas y margas (Fig. 2.8), alcanzando varios kilómetros de potencia (> $5 \mathrm{~km}$ ) en los depocentros. Las sales triásicas suprayacentes jugaron un importante papel en la configuración de las cuencas jurásicas. Por un lado, generaron altos diapíricos que condicionaron la distribución de facies dentro de la plataforma carbonatada (p. ej., Teixell et al., 2017), pero además condicionaron la subsidencia registrada por las cuencas, generando espacio de acomodación por migración de sales (Moragas et al., 2016).

En el Jurásico Medio (Bathoniense) se produce una continentalización en la sedimentación debido principalmente a la elevación del Arco Occidental Marroquí (Ghorbal et al., 2008; Saddiqi et
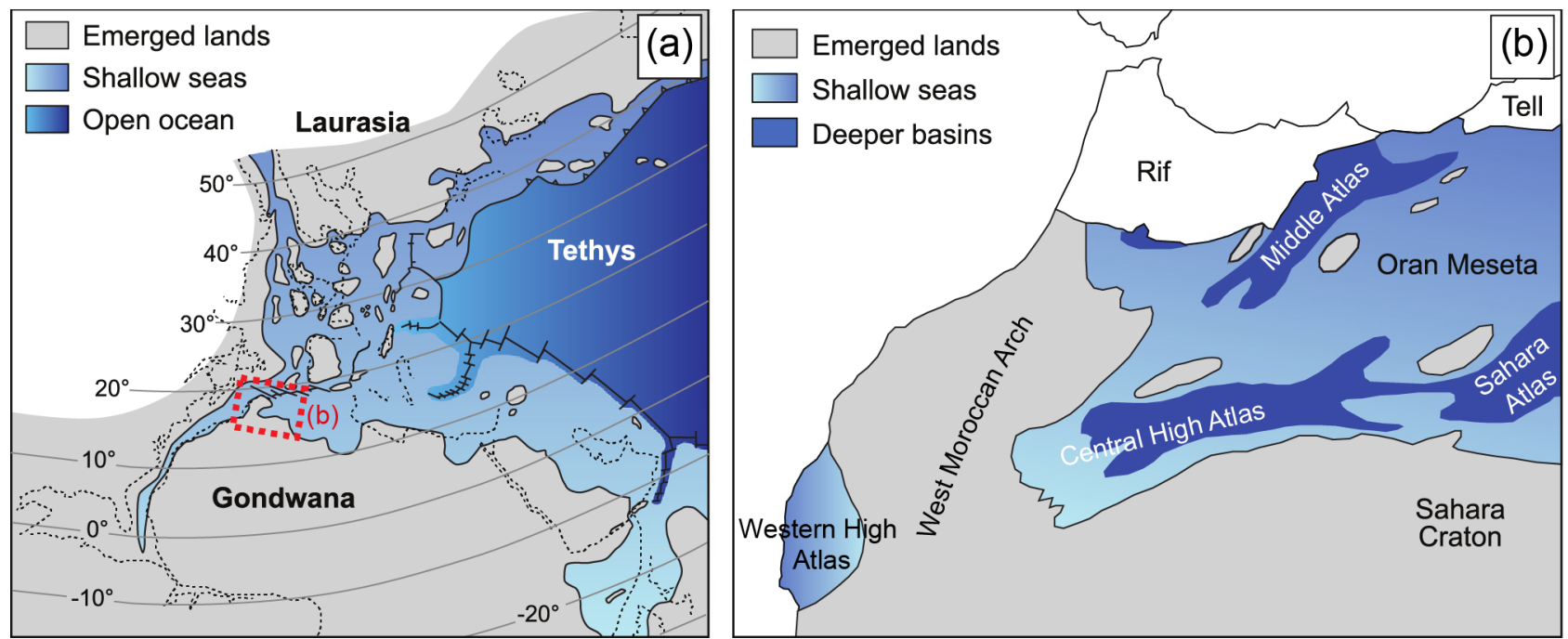

Figura 2.7. (a) Mapa paleogeográfico mostrando el Tethys occidental durante el Jurásico Inferior. En rojo se muestra la posición de la figura de la derecha. (b) Distribución de dominios sedimentarios en el área de Marruecos y oeste de Argelia, mostrando los principales dominios del Atlas, así como la posición del Arco Marroquí Occidental (West Moroccan Arch). Modificado de Ait-Itto et al. (2018).

Figure 2.7. (a) Paleogeographic map at Early Jurassic times for the Western Tethys. The red square show the location of the figure $b$. (b) Sedimentary domain distribution showing the main Atlasic domains in Morocco and western Argelia as well as the position of the West Moroccan Arch. Modified from Ait-Itto et al. (2018). 


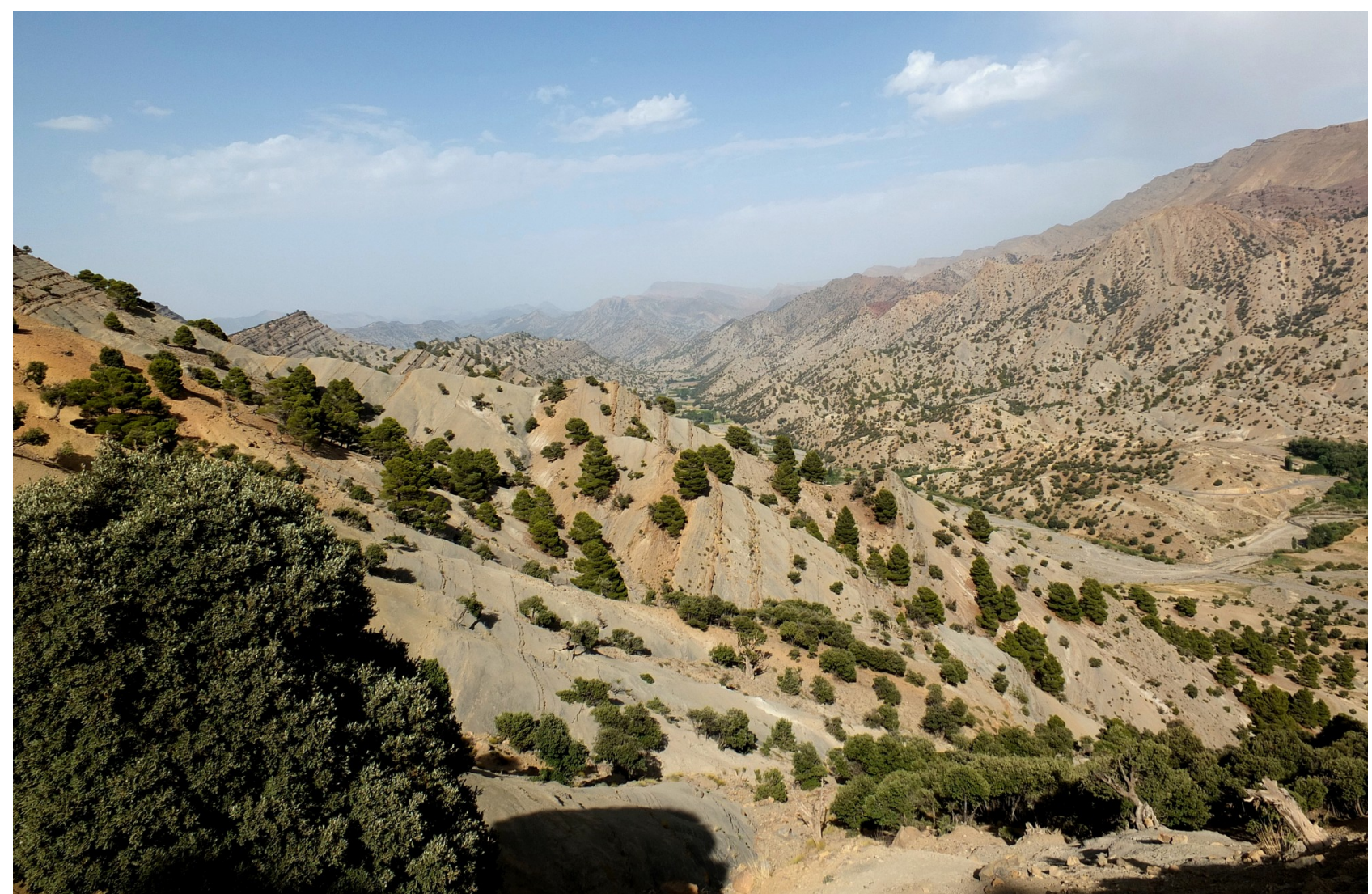

Figura 2.8. Serie aaleniense en el flanco norte del del anticlinal de Tassent, mostrando un predominio de facies margosas con intercalaciones da calizas. El Norte a la izquierda de la fotografía.

Figure 2.8. Aalenian marls at the northern limb of the Tassent anticline. North towards the left of the picture.

al., 2009) que, junto con el Dominio del Sáhara, actuarían como área fuente de los sedimentos detríticos depositados durante el Jurásico Medio y el Cretácico inferior en el Alto Atlas. Esto da lugar a la transición de una sedimentación marina a continental, caracterizada por sedimentos fluviales (Fig. 2.9). El contacto entre las unidades marinas y fluviales está caracterizado de manera generalizada por discordancias cartográficas, si bien a la escala del afloramiento existen notables diferencias en la relación estratigráfica entre distintas áreas (p. ej., Joussiane, 2016), observándose una continuidad estratigráfica en unos casos, o discordancias angulares en otros.

En la figura 2.10 puede observarse la migración de la linea de costa entre el Toarciense y el Calloviense, así como su relación con el área donde se observa actividad ígnea jurásica. Esta coincidencia parece indicar que la emersión de dicha área pudiera estar relacionada con procesos mantélicos (Bensalah et al., 2013). La actividad ígnea jurásica del Alto Atlas se evidencia tanto por la presencia de rocas intrusivas como por coladas basálticas intercaladas entre las capas rojas del Jurásico y el Cretácico Inferior. Atendiendo a sus características geoquímicas, ambos tipos de productos ígneos están relacionados y pertenecen al mismo evento magmático (Bensalah et al., 2013; Essaifi y Zayane, 2018), que se corresponden con un magmatismo anorogénico relacionado con la extensión jurásica y fruto del adelgazamiento litosférico. 


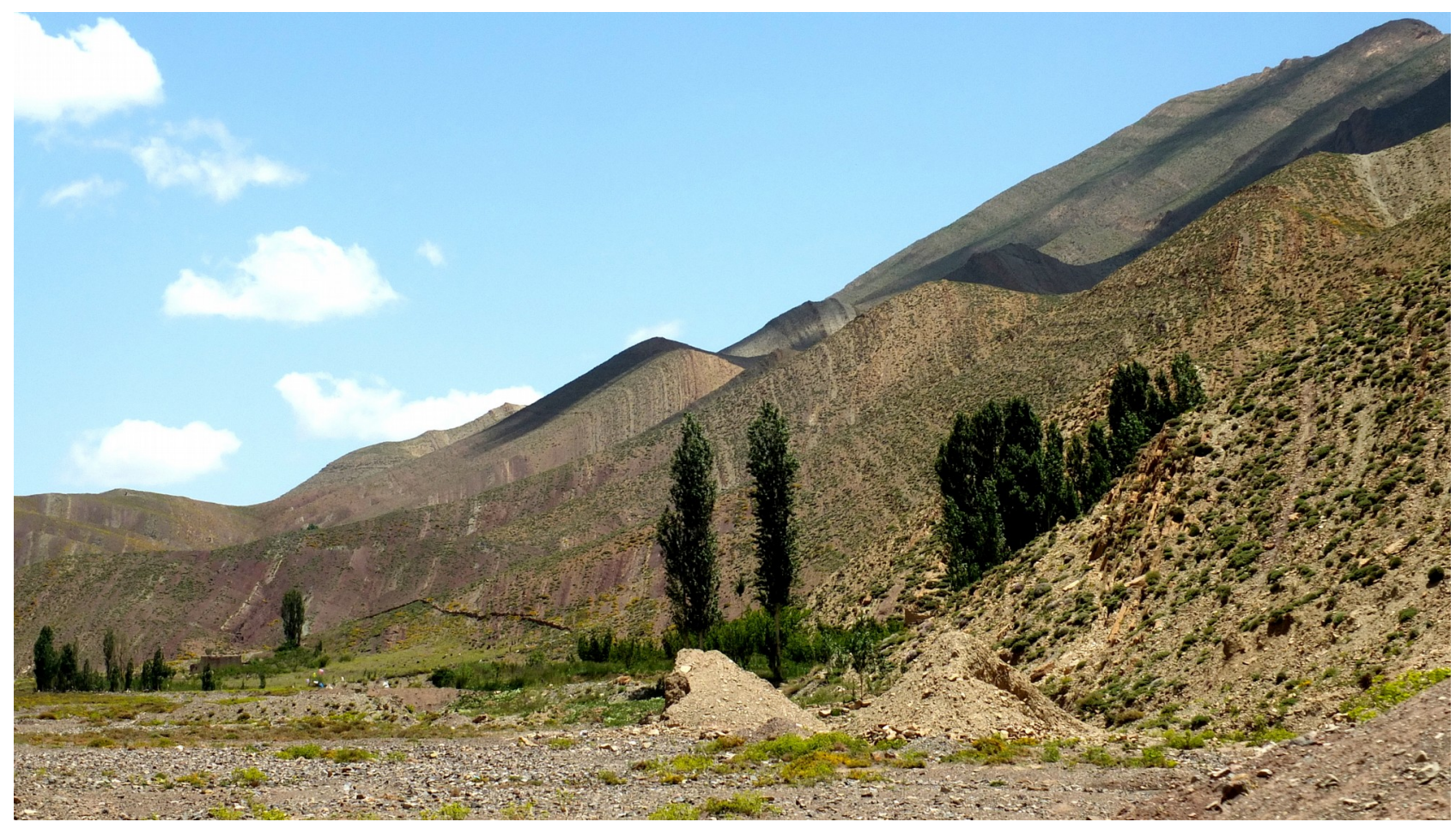

Figura 2.9. Tránsito marino - continental en las capas Bajocienses-Bathonienses en el flanco S del sinclinal de Ikkou. El Norte a la izquierda de la fotografía.

Figure 2.9. Marine - continental transition in the Bajocian-Bathonian series in the S limb of the Ikkou syncline. North towards the left of the picture.

Los materiales plutónicos afloran extensamente en el núcleo de los anticlinales (Fig. 2.10) mostrando una suite magmática compuesta por troctolitas, gabros y sienitas, consecuencia de un

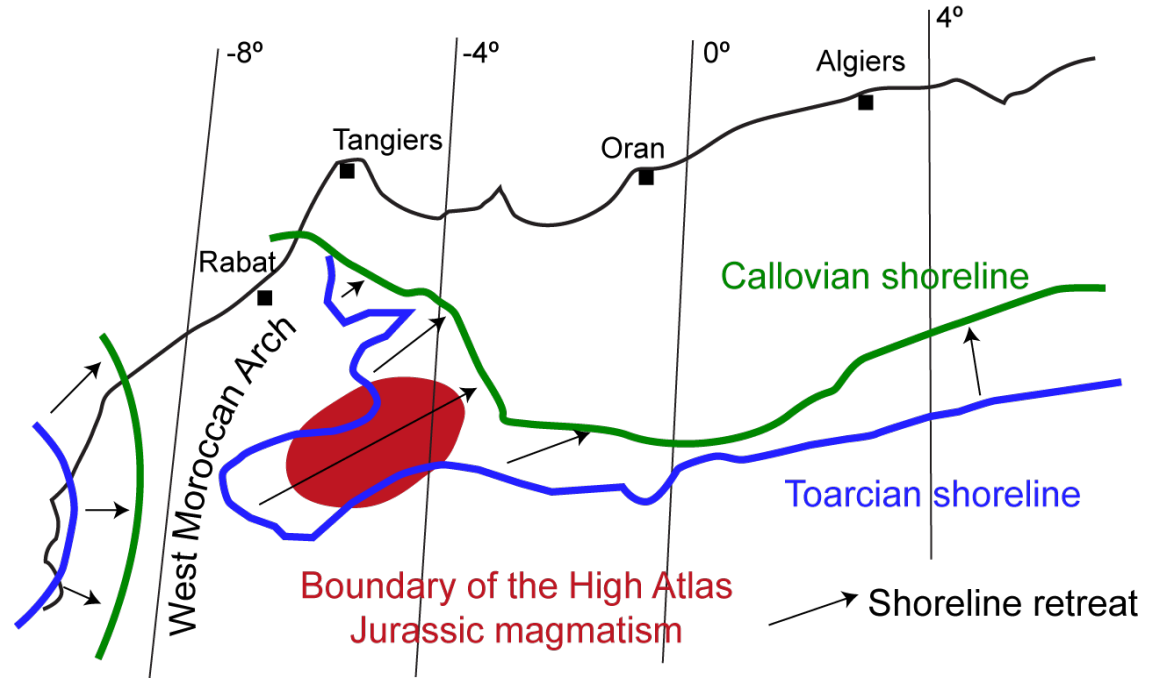

Figura 2.10. Movimiento de la linea de costa entre el Toarciense y el Calloviense y su relación con el área del Alto Atlas con magmatismo jurásico. Re-dibujado de Lamotte et al. (2008).

Figure 2.10. Shoreline migration between Toarcian and Callovian times and its relation with the High Atlas Jurassic magmatism. Redraw from Frizon de Lamotte et al. (2008). proceso de cristalización fraccionada (Zayane et al., 2002). La cristalización y solidificación de los materiales se debió producir a baja presión, a profundidades en torno a $10 \mathrm{~km}$ (posiblemente reemplazando los materiales dúctiles triásicos), y el ascenso a posiciones más superficiales se produjo durante el enfriamiento (Essaifi y Zayane et al., 2018). Una de las características comunes a todos los afloramientos de 


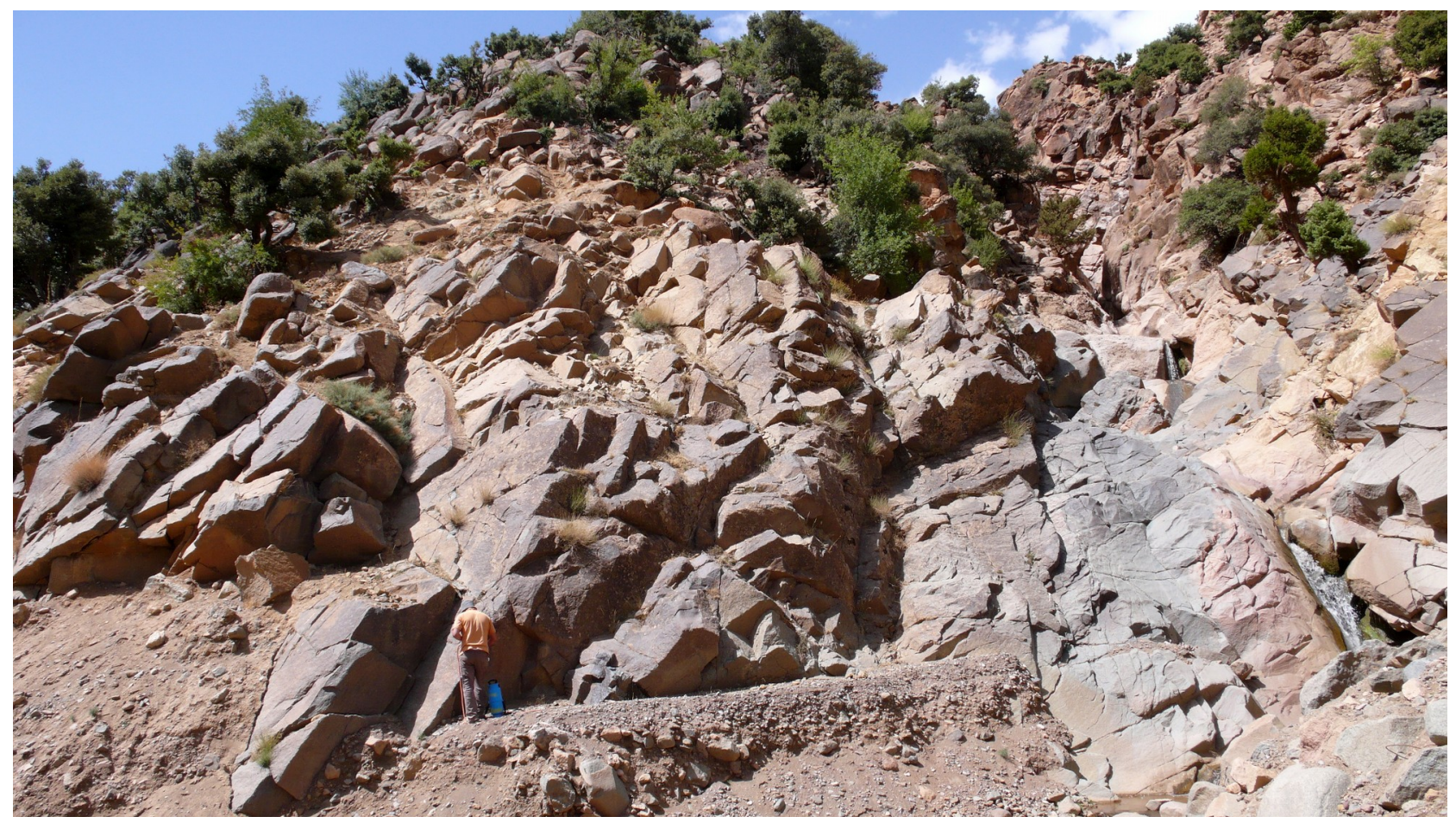

Figura 2.11. Afloramiento de gabros jurásicos en la ridge de Anefgou.

Figure 2.11. Jurassic gabbro outcrop in the Anefgou ridge.

gabros es la ausencia casi total de aureolas de metamorfismo en los materiales carbonatados encajantes. La edad de enfriamiento de estas rocas fue datada en el anticlinal de Tassent mediante K-Ar en biotita en $160 \pm 3$ Ma y $152 \pm 3$ Ma (Hailwood y Mitchell, 1971), y en el anticlinal de Anefgou mediante Ar-Ar en biotita en $151 \pm 0.5$ Ma y $146 \pm 0.5$ Ma (Armando, 1999); los diques asociados a dicho evento magmático fueron datados en el área de Tassent entre $119 \pm 3$ Ma y $134 \pm$ 3 Ma mediante K-Ar en biotita (Hailwood y Mitchell, 1971). Por otro lado, la edad de las coladas basálticas está bien constreñida por la serie sedimentaria entre la que se intercalan, observándose dos eventos distintos: uno de edad Bathoniense-Calloviense, sincrónico a la continentalización de las cuencas y la intrusión de la suite plutónica, y el segundo de edad Barremiense.

Por otro lado, durante el Cretácico se produce un cambio drástico en los movimientos relativos entre África y Eurasia consecuencia de la apertura del Atlántico Sur, dando paso de un movimiento sinistro de África con respecto a Eurasia desde ca. $175 \mathrm{Ma}$, a una convergencia N-S entre ca. 90 y 45 Ma (ver revisión en Rosenbaum et al., 2002). A lo anterior se superpone la subida generalizada del nivel del mar durante el Cenomaniense-Turoniense, favoreciendo una transgresión generalizada. A pesar de que se ha considerado la presencia de dos zonas emergidas debido a la falta de afloramientos, las facies de la plataforma marina son homogéneas allí donde están presentes, sin presencia de materiales costeros que podrían evidenciar dichas zonas emergidas (ver Frizón de Lamotte et al., 2009 y referencias allí incluidas). La ausencia de afloramientos de materiales a partir del Senoniense ha sido atribuida a la respuesta inicial a la compresión N-S (Cloetingh et al., 1999) que generaría pliegues litosféricos de gran longitud de onda $(\sim 500 \mathrm{~km})$, coincidiendo la zona del Atlas con un sinclinal y el Anti-Atlas con un anticlinal (Frizon de Lamotte et al., 2009). 


\subsection{La inversión cenozoica}

A final del Mesozoico se produce el proceso de inversión tectónica de las cuencas mesozoicas (p. ej., Beauchamp et al., 1996; Arboleya et al., 2004), consecuencia de la convergencia entre África e Iberia y Eurasia (Mattauer et al., 1977; Gomez et al., 2000). Tras la etapa de plegamiento litosférico que afecta al N de África (Fig. 2.12a) se produce la compresión principal y la consecuente inversión de la cuenca. Según Tesón y Teixell (2008) la compresión fue más o menos contante y homogénea desde el Oligoceno hasta la actualidad, mientras que otros autores (p. ej., Frizón de Lamotte et al., 2009; Ellero et al., 2012, y referencias allí incluidas) indican la presencia de dos etapas principales de compresión (Fig. 2.12), durante el Eoceno-Oligoceno y el Plio-Pleistoceno, separadas por una etapa con menos actividad compresiva.

La inversión de las cuencas tiene lugar bajo una compresión NNE-SSO (Fig. 2.12), lo que favorece un contexto transpresivo en el Atlas Medio y compresivo en el Alto Atlas (Arboleya et al., 2004), si bien algunos autores han observado evidencias de transpresión en el Alto Atlas (Ellero et al., 2012) con partición de la deformación a lo largo de las estructuras ENE-OSO. A partir de diferentes cortes geológicos se han estimado valores de acortamiento entre el 15\% y el 24\% para el Alto Atlas Central, siendo progresivamente mayores de E a O, y del 10\% (sin considerar posibles movimientos direccionales) en el Atlas Medio (Teixell et al., 2003; Arboleya et al., 2004; Gomez et al., 2004).

En general, y tanto en el Alto Atlas de Marrakech como en el Alto Atlas Central, el tipo de deformación es de piel gruesa, estando el basamento involucrado en la deformación alpina (p. ej., Beauchamp et al., 1999; Teixell et al., 2003; Arboleya et al., 2004; Ellero et al., 2012), si bien la presencia de diferentes niveles de despegue (Silúrico, Triásico y Cretácico Superior) favorecen un desacople entre las diferentes unidades (Beauchamp et al., 1999). En la figura 2.13 se muestran tres cortes geológicos realizados por diferentes autores a lo largo de secciones análogas, ilustrando la estructura del área de estudio. En todos ellos se muestra la cadena intraplaca invertida de doble vergencia; en las áreas más externas la vergencia hacia sendos antepaíses está bien definida, mientras que en área central es menos evidente. El grado de implicación del basamento en la estructura principal se interpreta de formas diferentes. Poisson et al. (1998) y Teixell et al. (2003) consideran que éste está involucrado en todas las estructuras, y el despegue de la cobertera jurásica a favor de los niveles dúctiles triásicos únicamente se produce en los bordes de la cadena, donde la potencia de sedimentos mesozoicos es menor. Sin embargo, el basamento presenta una menor importancia en la definición de la estructura de la cobertera según Michard et al. (2011), y se puede observar que todas las estructuras que afectan a la cobertera jurásica están relacionadas con los materiales triásicos, bien porque despeguen de éste último (en los bordes de la cadena) o porque sean cortados por ellos generando diapiros (zona central). Así mismo, también varía el volumen de rocas ígneas jurásicas representados por los diferentes autores. El área de estudio se encuentra en dicha zona central, donde la vergencia está menos definida y las estructuras han sido interpretadas tanto como compresivas o diapíricas. 

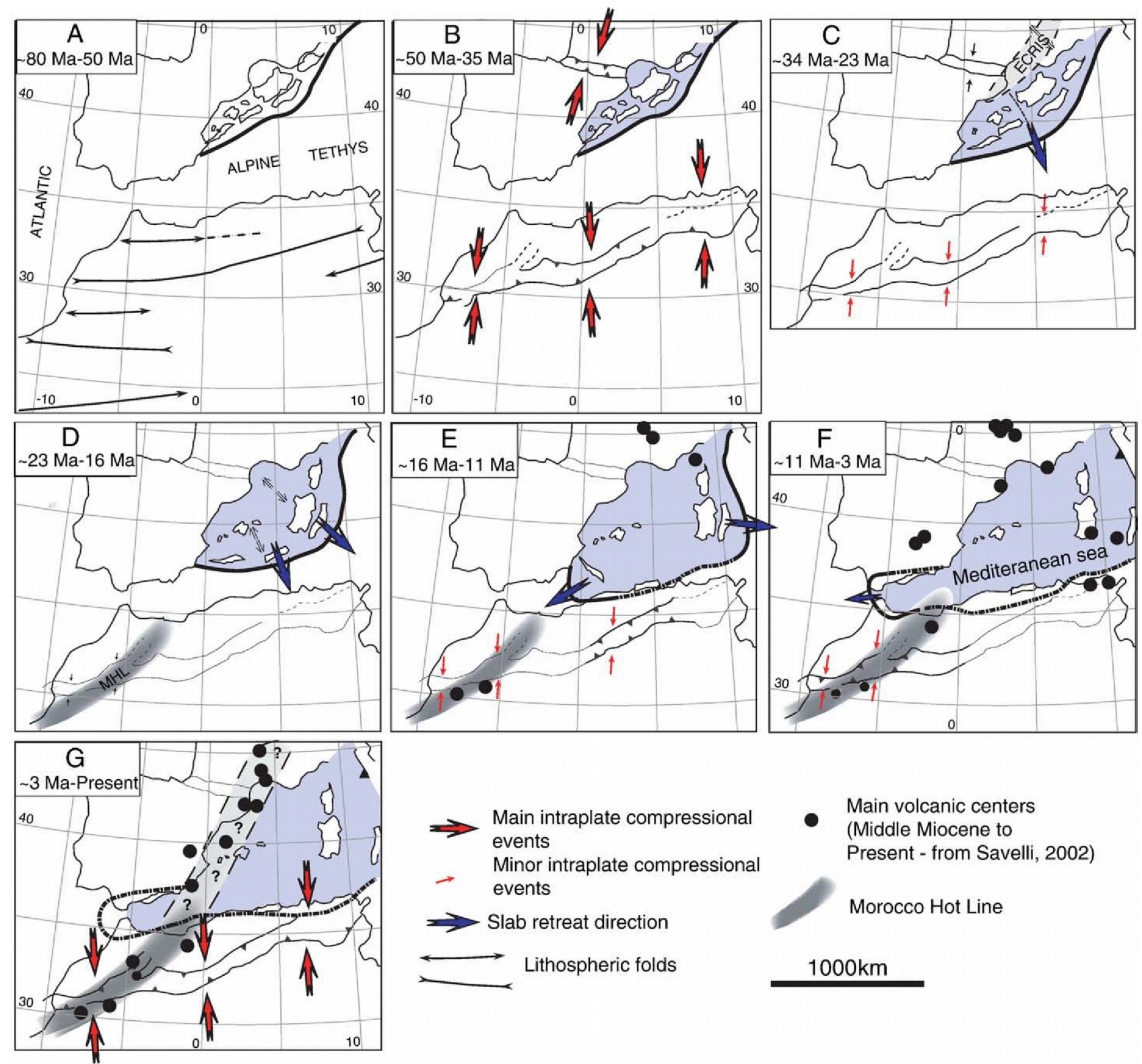

Main volcanic centers (Middle Miocene to Present - from Savelli, 2002)

Morocco Hot Line

$1000 \mathrm{~km}$

Figura 2.12. Contexto geodinámico del Mediterráneo occidental desde el Cretácico Superior hasta la actualidad, mostrando la evolución de la compresión alpina desde el inicio de la subducción del Tethys y la formación de pliegues litosféricos en el Norte de África (a) hasta la compresión y el vulcanismo reciente en la zona del Atlas (g). Modificado de Missenard (2006)

Figure 2.12. The shown is the geodynamic evolution of the Western Mediterranean since the Upper Cretaceous to the present day, showing the evolution of the Alpine compression from the initiation of the subduction of the Tethys and the development of lithospheric folds in the North Africa (a) to the present day compression and volcanism. Modified from Missenard (2006). 

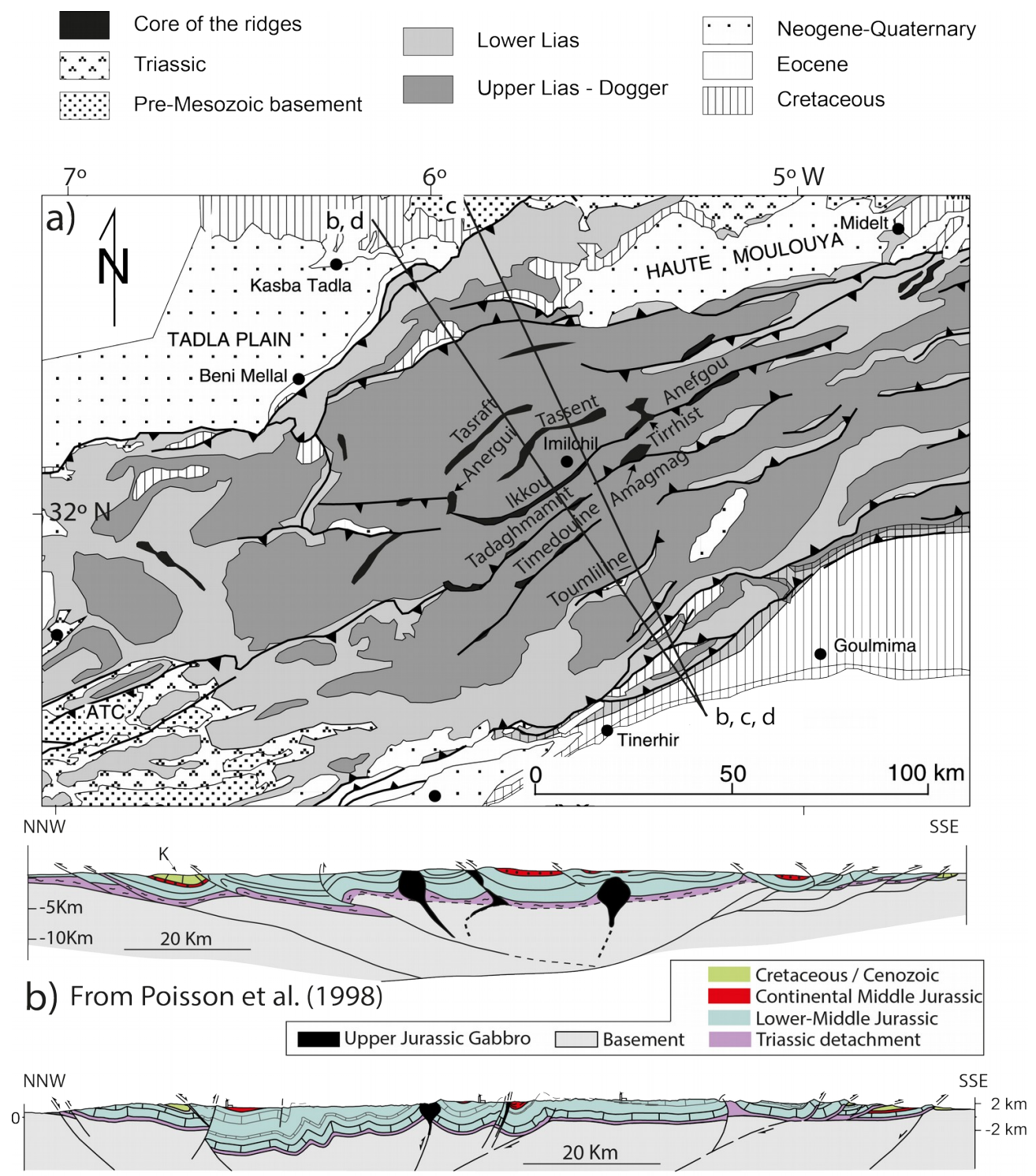

c) From Teixell et al. (2003)

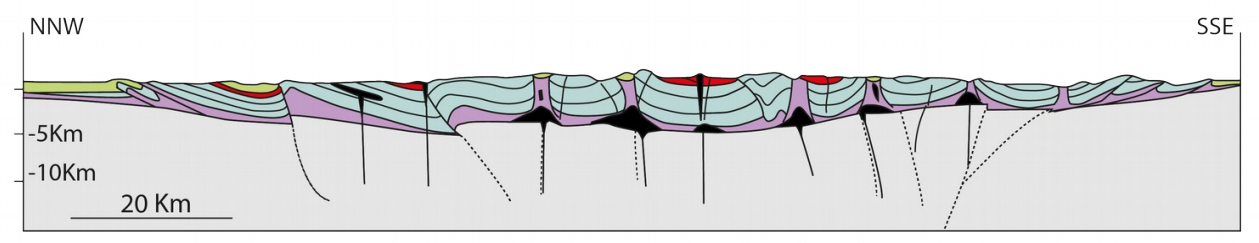

d) From Michard et al. (2011)

Figura 2.13. (a) Mapa geológico del Alto Atlas Central, caracterizado por afloramientos de rocas jurásicas. La posición de los cortes geológicos NNO-SSE está indicada. Modificado de Teixell et al. (2003). (a, b, c) Cortes geológicos a lo largo de la misma transversal según Poisson et al. (1998), Teixell et al. (2003) y Michard et al. (2011). La linea discontinua roja define el área de estudio de esta tesis doctoral (Fig. 2.15).

Figure 2.13.(a) Geologic map of the Central High Atlas, which is characterized by Jurassic outcrops. The location of the NNW-SSE cross-sections is also indicated. Modified from Teixell et al. (2003). ( $a, b, c)$ Cross-sections along the same profile according to Poisson et al. (1998), Teixell et al. (2003) and Michard et al. (2011). The study area addressed in this thesis is delimited by red-dashed lines (Fig. 2.15). 


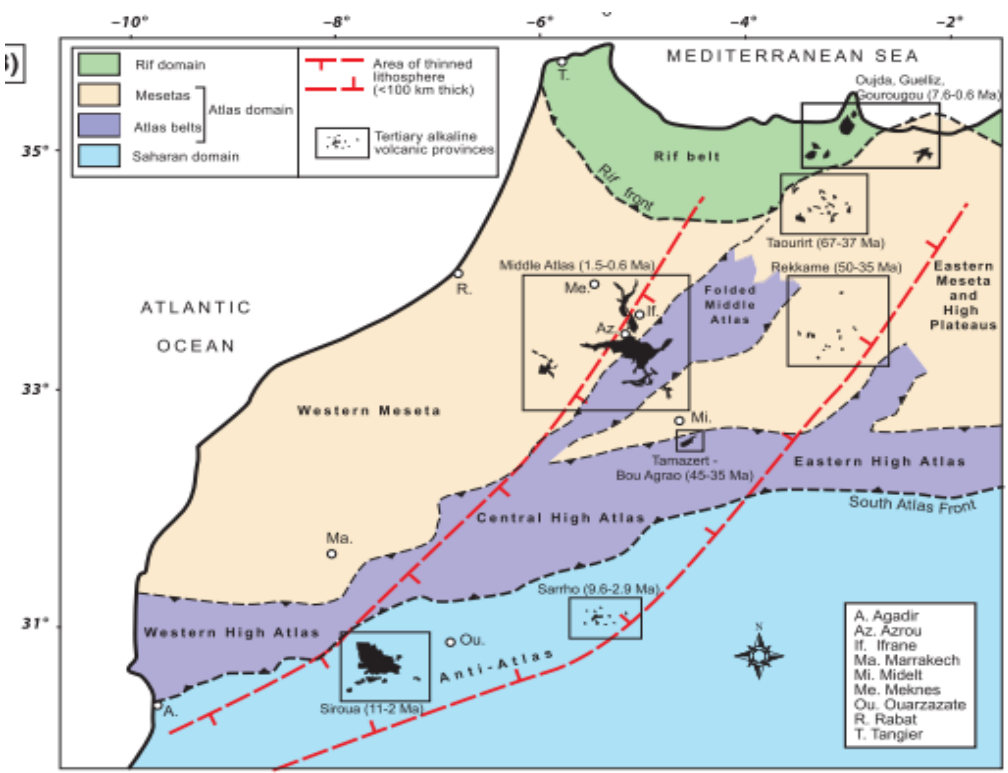

Figura 2.14. Relación espacial entre el Atlas, la zona de adelgazamiento litosférico (limitada por líneas discontinuas rojas, y las áreas de vulcanismo cenozoico. Modificado de Missenard y Cadoux (2012).

Figure 2.14. Spatial relationship between the Atlas, the area of thinned lithosphere (bracketed by red-dashed lines) and the Cenozoic volcanism. Modified from Missenard and Cadoux (2012).

Missenard et al. (2008) estiman que aproximadamente $1000 \mathrm{~m}$ del levantamiento del Atlas pueden ser explicados por este proceso, el cual está estrechamente relacionado con el vulcanismo cuaternario (Teixell et al., 2005; Missenard et al., 2006) y la zona de adelgazamiento litosférico (de orientación NE-SO y por tanto oblicuo a la cadena) es coincidente con la extensión de los afloramientos ígneos (Fig. 2.14). Concretamente, y a partir de diferentes observaciones geológicas (levantamiento y basculamiento de series Cenozoicas, relleno de paleo-valles por coladas basálticas, anomalías en la red de drenaje), Babault et al. (2008) estiman que el levantamiento es posterior al Plioceno Superior, edad de las calizas lacustres basculadas e incididas por la red de drenaje en la cuenca de Saïss, y previo a 0-5 Ma, edad de las lavas más modernas que rellenan las incisiones generadas en dichas calizas.

Sin embargo, el origen del adelgazamiento mantélico presenta mayor controversia y se han propuesto diferentes hipótesis: adelgazamiento debido a la presencia de slabs procedentes de la subducción en el Mediterráneo (Teixell et al., 2005), delaminación mantélica tras el engrosamiento cortical y generación de un corredor en el que se propagaría la pluma asociada al vulcanismo de Canarias (Duggen et al., 2009) o migración de plumas mantélicas relacionadas con el vulcanismo canario (Fullea et al., 2010). Sin embargo, Missenard y Cadoux. (2012) descartan las anteriores por diferentes causas y proponen la presencia de corrientes de convección locales en el límite sur del Atlas. Este proceso convectivo ocurre por el contraste térmico que se produce en el contacto vertical existente entre el cratón (más frío) y la astenosfera situada bajo el dominio atlásico (más caliente). 
La principal observación que lleva a estos autores a proponer esta hipótesis es la coincidencia entre las dos etapas de vulcanismo cuaternario con los periodos de menor velocidad de movimiento de la placa africana, un factor necesario para que se generen dichas corrientes de convección.

\subsection{Estructura del área de estudio}

La zona de estudio (Figs. 2.13 y 2.15) presenta una directriz estructural principal ENE-OSO (Fig. 2.16) a la que se superpone una directriz estructural secundaria NE-SO. Está caracterizada por estrechas estructuras antiformales (las denominadas ridges en la literatura científica) que presentan flancos con buzamientos de moderados a altos, que limitan sinclinales anchos con bajo buzamiento de sus flancos en la mayoría de casos (Figs. 2. 16e y 2.17).

Los materiales aflorantes son de manera dominante calizas, margocalizas y margas del Jurásico Inferior-Medio. Las calizas y dolomías del Jurásico basal se limitan a los flancos cabalgantes de algunas estructuras (p. ej., Anergui y Toumliline), y en el núcleo de los sinclinales centrales (Lake Plateau e Ikkou) afloran los materiales más modernos compuestos por capas rojas (lutitas y areniscas) continentales de edad Bathoniense-Calloviense. Aunque en diferente proporción, en el núcleo de los anticlinales afloran materiales triásicos, arcillas y basaltos (y sales en la ridge de Toumliline), y rocas plutónicas jurásicas. Éstas últimas son dominantes en las estructuras más nororientales, mientras que en las estructuras del sur y del oeste dominan los materiales triásicos. Los materiales ígneos jurásicos afloran en el núcleo de los anticlinales con independencia de la directriz estructural de estos, indicando que ambas orientaciones reflejan la estructura del basamento y estarían conectadas con fracturas profundas por las que se habría producido el ascenso magmático. Es destacable la ausencia generalizada en el área de estudio de aureolas de metamorfismo que pudieran estar relacionadas con la intrusión de las rocas ígneas jurásicas; de hecho, los contactos observados entre las mismas y tanto los carbonatos encajantes como los materiales triásicos del núcleo son de tipo mecánico.

Toda el área está afectada por una foliación tectónica relacionada con los pliegues, con alto buzamiento y relaciones variables con la estratificación (Fig. 2.16). Se trata de una foliación de presión-disolución en calizas y pizarrosa en materiales margosos. Puede observarse como (i) una foliación vertical paralela a las estructuras principales en las cercanías de las ridges principales, donde puede considerarse como una foliación asociada a buttresing, como (ii) una foliación vertical afectando a zonas tabulares de capas horizontales y que estaría relacionada con procesos de acortamiento paralelo a las capas (layer parallel shortening), o como (iii) una foliación de plano axial asociada a pliegues dominantemente angulosos. 


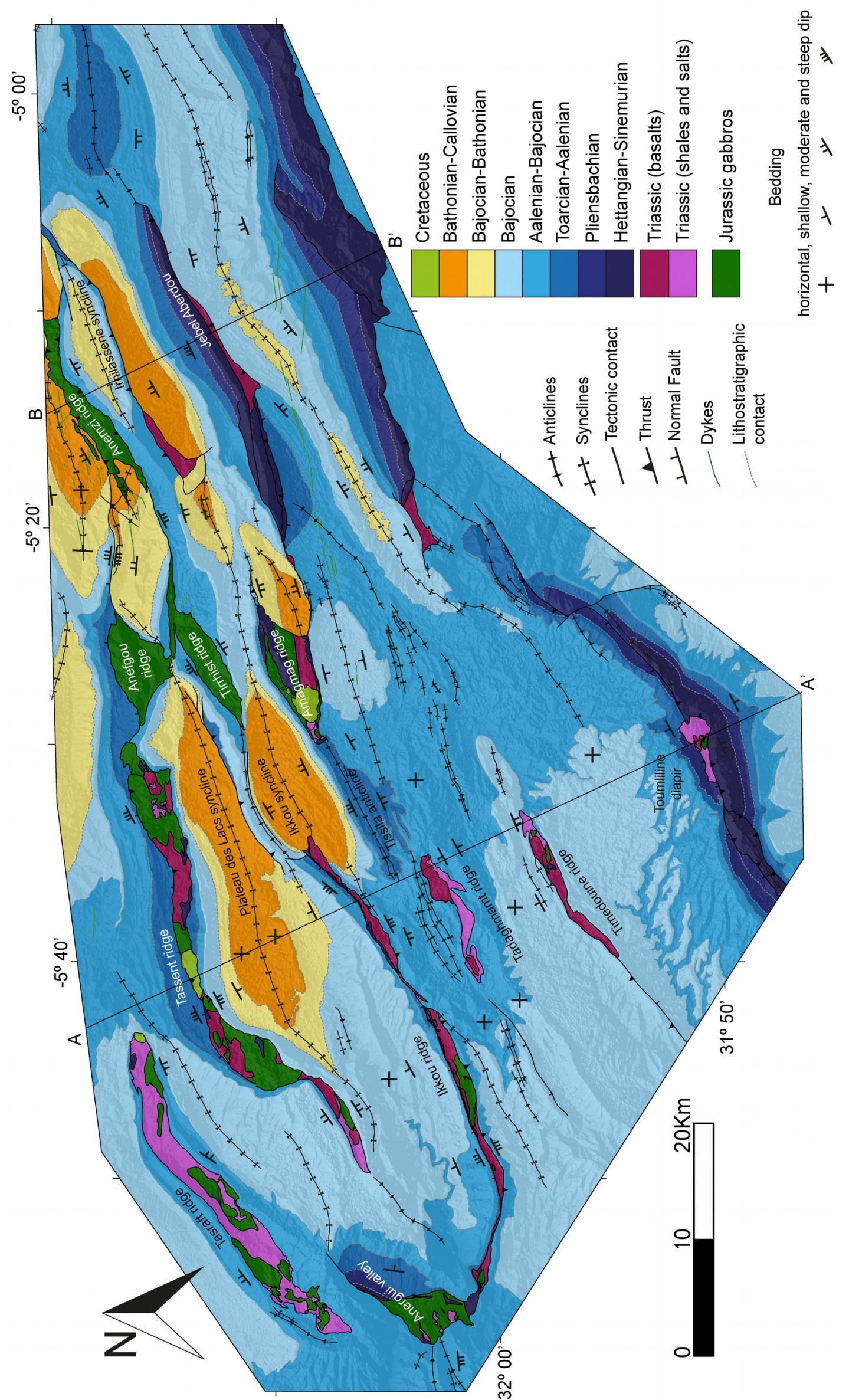

Figura 2.15. (a) Mapa geológico del área de estudio, mostrando las principales estructuras y la posición de los cortes geológicos de la Fig. 2.16.

Figure 2.15.(a) Geologic map of the study area showing the main structures and the location of the location of the geological cross-sections that appears in the Fig. 2.16. 
Las estructuras de Anergui y Tasraft, de dirección NE-SO, son las más occidentales del área de estudio. Ambas presentan buzamientos moderados de sus flancos, y su núcleo está compuesto de manera mayoritaria por gabros jurásicos en el caso de Anergui y por rocas triásicas en Tasraft. La zona de Anergui separa un área al E dominada por las estructuras antiformes que limitan sinclinales laxos, de otra zona al O donde la tectónica compresiva es más intensa y pueden observarse importantes cabalgamientos a los que se asocian pliegues vergentes al $\mathrm{N}$ con desarrollo de foliación muy penetrativa. Estos cabalgamientos pueden seguirse a decenas de kilómetros hacia el $\mathrm{O}$ en dirección E-O.

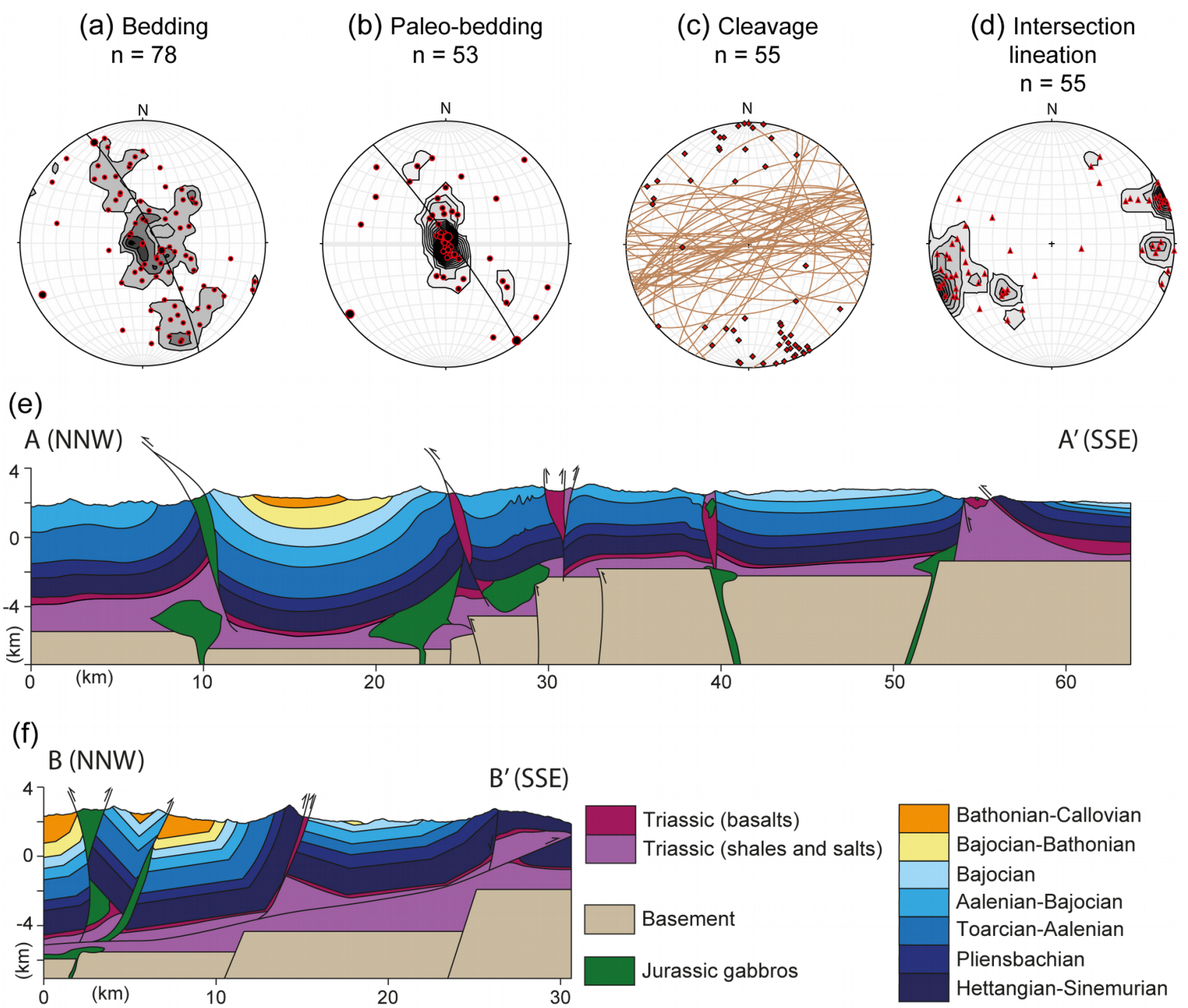

Figura 2.16. (a, b, c, d) Proyecciones de igual área (hemisferio inferior) mostrando diferentes elementos estructurales que caracterizan el área de estudio. En (a, b, d) se muestran los contornos de densidad así como el mejor ajuste cilíndrico para cada set de datos. (e, f) Cortes geológicos mostrando la estructura del área de estudio. Ver posición en la Fig. 2.15.

Figure 2.16. ( $a, b, c, d)$ Lower hemisphere equal area projections showing the main structural features present in the study area. In $(a, b, d)$ are shown the density contours and the cylindrical best fit for each dataset. (e, f) Geological cross-sections showing the structure of the study area. See location in Fig. 2.15. 
La estructura de Tassent, de más de 20 km, presenta segmentos de dirección ENE-OSO y NE-SO. Los flancos presentan altos buzamientos a lo largo de la misma, y se pueden observar variaciones de espesor y estructuras onlap en la serie Aalaniense que se desarrolla en el flanco N. La distribución de gabros jurásicos a lo largo del núcleo es desigual, presentando dos zonas con mayor volumen de ellos. Estas zonas corresponden con dos ensanchamientos del núcleo, que pueden estar relacionados precisamente por la intrusión de los mismos.

Hacia el E la estructura de Tassent conecta con la de Anefgou, con morfología más o menos circular y cuyo núcleo está formado casi exclusivamente por gabros jurásicos. De características similares es la ridge de Tirrhist, si bien en este caso la directriz estructural ENE-OSO está más definida y presenta una clara vergencia NNO. La estructura de Tirrhist conecta hacia el SO con la ridge de Ikkou, que se extiende más de 20 km hasta conectar con el extremo S de Anergui.

La ridge de Ikkou presenta flancos de buzamientos elevados, y su estrecho núcleo está formado esencialmente por basaltos triásicos. Las ridges de Ikkou y Tirrhist están separadas por el sinclinal de Ikkou que cabalga hacia el $\mathrm{N}$, si bien deben de conectarse en profundidad y ser parte de la misma estructura. El sinclinal de Ikkou presenta una corta extensión lateral ( $10 \mathrm{~km}$ ), pasando lateralmente a capas horizontales. Además, este sinclinal es coincidente con las mayores potencias de capas rojas jurásicas, indicando que actuó como depocentro durante el Jurásico. Entre las ridges de Ikkou, Tassent y Tirrhist se encuentra el sinclinal Lake Plateau, una estructura laxa y de gran extensión lateral donde afloran rocas del Jurásico Medio.

El sinclinal de Ikkou está limitado al S por el anticlinal de Tissila, vergente al N, cuyo flanco $\mathrm{N}$ presenta altos buzamientos y el $\mathrm{S}$ da lugar al área tabular que se extiende hasta Toumliline. Esta área tabular, en su parte occidental, está interrumpida por las ridges de Tadaghmamt y Timedouine, que constituyen dos salt-walls donde afloran materiales triásicos en el núcleo, pero la deformación de los flancos es baja y limitada a las inmediaciones de sendos núcleos. La zona oriental del área tabular está caracterizada por capas horizontales que son interrumpidas por pliegues angulosos de doble vergencia y foliación de plano axial.

La estructura más meridional corresponde con la ridge de Toumliline. Presenta orientación ENE-WSW y en la zona central aparece el diapiro con el mismo nombre, único lugar del área de estudio donde afloran sales triásicas. En el flanco S de la estructura afloran materiales del Jurásico Inferior, que cabalgan hacia el N sobre materiales del Jurásico Medio.

Hacia el este la estructura compresiva es más evidente, y se observan cabalgamientos vergentes tanto al $\mathrm{N}$ como al $\mathrm{S}$, limitando sinclinales apretados $\mathrm{y}$ en ocasiones con flancos invertidos donde afloran los materiales del Jurásico Medio. 

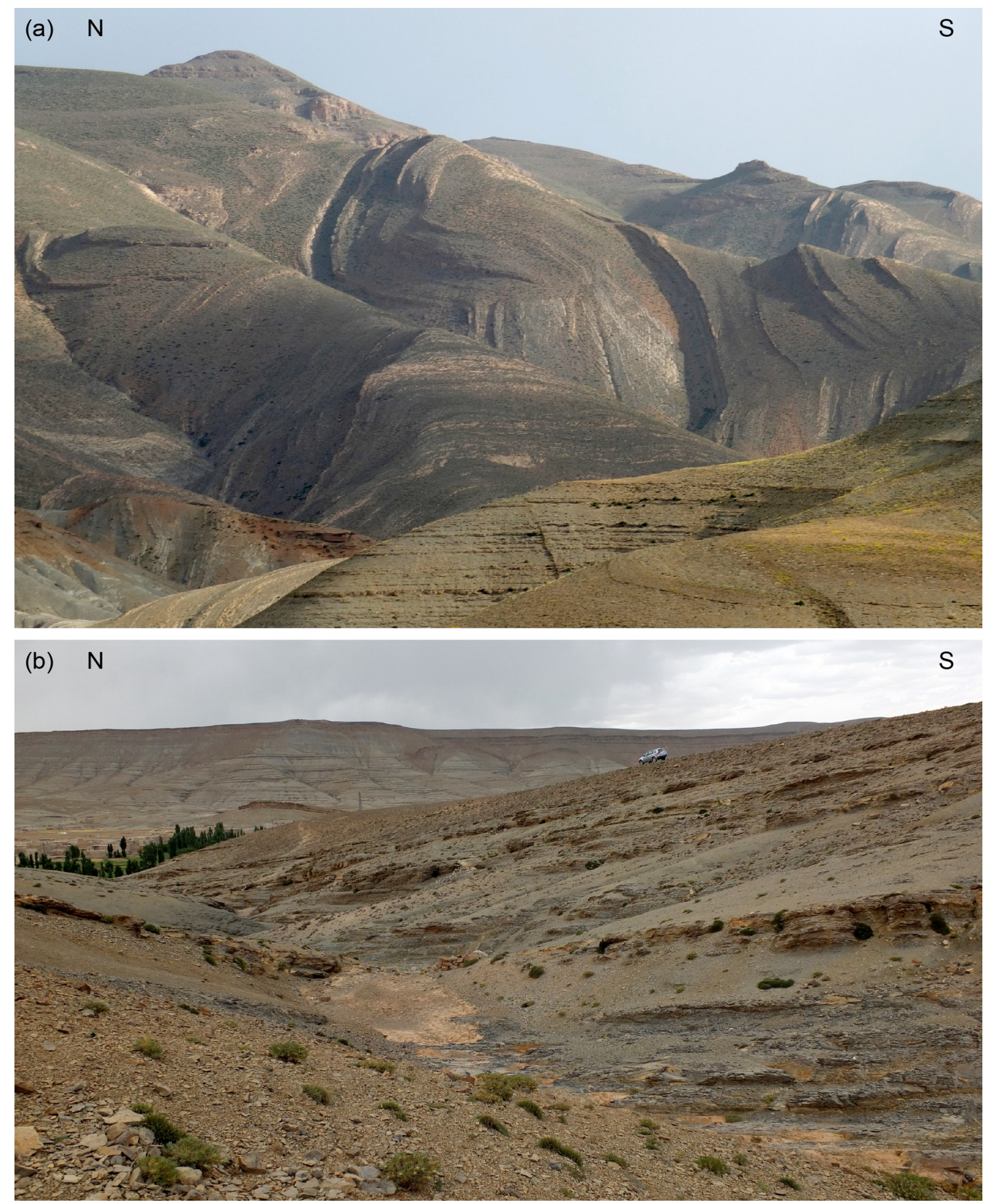

Figura 2.17. (a) Flanco S del anticlinal de Tassent, mostrando un tren de pliegues vergentes al S. (b) Flanco $S$ del sinclinal de Lake Plateau, mostrando bajos buzamientos en primer plano y capas horizontales hacia el núcleo de la estructura.

Figure 2.17.(a) S limb of the Tassent anticline showing angular south verging folds. (b) S limb of the Lake Plateau syncline in which the low to horizontal dips are dominants. 



\section{Metodología I}

\section{Técnicas de muestreo y laboratorio}

3.1 Trabajo de campo.................................................... 57

3.2 Desmagnetización de la magnetización remanente natural......................... 58

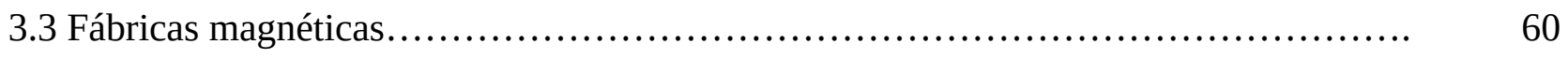

3.4 Mineralogía magnética de calizas remagnetizadas............................... 63

3.5 Mineralogía magnética de rocas ígneas.................................... 69 

En este capítulo se presentarán las metodologías de campo y laboratorio más relevantes utilizadas en esta tesis doctoral, tanto por su uso extensivo como por el desarrollo metodológico que se ha realizado y que no pueden encontrarse en los manuales básicos de paleomagnetismo. Conceptos básicos del paleomagnetismo, y los métodos y técnicas aplicados de forma rutinaria son fácilmente accesibles en libros y compendios (p. ej., Butler, 1992; Tarling y Hrouda, 1993; Tauxe, 2010). Dichos conceptos y procedimientos no serán tratados aquí, donde se hará referencia a los mismos cuando se trate de planteamientos innovadores en la aplicación de cada técnica concreta.

\subsection{Trabajo de campo}

El trabajo de campo (Fig. 3.1) ha tenido dos finalidades básicas: (i) realizar observaciones geológicas y toma de datos, normalmente de tipo estructural, y (ii) realizar el muestreo paleomagnético.

Dada la finalidad de este trabajo, que es la aplicación del paleomagnetismo para resolver problemas geológicos, las observaciones geológicas son importantes por ser la base sobre la que se realizarán todas las interpretaciones posteriores. En este sentido, además de la medida de la orientación de los planos de estratificación, es importante conocer la presencia de discordancias dentro de la serie sedimentaria, relaciones entre rocas ígneas y su encajante, estilo de deformación, relación entre la foliación tectónica y los pliegues, etc. Además de las observaciones geológicas

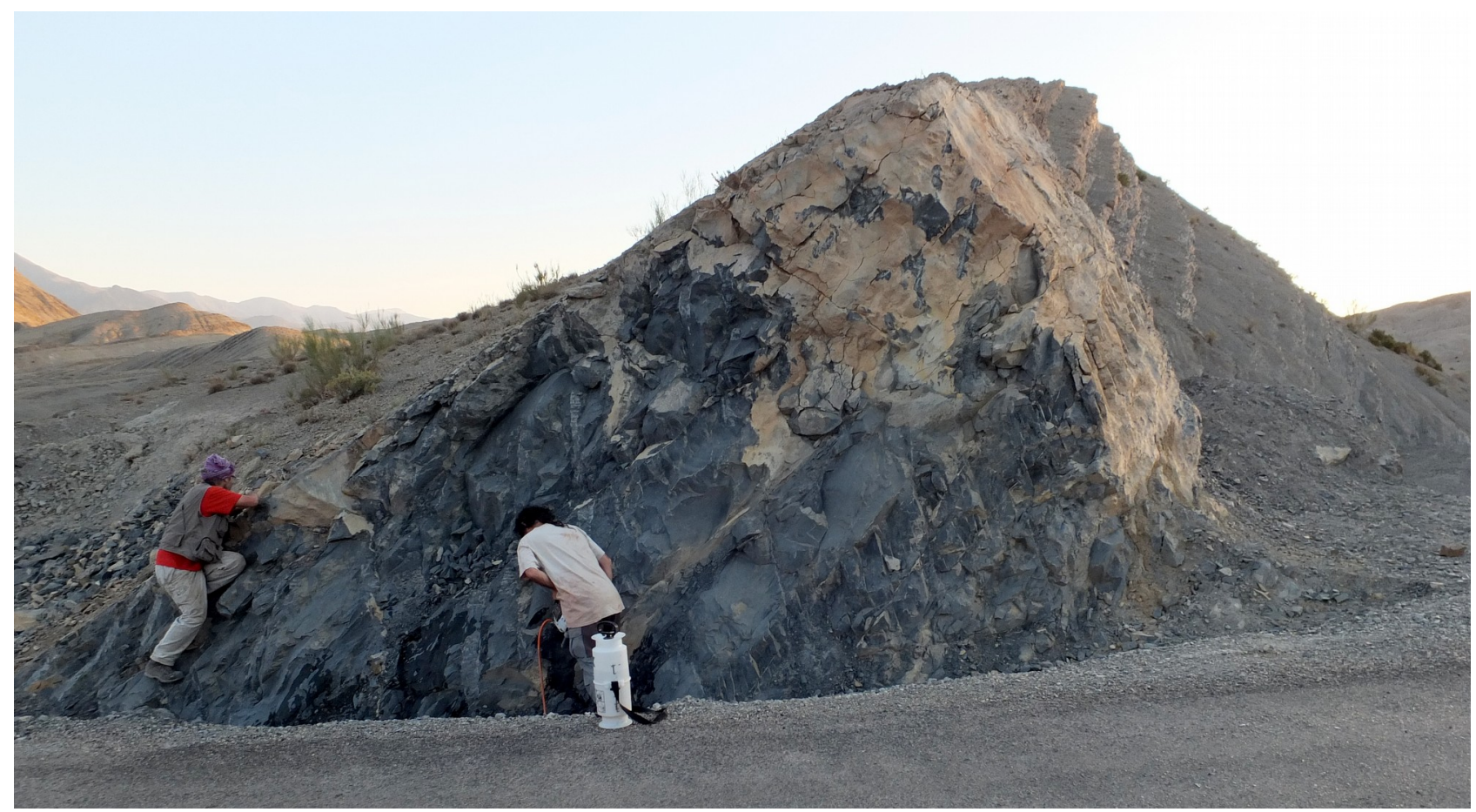

Figura 3.1 Antonio tomando muestras paleomagnéticas y Juanjo midiendo la estratificación en calizas Aalenienses del entorno de Amouguer (Alto Atlas Central).

Figure 3.1 The shown is Antonio sampling paleomagnetic samples and Juanjo measuring the bedding in Aalenian limestones around Amouguer (Central high Atlas). 
tomadas en las estaciones paleomagnéticas, se han realizado mediciones en varias estaciones para controlar las relaciones entre estratificación y foliación tectónica.

Por otro lado, el muestreo paleomagnético se ha realizado según el estándar usado habitualmente en paleomagnetismo para la extracción de muestras de roca orientadas en materiales competentes (i.e., calizas y gabros). Para ello se han utilizado perforadoras de gasolina, que permiten la obtención de muestras de diámetro estándar (25 mm). Como patrón, se han obtenido de forma sistemática al menos ocho muestras por estación paleomagnética.

\subsection{Desmagnetización de la magnetización remanente natural}

Una misma roca puede contener diferentes minerales ferromagnéticos s.l., con diferentes poblaciones caracterizadas por sus espectros de tamaño de grano, que pueden registrar distintas magnetizaciones. La magnetización remanente natural (NRM) puede ser definida como el vector suma de todas las contribuciones parciales provenientes de las distintas poblaciones de granos ferromagnéticos presentes en la roca. Los trabajos paleomagnético modernos usan diferentes técnicas que permiten aislar (en el mejor de los casos) cada uno de los vectores magnetización correspondientes a cada familia de granos (denominado componente paleomagnética) que sumados conforman la NRM. Actualmente, las técnicas más usadas son la desmagnetización térmica (TH) y por campos alternos (AF). Ambas son técnicas progresivas consistentes en la destrucción gradual de la magnetización, con un criterio selectivo de temperatura de desbloqueo o coercitividad, respectivamente, de cada una de las poblaciones minerales que registran las diferentes componentes paleomagnéticas. Generalmente (más en rocas sedimentarias que en rocas ígneas), cada población mineralógica presenta un rango relativamente amplio de temperaturas de desbloqueo y/o coercitividades, relacionadas con distribuciones amplias en el tamaño de grano dentro de la población que registra la misma componente paleomagnética; en estos casos se observa una desmagnetización progresiva de la componente en cuestión. Sin embargo, hay ocasiones en las que una componente paleomagnética es portada por una población mineralógica con una variación de tamaño muy pequeña; en estos casos la desmagnetización de la componente es rápida, en un rango estrecho de temperaturas y/o coercitividades (la desmagnetización térmica es más sensible a este efecto que la AF, donde las caídas suelen ser más progresivas).

La elección de una u otra técnica de desmagnetización depende de la mineralogía magnética de las muestras y su comportamiento. Generalmente, cuando se desconoce el comportamiento paleomagnético de las rocas, se suele realizar una desmagnetización piloto en especímenes provenientes de la misma muestra para comparar resultados y seleccionar la técnica más efectiva de forma sistemática. En nuestro caso se utilizaron muestras piloto de cada serie de estaciones, y se aprovechó también la experiencia previa del equipo en la zona (Torres-López et al., 2014; Moussaid et al., 2015) para determinar los rangos de temperatura y campo para la desmagnetización. 

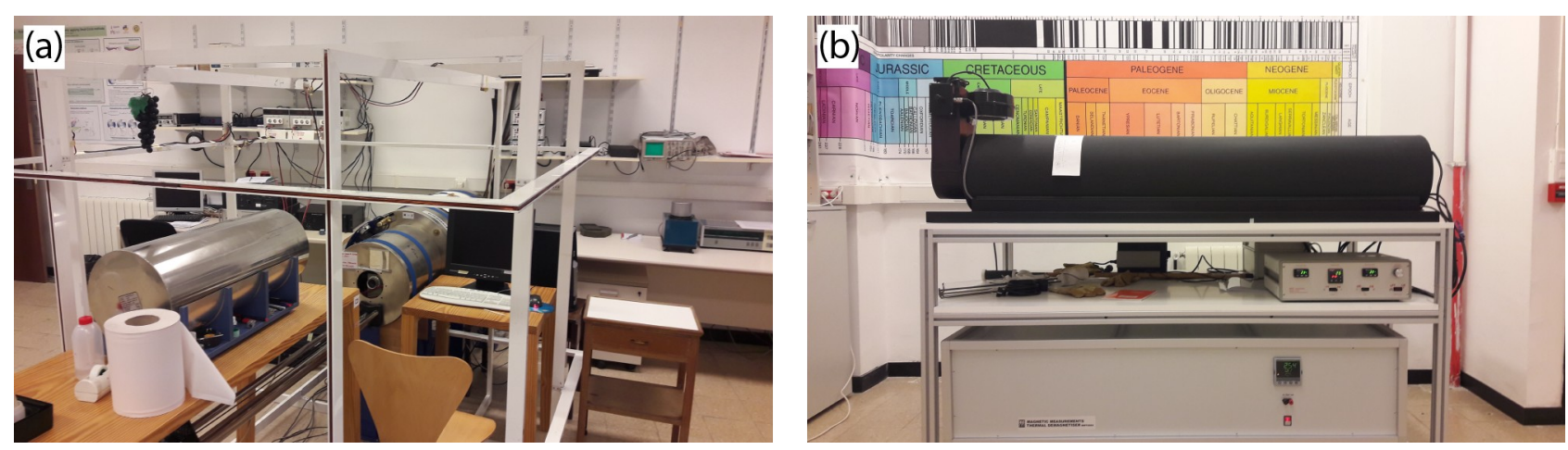

Figura 3.1 (a) Magnetómetro criogénico 755 (2G) y (b) desmagnetizadores térmicos TD48-DC (ASC Scientific) y MMTD80A (Magnetic Measurements) en la parte superior e inferior respectivamente.

Figure 3.1 (a) Cryogenic magnetometer 755 (2G) and (b) thermal demagnetizers TD48-DC (ASC Scientific) and MMTD80A (Magnetic Measurements) at the top and the bottom of the picture respectively.

La técnica de AF sólo permite desmagnetizar minerales con coercitividades inferiores a 100$200 \mathrm{mT}$ (100 mT en el laboratorio de paleomagnetismo de Burgos), siendo por tanto una técnica válida cuando el mineral portador de la magnetización es la magnetita, no así cuando queremos aislar la señal paleomagnética que registran minerales con coercitividades más altas, como la pirrotina o la hematites. Este hecho, junto con el ocasional solapamiento de diferentes componentes, son las principales desventajas frente a la desmagnetización térmica. Por el contrario, esta técnica tiene la ventaja de la no alteración térmica de la roca, con lo cual se evita la posible neoformación de minerales ferromagnéticos s.l. durante el proceso. Dicha creación de nuevos minerales magnéticos por elevación de temperatura es un efecto común en ciertas rocas sedimentarias, especialmente cuando no han sufrido temperaturas altas durante su historia geológica, y particularmente cuando presentan sulfuros de hierro. Además, al no ser tratadas térmicamente, suelen ser válidas para medidas posteriores tanto de la fábrica magnética (ver Biedermann et al., 2017), como para experimentos de magnetismo de las rocas. Por otra parte, la desmagnetización térmica, excepto cuando se generan nuevos minerales ferromagnéticos s.l. durante el calentamiento, suele ser la técnica más efectiva para separar diferentes componentes paleomagnéticas. Antes se indicaba que componentes paleomagnéticas portadas por una mineralogía con un rango estrecho de tamaños de grano presenta su desmagnetización en un intervalo de temperaturas pequeño, no ocurriendo lo mismo en AF donde el rango puede ser mayor. Aplicando este hecho a dos poblaciones de magnetita, sea cual sea el rango de tamaños de cada una de las poblaciones, la desmagnetización por AF puede presentar rangos más amplios de coercitividades, favoreciendo un solapamiento entre ambas componentes, mientras que serán más fácilmente separables mediante desmagnetización térmica. Finalmente, ambas técnicas pueden ser combinadas en virtud de las características de las muestras de estudio; por ejemplo en calizas con pirrotina y magnetita, con neoformación de magnetita durante el calentamiento a temperaturas superiores a por ejemplo 400 ${ }^{\circ} \mathrm{C}$, puede realizarse una desmagnetización térmica hasta $330{ }^{\circ} \mathrm{C}$ para obtener la señal portada por la pirrotina, seguida de una desmagnetización progresiva por AF hasta $100 \mathrm{mT}$ para conocer la 
información registrada por la magnetita, evitando crecimiento de minerales magnéticos al calentar por encima de $400{ }^{\circ} \mathrm{C}$.

Durante el desarrollo de esta tesis se realizaron desmagnetizaciones piloto tanto en los gabros como en las calizas remagnetizadas, decantándonos finalmente en todos los casos por la desmagnetización térmica con excepción de las estaciones de garbos IC. A modo de ejemplo de los diferentes resultados provenientes de desmagnetización TH y AF, en algunas muestras de gabros pueden observarse dos componentes con direcciones claramente diferenciadas en TH, mientras que en AF sólo se observa una componente con dirección intermedia entre ellas (apartado 7).

Sin considerar las muestras gemelas en las desmagnetizaciones piloto, se han analizado 33 estaciones paleomagnéticas de rocas ígneas, fundamentalmente gabros (25 térmicamente y 8 por campos alternos) y 89 de calizas jurásicas (todas mediante tratamiento térmico). En cada estación se han desmagnetizado sistemáticamente ocho especímenes. Para esta tarea, se ha utilizado un magnetómetro criogénico 755 (2G) con bobinas de campos alternos integradas, así como los desmagnetizadores térmicos TD48-DC (ASC Scientific) y MMTD80A (Magnetic Measurements).

Las componentes paleomagnéticas fueron calculadas mediante el análisis de componentes principales (Kirschvink, 1980), usando el programa Remasoft 3.0 (Chadima y Hrouda, 2006). El posterior tratamiento estadístico de las componentes calculadas se realizó acorde con Fisher (1953).

\subsection{Fábricas magnéticas}

La caracterización de la fábrica magnética es una herramienta que permite evaluar, de manera rápida y fidedigna, la petrofábrica de una roca (p. ej., Graham, 1966; Tarling y Hrouda, 1993, Parés, 2015). La técnica más ampliamente utilizada para ello es la anisotropía de la magnetización inducida a bajo campo ( $<1 \mathrm{mT}$ ) medida a temperatura ambiente (RT-AMS), denominada anisotropía de la susceptibilidad magnética. Ésta integra la información magnética proveniente de todas las mineralogías presentes en la roca. Sin embargo, en ocasiones es necesario utilizar distintas técnicas que permiten medir subfábricas, es decir, que permiten separar la información magnética proveniente de diferentes las diferentes poblaciones mineralógicas atendiendo a sus propiedades magnéticas (diamagnéticas, paramagnéticas y ferromagnéticas s.l.).

Entre las técnicas utilizadas para caracterizar subfábricas paramagnéticas podemos destacar la anisotropía de la susceptibilidad magnética medida a temperatura de ebullición del nitrógeno a presión atmosférica (77 K; LT-AMS) (Richter y van der Pluijm, 1994), y la anisotropía de la magnetización inducida a alto campo (Martín-Hernández y Hirt, 2004). Ambas técnicas se basan en el distinto comportamiento entre los minerales para- y ferromagnéticos s.l. bajo distintas condiciones. La LT-AMS busca realzar la señal paramagnética disminuyendo la temperatura, dado que según la ley de Curie-Weiss la susceptibilidad paramagnética a $77 \mathrm{~K}$ es 3.8 veces mayor que a temperatura ambiente (p. ej., Morrish, 1965; Lüneburg et al., 1999). Por otro lado, la susceptibilidad magnética a alto campo se basa en que la relación entre campo aplicado y magnetización inducida se relaciona directa y linealmente en materiales paramagnéticos, mientras que los materiales 
ferromagnéticos presentan una magnetización de saturación a partir de la cual mantienen constante su magnetización inducida. Respecto a la fábrica ferromagnética s.l., además de las técnicas basadas en la medida a alto campo (Martín-Hernández y Hirt, 2004), las técnicas más ampliamente utilizadas para su caracterización están basadas en la medida de la magnetización remanente (p. ej., Jackson, 1991), que permiten además la separación de distintas subfábricas portadas por diferentes poblaciones de minerales ferromagnéticos s.l. en base a su diferente coercitividad. En el desarrollo de esta tesis se han utilizado las técnicas de RT-AMS, LT-AMS y la anisotropía de la magnetización remanente anhisterética (AARM); los protocolos de medida serán explicados más detalladamente a continuación. Sin embargo, algunos parámetros y consideraciones son comunes a las diferentes subfábricas.

Un material isótropo presentará la misma respuesta magnética independientemente de la dirección con que se aplique el campo sobre la muestra. Sin embargo, la mayoría de componentes mineralógicos que forman una roca presentan diferentes grados de anisotropía. A la escala del grano se puede distinguir la (i) anisotropía cristalina, que favorece una susceptibilidad mayor sobre determinados ejes del cristal y la (ii) anisotropía de forma, que tiene su origen en la distribución de polos magnéticos en la superficie del grano y que favorece la susceptibilidad a lo largo de los ejes de elongación del mismo. La forma del grano y por tanto la anisotropía de forma puede estar también controlada por la estructura cristalina y por la historia deformacional que registre cada partícula (p. ej., deformación de filosilicatos). Por otro lado, (iii) la anisotropía puede estar controlada por por una distribución anisótropa de las partículas, que puede ser debida a diferentes procesos geológicos (p. ej., disposición preferente del eje largo de los minerales paralelo al flujo sedimentario o ígneo).

Para que en la roca se genere una anisotropía, las partículas deben ser por sí mismas anisótropas, puntos (i) y (ii), y/o presentar una distribución anisótropa, punto (iii). Partículas anisótropas que están dispuestas de manera aleatoria generarán una fábrica isótropa. Partículas esféricas totalmente isótropas, que no interactúen entre ellas, empaquetadas preferentemente según una fábrica anisótropa, presentarán una fábrica isótropa. Sin embargo, partículas esféricas próximas que interactúen magnéticamente entre ellas se comportan de manera análoga a las partículas con anisotropía de forma (Hargraves et al., 1991; Stephenson, 1994), de modo que pueden generar una fábrica anisótropa si están distribuidas de manera anisótropa. En la naturaleza, ni el granito más isótropo a escala de muestra o afloramiento suele ser realmente isótropo (Bouchez, 1997), y por muy débil que sea la anisotropía de una roca, las fábricas magnéticas suelen permitir su caracterización.

La anisotropía de la susceptibilidad magnética de las rocas puede expresarse de distintos modos, pero el más completo es por medio del elipsoide de anisotropía. Se trata de un tensor simétrico de segundo orden cuyos ejes principales nos indican la orientación de los ejes del elipsoide magnético de anisotropía $\left(k_{\max }>k_{\text {int }}>k_{\min }\right)$. La forma del elipsoide y su grado de anisotropía son definidos según las relaciones entre los valores propios de los ejes principales, por ejemplo mediante los parámetros T y Pj (Jelinek, 1981), y la susceptibilidad media es definida por $\mathrm{k}_{\mathrm{m}}=\left(\mathrm{k}_{\mathrm{max}}+\mathrm{k}_{\mathrm{int}}+\mathrm{k}_{\mathrm{min}}\right) / 3$ (Nagata, 1961). Estos parámetros nos permiten caracterizar, por tanto, la 
susceptibilidad total de la roca, así como la relación entre los valores propios del tensor. Es necesario indicar que la comparación de los parámetros $\mathrm{T}$ y Pj entre diferentes técnicas de medida no puede realizarse de manera directa dado que la forma y anisotropía del elipsoide magnético puede cambiar cuando varían la condiciones de medida (p. ej., Stephenson et al., 1986). Por ejemplo, se ha observado que al medir a $77 \mathrm{~K}$ el valor de $\mathrm{k}_{\max }$ aumenta en mayor grado respecto del valor a temperatura ambiente que el resto de ejes principales (Parés y van der Pluijm, 2002), generando posiblemente valores mayores de Pj y elipsoides más prolatos (valores menores de T).

\subsubsection{RT-AMS y LT-AMS}

Los experimentos de AMS fueron llevados a cabo usando el puente de susceptibilidad KLY-4S (AGICO) de la Universidad de Burgos, utilizando un campo de $300 \mathrm{~A} / \mathrm{m}$ con una frecuencia de 875 Hz. Para las medidas de baja temperatura (Parés y van der Pluijm, 2002) las muestras fueron sumergidas en nitrógeno líquido durante $45 \mathrm{~min}$ antes de comenzar el experimento, y $15 \mathrm{~min}$ nuevamente entre cada una de las cuatro posiciones que son necesarias en dicho aparato. La visualización de los datos y su tratamiento estadístico se realizó usando el programa Anisoft 3.0 (Chadima y Jelinek, 2009).

\subsubsection{AARM}

McCabe et al. (1985) utilizaron por primera vez la anisotropía de la magnetización remanente anhisterética (AARM) para la caracterización de la fábrica ferrimagnética de calizas remagnetizadas procedentes de los Montes Apalaches, quienes la denominaron inicialmente anisotropía de la susceptibilidad anhisterética. Del mismo modo que la AMS, la AARM muestra la diferente respuesta de una muestra cuando se le aplica un campo en diferentes direcciones. Sin embargo, en el caso de la AARM, no se mide la magnetización inducida sino la magnetización remanente anhisterética (ARM) (p. ej., Tauxe, 2010).

El procedimiento de medida utilizado es muy similar al descrito por McCabe et al. (1985), consistente en aplicar y medir la ARM en las nueve posiciones (Fig. 3.3) definidas por Girdler (1961) que permiten obtener el tensor que define la AARM. Es necesario indicar que son seis las posiciones mínimas necesarias para caracterizar la matriz simétrica de 3x3 que define la AARM; por tanto, las tres medidas extras permiten estimar el error en el cálculo del tensor. La AARM fue medida en el laboratorio de paleomagnetismo de la Universidad de Burgos, utilizando el magnetómetro criogénico 2G-755, el cuál permite la aplicación de ARMs.

El experimento para caracterizar la AARM consiente por tanto en medir la ARM aplicada según nueve ejes distintos de una muestra previamente desmagnetizada. Las ARMs fueron aplicadas usando un campo continuo $\left(\mathrm{B}_{\mathrm{DF}}\right)$ de $0.05 \mathrm{mT}$ coaxial con un campo alterno $\left(\mathrm{B}_{\mathrm{AF}}\right)$ de 100 mT. Después de cada medida de la ARM la muestra fue desmagnetizada con un $\mathrm{B}_{\mathrm{AF}}$ de $100 \mathrm{mT}$ aplicado sólo sobre el eje en que había sido impartida la ARM y ese valor de magnetización fue usado como base para eliminar la contribución de la fracción ferromagnética s.l. con coercitividades superiores a $90 \mathrm{mT}$. Tras la medida de la ARM y la magnetización base en las nueve posiciones 


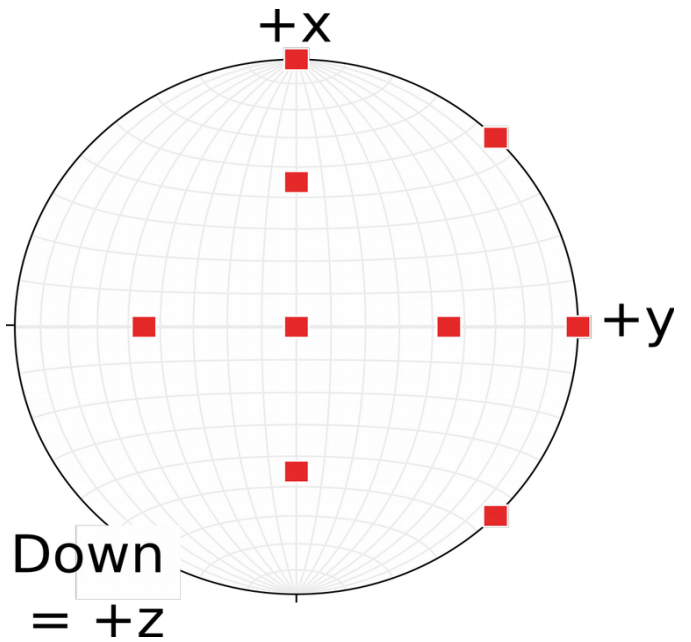

Figura 3.3 Proyección equiareal (hemisferio inferior) en coordenadas de la muestra mostrando las nueve direcciones de aplicación de la ARM utilizadas para la caracterización de la AARM.

Figure 3.3 Lower-hemisphere equal area projection in sample coordinates showing the nine directions under which the ARM was imparted to characterized the AARM.

(Fig. 3.3), el tensor de segundo orden que define la AARM fue calculado mediante mínimos cuadrados (Girdler, 1961) usando para ello una hoja de cálculo programada por el Dr. Mike Jackson (IRM, Universidad de Minnesota).

\subsection{Mineralogía magnética de calizas remagnetizadas}

La mineralogía magnética de calizas afectadas por procesos de remagnetización química con generación de magnetita está bien caracterizada, y es distintiva cuando se la compara con calizas no remagnetizadas. Esto se hace patente especialmente en los parámetros de la histéresis, que muestran que la mineralogía magnética está formada principalmente por granos de magnetita con comportamiento superparamagnético (SP) y monodominio estable (SSD) (Channell y McCabe, 1994; Jackson y Swanson-Hysell, 2012). Experimentos básicos de magnetismo de rocas (ciclos de histéresis, curvas termomagnéticas, desmagnetizaciones térmicas de la IRM en tres ejes, etc.) en las calizas remagnetizadas del Alto Atlas pueden observarse en Torres-López et al. (2014) en el que se observa un comportamiento similar al reportado por otros autores en otras cadenas montañosas.

En el desarrollo de la tesis, uno de los mayores esfuerzos en la caracterización de la mineralogía magnética de las calizas del Alto Atlas radica en la realización de extractos magnéticos, con la finalidad de observar los portadores de la remagnetización mediante microscopía electrónica (SEM y TEM). Desde los años 90 se lleva intentando realizar tales observaciones, pero dado el pequeño tamaño de grano de los portadores de la remagnetización (en el rango de una decena de nanómetros), es algo que todavía no se ha conseguido (Van der Voo y Torsvik, 2012; a modo de revisión).

Los procedimientos de separación y extracción magnética se realizaron como consecuencia de la primera estancia breve de investigación, en el Institute for Rock Magnetism (Universidad de Minnesota), con la colaboración del Dr. Mike Jackson y la Dra. Jennifer Strehlau. 


\subsubsection{Extractos magnéticos en calizas remagnetizadas}

La metodología seguida en el proceso de separación y extracción de los minerales ferromagnéticos s.l. presentes en las calizas remagnetizadas está basada en Strehlau et al. (2014), que a su vez es una modificación de la metodología propuesta por Hounslow y Maher (1996). La extracción magnética (Fig. 3.3) comienza con la disolución de $\sim 5 \mathrm{~g}$ de caliza fragmentada en una solución tampón (relación de 4:1 de $\mathrm{CH}_{3} \mathrm{COOH} 2 \mathrm{M}$ y $\mathrm{NaCH}_{3} \mathrm{COO} 1 \mathrm{M}$ ). La disolución se lleva a cabo en un matraz situado sobre un agitador orbital $(220 \mathrm{rpm}$ ) durante uno a tres días (o hasta la completa disolución del carbonato). Mediante este proceso se disuelve el material carbonatado, quedando el residuo formado por partículas insolubles. Tras un centrifugado a $14 \mathrm{kp}$ durante 3 min se elimina el material flotante y el residuo es lavado con agua destilada Mili-Q, que se coloca en un matraz Erlenmeyer junto con agua Mili-Q. Un imán de neodimio es adosado a un lateral del matraz, el cuál es agitado a $220 \mathrm{rpm}$ durante al menos 15 min. Este proceso permite separar el extracto magnético que queda adosado al matraz junto al imán del no magnético, que queda en el fondo del matraz. Ambos extractos son guardados para posteriores análisis.

\section{Disolución}

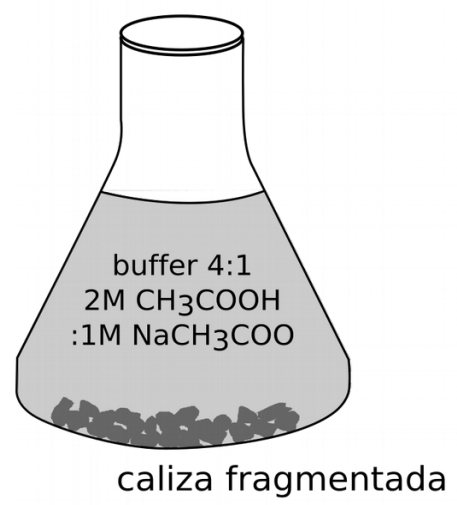

\section{Separación}

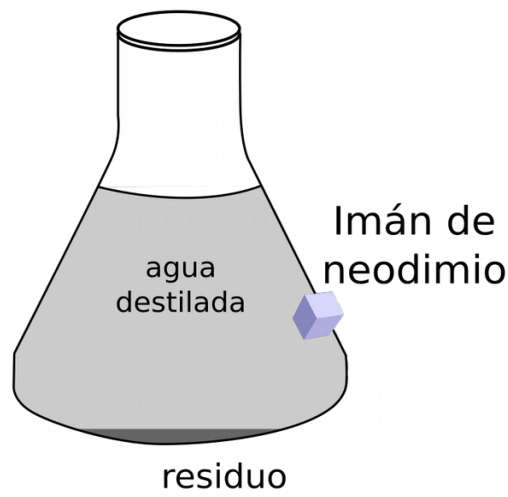

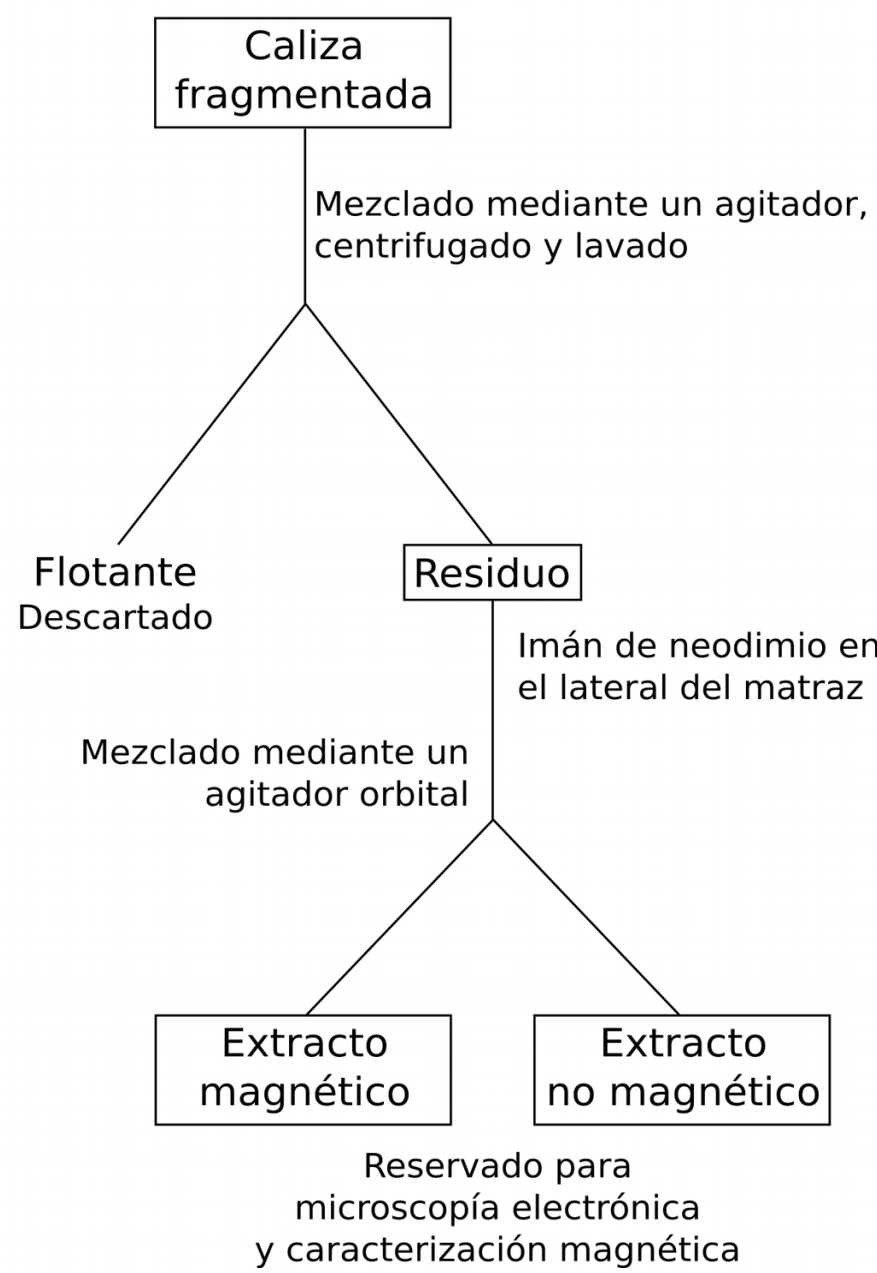

Figura 3.3. Procedimiento de trabajo seguido en la separación y extracción de los componentes ferromagnéticos s.l. en calizas remagnetizadas. Modificado a partir de Strehlau et al. (2014).

Figure 3.3. Workflow followed in the separation and extraction procedure of ferromagnetic s.l. components contained in remagnetized carbonates. Modified from Strehlau et al. (2014). 


\subsubsection{Caracterización magnética de la remanencia}

Se han realizado diferentes experimentos con la finalidad de caracterizar la mineralogía magnética de los portadores de la magnetización y de la susceptibilidad magnética. Estos experimentos se han realizado tanto sobre roca total, como en los diferentes subproductos provenientes de la extracción magnética.

\subsubsection{Ciclos de histéresis y backfield}

Una de las pruebas diagnósticas para la caracterización de calizas remagnetizadas es la representación del diagrama de Day (Day et al., 1977) usando las curvas de mezcla de tamaños de grano de magnetita (Dunlop, 2002). Las ratios usadas para la representación del diagrama de Day (Fig. 3.4a) son obtenidos de los ciclos de histéresis y las curvas de backfield. Concretamente, se obtienen los valores de magnetización de saturación $\left(\mathrm{M}_{\mathrm{s}}\right)$, magnetización remanente de saturación $\left(\mathrm{M}_{\mathrm{r}}\right)$, coercitividad $\left(\mathrm{B}_{\mathrm{c}}\right)$ y coercitividad remanente $\left(\mathrm{B}_{\mathrm{cr}}\right)$ (Fig. 3.4b). Si bien, tal y como indican Roberts et al. (2018), el uso del diagrama de Day puede conducir a conclusiones equívocas y/o ambiguas para caracterizar directamente el estado de dominios de las partículas magnéticas, éste presenta gran utilidad a la hora de comparar el comportamiento magnético de litologías y materiales con similares características magnéticas, como son los carbonatos cuyo principal material magnético es magnetita.

Cuando se representan calizas remagnetizadas y no remagnetizadas sobre un diagrama de Day, las diferencias entre ellas son patentes (Fig. 3.4a). Mientras que las calizas no remagnetizadas suelen situarse sobre la curva de mezcla entre monodominio estable (SSD) y multidominio (MD), las calizas remagnetizadas suelen desplazarse hacia valores más altos en el eje Bcr/Bc, sobre las curvas de mezcla de magnetita superparamagnética (SP) y SSD (Fig. 3.3a) (Channell y McCabe, 1996; Jackson y Swanson-Hysell, 1992). Este desplazamiento se produce como consecuencia de la
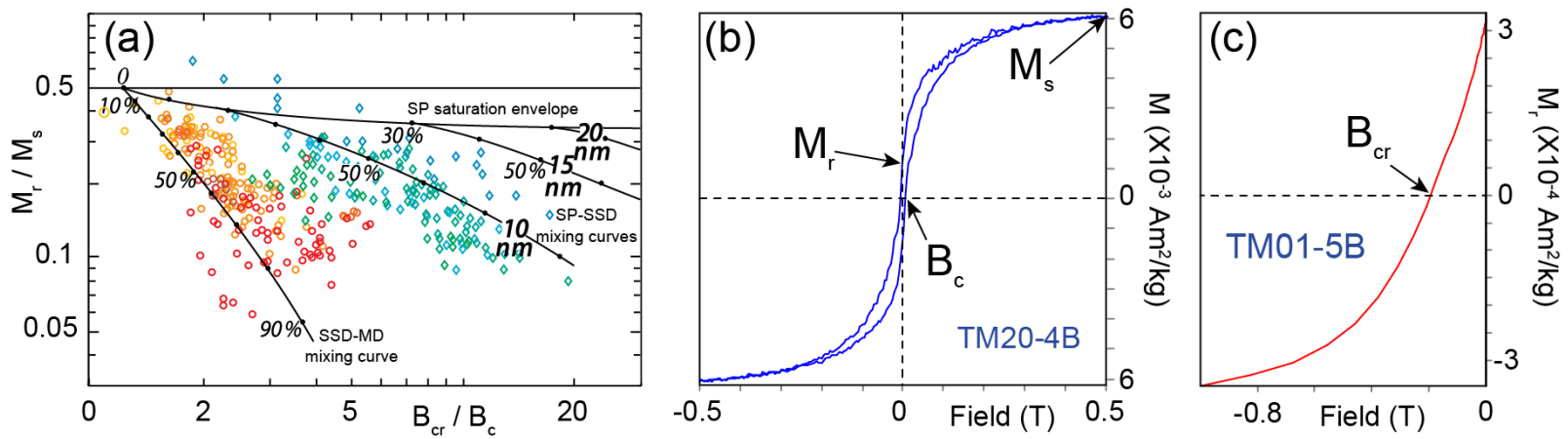

Figura 3.4 (a) Diagrama de Day mostrando calizas no remagnetizadas (colores cálidos) y calizas remagnetizadas (colores fríos) sobre las curvas de mezcla SSD-MD y SP-SSD (Dunlop, 2002a) respectivamente. (b) Ciclo de histéresis y (c) backfield de calizas remagnetizadas mostrando los parámetros utilizados para la representación en el diagrama de Day.

Figure 3.4 (a) Day plot showing no remagnetized carbonates (warm colors) and remagnetized ones (cold colors) over the SSD-MD and SP-SSD mixing curves (Dunlop, 2002a) respectively. (b) Hysteresis loop and (c) backfield of remagnetized limestones showing the parameters used in the Day plot. 
mezcla de dos fases minerales con diferente coercitividad, que genera curvas de histéresis con forma de 'cintura de avispa' (Tauxe et al., 1996), en este caso la magnetita SSD y la SP. La presencia de material SP hace que disminuya el valor de $\mathrm{B}_{\mathrm{c}}$ (obtenido del ciclo de histéresis y por tanto considerando magnetización inducida con aportación tanto de los granos SSD como de los SP), mientras que el valor de coercitividad remanente está controlado únicamente por los granos con remanencia (se obtiene de la curva de backfield), la magnetita SSD.

A lo largo de este trabajo, se han realizado estos experimentos en la Universidad de Burgos sobre roca total pulverizada por medio de una balanza de traslación de campo variable MMVFBT (Magnetic Measurements), y en el Institute for Rock Magnetism (IRM, Universidad de Minnesota) en roca total así como en los diferentes subproductos obtenidos en el proceso de extracción magnética por medio de los magnetómetros por vibración micro-VSM (Princeton Measurements) y de gradiente alterno de campo AGFM (Princeton Measurements).

\subsubsection{Experimentos a baja temperatura}

Estos experimentos se han realizado principalmente con el fin de caracterizar los subproductos obtenidos durante el proceso de extracción magnética. Para ello se ha utilizado el magnetómetro criogénico MPMS (Quantum design) que permite realizar diferentes rutinas de medida, midiendo tanto magnetización como susceptibilidad, en el rango de temperaturas entre 20-300 K. Con la aplicación de las diferentes rutinas se puede estimar la presencia o no de mineral magnético, así como el estado de dominios dominante.

\subsubsection{Doble adquisición de la IRM (DIRM)}

Las curvas de la adquisición de la magnetización remanente isoterma (IRM) consisten en aplicar campos, progresivamente más altos, y medir la magnetización remanente de la muestra estudiada. Este experimento, consistente en la aplicación doble de una IRM (DIRM), fue diseñado por Mitra et al. (2011) para la caracterización de la forma (uniaxial versus multiaxial) de las partículas magnéticas presentes en la muestra. Se basa en una doble medida en cada paso, primero aplicando el pulso magnético paralelo a un eje de la muestra y midiendo la magnetización remanente en dicho eje $\left(\mathrm{M}_{\mathrm{r}}(\mathrm{z})\right)$, y posteriormente aplicando el mismo campo sobre el mismo eje pero en sentido contrario $\left(\mathrm{M}_{\mathrm{r}}(-\mathrm{z})\right)$.

El experimento permite distinguir entre granos SSD con anisotropía multiaxial y uniaxial, controlados respectivamente por la anisotropía magnetocristalina y de forma (p. ej., Tauxe, 2010). En el caso de la magnetita, con una estructura cristalina tipo espinela, los SSD multiaxiales presentan tres direcciones de fácil imanación (ejes cristalográficos 111) y por tanto seis opciones para la magnetización espontánea, mientras que los granos con anisotropía uniaxial presentan un solo eje de fácil imanación paralelo a la elongación del cristal y por tanto dos posibilidades para la magnetización espontánea. Cabe indicar que una pequeña elongación en un cristal de magnetita (superior al 1.1) favorecerá la anisotropía uniaxial frente a la multiaxial (Winklhofer et al., 1997). 
Dicho lo anterior, el hecho de que al aplicar un campo magnético a una muestra se produzca un salto de la magnetización espontánea de cada cristal dependerá, por un lado, de la intensidad del campo (y la coercitividad del cristal), y por otro de la relación angular entre los ejes de fácil imanación y la dirección del campo aplicado. Cuando se aplica el experimento DIRM a una muestra con una población de partículas SSD uniaxiales, distribuidas de manera aleatoria (Fig. 3.5a), cada paso afectará a un determinado número de partículas que generarán una magnetización remanente

(a) DIRM sobre partículas uniaxiales

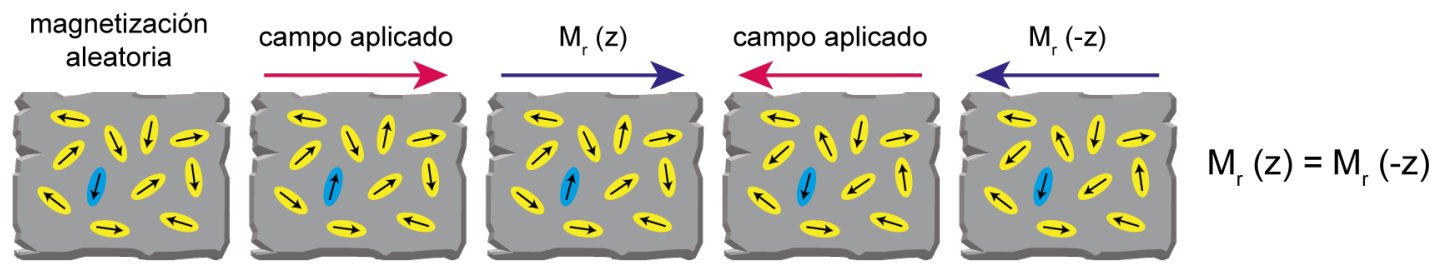

(b) DIRM sobre partículas multiaxiales
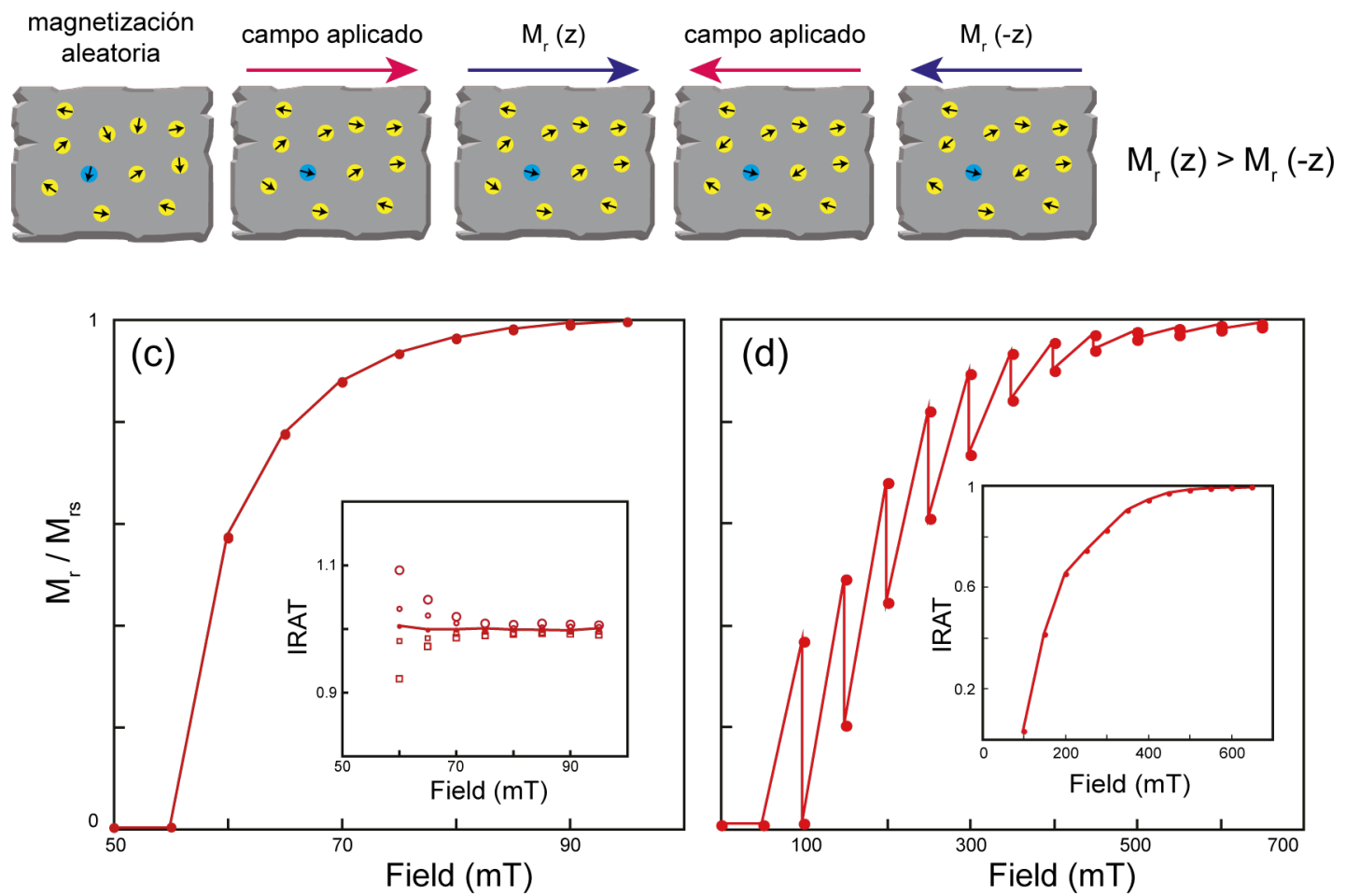

Figura 3.5 Esquema mostrando la base del experimento de la DIRM, para partículas uniaxiales (a) y multiaxiales (b). Se puede observar cómo en (a) la relación angular entre el campo aplicado y el eje magnetizado de cada partícula no cambia con el sentido del campo. Por el contrario, en (b) dicha relación cambia en algunas partículas (compárese la partícula azul en ambos ejemplos). Curvas de adquisición DIRM para (c) magnetita monodominio uniaxial y (d) hematites multiaxial mostrando los dos comportamientos antagónicos. Se muestra también el valor de IRAT para ambos ejemplos. (a) y (b) de Jackson y Swanson-Hysell (2012) y (c) y (d) de Mitra et al. (2011).

Figure 3.5 Sketch showing the base of the DIRM experiment for uniaxial (a) and multiaxial (b) particles. The angular relation between the net magnetization of each particle and the applied field is constant with independence of the sense of the applied field in (a), but changes in some particles in (b) as the blue one. Acquisition DRIM of a uniaxial single domain magnetite (c) and of a multiaxial hematite (d) showing the two antagonistic behaviors. (a) and (b) from Jackson and Jackson-Hysell (2012) and (c) and (d) from Mitra et al. (2011). 
determinada $\mathrm{M}_{\mathrm{r}}(\mathrm{z})$. Cuando se aplica el campo en la dirección contraria, todas las partículas que se habían visto afectadas en el paso anterior, también lo serán ahora, dado que el campo aplicado es el mismo y la relación angular entre los ejes de fácil imanación y el campo no ha variado. Por tanto, los valores de $\mathrm{M}_{\mathrm{r}}(\mathrm{z})$ serán iguales o similares a los de $\mathrm{M}_{\mathrm{r}}(-\mathrm{z})$. Por el contrario, si consideramos una población de partículas similar, pero con anisotropía multiaxial, la mencionada relación angular cambia entre ambos pasos. Esto es especialmente notable en los granos que presentaban la imanación original en un eje perpendicular al campo aplicado. Estos granos cambiarán su eje de imanación para un campo dado; sin embargo, tras el cambio de eje magnetizado, al aplicar el campo en sentido contrario, la relación angular habrá cambiado, siendo el eje de magnetización y la dirección del campo casi paralelos, y posiblemente no se reorientará con el nuevo hasta campos más elevados. Esto deriva en valores más bajos en $\mathrm{M}_{\mathrm{r}}(-\mathrm{z})$ que en $\mathrm{M}_{\mathrm{r}}(\mathrm{z})$. Por tanto, las curvas de adquisición DIRM (Fig. 3.3b), así como el valor de IRAT, el ratio entre $\mathrm{M}_{\mathrm{r}}(\mathrm{z})$ y $\mathrm{M}_{\mathrm{r}}(-\mathrm{z})$, son una herramienta para estimar el tipo de anisotropía de las partículas magnéticas presentes en una roca. Para un análisis más detallado del método, así como para la valoración en términos energéticos de ambos comportamientos, el lector es referido a Mitra et al. (2011).

Estos experimentos se han realizado en la Universidad de Burgos, usando un magnetómetro de impulso M2T-1 (Ferronato) para aplicar los campos, y un magnetómetro criogénico (2G-755) para la medida de la magnetización remanente.

\subsubsection{Adquisición de la ARM}

El análisis de las curvas de adquisición de la magnetización remanente anhisterética (ARM) permite hacer algunas aproximaciones sobre las partículas magnéticas que portan la remagnetización en una roca. El análisis se basa tanto en la forma de la curva (más o menos lineal) como en la intensidad de la misma (Sugiura, 1979).

Si observamos diferentes curvas de adquisición de la ARM (Fig. 3.6), podemos apreciar que las curvas 1 y 2 alcanzan mayores valores de magnetización para campos inferiores, y que dichas curvas no tienen una pendiente constante. Por el contrario, las curvas 5 y 6 presentan una pendiente más regular y valores de magnetización inferiores. Sugiura (1979) relaciona esto con la interacción y/o mayores tamaños de granos en las últimas frente a las primeras. Jackson y Swanson-Hysell (2012) han observado comportamientos similares a las primeras en calizas remagnetizadas.

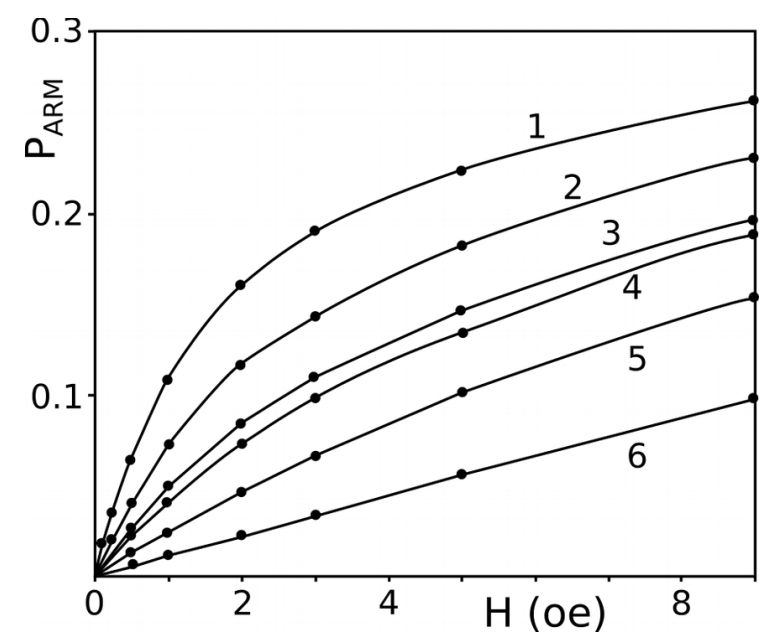

Fig. 3.6 Curvas de adquisición de la ARM en seis muestras con diferente estado de dominios. A partir de Sugiura (1976).

Figure 3.6 ARM acquisition curves for six samples with different domain state. Redraw from Sugiura (1976). 


\subsubsection{Caracterización magnética de la susceptibilidad}

La propia comparación entre subfábricas magnéticas, y los resultados de los experimentos realizados para caracterizar los portadores de la remanencia, proporcionan gran cantidad de información sobre los portadores de la susceptibilidad magnética. No obstante, y dado el alto grado de heterogeneidad observado en la RT-ASM, se han realizado experimentos específicos para tratar de caracterizar con detalle los diferentes portadores de la susceptibilidad y relacionar esta información con los diferentes comportamientos observados en la RT-ASM.

Con el fin de conocer qué minerales son los portadores de la susceptibilidad en las distintas subfábricas medidas, se han realizado experimentos específicos concretamente enfocados a caracterizar la fracción paramagnética y la ferromagnética s.l., y dentro de esta última, el peso relativo de los granos SP en la susceptibilidad total. Es importante mencionar que todos estos experimentos son indicadores de la contribución mineralógica sobre la susceptibilidad total, no sobre las fábricas magnéticas, puesto que estas últimas dependen tanto de la susceptibilidad como de la anisotropía y distribución de las partículas.

Se realizaron curvas de variación de la susceptibilidad con la temperatura (entre -196 y 700 ${ }^{\circ} \mathrm{C}$ ) y se calcularon los ratios entre la susceptibilidad a temperatura de nitrógeno líquido $\left(-196{ }^{\circ} \mathrm{C} \mathrm{o}\right.$ $77 \mathrm{~K}$ ) y temperatura ambiente (Fig. 3.7). Estos ratios, así como el ajuste de las curvas mediante el programa Cureval 8.0 (Chadima y Hrouda, 2009), permiten realizar una estimación sobre la contribución de los minerales paramagnéticos y ferromagnéticos s.l. a la susceptibilidad. Para ello, se utilizó el puente de susceptibilidad KLY4-S (AGICO) con un criostato CSL (desde -195 a $0{ }^{\circ} \mathrm{C}$ ) y un horno CS3 (rango de temperaturas entre 25 y $700{ }^{\circ} \mathrm{C}$ ). Además, los valores de la susceptibilidad a bajo campo y la anhisterética fueron comparadas con el comportamiento de la RT-ASM. Finalmente, y dada la propiedad intrínseca de los minerales SP, que varían su contribución a la susceptibilidad dependiendo de la frecuencia del campo al que son sometidos, la fracción SP fue estimada mediante la parámetro de variación de la susceptibilidad con la frecuencia (Dearing et al., 1996). Para ello se utilizó el puente de susceptibilidad MS2 (Bartington) que permite medir la susceptibilidad a dos frecuencias: $0.465 \mathrm{kHz}$ y $4.65 \mathrm{kHz}$.

\subsection{Mineralogía magnética de rocas ígneas}

Se han realizado varios experimentos de magnetismo de rocas con el fin de conocer la mineralogía magnética de los gabros jurásicos del Alto Atlas Central. Han sido muestreadas un total de 33 estaciones paleomagnéticas, pero sólo se ha podido aislar la componente característica en 19 de ellas. Los experimentos de magnetismo de rocas han sido enfocados tanto a caracterizar mineralógicamente los portadores de la remanencia y la susceptibilidad, como a tratar de entender los diferentes comportamientos paleomagnéticos observados entre las estaciones.

En la Universidad de Burgos se han realizado diferentes experimentos sobre roca total, tales como curvas de adquisición de la IRM, curvas de variación de la magnetización inducida con la temperatura, ciclos de histéresis y backfield mediante la balanza de traslación de campo variable 

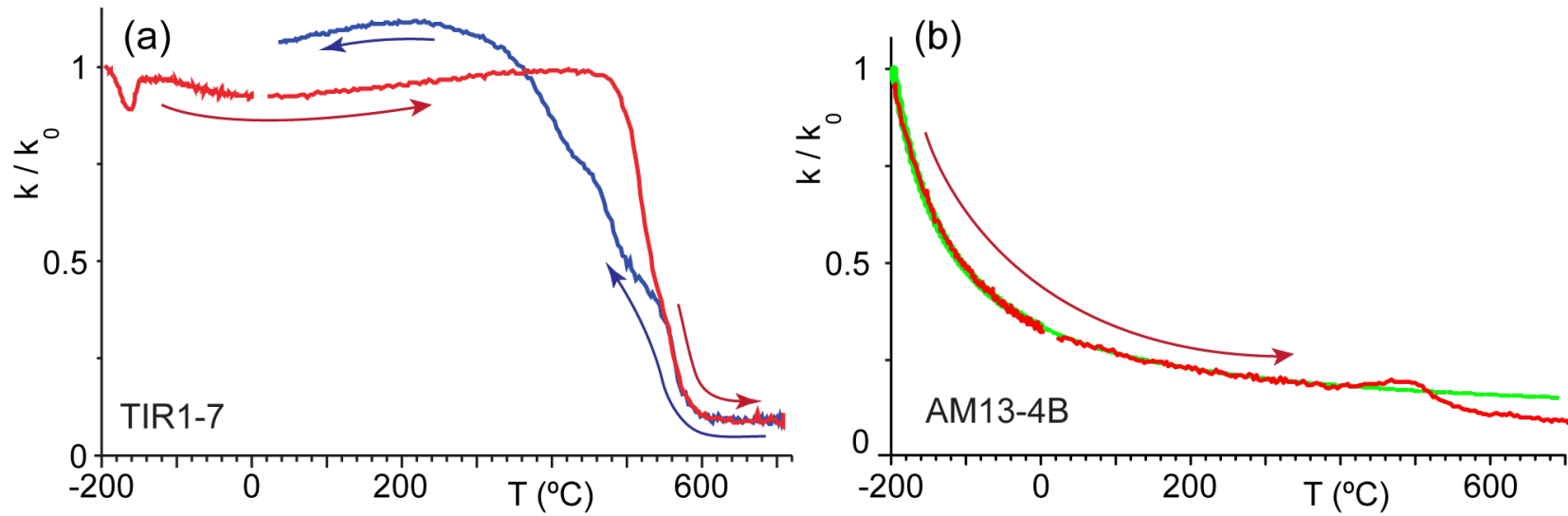

Figura 3.7 Curvas de variación de la susceptibilidad frente a la temperatura en (a) un gabro con predominio ferromagnético y (b) una caliza con contribución paramagnética dominante. En rojo, las curvas de calentamiento, en azul, las de enfriamiento, y en verde, el ajuste hiperbólico a la fracción paramagnética.

Figure 3.7 Temperature-dependent susceptibility curves showing (a) the ferromagnetic behavior in a gabro and (b) the paramagnetic behavior in a limestone. In red, the heating curves; in blue, the cooling ones; in green, the best fit to the paramagnetic behavior.

MMVFBT. Se ha realizado la desimanación térmica de la IRM impartida en tres ejes ortogonales (Lowrie, 1990); para ello, se aplicaron campos continuos sobre los ejes z, y, x de 2 T, 0.4 T, y 0.25 T respectivamente mediante un imanador de impulso M2T-1 (Ferronato) y se midió la magnetización remanente mediante el magnetómetro criogénico 2G-755 tras pasos sucesivos de desimanación térmica.

En la Universidad Complutense de Madrid, el Dr. Carlos Rossi realizó una separación mecánica de cristales de silicatos de una de las estaciones de los gabros. Los cristales de plagioclasa, anfíbol y piroxeno obtenidos fueron sometidos a diferentes experimentos en el Institute for Rock Magnetism en la Universidad de Minnesota. Concretamente, se realizaron curvas de susceptibilidad y magnetización a baja temperatura mediante el magnetómetro criogénico MPMS (Quantum Design), y curvas de histéresis y backfield mediante el magnetómetro de gradiente alternante AGFM (Princeton Measurements). Los parámetros de la histéresis obtenidos en los experimentos realizados sobre los cristales de silicato aislados fueron comparados con los obtenidos en roca total mediante el diagrama de Day (Day et al., 1977).

Con el fin de caracterizar los portadores de la susceptibilidad y relacionar las fábricas magnéticas con la petrofábrica, se realizaron diversos experimentos además de la comparación de subfábricas magnéticas. En la Universidad de Zaragoza se observaron mediante microscopio petrográfico 18 láminas delgadas y su petrofábrica fue comparada con los resultados de las fábricas magnéticas. Además, para calcular la importancia de la fracción paramagnética y ferromagnética en la susceptibilidad total, se realizaron curvas de variación de la susceptibilidad con la temperatura (entre -196 y $700{ }^{\circ} \mathrm{C}$ ) y se calcularon las ratios entre la susceptibilidad a temperatura de nitrógeno líquido (-196 ${ }^{\circ} \mathrm{C}$ o $\left.77 \mathrm{~K}\right)$ y temperatura ambiente. Para ello, se utilizó el puente de susceptibilidad KLY4-S (AGICO) con un criostato CSL (desde -195 a $0{ }^{\circ} \mathrm{C}$ ) y un horno CS3 (rango de temperaturas entre 25 y $700{ }^{\circ} \mathrm{C}$ ). 


\section{Metodología II}

\section{Círculos menores y restitución}

4.1. pySCu: a new python code for analyzing remagnetizations directions by means of

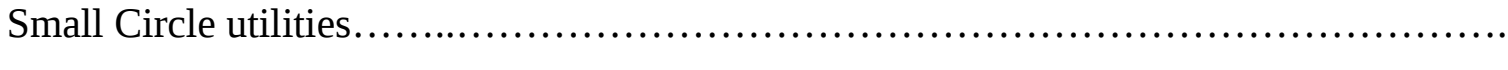

4.2 Vertical axis rotations and non-coaxial horizontal axes rotations. To what extent do SC tools work when the initial assumptions are not fulfilled?............................. 

La herramienta de los círculos menores (small circles, SC) es uno de los pilares en los que se basa esta tesis doctoral. En el apartado 4.1 se realiza una introducción al desarrollo histórico de los métodos basados en los SC, así como las ventajas que presentan respecto a los clásicos test del pliegue (e.g., Graham, 1949) más ampliamente usados en la literatura científica. En este capítulo se presentan tres importantes aportaciones de esta tesis respecto a las técnicas de los SC: (i) aplicación de la técnica de bootstrap al cálculo de la dirección de remagnetización, permitiendo caracterizar la incertidumbre (Kent, 1982) asociada a la dirección calculada. (ii) Se presenta un nuevo programa informático, pySCu, programado en lenguaje Python, que permite aplicar los métodos SC integrando las mejoras metodológicas. (iii) Se realiza una evaluación de la incertidumbre dependiendo de la mayor o menor concentricidad de los SC y su relación con la elipse de confianza; del mismo modo, se proponen unas pautas de uso y análisis de los SC para que sean utilizados de la manera más rigurosa posible.

Estos métodos se basan en la asunción de que la desviación de las direcciones paleomagnéticas desde la dirección original de la remagnetización se ha producido al ser rotadas según los ejes definidos por las direcciones de estratificación, definiendo los SCs; esto ocurre cuando los ejes de rotación previos y posteriores a la adquisición de la remagnetización son los mismos. Sin embargo es habitual en la naturaleza la presencia de rotaciones de eje vertical o la presencia de varios ejes de rotación diferentes (plegamiento no coaxial) afectando a las rocas de una cadena montañosa o una cuenca sedimentaria; este proceso hace obsoleta la premisa de que las direcciones paleomagnéticas únicamente han podido encontrarse sobre los SCs y que por tanto generará errores en el uso de dichos métodos. En el apartado 4.2. se analiza la influencia de estos procesos (rotaciones de eje vertical y no coaxialidad entre ejes de rotación de eje horizontal) en el cálculo de la dirección de remagnetización y de los paleo-buzamientos. En general, se puede indicar que la presencia de rotaciones de eje vertical tiene una fuerte influencia en ambos cálculos, pero generando pautas características que pueden permitir detectar la presencia de este proceso cuando se trabaje con datos reales. Por el contrario, la presencia de dos ejes horizontales de rotación diferentes genera errores menores, pero no generan pautas características que puedan permitir detectar el proceso de manera sencilla. 

Research paper

\title{
pySCu: A new python code for analyzing remagnetizations directions by means of small circle utilities
}

\author{
Pablo Calvín ${ }^{\text {a, }}$, Juan J. Villalaín ${ }^{\text {a }}$, Antonio M. Casas-Sainz ${ }^{\text {b }}$, Lisa Tauxe ${ }^{\text {c }}$, Sara Torres-López ${ }^{\text {a }}$ \\ ${ }^{a}$ Dep. de Física, Lab. de Paleomagnetismo, Universidad de Burgos, Spain \\ ${ }^{\mathrm{b}}$ Dep. de Ciencias de la Tierra, Universidad de Zaragoza, Spain \\ c Scripps Institution of Oceanography, University of California San Diego, La Jolla, CA 92093-0220, USA
}

\section{A R T I C L E I N F O}

\section{Keywords:}

Small circle

SCI method

Fold-test

Remagnetization

Synfolding

pySCu

\begin{abstract}
A B S T R A C T
The Small Circle (SC) methods are founded upon two main starting hypotheses: (i) the analyzed sites were remagnetized contemporarily, acquiring the same paleomagnetic direction. (ii) The deviation of the acquired paleomagnetic signal from its original direction is only due to tilting around the bedding strike and therefore the remagnetization direction must be located on a small circle (SC) whose axis is the strike of bedding and contains the in situ paleomagnetic direction. Therefore, if we analyze several sites (with different bedding strikes) their SCs will intersect in the remagnetization direction.

The SC methods have two applications: (1) the Small Circle Intersection (SCI) method is capable of providing adequate approximations to the expected paleomagnetic direction when dealing with synfolding remagnetizations. By comparing the SCI direction with that predicted from an apparent polar wander path, the (re)magnetization can be dated. (2) Once the remagnetization direction is known, the attitude of the beds (at each site) can be restored to the moment of the acquisition of the remagnetization, showing a palinspastic reconstructuion of the structure. Some caveats are necessary under more complex tectonic scenarios, in which SC-based methods can lead to erroneous interpretations. However, the graphical output of the methods tries to avoid 'black-box' effects and can minimize misleading interpretations or even help, for example, to identify local or regional vertical axis rotations. In any case, the methods must be used with caution and always considering the knowledge of the tectonic frame.

In this paper, some utilities for SCs analysis are automatized by means of a new Python code and a new technique for defining the uncertainty of the solution is proposed. With pySCu the SCs methods can be easily and quickly applied, obtaining firstly a set of text files containing all calculated information and subsequently generating a graphical output on the fly.
\end{abstract}

\section{Introduction}

The paleomagnetic fold-test (Graham, 1949) is a basic tool for recognizing pre-, syn- or post-folding magnetizations. However, for structural reconstructions using synfolding remagnetizations (defining "synfolding" as either a magnetization acquired between two different folding events -i.e. between the end of the first folding stage and before the beginning of the second one, or during the development of a fold in a single event-) this method cannot be used because the incremental fold-test (McCabe and Elmore, 1989; McFadden, 1990; Bazhenov and Shipunov, 1991; Watson and Enkin, 1993; Tauxe and Watson, 1994) assumes proportional folding at the different limbs and this is an assumption not necessarily met in nature (e.g. Suppe, 1983; Cairanne et al., 2002; Delaunay et al., 2002; Villalaín et al., 2003).

To overcome the (sometimes) erroneous assumption of proportional folding and to obtain the correct restoration of bedding, some authors proposed more detailed analyses with non-symmetric unfolding of the different fold limbs. These efforts are based on the fact that the transformation of a paleomagnetic vector from geographic to stratigraphic coordinates (i.e. tilt correction) implies the rotation of the vector along a small circle (SC) whose axis is the strike of the bed and the amount of rotation is the dip angle. In this way, McClelland-Brown (1983) treated synfolding remagnetizations by comparing different percentages of unfolding of the limbs and analyzing the path of the paleomagnetic direction upon the corresponding SC. Surmont et al. (1990) observed maximum clustering of the paleomagnetic direction after applying partial

\footnotetext{
* Corresponding author. Dep. Física, Escuela Politécnica Superior, Río Vena, Universidad de Burgos, Av. Cantabria s/n, 09006 Burgos, Spain.

E-mail address: calvinballester@gmail.com (P. Calvín).
} 


\section{(a) Parameters of one SC}

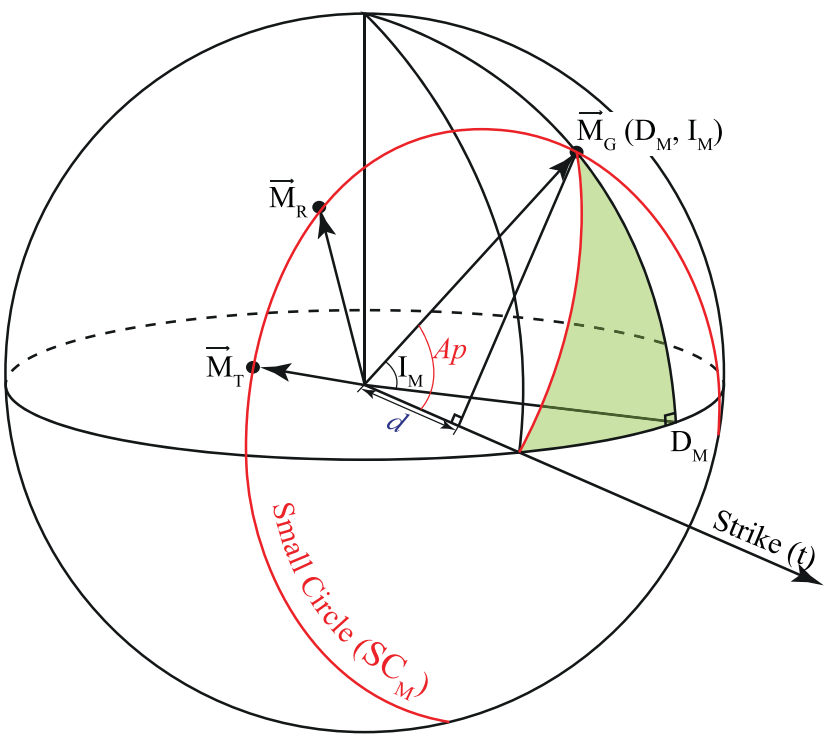

$\overrightarrow{\mathrm{M}}_{\mathrm{G}}$ : In situ magnetization vector

$\overrightarrow{\mathrm{M}}_{\mathrm{T}}$ : ATBC magnetization vector

$\overrightarrow{\mathrm{M}}_{\mathrm{R}}$ : Remagnetization vector

$\mathrm{SC}_{\mathrm{M}}:$ Small circle associated with $\overrightarrow{\mathrm{M}}$ $A p$ : Apical angle of the SC

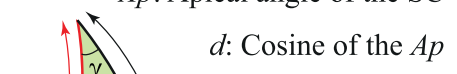

(b) P, Q and angular distance ( $\alpha$ ) between P and SC

$\mathrm{SC}_{\mathrm{M}}:$ Small circle whose axis is ' $t$ ' and contains $\overrightarrow{\mathrm{M}}$ Q: nearest point between $\mathrm{P}$ and $\mathrm{SC}_{\mathrm{M}}$

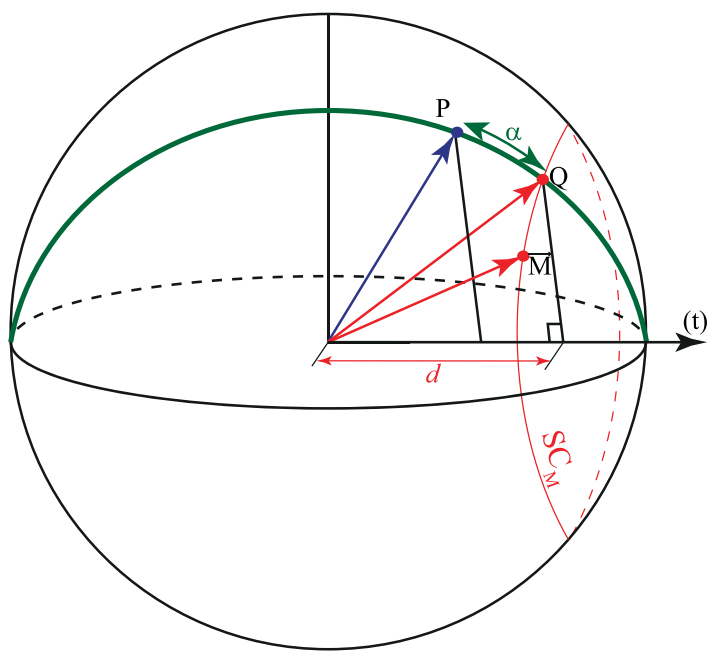

Looking perpendicular to the great circle in which $\mathrm{P}$ and strike are (the green one)

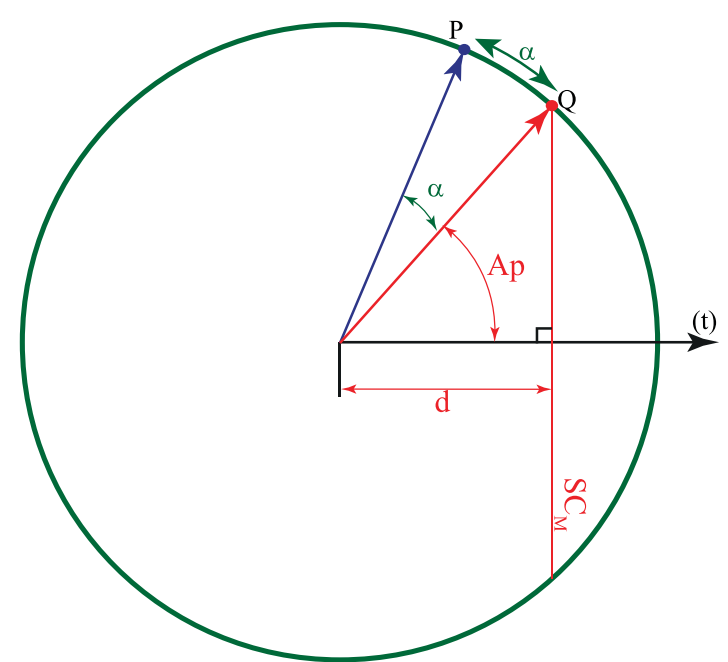

Fig. 1. (a) A small circle (SC) associated with one paleomagnetic site is defined by the strike of the bedding ( $t$ ) and by the direction of the magnetization (M) and therefore it can be parametrized by $t$ and the apical angle (Ap) of the SC which is equal to the angle between the magnetization and strike vectors. Working in a unit sphere, Ap can be defined by its cosine $d$. (b) $\alpha$ is the minimum angular distance between the given direction $\mathrm{P}$ and the $\mathrm{SC}_{\mathrm{M}}$ and is defined as the angle between $\mathrm{P}$ and $\mathrm{Q}$, the latter being the intersection between the $\mathrm{SC}_{\mathrm{M}}$ and the great circle that contains $\mathrm{P}$ and $\mathrm{t}$.

tilt corrections at the sites (i.e. the space region showing higher concentration of intersection between the SC); they considered this cluster as the remagnetization direction and the discrepancy with the expected direction was attributed to vertical axis rotation. A similar work was presented by Villalaín et al. (1992) who calculated a local remagnetization direction as intersection of the SCs and restored each limb separately.

An important forward step was done by Shipunov (1997) who clearly established the Small Circle Intersection (SCI) as a useful method to calculate local remagnetization directions. When the paleomagnetic direction corresponds with a synfolding remagnetization (i.e. the magnetization was acquired after partial folding of beds) and supposing only tilting of the beds around a horizontal axis (e.g. absence of differential vertical axis rotation between each paleomagnetic site), the actual local direction of the remagnetization must be coincident for all sites and located along each SC. In other words, the small circles must show a common direction (or narrow spatial distribution), corresponding to the local direction of the remagnetization (Shipunov, 1997).

More improvements for the SCI method were made by Henry et al. (2004), who established the reliability of the method depending on the geological conditions (e.g. the distribution of strikes of the beds), and modified the way to calculate the remagnetization direction. They also 

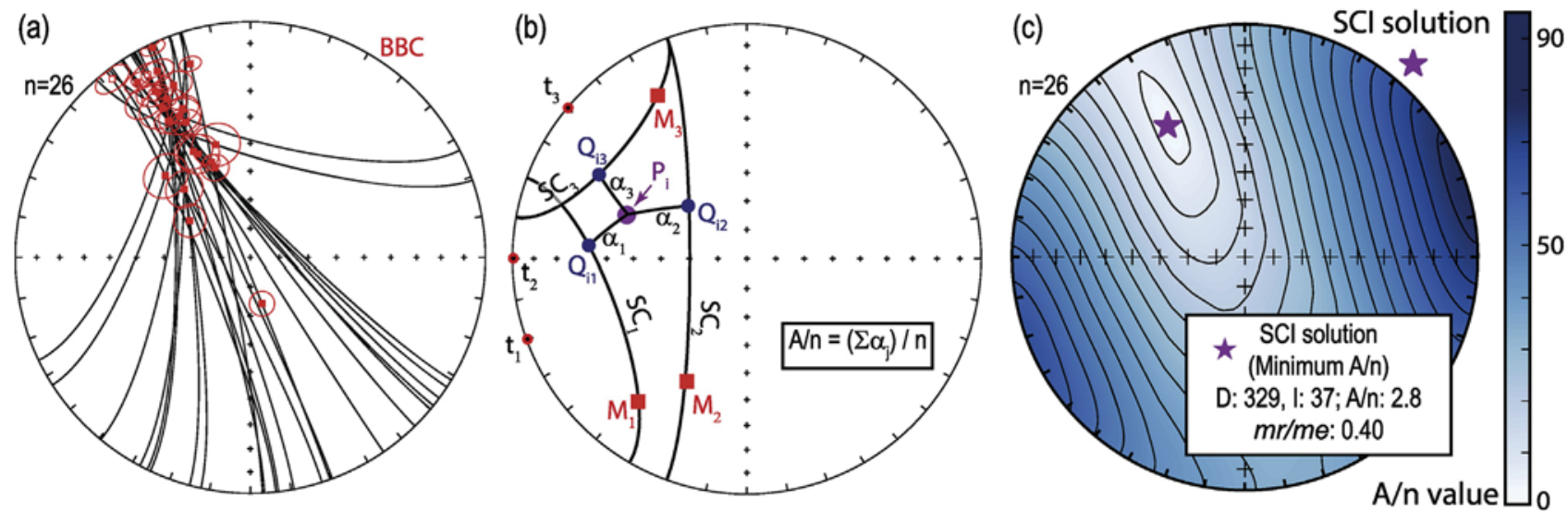

Fig. 2. Lower hemisphere, equal area projections showing the basis of the SCI method. (a) Paleomagnetic dataset showing the paleomagnetic directions (before bedding correction, BBC) and their respective SCs. (b) The parameter $A / n$ is the sum of all $\alpha_{\mathrm{j}}$ normalized by the number of sites and can be calculated for the directions susceptible to be the remagnetization direction. (c) $A / n$ contour plot. The remagnetization direction corresponds with the minimum value of $A / n$ (SCI solution). The ratio $m r / m e$ between the real and the possible number of intersection is also indicated. Paleomagnetic data come from remagnetized limestones (see supplementary data).

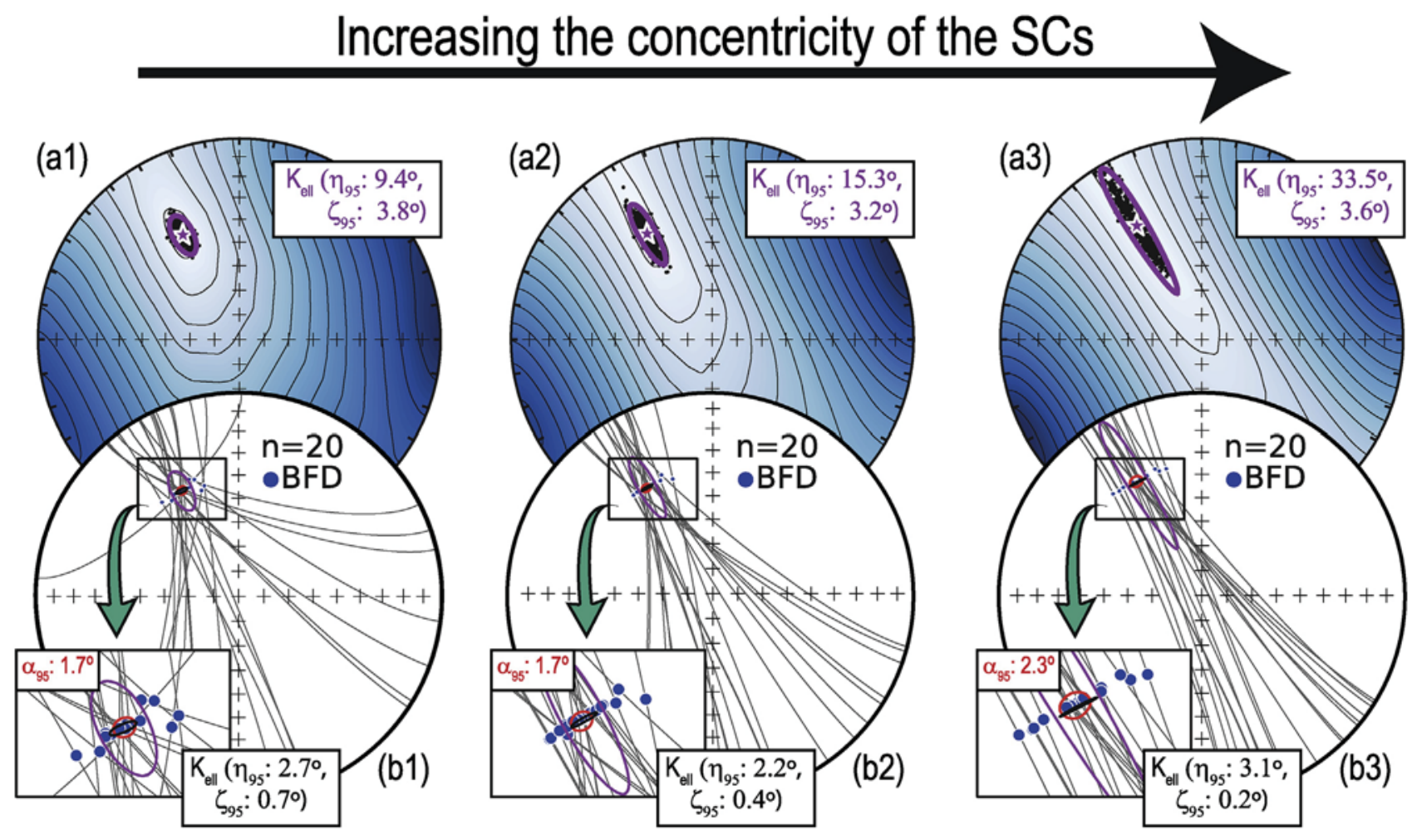

Fig. 3. (a) A/n contour plots obtained from three examples of SCI solution (star) from three different distributions of 20 SCs with different degree of concentricity. The calculated SCIs solutions (small black points; i.e. different solutions considering the uncertainty coming from bedding and paleomagnetic data) and their $95 \%$ confidence ellipses and statistical parameters (Kent, 1982). (b) Equal area projections showing the three corresponding SC distributions and the best fit directions (BFD). 95\% confidence circle (Fisher, 1953) and 95\% confidence ellipse (Kent, 1982) corresponding to the 20 BFDs are depicted for comparison. Statistical parameters $\alpha_{95}$ and maximum and minimum semi-angles ( $\eta_{95}$ and $\zeta_{95}$ ) are also indicated. The used paleomagnetic dataset can be found in the supplementary material.

provided a useful discussion about the uncertainties in the calculation of the paleomagnetic direction (a weak point in paleomagnetism in general, and in the SCI method, in particular).

Finally, Waldhör (1999) and Waldhör and Appel (2006) substantially improved the SCI method as a tool to calculate remagnetization directions. They discussed widely the applicability of the SCI method, focusing their work in testing it under different conditions, such as the distribution of the strike of the beds and the corresponding dispersion pattern of the intersections. In addition, these authors introduced the statistic A, the sum of the minimum angle between any direction and each SC. The direction minimizing $A$ is assumed to be the remagnetization direction. Moreover, the distribution of A values (or $\mathrm{A} / \mathrm{n}$, normalizing the $\mathrm{A}$ value for the number of sites $\mathrm{n}$ ) for all directions can be used as an indicator of dispersion of the SC distribution, or at least as an indicator of the reliability of the remagnetization direction.

Following this line of logic, an important concept is the best fit direction (BFD) which is the vector located along each SC closest to the calculated remagnetization direction. The angle between the BFD and the paleomagnetic direction for each site before bedding correction (BBC) is the unfolding angle (Villalaín et al., 2003) and the angle between the BFD and the paleomagnetic direction after total bedding correction (ATBC) is the paleodip of the bed (i.e. the dip of the beds to the moment of the 
acquisition of the remagnetization). This was the workflow followed by Villalaín et al. (2003) who introduced the term of 'asymmetrical solution', consisting of differential unfolding of each limb depending of the calculated paleodip. Hence, the reconstruction of the beds through this method offers a unique image of the geological structures at the moment of the remagnetization.

Since its introduction, several investigators have presented different applications of the SC methods. Meijers et al. (2011) use it as a conventional fold test. Others use SC analysis for reconstructing the paleo-geometry of sedimentary basins (Villalaín et al., 2003; Soto et al., 2008, 2011; Casas et al., 2009; Torres-López et al., 2016), for separating deformation generated under different tectonic phases (Smith et al., 2006) or for relative dating of geological structures (Calvín et al., 2017). An extended review of the restoration methodology by using the SC methods (focused in intraplate basins) can be found in Villalaín et al. (2016). Promising results show also the applicability of the SCI method in geological frameworks with regional vertical axis rotations (VARs) generated after the acquisition of the remagnetization (e.g. Waldhör et al., 2001; Antolín et al., 2012; Rouvier et al., 2012). These VARs are added to the tilting recorded by the beds. In this context, and starting from the knowledge of an external paleomagnetic reference direction, it is possible to calculate the amount of tilting and VAR recorded by the rocks; however, more knowledge about the behavior of the SCs methods under tectonic frames affected by VAR is necessary to avoid misleading interpretations. Finally, another use derived from the calculation of the paleomagnetic direction is the dating of the remagnetization by comparison with the Apparent Polar Wander Path (APWP) in local coordinates (e.g. Henry et al., 2001; Gong et al., 2009; Torres-López et al., 2014). Needless to say that the presence of younger regional tilting or VARs will complicate this task (e.g. Jordanova et al., 2001).

In summary, the inherent uncertainty of the tectonic correction in synfolding remagnetizations makes analysis using the SC methods useful for inferring paleomagnetic directions. One of the main advantages of the SC methods for structural reconstructions based on synfolding remagnetizations lies in the fact that it does not assume proportional unfolding in each limb. Moreover, the SC offers the possibility of a graphical output allowing us to explore complex situations while minimizing possible "black-box" effects. These are two key points, while the classical and progressive fold-test can be used to check the primary or secondary origin of the magnetization, the SC methods have the potential for additional information. If the required external conditions for applying the methods are fulfilled (actually, or as a working hypothesis), they allow the calculation of the direction of a remagnetization, and of restoring each site separately to the moment of its acquisition.

The main problem for the application of the SC methods was the absence of software to do the necessary calculations in an straightforward way. Only two unpublished software packages, one of them written by B. Henry (IPGP, Paris) and another by M. Waldhör (UT, Tübingen) as an excel spreadsheet, have allowed application of the SCI method to paleomagnetic datasets, although they do not provide restoration utilities. Recently, the new version of VPD software (Ramón et al., 2017) also allows application of the SCI method. Therefore, although it is certain that many researchers are grateful for these programs, the absence of user-friendly, open source software has precluded widespread application of the SC methods and its regular use has been restricted to a few research groups (IPGP of Paris -France-, Tübingen University -Germany-, Burgos and Zaragoza Universities -Spain-).

In this paper, we present pySCu as the new Python-based software package which allows easy calculation of the remagnetization direction (SCI solution) for a dataset and provides the paleo-dip of each site (for bedding restoration) among other parameters. In this way, we propose (and we consider it necessary) the routine use of this method in magnetotectonic investigations in the same way that the classical fold test has been used traditionally. The software is based on the iterative method for calculating the remagnetization direction used in the previous software, especially Waldhörs spreadsheet. In addition, pySCu provide an
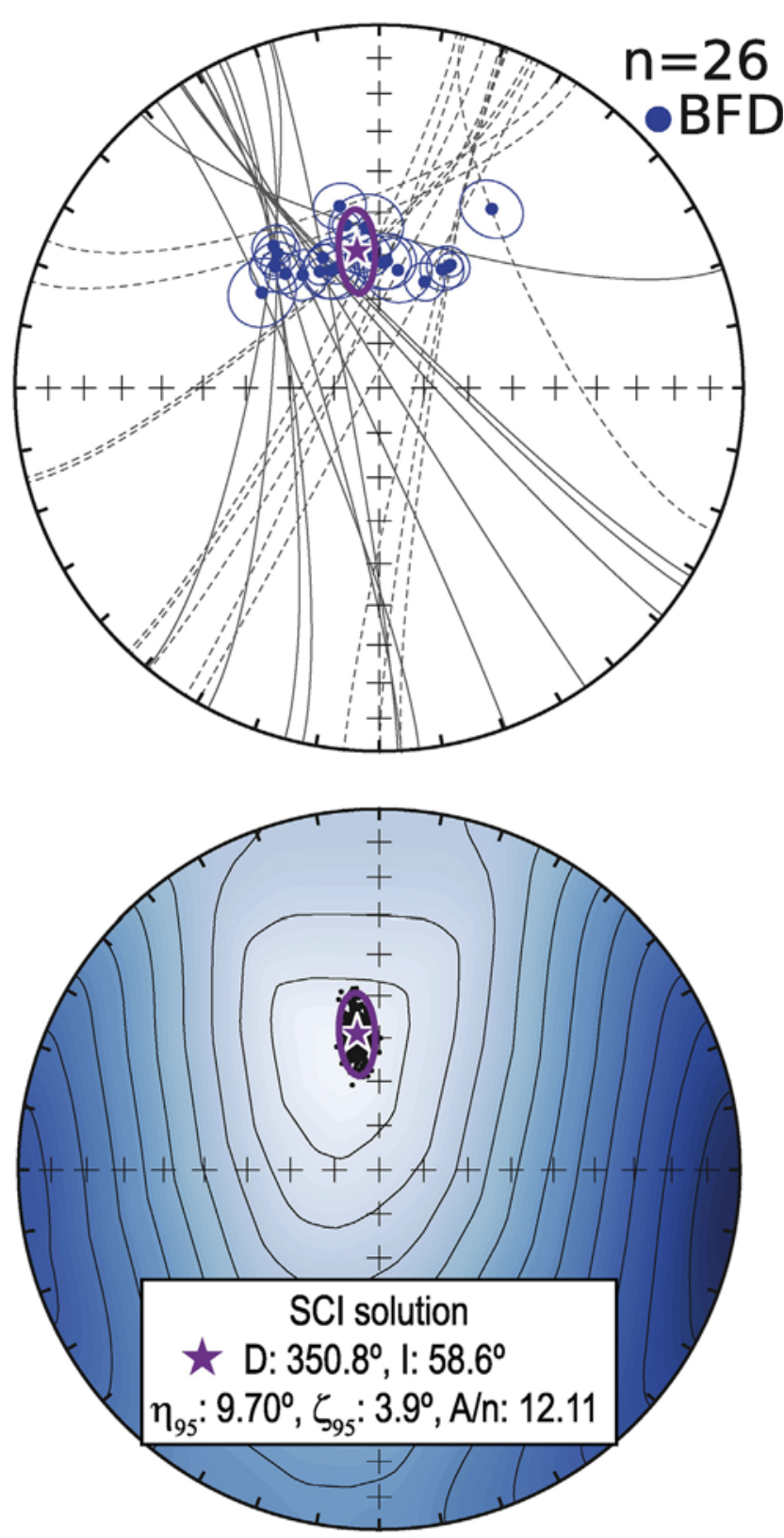

$\mathrm{mr} / \mathrm{mp}=0.38 ; \bullet \mathrm{SCls}$ solutions $(\mathrm{n}=500)$

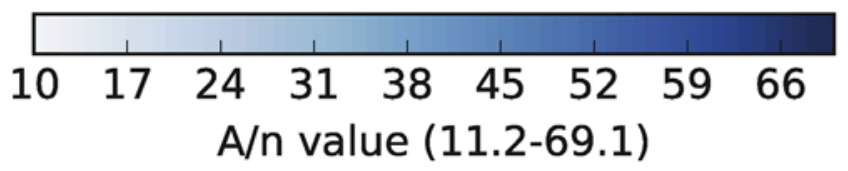

Fig. 4. Equal area projection showing the SCs and the best fit directions (BFD) of the same dataset shown in Fig. 2, in which some data (dashed SC) have been artificially rotated $50^{\circ}$ according to a clockwise vertical axis rotation. Note that there are two concentrations of intersections corresponding with both populations easily identifiable by visual inspection. However, the contour plot of $\mathrm{A} / \mathrm{n}$ shows a unique relatively well defined SCI solution. This is not correct because it is calculated from two datasets with different intersections as can be recognized in the SC distribution. In any case, by way of example of how to show the calculated SCI solution, it is shown together with the statistical parameters ( $\eta_{95}$ and $\zeta_{95}$ are the major and minor semi-angles according Kent -1982- and A/n is the parameter introduced by Waldhör and Appel -2004-). The used paleomagnetic dataset can be found in the supplementary material.

uncertainty ellipse for the SCI solution on the basis of parametric bootstrapping techniques. Besides, it follows the philosophy of the new PmagPy software package (Tauxe et al., 2016) with open source code 

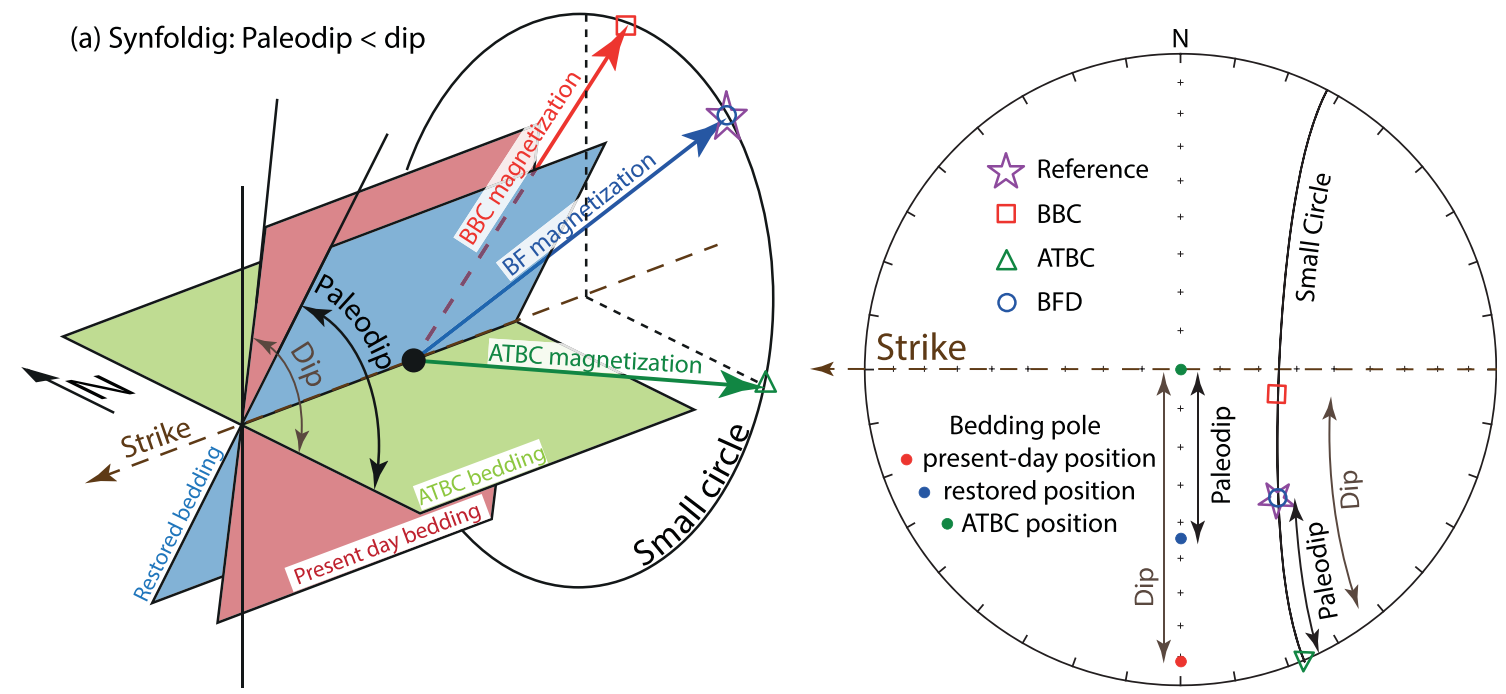

(b) Synfoldig: Paleodip > dip

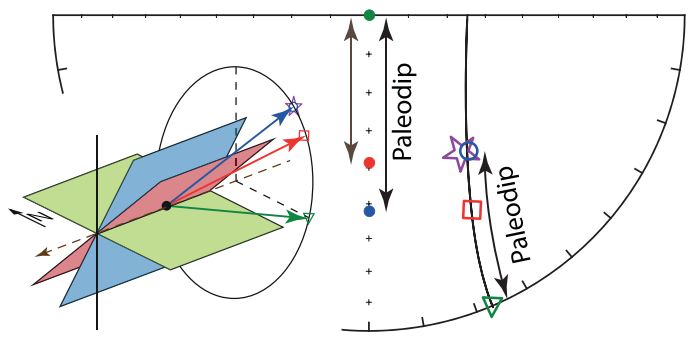

(d) Prefolding: Paleodip $=0^{\circ}$

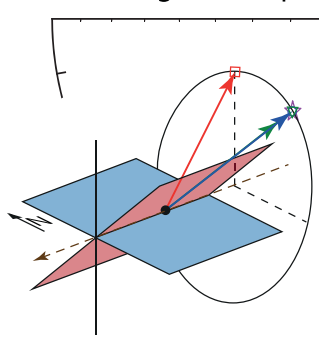

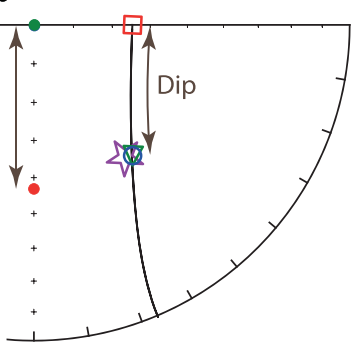

(c) Synfoldig: Change of dip sense

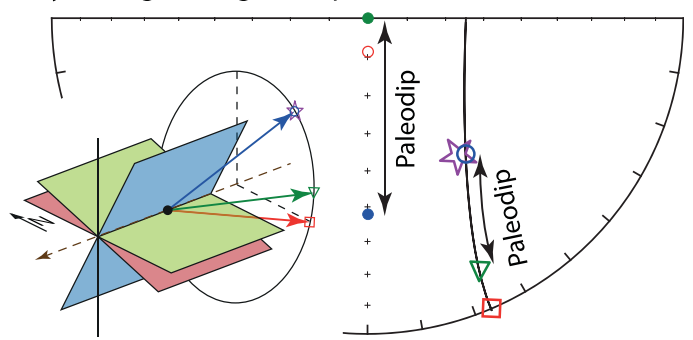

(e) Postfolding: Paleodip = dip

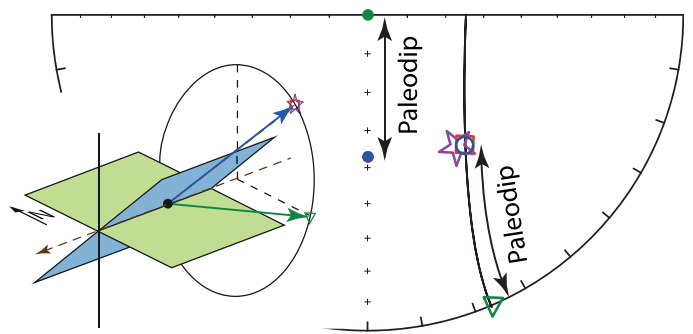

Fig. 5. Different examples of paleodip restorations depending of relationship of timing between tilting and acquisition of the remagnetization: (a), (b) and (c) show synfolding remagnetizations with different tilting histories, (d) and (e) show pre-folding and post-folding remagnetization respectively. Each situation illustrates the relationship between bedding and paleomagnetic direction with a 3D sketch and in equal area projection. Red, blue and green correspond respectively with BBC, BFD and ATBD paleomagnetic directions. In equal area projection, solid symbols are represented in the lower hemisphere and hollow symbols in the upper one; note that the reference direction has negative inclination. (For interpretation of the references to colour in this figure legend, the reader is referred to the web version of this article.)

which can be easily modifiable for specific cases or for future improvements of the method; in fact, the drawing module (pySCu_draw.py) uses code from PmagPy to avoid repeating this code with the same aim.

\section{Theoretical background}

\subsection{Definition of parameters}

Small circles (SCs) are the key of the SC methods. One SC corresponds to the path followed by the paleomagnetic direction with progressive rotation around an axis parallel to the bedding strike (Fig. 1a). For each site, the SC is defined by the bedding strike ( $t$, according to the right hand rule -RHR-) and the in situ magnetization (i.e. the SC that contains the magnetization and whose axis is $t$ ) (Fig. 1a). Therefore, each SC can be parametrized by $t$ and its apical angle $A p$ (or by $d$, the cosine of $A p$, since calculations are performed on a unit sphere). $A p$ is the angle between the vector magnetization and the strike.

The program works by minimizing angular distances. For this purpose, it must calculate the minimum angular distance $(\alpha)$ between different directions (P, directions susceptible of being the remagnetization direction, see next subsection) and each SC (Fig. 1b). The minimum angular distance $\alpha$ is measured over a great circle that contains $\mathrm{P}$ and whose strike is $t$ (Fig. 1b).

Once the angular distances between $\mathrm{P}$ and each SC have been calculated, the coordinates of the closest point to P located along the SCs are calculated. This point (Q) corresponds to the intersection between the SC and the great circle that contains P (Fig. 1b).

\subsection{The remagnetization direction (SCI method)}

The SCI method is based on the following assumptions. (i) The analyzed sites were remagnetized contemporarily and therefore they acquired the same remagnetization direction. (ii) Assuming, that only tilting of the bedding strike is responsible for the dispersion of the paleomagnetic direction from their original direction, the remagnetization direction must be placed upon the SC that links the paleomagnetic 


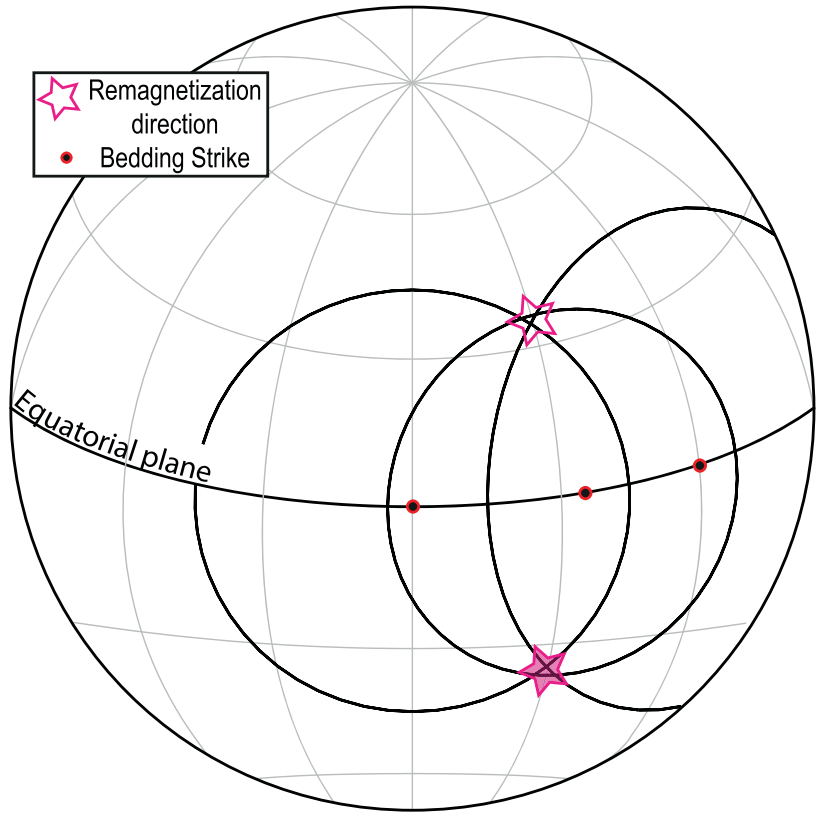

Fig. 6. Schmidt projection of a set of SCs showing the symmetry of the SCs between the upper and lower hemispheres and hence the two possible remagnetization direction having the same declination but opposite inclinations could be right.

Table 1

Example of input data file. Remember that this must to be a comma separated text file. SITE: name of the site; rem D/rem I: in situ (BBC) declination and inclination of the remanence. alpha95 and kappa: semi-angle of the cone of confidence $\alpha_{95}$ and $\mathrm{k}$ parameter (Fisher, 1953) associated to the paleomagnetic direction; Dipdir/Dip: Dip direction and dip of the bedding; k_bed: $\mathrm{k}$ parameter (Fisher, 1953) associated to the bedding.

\begin{tabular}{llllllll}
\hline SITE & rem D & rem I & alpha95 & kappa & Dipdir & Dip & k_bed \\
\hline St01 & 300.6 & 62.1 & 3.2 & 300.6 & 321 & 55 & 120 \\
St02 & 348 & 27 & 3.9 & 202.7 & 270 & 21 & 120 \\
St03 & 268 & 27 & 4.6 & 146.0 & 310 & 84 & 120 \\
\hline
\end{tabular}

direction in BBC (before bedding correction) and ATBC (after total bedding correction) (Fig. 1a). If these two conditions are true, then it follows that all SCs should intersect in the remagnetization direction. For the method to work effectively, the beds must have different strikes because otherwise all SCs would be concentric with no intersection.

Because of the noise in data collection, intersections of SCs will be scattered, and the typical dataset (Fig. 2a) will show an area in which the intersections between the different SCs cluster. According to Waldhör and Appel (2006), one way to calculate the remagnetization direction is to try and find the direction that minimizes its angular distances to the set of SCs. For this, the minimum angle between any particular direction and the SCs $\left(\alpha_{j}\right)$ can be calculated (Fig. 1b); the value of $A / n$, which is the sum of all individual angles $\left(\alpha_{i}\right)$ normalized for the number of sites can be calculated $\left(\frac{1}{n} \sum \alpha_{j}\right.$, Fig. 2 b). The SCI solution will be the one with minimum $A / n$ value (i.e. the closest direction to the set of SCs; Fig. $2 c$ ). Once the SCI solution is calculated this becomes in the reference and the final points $\mathrm{Q}$ converge to the best fit direction (BFD), the closest direction between each SC and the reference.

\subsubsection{Uncertainty estimation}

Estimating the uncertainty associated with the calculated remagnetization direction is a complex issue. The difficulty stems from several aspects, such as the homogeneity of the attitude of bedding (the greater the homogeneity the greater the uncertainty along the SCs), the relationship between the remagnetization direction and regional structural trend, the non-coaxial nature of the pre- and post-remagnetization deformation, and/or the quality of the bedding and paleomagnetic

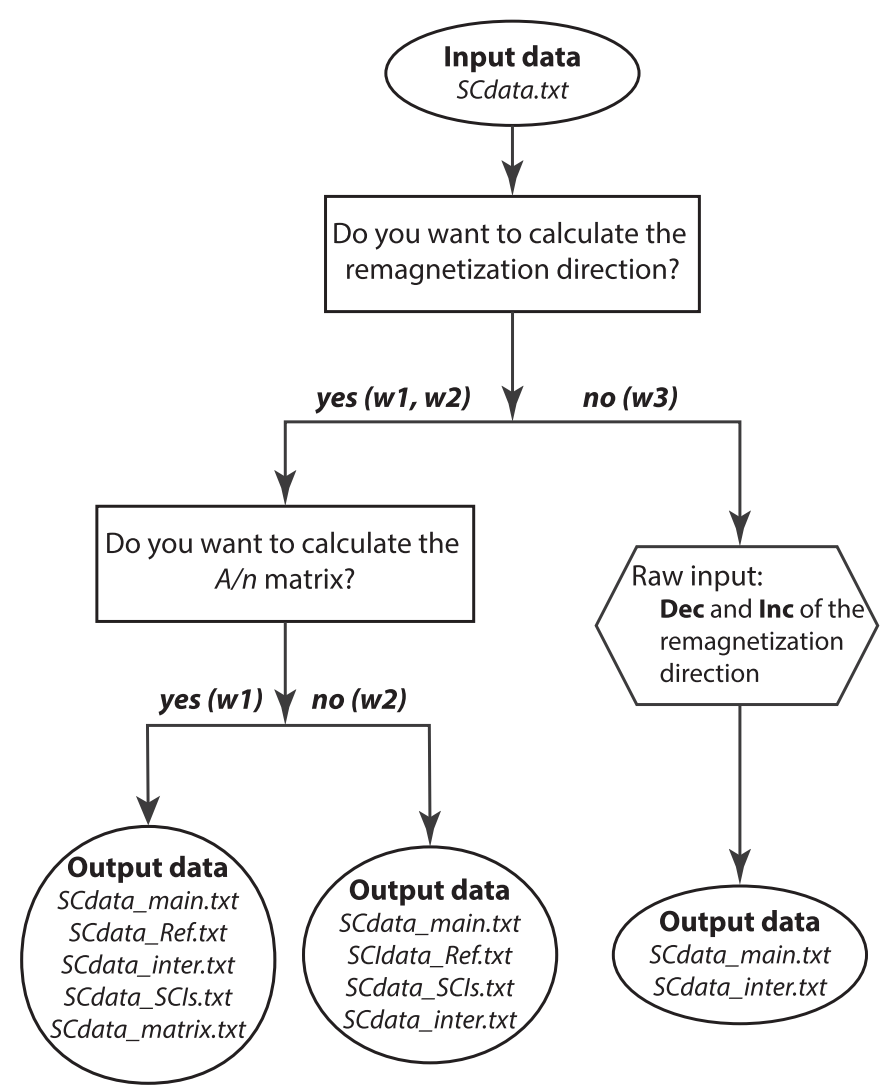

Fig. 7. Possible different workflows (w1, w2, and w3) within the pySCu_calc.py module.

data. Given a SCI solution as in Fig. 2, the SC intersection pattern, as well as the $A / \mathrm{n}$ contour plot, gives a qualitative approximation of the uncertainty associated with the calculated direction; the uncertainty increases with the concentricity of the SCs and the eccentricity of A/n contours (Fig. 3a). However, $A / n$ cannot be used as the regular confidence zones used in paleomagnetism with a quantitative statistical significance, precluding the use, for example, to compare with the apparent polar wander path for remagnetization dating. This issue has been traditionally assessed by means of Fisher (1953) statisticss of the BFDs. This approach has two main flaws: (i) the BFDs do not usually follow a Fisherian distribution and (ii) these directions are artificially calculated (the BFD corresponds with the direction on each SC closest to the calculated direction which also invalidates non-Fisherian approach using the BFDs). As a consequence of this misuse, misleading confidence regions are obtained, and they tend to be elongated just in the direction perpendicular to the actual uncertainty (Fig. 3b); BFDs are forced in the uncertainty direction which is the same than the SC paths, and therefore they cannot show dispersion in this direction. Another consequence is that, whereas the real uncertainty of the solution increases with more concentric SC (magenta ellipse in Fig. 3), small variation can be observed between the confidence zones of the BFDs (red circle and black ellipse Fig. 3), indicating an absence of statistical significance of the latter.

Following ann approach similar to Henry et al. (2004), the uncertainty of the SCI solution can be estimated by means of confidence areas with statistical significance if several solutions are calculated. This is possible if many pseudosamples of the input data (i.e. paleomagnetic directions and bedding) are generated through parametric bootstrap (Fisher et al., 1987; Watson and Enkin, 1993; Tauxe and Watson, 1994). Combining pairs of paleomagnetic directions and para-bedding, in each pseudosample, new bootstrapped-SCs can be defined and used to calculated new SCI solutions. If a large number of SCI solutions are calculated (e.g. more than 100), the confidence zone can be calculated. In agreement with the results obtained in the previous examples (Fig. 3), the 
dispersion of the 500 SCI solutions follows an elliptical distribution; therefore, and following the work of Tauxe et al. (1991), Kent (1982) statistic is used to calculate the $95 \%$ confidence ellipse.

The pseudosamples generated by parametric bootstrap will follow the same Fisherian distribution than the input data (by design) and share Fisher (1953) k parameter. Therefore, since either the paleomagnetic direction and the bedding have an error defined by the Fisherian distribution with precision parameter $\mathrm{k}$ (for bedding a $\mathrm{k}$ of $120-150$ can be realistic), the propagation of this error to the SCs can be introduced in the SCI solution in this way, which is exactly what this confidence region implies.

Even when used together with the confidence zone, the SCI solution can be unrealistic if some of the initial assumptions are not fulfilled. For example, if the SCI method is applied to a dataset affected by differential VAR, we will obtain wrong solutions even having reasonable $A / n$ distributions and confidence zones (Fig. 4). For this, in our opinion, the best way to assess the uncertainty of the calculated remagnetization direction is through the confidence zone and the $A / n$ value always accompanied with the SCs (or their intersections) and $A / n$ values distribution (Fig. 4).

\subsection{The paleodip calculations}

The paleodip is the dip of the bedding plane at the moment of the acquisition of the remagnetization, obtained from simple calculations. (i) Once the reference is known, it is possible to calculate for each paleomagnetic site the direction within their corresponding SC closest to it, i.e. the BFD. (ii) The angle measured along the SC between the ATBC and the
BFD paleomagnetic directions corresponds with the paleodip (Fig. 5).

The frequently encountered situation working with synfolding remagnetizations is the one in which the paleodip shows an intermediate position between the BBC and ATBC attitudes (Fig. 5a), caused by a progressive tilting with the same sense along folding time (pre- and postremagnetization tilting show the same dip direction). However, it is also possible to obtain opposite senses of tilting of the pre- and postremagnetization stage, thus giving higher paleodips than present-day dips (Fig. 5b) or even changing the sense of dip of beds (Fig. 5c). In case of working with pre-folding remagnetizations, the paleodip will be $0^{\circ}$ (Fig. 5d) and for post-folding remagnetizations the paleodip will coincide with the present-day dip (Fig. 5e). Real examples of these cases can be found in the literature (e.g. Smith et al., 2006; García-Lasanta et al., 2017; among others).

\subsubsection{The uncertainty in the paleodip}

Uncertainty in the paleodip comes from the uncertainties in the bedding, in the paleomagnetic direction of each site and in the SCI solution. Bedding and paleomagnetic directions errors act at site-scale and the paleogeometry of the structures can be artificially modified. Therefore, the use of sites with high paleomagnetic direction uncertainties should be avoided, and just in case they can be used as a source of qualitative information. Besides, this uncertainty not only affects the magnitude of the $\alpha_{95}$ of the paleomagnetic direction, but also the apical angle of the SC: for high apical angles ( $90^{\circ}$ maximum), an $\alpha_{95}$ of $5^{\circ}$ will generate around $5^{\circ}$ of paleodip uncertainty; however, for low apical angles (e.g. $20^{\circ}$ ), an $\alpha_{95}$ of $5^{\circ}$ will generate around $30^{\circ}$ of paleodip
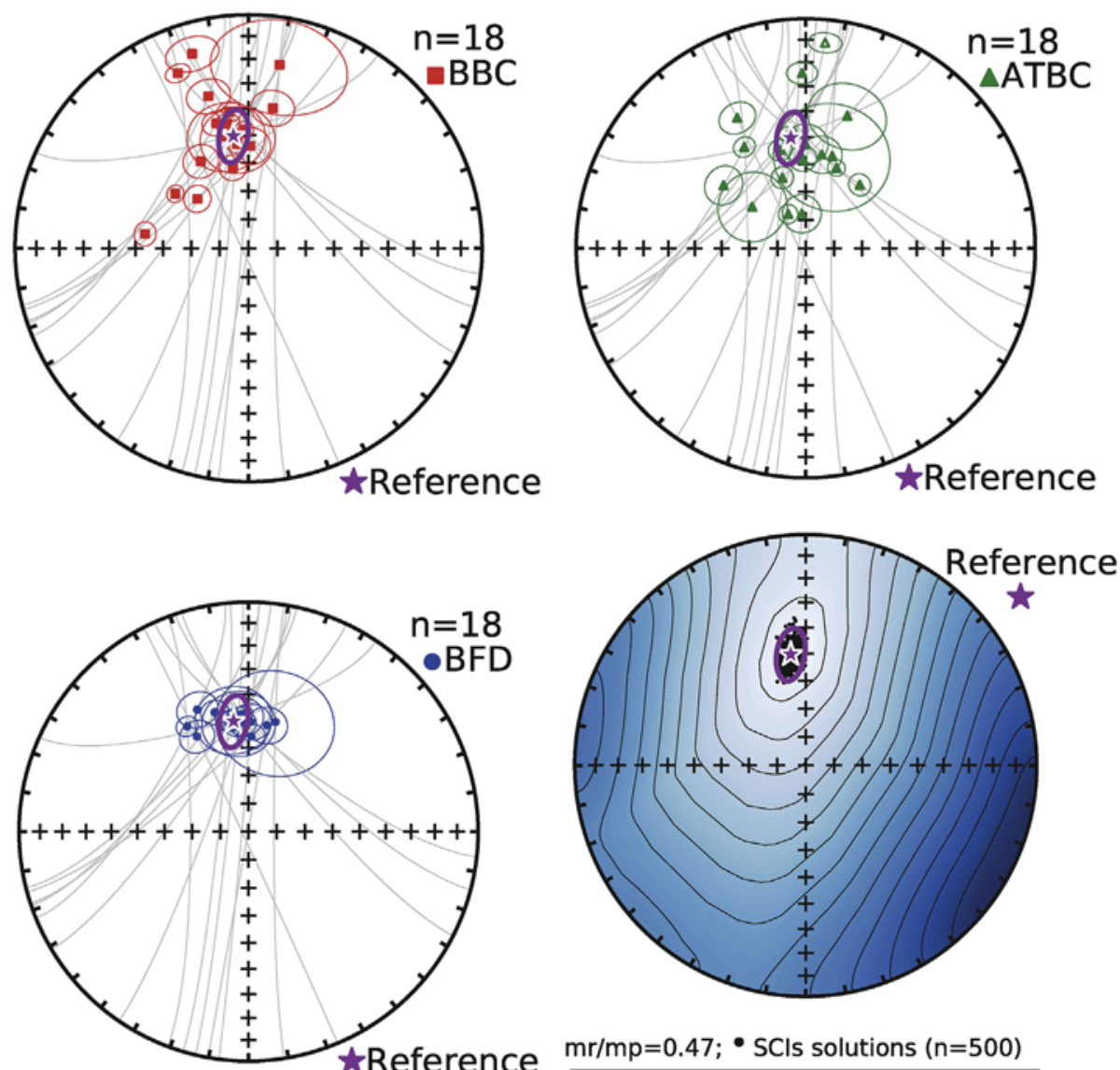

$\mathrm{mr} / \mathrm{mp}=0.47 ; \cdot \mathrm{sCls}$ solutions $(\mathrm{n}=500)$

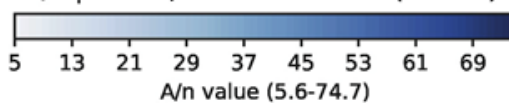

Fig. 8. Example of the output plots from pySCu_draw.py. (a), (b), (c) show the SCs and BBC, BFD and ATBC paleomagnetic directions respectively. (d) Contour plot of A/n, the different calculated SCI solutions and their $95 \%$ confidence zone. Paleomagnetic data from Soto et al. (2011). 


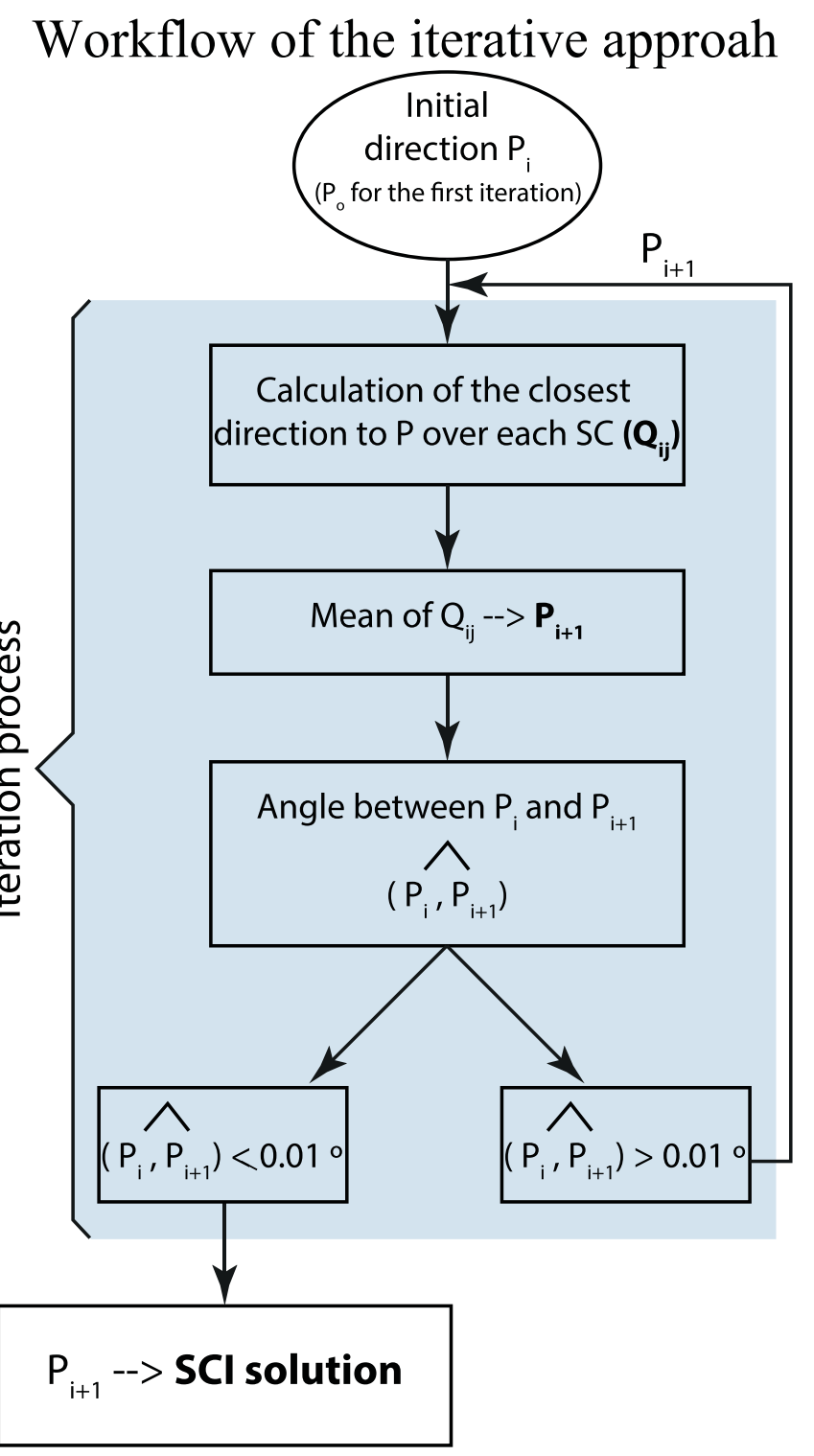

Fig. 9. Workflow followed by pySCu using the iterative approach. Given an initial direction $\mathrm{P}_{0}$, the program starts the process with the calculation of all $\mathrm{Q}_{0,0}$ points, and the mean of the calculated $Q_{1 j}$ directions (the $Q_{1 j}$ mean being transferred to the new point $P_{1}$ ). In each iteration the angle between $P_{i}$ and $P_{i+1}$ is calculated. The iteration process goes on until the angle is lower than $0.01^{\circ}$. This process is repeated $n$ times (500 by default) using a different para-dataset of SCs for calculating the different SCI solutions with which the $95 \%$ confidence zone is calculated.

uncertainty. Regarding uncertainties in bedding attitude, this is the same as for the dip and can be neglected for purposes of reconstruction of the structure.

Otherwise, the uncertainty in the SCI solution is common to all sites, and hence this will only affect the general attitude of the sites regarding an external reference, but will not affect the relative attitude between sites. In other words, the interlimb angle will be constrained, but the structures can be artificially tilted.

\subsection{Considerations before using the SC methods}

Some caveats must be taken into account when using the SC methods for calculating the reference direction and paleodips:

- There is an intrinsic ambiguity in the calculation of the reference direction (SCI solution), because it is always possible to calculate two remagnetization directions with the same declination and opposite inclinations (Fig. 6). Other sources of information (e.g. paleomagnetic direction in horizontal sites) will be necessary to discriminate between both.

- For very similar strikes of bedding, the uncertainty in the calculated remagnetization direction will be high (Fig. 3b; e.g. Cairanne et al., 2002; Gong et al., 2009).

Because the SCs methods works with remagnetization directions, we must be sure that we are working with a real remagnetization and not with an artifact, which can be generated by different processes. (i) Overlapping between two paleomagnetic components could be interpreted as a syn-folding remagnetization (Rodriguez-Pintó et al., 2013). (ii) Internal deformation of sedimentary beds can rotate a primary paleomagnetic components that shows the same behavior that a syn-folding remagnetization (e.g. Van der Pluijm, 1987; Stamatakos and Kodama, 1991). Anisotropy of the remanence measurements or sampling in different lithologies (e.g. limestones and marls) and therefore with different response to deformational mechanism can shed light to avoid these problems.

The weight that each SC has in the SCI solution depends on the strike distribution (Waldhör and Appel, 2006). For example, in a case with several SCs defined by similar strikes and few SCs with axes at a high angle to the others, the remagnetization direction will be strongly conditioned by the latter.

- Generally, the SC methods are useful and reliable in contexts without complex tectonic histories (i.e. similar tilt axis during the pre- and post-remagnetization stages, Villalaín et al., 2016). Otherwise, in complex tectonic frames it can be necessary to restore the most recent deformation(s) before applying the SCs methods.

In tectonic contexts with VAR postdating the remagnetization, the SCI method should be used with caution but it can still provide useful constraints (see Waldhör et al., 2001; Waldhör and Appel, 2006; Antolín et al., 2012; Rouvier et al., 2012). For example, it can be possible to assess the presence of differential VAR recorded by the different sites according to the SCs distribution, to calculate regional VAR if the paleomagnetic reference is known, etc.

- It is important to differentiate in these complex tectonic frames (last two points) between differential and regional VARs. The first will increase the noise in the calculated remagnetization direction and in the restoration. However, homogeneous VARs will preclude a right calculation of the remagnetization direction (and consequently its use for dating the remagnetization); structural relationship between sites will be accurate, but the general structures can be biased with respect to an external reference. In these complex tectonic frames external markers (e.g. geological markers) can help to avoid these effects. According to our experience, a large dataset can help minimizing the noise in the calculation of the remagnetization direction derived from anomalous strikes, uncontrolled sites with local VAR, etc.

The many caveats notwithstanding, it is worth noting that most of them are common to other paleomagnetic approaches applied to unravel the deformational history of the mountain belts, either working with primary or secondary remanences (e.g. Pueyo et al., 2016). Therefore the SC methods do not have more limitations than other techniques. In any case, it is a technique that works really well in simple tectonic frames, but also, combined with other methods, can help to understand complex deformational histories.

\section{How to use pySCu}

The pySCu program is written in Python 2.7 and consists of two different modules (each with their python file). pySCu_calc.py is the main module which does the calculations and pySCu_draw.py provides the graphical output for the program. This can be used either as a standalone software (downloading it from GitHub.com) or as a tool inside of the paleomagnetic set of tools PmagPy (Tauxe et al., 2016).

Following the first option (as an individual software), just search 
(a) $\alpha$ value and $Q$ coordinates calculation

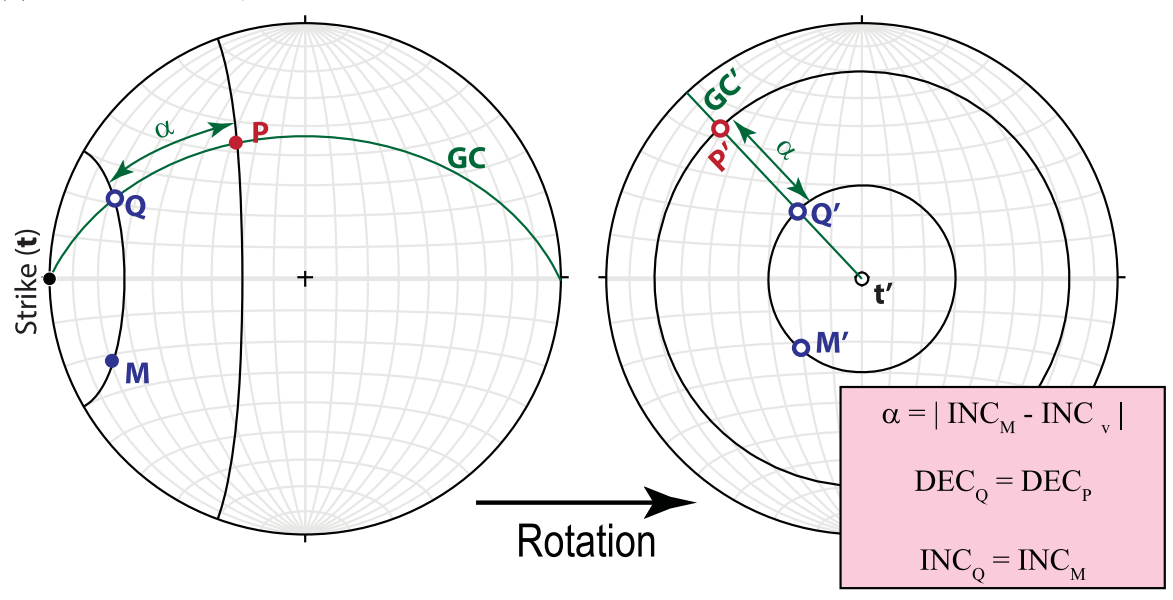

(b) Paleodip $(\phi)$ calculation

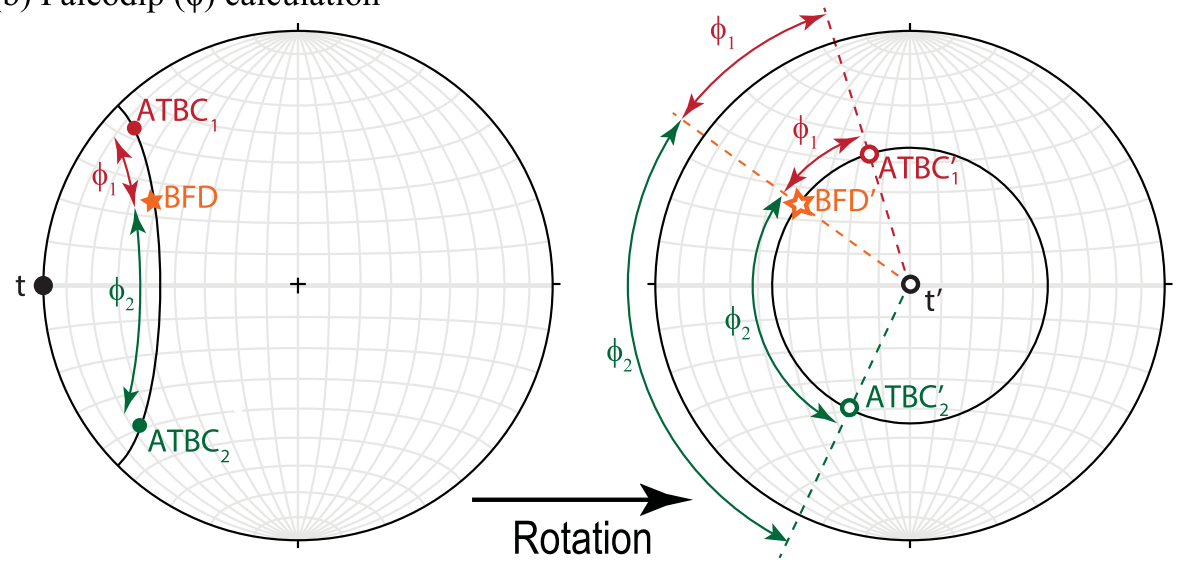

Fig. 10. (a) Equal area projection showing, as in Fig. 1, the relationship between P, M, Q and $\alpha$ (abbreviations are the same than in previous figures and in the text). In the box, the calculations performed for calculating the $\alpha$ value and the $\mathrm{Q}$ coordinates after the clockwise rotation of the elements looking to $t+90$. (b) After the same clockwise rotation the paleodip ( $\phi$ ) can be calculated as a difference between declinations. Different possibilities exist depending on whether the sense of tilting between the pre- and post-remagnetization tilting is the same or opposite (elements 1 and 2 respectively).

pySCu in www.GitHub.com webpage and download it (this also incorporates a 'readme' with the instructions). The program uses some basic Python libraries as Matplotlib-1.5.3 and Numpy-1.11.2 so it will not run on the standard Mac OS and Windows versions of python; we recommend either the Anaconda or Canopy installations. On the other hand, if you choose the PmagPy installation (which includes many other paleomagnetic tools), use pySCu as the other PmagPy's tools. The user is referred to the instructions for PmagPy and Anaconda or Canopy installations in the PmagPy cookbook at: https://earthref.org/PmagPy/.

\section{1. pySCu_calc.py}

The input data file is a spaced delimited text file with header as shown in Table 1. All output data files (five as maximum) have this same format. Some communication with the program is necessary and it will be introduced through raw input.

The pySCu_calc.py does different calculations: the parameters that define each SC, the possible intersections between each pair of SCs, the SCI solution and its confidence ellipse (through the calculation of 500 SCI solutions), the $\mathrm{A} / \mathrm{n}$ matrix (a grid with the $\mathrm{A} / \mathrm{n}$ values for all possible directions) and the paleodip for each site. These calculations can be performed following three different workflows (Fig. 7) depending on the user's requirements. (i) The basic step (w1, Fig. 7) is to do all calculations. (ii) Sometimes it can be interesting to quickly calculate remagnetization directions (w2, Fig. 7) using different datasets to assess the reliability of some sites without calculating the $\mathrm{A} / \mathrm{n}$ matrix (this takes some minutes). (iii) Finally, it is also possible to calculate the paleodips of the entire dataset using a remagnetization direction either calculated previously (SCI solution) or from other sources as the APWP (w3, Fig. 7a).

\section{2. pySCu_draw.py}

The graphical output is mostly based on the PmagPy package (Tauxe et al., 2016). After running the program, it asks about the *main.txt output file generated with pySC_calc.py. Then, a set of four equal area plots is generated (Fig. 8) representing the SCs, the BBC, BFD and ATBC paleomagnetic directions, the contour plot of the $\mathrm{A} / \mathrm{n}$, the $500 \mathrm{SCI}$ solutions and the intersections of the SCs (the last three are optional). Besides, a modified version of this module is available (pySCu_draw_labels.py); this module draws only one equal area plot with the SCs, the reference direction, the BBC, BFD and ATBC paleomagnetic directions and the labels of the different sites. This is meant to use with few sites, for example for showing the results coming from a single fold.

Output plots from these modules are drawn with the matplotlib library and therefore they follow the design of this library. One important question is that this library allows saving the plots in different formats. The code of pySCu_draw.py is easily modifiable to change the color, the size or the shape of the different elements as well as the configuration of the contour plot (just open it with a code editor). 


\section{How does pySCu work?}

\subsection{The iterative approach}

The main workflow proceeds through an iterative approach (Fig. 9) in order to find the direction closest to the set of SCs, i.e. the SCI solution (Fig. 2). Given a starting point $\left(\mathrm{P}_{0}\right)$, the program calculates, for each site, the closest direction $\left(Q_{0 j}\right)$ over the $S_{0, j}$ to the point $P_{0}$. When all $Q_{0, j}$ are known, their mean is calculated, defining the new reference point $P_{i+1}$. If the angular distance between $\mathrm{P}_{\mathrm{i}}$ and $\mathrm{P}_{\mathrm{i}+1}$ is higher than $0.01^{\circ}$, it is far from the solution and the process starts again using as a reference the new point $\mathrm{P}_{\mathrm{i}+1}$. Otherwise, if $\mathrm{P}_{\mathrm{i}}$ and $\mathrm{P}_{\mathrm{i}+1}$ are similar (angular distance between them smaller than $0.01^{\circ}$ ), this means that $P_{i}$ is the closest direction to all SCs (Fig. 8) and it becomes the SCI solution.

In practice, the program repeats this entire process 500 times, using each time a different pseudo-sample generated by parametric bootstrapping. For this, 30 new para-elements of bedding and BBC magnetization are generated at each site; the new families of para-elements have the same Fisherian distribution (same k) than the input data. For each of the 500 repetitions of the iterative method, a pair of para-elements (bedding and $\mathrm{BBC}$ magnetization) is randomly chosen at each site to generate one different SC each time (see section 2.2.1). Once the program has calculated 500 SCI solutions, Kent (1982) statistic are apply to found the final SCI solution and the $95 \%$ confidence ellipse.

\subsection{The $A / n$ matrix approach}

The program calculates the remagnetization direction using the iterative approach, but in addition, it calculates the value of $A / n$ for all possible directions (one-degree grid spacing). The end result is a contour plot of $A / n$ which allows graphical analysis of the results. Both approaches must be convergent because they are based upon the same assumptions and same input data. However, there are some differences between them that explain why both are used in this program. The iterative approach is fast and allows calculating several SCI solutions for calculating the confidence ellipse. Conversely, the $\mathrm{A} / \mathrm{n}$ approach takes a few minutes for calculating the $A / n$ value for all directions $(32,400$ in total) but it provides a contour map of $A / n$ values which gives us information about the reliability of the calculated paleomagnetic direction.

\subsection{Some calculations}

Except for the calculation of the $d$ value and the apical angle of the SCs, pySCu uses an angle conversion for the rest of the calculations. The different elements presented in previous sections can be calculated by regular spherical trigonometry but due to the different situations regarding possible relationships between elements we decided to do the calculations starting from a $90^{\circ}$ rotation of the reference system and consequently of all elements (the strike of the bed -t-, SC, paleomagnetic vectors, etc.) around an axis perpendicular to the trend and in a clockwise sense (looking to $t+90^{\circ}$ ). Then: (i) the strike $t$ becomes the vertical axis, and (ii) all elements placed the same SC will have the same inclination. In this way, all calculations can be done by scalar subtractions of declinations or inclinations (Fig. 10).

\subsection{1. $\alpha$ value and $Q$ coordinates}

As indicated in the previous sections, $\alpha_{\mathrm{j}}$ is the minimum angular distance between $\mathrm{P}$ and a particular $\mathrm{SC}_{\mathrm{j}}$ and it is measured along a great circle (GC) having the same strike that the SC. After the above mentioned $90^{\circ}$ rotation of the cone axis, the plane represented by this great circle becomes vertical with the same declination than P (Fig. 10a) and therefore the angle $\alpha$ corresponds to the difference in inclination between $\mathrm{P}$ and $\mathrm{M}$ vectors (in absolute value).

$Q_{j}$ is defined as the intersection between the great circle that contains $P$ and whose strike is $t$. Therefore, after the rotation, the inclination of $Q_{j}$ and $\mathrm{M}_{\mathrm{j}}$, on one side, and the declination of $\mathrm{P}_{\mathrm{j}}$ and $\mathrm{M}_{\mathrm{j}}$, on the other, will be the same (Fig. 10a).

\subsubsection{Paleodip calculation}

The paleodip is the dip of the bed when the remagnetization occurred. When the remagnetization direction is finally calculated, $\mathrm{P}$ becomes the reference for this particular bed (the remagnetization direction) and $Q_{j}$ becomes the BFD (best fit direction), the theoretical paleomagnetic direction of the site at the moment of the remagnetization.

Since the actual dip of the beds is the angular distance (measured on the SC) between the $\mathrm{BBC}$ and ATBC paleomagnetic directions, the paleodip $(\phi)$ is the angle between BFD and ATBC paleomagnetic direction (Fig. 10b). This angle can be calculated from the dihedron between the planes defined by 1 ) the horizontal vector corresponding to the strike of the bed and the BFD for each plane on one side, and by 2) the bedding strike and the ATBC vector on the other. After the $90^{\circ}$ rotation of the reference system, this calculation is simpler because it equals the angular difference of the declinations between ATBC and BFD vectors.

Some considerations regarding the relationship between the declination of the BFD and ATBC directions must be taken into account. According to the strike of the bed of the example shown in Fig. 10b, point 1 $\left(\mathrm{ATBC}_{1}\right)$ agrees with a bed whose paleodip is between the present day paleodip and the horizontal (i.e. the pre- and post-remagnetization tilts have the same sense, see section 2.2), whereas point 2 (ATBC ${ }_{2}$ ) illustrates a bed whose paleodip has the opposite sense than the actual dip. This is important because the paleostrike (according to the RHR, right hand rule) will be the same than the strike for ATBC $_{1}$ but for ATBC ${ }_{2}$ it will be the strike plus $180^{\circ}$. The program considers these situations for restoring the bed in the proper way.

\section{Conclusions}

When dealing with synfolding remagnetizations, the SC methods have several applications, such as performing detailed reconstructions of the attitude of each bed at the time of the remagnetization, calculating the local direction of the remagnetization or evaluating the presence of vertical axis rotations. All in all, one of the most important applications of the SC methods is that they allow graphical analysis of paleomagnetic datasets, avoiding possible "black-box" effects.

Application of parametric bootstrap allows us to assess the propagation of the error coming from the bedding and the paleomagnetic data. Working in this way it is possible to calculate the remagnetization direction together with its confidence ellipse.

Here the pySCu software, written in Python 2.7, for direct application of different SC applications is presented. It shows the advantage of being user-friendly, fast and easy, allowing a broader use of the SCI method in the paleomagnetic community, specifically applied to magnetotectonic studies using synfolding remagnetizations.

\section{Acknowledgments}

This study was financed by the research projects CGL2012-38481 and CGL2016-77560 of the MINECO (Spanish Ministry of Economy and Competitiveness) with also FEDER founding (European Union). PC acknowledges the MINECO for the F.P.I. research grant BES-2013-062988. LT acknowledges support from National Science Foundation grant \# EAR 1345003. The authors sincerely thank the constructive comments and suggestions of the reviewers Bernard Henry and Emilio L. Pueyo, which have helped to improve the SC methods and constrain their application limits.

\section{Appendix A. Supplementary data}

Supplementary data related to this article can be found at http://dx. doi.org/10.1016/j.cageo.2017.07.002. 


\section{References}

Antolín, B., Schill, E., Grujic, D., Baule, S., Quidelleur, X., Appel, E., Waldhör, M., 2012. $\mathrm{E}-\mathrm{W}$ extension and block rotation of the southeastern Tibet: unravelling late deformation stages in the eastern Himalayas (NW Bhutan) by means of pyrrhotite remanences. J. Struct. Geol. 42, 19-33. http://dx.doi.org/10.1016/ j.jsg.2012.07.003.

Bazhenov, M.L., Shipunov, S.V., 1991. Fold test in paleomagnetism: new approaches and reappraisal of data. Earth Planet Sci. Lett. 104, 16-24. http://dx.doi.org/10.1016/ 0012-821X(91)90233-8.

Cairanne, G., Aubourg, C., Pozzi, J.P., 2002. Syn-folding remagnetization and the significance of the small circle test examples from the Vocontian trough (SE France). Phys. Chem. Earth 27, 1151-1159. http://dx.doi.org/10.1016/S1474-7065(02) 00106-7.

Calvín, P., Casas-Sainz, A.M., Villalaín, J.J., Moussaid, B., 2017. Diachronous folding and cleavage in an intraplate setting (Central High Atlas, Morocco) determined through the study of remagnetizations. J. Struct. Geol. 97, 144-160. http://dx.doi.org/ 10.1016/j.jsg.2017.02.009.

Casas, A.M., Villalaín, J.J., Soto, R., Gil-Imaz, A., del Río, P., Fernández, G., 2009. Multidisciplinary approach to an extensional syncline model for the Mesozoic Cameros Basin (N Spain). Tectonophysics 470, 3-20. http://dx.doi.org/10.1016/ j.tecto.2008.04.020

Delaunay, S., Smith, B., Aubourg, C., 2002. Asymmetrical fold test in the case of overfolding: two examples from the Makran accretionary prism (Southern Iran). Phys. Chem. Earth, Parts A/B/C 27, 1195-1203. http://dx.doi.org/10.1016/S14747065(02)00130-4.

Fisher, R.A., 1953. Dispersion on a sphere. Proc. R. Soc. Lond. 217A, 295-305.

Fisher, N., Lewis, T., Embleton, B., 1987. Statistical Analysis of Spherical Data. Cambridge University Press, Cambridge. http://dx.doi.org/10.1017/CBO9780511623059.

García-Lasanta, C., Casas-Sainz, A., Villalaín, J.J., Oliva-Urcia, B., Mochales, T., Speranza, F., 2017. Remagnetizations used to unravel large-scale fold kinematics: a case study in the Cameros basin (N Spain). Tectonics. http://dx.doi.org/10.1002/ 2016TC004459.

Gong, Z., van Hinsbergen, D.J.J., Dekkers, M.J., 2009. Diachronous pervasive remagnetization in northern Iberian basins during Cretaceous rotation and extension. Earth Planet. Sci. Lett. 284, 292-301. http://dx.doi.org/10.1016/j.epsl.2009.04.039.

Graham, J.W., 1949. The stability and significance of magnetism in sedimentary rocks. J. Geophys. Res. 54, 131-167. http://dx.doi.org/10.1029/JZ054i002p00131.

Henry, B., Rouvier, H., Le Goff, M., 2004. Using syntectonic remagnetizations for fold geometry and vertical axis rotation: the example of the Cévennes border (France). Geophys. J. Int. 157, 1061-1070. http://dx.doi.org/10.1111/j.1365246X.2004.02277.x.

Henry, B., Rouvier, H., le Goff, M., Leach, D., Macquar, J.-C., Thibieroz, J., Lewchuk, M.T., 2001. Palaeomagnetic dating of widespread remagnetization on the southeastern border of the French Massif central and implications for fluid flow and Mississippi Valley-type mineralization. Geophys. J. Int. 145, 368-380. http:// dx.doi.org/10.1046/j.0956-540x.2001.01382.x.

Jordanova, N., Henry, B., Jordanova, D., Ivanov, Z., Dimov, D., Bergerat, F., 2001. Paleomagnetism in northwestern Bulgaria: geological implications of widespread remagnetization. Tectonophysics 343, 79-92. http://dx.doi.org/10.1016/S00401951(01)00220-7.

Kent, J.T., 1982. The Fisher-Bingham distribution on the sphere. J. R. Stat. Soc. Ser. B 44, 71-80.

McCabe, C., Elmore, R.D., 1989. The occurrence and origin of Late Paleozoic remagnetization in the sedimentary rocks of North America. Rev. Geophys. 27, 471. http://dx.doi.org/10.1029/RG027i004p00471.

McClelland-Brown, E., 1983. Palaeomagnetic studies of fold development and propagation in the Pembrokeshire old red sandstone. Tectonophysics 98, 131-149. http://dx.doi.org/10.1016/0040-1951(83)90214-7.

McFadden, P.L., 1990. A new fold test for palaeomagnetic studies. Geophys. J. Int. 103, 163-169. http://dx.doi.org/10.1111/j.1365-246X.1990.tb01761.x.

Meijers, M.J.M., van Hinsbergen, D.J.J., Dekkers, M.J., Altõner, D., Kaymakcõ, N., Langereis, C.G., 2011. Pervasive Palaeogene remagnetization of the central Taurides fold-and-thrust belt (southern Turkey) and implications for rotations in the Isparta angle. Geophys. J. Int. 184, 1090-1112. http://dx.doi.org/10.1111/j.1365246X.2010.04919.x.

Pueyo, E.L.L., Sussman, A.J.J., Oliva-Urcia, B., Cifelli, F., 2016. Palaeomagnetism in fold and thrust belts: use with caution. Geol. Soc. Lond. Spec. Publ. 425, 259-276. http:// dx.doi.org/10.1144/SP425.14.

Ramón, M.J., Pueyo, E.L., Oliva-Urcia, B., Larrasoaña, J.C., 2017. Virtual directions in Paleomagnetism: a global and rapid approach to evaluate the NRM components. Front. Earth Sci. 5, 1-14. http://dx.doi.org/10.3389/feart.2017.00008.
Rodriguez-Pintó, A., Pueyo, E., Barnolas, A., Pocoví, A., Oliva-Urcia, B., Ramón, M.J., 2013. Overlapped paleomagnetic vectors and fold geometry: a case study in the Balzes anticline (Southern Pyrenees). Phys. Earth Planet. In. 215, 43-57. http:// dx.doi.org/10.1016/j.pepi.2012.10.005.

Rouvier, H., Henry, B., Le Goff, M., 2012. Mise en evidence par le paleomagnetisme de rotations regionales dans la virgation des Corbieres (France). Bull. Soc. Geol. Fr. 183, 409-424.

Shipunov, S.V., 1997. Synfolding magnetization: detection, testing and geological applications. Geophys. J. Int. 130, 405-410. http://dx.doi.org/10.1111/j.1365246X.1997.tb05656.x.

Smith, B., Derder, M.E.M., Henry, B., Bayou, B., Yelles, A.K., Djellit, H., Amenna, M. Garces, M., Beamud, E., Callot, J.P., Eschard, R., Chambers, A., Aifa, T., Ait Ouali, R., Gandriche, H., 2006. Relative importance of the Hercynian and post-Jurassic tectonic phases in the Saharan platform: a palaeomagnetic study of Jurassic sills in the Reggane Basin (Algeria). Geophys. J. Int. 167, 380-396. http://dx.doi.org/10.1111/ j.1365-246X.2006.03105.x.

Soto, R., Villalaín, J.J., Casas-Sainz, A.M., 2008. Remagnetizations as a tool to analyze the tectonic history of inverted sedimentary basins: a case study from the BasqueCantabrian basin (north Spain). Tectonics 27. http://dx.doi.org/10.1029/ 2007 TC002208 n/a-n/a.

Soto, R., Casas-Sainz, A.M., Villalain, J.J., 2011. Widespread Cretaceous inversion event in northern Spain: evidence from subsurface and palaeomagnetic data. J. Geol. Soc. Lond. 168, 899-912. http://dx.doi.org/10.1144/0016-76492010-072.

Stamatakos, J., Kodama, K.P., 1991. Flexural flow folding and the paleomagnetic fold test: an example of strain reorientation of remanence in the Mauch Chunk formation. Tectonics 10, 807-819. http://dx.doi.org/10.1029/91TC00366.

Suppe, J., 1983. Geometry and kinematics of fault-bend folding. Am. J. Sci. 283, 684-721. http://dx.doi.org/10.2475/ajs.283.7.684.

Surmont, J., Sandulescu, M., Bordea, S., 1990. Mise en évidence dúne réaimantation fini crétacée des séries mésozoïques de lúnité de Bihor (Monts Apuseni, Roumanie) et de sa rotation horarie ultériore. Comptes Rendus L Acad. Des. Sci. Paris 310, 213-219.

Tauxe, L., Kylstra, N., Constable, C., 1991. Boostrap statistics for paleomagnetic data. J. Geophys. Res. 96, 723-740.

Tauxe, L., Watson, G.S., 1994. The fold test: an eigen analysis approach. Earth Planet Sci. Lett. 122, 331-341. http://dx.doi.org/10.1016/0012-821X(94)90006-X.

Tauxe, L., Shaar, R., Jonestrask, L., Swanson-Hysell, N.L., Minnett, R., Koppers, A.A.P., Constable, C.G., Jarboe, N., Gaastra, K., Fairchild, L., 2016. PmagPy: software package for paleomagnetic data analysis and a bridge to the Magnetics Information Consortium (MagIC) database. Geochem. Geophys. Geosystems 17, 2450-2463. http://dx.doi.org/10.1002/2016GC006307.

Torres-López, S., Villalaín, J.J., Casas, A.M., EL Ouardi, H., Moussaid, B., RuizMartínez, V.C., 2014. Widespread cretaceous secondary magnetization in the High Atlas (Morocco). A common origin for the Cretaceous remagnetizations in the western Tethys? J. Geol. Soc. Lond. 171, 673-687. http://dx.doi.org/10.1144/ jgs2013-107.

Torres-López, S., Casas, A.M., Villalaín, J.J., El Ouardi, H., Moussaid, B., 2016. PreCenomanian vs. Cenozoic folding in the High Atlas revealed by palaeomagnetic data. Terra Nova 28, 110-119. http://dx.doi.org/10.1111/ter.12197.

Van der Pluijm, B.A., 1987. Grain-scale deformation and the fold test - evaluation of synfolding remagnetization. Geophys. Res. Lett. 14 (2), 155-157. http://dx.doi.org/ 10.1029/GL014i002p00155.

Villalaín, J.J., Osete, M.L., Vegas, R., García-Dueñas, V., 1992. Evidencia de una reimanación terciaria en la Béticas Occidentales. Implicaciones Tectónicas. Física la Tierra 4, 165-184.

Villalaín, J., Fernández-González, G., Casas, A.M., Gil-Imaz, A., 2003. Evidence of a cretaceous remagnetization in the Cameros basin (North Spain): implications for basin geometry. Tectonophysics 377, 101-117. http://dx.doi.org/10.1016/ j.tecto.2003.08.024.

Villalaín, J.J., Casas-Sainz, A.M., Soto, R., 2016. Reconstruction of inverted sedimentary basins from syn-tectonic remagnetizations. A methodological proposal. Geol. Soc. Lond. Spec. Publ. 425, 233-246. http://dx.doi.org/10.1144/SP425.10.

Waldhör, M., 1999. The Small-circle Reconstruction in Palaeomagnetism and its Application to Palaeomagnetic Data from the Pamirs. Tübingen University.

Waldhör, M., Appel, E., 2006. Intersections of remanence small circles: new tools to improve data processing and interpretation in palaeomagnetism. Geophys. J. Int 166, 33-45. http://dx.doi.org/10.1111/j.1365-246X.2006.02898.x.

Waldhör, M., Appel, E., Frisch, W., Patzelt, A., 2001. Palaeomagnetic investigation in the Pamirs and its tectonic implications. J. Asian Earth Sci. 19, 429-451. http:// dx.doi.org/10.1016/S1367-9120(00)00030-4.

Watson, G.S., Enkin, R.J., 1993. The fold test in paleomagnetism as a parameter estimation problem. Geophys. Res. Lett. 20, 2135-2137. http://dx.doi.org/10.1029/ 93GL01901. 



\title{
Vertical axis rotations and non-coaxial horizontal axes rotations. To what extent do SC tools work when the initial assumptions are not fulfilled?
}

\author{
In collaboration with E. L. Pueyo, M. J., Ramón, A. M., Casas-Sainz and J. J. Villalaín
}

\begin{abstract}
Small circle tools are useful to analyze synfolding remagnetizations affecting sedimentary rocks. However, two main caveats must be taken into account when working with them: (i) the acquisition of the remagnetization must be synchronous at the scale of the studied zone and (ii) the pre- and post-deformational stages should be coaxial. We analyze here the effect of non-coaxiality, that is consequence either of the obliquity between fold axes responsible for horizontal axes rotation or, alternatively, of the presence of vertical axis rotations.
\end{abstract}

By means of synthetic data we analyze the effect of non-coaxiality in the calculation of both the remagnetization direction and the paleodips (i.e., the dips of bedding at the remagnetization time). Besides, the error generated by noncoaxiality is examined under different scenarios: (i) different vertical axis rotations (clockwise, symmetric or counterclockwise) and (ii) different angles between horizontal rotations $\left(\gamma=0^{\circ}, 45^{\circ}\right.$ or $\left.90^{\circ}\right)$, occurring under (a) variable inclinations of the remagnetization direction $\left(15^{\circ}, 45^{\circ}\right.$ or $\left.75^{\circ}\right)$ and (b) different relationships between bedding strike and declination of the remagnetization $\left(\alpha=0^{\circ}, 45^{\circ}\right.$ or $\left.90^{\circ}\right)$. Then, we offer several possible configurations in nature that potential users can apply to evaluate the uncertainty inherent to their data.

Models indicate that presence of VARs have stronger effect than the presence of obliquity between two horizontal axes rotation, giving bigger errors both in the calculated remagnetization direction and in the paleodips. In presence of VARs, calculated errors (both in the remagnetization direction and in the paleodips) are highly dependent of the configuration of the SC, which are dependent of the inclination of the original remagnetization and the parameter $\alpha$. Both errors range from around $50^{\circ}$ when a $15^{\circ}$ inclination remagnetization is considered, to less than $10^{\circ}$ for a reference with $75^{\circ}$ of inclination. Regarding the parameter $\alpha$ under VAR scenarios, the error in the remagnetization is bigger for higher $\alpha$ but errors in paleodips are similar between models that share inclination. However, different patterns can be observed for different $\alpha$; for $\alpha=90^{\circ}$ the paleodip error is not dependent on the VAR recorded in each site, something that happens for $\alpha=0^{\circ}$. In both cases, the behavior between both limbs of the theoretical fold is opposite. On the other hand, when two horizontal axis are considered, errors are significantly lower and they are between $0^{\circ}$ and $25^{\circ}$, being around $0^{\circ}$ and $10^{\circ}$ in most of cases. Conversely to the VARs scenario, there are not significant differences in the different studied configurations.

In an overall view, the presence of VARs results in higher errors in the calculations of both the reference and the paleodips (both between $0^{\circ}$ and $50^{\circ}$ ), specially for low inclinations of the remagnetization, whereas the presence of two different horizontal axes rotation favors errors between 0 and $20^{\circ}$ in most cases. However, error distributions in VAR models show characteristic patterns that can help to identify this phenomenon, whereas this task is more difficult in the second models.

\section{Introduction}

Small Circle (SC) tools (McClelland-Brown, 1983; Surmont et al., 1990; Villalaín et al., 1992; Shipunov, 1997; Waldhör, 1999; Henry et al., 2004; Waldhör and Appel, 2006; Villalaín et al., 
2003, 2016; Calvín et al. 2017a) provide useful workflows with which to analyze remagnetizations. Classical or incremental fold-tests (e.g., Graham, 1949; McFadden, 1990; Bazhenov and Shipunov, 1991; Watson and Enkin, 1993; Tauxe and Watson, 1994) are useful and widely used by the paleomagnetic community to test the temporal relationship between folding and acquisition of magnetizations. These techniques assume proportional folding between limbs and therefore they cannot be used in the calculation of the remagnetization direction or in structural reconstructions since this is not always a fulfilled assumption in nature (e.g., Suppe, 1983; Cairanne et al., 2002; Delaunay et al., 2002; Villalaín et al., 2003).

However, when working with synfolding remagnetizations affecting sedimentary rocks, SC tools allow, beyond the classic use as fold test (e.g., Meijers et al., 2011), (i) to determine the remagnetization direction (e.g., Shipunov, 1997) and therefore (ii) to date it comparing with the Apparent Polar Wander Path (APWP) (e.g., Henry et al., 2001), (iii) and to calculate the attitude of beds (paleodips) at the remagnetization time (see Villalaín et al., 2016; for review). These utilities can be used to reconstruct the paleogeometry of sedimentary basins at the pre-inversional stage (e.g., Soto et al., 2008), to separate deformation generated under different tectonic phases (Smith et al., 2006) or for relatively dating geological structures (Calvín et al., 2017b). However, some starting hypotheses are necessary for working with SC tools:

1) The acquisition of the remagnetization must be synchronous at geological scale in the analyzed area.

2) Pre- and post-remagnetization deformation must be coaxial.

Why is coaxiality so important for SC tools? Because SCs are defined by the in situ paleomagnetic direction and the bedding strike. Each SC is the path followed by a paleomagnetic direction when it is rotated around the strike axis (Fig. 1a); in absence of rotations axes other than the strike, the SC limits the possible directions that could present the paleomagnetic direction in previous stages. Then, a set of paleomagnetic sites affected by the same synfolding remagnetization must share this paleomagnetic direction, but if they were deferentially folded in the postremagnetization stage they will show different in situ paleomagnetic directions (Fig. 1b). However, the SCs of all sites must intersect in the paleomagnetic direction that is common to all of them (Fig. 1b), i.e. the remagnetization direction (Calvín et al., 2017a; for review). Nevertheless, this will only be true if SCs really represent the path followed by the paleomagnetic direction during deformation.

Both coaxiality and non-coaxiality are common in nature in fold-and-thrust belts. Noncoaxiality can be generated both by the presence of different horizontal axes rotation (hereinafter called non-coaxial) (e.g., Ramsay \& Huber, 1987; Simón, 2004; Baidder et al., 2016; Deng et al., 2016), and by vertical axis rotations (VARs) (e.g., MacDonald, 1980; Allerton, 1998; Pueyo et al., 2003, 2004; Soto et al., 2006) in any tectonic stage after the remagnetization acquisition. In any case, both processes are responsible for the SC not to represent the possible positions of the paleomagnetic direction in the past because the present day strike is not coincident with the rotation axis by which the bedding and the paleomagnetic directions have been rotated (Pueyo et al., 2016). 
This paper focuses in the effect of VARs and non-coaxiality in the calculation of the remagnetization direction and in the reconstruction of the paleodips (i.e., the dips of bedding at the remagnetization time), considering a interfolding remagnetization (note that we use the term "interfolding" to distinguish it from "synfolding" that can be interpreted as an event that occurs during magnetization) that clearly separates two different deformational events, i.e. a remagnetization that is bracketed between two deformational stages, but which was acquired during a tectonic quiescence period. This is the example of several Mesozoic sedimentary basins analyzed in the Western Tethyan margin (e.g., Casas et al., 2009; Soto et al., 2011; Torres-López et al., 2014; García-Lasanta; 2017).

\section{Models construction}

\subsection{VAR models}

The initial position of VAR models is a pre-remagnetization symmetric fold that acquires a remagnetization (initial Declination is always $000^{\circ}$ and inclination changes between $15^{\circ}, 45^{\circ}$ and $75^{\circ}$ ). The models consider 30 sites, 15 in each limb, with $45^{\circ}$ dip and an original random dispersion in strike of $\pm 10^{\circ}$ from the main structural trend. The trend of the fold and therefore the strikes of sites are variable in the models according to $\alpha$, which is the angle between the remagnetization and the fold trend $\left(0^{\circ}, 45^{\circ}\right.$ and $90^{\circ}$ values for $\left.\alpha\right)$.
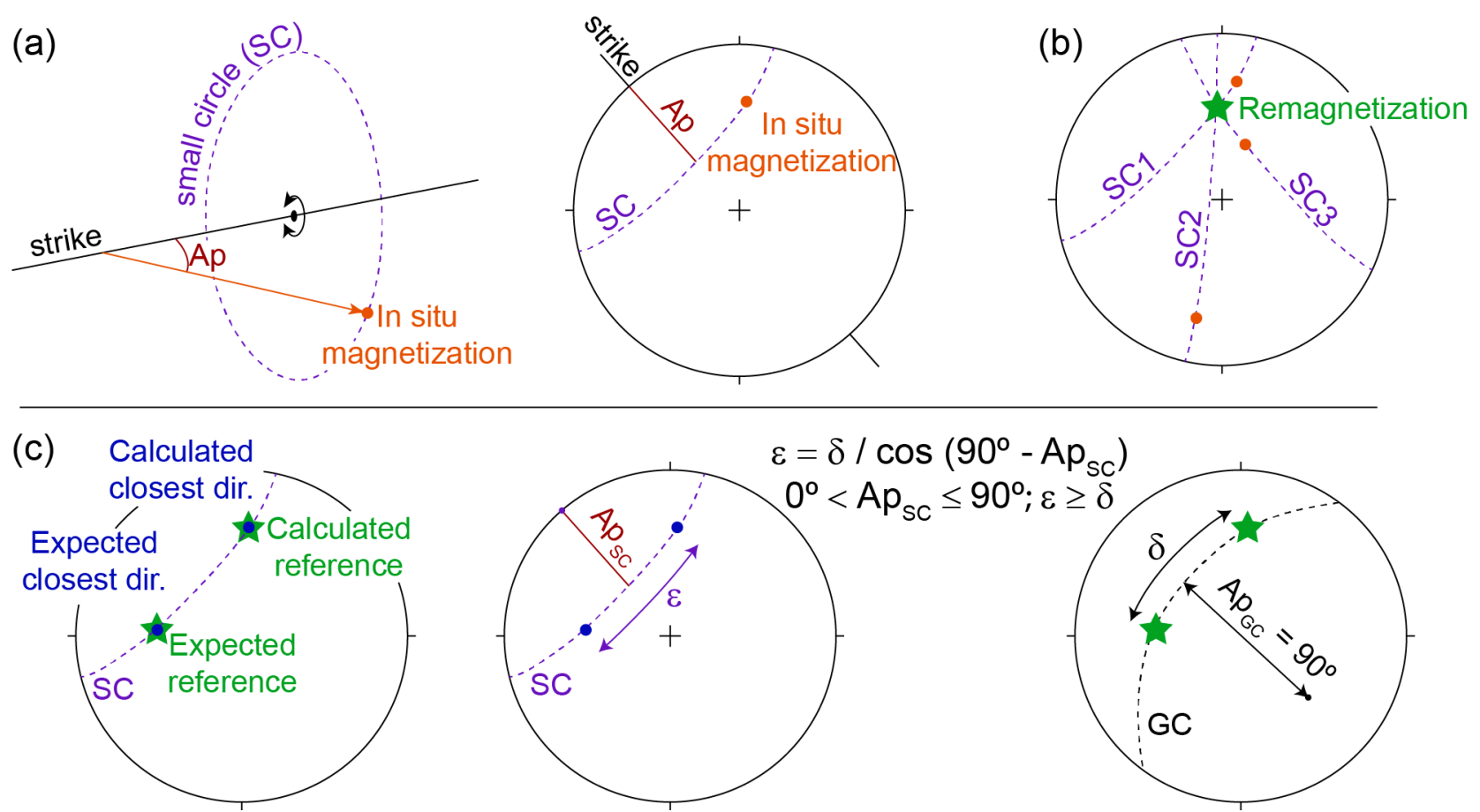

Figure 1. (a) Each small circle is the path followed by the in situ magnetization when it is rotated around the bedding strike. 3D view (left) and equal area projection (right). (b) Working with a set of paleomagnetic sites that record the same remagnetization, and in absence of non-coaxial rotation, the small circles must intersect in the remagnetization direction. (c) The relationship between the error in the paleodip $(\delta)$ and the error in the reference calculation $(\varepsilon)$ depends of the differences between the apical angle of the SC (Ap) and the apical angle of the great circle (GC) that contains the expected and the calculated reference, which always is $90^{\circ}$. 
Over the initial frame (Fig. 2a) were applied differential VARs (Fig. 3), which affect to 10 sites of each limb (then, five sites of each are not rotated by VAR). These VARs are applied randomly in each site within a range of $30^{\circ}$ : from $-30^{\circ}$ to $0^{\circ}$ for counter-clockwise (CCW) rotation models, from $-15^{\circ}$ to $+15^{\circ}$ for symmetric model and from $0^{\circ}$ to $+30^{\circ}$ for clockwise (CW) rotation model (note that positive values indicate CW rotations and negative ones are CCW rotations). Rotated bedding and paleomagnetic directions are used as input data for models. In one set of models the remagnetization direction and the paleodips are calculated (Fig. 3) and compared with the original remagnetization direction $\left(\mathrm{D}=000^{\circ}\right.$; $\left.\mathrm{I}=15^{\circ}, 45^{\circ}, 75^{\circ}\right)$ and the original paleodips $\left(45^{\circ}\right)$. In the other set of models, paleodips are calculated forcing to the original remagnetization direction (Fig. 4). A dispersion parameter $\mathrm{k}$ (Fisher, 1953) of 10000 and 50 bootstraps have been considered in the small circle intersection calculation, which have been done using Python code based in the pySCu software (Calvín et al., 2017a).

(a) $\operatorname{lnc}=15^{\circ}$

$$
\alpha=90^{\circ}
$$

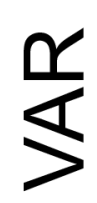

(b)
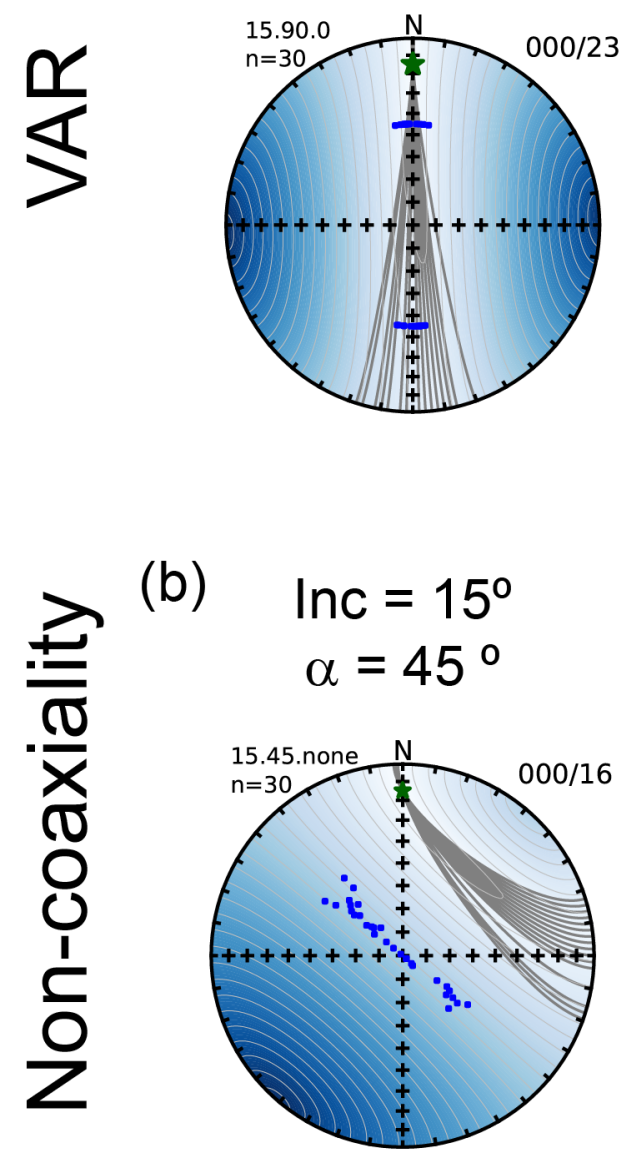

$$
\text { Inc }=45^{\circ}
$$$$
\alpha=45^{\circ}
$$

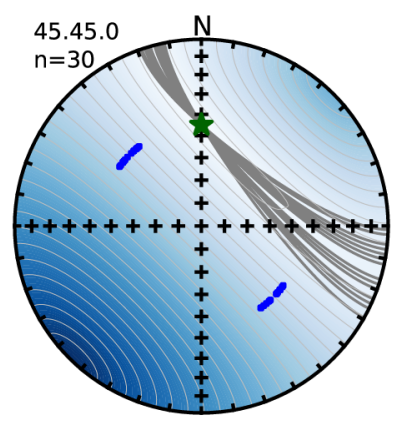

$$
\begin{gathered}
\operatorname{Inc}=45^{\circ} \\
\alpha=0^{\circ}
\end{gathered}
$$

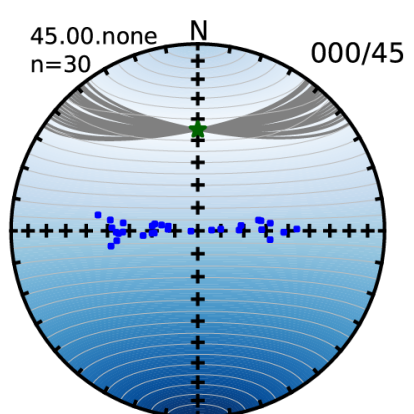

$$
\begin{gathered}
\operatorname{Inc}=75^{\circ} \\
\alpha=0^{\circ}
\end{gathered}
$$

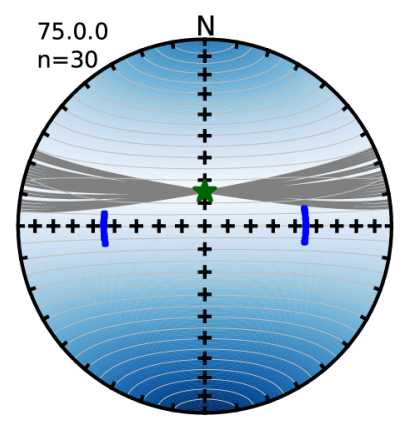

$$
\begin{gathered}
\text { Inc }=75^{\circ} \\
\alpha=90^{\circ}
\end{gathered}
$$

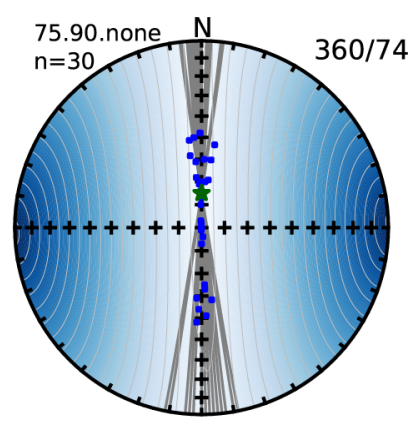

Figure 2. Original configuration of some synthetic models before applying VARs (a) or rotation by different horizontal axes (b) for different inclinations of the remagnetization and different $\alpha$ values. The green star represents the original remagnetization and the blue dots the bedding poles. The bluish contour plot represents the A/n values (see Calvín et al., 2017a), in which light colors represent lower values and dark colors higher ones. 


\subsection{Non-coaxial models}

The starting point for non-coaxial models are folded sites affected by a remagnetization $\left(\mathrm{D}=000^{\circ} ; \mathrm{I}=15^{\circ}, 45^{\circ}, 75^{\circ}\right)$, with a random dip between $\left(-45^{\circ}\right.$ and $\left.+45^{\circ}\right)$ and an original random dispersion in strike of $\pm 10^{\circ}$ from the main structural trend. As in VAR models, different $\alpha$ values are considered (Fig. 2b). Then, each site is affected by a random tilting in a range of $-45^{\circ}$ to $45^{\circ}$ according to a horizontal rotation axis defined by the parameter $\gamma$ (angle between the original strike of each site and the post-remagnetization rotation axis). Note that post-remagnetization tilting can affect to the sites either increasing or decreasing their original dip up to a maximum of $+90^{\circ}$ or $-90^{\circ}$ (positive or negative dips refer to opposite limbs considering the same strike and the right hand rule). Post-remagnetization rotated data are used as input data, as in VAR models, for calculating the remagnetization direction and the paleodips (Fig. 5), also fixing the remagnetization direction to the known direction in one of the set of models (Fig. 6).

\section{Significance of the apical angle}

The apical angle Ap of a SC is defined as the angle between the in situ paleomagnetic direction and the bedding strike (Fig. 1a). This parameter has a main influence in the calculated errors that it is necessary to keep in mind before analyzing the models.

The paleodip error $(\varepsilon)$ is the difference between the original paleodip and the calculated paleodip. This also can be expressed as the angle between the direction over the SC closest to the original reference (the expected one) and the same closest to the calculated one (Fig. 1c). This angle is measured over the SC because its meaning is the necessary rotation around the strike that defines the SC (rotations around the strike change the dip of the beds), to rotate one of the directions to the other. Otherwise, the error in the reference calculation $(\delta)$ is the angle between the original and the calculated reference. It can be measured as the minimum angle between them (Fig. 1c). Although both points are the same considering that the reference is also contained in the SC, the measured angles are different because $\varepsilon$ is measured over a small circle and $\delta$ over a great circle. The paleodip error $(\varepsilon)$ and the reference error $(\delta)$ are related by their respective apical angles

$$
\varepsilon=\delta / \cos (90-A p)
$$

eq. 1

where 90 is the apical angle of the great circle over $\delta$ is measured and Ap the apical angle of the SC (Fig. 3c). Then, higher $\delta$ will generate higher $\varepsilon$, and higher Ap will generate lower $\varepsilon$.

\section{Analyzing the VAR models}

$\varepsilon$ and $\delta$ are in relation with several parameters as (i) the inclination of the original remagnetization, (ii) the angle between the vertical plane that contains the remagnetization and the structural trend and (iii) the sense of post-remagnetization VARs. These factors, specially (i) and (ii), have a major influence because they configure the SCs and the position of the original remagnetization over them. 


\subsection{Errors in the calculated remagnetization}

Models with $\alpha=0^{\circ}$ present different Ap depending of the inclination of the original remagnetization (Fig. 3), and this one is always placed in the center of the SC traces. When a set of almost concentric SCs (with the exception of the initial dispersion in strike) is affected by differential VARs, the direction closest to all SCs and therefore the remagnetization direction (that can also be viewed as the sector with higher density of intersections) is moved in the sense of the VARs up to the center of the SCs that record intermediate VARs (Fig. 3). Therefore, the calculated remagnetization direction presents CCW or CW deviations for CCW and CW models, respectively and have no error for symmetric models. Besides, this error is mainly in declination since changes in the direction upon a SC with the given configuration generate bigger changes in declination than in inclination.

In models with $\alpha=45^{\circ}$, the calculated remagnetization is also displaced toward the middle part of the SCs that record intermediate VARs. However, in these models, the original remagnetization is not placed in the middle of the SCs and this depends on its inclination, being closest to the center for high inclinations than for lower ones (Fig. 3). Then, bigger errors appear for lower inclinations and also more affection to the declination of the remagnetization but also with significant inclinations errors. The reason for this is that in models with low inclination for the expected remagnetization direction, the intersection area is conditioned by the dispersion generated in the SCs by the differential VARs, while in those with high inclination the magnetization direction is very close to the rotation axis (vertical). A difference with $\alpha=0^{\circ}$ models is that the error is always $\mathrm{CW}$, towards the concavity of the SC. In these cases the sense of VARs is not so important, generating the biggest errors when the sense of VARs is towards the concavity of the SCs (i.e. $\delta_{\mathrm{Cw}}>$ $\delta_{\mathrm{sym}}>\delta_{\mathrm{CCW}}$ for the configuration of these models).

Finally, models with $\alpha=90^{\circ}$ present SCs with Ap $=90^{\circ}$ and therefore directions over them present negligible changes in declination but strong changes in inclination (Fig. 3). Then, the calculated directions show high inclinations (between $64^{\circ}$ and $85^{\circ}$ in the presented models) in all cases and therefore models with low original inclinations present the biggest errors.

In an overall view, $\delta$ increases either by increasing $\alpha$ or by decreasing the inclination of the original remagnetization. For $\alpha=0^{\circ}$ the calculated remagnetization moves towards the VAR sense, for $\alpha=45^{\circ}$ it moves towards the concavity of the SC (highest inclinations of the belt described by the SCs) and for $\alpha=90^{\circ}$ it moves towards higher inclinations.

\subsection{Errors in the paleodips}

Errors in the calculated paleodips $(\varepsilon)$ are conditioned both by $\delta$ and by the apical angle of the SC, working in opposite directions. On one hand, higher apical angles favor higher $\delta$ but at the same time higher apical angles favor lower $\varepsilon$ (according to the conditions exposed in section 3 and figure $1 \mathrm{c}$ ). In this way, $\varepsilon$ is compensated by both conditioners and their magnitudes are similar independently of $\alpha$ (Fig. 3). A noteworthy point is that $\varepsilon$ are opposite in the two considered limbs of 
the original fold: the paleodip is overestimated in one limb and underestimated in the other, symmetrically. For $\alpha$ values of $90^{\circ}$, for example with an inclination of $45^{\circ}$ (Fig. 3b), the magnitude of $\varepsilon$ is constant in each limb and therefore independent of the recorded VAR, being overestimated around $50^{\circ}$ in one limb and underestimated around $50^{\circ}$ in the other. Since the original paleodip was $45^{\circ}$, this means that the reconstruction of the structure will be a monocline with subhorizontal and subvertical limbs rather than the actual symmetric fold with limbs dipping $45^{\circ}$. On the contrary, for $\alpha$ values of $0^{\circ}, \varepsilon$ is dependent of the recorded VAR: sites affected by intermediate VARs (i.e. $15^{\circ}$ for $\mathrm{CW}$ models) do not present error in the paleodip and extreme sites, which record $0^{\circ}$ or $30^{\circ} \mathrm{VAR}$ (for the CW models) present the strongest $\varepsilon$. Besides, in one of the limbs, the sites that record values of VARs of $0-15^{\circ}$ the paleodip is overestimated whereas sites that record values of VARs between 15 and $30^{\circ}$ underestimated the paleodip, and the opposite happens in the opposite limb (Fig. 3).

Otherwise, $\varepsilon$ values are derived from $\delta$ and Ap and they do not depends of the initial dip of bedding in each site. Besides, as it has been expressed previously, $\varepsilon$ is the angle between the expected best fit direction and the calculated best fit direction (Fig. 1c; the direction upon the SCs closest to the expected and the calculated remagnetization, respectively). This points out that the original dip of bedding is not a crucial factor in VARs models.

On the other hand, when the remagnetization direction is fixed in its original position (Fig. 4) (e.g., because the remagnetization direction is known from a different approach) $\varepsilon$ values are only significant when low to intermediate $\alpha$ values $\left(0^{\circ}\right.$ or $\left.45^{\circ}\right)$ and low to intermediate inclinations $\left(15^{\circ}\right.$ or $\left.45^{\circ}\right)$ are combined. In these cases, the pattern is different than the observed in the previous models and the sites that do not record VAR are those that do not present $\varepsilon$ significant values (Fig. 4) versus sites that record intermediate VARs (Fig. 3). In the other cases, $\varepsilon$ is negligible (Fig. 4). In an attempt to relate $\varepsilon$ with the angular distance between the best fit direction and the remagnetization direction (Fig. 4), there seems to be some relationship between them, with higher $\varepsilon$ for bigger angular distances but without being able to establish a clear pattern. Although there is a correlation between both parameters, the slope of the regression line changes between models. In any case, sites with higher angular distances are likely to present higher errors. 


\section{(a) Inclination $=15^{\circ}$}

$\mathrm{CCW}$
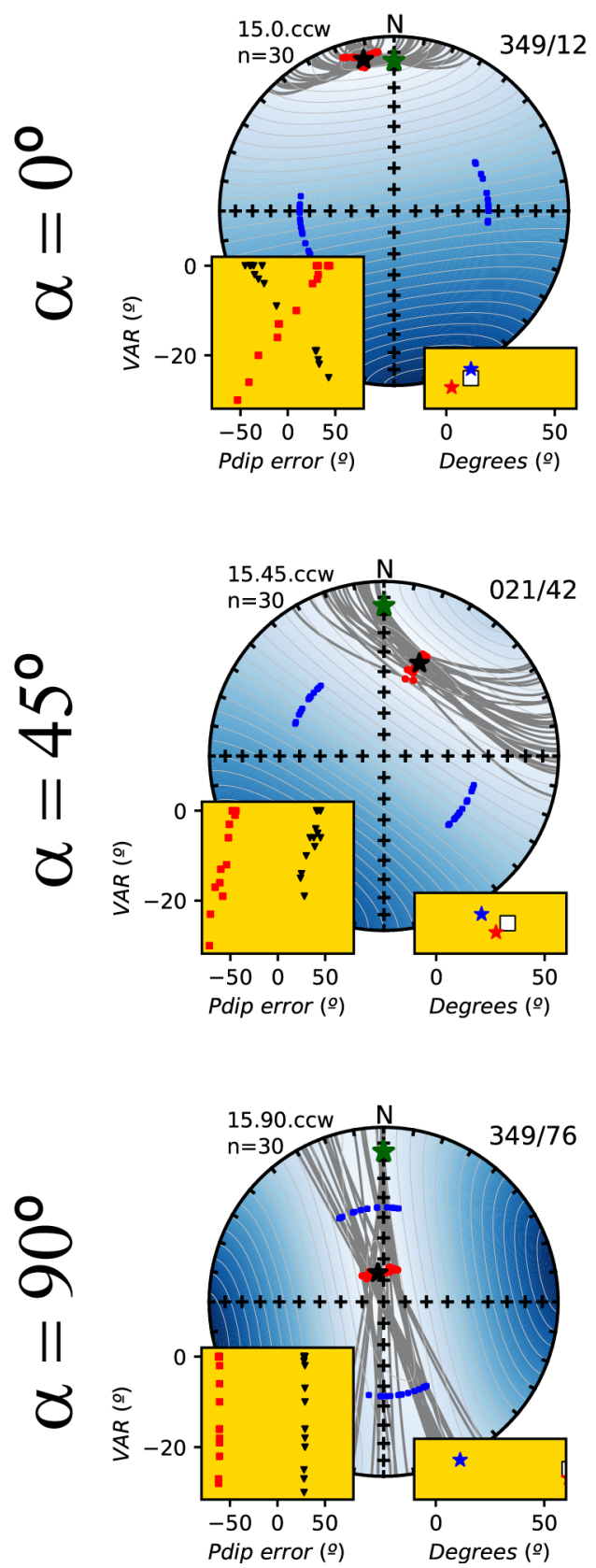

Sym.
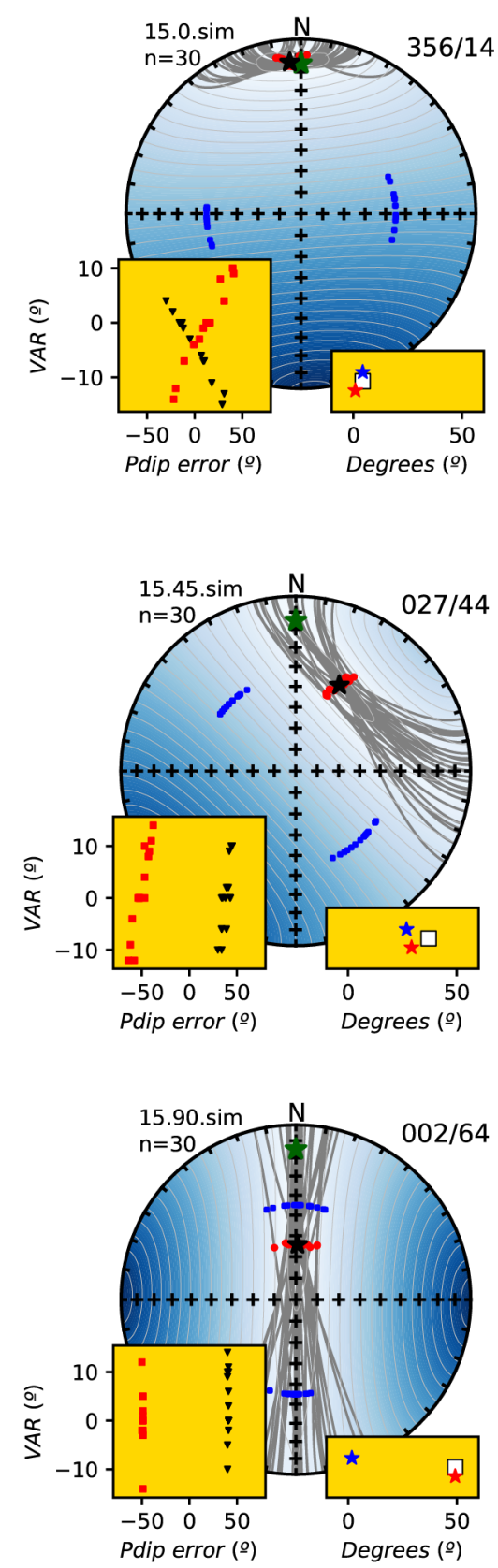
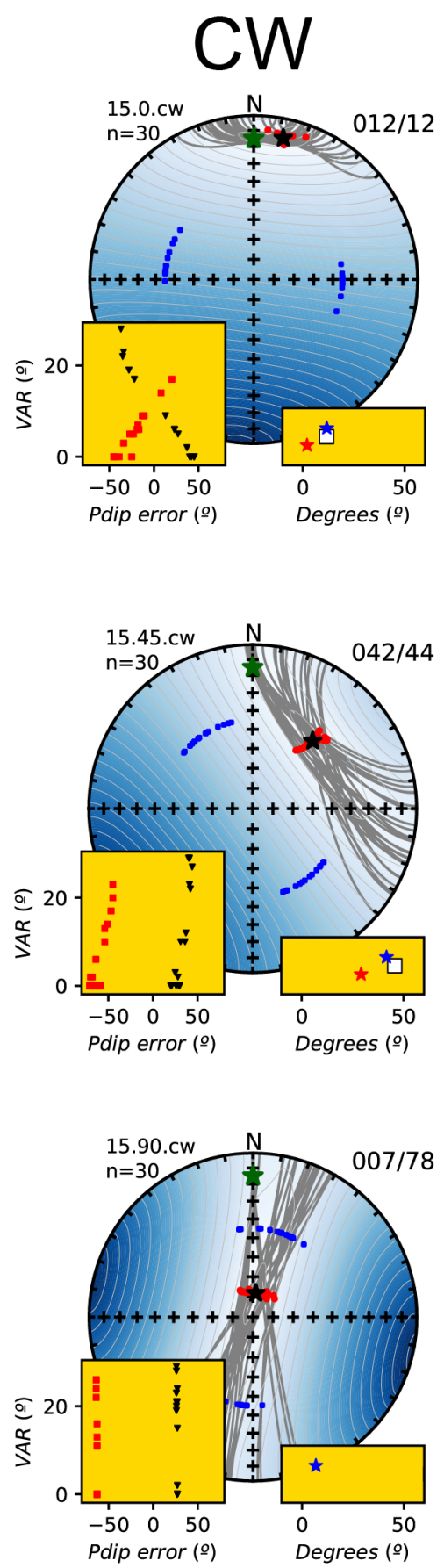

Figure 3. VARs Models for different inclinations of the remagnetization: (a) $15^{\circ}$, (b) $45^{\circ}$ and (c) $90^{\circ}$. The green star represents the original remagnetization direction and the black star the calculated one. Blue dots are the bedding poles, red dots are the best fit directions (i.e. the closest directions over each SC to the calculated reference). Low-right insets represent the overall error in the remagnetization calculation (white square) that is also separated in declination (blue star) and inclination (red star) error (note that y axis represents nothing). Low-left insets show the paleodip error versus the recorded VAR for each site, with the two limbs distinctly represented by the red and black symbols. In the upper-right is the calculated remagnetization direction and in the upper-left, the name of the model (the meaning is inclination . $\alpha$. VAR) and the number of sites. 


\section{(b) Inclination $=45^{\circ}$}
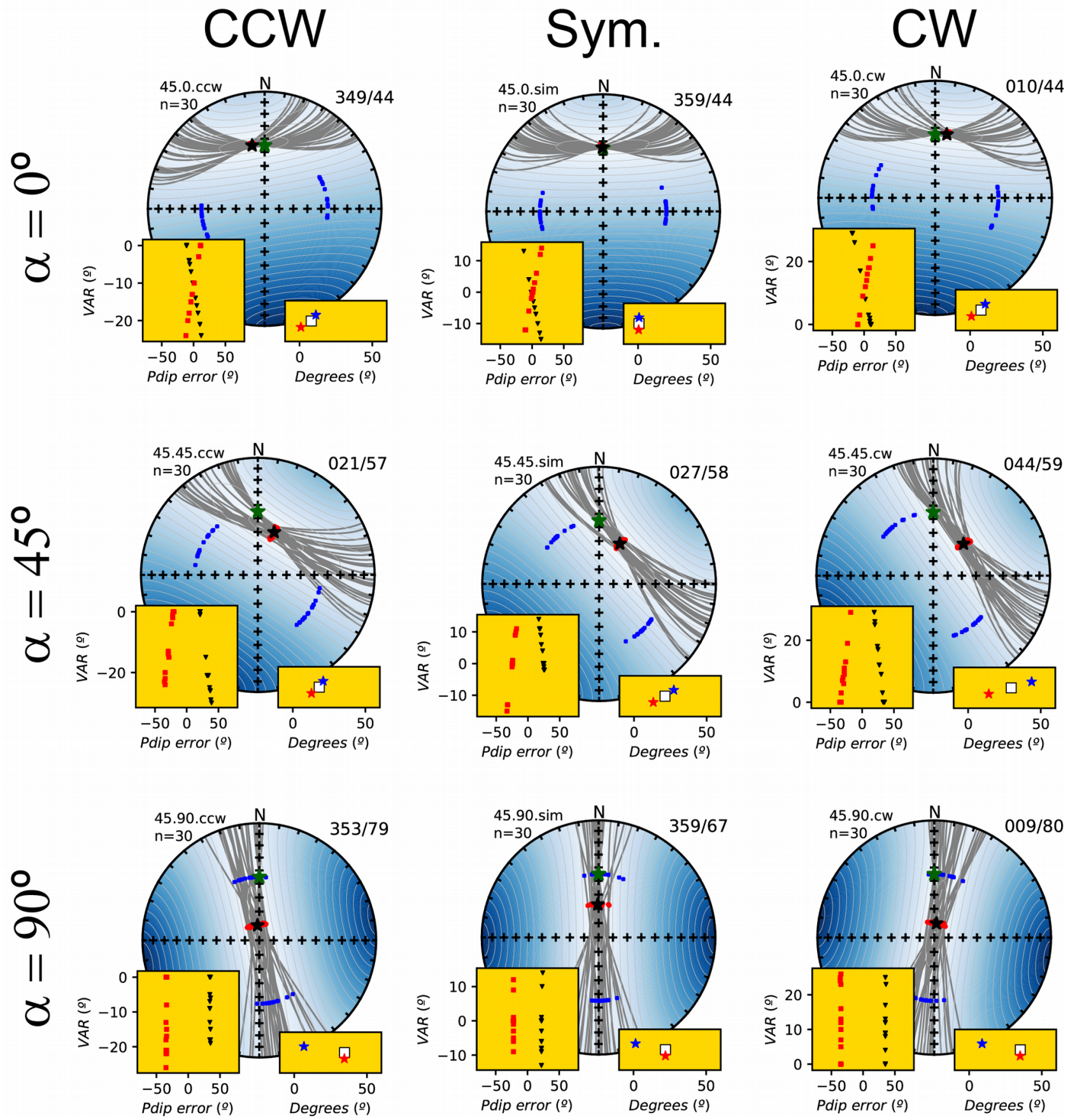

Figure 3. (Continuation) 


\section{(c) Inclination $=75^{\circ}$}
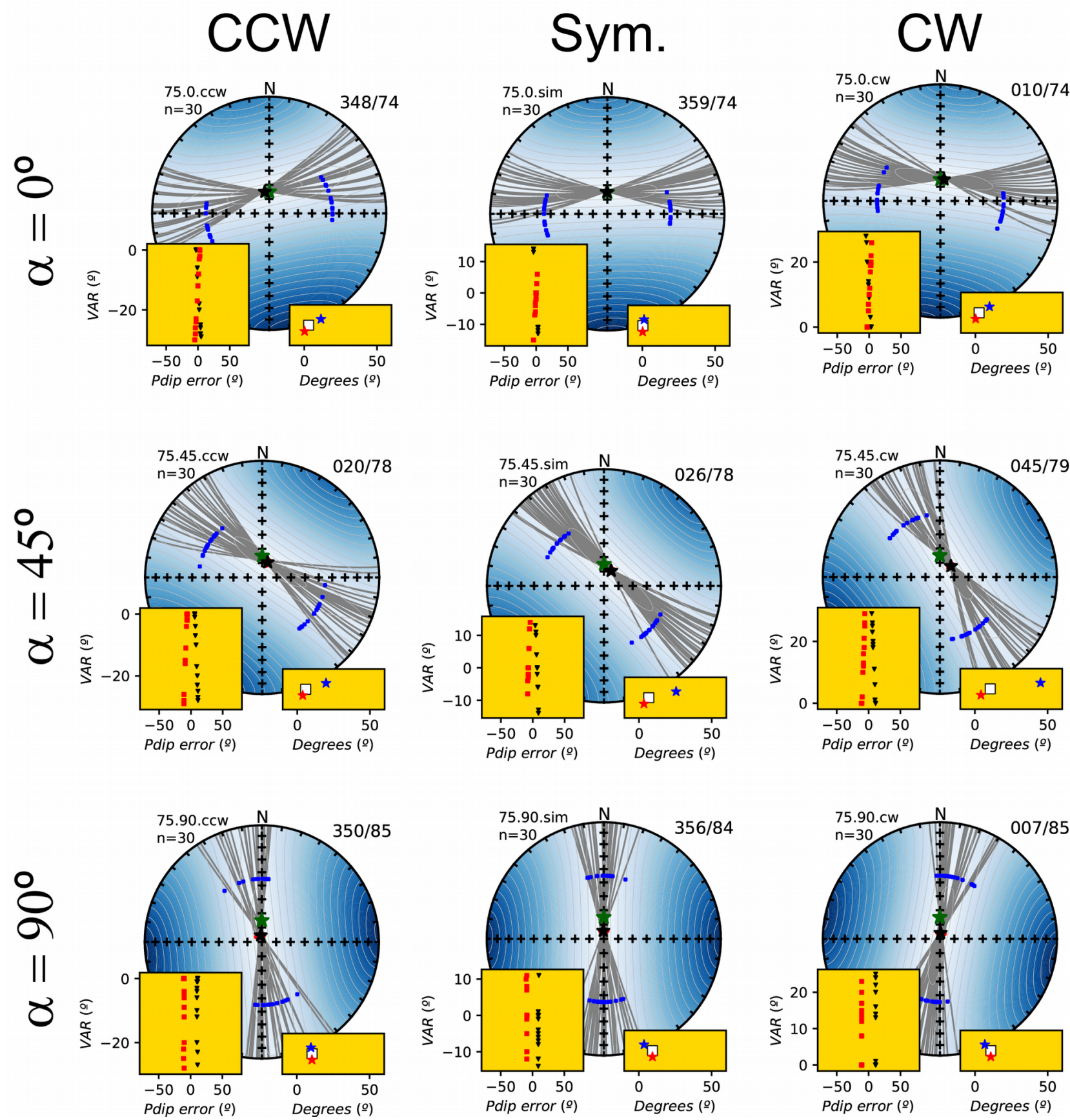

Figure 3. (Continuation) 


\section{Fixed reference}
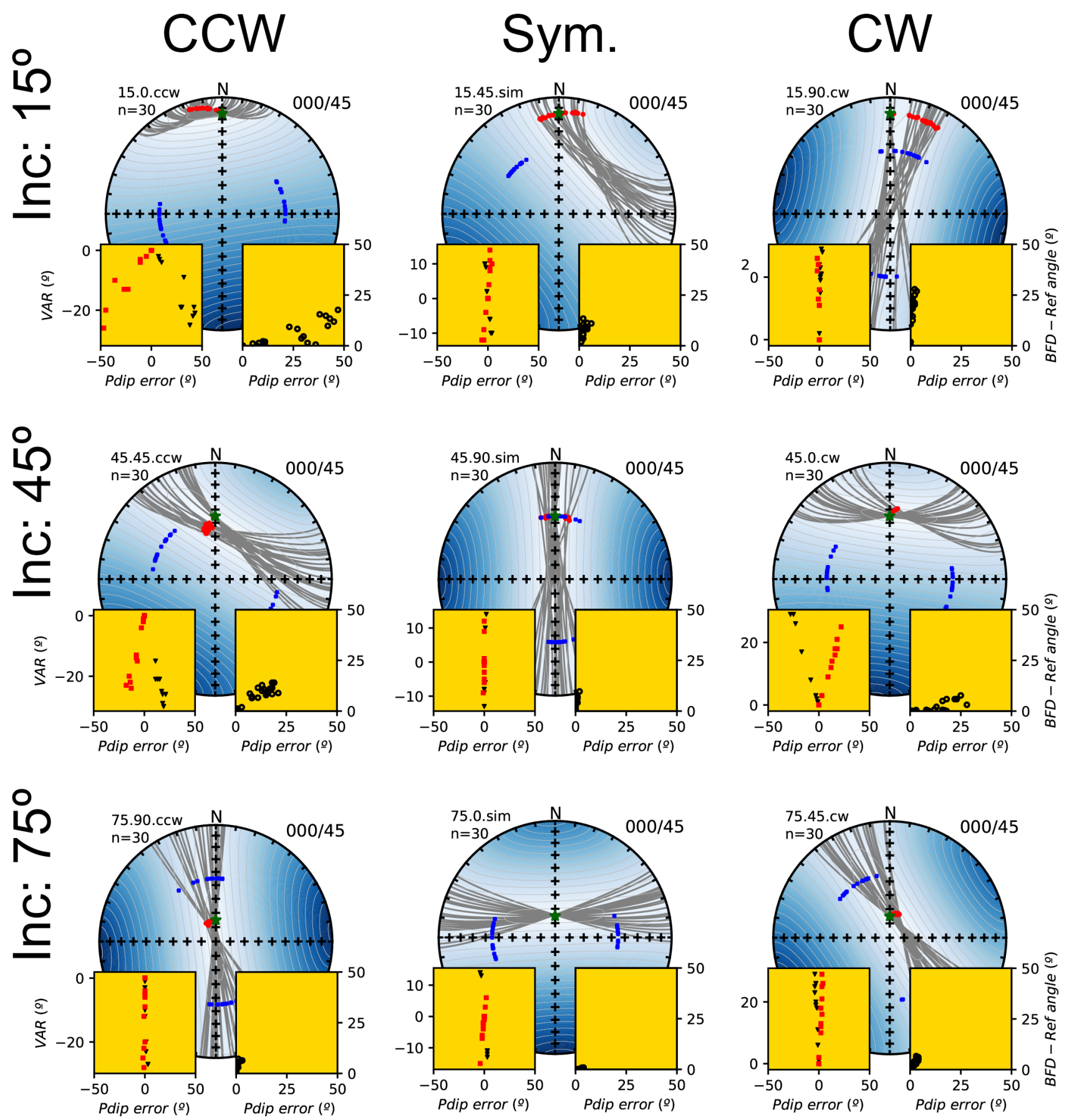

Figure 4. VARs models carried out with the original fixed remagnetization direction. All is as in Figure 3, with the exception of the low-right insets in which $\varepsilon$ is plotted versus the angle between the best fit direction and the remagnetization. 


\section{Analyzing non-coaxial models}

Bedding planes affected by VARs only change their strikes but not their dips; paleomagnetic directions affected by VARs only undergo changes in declination but not in inclination. Besides, strikes and declinations change in the same way under VAR processes. Then, the SCs only change their axes, but the Ap remain constant. On the contrary, non-coaxiality changes both the strike and the dip of bedding as well as the declination and the inclination of the paleomagnetic directions. The result is that SCs change both in the trend of their axes and in the Ap. This makes that VARs models show characteristic patterns in the dispersion of the SCs and in the errors, depending on the analyzed variables, but this is not happening in non-coaxial models (Fig. 5), where SCs show similar patterns, and similar errors are derived for the same inclinations as well, independently of the non-coaxiality angle $\left(\gamma=45^{\circ}\right.$ or $\left.90^{\circ}\right)$ (Fig. 5).

As expected, coaxial models $\left(\gamma=0^{\circ}\right)$ have neither $\delta$ nor $\varepsilon$. Non-coaxial models (either $\gamma=$ $45^{\circ}$ or $90^{\circ}$ ) always present low $\delta$ values, below $10-15^{\circ}$ in most of cases. Big errors in declination happen for high inclination values of the original remagnetization, since small $\delta$ can mean strong variations in declination. $\varepsilon$ are between $0^{\circ}$ and $20-25^{\circ}$ in all cases, being significantly greater the number of sites without error than those with errors. Therefore, non-coaxiality do not provide characteristic patterns, either in $\delta$ or in $\varepsilon$, but on the other hand these errors are assumable in most of cases, more so when the remagnetization direction is fixed to its known direction (Fig. 6), where $\varepsilon$ are generally negligible. 


\section{(a) Inclination $=15^{\circ}$}
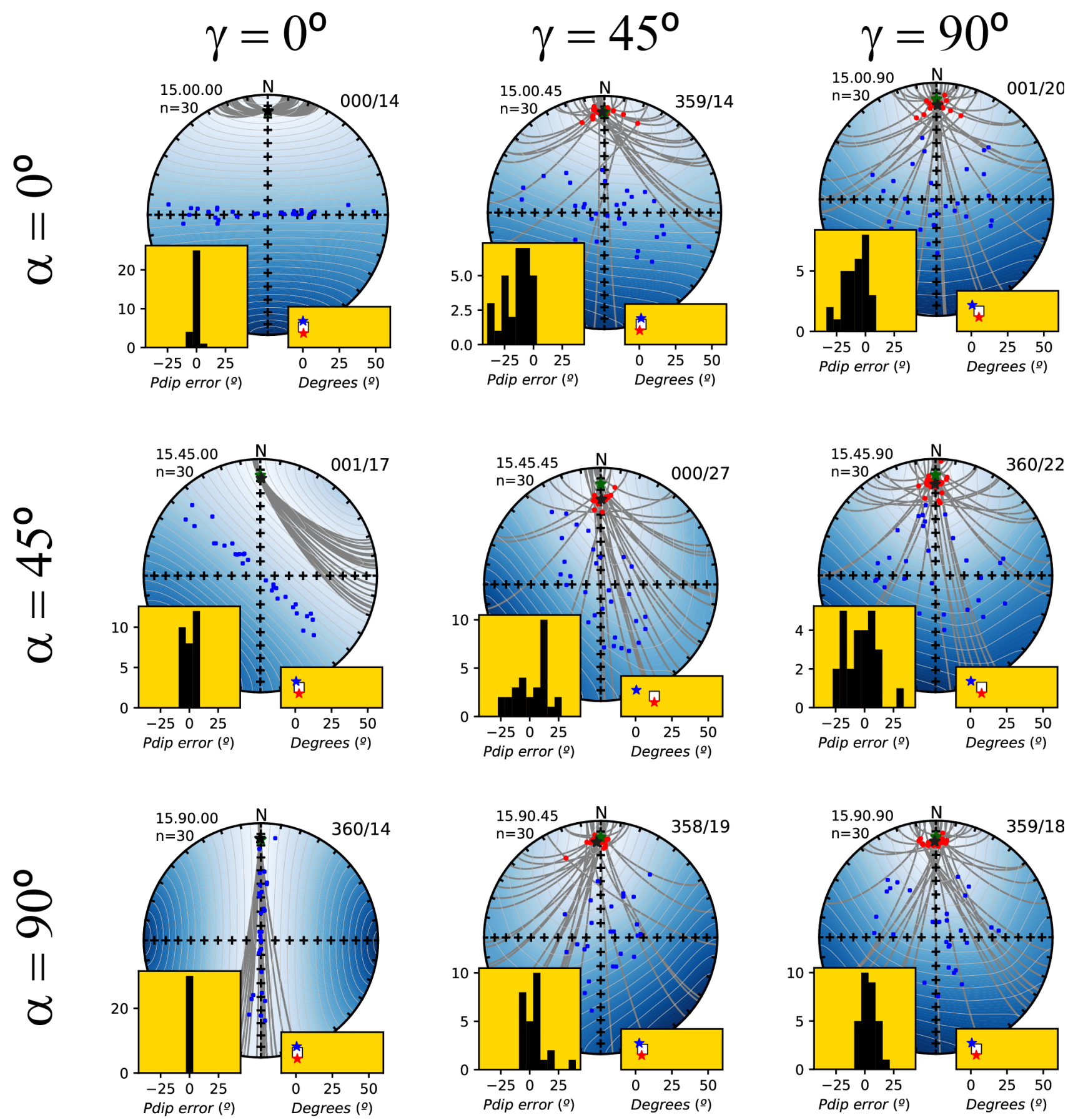

Figure 5. Non-coaxial models for different inclinations of the remagnetization: (a) $15^{\circ}$, (b) $45^{\circ}$ and (c) $75^{\circ}$. The green star represents the original remagnetization direction and the black star the calculated one. Blue dots are the bedding poles, red dots are the best fit directions (i.e. the closest directions to the calculated reference on each SC). Low-right insets represent the overall error in the remagnetization calculation (white square) and is also separated in declination (blue star) and inclination (red star) errors (note that y axis does represent any variable). Low left insets show histograms showing the number of paleomagnetic sites corresponding to each paleodip error band. 


\section{(b) Inclination $=45^{\circ}$}
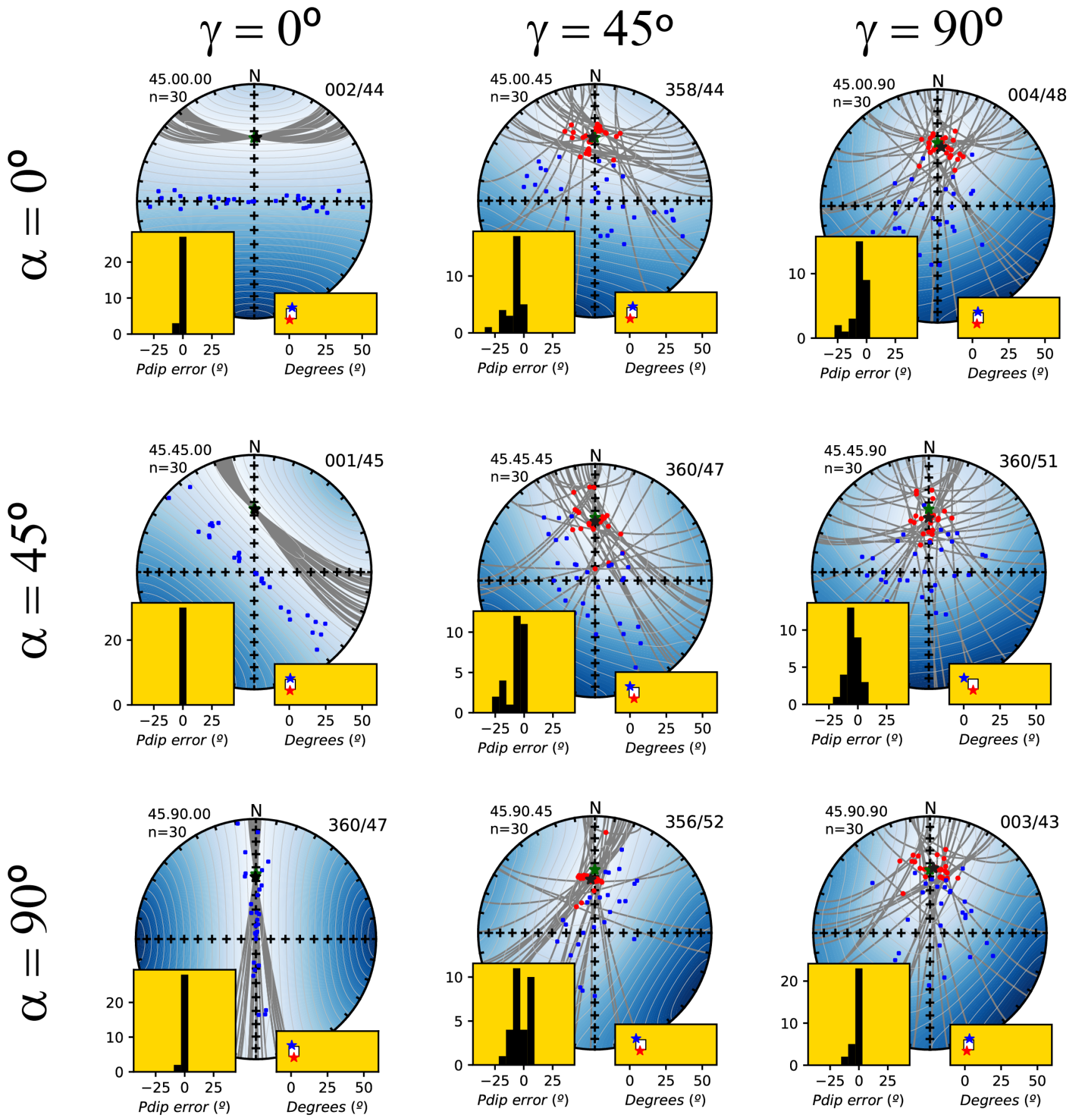

Figure 5. (Continuation) 


\section{(c) Inclination $=75^{\circ}$}
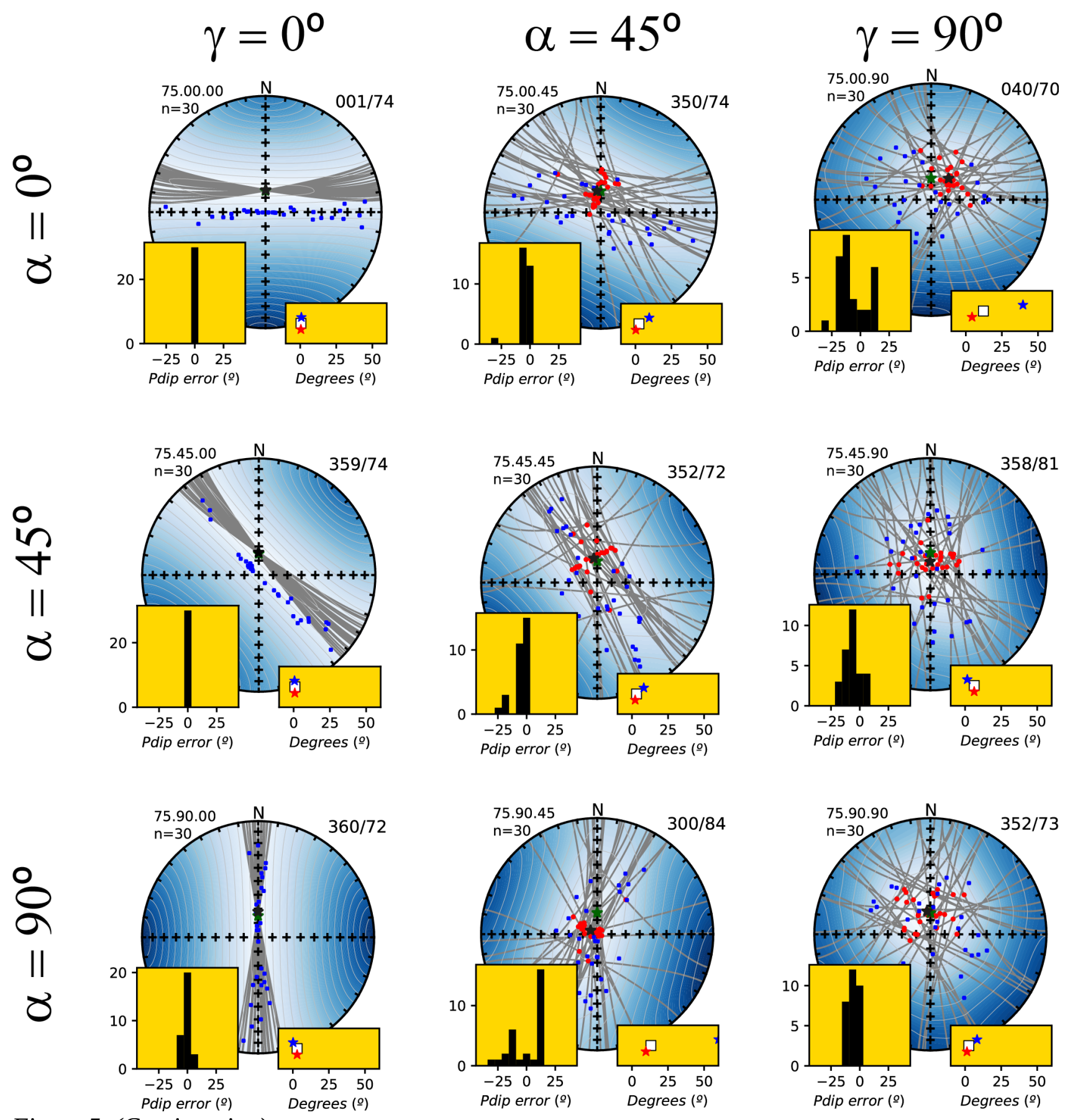

Figure 5. (Continuation) 


\section{Fixed reference}
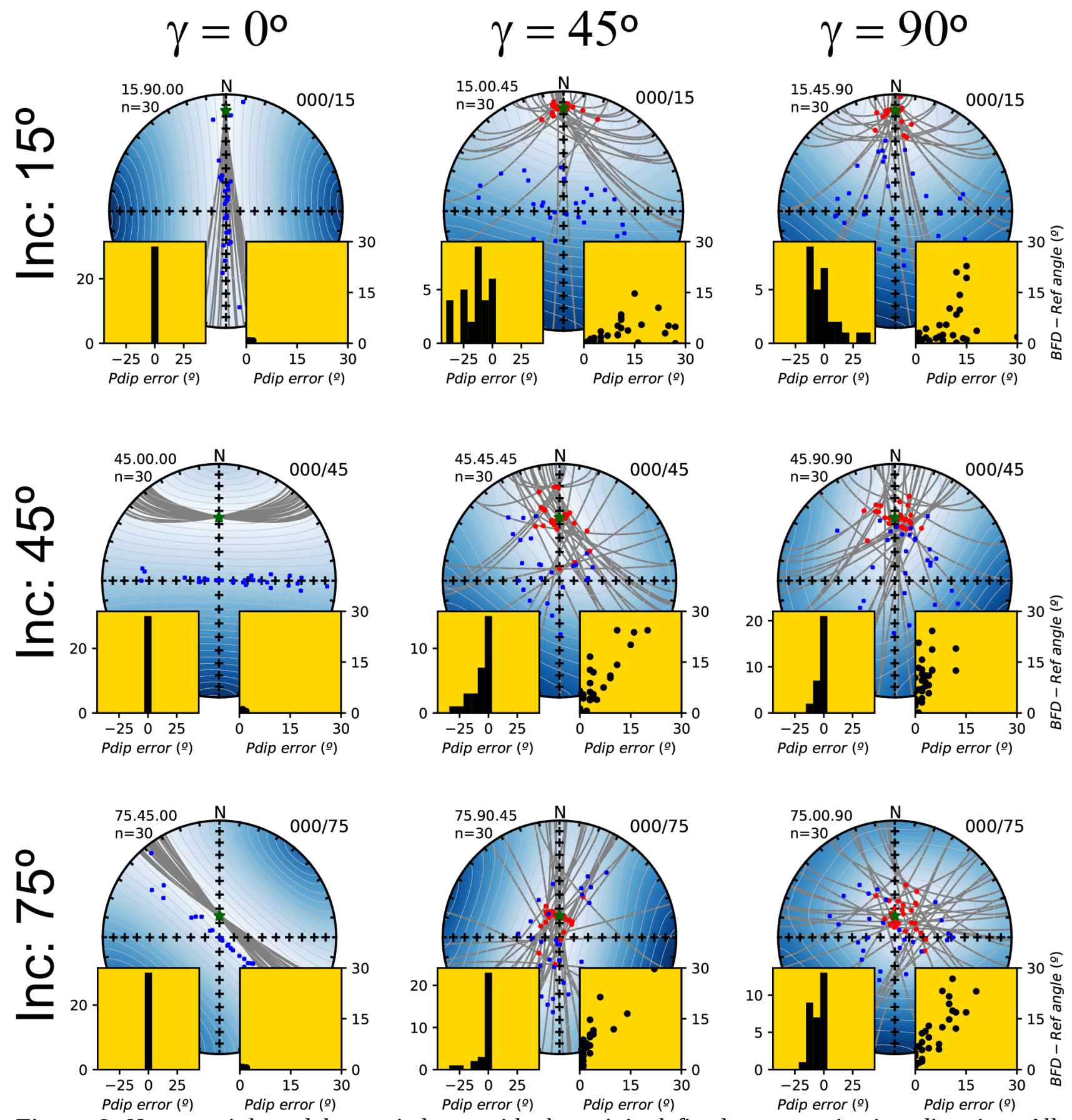

Figure 6. Non-coaxial models carried out with the original fixed remagnetization direction. All symbols as in Figure 3, with the exception of the low-right insets in which $\varepsilon$ is plotted versus the angle between the best fit direction and the remagnetization. 


\section{Hints to discover VARs and non-coaxiality}

Errors derived from SC tools can be significant if some of the starting hypotheses are not fulfilled, as for example the presence of post-remagnetization VARs. Sometimes it can be difficult to discover the presence of these processes leading to errors in the calculation of remagnetization directions or in structural reconstructions. Synthetic models give clues that can make us suspect that something is wrong if we detect similar patterns in the real cases that we are analyzing.

\subsection{Detecting VARs}

VARs, even if moderate (from $0^{\circ}$ to $30^{\circ}$ ), generate meaningful $\delta$ and $\varepsilon$ values, but, fortunately, these errors present characteristic patterns that can help us to detect them. It must be stressed that only VAR that took place after the remagnetization acquisition can be detected. In addition, in the presented models, rotations have been considered as occurring after the two deformation events.

- In VAR models the calculated remagnetization tend to high inclinations, within the Ap limits, and hence tend to be placed in the central sectors of the SCs. Therefore, calculated directions with inclinations lower than the limit imposed by the SCs are likely actual directions and on the contrary, inclinations limited by Ap are suspicious of having underwent VARs. Comparison of the inclination with external data (e.g., the apparent polar wander path) can be decisive in identifying VARs.

- In gradual and small VARs, as in the analyzed models, the SC distribution does not give any clue about the presence of VARs.

- The analysis of the paleodips can be interesting to detect VARs, and we must remember that this analysis should be done considering the $\alpha$ parameter. General structure with systematic higher dips on limbs dipping in one sense versus the opposite limbs (for $\alpha=0^{\circ}$ ) or non-sense reconstructed structures (for $\alpha=90^{\circ}$ ) can be indicators of presence of VARs.

\subsection{Detecting non-coaxiality}

Analyzed models show that non-coaxiality is difficult to detect from $\delta$ and $\varepsilon$ but, fortunately, errors derived from non-coaxiality are low and generally acceptable in structural reconstructions. Perhaps the only way to detect non-coaxiality is analyzing the SC distribution as well as the bedding distribution. Bedding poles showing high scattering in the cylindrical best fit according to the general structural trend are suspicious of being the result of non-coaxiality. However, this also can be due to an initial scatter in the strikes of bedding. 


\section{Concluding remarks}

A small circle (SC) is the path defined by a paleomagnetic direction when it is rotated around a specific axis. In SC tools this axis is the bedding strike of the respective paleomagnetic site. These methods assume that the deviation of the remagnetization vector from its original direction was through the bedding strikes of each site. Then, rotations around axes different than the strike affect to the final result derived from the SC tools, giving errors in the calculated remagnetization direction $(\delta)$ and in the paleodips $(\varepsilon)$. Modeling synthetic data allows to evaluate how affect in the results (i) the presence of post-remagnetization differential vertical axis rotation (VAR) and (ii) the non-coaxiality between the axes of pre- and post-remagnetization tilting.

VARs have a strong effect in the calculation of both $\delta$ and $\varepsilon$. $\delta$ presents systematically higher inclinations than expected, specially when the angle between the declination of the remagnetization and the structural trend is high $\left(\alpha>45^{\circ}\right) . \varepsilon$ are around $40-50^{\circ}$ in most sites, showing opposite behavior between both limbs related to the recorded VAR: in one limb the paleodip is overestimated and, conversely, in the other it is underestimated. $\varepsilon$ are also in the same range when models consider the know reference for paleodip calculations. Although errors are high when VARs occur, the distinctive behavior observed in both $\delta$ and $\varepsilon$ can be useful to detect VARs working with natural data.

Non-coaxiality have lower influence in $\delta$ and $\varepsilon$, with $\delta$ lower than $15^{\circ}$ in most cases and $\varepsilon$ between 0 and $15^{\circ}$, which is acceptable for most regional structural restorations of the paleogeometry. However, absence of distinctive patterns in $\delta$ and $\varepsilon$ makes it more difficult to find clues evidencing this process.

\section{References}

Allerton, S., 1998. Geometry and kinematics of vertical-axis rotations in fold and thrust belts. Tectonophysics 299, 1530. https://doi.org/10.1016/S0040-1951(98)00196-6

Baidder, L., Michard, A., Soulaimani, A., Fekkak, A., Eddebbi, A., Rjimati, E.-C., Raddi, Y., 2016. Fold interference pattern in thick-skinned tectonics; a case study from the external Variscan belt of Eastern Anti-Atlas, Morocco. J. African Earth Sci. 119, 204-225. https://doi.org/10.1016/j.jafrearsci.2016.04.003

Bazhenov, M.L., Shipunov, S. V., 1991. Fold test in paleomagnetism: new approaches and reappraisal of data. Earth Planet. Sci. Lett. 104, 16-24. https://doi.org/10.1016/0012-821X(91)90233-8

Cairanne, G., Aubourg, C., Pozzi, J.P., 2002. Syn-folding remagnetization and the significance of the small circle test examples from the Vocontian trough (SE France). Phys. Chem. Earth 27, 1151-1159. https://doi.org/10.1016/S1474-7065(02)00106-7

Calvín, P., Casas-Sainz, A.M., Villalaín, J.J., Moussaid, B., 2017b. Diachronous folding and cleavage in an intraplate setting (Central High Atlas, Morocco) determined through the study of remagnetizations. J. Struct. Geol. 97, 144-160. https://doi.org/10.1016/j.jsg.2017.02.009 
Calvín, P., Villalaín, J.J., Casas-Sainz, A.M., Tauxe, L., Torres-López, S., 2017a. pySCu: a new python code for analyzing remagnetizations directions by means of Small Circle utilities. Comput. Geosci. 109. https://doi.org/10.1016/j.cageo.2017.07.002

Casas, A.M., Villalaín, J.J., Soto, R., Gil-Imaz, A., del Río, P., Fernández, G., 2009. Multidisciplinary approach to an extensional syncline model for the Mesozoic Cameros Basin (N Spain). Tectonophysics 470, 3-20. https://doi.org/10.1016/j.tecto.2008.04.020

Delaunay, S., Smith, B., Aubourg, C., 2002. Asymmetrical fold test in the case of overfolding: two examples from the Makran accretionary prism (Southern Iran). Phys. Chem. Earth, Parts A/B/C 27, 1195-1203. https://doi.org/10.1016/S1474-7065(02)00130-4

Deng, H., Koyi, H.A., Nilfouroushan, F., 2016. Superimposed folding and thrusting by two phases of mutually orthogonal or oblique shortening in analogue models. J. Struct. Geol. 83, $28-45$. https://doi.org/10.1016/j.jsg.2015.08.005

Fisher, R., 1953. Dispersion on a Sphere. Proc. R. Soc. A Math. Phys. Eng. Sci. $217,295-305$. https://doi.org/10.1098/rspa.1953.0064

García-Lasanta, C., Casas-Sainz, A., Villalaín, J.J., Oliva-Urcia, B., Mochales, T., Speranza, F., 2017. Remagnetizations used to unravel large-scale fold kinematics: a case study in the Cameros basin (N Spain). Tectonics. https://doi.org/10.1002/2016TC004459

Graham, J.W., 1949. The stability and significance of magnetism in sedimentary rocks. J. Geophys. Res. 54, $131-167$. https://doi.org/10.1029/JZ054i002p00131

Henry, B., Rouvier, H., Le Goff, M., 2004. Using syntectonic remagnetizations for fold geometry and vertical axis rotation: the example of the Cévennes border (France). Geophys. J. Int. 157, 1061-1070. https://doi.org/10.1111/j.1365-246X.2004.02277.x

Henry, B., Rouvier, H., le Goff, M., Leach, D., Macquar, J.-C., Thibieroz, J., Lewchuk, M.T., 2001. Palaeomagnetic dating of widespread remagnetization on the southeastern border of the French Massif Central and implications for fluid flow and Mississippi Valley-type mineralization. Geophys. J. Int. 145, 368-380. https://doi.org/10.1046/j.0956-540x.2001.01382.x

MacDonald, W.D., 1980. Net tectonic rotation, apparent tectonic rotation, and the structural tilt correction in paleomagnetic studies. J. Geophys. Res. Solid Earth 85, 3659-3669. https://doi.org/10.1029/JB085iB07p03659

McClelland-Brown, E., 1983. Palaeomagnetic studies of fold development and propagation in the Pembrokeshire old red Sandstone. Tectonophysics 98, 131-149. https://doi.org/10.1016/0040-1951(83)90214-7

McFadden, P.L., 1990. A new fold test for palaeomagnetic studies. Geophys. J. Int. 103, $163-169$. https://doi.org/10.1111/j.1365-246X.1990.tb01761.x

Meijers, M.J.M., van Hinsbergen, D.J.J., Dekkers, M.J., Altıner, D., Kaymakcı, N., Langereis, C.G., 2011. Pervasive Palaeogene remagnetization of the central Taurides fold-and-thrust belt (southern Turkey) and implications for rotations in the Isparta Angle. Geophys. J. Int. 184, 1090-1112. https://doi.org/10.1111/j.1365246X.2010.04919.X

Pueyo, E.L., Pocoví, A., Millán, H., Sussman, A.J., 2004. Map-view models for correction and calculating shortening estimates in rotated thrust fronts using paleomagetic data. Geol. Soc. Am. Spec. Pap. 383, 57-71. https://doi.org/10.1130/0-8137-2383-3(2004)383[57:MMFCAC]2.0.CO;2 
Pueyo, E.., Parés, J.., Millán, H., Pocoví, A., 2003. Conical folds and apparent rotations in paleomagnetism (a case study in the Southern Pyrenees). Tectonophysics 362, 345-366. https://doi.org/10.1016/S0040-1951(02)00645-5

Pueyo, E.L.L., Sussman, A.J.J., Oliva-Urcia, B., Cifelli, F., 2016. Palaeomagnetism in fold and thrust belts: use with caution. Geol. Soc. London, Spec. Publ. 425, 259-276. https://doi.org/10.1144/SP425.14

Ramsay, J.G., Huber, M.I., 1987. The Techniques of Modern Structural Geology. Volume 2: Folds and Fractures. Academic Press, London.

Shipunov, S. V, 1997. Synfolding magnetization: detection, testing and geological applications. Geophys. J. Int. 130, 405-410. https://doi.org/10.1111/j.1365-246X.1997.tb05656.x

Simón, J.L., 2004. Superposed buckle folding in the eastern Iberian Chain, Spain. J. Struct. Geol. 26, $1447-1464$. https://doi.org/10.1016/j.jsg.2003.11.026

Smith, B., Derder, M.E.M., Henry, B., Bayou, B., Yelles, a. K., Djellit, H., Amenna, M., Garces, M., Beamud, E., Callot, J.P., Eschard, R., Chambers, A., Aifa, T., Ait Ouali, R., Gandriche, H., 2006. Relative importance of the Hercynian and post-Jurassic tectonic phases in the Saharan platform: a palaeomagnetic study of Jurassic sills in the Reggane Basin (Algeria). Geophys. J. Int. 167, 380-396. https://doi.org/10.1111/j.1365-246X.2006.03105.x

Soto, R., Casas-Sainz, A.M., Villalain, J.J., 2011. Widespread Cretaceous inversion event in northern Spain: evidence from subsurface and palaeomagnetic data. J. Geol. Soc. London. 168, 899-912. https://doi.org/10.1144/001676492010-072

Soto, R., Casas-Sainz, A.M., Pueyo, E.L., 2006. Along-strike variation of orogenic wedges associated with vertical axis rotations. J. Geophys. Res. 111, B10402. https://doi.org/10.1029/2005JB004201

Soto, R., Villalaín, J.J., Casas-Sainz, A.M., 2008. Remagnetizations as a tool to analyze the tectonic history of inverted sedimentary basins: A case study from the Basque-Cantabrian basin (north Spain). Tectonics 27, n/a-n/a. https://doi.org/10.1029/2007TC002208

Suppe, J., 1983. Geometry and kinematics of fault-bend folding. Am. J. Sci. 283 , 684-721. https://doi.org/10.2475/ajs.283.7.684

Surmont, J., Sandulescu, M., Bordea, S., 1990. Mise en évidence dúne réaimantation fini crétacée des séries mésozoïques de l'unité de Bihor (Monts Apuseni, Roumanie) et de sa rotation horarie ultériore. Comptes Rendus L Acad. Des Sci. Paris 310, 213-219.

Tauxe, L., Watson, G.S., 1994. The fold test: an eigen analysis approach. Earth Planet. Sci. Lett. 122, 331-341. https://doi.org/10.1016/0012-821X(94)90006-X

Torres-López, S., Villalaín, J.J., Casas, A.M., EL Ouardi, H., Moussaid, B., Ruiz-Martínez, V.C., 2014. Widespread Cretaceous secondary magnetization in the High Atlas (Morocco). A common origin for the Cretaceous remagnetizations in the western Tethys? J. Geol. Soc. London. 171, 673-687. https://doi.org/10.1144/jgs2013107

Villalaín, J.J., Osete, M.L., Vegas, R., García-Dueñas, V., 1992. Evidencia de una reimanación terciaria en la Béticas Occidentales. Implicaciones tectónicas. Física la Tierra 4, 165-184.

Villalaín, J., Fernández-González, G., Casas, A.M., Gil-Imaz, A., 2003. Evidence of a Cretaceous remagnetization in the Cameros Basin (North Spain): implications for basin geometry. Tectonophysics 377, 101-117. https://doi.org/10.1016/j.tecto.2003.08.024 
Villalaín, J.J., Casas-Sainz, A.M., Soto, R., 2016. Reconstruction of inverted sedimentary basins from syn-tectonic remagnetizations. A methodological proposal. Geol. Soc. London, Spec. Publ. 425, $233-246$. https://doi.org/10.1144/SP425.10

Waldhör, M., 1999. The small-circle reconstruction in palaeomagnetism and its application to palaeomagnetic data from the pamirs. Tübingen University.

Waldhör, M., Appel, E., 2006. Intersections of remanence small circles: new tools to improve data processing and interpretation in palaeomagnetism. Geophys. J. Int. 166, 33-45. https://doi.org/10.1111/j.1365246X.2006.02898.x

Watson, G.S., Enkin, R.J., 1993. The fold test in paleomagnetism as a parameter estimation problem. Geophys. Res. Lett. 20, 2135-2137. https://doi.org/10.1029/93GL01901Allerton, S., 1998. Geometry and kinematics of vertical-axis rotations in fold and thrust belts. Tectonophysics 299, 15-30. https://doi.org/10.1016/S00401951(98)00196-6 



\section{Extractos magnéticos en calizas remagnetizadas}

5.1. Extractos magnéticos y observaciones mediante microscoía electrónica en carbonatos magnetizados jurásicos / Magnetic extractions and electronic microscopy observations in

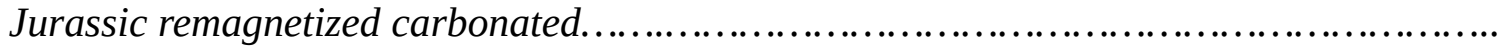



The characteristics of the magnetite authigenic grains, one of the common carriers of chemical remagnetizations in carbonates, is well know at present (Jackson and Swanson-Hysell, 2012). Now we know that during the remagnetization processes a big amount of single domain grains, both with superparamagnetic (SP) and stable single domain (SSD) behavior, are able to grow. In the cases where this property has been tested, the grains display shape anisotropy. However, there are still unresolved issues, as for example, why the maximum unblocking temperatures are around $500^{\circ} \mathrm{C}$. This can be related either to the chemical composition of the magnetite or to an unknown volume limitation or even to the crystals shape.

In this chapter, a magnetic extraction in limestones from the Atlas and the Cabuérniga basins is presented. Trying not to fall in the same pitfalls that previous attempts, in which some authors observed that the remagnetization carriers were lost during the extraction procedure, we follow the procedure presented by Strehlau et al. (2014) that has been successfully tested in stalagmites. In order to prove if loss of magnetic material occurs, rock magnetic experiments are done in the different phases derived from the extraction processes.

This work was done in the Institute for Rock Magnetism (Minnesota University) in collaboration with Jennifer H. Strehlau and Mike Jackson. 



\title{
Extractos magnéticos y observaciones mediante microscopía electrónica en carbonatos remagnetizados jurásicos
}

\author{
Magnetic extractions and electronic microscopy observations in Jurassic remagnetized \\ carbonates
}

\author{
P. Calvín ${ }^{1}$ J. Strehlau², M. Jackson ${ }^{3}$ y JJ. Villalaín ${ }^{1}$ \\ 1 Dep. Física, U. Burgos, Escuela Politécnica Superior, Avda. Cantabria s/n 09006 Burgos, España. pcalvin@ubu.es, villa@ubu.es. \\ 2 Dep. Chemistry, U. Minnesota, 207 Pleasant Street SE, Minneapolis, Minnesota 55455-0240, EEUU. degre019@umn.edu. \\ 3. Institute for Rock Magnetism, U. Minnesota, 291 Sheperd Lab, 100 Union Street SE, Minneapolis, Minnesota 55455-0153, EEUU. irm@umn.edu.
}

\begin{abstract}
Resumen: El estudio de la remagnetización en rocas carbonatadas viene realizándose durante los últimos 40 años, tanto por medio del análisis de sus propiedades magnéticas como tratando de realizar observaciones por medio de microscopía electrónica (SEM/TEM). Los resultados obtenidos con el primer análisis han proporcionado numerosos datos y hoy en día sabemos que generalmente la remagnetización es portada por magnetita. Ésta es de tamaño nanométrico generada durante la diagénesis, correspondiéndose con una remagnetización química. Sin embargo, los numerosos intentos de observación de dichos cristales por medio de SEM/TEM siempre han sido infructuosos y los cristales observados siempre presentan tamaños dentro del rango multidominio. En un nuevo intento de observación directa de dichos cristales mediante microscopía electrónica, hemos realizado nuevos ensayos sobre extractos magnéticos en calizas jurásicas remagnetizadas de las cuencas del Alto Atlas (Marruecos), Cameros y Vasco-Cantábrica (España) según las últimas técnicas propuestas en la literatura. Las propiedades magnéticas de los diferentes subproductos provenientes del proceso de extracción indican una pérdida de material magnético durante el mismo, principalmente las partículas de grano más fino (granos de tamaño monodominio y superparamagnético). Igualmente, mediante SEM/TEM únicamente han podido observarse cristales de magnetita multidominio.
\end{abstract}

Palabras clave: Extracción magnética, remagnetización, carbonatos, magnetita, microscopía electrónica.

\begin{abstract}
Since the last 40 years the analysis of remagnetized carbonates is under debate, by studying their magnetic properties and by using electronic microscopy (SEM/TEM). Results obtained from the first analyses allowed to infer that remagnetization is carried generally by nanometric magnetite and generated during the diagenesis, therefore it corresponds to a chemical remagnetization. However, several attempts to observe these magnetites by SEM/TEM were unsuccessful and in all cases the observed magnetite was in the range of multidomain size. In a new attempt to observe these crystals by electronic microscopy we did new magnetic extracts (according the last techniques proposed in the literature) in Jurassic remagnetized limestones of the High Atlas (Morocco), Cameros and Basque-Cantabrian (Spain) basins. Magnetic properties of the different sub-products of the extracts show a lost of magnetic material during the procedure, mostly of the smallest size (superparamagnetic and single-domain size). Likewise, only multi-domain magnetite grains were observed by SEM/TEM.
\end{abstract}

Key words: Magnetic extraction, remagnetization, limestones, magnetite, electronic microscopy.

\section{INTRODUCCIÓN}

El estudio de calizas remagnetizadas se ha desarrollado a lo largo de décadas, inicialmente desde el punto de vista paleomagnético y sus aplicaciones principalmente tectónicas. Sin embargo, paralelamente se han desarrollado estudios de magnetismo de rocas tratando de ahondar en el conocimiento de los portadores de la magnetización, que predominantemente es magnetita (ver Van Der Voo y Torsvik (2012) y referencias allí incluidas). Estos últimos trabajos indican que la remagnetización de estas rocas es de tipo químico, con el crecimiento de cristales de magnetita debido a diferentes procesos entre los que caben destacar los ligados al enterramiento y a procesos de transformación de arcillas durante etapas diagenéticas profundas (Elmore et al., 2012). Estas remagnetizaciones se han descrito tanto en cinturones de pliegues y cabalgamientos en contextos compresivos como en cuencas sedimentarias en contextos extensivos. Independientemente del contexto y el proceso generador de las magnetitas neoformadas, los experimentos de magnetismo de rocas indican la neoformación de una población de magnetita con una distribución de tamaño que varía de manera progresiva desde el rango superparamagnético al monodominio (SP y SD respectivamente acorde a sus siglas en inglés). Así mismo, experimentos realizados por Jackson y Swanson-Hysell, (2012) muestran una anisotropía de forma en los granos SD, de modo que el tamaño esperado de dichos cristales 
será menor a $60 \mathrm{~nm}$, que presentaría temperaturas de desbloqueo en torno de $450{ }^{\circ} \mathrm{C}$ (Winklhofer et al., 1997), coincidente con la típica temperatura de desbloqueo máxima de estos materiales.

La realización de extractos magnéticos en estos materiales con la finalidad de observar mediante microscopía electrónica los cristales que portan la remagnetización se vienen realizando desde la década de los 80 (McCabe et al., 1983), si bien nunca ha sido posible observar los verdaderos portadores de la remagnetización, ya que los cristales de magnetita observados son demasiado grandes para portar una señal estable. Sin embargo, las observaciones realizadas han mostrado la presencia de framboides de pirita reemplazadas parcialmente por magnetita y/o cristales de magnetita autigénicos, llevando a algunos autores a pensar que la magnetita se neoforma a partir de la alteración de dichos sulfuros (Suk et al., 1990 entre otros).

En los últimos años se han propuesto rutinas de laboratorio para realizar el procedimiento de extractos magnéticos utilizando soluciones tampón que no afectan a los granos de magnetita (Hounslow and Maher, 1996). Strehlau et al., (2014) proponen una rutina de laboratorio relativamente simple y que ofrece resultados satisfactorios en diferentes carbonatos tanto sintéticos como naturales. Strauss et al., (2013) aplica esta última técnica en estalagmitas con buenos resultados, si bien los cristales observados son de tamaño micrométrico, mayores que los esperados en las calizas remagnetizadas.

Por otro lado, observaciones mediante SEM (microscopía electrónica de barrido) y TEM (microscopía electrónica de transmisión) se han realizado sobre cristales de magnetita SD tanto sintéticos como biogénicos.

\section{METODOLOGÍA}

El proceso de extracción magnética se ha realizado en el departamento de química de la Universidad de Minnesota siguiendo el procedimiento propuesto por Strehlau et al. (2014), que a su vez es una modificación disolución de aproximadamente 5 gr de caliza pulverizada en una solución tampón (relación 4:1 de $\mathrm{CH}_{3} \mathrm{COOH} 2 \mathrm{M}$ y $\mathrm{NaCH}_{3} \mathrm{COO} 1 \mathrm{M}$ ) entre 1 y 3 días (o hasta la completa disolución del carbonato) sobre un agitador orbital a $220 \mathrm{rpm}$. Tras ello se aplica un centrifugado a $14 \mathrm{Kp}$ durante $3 \mathrm{~min}$ y el residuo es lavado con agua Mili-Q. El residuo se coloca en un matraz Erlenmeyer y se añade agua Mili-Q. Un imán de neodimio es adosado en la parte externa y el conjunto es agitado a $220 \mathrm{rpm}$ durante al menos 15 min. Tras ello, se extrae el agua con el residuo con la precaución de no arrastrar el material magnético adherido al imán, que posteriormente es guardado en agua destilada.

Durante el proceso de extracción, se obtenían entonces dos subproductos de la roca total, el extracto magnético y el no magnético. Sobre una de las muestras se aplicó todo el proceso anteriormente descrito excepto el último paso, con el fin de comparar las propiedades magnéticas de la roca original y la roca tras haber sido expuesta a la solución tampón (extracto total).

Parte del material magnético extraído fue usado para las observaciones de SEM/TEM y parte para experimentos de magnetismo de rocas.

Los experimentos de magnetismo de rocas, aplicado a todos los subproductos, tienen la finalidad de comparar los resultados y evidenciar posibles cambios en las propiedades magnéticas durante el proceso de extracción. Los experimentos, que se realizaron en el Institute for Rock Magnetism de la Universidad de Minnesota, consistieron en curvas de histéresis y de backfield haciendo uso del Vibrating Sample Magnetometer (VSM, Princenton) para roca total y residuo y el Alternating Gradient Magnetometer (AGM, Princenton) para el extracto. Además, se hicieron curvas de remanencia y susceptibilidad magnética en función de la temperatura por medio de un Magnetic Property Measurement System (Quantum Desing).

Para la caracterización por medio de microscopía electrónica se utilizó un JEOL 6500 SEM con un
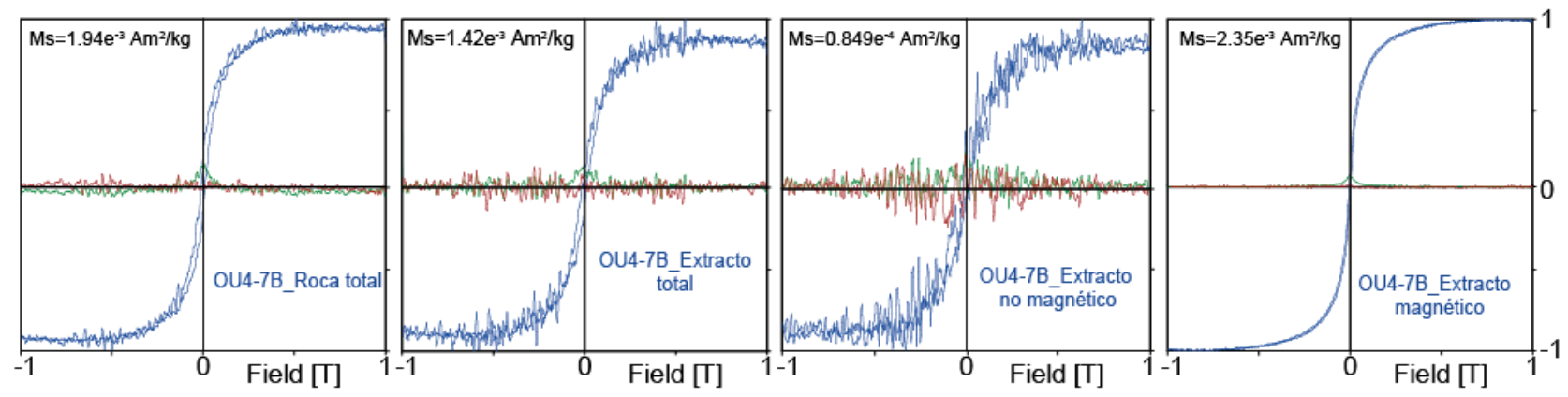

FIGURA 1. Curvas de histéresis de los diferentes subproductos de la muestra OU4-7B 
dispersiva (EDS) Thermo-Noran Vantage y el FEI Tecnai T12 de alta resolución (HRTEM) a $120 \mathrm{kV}$ equipado con una fuente de electrones de $\mathrm{LaB}_{6}$, pertenecientes a la Universidad de Minnesota. Las muestras fueron preparadas sobre carbono.

\section{RESULTADOS}

\section{Magnetismo de rocas}

Las curvas de histéresis (Fig. 1) muestran propiedades magnéticas similares a las descritas por (Jackson y Swanson-Hysell, 2012) para calizas remagnetizadas, cuya mineralogía magnética está caracterizada por una mezcla de granos de magnetita SP y SD.

Las curvas de remanencia y susceptibilidad a baja temperatura (Fig. 2) muestran claramente variaciones en la magnetización en torno a $120 \mathrm{~K}$ que se corresponde con la transición cristalográfica de Verwey en magnetita (Verwey, 1939). Además, el hecho de que dicha transición se encuentre tan marcada y centrada en dicha temperatura, indica que la magnetita es estequiométrica (Jackson y Swanson-Hysell, 2012). Es significativa la disminución tanto de la magnetización de saturación (Fig. 1), la magnetización remanente y la susceptibilidad magnética (Fig. 2) entre cada uno de los subproductos. No son comparables los valores de magnetización remanente, de saturación y susceptibilidad magnética entre el extracto magnético y el resto de subproductos dada la imposibilidad de estimar la masa del primero. Por otro lado, el mayor valor de magnetización remanente en torno a 20-40 K puede deberse tanto a la presencia de granos SP como a la presencia de minerales paramagnéticos. Las curvas de dependencia de la susceptibilidad magnética con la frecuencia indican la presencia de granos SP cuando se observan valores diferentes de susceptibilidad magnética lo que se observa en la roca total pero no en el extracto total o el extracto no magnético (Fig. 2). Por tanto, los valores más altos tanto de susceptibilidad como de remanencia magnéticas en torno a 20-40 K se deben a la presencia de minerales paramagnéticos (posiblemente filosilicatos), ausentes prácticamente en el extracto magnético.

\section{SEM/TEM}

Las observaciones mediante microscopía electrónica han permitido diferenciar (Fig. 3) granos de magnetita de tamaño micrométrico, así como filosilicatos y framboides de pirita. Los resultados provenientes de EDS indican la ausencia de titanio en las magnetitas, esperable en magnetitas detríticas de origen ígneo. Además, los cristales de magnetita presentan generalmente morfologías prismáticas o esféricas. Dado su tamaño, estos cristales se encuentran dentro del rango multidominio (MD). Hasta el momento las observaciones mediante TEM no han arrojado ningún resultado y no se han podido observar cristales de magnetita nanométricos.

\section{DISCUSIÓN Y CONCLUSIONES}

Los experimentos de magnetismo de rocas sobre los diferentes productos indican la pérdida sustancial de material magnético durante el proceso de extracción. Serían esperables, por un lado, valores mayores de magnetización y susceptibilidad magnética en el extracto total con respecto a la roca total. Por otro lado sería esperable la ausencia de minerales magnéticos en el extracto no magnético, pero ninguna de estas dos premisas se cumple y tanto los valores como la forma de las curvas son muy similares entre los dos extractos aunque diferentes de las curvas de roca total. Estas observaciones se deben tanto (i) a la exposición de la roca a la solución tampón como (ii) al propio proceso de extracción magnética con el imán de neodimio; el primer proceso parece destruir granos de magnetita, principalmente los de menor tamaño, y el segundo proceso no realiza la extracción magnética de manera completa.
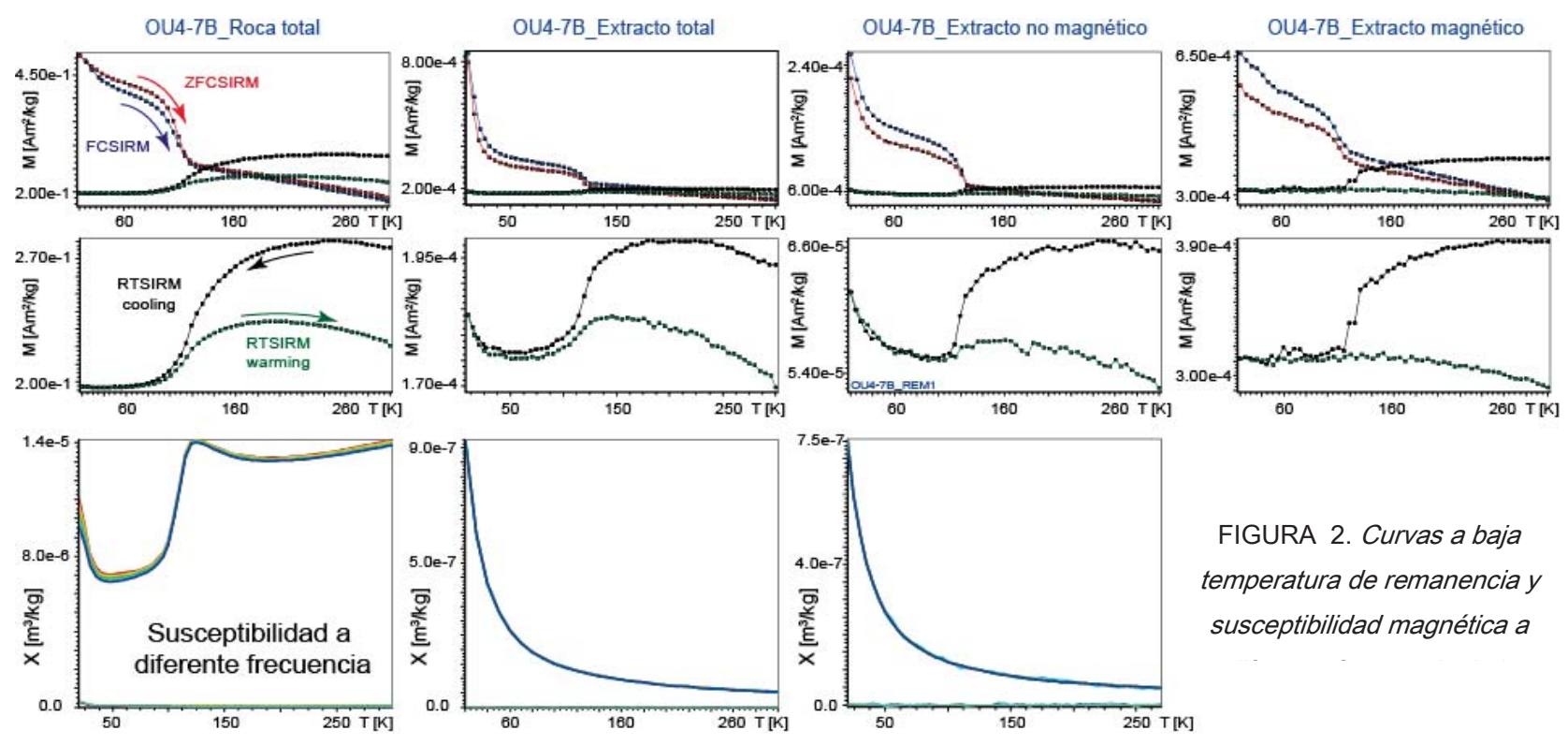

FIGURA 2. Curvas a baja temperatura de remanencia y susceptibilidad magnética a 
Por otro lado, las curvas de susceptibilidad magnética indican una pérdida importante de material SP, de tamaño muy cercano a los cristales de magnetita que portan la remagnetización, cuyas propiedades magnéticas indican que deben ser de tamaño nanométrico. Por tanto, y como así parecen atestiguar las observaciones con microscopía electrónica, este método de extracción no permite separar los granos SD y SP, más susceptibles a la alteración química.
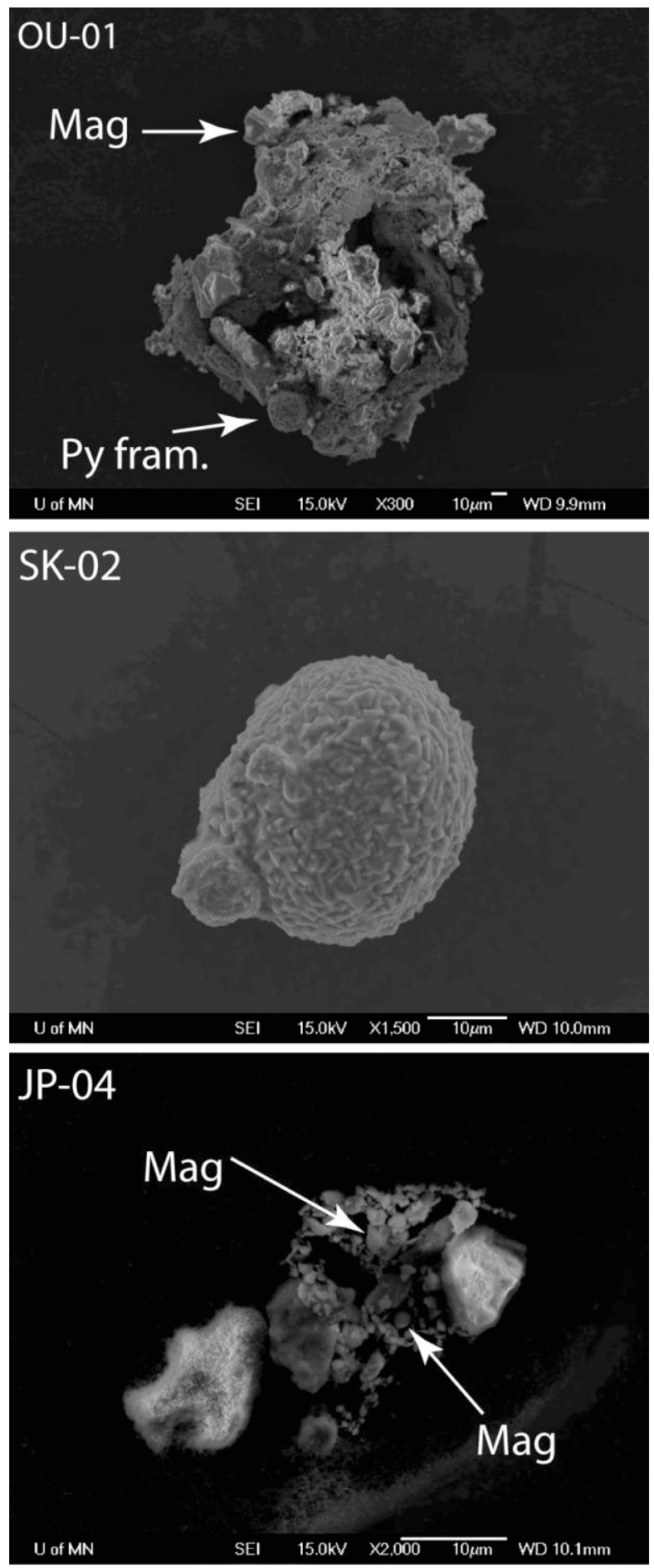

FIGURA 3. Imágenes SEM de los extractos magnéticos provenientes de diferentes muestras.
Como ya indicaban Van Der Voo y Torsvik (2012), la observación mediante microscopía electrónica de los hipotéticos cristales que portan la remagnetización en carbonatos es todavía un asunto por resolver.

\section{AGRADECIMIENTOS}

Este trabajo ha sido financiado por el proyecto CGL2012-38481 de la DGICyT, MINECO y fondos FEDER de la Unión Europea, así cómo por el programa de financiación de la NSF (EEUU) al Institute for Rock Magnetism. Pablo Calvín agradece la financiación obtenida de la beca F.P.I. del MINECO.

\section{REFERENCIAS}

Elmore, R.D., Muxworthy, A.R. y Aldana, M. (2012): Remagnetization and chemical alteration of sedimentary rocks. Geological Society, London, Special Publications, 371: 1-21.

Hounslow, M.W. y Maher, B.A. (1996): Quantitative extraction and analysis of carriers of magnetization in sediments. Geophysical Journal International, 124:57-74.

Jackson, M. y Swanson-Hysell, N.L. (2012): Rocl magnetism of remagnetized carbonate rocks. Geological Society, London, Special Publications, 371: 229-251

McCabe, C., Van der Voo, R., Peacor, D, Scotese, C.R. y Freeman, R. (1983): Diagenetic magnetite carries ancient yet secondary remanence in some Paleozoic sedimentary carbonates. Geology, 11:221-223.

Strauss, B.E., Strehlau, J.H., Lascu, I., Dorale, J.A., Penn, R.L. y Feinberg, J.M. (2013): The origin of magnetic remanence in stalagmites: Observations from electron microscopy and rock magnetism. Geochemistry, Geophysics, Geosystems, 14: 50065025.

Strehlau, J.H., Hegner, L., Strauss, B.E., Feinberg, J.M. y Penn, R.L. (2014): Simple and efficient separation of magnetic minerals from speleothems and other carbonates. Journal of Sedimentary Research, 84: 1096-1106.

Suk, D., Peacor, D.R. y Van der Voo, R (1990): Replacement of pyrite framboids by magnetite in limestones and implications for paleomagnetism. Nature, 345: 611-613

Verwey, E.J. (1939): Electronic conduction of magnetite (Fe3O4) and its transition point at low temperatures. Nature, 144: 327-328.

Van der Voo, R. y Torsvik, T.H. (2012): The history of remagnetization of sedimentary rocks: deceptions, developments and discoveries. Geological Society, London, Special Publications, 371: 23-53.

Winklhofer, M., Fabian, K. y Heider, F. (1997): Magnetic unblocking temperatures of magnetite calculated with a three-dimensional micromagnetic model. Jornal of geophysical Research, 102: 22695. 


\section{Restoration of structures using the ca. $100 \mathrm{Ma}$ remagnetization in the Central High Atlas}

6.1 Diachronous folding and cleavage in an intraplate setting (Central High Atlas,

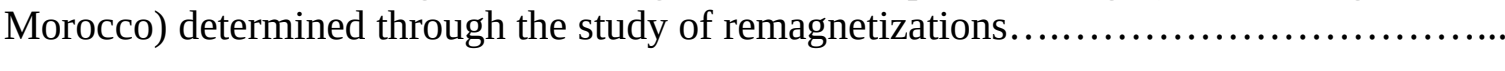

6.2 Extensional vs. compressional deformation in the Central High Atlas salt province: A paleomagnetic approach. 

The use of the restorations of the paleodips at the remagnetization occurrence time gives a valuable information about the pre-compressional geometry, supposedly derived from the extensional stage. This tool has been successfully proved both in basins of the Iberian Peninsula (e.g., Soto et al., 2011) and in the Central High Atlas (e.g., Torres-López et al., 2016). This technique is applied here to address two geological problems of the Central high Atlas.

The development of the pervasive cleavage present in some sectors of the Central High Atlas has been largely attributed to Jurassic times (e.g., Laville and Piqué, 1992). Although some authors have proved the absence of a general uplift until the end of the Cretaceous and the Cenozoic (Barbero et al., 2007), the cleavage has not been dated yet, and development during the Jurassic without a main uplift is (was) a feasible option. We combine structural analysis and paleomagnetic work to date the cleavage regarding the age of the remagnetization (ca. $100 \mathrm{Ma}$ ) which can finish with the discussion about the age of this deformation event.

On the other hand, the role of syn-sedimentary halokinetic processes is being proposed as one of the major structuring processes of the structures present in the Central High Atlas (Saura et al., 2014). The present-day geometry of the anticlines is similar between them, and they are long and narrow structures with steep limbs. But whether this geometry is in all cases inherited from the extensional diapiric structure, under which salt-walls were generated, or there are different degrees of Jurassic development, is a difficult question to answer. Here, the restoration of four diapiric structures is addressed to assess the role of the early halokinetic processes, and after that we present an evaluation of the role played by the inherited geometry during the Cenozoic compression. 



\title{
Diachronous folding and cleavage in an intraplate setting (Central High Atlas, Morocco) determined through the study of remagnetizations
}

\author{
P. Calvín ${ }^{\text {a, }{ }^{*}, \text { A.M. Casas-Sainz }}{ }^{\text {b }}$, J.J. Villalaín ${ }^{\text {a }}$, B. Moussaid ${ }^{c}$ \\ ${ }^{a}$ Laboratorio de Paleomagnetismo, Universidad de Burgos, Spain \\ b Departamento de Ciencias de la Tierra, Universidad de Zaragoza, Spain \\ ${ }^{\mathrm{c}}$ Laboratoire de " BGIM », Ecole Normale Supérieure, Université Hassan II. Casablanca, Morocco
}

\section{A R T I C L E I N F O}

\section{Article history:}

Received 28 October 2016

Received in revised form

17 February 2017

Accepted 18 February 2017

Available online 22 February 2017

\section{Keywords:}

Cretaceous remagnetization

Cleavage

Intracontinental basin

Central High Atlas

Small circle intersection method

\begin{abstract}
A B S T R A C T
Remagnetizations are common in intraplate basins. When remagnetizations occur at an intermediate stage between different tectonic processes, they can be used for paleo-geometrical reconstructions and relative dating of different structures. This has a particular interest in geological frameworks where other geological time markers are absent. In order to apply this methodology, it is necessary to calculate the regional remagnetization direction and subsequently to use this reference direction to restore the attitude of the beds at the moment of remagnetization acquisition. In this work, we use this methodology for dating a pervasive cleavage (whose time of formation is controversial) and the associated structures in the Central High Atlas (Morocco). Paleomagnetic directions from 64 sites were used to calculate the remagnetization direction $\left(\mathrm{D}=330.7^{\circ}, \mathrm{I}=35.1^{\circ}, \mathrm{A} / \mathrm{n}=6.107\right.$ ) which is coincident with the AlbianCenomanian (ca. 100 M.a.) expected direction for NW Africa. This direction was used to restore the Mesozoic paleo-geometry of beds allowing us to analyze bedding orientation, cleavage and folding relationships between the present day and the Cretaceous geometry. After restoration we conclude that the development of cleavage post-dates remagnetization, being in relation with Cenozoic basin inversion. However, the paleo-geometry shows incipient folds at Cretaceous times, which can be related to an intraMesozoic compressional event.
\end{abstract}

๑) 2017 Elsevier Ltd. All rights reserved.

\section{Introduction}

Defining the relationships between cleavage and folding is a classical tool in structural geology, helping to decipher the tectonic evolution of orogenic areas (see e.g. Séguret, 1972; Mattauer, 1973; Williams, 1985; Mitra and Yonkee, 1985; Ramsay and Huber, 1987; Marshak and Mitra, 1988; Lüneburg and Lebit, 1998). This task requires the definition of the relative age of cleavage with respect to folding and their geometrical relationships in large-scale and small-scale folds. Relative and absolute dating of cleavage in partially inverted intracontinental basins containing rocks which underwent very low to low metamorphic evolution is sometimes a difficult task. This is in relation with the generally weak

\footnotetext{
* Corresponding author. Dep. Física, Escuela Politécnica Superior, Río Vena, Universidad de Burgos, Av. Cantabria s/n, 09006, Burgos, Spain.

E-mail addresses: pcalvin@ubu.es, calvinballester@gmail.com (P. Calvín).
}

deformation and the lack of significant thermal events and/or the absence of syntectonic sediments associated with particular tectonic phases.

Controversy about timing of cleavage formation in relation to other structures is a long-term issue in the geological literature about the Central High Atlas (CHA; NW Morocco), which constitutes the intracontinental chain target of this work. A sinistral transpression phase during Late Jurassic times, coeval with intrusion of magmatic bodies and an associated hydrothermal metamorphic event, has been invoked to explain anomalous thermal gradients favoring cleavage development (Laville and Piqué, 1992; Laville et al., 1994). Strong uplift of the Mesozoic basin associated with Jurassic compression proposed by these authors was contradicted by Charrière et al. (2009), dating as Paleocene the supposed Callovian-Lower Cretaceous sediments that lie uncomformably on the igneous intrusions and host rocks. Furthermore, Barbero et al. (2007) by means of fission tracks indicated that the main uplift of these igneous rocks occurred during Cenozoic times. However, 
although these arguments are in support of the absence of total basin inversion during Mesozoic times, cleavage-related folding could have been generated during the Mesozoic, as it occurs in other intracontinental basins (e.g. the Mesozoic cleavage in the Cameros basin, N Spain, Mata et al., 2001 and references therein), without an important uplift of the basin.

In this paper we propose a methodological approach using paleomagnetism and the analysis of remagnetization directions for the relative dating of folds and cleavage and, consequently, compressional phases occurring during the evolution of inverted extensional basins. A pervasive widespread remagnetization, dated around 100 M.a., has been observed in the CHA (Torres-López et al., 2014; Moussaid et al., 2015). From the application of the abovementioned method to this remagnetization, we demonstrate that cleavage in the CHA was generated during the Cenozoic compression, after the remagnetization stage, although some Mesozoic compressional folds actually formed in the area before remagnetization times. Moreover, since remagnetizations are common in intraplate extensional basins where a minimum thickness of sediments was accumulated (e.g. Villalaín et al., 2003; Moreau et al., 2005; Elmore et al., 2012; Van Der Voo and Torsvik, 2012; TorresLópez et al., 2014 and references therein), it can be used for resolving tectonic and structural problems related to the evolution of sedimentary basins as proposed here.

\section{Regional geological background}

The Atlas system is an intracontinental chain located in the foreland of the southernmost sector of the Mediterranean Alpine
System (Fig. 1), formed as the result of the inversion of extensional Mesozoic basins during the Cenozoic convergence between African and European plates (Mattauer et al., 1977; Gomez et al., 2000). The Mesozoic sedimentation in the CHA began with Triassic continental clastic sediments and evaporites during the first stage of rifting, which are intercalated by Triassic-Jurassic basalts. A second stage of rifting started during the Pliensbachian-Toarcian (Ettaki et al., 2000) and more than $5000 \mathrm{~m}$ of marine carbonates and fluvial red beds were accumulated during the Early-Middle Jurassic in the main basin depocenters (Frizon de Lamotte et al., 2008). During this stage, NE-SW normal faults were generated in addition to ENEWSW faults related to the NW-SE extension, and an important diapiric activity began, forming salt-walls limiting sub-basins (Saura et al., 2014). During the Late Jurassic-Early Cretaceous, the axial zone of the CHA emerged, and consequently rocks related to the basinal stage younger than the Upper Jurassic are not preserved in this area (e.g. Frizon de Lamotte et al., 2008; and references therein).

The extensional stage ended with an alkaline to transitional magmatic event, characterized by mafic intrusive rocks dated with $\mathrm{K}-\mathrm{Ar}$ in biotite at $160 \pm 3$ M.a. to $152 \pm 3$ M.a. (Hailwood and Mitchell, 1971) and with Ar-Ar in biotite at $151.3 \pm 0.5$ M.a. to $146 \pm 0.5$ M.a. (Armando, 1999).

The Alpine compression imprinted relatively weak deformation in the $\mathrm{CHA}$, with values of shortening ranging between $15 \%$ and $24 \%$ (Teixell et al., 2003) in a NW-SE direction (without considering internal deformation associated with cleavage). The structure of the CHA is conditioned by the presence of the thick plastic rocks of the Triassic which are the main décollement level, favoring a
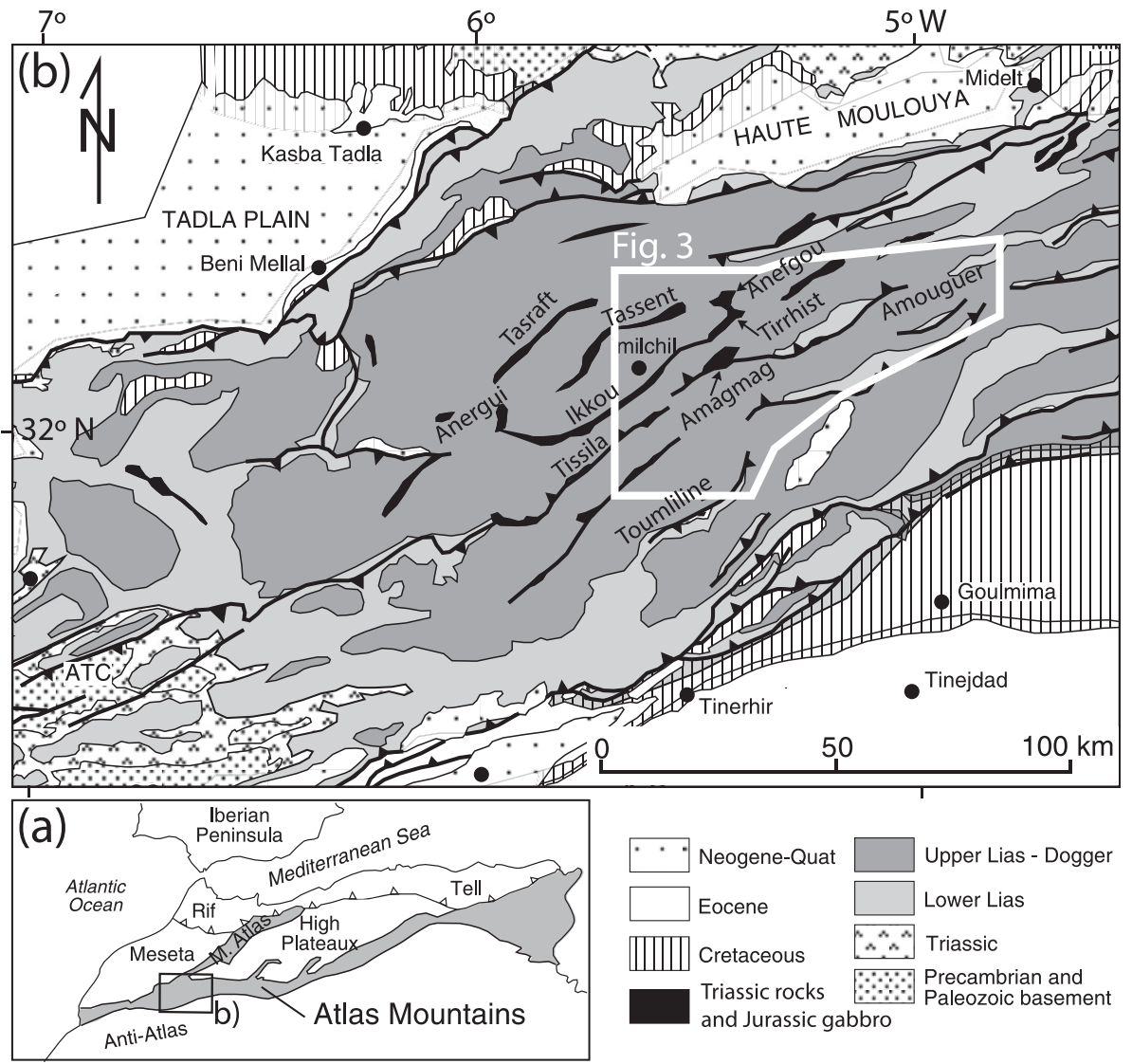

Fig. 1. A) The Atlas Mountains in the context of the West Mediterranean framework. b) Simplified geological map of the Central High Atlas showing the study area (Fig. 3); modified from Teixell et al. (2003). 
decoupling between the basement and the Jurassic cover. This is characterized by tight anticlines with steeply-dipping limbs parallel to the ENE-WSW general trend of the chain, cored by Triassic shales and basalts and Jurassic gabbros, which limit wide, gentle synclines. These anticlines were partially developed during the Mesozoic (Torres-López et al., 2016) primarily because of diapiric processes (Bouchouata et al., 1995; Ettaki et al., 2007; Michard et al., 2011; Saura et al., 2014) and also enhanced by Jurassic igneous intrusions. In the central sector of the CHA, a pervasive cleavage appears showing varying attitudes along and across the main structural trends (Laville and Piqué, 1992).

\section{The remagnetization in the CHA}

Torres-López et al. (2014) described the presence of an AlbianCenomanian (ca. 100 M.a.) widespread remagnetization in the CHA affecting the Jurassic carbonate rocks and red beds of the central part of the chain. This event is responsible for the particular magnetic behavior of rocks both in the demagnetization processes and in rock magnetic experiments, similar to those observed in other carbonate rocks affected by remagnetizations (e.g. Soto et al., 2008; Van Der Voo and Torsvik, 2012; Jackson and Swanson-Hysell, 2012; and references therein). These characteristic paleomagnetic properties are the following. (i) Dominance of magnetite as carrier of the magnetization, although sometimes pyrrhotite can appear if rocks reached maximum temperatures above $200{ }^{\circ} \mathrm{C}$ (Aubourg et al., 2012). (ii) When the carrier is magnetite (as in the CHA), typical wasp-waist hysteresis loops as a consequence of stable single domain (SSD) and superparamagnetic (SP) grain size (Channell and McCabe, 1994). (iii) Maximum unblocking temperatures around $450-500{ }^{\circ} \mathrm{C}$. Shape of the magnetite-bearing remagnetization grains is not known at the moment due to the absence of direct observations (Van Der Voo and Torsvik, 2012); rock-magnetic approximation (Jackson and Swanson-Hysell) seems to indicate a dominance of uniaxial anisotropy. However, only a 1.1 elongation is necessary in SSD magnetites to give them a shape anisotropy (Winklhofer et al., 1997).

This characteristic magnetic behavior is typical in chemical remagnetizations in which a population of small grains of magnetite grow up in the carbonate rocks. The triggers of the remagnetizations have been widely discussed in the literature (e.g. Elmore et al., 2012 for reviews), including increase of temperature linked either with burial or with regional thermal anomalies (or both), hydrocarbons migration triggered by tectonic activity, etc. In the case of the CHA, the remagnetizations could be linked with an external factor which triggered the remagnetization, because there is not any report of increasing of tectonic activity (e.g. Frizon de Lamotte et al., 2008; and references therein) which allow to explain this widespread processes.

In agreement with this link between some remagnetizations in carbonate rocks and burial, Torres-López et al. (2014) reported that the remagnetization of the CHA is restricted to the central part of the High Atlas, along the basin depocenter(s) and cannot be recognized in marginal areas (northern and southern margins of the CHA) of the Atlasic basin.

Following the technique described in Villalaín et al. (2015) and based in Small Circles (SCs) analysis, Torres-López et al. (2016) used this remagnetization to restore the attitude of the beds at the moment of its acquisition. They found that this is a syn-folding remagnetization in the sense that characteristic anticlines (ridges) of the CHA were already partially formed before the remagnetization, in agreement with works that invoke halokinetic synsedimentary processes during the Jurassic as the generators of the ridges (Bouchouata et al., 1995; Ettaki et al., 2007; Saura et al., 2014), that were tightened during the Cenozoic compression. The value of the paleomagnetic restoration, in addition to the tectonostratigraphics works, is that the first allows the quantification of the pre- and post-remagnetization deformation and to carry out palinspastic reconstruction at the moment of the acquisition of the remagnetization (ca. 100 M.a.).

\section{Starting hypothesis/work methodology}

The aim of this work is to relatively date the cleavage of the CHA with respect to the ca. $100 \mathrm{Ma}$ remagnetization (i.e. to characterize it either as a pre- or a post-remagnetization cleavage) analyzing together structural and paleomagnetic data. Syn-remagnetization cleavage is not considered a priori since there are not evidences of a ca. 100 M.a. deformational event (e.g. Frizon de Lamotte et al., 2008 for reviews).

The folding-magnetization chronological relationships have been classically and widely evaluated mainly through fold-test (e.g. McFadden, 1990; Bazhenov and Shipunov, 1991; Watson and Enkin, 1993; Tauxe and Watson, 1994) or through SCs methods (e.g. Shipunov, 1997; Henry et al., 2004; Waldhör and Appel, 2006; Villalaín et al., 2015; among others).

On the other hand, structural analysis (bedding-cleavagefolding geometrical relationship) provides the necessary tools (e.g. Ramsay and Huber, 1987) in order to constrain the chronological relations between cleavage and folds (i.e. pre-, syn- or post-folding cleavage). Fig. 2 summarizes a simplified view of the three endmember possibilities of folding-cleavage relationships. (i) Synfolding cleavage (Fig. 2a) is parallel (average orientation of planes) to the axial surface, and in addition it will show coherence in the different limbs of the folds (e.g. symmetry regarding the axial plane in the case of symmetric folds). Conversely, (ii) a pre-folding cleavage (Fig. 2b) will appear folded (e.g. due to hinge migration or other attitude) showing discrepancies between the different limbs of the folds. Finally, (iii) post-folding cleavage (Fig. 2c) will show more homogeneous attitude, independently of the sector of the fold in which it appears, cutting through its axial plane.

Summarizing, structural analysis can give us the temporal framework for the development of cleavage in relation to folding, whereas the paleomagnetic approach (Fig. 2) allows inferring the temporal relationship between folds and remagnetization. Combining both information sources, the temporal relationship between cleavage and remagnetization can become unraveled.

Syn-folding cleavage (Fig. 2a), shows a relationship with magnetization similar to that of pre- or post-remagnetization folds. Pre-folding cleavage (Fig. 2b), can also characterized as preremagnetization if the fold pre-dates the remagnetization, but the cleavage age cannot be discerned in any case if the fold totally post-dates the remagnetization. Finally, post-folding cleavage can be characterized either as post-remagnetization or undetermined if the development of folds is previous to the remagnetization.

Special mention deserves the case of syn-folding remagnetization (in our case this means that there exists pre- and postremagnetization deformation, but belonging to different deformation events, without evidences of deformation contemporary with the acquisition of the remagnetization). For pre- and synfolding cleavage, the cleavage age is a priori undetermined and structural interpretation about the pre- and post-deformation will be necessary. For example, for syn-folding cleavage (Fig. 2a), under strong post-remagnetization compressional deformation, it is possible to ensure that the end of the development of cleavage post-dates the remagnetization, but cleavage development could have started during the pre-remagnetization deformation stage (in case of having a suitable tectonic frame suitable for it). For prefolding cleavage its age also will be a priori undetermined and the only feasible approach is to try and decipher which deformation 


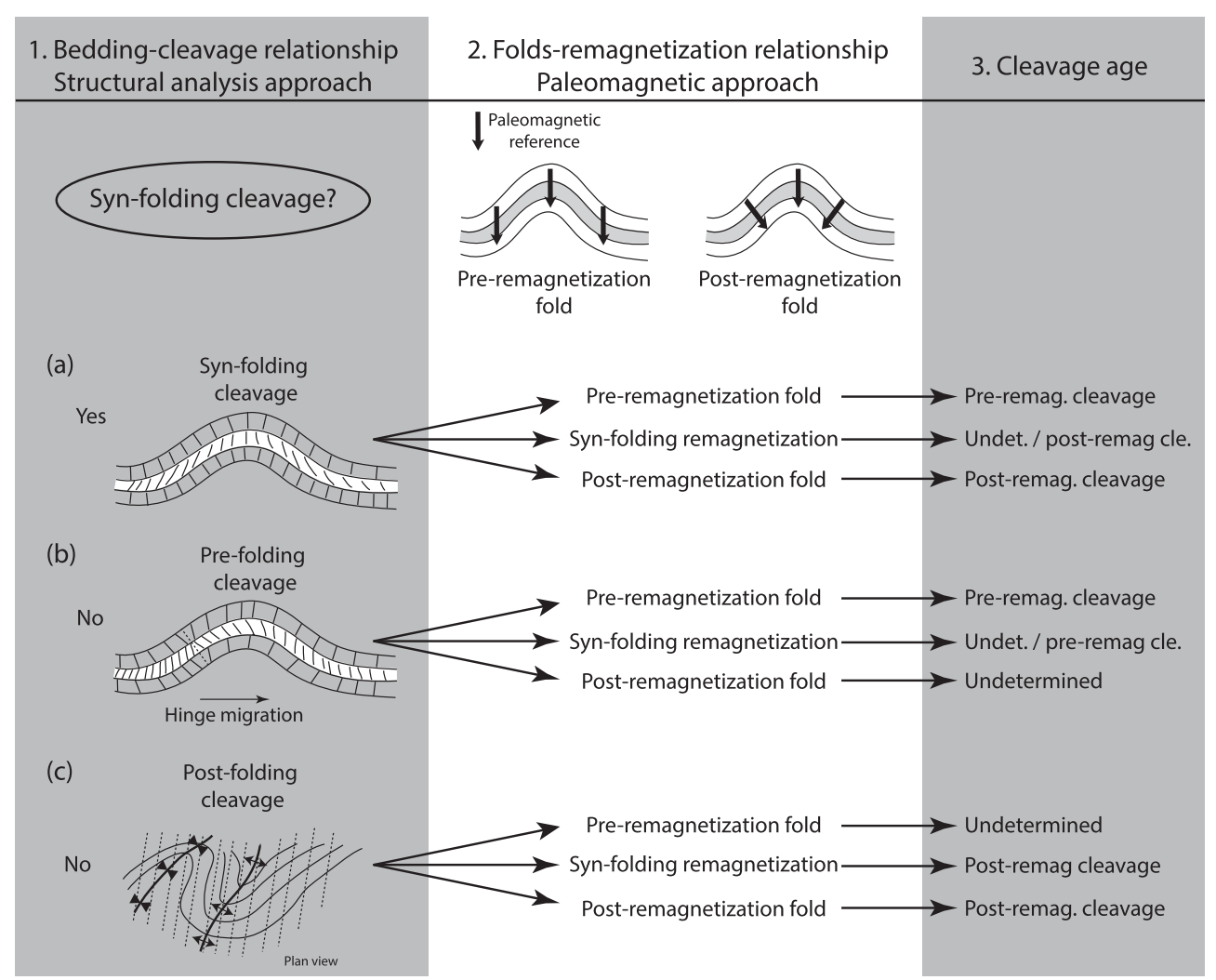

Fig. 2. Sketch explaining the starting hypothesis and the work methodology. In order to date the relative age of the cleavage regarding the remagnetization, (1) the structural analysis focused in cleavage-folds relationship in order to establish if they are genetically controlled, as in the case of a syn-folding cleavage (a), or conversely the cleavage pre-dates (b) or post-dates (c) the development of the folds. On the other hand, (2) the paleomagnetic approach allows knowing the temporal relationship between remagnetization and folding. Combining (1) structural and (2) paleomagnetic information can enable to decipher (3) the cleavage age. This picture represents a simplified model and a more complex frame (e.g. with deformation pre- and post-remagnetization) will need a more detailed analysis. In the folds shown on the left column, grey beds represent limestones with normal, convergent cleavage fan and white beds represent marls with divergent, reverse cleavage fan. In (a) there exists a symmetry of the cleavage with respect to the axial plane, regardless the lithology, whereas in (b) this symmetry does not appear due to hinge migration (if we restore the bedding to the horizontal, the symmetry plane will mark the paleoaxial plane -the dashed line in the picture-). The plan view of the post-folding cleavage example (c) represents a straight and sub-parallel cleavage which cuts the folds and their axial planes.

event is responsible for cleavage folding (the pre- or the postremagnetization folding) by means of the restitution of the attitude of the bedding at the moment of the acquisition of the remagnetization, and restoring also the cleavage as a passive marker within bedding. Finally, if cleavage post-dates a synremagnetization fold, it also will post-date the remagnetization.

\section{Methodology of paleomagnetic analysis}

\subsection{Sampling and paleomagnetic measurements}

Fifty-six new sites were sampled (Fig. 3 and supplementary data; 53 sites in Jurassic carbonate rocks, namely marls and limestones, and 3 in red beds), taking at least eight cores per site with a gasoline-powered drilling machine. In addition to the paleomagnetic sites, bedding and cleavage were also measured in 26 additional structural sites. Paleomagnetic analyses were conducted on 360 samples using a 2G cryogenic magnetometer at the Paleomagnetic Laboratory of the University of Burgos (Spain), which integrates Alternating Field (AF) coils. Stepwise thermal (Th) demagnetization was conducted with a TD48-DC thermal demagnetizer. 6 to 16 steps were taken from room temperature up to $450-500{ }^{\circ} \mathrm{C}$ for limestones and to $670^{\circ} \mathrm{C}$ in red beds.

Paleomagnetic directional components were calculated by principal component analysis (orientation and maximum angular deviation error -MAD- of the component; Kirschvink, 1980) on orthogonal demagnetization diagrams using Remasoft 3.0 software (Chadima and Hrouda, 2006). Then, the mean site directions and related statistical parameters were calculated (Fisher, 1953).

\subsection{Fold-test and small circles methods}

According to Torres-López et al. (2014) and Moussaid et al. (2015), carbonate rocks and red beds from the CHA carry a synfolding remagnetization dated ca. 100 M.a. Since the remagnetization was acquired at the same moment (at geological scale) in all sites, and in absence of a complex deformational context (e.g. two different axes of horizontal rotation, among others; see Waldhör and Appel, 2006) it is possible to calculate a local remagnetization direction (the reference or expected direction) for the study area using the Small Circle Intersection (SCI) method (Shipunov, 1997; Henry et al., 2004; Waldhör and Appel, 2006).

Once the expected direction is obtained, it is possible to restore the attitude of beds to the moment of the remagnetization event, following the methodology explained in Villalaín et al. (2015) which is based in the use of the SCs. For each site, one SC, whose axis is the bedding strike, links the paleomagnetic directions before the bedding correction (BBC) and after the total bedding correction (ATBC). Actually, these SCs are the paths of the paleomagnetic directions during the bedding correction. On each SC there is a direction which best approaches the local remagnetization direction (in fact, theoretically the remagnetization direction should be 


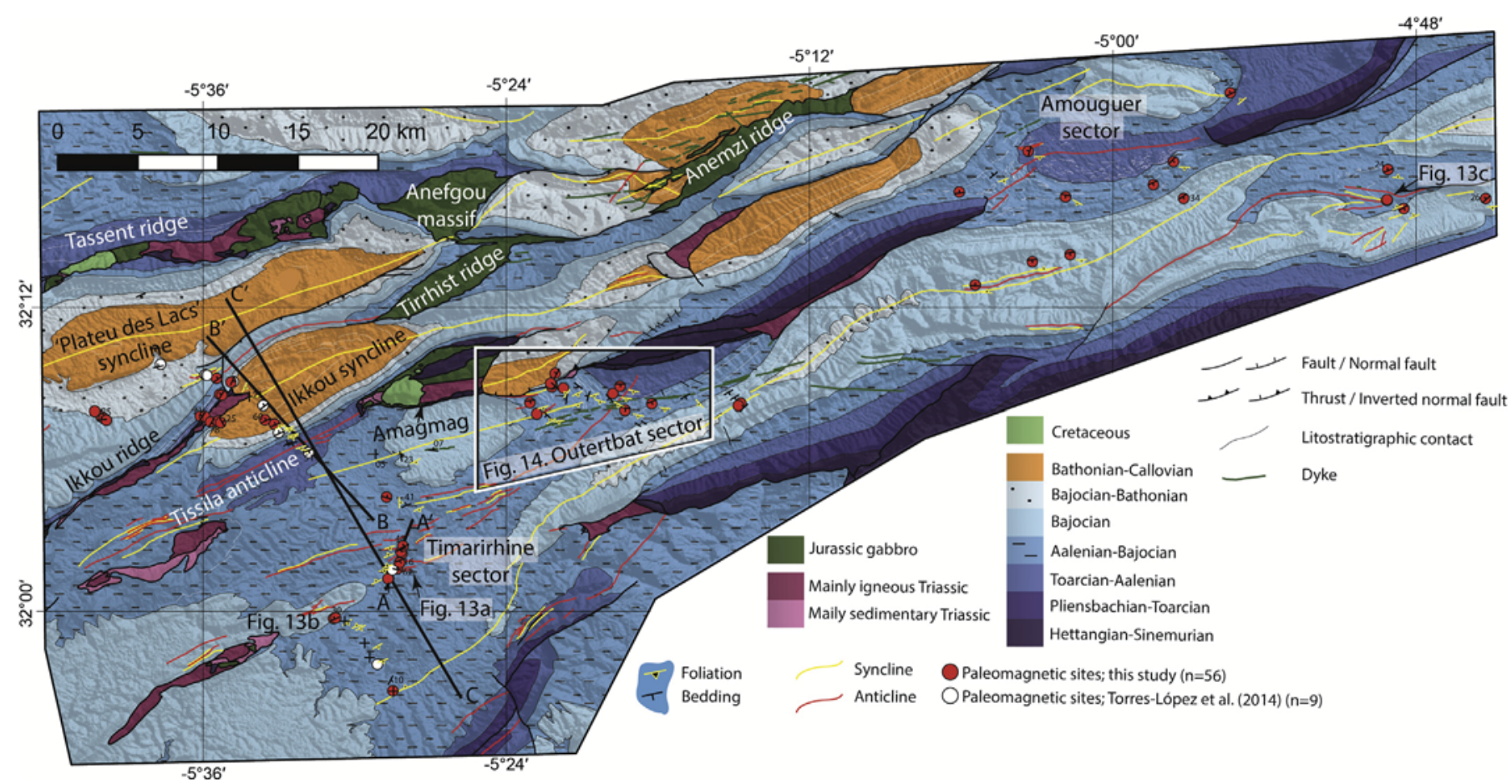

Fig. 3. Geological map of the study area showing the paleomagnetic sites used in this work, as well as the location of the geological cross-sections and some figures, and the names of the main structures and sectors (see also *.kmz supplementary data file).

located on all SCs), namely the best fit direction (BFD). The angle, measured along the SC, between the BFD and ATBC is the paleodip of the bed, i.e. the bedding dip at the moment of the acquisition of the remagnetization (Villalaín et al., 2003; Soto et al., 2008; TorresLópez et al., 2016). In this way, it is possible to restore the beds and to offer a palinspastic view of the structure.

SCs methods (SCI and bedding restoration) were applied using pySCu software (Calvín et al., in prep.). Together with the SCs methods, bootstrap fold-test (Tauxe and Watson, 1994; Tauxe et al., 2010) was applied using PmagPy software (Tauxe et al., 2016) in order to quantify the amount of pre- and post-remagnetization deformation.

\section{Paleomagnetic results}

\subsection{Natural remanent magnetization (NRM) and paleomagnetic directions}

Standard paleomagnetic analysis allowed us to calculate in each site statistically well-defined paleomagnetic directions with systematic normal polarity (Table 1 ) and typical unblocking temperatures between $300{ }^{\circ} \mathrm{C}$ to $450{ }^{\circ} \mathrm{C}$ in carbonates and $400 / 500{ }^{\circ} \mathrm{C}$ to $600 / 660{ }^{\circ} \mathrm{C}$ in red beds, after removal of viscous overprint and thermal alteration (Fig. 4). Both in limestones and in red beds, most samples show intensities of NRM around $1-10 \times 10^{-3} \mathrm{~A} / \mathrm{m}$ and the characteristic remanence (ChRM) represents about $30-50 \%$ of the total NRM. In most of the limestones the ChRM goes to the origin. However, in red beds the ChRM does not pass through the origin, but it is not possible to isolate the high-temperature component because spurious components induced during heating mask it (see Fig. 4).

This behavior is the same described by Torres-López et al. (2014) and Moussaid et al. (2015) in the CHA, and similar to other remagnetized limestones around the world (see Jackson and Swanson-Hysell, 2012; for reviews). According with the observed paleomagnetic behavior and following the latter authors, the carbonates show the typical signature for chemical-remagnetized limestones, in which a population of fine-grained magnetite grew during the diagenesis, generating the typical mixture of SP and SSD magnetite (see section 3). Detailed description of magnetic properties of these rocks can be found in Torres-López et al. (2014) and Moussaid et al. (2015).

\subsection{Remagnetization direction and SCI solution}

Applying the SCI method to a total of 64 paleomagnetic site mean directions ( 56 paleomagnetic directions from this work and 9 from Torres-López et al., 2014; Table 1), the direction of the remagnetization was calculated obtaining a value of $\mathrm{D}=330.9^{\circ}$, $\mathrm{I}=35.1^{\circ}, \mathrm{A} / \mathrm{n}=6.107$. This direction is coincident with that obtained in two sites having horizontal bedding and also agrees with the ca. 100 M.a. expected direction determined from the Global Apparent Polar Wander Path (GAPWP) in NW Africa coordinates (Fig. 5, Torsvik et al., 2012). The good clustering of the best fit direction (BFD) for most sites (Fig. 5c) indicates the absence of complex rotations that could preclude the application of this method. However, some sites show angles between the BFD and the expected direction larger than $10^{\circ}$ (Table 1 ), mainly sites of the OuterbatAmouguer sector. These sites must be analyzed carefully (or directly rejected) before considering them for palinspastic restoration.

\subsection{The fold test}

The bootstrap fold test (Tauxe and Watson, 1994; Tauxe et al., 2010) was applied in the four differentiated areas (see Fig. 3), three of them belong to the Tissila-Amouguer sector and the last one to the Timarirhine sector. All tests (Fig. 6) show that the remagnetization is clearly syn-folding, with unfolding percentages to reach better grouping between 19 and $86 \%$. However, whereas in 
Table 1

Remanent magnetization parameters for the ChRM. n/N: number of samples used to calculate the paleomagnetic direction/number of measured samples. Lit: sample lithology (Car: carbonate rocks -limestones and marls-, Rb: red beds -sandstones and shales-). $\alpha_{95}$ and $к$, Fisher statistical parameters (Fisher, 1953). BFD-expec dir angle: angle between the calculated best fit direction in each site and the calculated reference paleomagnetic direction for the area. Ref: literature reference of the data (A, this work; B, Torres-López et al., 2014). For location of each site, *.kmz supplementary data file.

\begin{tabular}{|c|c|c|c|c|c|c|c|c|c|c|c|c|c|c|}
\hline \multirow[t]{2}{*}{ Site } & \multirow[t]{2}{*}{$\mathrm{n} / \mathrm{N}$} & \multirow[t]{2}{*}{ Lit } & \multicolumn{2}{|c|}{ In situ (BBC) } & \multirow[t]{2}{*}{$\alpha_{95}$} & \multirow[t]{2}{*}{ к } & \multicolumn{2}{|c|}{$\begin{array}{l}100 \% \text { corrected } \\
\text { (ATBC) }\end{array}$} & \multicolumn{2}{|c|}{$\begin{array}{l}\text { Best Fit } \\
\text { Direction }\end{array}$} & BFD-expec.dir angle & Bedding & Paleo-bedding & Ref \\
\hline & & & DEC & INC & & & DEC & INC & DEC & INC & & DipDir/Dip & DipDir/Dip & \\
\hline AG01 & $6 / 6$ & Car & 314.9 & 70.5 & 11.2 & 36.7 & 334.6 & 4.7 & 332.5 & 35.4 & 1.4 & $344 / 68$ & $344 / 31$ & A \\
\hline AG02 & $6 / 6$ & Car & 329 & 32.9 & 4.5 & 219.4 & 329 & 32.9 & 328.6 & 34.9 & 1.8 & $344 / 00$ & $344 / 02$ & A \\
\hline AM01 & $8 / 8$ & Car & 335.5 & 31.3 & 4.9 & 130.1 & 338.9 & 16.1 & 333.7 & 36 & 2.3 & $004 / 17$ & $004 / 22$ & A \\
\hline AM02 & $8 / 8$ & Car & 335 & 2 & 3.2 & 293.6 & 317.1 & 56.2 & 330.3 & 35.1 & 0.5 & $175 / 60$ & $175 / 24$ & A \\
\hline AM03 & $8 / 8$ & Car & 342.7 & 15 & 3.1 & 316.6 & 331.6 & 67.1 & 341.2 & 36.4 & 8.5 & $170 / 53$ & $170 / 31$ & A \\
\hline AM04 & $8 / 8$ & Car & 334.5 & 36.6 & 4.7 & 138.6 & 319.1 & 52.6 & 334.5 & 36.5 & 3 & $191 / 22$ & $191 / 22$ & A \\
\hline AM05 & $8 / 8$ & Car & 44.2 & 77.6 & 6.9 & 64.7 & 347.5 & 30 & 348.2 & 34.4 & 14.4 & $334 / 55$ & $334 / 04$ & A \\
\hline AM06 & $8 / 8$ & Car & 327.1 & 12.4 & 3.8 & 185.9 & 331.7 & 43.3 & 329.7 & 35.4 & 0.6 & $134 / 32$ & $134 / 08$ & A \\
\hline AM07 & $6 / 8$ & Car & 331.7 & 47.7 & 6.3 & 114 & 327.9 & 22.2 & 329.3 & 35.4 & 1 & $318 / 26$ & $318 / 13$ & A \\
\hline AM08 & $7 / 8$ & Car & 326.7 & 31.7 & 14.3 & 18.8 & 305.8 & 83.1 & 326.6 & 35.1 & 3.3 & $150 / 52$ & $150 / 49$ & A \\
\hline AM09 & $5 / 6$ & Car & 333.2 & 49.3 & 7 & 120.3 & 329.7 & 36.8 & 329.5 & 35.4 & 0.8 & $315 / 13$ & $135 / 01$ & A \\
\hline AM10 & $4 / 4$ & Car & 329.8 & 38.6 & 8.6 & 114.2 & 320.1 & 11 & 328.3 & 36.3 & 1.8 & $288 / 34$ & $288 / 31$ & A \\
\hline AM11 & $5 / 5$ & Car & 321.9 & 25.4 & 4.2 & 327.7 & 282.9 & 45.3 & 319.3 & 29.3 & 11.7 & $193 / 53$ & $193 / 47$ & A \\
\hline AM12 & $8 / 8$ & Car & 313.8 & 48.6 & 7.6 & 54.1 & 320.4 & 26.1 & 318.9 & 33.9 & 9.8 & $338 / 24$ & $338 / 08$ & A \\
\hline AM13 & $8 / 8$ & Car & 330.7 & 20.8 & 3 & 350.9 & 332.4 & 54.7 & 331.1 & 35.2 & 0.4 & $148 / 34$ & $148 / 20$ & A \\
\hline AM14 & $8 / 8$ & Car & 301.1 & 65.4 & 5.6 & 97.5 & 331.5 & 26.5 & 329.5 & 34.9 & 1.2 & $353 / 46$ & $353 / 09$ & A \\
\hline AM15 & $8 / 8$ & Car & 343 & 48.6 & 7.9 & 50.4 & 327.8 & 34.3 & 329 & 36.1 & 1.2 & $285 / 22$ & $285 / 02$ & A \\
\hline AM16 & $6 / 8$ & Car & 330.1 & 19.7 & 5.7 & 139.9 & 326.8 & 55.5 & 329.4 & 35.1 & 1.1 & $155 / 36$ & $155 / 21$ & A \\
\hline DP01 & $8 / 8$ & Car & 194.8 & 62.5 & 6.4 & 75.5 & 342.4 & 44.4 & 343.7 & 37.1 & 10.5 & $355 / 71$ & $175 / 07$ & A \\
\hline DP02 & $8 / 8$ & Car & 253.3 & 70.2 & 4.3 & 166.7 & 327.1 & 30.3 & 326 & 34.3 & 4.1 & $350 / 60$ & $350 / 04$ & A \\
\hline DP03 & $7 / 8$ & Car & 314.7 & 60.3 & 5 & 144.4 & 333.1 & 40 & 334.7 & 36.1 & 3.1 & $001 / 25$ & $181 / 04$ & A \\
\hline DP04 & $8 / 8$ & Car & 320.5 & 52 & 6.8 & 68.1 & 328 & 39.9 & 329.8 & 35 & 0.9 & $355 / 14$ & $175 / 06$ & A \\
\hline DP05 & $8 / 8$ & Car & 325 & 45.1 & 5.6 & 99.2 & 319.9 & -34.1 & 321.4 & 38.2 & 7.6 & $293 / 87$ & $293 / 79$ & A \\
\hline DP06 & $8 / 8$ & Car & 328 & 48.4 & 6.6 & 70.4 & 319.4 & -7.5 & 323.5 & 36.8 & 5.7 & $303 / 59$ & $303 / 46$ & A \\
\hline DP07 & $8 / 8$ & Car & 90.7 & 79.2 & 1.6 & 1178.8 & 334.7 & 26 & 335.7 & 34.9 & 4.2 & $325 / 70$ & $325 / 09$ & A \\
\hline DP08 & $7 / 8$ & Car & 345.1 & 24.6 & 8.7 & 48.8 & 83.9 & 59.3 & 347.3 & 32.2 & 14.3 & $138 / 82$ & $138 / 73$ & A \\
\hline DP09 & $8 / 8$ & Car & 332.1 & 16.4 & 4.1 & 185.7 & 46.5 & 62.4 & 336.9 & 33.6 & 5.6 & $124 / 78$ & $124 / 58$ & A \\
\hline DP10 & $7 / 8$ & Car & 321.9 & 31.2 & 5.7 & 115.1 & 320.8 & -38.7 & 321.5 & 34.7 & 7.6 & $333 / 71$ & $333 / 75$ & A \\
\hline DP11 & $8 / 8$ & Car & 323.4 & 36.1 & 3.7 & 219.5 & 320.2 & -13 & 323.5 & 36.6 & 5.7 & $305 / 51$ & $305 / 52$ & A \\
\hline DP12 & $5 / 8$ & $\mathrm{Rb}$ & 343.1 & 33.4 & 7.9 & 94.1 & 356.4 & 24.8 & 330.9 & 35.6 & 0.5 & $060 / 25$ & $060 / 43$ & A \\
\hline ICO2 & $7 / 8$ & Car & 325.6 & -2.7 & 4.6 & 170.4 & 318.9 & 32 & 319.1 & 31.6 & 10.6 & $178 / 42$ & $178 / 00$ & B \\
\hline ICO3 & $7 / 8$ & Car & 85 & 87.4 & 7.9 & 59 & 340.7 & 24.7 & 341 & 35.4 & 8.4 & $338 / 66$ & $338 / 11$ & B \\
\hline ICO4 & $8 / 8$ & Car & 336.4 & 46.6 & 21.6 & 12.2 & 339.2 & 24.9 & 338.2 & 36 & 6 & $348 / 22$ & $348 / 11$ & B \\
\hline IC44 & $7 / 8$ & Car & 326.9 & 24.1 & 18.4 & 11.7 & 15.6 & 60.7 & 331.1 & 35.1 & 0.8 & $115 / 57$ & $115 / 44$ & B \\
\hline IC46 & $7 / 8$ & $\mathrm{Rb}$ & 31.6 & 65.8 & 19.1 & 10.9 & 349.6 & 28.7 & 350.7 & 32.4 & 16.9 & $324 / 49$ & $324 / 04$ & B \\
\hline IC47 & $8 / 8$ & Car & 323.1 & 48.7 & 13.2 & 18.6 & 327.1 & -33.8 & 326.9 & 34.8 & 3.2 & $342 / 85$ & $342 / 70$ & B \\
\hline IC48 & $7 / 8$ & Car & 328.4 & 2.9 & 5.5 & 119.9 & 320.2 & 52.1 & 325.6 & 34.6 & 4.2 & $161 / 51$ & $161 / 18$ & B \\
\hline IC50 & $9 / 10$ & Car & 334.6 & 30.4 & 3.1 & 273.1 & 337.9 & 39.2 & 335.8 & 34.1 & 4.6 & $128 / 10$ & $128 / 06$ & B \\
\hline IC51 & $9 / 10$ & Car & 337.9 & 25.3 & 4.4 & 136.6 & 342.3 & 42.1 & 339.7 & 34 & 7.7 & $139 / 18$ & $139 / 09$ & B \\
\hline OU01 & $8 / 8$ & Car & 319.8 & 42.8 & 7.4 & 57.5 & 294.4 & 36.9 & 333.7 & 40.4 & 4.9 & $228 / 30$ & $228 / 46$ & A \\
\hline OU02 & $6 / 8$ & Car & 11.9 & 45.1 & 5.9 & 131.7 & 346.6 & 25.3 & 348.3 & 28.2 & 16.9 & $298 / 39$ & $298 / 04$ & A \\
\hline OU03 & $6 / 8$ & Car & 351.6 & 35.8 & 9.6 & 50.1 & 345.5 & -18.7 & 349.3 & 31 & 16.3 & $314 / 64$ & $314 / 58$ & A \\
\hline OU04 & $8 / 8$ & Car & 286.5 & 22.3 & 4 & 190.1 & 157.6 & 42.3 & 283.6 & 34.5 & 38.4 & $129 / 110$ & $129 / 97$ & A \\
\hline OU05 & $8 / 8$ & Car & 297.6 & 35.3 & 3.7 & 223.2 & 278.7 & 17.7 & 330.4 & 34.4 & 1.5 & $223 / 40$ & $223 / 84$ & A \\
\hline OU06 & $8 / 8$ & Car & 337 & 26.5 & 8.3 & 45.2 & 331.6 & 39 & 333.3 & 36 & 1.9 & $188 / 15$ & $188 / 04$ & A \\
\hline OU07 & $5 / 8$ & Car & 333 & 13.2 & 8.5 & 82.4 & 224.3 & 82.4 & 331.6 & 35.2 & 0.8 & $160 / 80$ & $160 / 58$ & A \\
\hline SK01 & $7 / 8$ & Car & 333.4 & 33.4 & 6.7 & 82.8 & 32.2 & 47.1 & 333.7 & 33.7 & 3.4 & $103 / 61$ & $103 / 61$ & A \\
\hline SK02 & $6 / 8$ & $\mathrm{Rb}$ & 356.8 & 52.3 & 9.6 & 49.6 & 348.6 & -5.7 & 351.2 & 34.3 & 16.9 & $336 / 60$ & $336 / 41$ & A \\
\hline SKO3 & $7 / 8$ & $\mathrm{Rb}$ & 349.8 & 66.2 & 8.1 & 56.4 & 343.4 & -8.4 & 344.3 & 35.3 & 11.1 & $339 / 75$ & $339 / 44$ & A \\
\hline SK04 & $8 / 8$ & Car & 313.2 & 40 & 3.7 & 228.2 & 324.7 & 28.7 & 322.9 & 31.1 & 8.1 & $015 / 20$ & $015 / 04$ & A \\
\hline SK05 & $8 / 8$ & Car & 315.9 & 56.8 & 6.4 & 76.7 & 323.6 & 9.8 & 321.7 & 34.7 & 7.3 & $333 / 48$ & $333 / 25$ & A \\
\hline SK06 & $7 / 7$ & Car & 325.9 & -21.2 & 6.2 & 94.8 & 320 & 48.4 & 324 & 34.5 & 5.6 & $160 / 72$ & $160 / 15$ & A \\
\hline SK07 & $8 / 8$ & Car & 329.5 & 27.3 & 7.4 & 57.2 & 327.6 & 41 & 328.6 & 35 & 1.8 & $160 / 14$ & $160 / 06$ & A \\
\hline SK08 & $7 / 8$ & Car & 322.2 & -4.6 & 5 & 144.3 & 316.5 & 42.2 & 318.9 & 33.9 & 9.8 & $158 / 49$ & $158 / 09$ & A \\
\hline SK09 & $7 / 7$ & Car & 332.1 & 25 & 3.3 & 335.8 & 327 & 38.8 & 329 & 34.7 & 1.8 & $180 / 16$ & $180 / 05$ & A \\
\hline SK10 & $8 / 8$ & Car & 338.4 & 56.3 & 4.7 & 141.5 & 331.4 & 27.2 & 332.4 & 35.1 & 1.5 & $320 / 30$ & $320 / 08$ & A \\
\hline SK11 & $8 / 8$ & Car & 165.7 & 73.7 & 4.3 & 167.7 & 335.5 & 32.1 & 335.4 & 35.4 & 3.8 & $338 / 74$ & $338 / 03$ & A \\
\hline SK12 & $8 / 8$ & Car & 333.4 & 33.4 & 2.9 & 366.1 & 333.4 & 33.4 & 331.7 & 35.6 & 0.5 & $020 / 00$ & $020 / 03$ & A \\
\hline SK13 & $8 / 8$ & Car & 296.5 & 66.7 & 5.7 & 96.2 & 348.8 & 20.5 & 343.1 & 39.5 & 10.4 & $013 / 62$ & $013 / 21$ & A \\
\hline SK14 & $8 / 8$ & Car & 333.4 & 12.6 & 4.7 & 140 & 293.1 & 61.6 & 328 & 34.4 & 2.6 & $180 / 64$ & $180 / 39$ & A \\
\hline SK15 & $8 / 8$ & Car & 335.9 & 21.1 & 5.5 & 102.7 & 312.6 & 44.1 & 328.2 & 33.6 & 3.1 & $202 / 41$ & $202 / 22$ & A \\
\hline SK16 & $8 / 8$ & Car & 337.8 & 54 & 2.7 & 404.8 & 332.4 & 36.8 & 332.1 & 35.1 & 1.3 & $318 / 18$ & $138 / 02$ & A \\
\hline SK17 & $7 / 8$ & Car & 330.6 & -12 & 4.8 & 159 & 333.1 & 42.5 & 332.1 & 35.1 & 1.3 & $143 / 55$ & $143 / 07$ & A \\
\hline SK18 & $8 / 8$ & Car & 306.8 & 34.1 & 4.2 & 174.3 & 249.4 & 53.9 & 309.5 & 29.4 & 18.9 & $171 / 55$ & $171 / 61$ & A \\
\hline SK19 & $8 / 8$ & Car & 320.6 & 26 & 4.5 & 149.4 & 306.1 & 46.6 & 318.3 & 31.5 & 11.2 & $177 / 28$ & $177 / 21$ & A \\
\hline
\end{tabular}

the areas belonging to the Tissila-Amouguer sector the preremagnetization tilting is bigger than, or at least similar, the post- remagnetization one (19-66\% unfolding), in the Timarirhine sector tilting is mainly post-100 M.a. (61-86 \% unfolding). This fact 
(a) Red bed
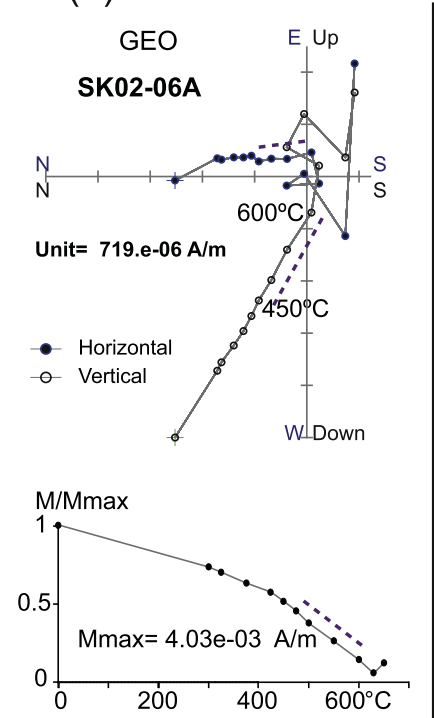

(b) Limestone

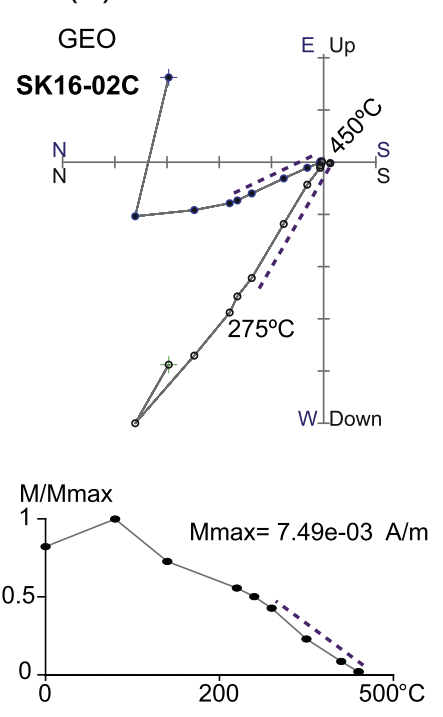

Fig. 4. Orthogonal plot of NRM thermal demagnetization of representative samples in geographic coordinates of a) red beds and b) limestones. Solid black symbols are projected onto the horizontal plane ( $\mathrm{N}$ towards the left and $\mathrm{W}$ downwards) and open symbols onto the vertical E-W plane). Purple dashed lines show the remagnetization component. Normalized NRM intensity is shown. (For interpretation of the references to colour in this figure legend, the reader is referred to the web version of this article.)

agrees with the geological differences discussed in the next section, showing a different evolution between these two areas.

\section{Geometry of cleavage and folding}

In the study area two different sectors can be differentiated from the structural point of view: (i) the central or Tissila-Amouguer sector (Tissila, Outerbat and Amouguer areas) and (ii) the southwestern, Timarirhine sector (Figs. 3 and 7). The main difference between both is the presence or absence (in the first and the second respectively) of ENE-WSW trending Mesozoic inherited structures (normal faults, diapirs and gabbroic intrusions) which conditioned the Cenozoic compressive structure, and explains the pre-100 M.a. deformation (Fig. 6), bigger in the first sector and probably linked with the extensional-halokinetic structures. The first one is characterized by folds whose axis can be followed as far as $100 \mathrm{~km}$ along trend, although most of them show lengths between 20 and $50 \mathrm{~km}$. Many of the anticlines (in whose core the basal levels of the Lower Jurassic crop out) are cut by extensional/halokinetic faults inherited from the rift stage (they can be considered as the limit of the flattened salt-walls) and show large amounts of gabbros in their cores (Figs. 3 and 7). These faults are linked in many cases to complications of the structure and are the main responsible for the interruptions of fold axes along trend. Towards the SW, the Timarirhine sector (Figs. 3 and 7) is characterized by the absence of the tight anticlines, being a tabular region with doubly-vergent box folds with moderately-dipping beds (Figs. 3 and 7).

Cleavage shows an uneven distribution throughout the study area (Laville and Piqué, 1992; Laville et al., 2004), probably conditioned by the sedimentary load, since it is more pervasive approaching the sectors with thicker syn-rift Jurassic series. This area coincides with the Mesozoic basin depocenters, as stated from illite crystallinity studies (Schaer and Persoz, 1976; Schaer, 1987). Although having many complications in detail, as will be described below (see also Laville and Piqué, 1992; Schaer, 1987), cleavage shows in general steep dips and runs parallel to the main structures (Figs. 3 and 7).
The present-day geometry of the Timarirhine sector is characterized by a tabular, sub-horizontal bedding interrupted by (i) large-scale folds with moderate limb dips, showing amplitudes of hundreds of meters and wavelengths of few kilometers (e.g. Timarirhine anticline) and (ii) deca- to hectometric-scale structures. These include doubly-vergent box anticlines having angular hinges (Fig. 8a) and limbs dipping about $50^{\circ}$. Amplitude of these anticlines rarely exceeds $100 \mathrm{~m}$. Some thrusts appear in the area, either in relation with the cores of the folds or involving individual beds or groups of beds with subhorizontal attitude (Fig. 8b), favored by the existence of incompetent levels within the Jurassic series. Slickenside striae appear on bedding surfaces subparallel to fold axes. A pervasive fold-parallel (ENE-WSW) cleavage can be recognized in soft and hard lithologies, showing pressure-solution features in calcareous rocks (Fig. 9a, b and Fig. 10) whereas slaty cleavage dominates in marls and shales (Fig. 9c, d). Cleavage shows in general steep dips (Figs. 7 and 11), and variable angles to bedding, depending on the dip of beds and the lithology; in the horizontal beds it is always sub-vertical, whereas in the limbs of the folds it shows high angles with bedding in limestones (defining normal or convergent cleavage fans) and low angles in marls (defining reverse or divergent cleavage fans), generating cleavage refraction (Fig. 9e). In general, it can be considered as an axial-plane syn-folding cleavage. Folds do not show a dominant vergence, although a prevalent southward dip of cleavage can be interpreted from the complete dataset (Fig. 11).

The Tissila-Amouguer sector (Figs. 3 and 7) is characterized by tight, kilometer-scale anticlines (Fig. 8c) separated by wider, gentler synclines (Fig. 8d), sometimes with angular hinges (Fig. 8e), in whose cores Middle Jurassic red beds crop out. Although fold trend is relatively constant, numerous changes of the strike of beds, linked to re-activation of extensional normal faults, periclines and relays between fold axes can be observed in the geological map (Fig. 3). Some of the synclines show chevron geometries (Fig. 8e) whereas rounded hinges are more common near the periclinal termination of folds. In general, a combination of kink and flexural fold mechanism can be inferred from fold reconstruction. Cleavage appears discontinuously, more pervasive when approaching the core of anticlines and seldom in the Bathonian-Callovian red beds cropping out at the cores of the synclines. The Ikkou syncline is a remarkable exception to this rule, since pervasive subvertical cleavage (Figs. 7 and 9c) can be observed along the red beds at its core (mainly in its Southern limb). Cleavage shows in general a homogeneous and almost vertical attitude regardless the bedding orientation, running parallel to the main structures and showing axial-plane relationship with minor folds.

Cleavage in limestones is associated with pressure-solution features, as inferred from thin sections (Fig. 10), with different degrees of development from short, discontinuous planes characterized by the accumulation of iron oxides in rocks without evidences of macroscopic cleavage at the outcrop scale (Fig. 10a, b and c) to an almost continuous cleavage and extremely thin microlithons (Fig. 10d, e and f). Some samples show an en echelon disposition of the cleavage planes (Fig. 10b, d) indicating simpleshear processes. It is remarkable the apparent absence of phyllosilicates (according to optical microscope observations) related to cleavage, being carbonates, quartz, iron oxides, iron sulphides and organic matter the components of the limestones. Pyrites are not related to cleavage and probably were formed during the early diagenetic stages.

The previous observations indicate both layer-parallel shortening (cleavage perpendicular to bedding in shallow-dipping layers) and flattening which can be combined with flexural-flow in marls (cleavage defining divergent fans at the limbs of folds) or with flexural-slip in limestones (cleavage defining convergent fans) 

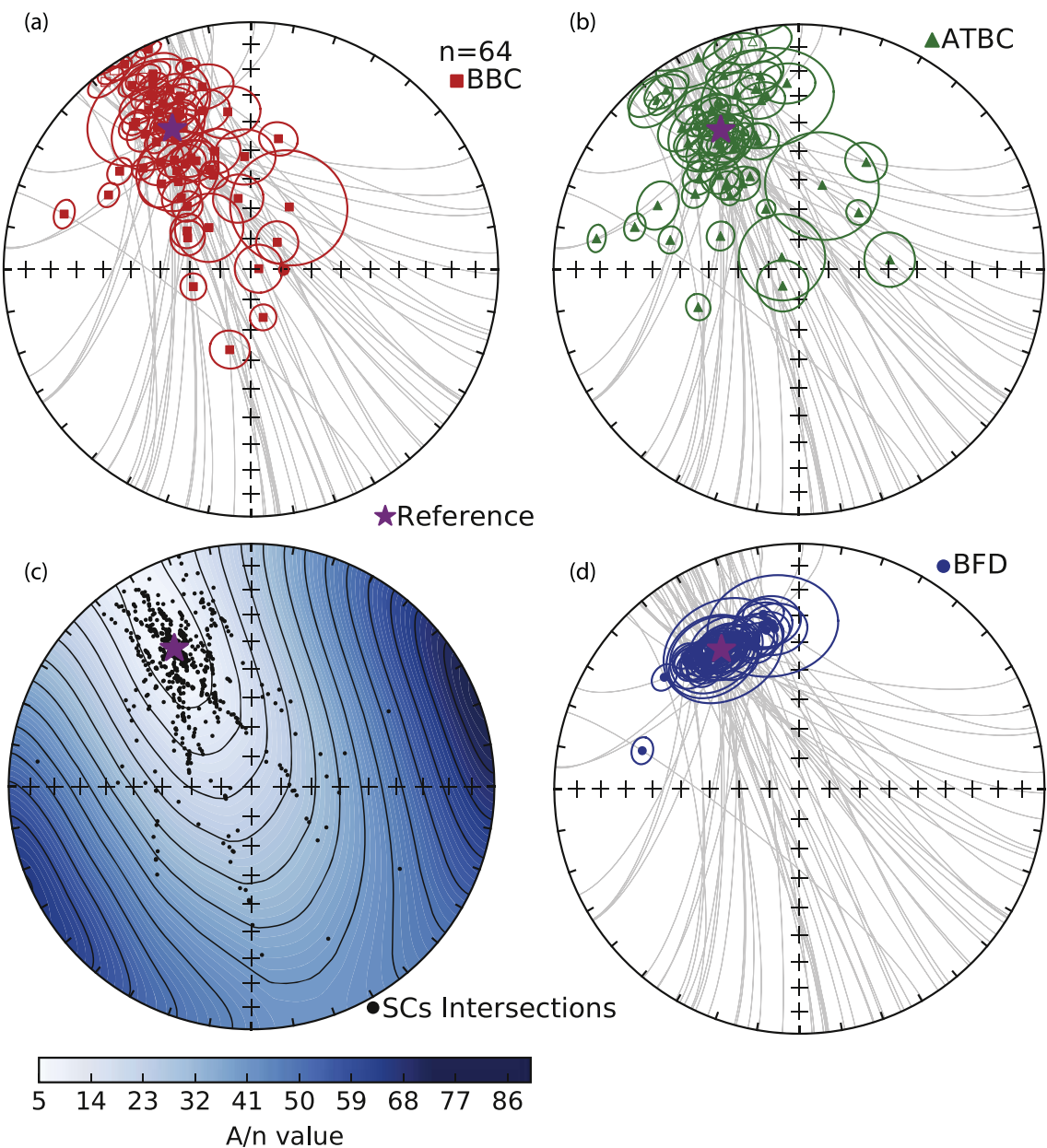

\section{$A / n$ value}

Fig. 5. Equal-area projection (lower hemisphere) of paleomagnetic directions (with $\alpha 95$ ) in a) GEO and b) TILT coordinates (before and after bedding correction respectively). c) Contours of parameter A/N (Waldhör and Appel, 2006) calculated for these data (Table 1). d) Optimal paleomagnetic direction and its corresponding small circles.

\section{Tissila-Amouguer sector}

\section{Tissila area}

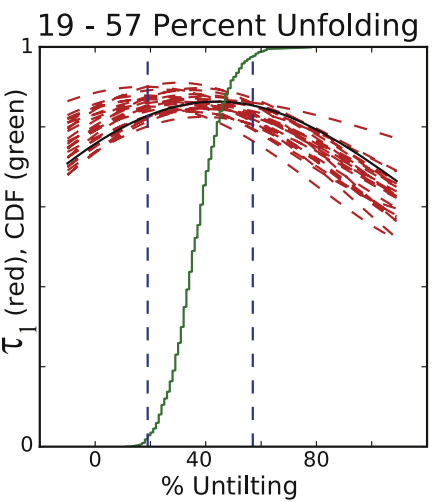

\section{Outerbat area}

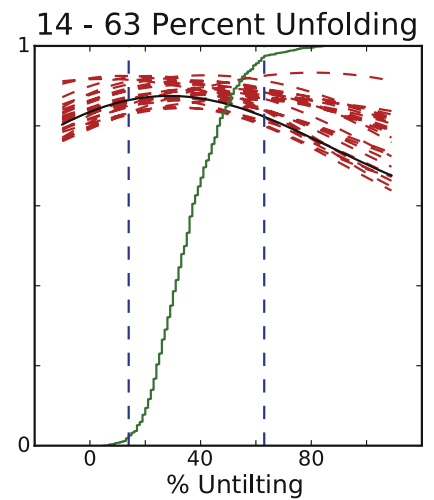

\section{Amouguer area}

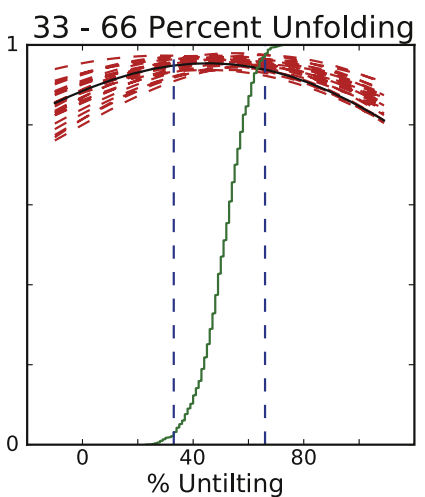

\section{Timarirhine sector}

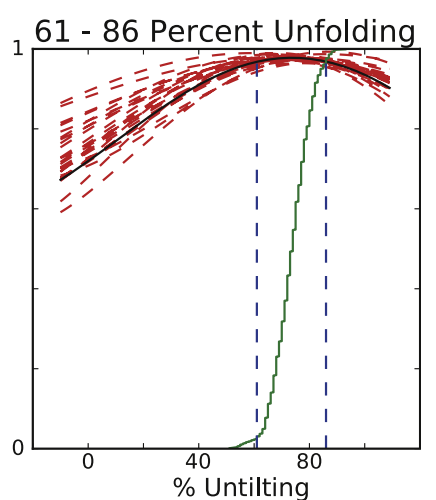

Fig. 6. Bootstrap fold-test (Tauxe and Watson, 1994; Tauxe et al., 2010) of the four representative areas. The largest value of $\tau_{1}$ shows in all cases a syn-folding remagnetization, with the best clustering between 19 and $66 \%$ of untilting in the Tissila-Amouguer sector and between 61 and $86 \%$ of untilting.

as the main mechanisms of cleavage formation. Their relative contribution depends on the mechanical stratigraphy and the dip of the sedimentary sequence. Layer-parallel shortening, having a weaker expression, is only recognized at presently horizontal beds because flattening and folding (and the associated flexural-flow or flexural-slip processes) are dominant at the limbs, obliterating incipient cleavage related with the first mechanism, if it existed. Whereas in the Timarirhine sector the three types of mechanism 


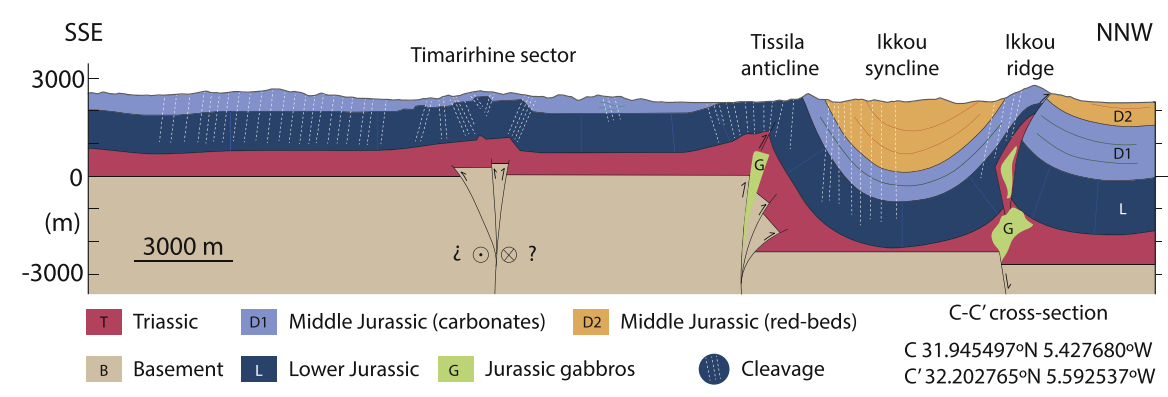

Fig. 7. General, idealized cross section of the studied area projecting cleavage data onto the plane of the section. See location at Fig. 3.
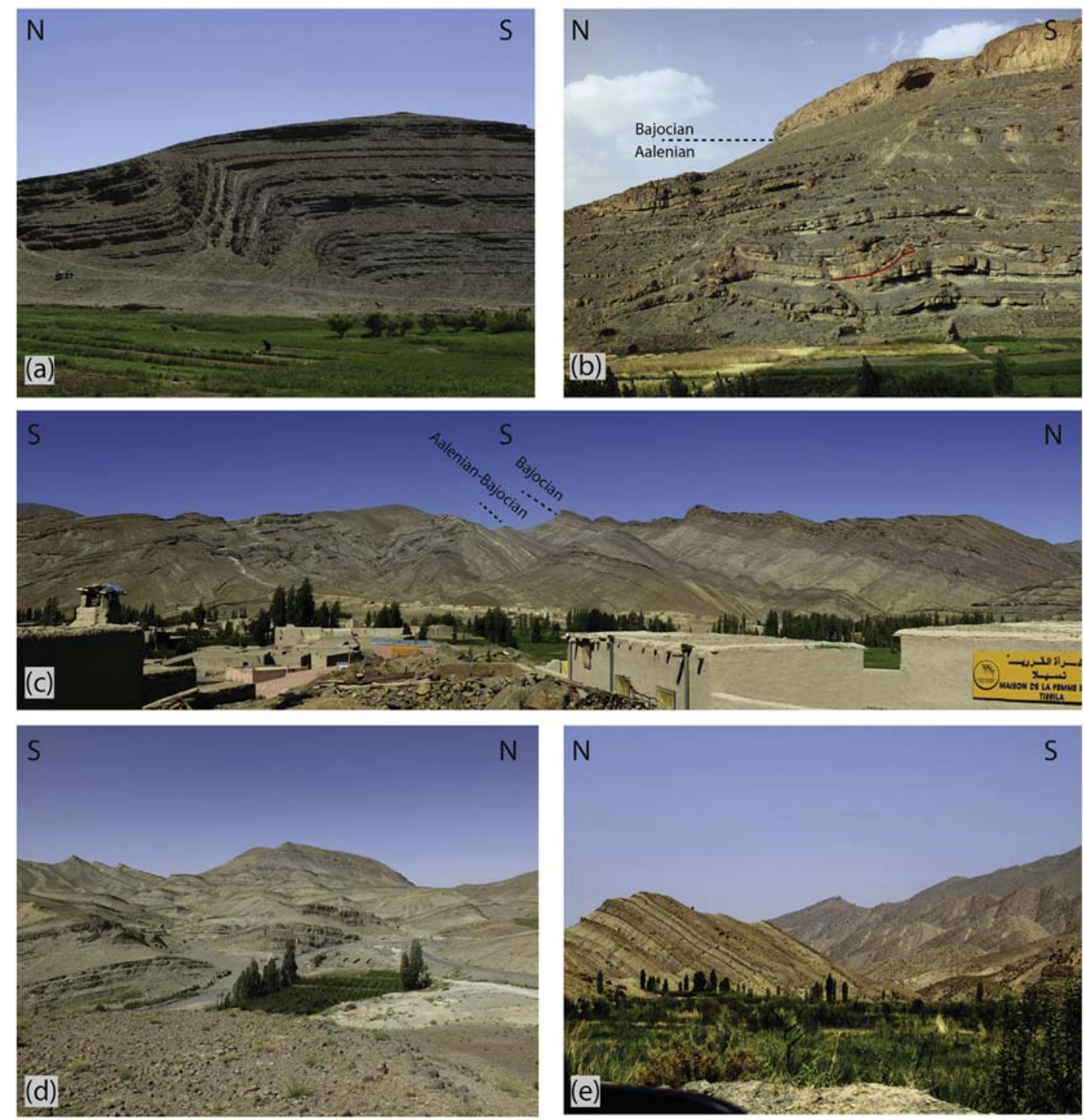

Fig. 8. Photographs showing representative structures in the study area. (a) North limb of a box fold with axial-plane cleavage located in the Timarirhine sector. (b) Tabular area located in the Timarirhine sector showing the Aalenian alternating beds of marl and limestone which favors small detachments as well as flexural-slip processes. (c) Tissila anticline (and homonymous village) showing some structural complications in its core; sedimentary sequence in the N limb is thicker and steeper than in the S limb. (d) Gentle, rounded syncline with steeply-dipping axial-plane cleavage. (e) Angular, asymmetric syncline located S of Outerbat-Amouguer areas without presence of cleavage. See *.kmz supplementary data file for photograph locations.

can be distinguished, flattening-related cleavage is clearly dominant in the Tissila-Amouguer sector. In any case, the previous observations show that in general it is in a regional, syn-folding axial plane cleavage that shows different relationship with bedding related to its development according to different mechanism, depending the structural domain in which it appears (limbs of folds, horizontal beds, cores of synclines, etc.). 

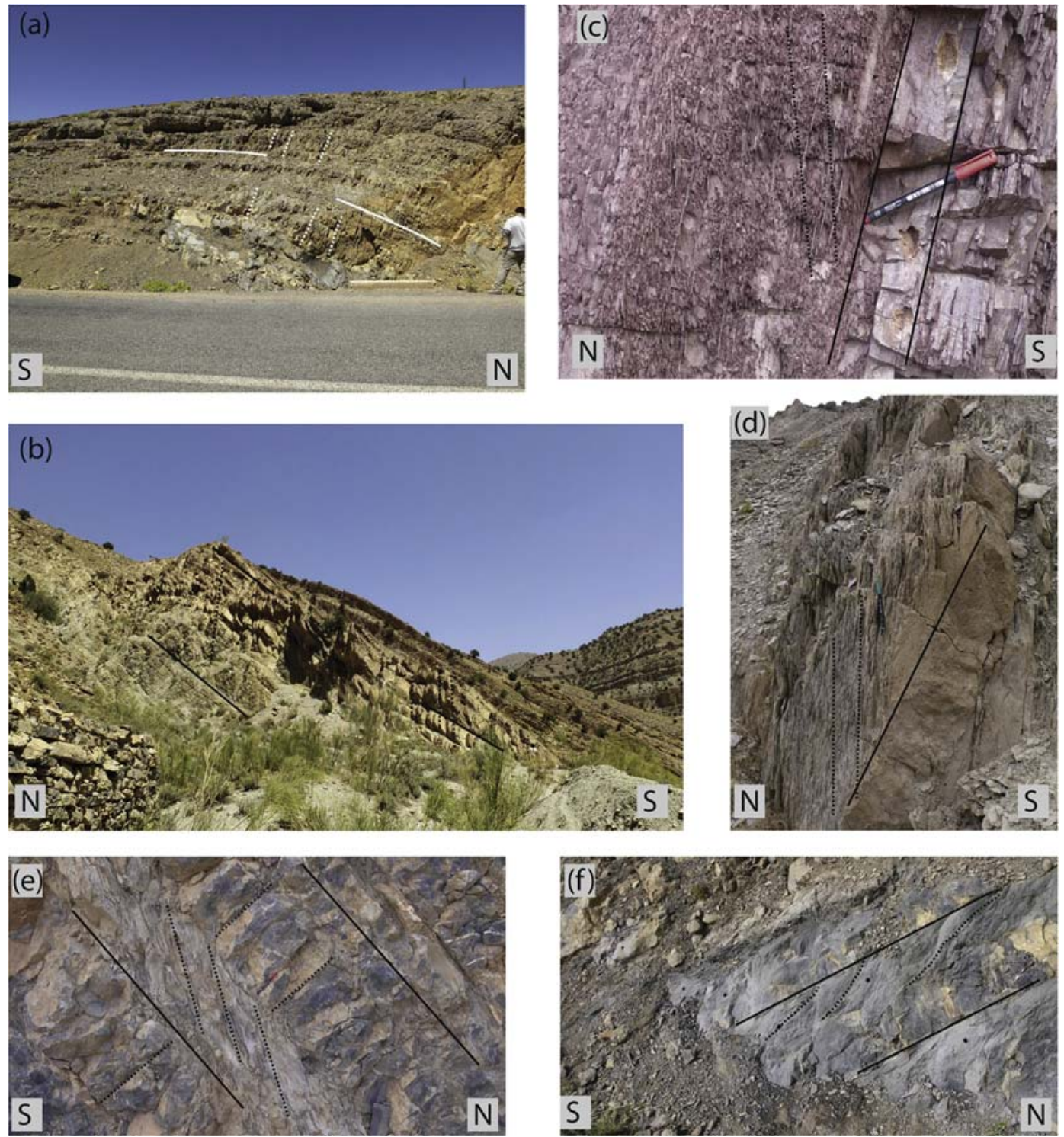

Fig. 9. Photographs showing the geometry of cleavage at the outcrop scale and its relationship with bedding. (a) Pressure-solution convergent fan cleavage in limestones of AG01 site. (b) Penetrative steep cleavage affecting the limestones S of Outerbat-Amouguer area. (c) Slaty cleavage in red beds of the Ikkoy syncline. (d) Steeply-dipping cleavage affecting marly limestones at the southern limb of Tissila anticline. (e) Cleavage refraction in alternating marl-limestone sequence in the Timarirhine sector. (f) Slaty cleavage in the marls of the Timarirhine area displaying a divergent-fan disposition. See *.kmz supplementary data file for photograph locations.

\section{Restoration of the structure at ca. 100 M.a. and relation with cleavage}

Two detailed cross-sections were restored using paleomagnetic data (Table 1) to their ca. 100 M.a. geometry (Fig. 12). Both crosssections, having a length of 5 and $15 \mathrm{~km}$ respectively, have been drawn considering cleavage and its geometrical relationships with bedding in two representative areas: the tabular Timarirhine sector (Figs. 3 and 12a), showing box folds and with a mainly postremagnetization deformation (see subsection 6.3), and the Tissila anticline-Ikkou syncline (in the Tissila area, Figs. 3 and 12b), in whose core the Middle Jurassic red beds crop out and showing an important pre-remagnetization tilting (see subsection 6.3). Furthermore, a detailed map of the Outerbat sector and three individual structures are also analyzed.

It is assumed that cleavage developed only in single deformation stage, either during the pre- or during the post-remagnetization deformation event. Thereby, cleavage can be rotated (according to the rotation applied to the bed that contains it) as a passive marker from its present-day attitude to its restored ca. 100 M.a. orientation. Comparing both cross-section (present-day and restored) and their bedding-cleavage relationship, and following the premises shown in of section 3 (Fig. 2), we try to decipher the cleavage age.

\subsection{The Timarirhine sector}

The cross-section in the Timarirhine sector (Fig. 12a) shows a rather flat geometry with a South-dipping envelope and box-fold anticlines. Cleavage shows northwards and southwards dips and appears both in the flat areas and at the limbs of the anticlines. Cleavage is particularly pervasive at the two sides of high-angle reverse faults located at the middle of the cross-section. The ca. 100 M.a. geometry (Fig. 12a) obtained from the restoration of paleomagnetic vectors shows incipiently developed folds with the same disposition as the current folds but having shallower dips at their limbs. The overall southwards tilting of the northern part of 

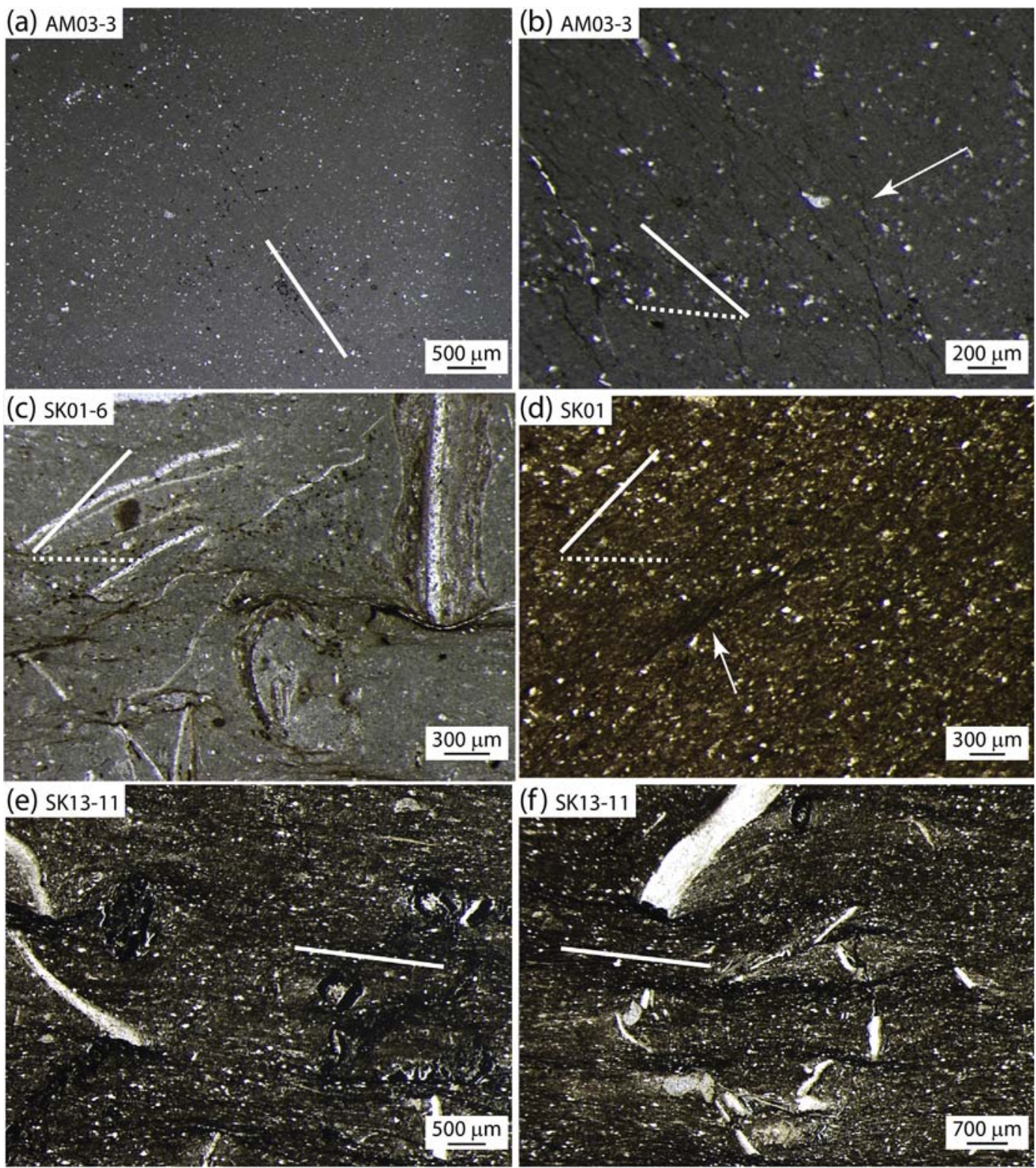

Fig. 10. Thin-sections photographs showing the morphology of cleavage at the microscale. Solid lines show the general attitude of the cleavage and dashed lines correspond with the bedding. Arrows show an en echelon disposition of the cleavage. (a) Limestone with poorly defined cleavage delineated by pressure-solution planes. (b) Limestones with pressure-solution cleavage; arrow shows a en echelon disposition of the cleavage. (c) Spaced cleavage defined by pressure-solution planes in which opaque minerals are concentrated. Note the presence of small pyrites. (d) Spaced cleavage in a quartz-rich limestone. (e and f) Organic matter-rich sample with a continuous cleavage with pressureshadows related with the presence of bioclasts and pyrite crystals.

the section post-dates the remagnetization. Interestingly, deformation associated with the reverse fault (associated with cleavage development) is absent in the palinspastic section (Figs. 12a and 13a). If cleavage is restored according to its present-day attitude and regarding angular relationship with bedding no changes occur in sub-horizontal beds, but changes are significant at the limbs of folds (sites AG01, SK06 and SK05), where cleavage becomes strongly oblique to their axial planes, acquiring inconsistent orientations in the restored cross-section (see Fig. 12a).

A detailed fold test (using the SCs method) was applied in a minor fold of this area (Fig. 13b) with associated axial-plane cleavage, showing that this structure (and thereby its associated cleavage) post-dates the remagnetization.

Therefore, and considering the starting hypothesis (Section 3, Fig. 2), this sector is characterized by a syn-folding remagnetization, and hence the relative dating of cleavage is not direct. However, some evidences denote a post-remagnetization development of the cleavage in this sector: (i) the main folding stage post-dates the remagnetization, (ii) cleavage does not show evidences of being folded, (iii) bedding-cleavage angular relationship are more coherent in the present-day geometry than after the restoration (before ca. 100 M.a.), and last not least (iv) some minor structures with genetically associated cleavage are totally postremagnetization.

\subsection{The Tissila-Amouguer sector}

The Tissila cross-section (Fig. 12b) depicts a wide syncline (Ikkou syncline) with a thick series of Lower-Middle Jurassic in its core, limited to the north by an inverted normal fault associated with 


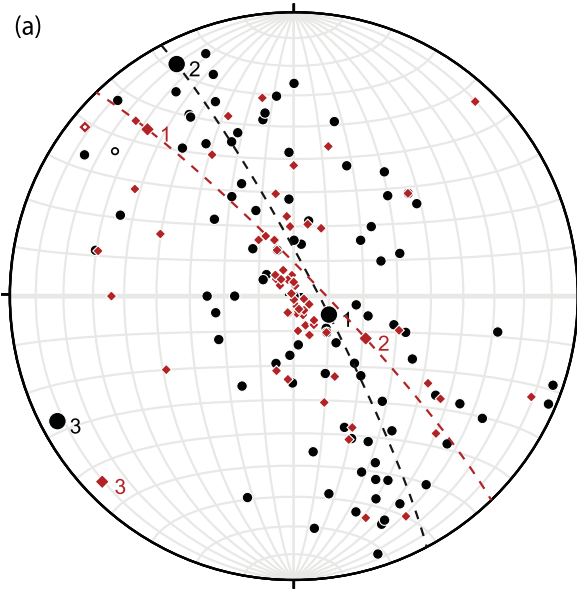

Bedding (black circles, $\mathrm{n}=95$ ) Paleo-bedding (red diamonds, $\mathrm{n}=65$ )

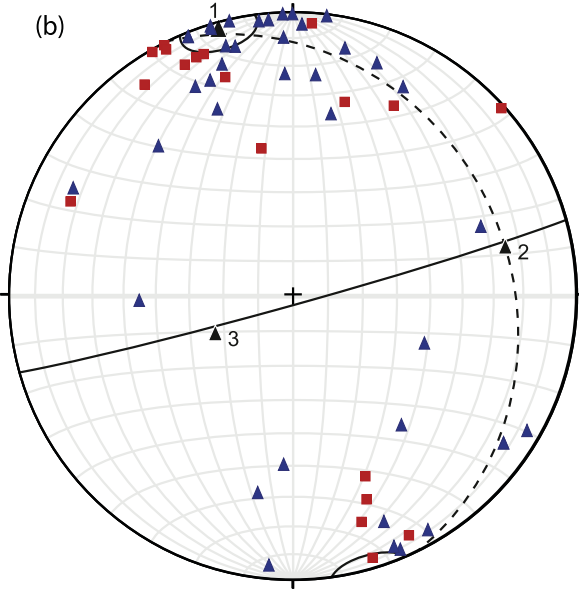

Cleavage Tissila-Amouguer sector (triangles, $\mathrm{n}=40$ )

Cleavage Timarirhine sector (cubes, $n=19$ )

Fig. 11. Lower hemisphere, equal-area projection showing structural data. (a) Poles from bedding and paleo-bedding (black circles and red diamonds, respectively) and cylindrical best fit for each data-set. (b) Poles for foliation and mean foliation plane (solid great circle), mean vector (and associated $\alpha 95$ ) and cylindrical best fit. (For interpretation of the references to colour in this figure legend, the reader is referred to the web version of this article.)

diapiric activity during the extensional stage, and to the south by the asymmetric Tissila anticline (see also Torres-López et al., 2016). Across the syncline a sub-vertical cleavage (more developed in its southern limb) with constant dip appears, regardless of the dip of beds and sub-parallel to the axial plane of the fold. After restoration of bedding and cleavage (following the same criteria applied in the Timarirhine cross-section) at 100 M.a., the structure shows a symmetric syncline limited by steeply-dipping limbs. The limit towards the $S$ is the Tissila asymmetric proto-anticline, with a steeper northern limb (towards the Ikkou syncline) and more shallowly-dipping southern limb. The $\mathrm{N}$ limit of the syncline was a salt-wall (this can still be seen towards the $\mathrm{W}$ ), partially welded in the present-day cross-section due to the tectonic transport towards the $\mathrm{N}$ of the Ikkou syncline, as can be inferred from the geological map (Fig. 3). This geometry, in addition to the thickness variation of some units that can be observed in the cartography (Fig. 3) are in agreement with observations by Saura et al. (2014) in the sense that this structure was generated under an extensional setting due to halokinetic processes linked to basement fault activity.

Regarding cleavage-bedding relationships, no strong changes between the present-day and the ca. 100 M.a. structure can be observed since the main structure was already developed before the acquisition of the remagnetization. Only in the southern limb of the Tissila anticline there are differences in the cleavage-bedding relationships, with better agreement in the present-day attitude than in the restored one.

Furthermore, cleavage developed around the Tissila anticline is consistent with axial-plane cleavage generated either during the pre- or post-remagnetization deformation events. Unlike in the Timarirhine structures, cleavage around the Tissila-Ikkou structures is related rather with flattening than with folding, as can be inferred from its steep regular dip regardless the bedding attitude. This fact, put together with the extensional origin of the preremagnetization structure, seems to indicate a late development of cleavage, after the structure (and mainly the syncline) was partially developed, and hence post-dates the remagnetization.

In the Outerbat sector (Fig. 14) bedding/cleavage relationships can be analyzed in plan-view within a relatively small area. The structural map shows the changing attitude of cleavage and bedding, with cross-cutting relationships at the limbs of the NE-SW trending syncline consistent with the axial plane but cutting perpendicular to beds and axial plane of the anticline. However, there are also dykes of Late Jurassic-Early Cretaceous age (Hailwood and Mitchell, 1971) cutting across the structure that are not folded with the beds (Fig. 14) indicating that folding pre-dates mostly the emplacement of the dykes. As it occurs with the geometries depicted in cross-sections, the ca. 100 M.a. geometry is at an intermediate point between horizontal beds and completely developed folds (Fig. 6). Cleavage runs steeper parallel to the main structure and could be generated either by flattening or by buttressing processes against the extensional structures. Changes in the cleavage trend (Fig. 14a) can be related with the same changes in the faults; however, the equal-area projection (Fig. 14c) of the bedding and cleavage could indicate that cleavage was slightly folded for the late folding stage. These relationship seems to indicate that cleavage development was late in relation to the structure. However, since this area was mainly structured before the acquisition of the remagnetization, and also due to the complex structural pattern resulting from the superposition of pre- and postremagnetization structures, apparently non totally coaxial, and that no minor folds with axial-plane cleavage could be sampled, it is difficult to relatively date cleavage in this sector.

Another point of view is given by a fold in the westernmost sector. In this case, the paleomagnetic approach indicates that most of the tilting at the limbs of this fold pre-dates the acquisition of the remagnetization (Fig. 13c). However, cleavage seems to be postfolding because it is almost vertical and parallel, cutting across the folds and their axial plane. In this situation, it is not possible to relatively date cleavage in relation to the remagnetization (Fig. 2).

\section{Discussion}

\subsection{Cleavage age}

Results indicate that to establish the cleavage-foldremagnetization relationship by means of the combination of a structural and paleomagnetic approach is a useful tool to relatively date tectonic processes in the absence of other markers. The use of this methodology in this work clearly indicates that the development of the cleavage is related to folding and post-dates the remagnetization in the Timarirhine area, solving the old discussion regarding the age of cleavage (with the proposed hypothesis of 
a)
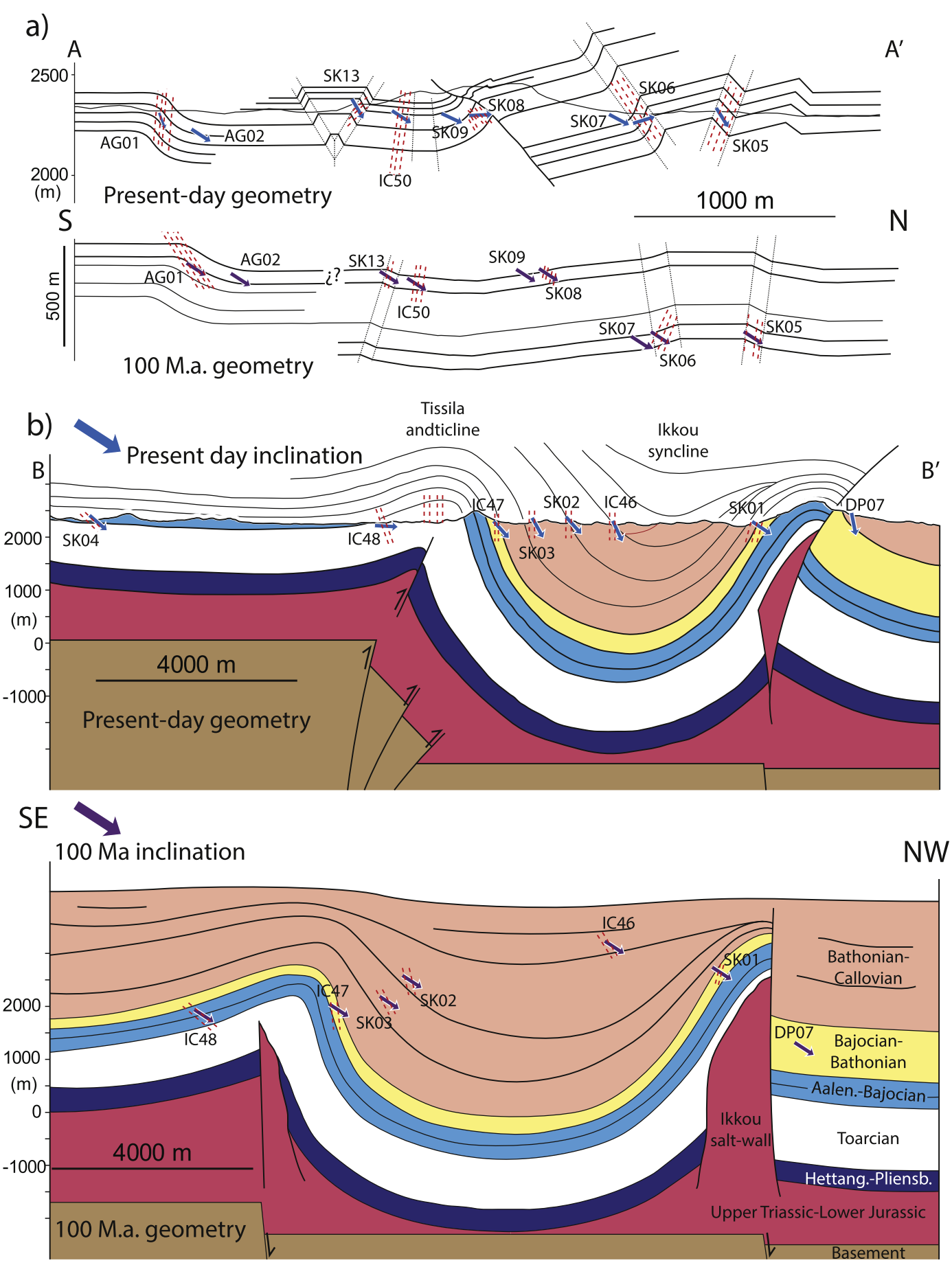

Fig. 12. Present-day and restored cross-section of the (a) Timarirhine and (b) Tissila areas. Arrows indicate the paleomagnetic inclination in each site before and after the correction to the Albian-Cenomanian paleomagnetic direction. See location of the cross-sections in Fig. 3.

Upper Jurassic or Cenozoic cleavage).

In the central sector there are not final evidences about the cleavage age, but existing evidences point towards a postremagnetization cleavage: (i) in the three described areas (Tissila and Outerbat and folded sector of Amouguer area) cleavage show a regular expression, with steep dip and strike parallel to the structures, what can be related either with flattening (in the Tissila area) or buttressing (in the Outerbat area), and that in any case it indicates a late development of cleavage (syn- to post-folding). (ii) According to the starting hypothesis (Fig. 2), in a context with a syn- folding remagnetization and syn- to post-folding cleavage, the cleavage age is undetermined or more probably postremagnetization (depending on whether cleavage is rather synfolding or post-folding, respectively), but since the deformation is mainly pre-remagnetization, this is not totally conclusive. (iii) There are not differences allowing to differentiate two types of cleavage according to their age in the different sectors of the study area; this also seems to indicate that the origin of the cleavage is the same throughout the CHA domain. (iv) Finally, it is easier to explain only one deformation event of cleavage development than two 


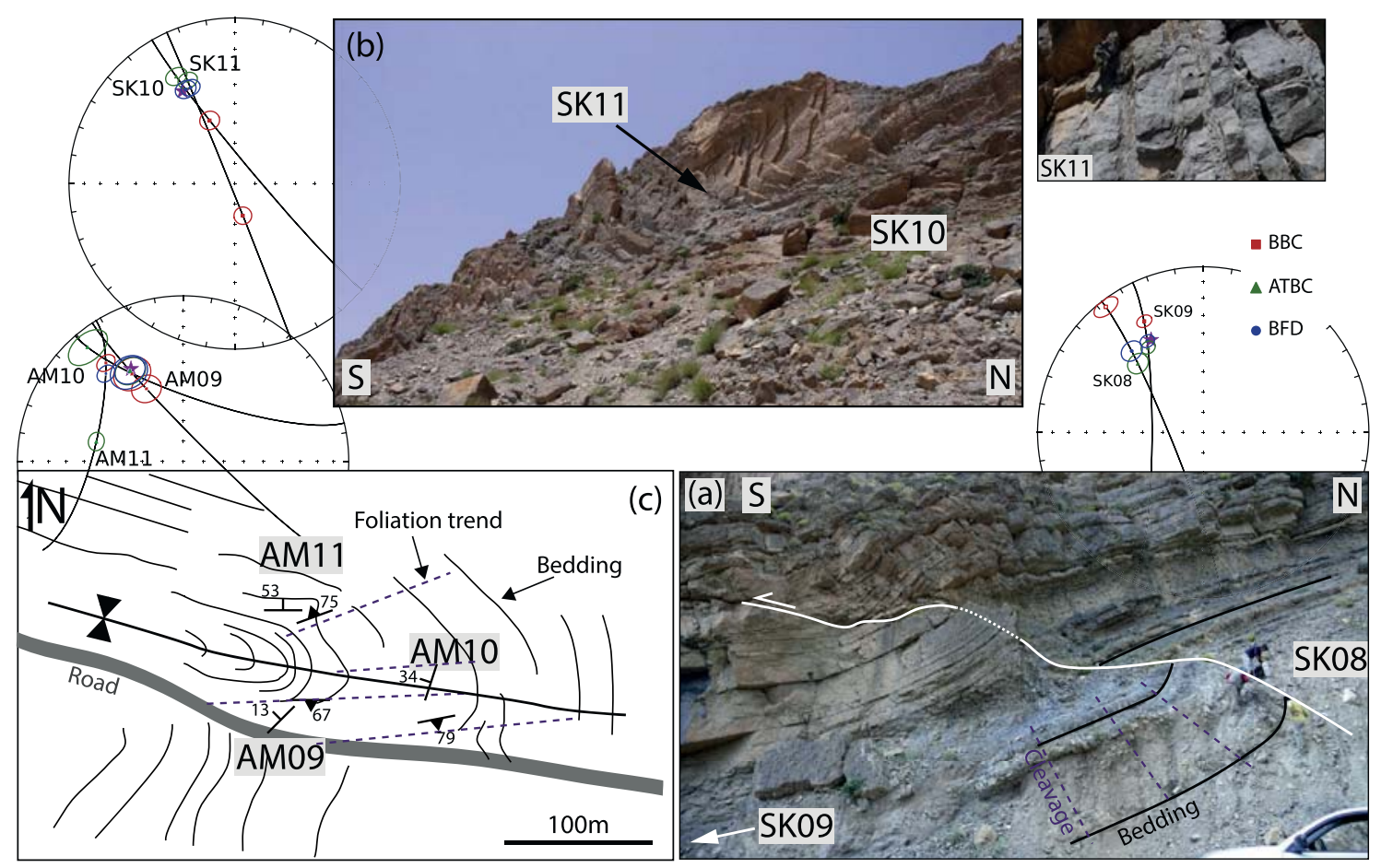

Fig. 13. Key outcrops showing different behavior offolds regarding cleavage and remagnetization. (a) Minor thrust and associated drag folds with axial-pla SK08 and SK09 sites (see Timarirhine cross-section, Fig. 12a); the coincidence between BFD and ATBD paleomagnetic directions indicates that this structure post-dates the remagnetization acquisition. (b) As in (a) this anticline with axial-plane cleavage post-dates the remagnetization. (c) Plan-view sketch of a preremagnetization fold (coincidence between BFD and BBC paleomagnetic directions); cleavage shows steep dips that apparently cut along the structure, what indicates that it was generat AM11 is slightly displaced from the AM10-AM09 intersection and the paleomagnetic reference; this could be related with the slight change of attitude

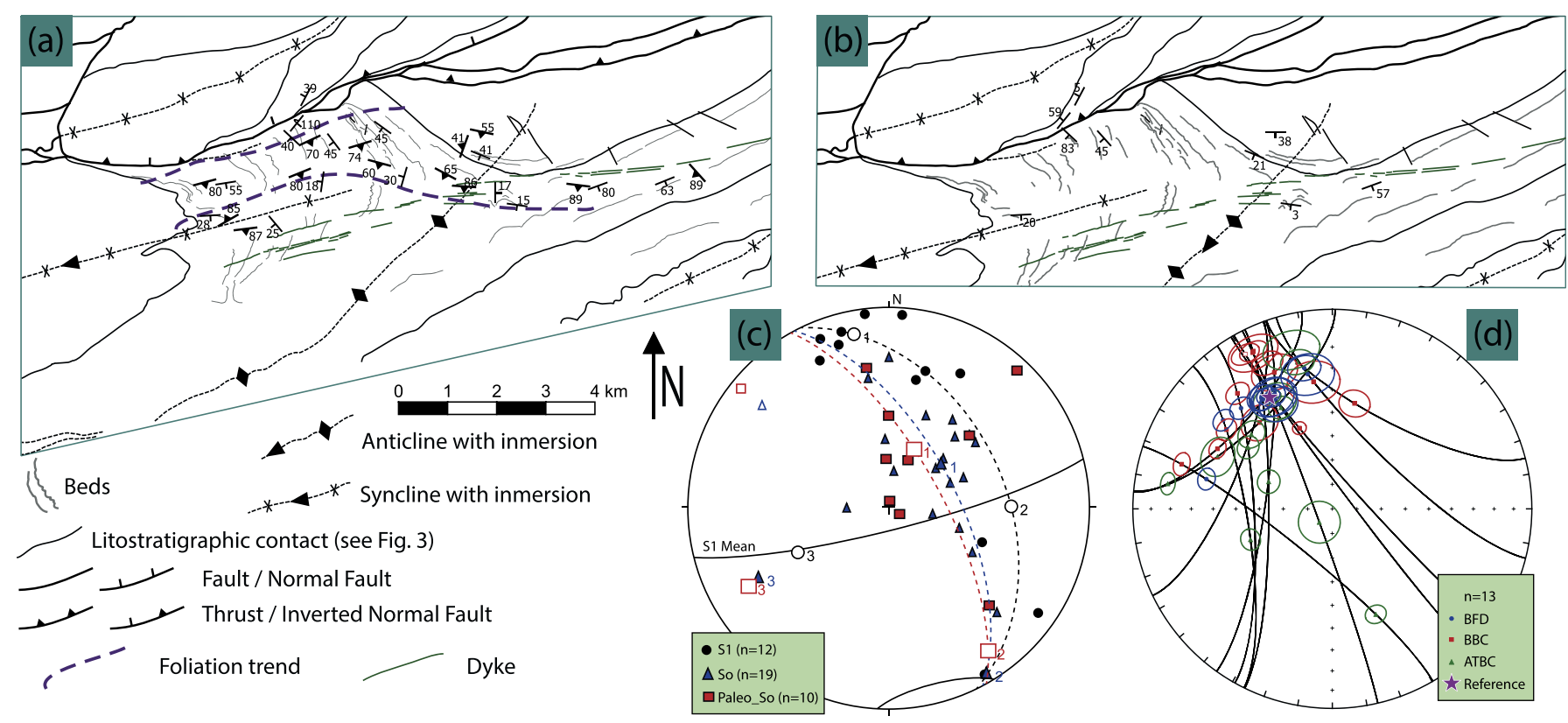

Fig. 14. Schematic geological map of the Outerbat sector showing relationships between different structures: bedding, cleavage, folds and dikes. a) Presen dikes cut across bedding and that bedding-cleavage relationship vary along the structure. (b) Map with paleo-bedding. Note that the structures, the (except the bedding dip) is not restored, only for spatial reference. c) Lower hemisphere, equal-area stereoplots showing structural data (S1: clea bedding) and cylindrical best fit of each data-set. d) Paleomagnetic direction (Geo, Tilt and BFD) and associated small-circle for each site.

t day attitude; note that dykes, and other elements vage, So: bedding, paleo-So: paleo- different deformation events producing cleavage with uniform appearance. Consequently, since cleavage in Timarirhine is postremagnetization, all studied cleavage can be considered to have a similar relationship with the ca. 100 M.a. remagnetization.

\subsection{Remagnetization-cleavage relationship}

Since cleavage and chemical remagnetizations can be triggered by common external processes (as a regional temperature increase) 
or the cleavage development can generate regional remagnetization events itself, further discussion about cleavageremagnetization relationship is necessary.

Both organic matter maturation (Brothers et al., 1996) and smectite-illite transformations (Katz et al., 2000) can generate authigenic magnetite with minimum formation temperatures around $90{ }^{\circ} \mathrm{C}$, similar in both processes (Pevear, 1999). Orogenic fluids can be the responsible for the formation of new magnetite grains (Elmore et al., 2012). Izquierdo-Llavall et al. (2013) found links between reflectance of the vitrinite, illite crystallinity and cleavage, all of them in relation with the critical temperature of $140{ }^{\circ} \mathrm{C}$ for cleavage development in the Pyrenees fold-and-thrust belt. In this way, and taking into account that remagnetization in the High Atlas is syn-folding, we could be led to interpret remagnetization and cleavage development as co-genetic in the frame of a main tectonic phase. However, the particularly fortunate conditions of the High Atlas provide two arguments that allow us to discard the link between these two events. On one side, the remagnetization is recognized more widely than the cleavage both in its areal extent as in its representation along the sedimentary series, what indicates that the remagnetization is less restrictive with regard to $\mathrm{p}-\mathrm{T}$ and deformation conditions (supposing that they were genetically related). On the other side, the chronological relationship between remagnetization and cleavage, when they can be clearly obtained from the bedding/cleavage geometrical relationships, systematically shows that cleavage post-dates the remagnetization. If they were contemporaneous, we should observe that cleavage both pre and post-dates the remagnetization, or else that the remagnetization always post-dates cleavage as it occurs in the Cameros basin (Villalaín et al., 2003) (since the remagnetization is less restrictive and therefore its acquisition should to finish after cleavage development). Hence, the remagnetization can be clearly bracketed in Cretaceous times, whereas cleavage development happened in the Cenozoic, related with folding during the main inversion of the CHA. Therefore, we can conclude that remagnetization and cleavage are two clearly different, unrelated processes, separated in time.

Another important question regarding this issue is the absence of phyllosilicates (according to optical microscope observations) in some of the cleaved limestones which are remagnetized. This point seems to indicate that there is no relation between remagnetization and illitization processes, being more important the presence of organic matter and iron sulphide (pyrite). This also explains the absence of a remagnetization related with the cleavage development since the latter is a pressure-solution cleavage and does not involve significant recrystallization processes.

\subsection{Interpretation of paleomagnetic data after development of cleavage}

Another question arising in paleomagnetic analysis in regions undergoing deformation and cleavage development is the possible deformation of paleomagnetic vectors (Kligfield et al., 1983; Cogné and Perroud, 1985; Hirt et al., 1986; Borradaile, 1997; Oliva-Urcia et al., 2009). In the CHA, cleavage post-dates remagnetization and therefore a caveat about possible deformation of the magnetic remanence can be considered. This possible deformation of the paleomagnetic vector depends on different factors: (i) the intensity of the deformation of the rock, (ii) the angle between the flattening direction and the paleomagnetic vectors (according to geometric relationship proposed by Ramsay and Huber (1987) the deformation of remanence would be lower than the confidence angle, becoming bigger for intermediate angles between these two vectors) and (iii) the morphology of the ferromagnetic minerals which carried the magnetization (SSD magnetite in this case), being anisotropic grains more likely to be rotated than isomorphic grains. Although the angle between flattening direction (according to cleavage geometry) and the paleomagnetic vector (Fig. 12), and the degree of deformation changes in different sites, there are not systematic differences in the paleomagnetic direction between cleaved or non-cleaved rocks. One possibility is that ferromagnetic minerals within microlithons have not been involved in deformation. Other possibility is that the magnetic grains are close to the multiaxial morphology. For the latter, a more detailed study analyzing the ferromagnetic fabric and the morphology of the magnetite grains in the sense of Jackson and Swanson-Hysell (2012) could shed light in the future in this subject. However, a uniaxial magnetic behavior of grains does not guarantee a uniaxial (anisotropic) behavior from a mechanical point of view because a small shape anisotropy (c/a axis relationship around 1.1) of the SD magnetite grains results in a uniaxial magnetic behavior of grains (Winklhofer et al., 1997).

\section{Conclusions}

From the study of the new sites we corroborate that the remagnetization in the CHA shows systematically normal polarity and shows a syn-folding behavior. According to the orientation of the paleomagnetic vectors, it has been dated as Albian-Cenomanian (ca. 100 M.a.).

The presence of remagnetizations in intraplate basins can allow restoring their geometry at the moment of the acquisition of the remagnetization; this methodology, together with structural analysis, can help to resolve controversies about geological process. In this work some key cross-sections of the Central High Atlas are compared in the present-day and the restored (at ca. 100 M.a.) geometry in order to relatively dating the tectonic cleavage (pre- or post-remagnetization) present in the area.

Cleavage-bedding geometrical relationships at present and at the ca. 100 M.a. restored cross-sections show that the development of cleavage clearly postdates the remagnetization acquisition. Besides, geometrical relationships indicate that folding and cleavage are genetically related and there are not evidences of subsequent folding of the cleavage. These facts support the absence of a general cleavage development in the CHA before the Albian-Cenomanian and therefore it is associated with the Cenozoic basin inversion and folding. Local cleavage associated with Late Jurassic intrusions and contact metamorphism (Schaer and Persoz, 1976; Laville and Piqué, 1992; Laville et al., 1994) is restricted to the surroundings of the igneous bodies.

- Structural analyses of folds and cleavage have allowed observing different cleavage development mechanism: The Timarirhine sector is a tabular area without extensional faults, and subhorizontal disposition only interrupted by box-folds (Fig. 12). Here, axial-plane cleavage can be interpreted as generated both by flattening associated with flexural-flow and flexural-slip folding mechanisms and layer-parallel shortening. The geometrical relationships along the Timarirhine cross-section (and folds close to it) clearly indicate a post-remagnetization development of cleavage, related to the Cenozoic inversion of the CHA.

- A completely different scenario appears in the central part of the studied area, where inherited extensional faults control the subsequent compressional structure. Cleavage is sub-vertical and their trend parallel to the folds and faults (as in Tissila and Outerbat sector), is indicative of flattening and buttressing processes, respectively, probably during the Cenozoic inversion, although this tentative chronology is not conclusive. 
Finally, the paleo-geometrical reconstruction developed from restoration of a syn-tectonic remagnetization has been demonstrated as a powerful methodology to analyze cleavage and folding history.

\section{Acknowledgments}

This study was financed by the research projects CGL201238481 and CGL2016-77560 of the MINECO (Spanish Ministry of Economy and Competitiveness) with also FEDER founding (European Union). Pablo Calvín also acknowledges the MINECO for the F.P.I. research grant BES-2013-062988. E. Izquierdo and an anonymous reviewer are thanked for their constructive comments that help to improve the manuscript.

\section{Appendix A. Supplementary data}

Supplementary data related to this article can be found at http:// dx.doi.org/10.1016/j.jsg.2017.02.009.

\section{References}

Armando, G, 1999. Intracontinental Alkaline Magmatism: Geology, Petrography, Mineralogy and Geochemistry of the Jebel Hayim Massif (Central High AtlasMorocco).

Aubourg, C., Pozzi, J., Kars, M., 2012. Burial, claystones remagnetization and some consequences for magnetostratigraphy. Geol. Soc. Lond. Spec. Publ. 371, 181-188. http://dx.doi.org/10.1144/SP371.4.

Barbero, L., Teixell, A., Arboleya, M.-L., Río, P. Del, Reiners, P.W., Bougadir, B., 2007 Jurassic-to-present thermal history of the central High Atlas (Morocco) assessed by low-temperature thermochronology. Terra Nov. 19, 58-64. http://dx.doi.org 10.1111/j.1365-3121.2006.00715.x.

Bazhenov, M.L., Shipunov, S.V., 1991. Fold test in paleomagnetism: new approaches and reappraisal of data. Earth Planet. Sci. Lett. 104 (1), 16-24. http://dx.doi.org/ 10.1016/0012-821X(91)90233-8.

Borradaile, G.J., 1997. Deformation and paleomagnetism. Surv. Geophys. 18, 405-436. http://dx.doi.org/10.1023/A:1006555906559.

Bouchouata, A., Canérot, J., Souhel, A., Gharib, A., 1995. Stratigraphie séquentielle et évolution géodynamique du Jurassique de la région Talmest-Tazoult (Haut Atlas central, Maroc). Comptes Rendus L'Academie Des. Sci. Paris 320, 749-756.

Brothers, L.A., Engel, M.H., Elmore, R.D., 1996. The late diagenetic conversion of pyrite to magnetite by organically complexed ferric iron. Chem. Geol. 130, 1-14. http://dx.doi.org/10.1016/0009-2541(96)00007-1.

Calvín, P., Villalaín, J.J., Casas, A., Tauxe, L., Torres-López, S. (in prep.). pySCu: a new Python code for analyzing remagentizations directions by means of Small Circle utilities.

Chadima, M., Hrouda, F., 2006. Remasoft 3.0 a user-friendly paleomagnetic data browser and analyzer. Trav. Géophys. 27, 20-21.

Channell, J.E.T., McCabe, C., 1994. Comparison of magnetic hysteresis parameters of unremagnetized and remagnetized limestones. J. Geophys. Res. 99 (B3) $4613-4623$

Charrière, A., Haddoumi, H., Mojon, P.-O., Ferrière, J., Cuche, D., Zili, L., 2009. Mise en évidence par charophytes et ostracodes de l'âge Paléocène des dépôts discordants sur les rides anticlinales de la région d'Imilchil (Haut Atlas, Maroc): conséquences paléogéographiques et structurales. Comptes Rendus Palevol 8 9-19. http://dx.doi.org/10.1016/j.crpv.2008.11.006.

Cogné, J.-P., Perroud, H., 1985. Strain removal applied to paleomagnetic directions in an orogenic belt: the Permian red slates of the Alpes Maritimes, France. Earth Planet. Sci. Lett. 72, 125-140. http://dx.doi.org/10.1016/0012-821X(85)90122-0.

Elmore, R.D., Muxworthy, A.R., Aldana, M., 2012. Remagnetization and chemica alteration of sedimentary rocks. Geol. Soc. Lond. Spec. Publ. 371, 1-21. http:// dx.doi.org/10.1144/SP371.15.

Ettaki, M., Ibouh, H., Chellaï, E.H., Milhi, 2007. Les structures “diapiriques” liasiques du Haut-Atlas central, Maroc: example de la ride d'Ikerzi. Afr. Geosci. Rev. 14 79-93.

Ettaki, M., Chellaï, E.H., Milhi, A., Sadki, D., Boudchiche, L., 2000. Le passage Lias moyen-Lias supérieur dans la région de Todrha-Dadès: événements biosédimentaires et géodynamiques (Haut Atlas central, Maroc). Comptes Rendus l'Académie Des. Sci. - Ser. IIA - Earth Planet. Sci. 331, 667-674. http://dx.doi.org 10.1016/S1251-8050(00)01458-0.

Fisher, R.A., 1953. Dispersion on a sphere. Proc. R. Soc. Lond. 217A, 295-305.

Frizon de Lamotte, D., Zizi, M., Missenard, Y., Hadif, M., El Azzouzi, M., Maury, R.C., Charrière, A., Taki, Z., Benammi, M., Michard, A., Hafid, M., Azzouzi, M. El, Maury, R.C., Charrière, A., Taki, Z., Benammi, M., Michard, A., 2008. The Atlas system. In: Michard, A., Saddiqi, O., Chalouan, A., Lamotte, D. de F. (Eds.), Continental Evolution: the Geology of Morocco. Lecture Notes in Earth Sciences 116. Springer, Berlin, Heidelberg, pp. 133-202. http://dx.doi.org/10.1007/978-3540-77076-3_4.
Gomez, F., Beauchamp, W., Barazangi, M., 2000. Role of the Atlas Mountains (northwest Africa) within the african-eurasian plate-boundary zone. Geology 28, 775. http://dx.doi.org/10.1130/0091-7613(2000)28<775:ROTAMN>2.0.CO·2.

Hailwood, E.A., Mitchell, J.G., 1971. Palaeomagnetic and radiometric dating results from jurassic intrusions in south Morocco. Geophys. J. Int. 24, 351-364. http:// dx.doi.org/10.1111/j.1365-246X.1971.tb02183.x.

Henry, B., Rouvier, H., Le Goff, M., 2004. Using syntectonic remagnetizations for fold geometry and vertical axis rotation: the example of the Cévennes border (France). Geophys. J. Int. 157, 1061-1070. http://dx.doi.org/10.1111/j.1365246X.2004.02277.x.

Hirt, A.M., Lowrie, W., Pfiffner, O.A., 1986. A paleomagnetic study of tectonically deformed red beds of the Lower Glarus Nappe Complex, eastern Switzerland. Tectonics 5, 723-731. http://dx.doi.org/10.1029/TC005i005p00723.

Izquierdo-Llavall, E., Aldega, L., Cantarelli, V., Corrado, S., Gil-Peña, I., Invernizzi, C., Casas, A.M., 2013. On the origin of cleavage in the Central Pyrenees: structural and paleo-thermal study. Tectonophysics 608, 303-318. http://dx.doi.org/ 10.1016/j.tecto.2013.09.027.

Jackson, M., Swanson-Hysell, N.L., 2012. Rock magnetism of remagnetized carbonate rocks: another look. Geol. Soc. Lond. Spec. Publ. 371, 229-251. http:// dx.doi.org/10.1144/sp371.3.

Katz, B., Elmore, R.D., Cogoini, M., Engel, M.H., Ferry, S., 2000. Associations between burial diagenesis of smectite, chemical remagnetization, and magnetite authigenesis in the Vocontian trough, SE France. J. Geophys. Res. Solid Earth 105, 851-868. http://dx.doi.org/10.1029/1999JB900309.

Kirschvink, J.L., 1980. The least-squares line and plane and the analysis of paleomagnetic data. Geophys. J. R. Astron. Soc. 62, 699-718. http://dx.doi.org/ 10.1111/j.1365-246X.1980.tb02601.x.

Kligfield, R., Lowrie, W., Hirt, A., Siddans, A.W.B., 1983. Effect of progressive deformation on remanent magnetization of permian redbeds from the alpes maritimes (France). Tectonophysics 98, 59-85. http://dx.doi.org/10.1016/00401951(83)90211-1.

Laville, E., Zayane, R., Honnorez, J., Piqué, A., 1994. Le métamorphisme jurassique du Haut Atlas central (Maroc); épisodes synschisteux et hydrothermaux. Comptes rendus l’Académie Des. Sci. Série 2. Sci. de la terre et des planètes 318 $1349-1356$.

Laville, E., Piqué, A., 1992. Jurassic penetrative deformation and Cenozoic uplift in the Central High Atlas (Morocco): a tectonic model. structural and orogenic inversions. Geol. Rundsch. 81, 157-170. http://dx.doi.org/10.1007/BF01764546.

Laville, E., Piqué, A., Amrhar, M., Charroud, M., 2004. A restatement of the Mesozoic atlasic rifting (Morocco). J. Afr. Earth Sci. 38, 145-153. http://dx.doi.org/10.1016/ j.jafrearsci.2003.12.003.

Lüneburg, C.M., Lebit, H.D.W., 1998. The development of a single cleavage in an area of repeated folding. J. Struct. Geol. 20, 1531-1548. http://dx.doi.org/10.1016/ S0191-8141(98)00039-X.

Marshak, S., Mitra, G., 1988. Basic Methods of Structural Geology. Prentice-Hall.

Mata, M.P., Casas, A.M., Canals, A., Gil, A., Pocovi, A., 2001. Thermal history during Mesozoic extension and tertiary uplift in the Cameros basin, Northern Spain. Basin Res. 13, 91-111. http://dx.doi.org/10.1046/j.1365-2117.2001.00138.x.

Mattauer, M., 1973. Les Déformations des Matériaux de ÍEcorce Terrestre. Hermann, Paris.

Mattauer, M., Tapponnier, P., Proust, F., 1977. Sur les mécanismes de formation des chaînes intracontinentales. l'exemple des chaînes atlasiques du Maroc. Bull. Société géologique Fr. 19, 321-326.

McFadden, P.L., 1990. A new fold test for palaeomagnetic studies. Geophys. J. Int.103(1) 163-169. http://dx.doi.org/10.1111/j.1365-246X.1990.tb01761.x.

Michard, A., Ibouh, H., Charrière, A., 2011. Syncline-topped anticlinal ridges from the high Atlas: a Moroccan conundrum, and inspiring structures from the Syrian arc, Israel. Terra Nov. 23, 314-323. http://dx.doi.org/10.1111/j.13653121.2011.01016.x.

Mitra, G., Yonkee, A.W., 1985. Relationship of spaced cleavage to folds and thrusts in the Idaho-Utah-Wyoming thrust belt. J. Struct. Geol. 7, 361-373. http:// dx.doi.org/10.1016/0191-8141(85)90041-0.

Moreau, M.G., Ader, M., Enkin, R.J., 2005. The magnetization of clay-rich rocks in sedimentary basins: low-temperature experimental formation of magnetic carriers in natural samples. Earth Planet. Sci. Lett. 230, 193-210.

Moussaid, B., Villalaín, J.J., Casas-Sainz, A., El Ouardi, H., Oliva-Urcia, B., Soto, R., Román-Berdiel, T., Torres-López, S., 2015. Primary vs. secondary curved fold axes: deciphering the origin of the Aït Attab syncline (Moroccan High Atlas) using paleomagnetic data. J. Struct. Geol. 70, 65-77. http://dx.doi.org/10.1016/ j.jsg.2014.11.004

Oliva-Urcia, B., Larrasoaña, J.C., Pueyo, E.L., Gil, A., Mata, P., Parés, J.M., Schleicher, A.M., Pueyo, O., 2009. Disentangling magnetic subfabrics and their link to deformation processes in cleaved sedimentary rocks from the Internal Sierras (west central Pyrenees, Spain). J. Struct. Geol. 31, 163-176. http:// dx.doi.org/10.1016/j.jsg.2008.11.002.

Pevear, D.R., 1999. Illite and hydrocarbon exploration. Proc. Natl. Acad. Sci. U. S. A 96, 3440-3446.

Ramsay, J.G., Huber, M.I., 1987. Modern Structural Geology. In: Folds and Fractures, vol. 2. Academic Press, London.

Saura, E., Vergés, J., Martín-Martín, J.D., Messager, G., Moragas, M., Razin, P., Grelaud, C., Joussiaume, R., Malaval, M., Homke, S., Hunt, D.W., 2014. Syn- to post-rift diapirism and minibasins of the Central High Atlas (Morocco): the changing face of a mountain belt. J. Geol. Soc. Lond. 171, 97-105. http:// dx.doi.org/10.1144/jgs2013-079.

Schaer, J.P., Persoz, F., 1976. Aspects structuraux et pétrographiques du Haut Atlas 
calcaire de Midelr (Maroc). Bull. La Soc. Geol. Fr. 7, 1239-1250.

Schaer, J.P., 1987. Evolution and structure of the high Atlas of Morocco. In: Schaer, J.P., Rodgers, J. (Eds.), The Anatomy of Mountain Ranges. Princeton University Press, pp. 107-128.

Séguret, M., 1972. Etude tectonique des nappes et séries décollées de la partie centrale du versant sud des Pyrenées. Caractére sedymentaire, rôle de la compression et de la gravité. Université des Sciences et Techniques du Languedoc (Montpellier II).

Shipunov, S.V., 1997. Synfolding magnetization: detection, testing and geological applications. Geophys. J. Int. 130, 405-410. http://dx.doi.org/10.1111/j.1365246X.1997.tb05656.x.

Soto, R., Villalaín, J.J., Casas-Sainz, A.M., 2008. Remagnetizations as a tool to analyze the tectonic history of inverted sedimentary basins: a case study from the Basque-Cantabrian basin (north Spain). Tectonics 27, TC1017. http://dx.doi.org/ 10.1029/2007TC002208.

Tauxe, L., Shaar, R., Jonestrask, L., Swanson-Hysell, N.L., Minnett, R., Koppers, A.A.P., Constable, C.G., Jarboe, N., Gaastra, K., Fairchild, L., 2016. PmagPy: software package for paleomagnetic data analysis and a bridge to the magnetics information consortium (MagIC) database. Geochem. Geophys. Geosys. 17, 2450-2463. http://dx.doi.org/10.1002/2016GC006307.

Tauxe, L., Watson, G.S.S., 1994. The fold test: an eigen analysis approach. Earth Planet. Sci. Lett. 122, 331-341. http://dx.doi.org/10.1016/0012-821X(94)90006$\mathrm{X}$.

Tauxe, L., Banerjee, S.K., Butler, R., Van der Voo, R., 2010. Essentials of Paleomagnetism. University of California Press, Berkeley.

Teixell, A., Arboleya, M.-L., Julivert, M., Charroud, M., 2003. Tectonic shortening and topography in the central High Atlas (Morocco). Tectonics 22. http://dx.doi.org/ 10.1029/2002TC001460 n/a-n/a.

Torres-López, S., Villalaín, J.J., Casas, A.M., EL Ouardi, H., Moussaid, B., RuizMartínez, V.C., 2014. Widespread Cretaceous secondary magnetization in the High Atlas (Morocco). A common origin for the Cretaceous remagnetizations in the western Tethys? J. Geol. Soc. Lond. 171, 673-687. http://dx.doi.org/10.1144/ jgs2013-107.

Torres-López, S., Casas, A.M., Villalaín, J.J., El Ouardi, H., Moussaid, B., 2016. PreCenomanian vs. Cenozoic folding in the High Atlas revealed by palaeomagnetic data. Terra Nov. 28, 110-119. http://dx.doi.org/10.1111/ter.12197.

Torsvik, T.H., Van der Voo, R., Preeden, U., Niocaill, C. Mac, Steinberger, B., Doubrovine, P.V., van Hinsbergen, D.J.J., Domeier, M., Gaina, C., Tohver, E., Meert, J.G., McCausland, P.J.A., Cocks, L.R.M., 2012. Phanerozoic polar wander, palaeogeography and dynamics. Earth-Sci. Rev. 114, 325-368. http://dx.doi.org/ 10.1016/j.earscirev.2012.06.002.

Van Der Voo, R., Torsvik, T.H., 2012. The history of remagnetization of sedimentary rocks: deceptions, developments and discoveries. Geol. Soc. Lond. Spec. Publ. 23-53. http://dx.doi.org/10.1144/SP371.2.

Villalaín, J., Fernández-González, G., Casas, A.M., Gil-Imaz, A., 2003. Evidence of a cretaceous remagnetization in the Cameros basin (north Spain): implications for basin geometry. Tectonophysics 377, 101-117. http://dx.doi.org/10.1016/ j.tecto.2003.08.024

Villalaín, J.., Casas-Sainz, A.M., Soto, R., 2015. Reconstruction of inverted sedimentary basins from syn-tectonic remagnetizations. A methodological proposal. Geol. Soc. Lond. Spec. Publ. 425, 233-246. http://dx.doi.org/10.1144/ SP425.10.

Waldhör, M., Appel, E., 2006. Intersections of remanence small circles: new tools to improve data processing and interpretation in palaeomagnetism. Geophys. J. Int. 166 (1), 33-45. http://dx.doi.org/10.1111/j.1365-246X.2006.02898.x.

Watson, G.S., Enkin, R.J., 1993. The fold test in paleomagnetism as a parameter estimation problem,. Geophys. Res. Lett. 20 (19), 2135-2137. http://dx.doi.org/ 10.1029/93GL01901.

Williams, P.F., 1985. Multiply deformed terrains-problems of correlation. J. Struct. Geol. 7, 269-280. http://dx.doi.org/10.1016/0191-8141(85)90035-5.

Winklhofer, M., Fabian, K., Heider, F., 1997. Magnetic blocking temperatures of magnetite calculated with a three-dimensional micromagnetic model. J. Geophys. Res. 102, 22695-22709. http://dx.doi.org/10.1029/97JB01730. 



\title{
Extensional vs. compressional deformation in the Central High Atlas salt province: A paleomagnetic approach
}

\author{
P. Calvín ${ }^{\mathrm{a}, *}$, A.M. Casas-Sainz ${ }^{\mathrm{b}}$, J.J. Villalaín ${ }^{\mathrm{a}}$, B. Moussaid ${ }^{\mathrm{c}}$ \\ ${ }^{a}$ Laboratorio de Paleomagnetismo, Universidad de Burgos, Spain \\ ${ }^{\mathrm{b}}$ Geotransfer Research Group (IUCA), Universidad de Zaragoza, Spain \\ ${ }^{\mathrm{c}}$ Laboratoire BGIM, Ecole Normale Supérieure, Université Hassan II. Casablanca, Morocco
}

\section{A R T I C L E I N F O}

\section{Keywords:}

Chemical remagnetization

Central High Atlas

Small circle methods

Salt-wall

Diapir

Paleomagnetic restoration

\begin{abstract}
A B S T R A C T
In this paper we address the problem of the distinction between diapiric, salt-driven and compressional structures, using the outstanding example of the Central High Atlas (Morocco). A remagnetized component carried by magnetite has been isolated in 32 new paleomagnetic sites. It is characterized by: maximum unblocking temperatures around $450^{\circ} \mathrm{C}$, syn-folding behavior and normal polarity.

These 33 mean paleomagnetic directions were analyzed together with other 68 from published works around the study area to construct a robust paleomagnetic dataset along a cross-section perpendicular to the main structures. The remagnetization direction (n: 100 , Dec: $332.2^{\circ}$, Inc: $34.5^{\circ}, \eta: 6.2^{\circ}, \xi: 2.0^{\circ}, \mathrm{A} / \mathrm{n}: 6.427^{\circ}$ ) and the paleo-dip of beds (the attitude of the beds at the remagnetization occurrence) were calculated through small circle methods. The remagnetization can be dated as ca. $100 \mathrm{Ma}$. Because of its occurrence between the extensional and compressional periods, this remagnetization offers the possibility of restore the basin to its preinversion geometry.

Comparison between present-day and pre-inversion structure allows discriminating three different evolutionary patterns: (i) thrusted and welded salt-walls mainly structured during the extensional stage (Ikkou ridge) with steep limbs close to the salt-wall core. (ii) Jurassic salt-walls with weaker deformation, restricted to the areas adjacent to the structure (Tadaghmamt and Timedouine); in this case, Cenozoic compression is limited to welding of the salt-walls and buttressing of the sedimentary sequences against faults. (iii) salt-rollers gently initiated during the Jurassic (Toumliline diapir), thrusted during the Cenozoic compression. Results show the importance of salt tectonics both during extension and compression, as well as the control of the compressional features by the inherited extensional structures. The performed restorations prove that paleomagnetism is a useful, independent tool to obtain palinspastic restorations and to separate, and quantify, the imprint generated during the basinal stage from the inversional features.
\end{abstract}

\section{Introduction}

Halokinetic processes are one of the main deformation mechanisms in inverted basins having basal or intermediate thick salt layers. Diapirrelated structures (salt-walls, diapirs, salt-cored anticlines, etc.) can develop either associated with extension during the basinal stage (e.g. Vendeville and Jackson, 1992; Ferrer et al., 2012; Jackson and Lewis, 2016) or with compression during subsequent basin inversion (Davis and Engelder, 1985; Costa and Vendeville, 2002; Santolaria et al., 2015). The triggering mechanism is commonly differential loading, easily generated as a consequence of extensional or compressional activity. At the same time, presence of salt levels and related halokinetic processes interact with regional tectonism, controlling basic aspects such as subsidence the location of depocenters (Jackson and Lewis, 2016, and references therein), or the style of folding or thrusting in the case of compression (e.g. Davis and Engelder, 1985). Furthermore, structures generated during extension are usually reactivated and squeezed during inversion and therefore their present-day geometry is a consequence of the contribution from both stages. The study of the geometry of strata adjacent to salt-bodies gives clues about the relationships between tectonic, halokinetic and sedimentation processes (e.g. Giles and Lawton, 2002). However, quantifying the deformation related to extension or compression is not straightforward and chronological constrains, provided that they are reliably placed within the frame of geological events, are necessary to address this issue.

Paleomagnetic works applied to diapirs are scarce, but they have

\footnotetext{
* Corresponding author at: Dep. Física, Escuela Politécnica Superior, Río Vena, Universidad de Burgos, Av. Cantabria s/n, 09006 Burgos, Spain.

E-mail address: calvinballester@gmail.es (P. Calvín).
} 
been successful in unraveling different topics regarding diapir emplacement and evolution. A pioneering work in this sense was carried by Weinberger et al. (1997) who distinguished two main stages of evolution of the Sedom Diapir (Dead Sea Rift). Henry et al. (2000) and Roca et al. (2013) shed light in the evolution of Triassic diapiric bodies in Tunisia and the Prebetic Zone (SE Spain), respectively, allowing to substantiate emplacement hypotheses. Finally, Torres-López et al. (2016) separated in the Central High Atlas (CHA) the Jurassic deformation directly caused by salt tectonics and igneous intrusions from the deformation due to the Cenozoic compression.

The exceptional outcrops of the CHA have been exploited in the development of several research works focused on the tectono-stratigraphic relationships in extensional setting in which halokinetic activity plays a major role (Bouchouata et al., 1995; Ettaki et al., 2007; Michard et al., 2011; Saura et al., 2014; Joussiane, 2016; Malaval, 2016; Martín-Martín et al., 2017; Teixell et al., 2017; Vergés et al., 2017). These works evidence the presence of an intense halokinetic activity during the Early and Middle Jurassic that, together with the activity of the extensional faults, controlled the sedimentation through ENE-WSW trending salt-walls (called 'ridges' in the literature), that limited sedimentary depocenters. During the subsequent Cenozoic inversion of the basin (Mattauer et al., 1977; Michard, 1976), these structures were squeezed, modifying their syn-extensional original geometry (Teixell et al., 2017; Vergés et al., 2017).

Nevertheless, the contribution of extensional (or diapiric) and compressional deformation to the final development of structures is still unknown. We even ignore whether similar structures have the same or different origins. The main objective of this paper is focused on deciphering the origin of structures by means of the quantification of their chronological development by means of paleomagnetic tools. We use the ca. 100 Ma remagnetization found in the CHA (Torres-López et al., 2014), which separates the basinal and the inversional stages, to quantify the deformation related to each process. We demonstrate that compressional features, and specially fold separation and wavelength, are beyond the laws of buckling (e.g. Fletcher, 1974; Kocher et al., 2006) and that other constraints, namely inherited heterogeneities and previous, diapiric folding are key in the process of fold growth. Consequently, folds formerly considered as compressional must be explained by growth during prevailing extensional tectonic regimes. In this way, paleomagnetism has revealed itself as a powerful to approach, from a quantitative point of view, to the original geometry resulting from the basinal stage and the subsequent development of folding during basin inversion.

\section{Geological framework}

The Atlas system is a set of intracontinental chains (Mattauer et al., 1977) located in the southwestern foreland of the Mediterranean Alpine System (Fig. 1). It extends from the Atlantic coast of Morocco to the Mediterranean coast of Tunisia, conforming a $100 \mathrm{~km}$ wide, $2000 \mathrm{~km}$ long mountain belt. The Atlas is the result of the tectonic inversion during the Cenozoic of extensional Mesozoic basins, due to the convergence between African and European plates (e.g. Mattauer et al., 1977; Gomez et al., 2000). The Central High Atlas (CHA) is located in the mid-western sector of the mountain chain and is characterized by thick Lower-Middle Jurassic sedimentary sequences, folded according to long, tight ENE-WSW anticlines that limit open, gentle synclines (Fig. 2).

A synthesis of the Mesozoic evolution of the CHA can be found in Frizon de Lamotte et al. (2008). Summarizing, this evolution shows a first rifting event during the Triassic (Fig. 1c), characterized by deposit of red beds which crop out towards the western part of the chain, in the Marrakech High Atlas (e.g. Domènech et al., 2015), and evaporites and shales to the top of the sequence, capped by basaltic rocks related to the CAMP event (e.g. Knight et al., 2004). Shales and salts are the regional décollement for many tectonic structures. It played a major role during the Mesozoic extension (and dominant in diapiric processes) and during the Cenozoic inversion (as the basal detachment that favors the decoupling between the basement and the cover) as well.

During the Early Jurassic, a new, intense rift stage took place, resulting in the deposit of thick sedimentary sequences: $>5000 \mathrm{~m}$ of Jurassic rocks accumulated in the depocenters until the end of Bajocian times (Frizon de Lamotte et al., 2008, and references therein). During this stage, diapiric processes also played an important role in the configuration of the basin (Ettaki et al., 2007; Michard et al., 2011), partly controlling the subsidence rate and localization of depocenters (Moragas et al., 2016), that were bounded by large salt-walls (Saura et al., 2014). The NE-SW to ENE-WSW trend of these structures is strongly conditioned by basement faults (Mattauer et al., 1977; Schaer, 1987; Charrière, 1990), what suggest that normal faulting was one of the main factors triggering halokinetic activity.

At the end of this extensional stage, a new alkaline to transitional magmatic event took place. It was characterized in the study area by mafic intrusions (mainly gabbros) dated as Upper Jurassic (Hailwood and Mitchell, 1971; Armando, 1999). These rocks crop out at the core of the anticlines, mixed in different proportions (in each particular structure) with Triassic rocks (Calvín et al., 2017b).

Absence of Upper Jurassic-Lower Cretaceous sedimentary rocks limit the precise bracketing of the evolution of the CHA during this time, and a general uplift during the Late Jurassic has been invoked (Laville and Piqué, 1992; Beauchamp et al., 1999; Frizon de Lamotte et al., 2008). However, a compressional uplift is in disagreement both with the fission tracks paths (Barbero et al., 2007) and with the ca. $100 \mathrm{Ma}$ widespread remagnetization (see next section for discussion). Besides, new geological evidences contradict the arguments upon which this uplift event was based: for example, the dating as Paleocene (Charrière et al., 2009) of the red-beds that overlie some of the gabbro outcrops, previously considered as Jurassic, or the clear attribution of the regional cleavage to the Cenozoic compression instead of to a Mesozoic stage (Calvín et al., 2017a). Towards the north, a Jurassic-Cretaceous continental series, topped by Cretaceous marine sediments, crop out in several basins (e.g. Bensalah et al., 2013). Moragas et al. (2016), combining new data of vitrinite reflectance, stratigraphic relationships, and subsidence curves, found that it is necessary to consider an extra burial of $1200 \mathrm{~m}$ corresponding to Upper Jurassic and Cretaceous sediments in the CHA.

The Cenozoic Alpine basin inversion shortened the High Atlas in a N-S direction between 15 and 24\% (Teixell et al., 2003), without considering internal deformation associated with tectonic cleavage (e.g. Laville and Piqué, 1992; Calvín et al., 2017a) or the interference with Mesozoic structures (Torres-López et al., 2016). In the central sector of the CHA, the geological structure is strongly conditioned by the presence of a thick décollement level, tectonic inheritance from the Jurassic extensional stage, and the thickness variations of the Jurassic series (Fig. 2b). Therefore, tightening of Jurassic diapirs favored the accommodation of shortening; the absence of evaporites in the cores of some anticlines (being replaced by Triassic and Jurassic competent igneous rocks; Fig. 2b) can be related to extrusion and squeezing during shortening. In areas lacking salt-walls and/or extensional structures the deformation is accommodated by minor thrusts rooted within the Jurassic sequence and folds associated with axial-plane cleavage (e.g. Calvín et al., 2017a).

\section{The ca. 100 Ma remagnetization in the CHA}

Torres-López et al. (2014) evidenced the presence of a widespread remagnetization in the CHA affecting the Jurassic carbonates. This remagnetization is characterized by its syn-tectonic behavior, systematic normal polarity with northwestern declination and positive inclination, and Albian-Cenomanian age (ca. $100 \mathrm{Ma}$ ), that has been established according to comparison with the apparent global wander path. Magnetic properties point to a chemical remagnetization, under which a 


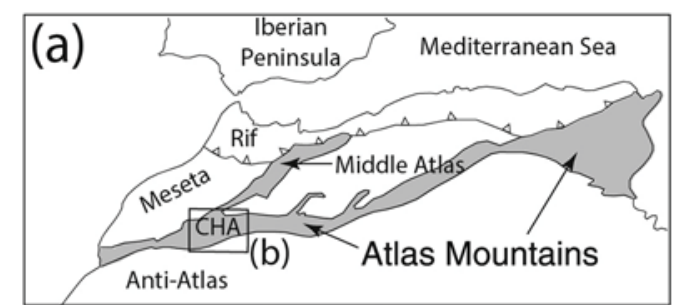

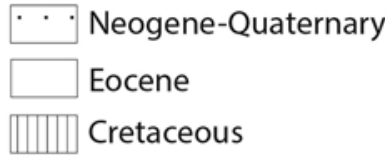

Core of the ridges

\section{Triassic rocks ans Jurassic gabbro}

$70 \quad 6^{\circ}$

\begin{abstract}
$6^{\circ}$
\end{abstract}

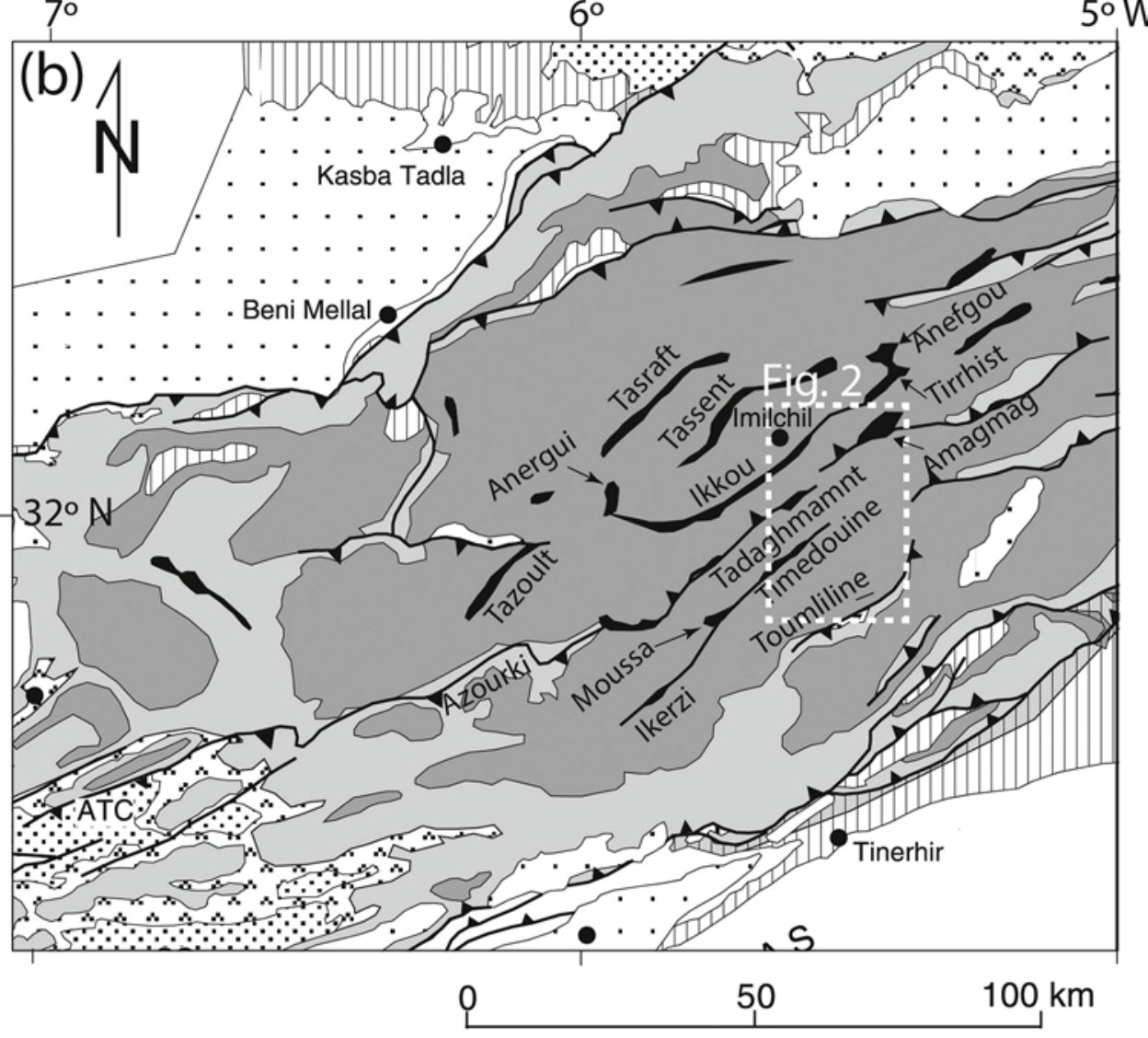

Lower-Middle Jurassic

Lower Jurassic

$\therefore$ Triassic

Pre-Triassic basement

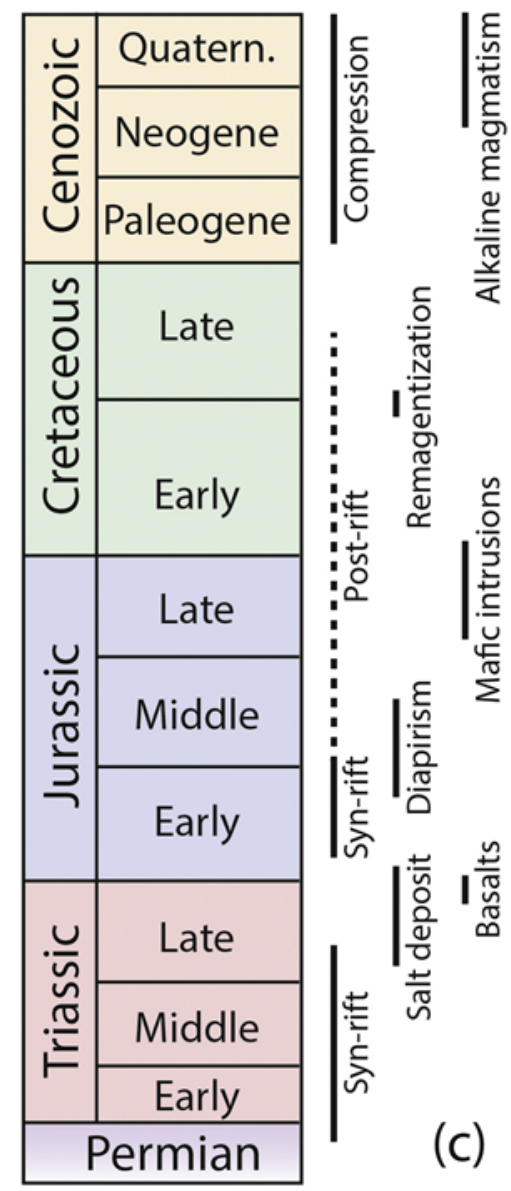

Fig. 1. (a) The Altlas Chain in the context of the Western Mediterranean framework. (b) Geological map of the Central High Altas (CHA) and location of the study area (Fig. 2). (c) Simplified temporal evolution of the main geological events occurred in the CHA. (a) and (b) modified after Teixell et al. (2003).

population of fine magnetite grains (from superparamagnetic -SP- to stable single domain -SSD-) grew, giving a typical signature characterized by wasp-waisted hysteresis and maximum unblocking temperatures around $450-500{ }^{\circ} \mathrm{C}$ (see Elmore et al., 2012; Jackson and Swanson-Hysell, 2012; Torres-López et al., 2014). This kind of remagnetization has been related to the growth of magnetite at the expense of pyrite in presence of organic matter (Katz et al., 2000) and associated with temperature increase in the basins (e.g. Aubourg et al., 2012). In the case of the CHA, the remagnetized carbonates are located in areas with a minimum preserved thickness of $3-4 \mathrm{~km}$ of the syntectonic basin filling (Torres-López et al., 2014), which corresponds with areas where at least $2 \mathrm{~km}$ sediments have been eroded.

The triggering mechanism for the remagnetization is still a matter of debate: it should be related to cooling below a critical temperature at basinal scale, because no differences in magnetic properties or paleomagnetic directions can be found along the Jurassic sequence (e.g. Torres-López et al., 2014; Moussaid et al., 2015). Therefore, this quick decrease (at the geological scale) of temperature could be related either with the decay of a mantle anomaly (in case of considering a regional, plate-scale origin of remagnetization) or with partial inversion, exhumation and erosion of the basin (when a local origin is considered). In any case, the triggering mechanism does not affect the use of the remagnetization for restoration purposes.

Similar chemical remagnetizations, both regarding magnetic behavior and age, have been recognized in other inverted intracontinental basins of the western sector of the Mediterranean Alpine System (Villalaín et al., 2003; Soto et al., 2008). A common point shared by these basins and the CHA is that they were affected by an extensional deformation during the Mesozoic (pre-remagnetization stage) and subsequently inverted by the Cenozoic, Alpine compression (post-remagnetization stage). In all of these basins, remagnetizations have been used to reconstruct the attitude of beds at the moment of the remagnetizations and to resolve geological issues, such as restoring the general geometry of the basins at the pre-compressional stage (Casas et al., 2009; Soto et al., 2011), determining the structuring age of the ridges of the CHA (Torres-López et al., 2016), restoring the geometry of pre-remagnetization folds (García-Lasanta et al., 2017) or dating the tectonic cleavage, controversial in age, in the CHA (Calvín et al., 2017a). All these issues demonstrate the applicability of remagnetizations in intracontinental basins as chronological markers to separate pre- and post-remagnetization deformation. 

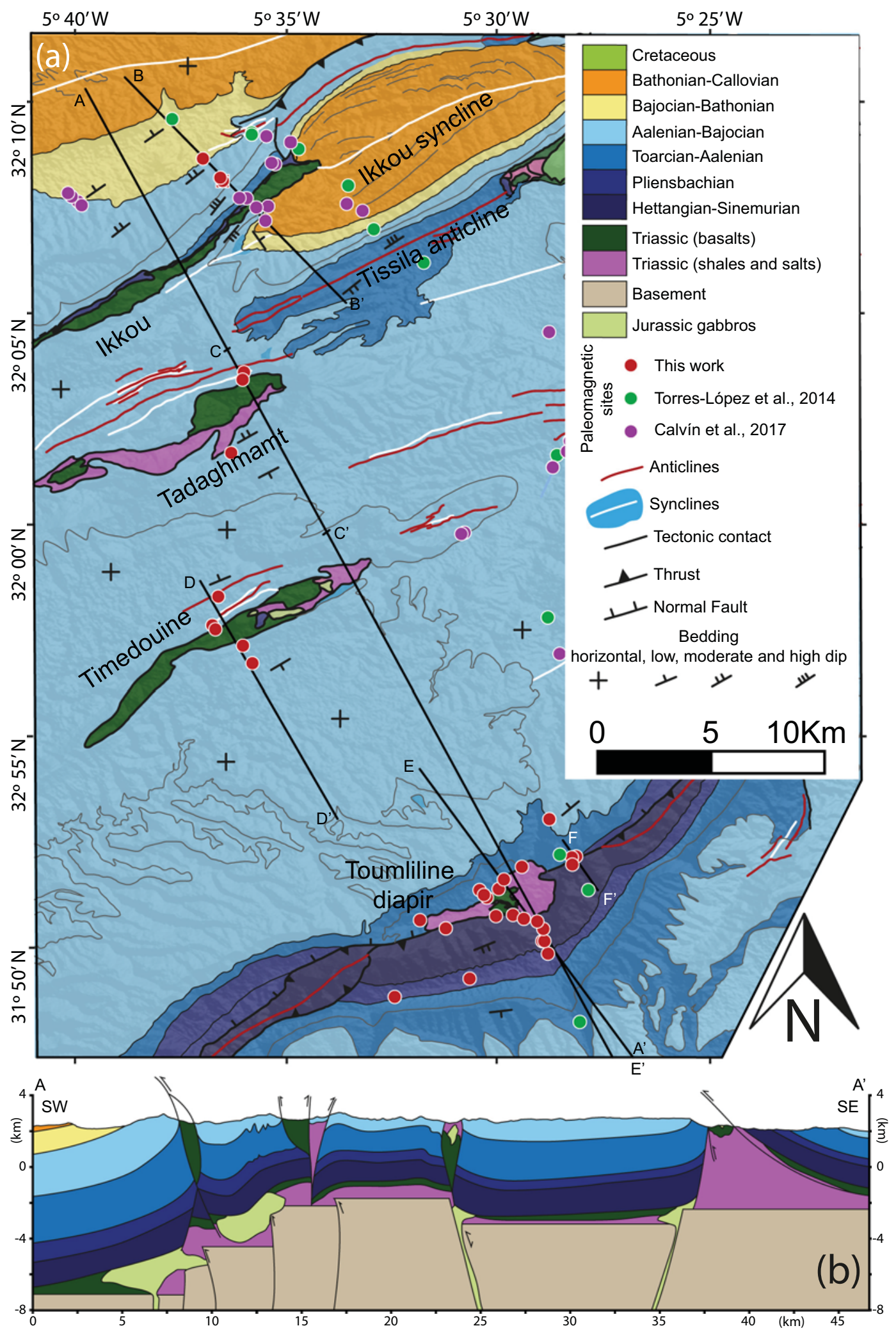

Fig. 2. Geological map (a) and A-A cross-section showing the four ridges analyzed in this work, as well as the paleomagnetic sites. A *kml file with the same information can be obtained in the Supplementary material. The geological cartography is based in previous works (Heitzmann and Stüder, 1990; Hadri, 1997; Milhi, 1997; Fadile, 2003; Michard et al., 2011; Saura et al., 2014; Calvín et al., 2017a, 2017b, 2017c). 
(a)
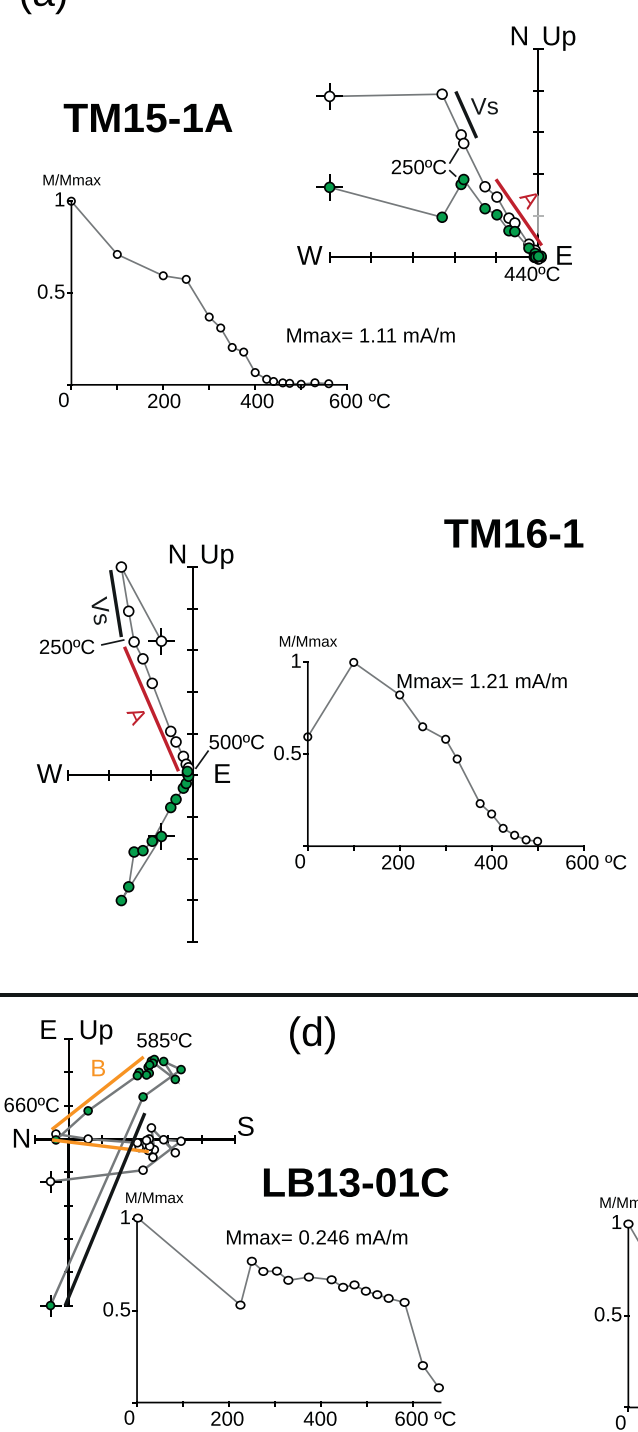

(b)
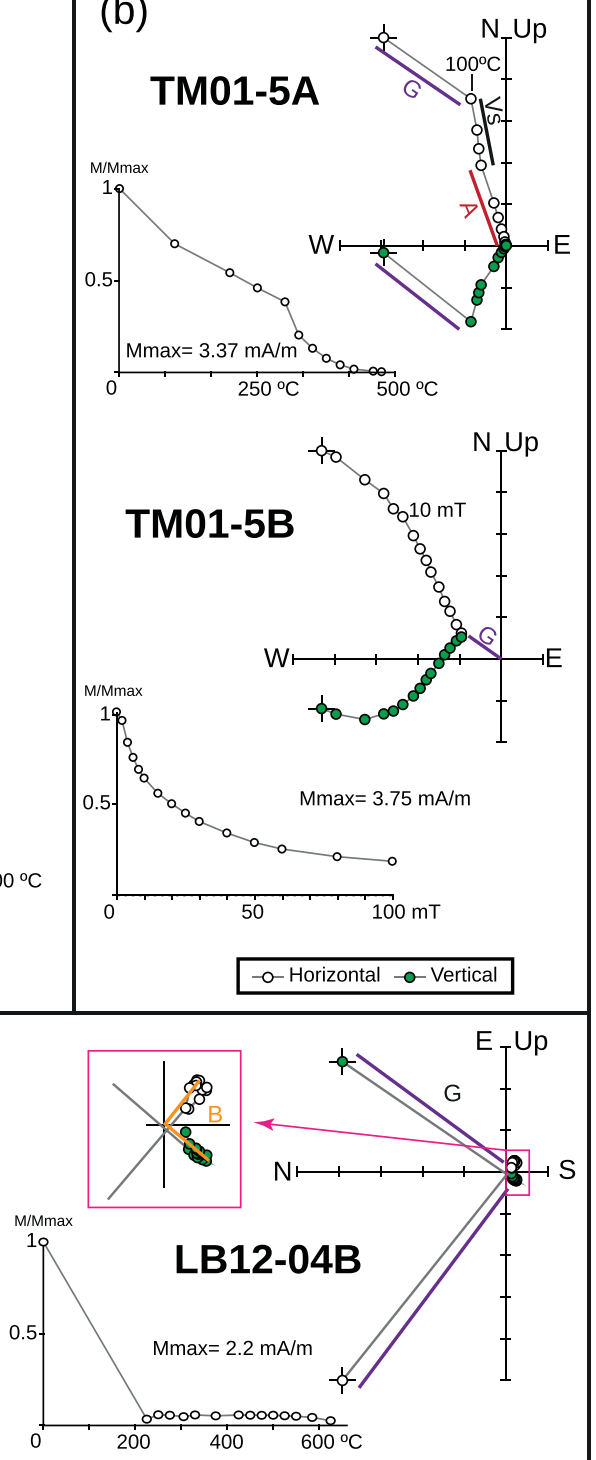

(c) TM09-5A

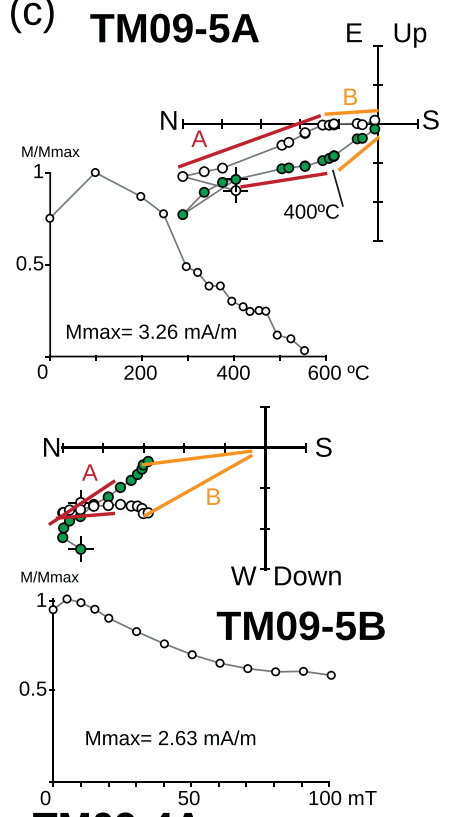

TM09-4A

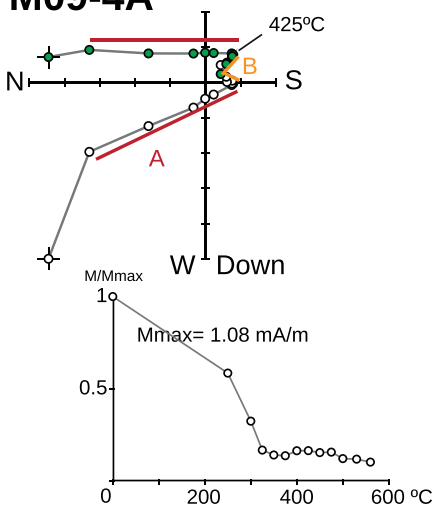

(e)

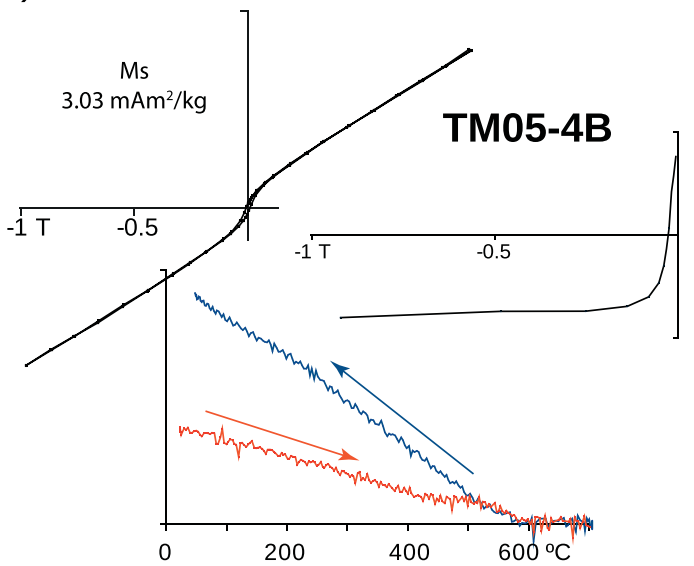

(f)

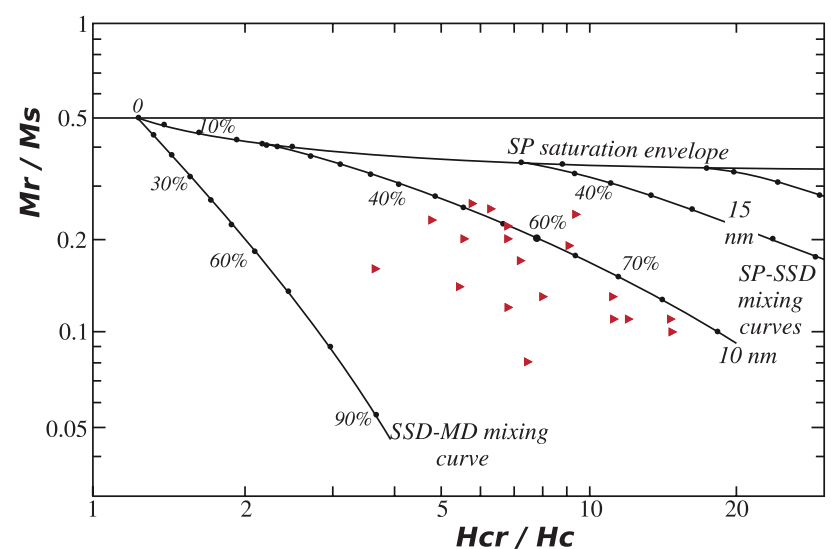

Fig. 3. Orthogonal plots of NRM of representative samples, plotted in in situ coordinates. (a) Typical signature of the samples, showing the component A with unblocking temperatures between 250 and $450{ }^{\circ} \mathrm{C}$, going to the origin. (b) Presence of goethite. (c) In some samples, the component A does not go to the origin because of the presence of the high temperature (up to $500{ }^{\circ} \mathrm{C}$ ) and high coercivity component B, which shows either normal and reverse polarities. (d) Samples with absence of component A. Calculated A and B component are in the Supplementary. (e) Hysteresis loops backfield cycle and thermomagnetic curves of one representative sample. (f) Hysteresis parameters plot and mixing curves for magnetite (Dunlop, 2002) showing a mixture between SP and SSD in the measured samples. 


\section{Methodology of paleomagnetic analysis}

\subsection{Sampling and paleomagnetic procedures}

Thirty-three new sites were sampled in Jurassic carbonatic rocks using a gasoline-powered machine; twenty-one of these sites are located around the Toumliline diapir (Fig. 2). Between six and eight samples per site were thermally demagnetized by means of thermal demagnetizers TD48-DC (ASC Scientific) (TM and DP sites) and MMTD80A (Magnetic Measurements) (ILA and ILB sites) following a stepwise procedure, with 6-15 steps from room temperature up to the total demagnetization of the specimens (usually $500-550{ }^{\circ} \mathrm{C}$ ). Magnetic measurements were conducted using a 755 Superconducting Rock Magnetometer (2G). Several rock magnetic experiments (hysteresis loops, backfield curves, magnetization thermomagnetic curves, etc.) were performed using a variable field translation balance MMVFTB (Magnetic Measurements). All these experiments were carried out at the Paleomagnetic Laboratory of Burgos University (Spain).

\subsection{Data processing: paleomagnetic directions, small circle analysis and structural restoration}

Paleomagnetic directions were calculated using Remasoft 3.0 software (Chadima and Hrouda, 2006) by principal component analysis (Kirschvink, 1980) on orthogonal demagnetization diagrams. Mean site directions and related statistical parameters were calculated (Fisher, 1953). Rock magnetic data were analyzed with Analyzer 1.0 software (Leonhardt, 2006). Bootstrap fold- tests (Tauxe and Watson, 1994) were performed by using Pmagpy software (Tauxe et al., 2016).

Synfolding remagnetizations acquired between two deformational events can be used to reconstruct basin geometry if we assume that (i) the remagnetization was acquired at the same moment (at geological scale) within the whole basin, (ii) each bed was rotated according to a horizontal axis that coincides with its present-day strike, both during the pre- and the post-remagnetization stages and accordingly (iii) beds have not been affected either by vertical axis rotations or successive non-coaxial deformations. If these conditions are met, it is possible to calculate the remagnetization direction using the Small Circle Intersection (SCI) method (Shipunov, 1997; Henry et al., 2004; Waldhör and Appel, 2006). This method is based on the principle that the paleomagnetic direction for each site must be the same, and all possible deviations are due to tilting of the paleomagnetic directions around the bedding strike. It is then possible to find the common direction to all sites (i.e. the remagnetization direction) analyzing the small circles intersections. These small circles (SCs) are the paths followed by the paleomagnetic direction during bedding restoration. Therefore, the small circles must intersect in a common direction that coincides with the remagnetization direction. The remagnetization direction is given with an uncertainty ellipse obtained from a population of 500 solutions beginning with a parametric bootstrap allowing propagation of errors of the in situ paleomagnetic directions and bedding (Calvín et al., 2017c).

The calculated paleomagnetic direction is used as the reference for restoring the attitude of beds at the moment of the remagnetization event, following the methodology explained in Villalaín et al. (2016). It consists in applying partial bedding corrections in order to identify the paleomagnetic direction for each site (i.e. within each small circle) in the closest orientation to the reference (i.e. the best fit direction, BFD), and in this way the paleo-dip of the bed can be easily calculated. For the case of remagnetization post-dating diapiric deformation, once the paleo-dip at ca. $100 \mathrm{Ma}$ has been calculated, it is possible to restore the geometry of the sedimentary cover around the diapir at its pre-inversion stage. SCs methods were applied using pySCu software (Calvín et al., 2017c).

Graphical inspection of the SCs distribution gives an idea about the degree to which initial assumptions are fulfilled (Calvín et al., 2017c and references therein). However, regional tilts or vertical axis rotations that presumably involve all sites as an only block cannot be appreciated in the SC distribution. These processes can lead to erroneous interpretations of the remagnetization direction and therefore of its age (usually established by comparison with the apparent polar wander path, APWP). All in all, however, large-scale horizontal or vertical axis rotations are not crucial for the structural restoration because the selected reference for paleo-dip calculations is the same for all sites, and therefore the angular relationships between sites are preserved. In any case, fulfillment of the previous requirements in the CHA has been positively assessed in previous works (Torres-López et al., 2016; Calvín et al., 2017a).

\section{Paleomagnetic results}

\subsection{Natural remanent magnetization (NRM) and paleomagnetic directions}

NRM demagnetization diagrams (Fig. 3) show a heterogeneous behavior, characterized by intensities of $0.5-30 \mathrm{~mA} / \mathrm{m}$ and several paleomagnetic components. The most common behavior (Fig. 3a) is the presence of a stable paleomagnetic component with an unblocking temperature spectrum comprised between 300 and $450{ }^{\circ} \mathrm{C}$ and intermediate coercivities (20-100 mT), hereinafter called A component (Fig. 3). This component shows systematically northwestwards declination and positive inclinations (normal polarity). In most samples, it appears together with a viscous component (Vs in Fig. 3) with unblocking temperatures between $100{ }^{\circ} \mathrm{C}$ and $250{ }^{\circ} \mathrm{C}$. In some cases, in addition to components $\mathrm{A}$ and $\mathrm{Vs}$, a low temperature $\left(<100^{\circ} \mathrm{C}\right)$, high coercivity (not destroyed at $100 \mathrm{mT}$ ) component, called $\mathrm{G}$, is also observed (Fig. 3b). It is probably due to the presence of goethite. In 14 samples a high temperature component (component B; see Supplementary material) that shows a direction clearly different from that of component A (Fig. 3c and d) has been isolated. In some cases, as in site TM09, component B shows normal and reverse polarities coexisting with the normal component A (Fig. 3c). However, in other cases such as sites LB12 and LB13, component B is patent but component A is absent (Fig. 3d). The B component shows variable maximum unblocking temperatures, in most cases over $625^{\circ} \mathrm{C}$ (Fig. 3d) and presents high coercivities ( $>100 \mathrm{mT}$ ) pointing to hematite as the mineral carrier.

A regional bootstrap fold-test (Tauxe and Watson, 1994) was performed considering components A and B (Fig. 4a). Component B shows an almost negative result with a range of confidence between $3 \%$ and $27 \%$ of unfolding thus pointing to a secondary origin. This is an interesting example of a secondary magnetization showing, however, normal and reverse polarities. B component was properly isolated in 14 samples and can be interpreted as syn-folding (almost post-folding) magnetization, suggesting that it was acquired most probably after the Cenozoic compression.

On the other hand, component A shows a clear syn-folding acquisition with a maximum grouping at about $50 \%$ of unfolding (Fig. 4a). This result reveals that it is a syn-folding remagnetization.

In spite of this heterogeneous behavior (even at site scale), A component was isolated in almost all sites (see Supplementary material) and was therefore considered as the Characteristic Remanent Magnetization (ChRM). It shows similar features to the remagnetization observed in the surrounding areas both in terms of magnetic properties and distribution of directions (Torres-López et al., 2014; Calvín et al., 2017a): (i) Its carrier is magnetite according to rock magnetic experiments (Fig. 3e) and NRM demagnetization behavior; parameters of the hysteresis loops (Fig. 3f) correspond to a mixture of SSD and SP magnetite (Dunlop, 2002), which is a typical behavior of chemical remagnetized limestones (Channell and McCabe, 1994; Jackson and Swanson-Hysell, 2012). (ii) The directions of A component show normal polarity and scattered directions before and after total bedding correction (BBC and ATBC respectively). Therefore we conclude that component $\mathrm{A}$ is the remagnetization described in the area by the 
(a) Before bedding correction
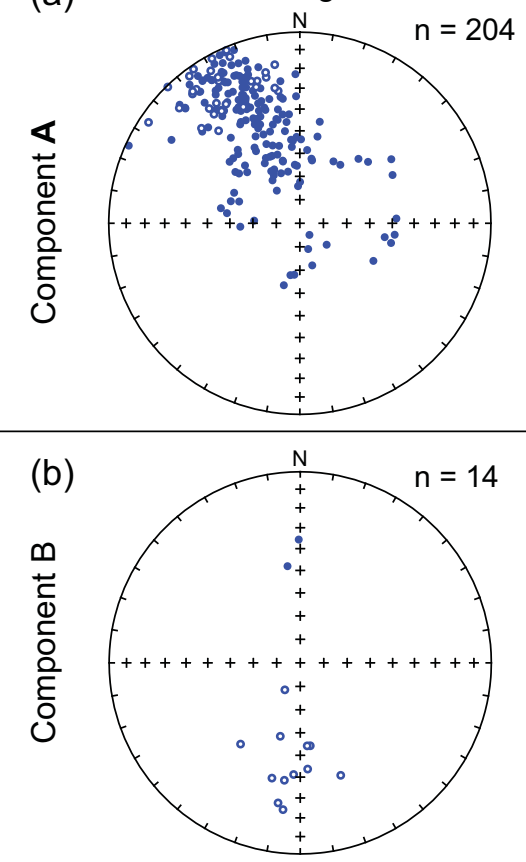

After total bedding correction
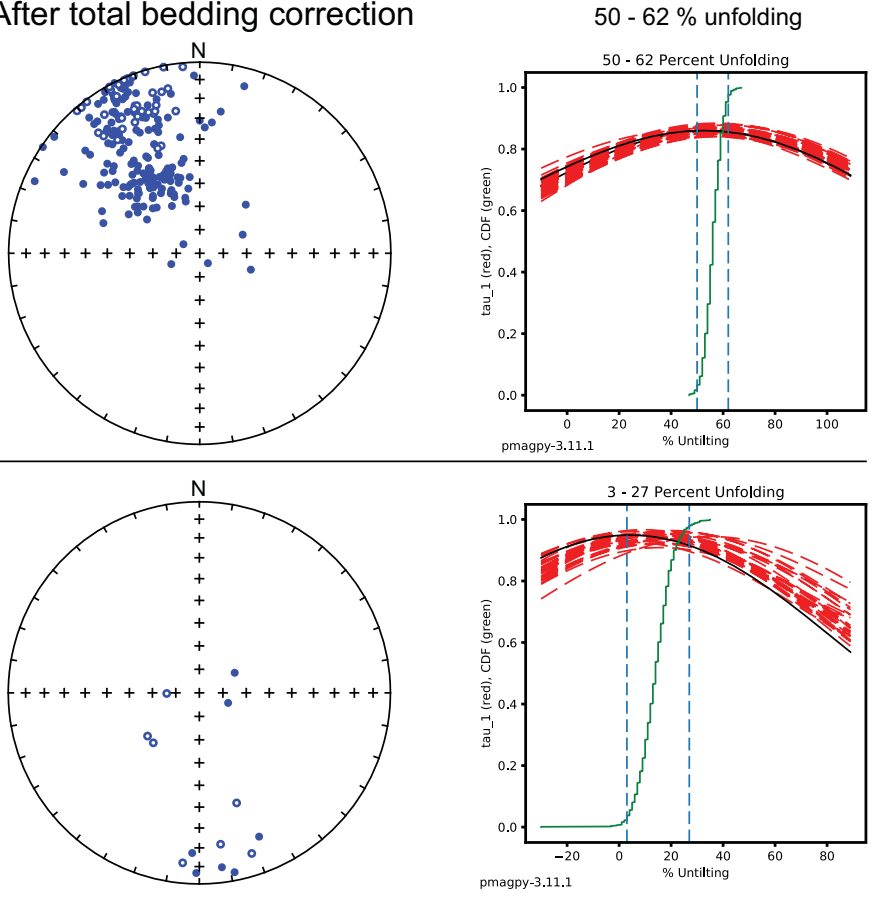

$\mathrm{SC}$ of A component

(c)
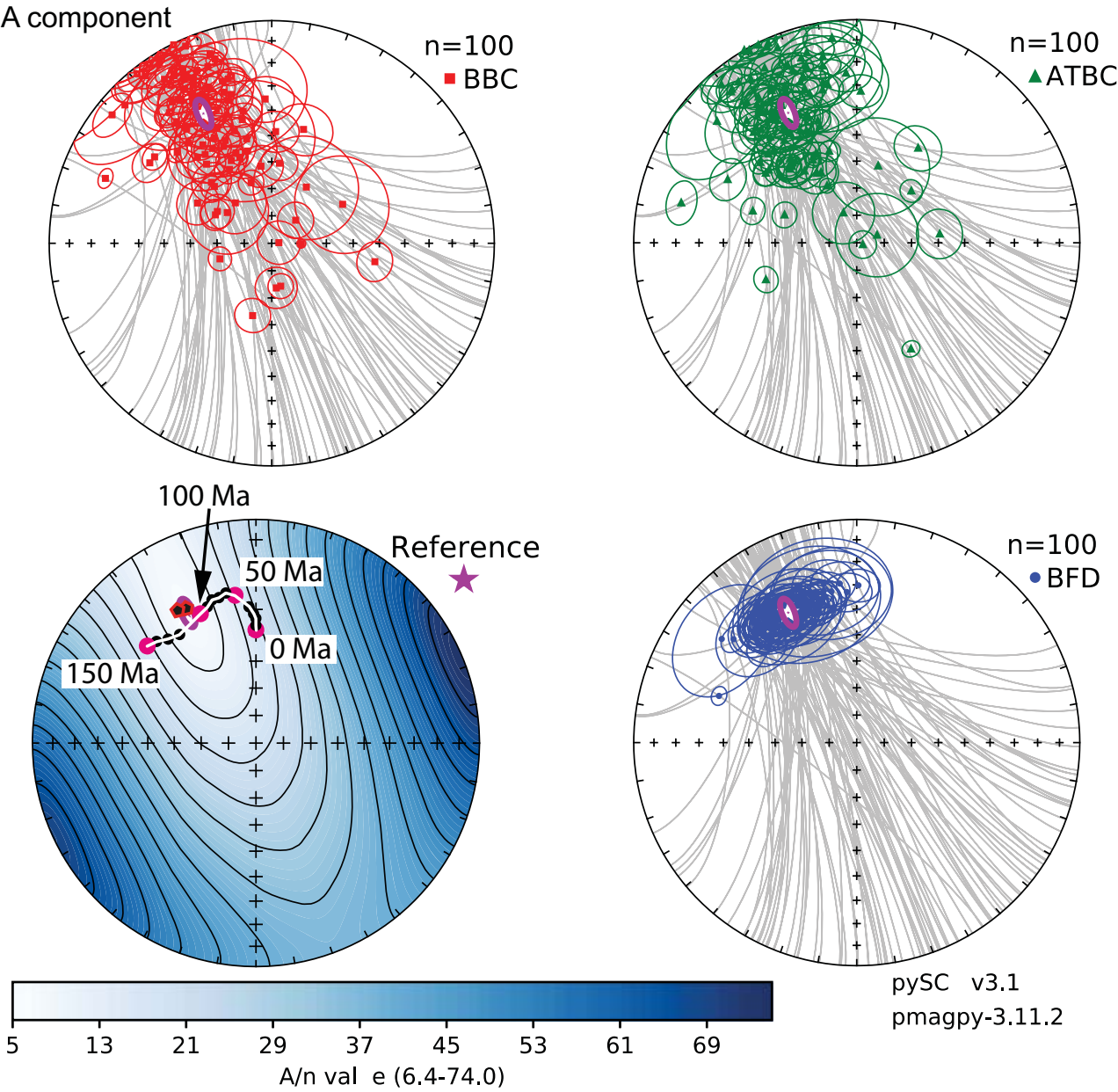

pmagpy-3.11.2

Fig. 4. (a-b) Bootstrap fold-test (Tauxe and Watson, 1994) of the components A and B using sample directions. Both components are interpreted as remagnetizations: component A can be clearly interpreted as a syn-folding remagnetization, whereas component B is almost post-folding. (a) Equal area projection of the site mean paleomagnetic directions of the ChRM (component A) and the corresponding small circles used to calculate the remagnetization direction. Mean directions of component A are in the Supplementary. BBC and ATBC: Before and after total tectonic correction respectively. BFD: Best fit direction. A/n matrix (Waldhör and Appel, 2006), calculated remagnetization direction (reference direction for restoration) and Kent's 95\% confidence ellipse (Calvín et al., 2017c). 


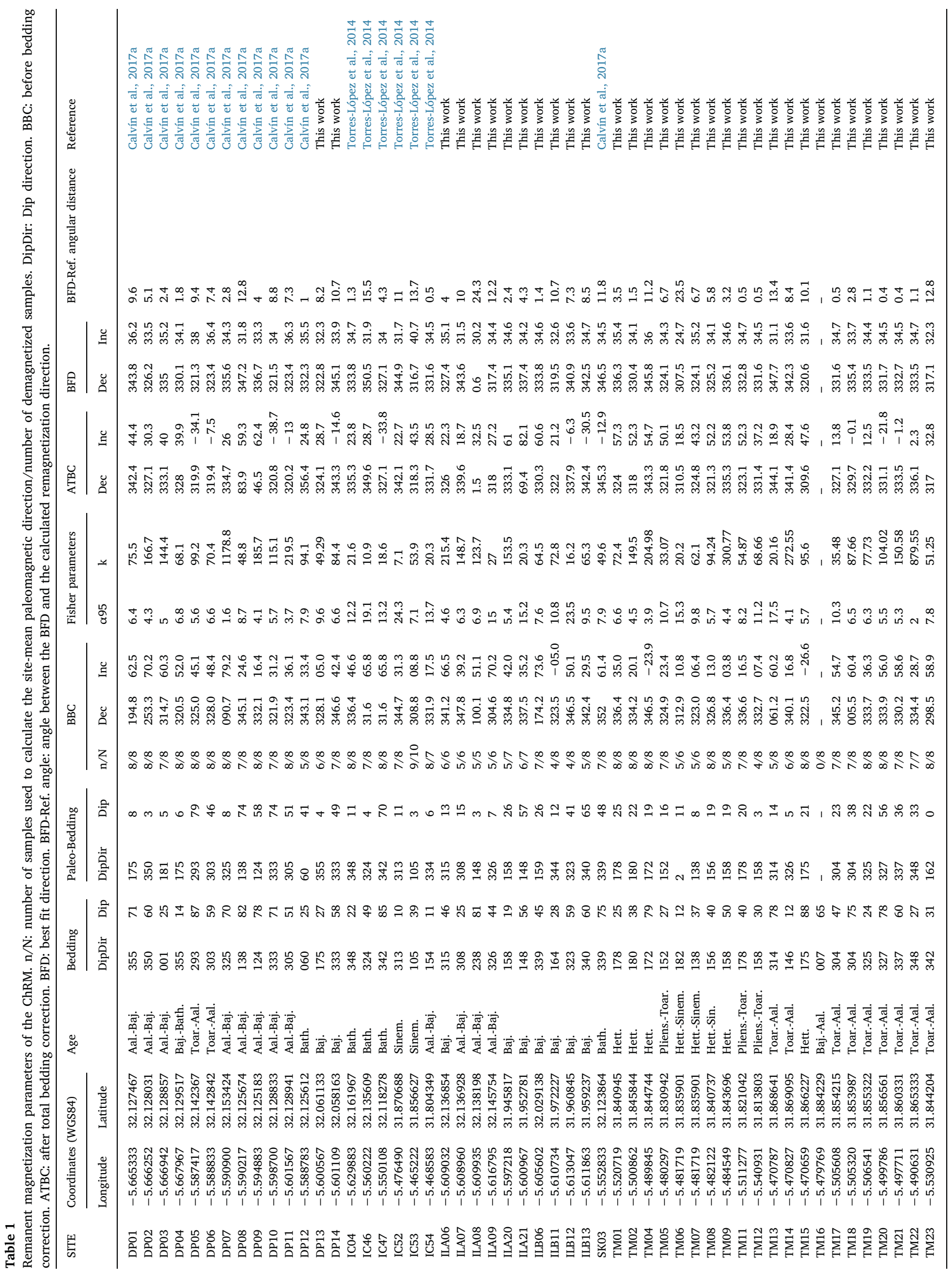


mentioned authors and dated at ca. $100 \mathrm{Ma}$.

\subsection{Remagnetization direction}

The 32 paleomagnetic site-mean directions of the ChRM obtained in this work were analyzed together with other 68 previously published paleomagnetic directions (Torres-López et al., 2014; Calvín et al., 2017a) (Table 1) from Jurassic rocks of the neighboring area. These data have been filtered in order to use only reliable directions (directions far from the calculated reference, and therefore suspicious of not fulfilling the requirements for the SC methods, were excluded). Using the 100 paleomagnetic directions, the SCI solution was calculated with its Kent's (1982) 95\% confidence ellipse (n: 100 , Dec: $332.2^{\circ}$, Inc: $34.5^{\circ}$, $\eta: 6.2^{\circ}, \xi: 2.0^{\circ}, \mathrm{A} / \mathrm{n}: 6.427^{\circ}$ ). This direction coincides with paleomagnetic vectors obtained from two horizontal sites of the study area (AG02 and SK12, Table 1; Fig. 4), and cuts the APWP in ca. $100 \mathrm{Ma}$; this direction is therefore used as reference for the best fit direction (BFD) and paleo-dip calculations (Table 1). These paleo-dips have been determined for the 32 sites of this study and 16 sites of previous works (Table 1) and they are used in the next section to restore the geometry of the structures to their pre-compressional stage (ca. $100 \mathrm{Ma}$ ).

From the dispersion pattern (Fig. 4), it can be observed that all SCs have their paths close to the calculated direction, giving BFDs close to it (Table 1). This is indicative of (i) absence of differential vertical axis rotation between sites and (ii) coaxiality between pre- and post-remagnetization deformation, at least as a general rule. The angle between the reference and the BFD (Table 1) is a good indicator of the reliability for each site and of the absence of local problems that could preclude the use of some particular site for structural considerations. For example, TM07 or ILA08 have values of this angle higher than $20^{\circ}$.

\section{Present-day and restored structure}

Four ENE-WSW diapiric structures can be observed in the study area (Fig. 2), following the general structural trend. In the next subsections we present a combination of field observations, cross-sections showing the structure at present and restored at ca. $100 \mathrm{Ma}$ through the analysis of the remagnetization (Figs. 5 to 9), and a general cross-section (with the present day and ca. $100 \mathrm{Ma}$ attitude) merging data from individual cross-sections (Fig. 9).

\subsection{The Ikkou ridge}

The Ikkou structure (Figs. 2 and 5 ) is a tight ( $<1 \mathrm{~km}$ wide), long salt-wall extending for several tens of kilometers along trend. In its core, Triassic basalts are dominant and in its northern outcrop there are fragments of a hook in Lower Jurassic rocks. Its present-day structure (Figs. 2 and 5a) shows that the overburden strikes sub-parallel to the salt-wall, with moderate to high dips, steeper when approaching the salt-wall. Although the presence of compressive structures is not prevalent in its $\mathrm{S}$ limb, its $\mathrm{N}$ limb shows north-verging chevron folds related to intra-Jurassic detachments (Fig. 5d). A detailed reconstruction of these folds (Fig. 5e) at ca. $100 \mathrm{Ma}$ shows that they post-date the remagnetization, and are therefore related to the Cenozoic compression. In the restoration of the Ikkou ridge (Fig. 5b) it can be observed that most of the tilting of the limbs was already developed during the extensional stage (with the exception of chevrons folds), with moderate dips of beds close to the ridge and showing a rapid decrease of dip with increasing distance from the ridge (compare DP10 and 11 with ILA sites, Fig. 5b). According to previous works (Torres-López et al., 2016; Calvín et al., 2017a) in the Ikkou syncline it was already developed during the extensional stage and was tightened during the Cenozoic, developing a N-verging thrust and subvertical cleavage. We interpret that, as it occurs in the cross-sections across the Ikkou syncline (Calvín et al., 2017a), the squeezing of the salt-wall was associated with northverging thrusting (Fig. 5a). This is in agreement with the rotation path recorded by gabbros (Calvín et al., 2017b) that crop out in the core of some of these ridges (i.e. Tasraft, Tassent, Tirrhist and Anefgou ridges). Although it is not possible to estimate the original width of the salt-wall during the pre-compressional stage, the almost absence of shales and salt in its core indicates that it was wider and was totally welded during the Cenozoic compression.

Differences in thickness can be observed between the Bajocian levels at both limbs of the ridge, being thicker in its $\mathrm{N}$ limb. However, the opposite happens regarding the Bathonian-Callovian redbeds, which are thicker in the $S$ limb. An unconformity at the base of the redbeds is especially evident close to the southern limb of the Ikkou ridge, indicating a change in the diapiric/subsidence activity.

\subsection{The Tadaghmamt ridge}

The Tadaghmamt salt-wall (Figs. 2 and 6) is elongated in an ENEWSW direction and about $10 \mathrm{~km}$ long and $1-2 \mathrm{~km}$ wide. Its core consists of both sedimentary and volcanic Triassic rocks. The Jurassic series shows low to moderate dips, and is strongly folded towards the NE, where the Tissila anticline is located (Fig. 2). The overall structure can be followed $>100 \mathrm{~km}$ along trend, relaying with other folds towards the SW. For example, the Tadaghmamt ridge connects with the Azourki Ridge (Vergés et al., 2017), through a N-dipping normal fault system and small diapirs. Towards the NE, the Tadaghmamt anticline ends without evidence of continuity or relay with other structures.

The $\mathrm{N}$ limb of the Tadaghmamt ridge is generally subhorizontal, although it shows decametric-scale south-verging folds and increasing dips close to the ridge axis. In the core of the ridge, Triassic basalts (mainly in the NE sector) and shales (along all the salt-wall), both capped by Bajocian limestones (Fig. 6d, e), crop out. The latter have been differentially folded, showing both gentle and tight folds. The $S$ limb is characterized by the presence of a kilometer-scale, north-verging asymmetric anticline; its $\mathrm{N}$ limb presents moderate dips (Fig. 6f) whereas its $\mathrm{S}$ limb shows low-to moderate dips that become sub-horizontal a few kilometers from the ridge (Fig. 6a). It is curious that both DP13 and ILB06 (dipping away from the ridge axis during the basinal stage), changed their sense of dip during compression (Fig. 6b) and show moderate dips towards the ridge rapidly changing near the thrust (DP13) or defining a secondary anticline (ILB06).

\subsection{The Timedouine ridge}

The Timedouine salt-wall (Figs. 2 and 7) is the NE end of a $50 \mathrm{~km}$ NE-SW to NNE-SSW striking, S-dipping normal fault system. The Ikerzi and Moussa diapirs (Fig. 1) and the Msemrir Bathonian-Callovian basin (Ettaki et al., 2007) are also associated with this fault system. The Timedouine structure is $13 \mathrm{~km}$ long, $1 \mathrm{~km}$ wide, and shows a NE-SW trend; it is cored by Triassic shales and basalts, and scarce outcrops of Jurassic gabbros. The presence of gabbros probably evidences its connection with a basement fault. The Mesozoic sedimentary cover is gently folded close to the ridge with low to moderate dips and folds in both limbs verging towards the ridge (Fig. 7a), and becoming subhorizontal at around $1 \mathrm{~km}$ from the salt-wall. In the eastern end of the ridge, compressional structures are more pervasive, and hectometerscale monoclines verging towards the ridge (Fig. 2b) and recumbent folds associated with detachments from the core of the ridge appear. In this area, slumps and local sedimentary unconformities in the AalenianBajocian marls can be observed (Fig. 7e).

When the geometry of the overburden is restored (Fig. 7b) the structure is similar to the one observed in the Tadaghmamt ridge, with steep to moderate dips close to the ridge that rapidly become subhorizontal away from it.

\subsection{The Toumliline ridge}

Finally, Toumliline (Figs. 2 and 8 ) is a $5 \times 1 \mathrm{~km}$ diapiric structure, 


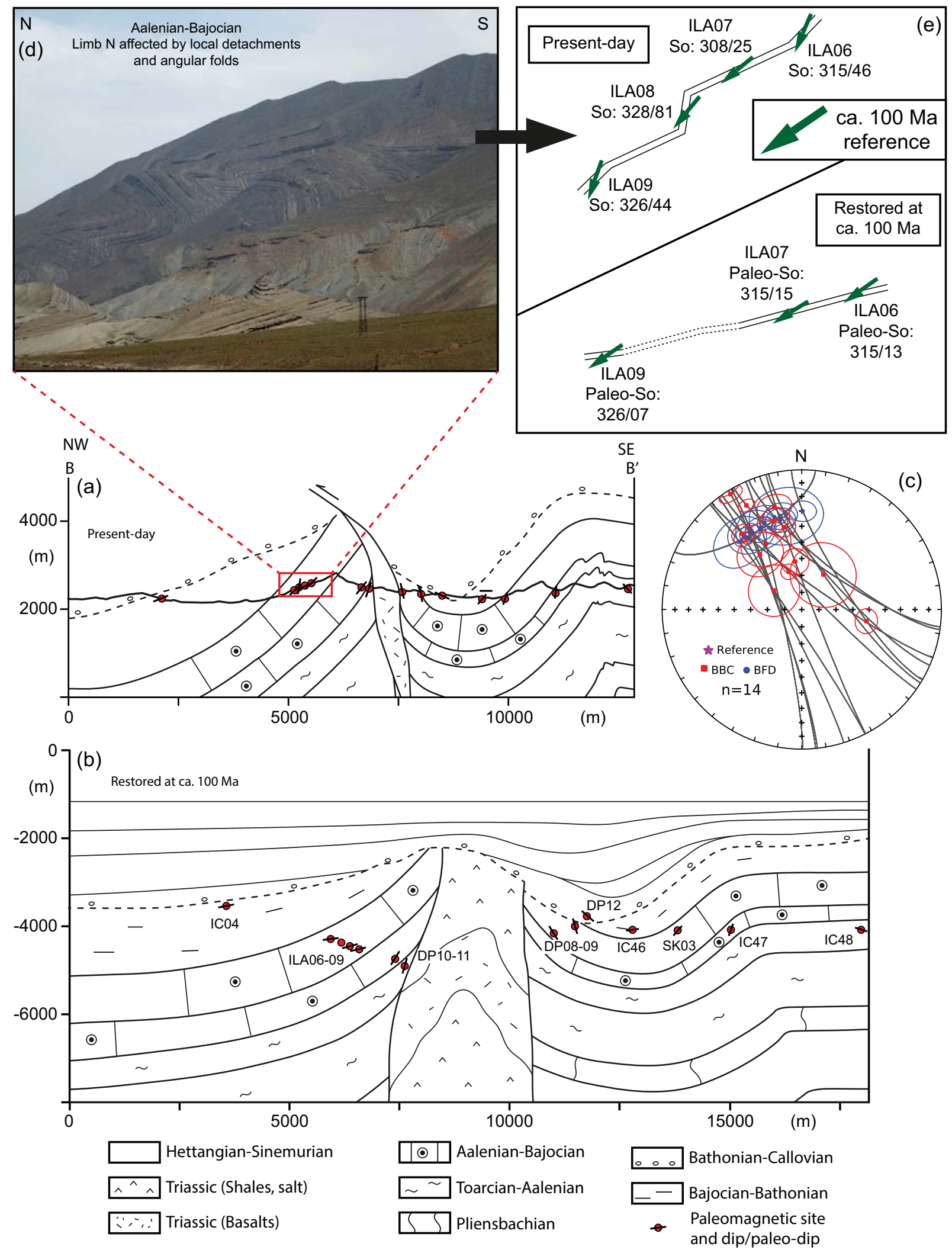

Fig. 5. Present-day (a) and ca. $100 \mathrm{Ma}$ (b) B-B' cross-sections across the Ikkou ridge, showing the paleomagnetic sites used in the restoration. (c) Paleomagnetic directions with their respective small circles used in this work. (d) Chevron north-verging folds of the northern limb of the ridge. (e) Restoration of the northern limb of the Ikkou structure. SK03, IC46, IC47 and IC48 sites are extrapolated from the East. 

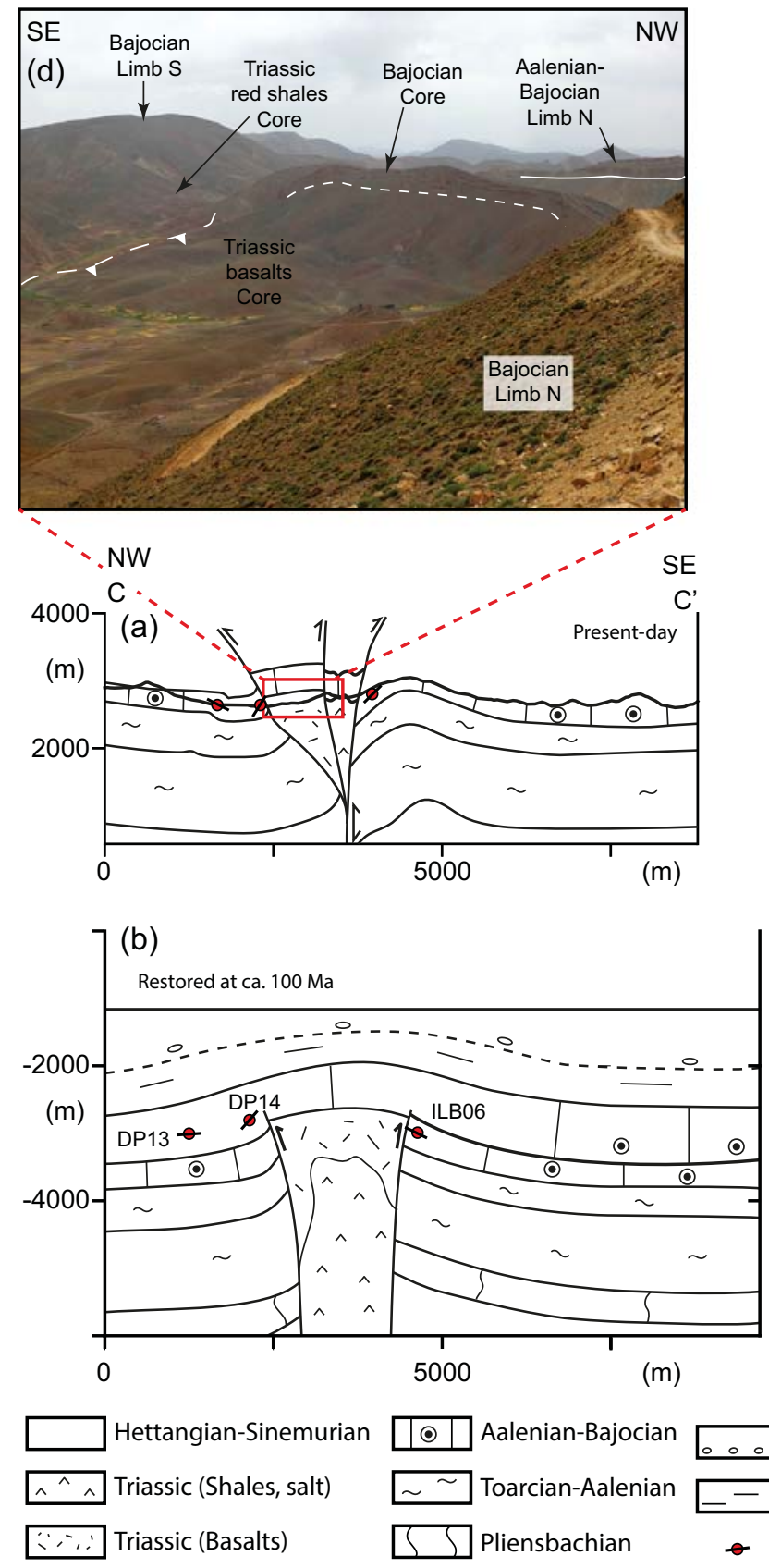
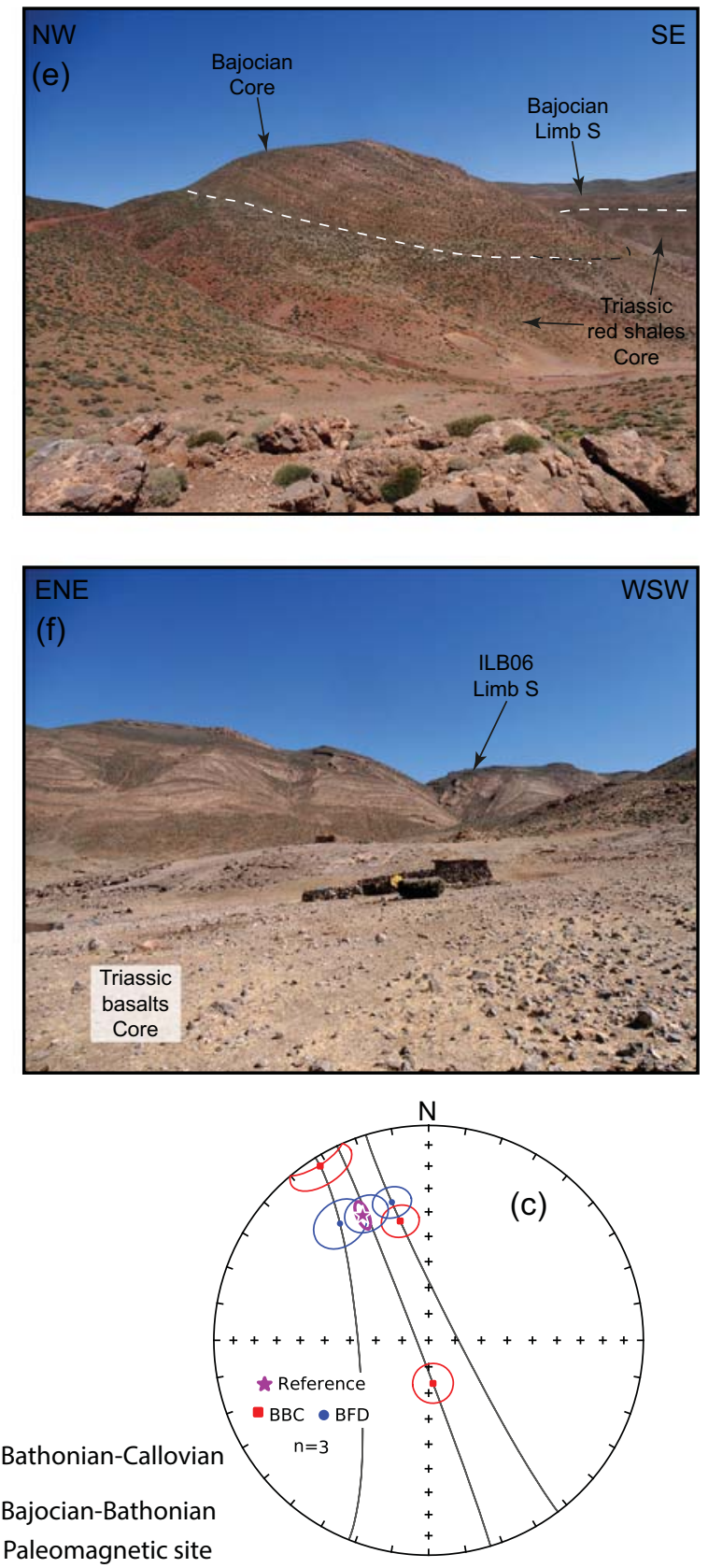

Paleomagnetic site
and dip/paleo-dip

Fig. 6. Present-day (a) and ca. $100 \mathrm{Ma}$ (b) C-C' cross-sections across the Tadaghmamt ridge and paleomagnetic sites used in the restoration. (c) Paleomagnetic directions with their respective small circles used in this work. (d) Core of the ridge showing the large amount of Triassic basalts, capped by Bajocian limestones. (e) Picture taken towards the W showing the core of the ridge, with Triassic red-shales capped by Bajocian limestones. (f) Core of the Ridge and fold in its southern limb.

elongated along the main structural trend, and related to a north-dipping basement normal fault (Fig. 2) (Teixell et al., 2003). Large amounts of salt, which has been the object of traditional exploitation (the name 'Toumliline' refers in the tamazight autochthonous language to the white color of the salt), crop out in its core. Besides, Triassic basalt and Jurassic gabbros can be recognized in the center of the diapir, suggesting a synformal structure. The Jurassic cover shows moderate to steep dips when approaching the core in the northern limb of the diapiric structure and shallow to moderate dips in its southern limb (Fig. 8a). Towards the WSW and ENE, the diapir ends and a north verging thrust can be observed superposing the Lower Jurassic over the Middle Jurassic rocks (Fig. 8d). The ca. 100 Ma structure shows a similar attitude but shallower dips. In the hanging wall, the paleo-dips obtained in the marls (Fig. 8b) change very quickly and this can be probably related to growth strata in this unit, although a section perpendicular to the fault would be needed to confirm this issue. In the footwall, the paleomagnetic sites close to the core show low dips towards the S (Fig. 8b, sites TM05, 07, 08, 09) whereas the farthest paleomagnetic site (IC54) presents a shallow northwards dip, defining a gentle syncline. This is consistent with salt migration during the extensional stage and the development of a salt-roller. The cross-section made towards the NE (Fig. 8e) cuts across a non-diapiric zone, and shows the lower part of the thrust that can be observed towards the SW; in the restored cross-section this thrust shows shallow dips. The restored structure shows that the folds associated with the north-verging thrust were developed during the Cenozoic, because they do not appear in the ca. $100 \mathrm{Ma}$ structure, which in turn is similar to the section that cuts across the diapir (Fig. 8a). 

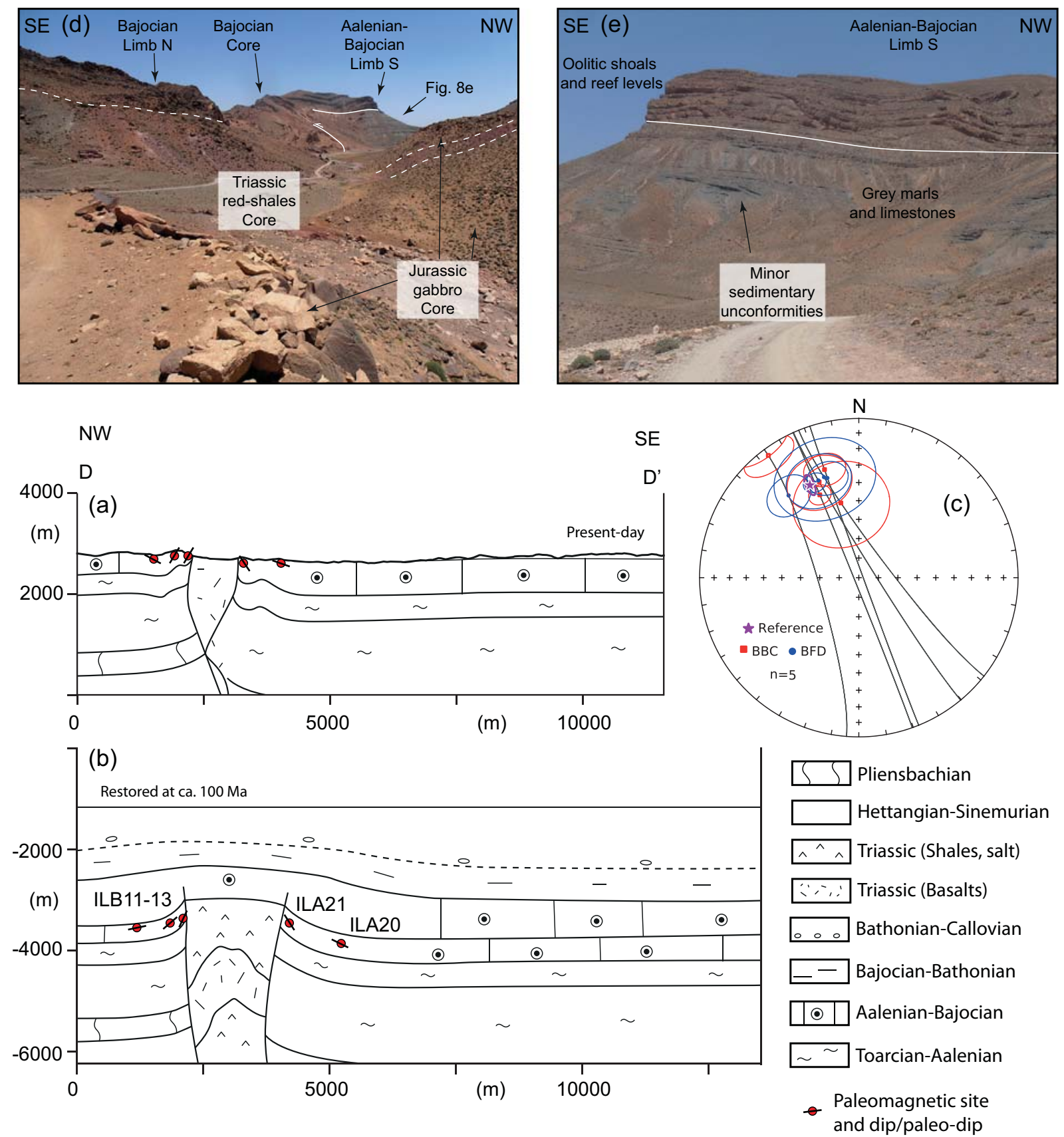

Fig. 7. Present-day (a) and ca. $100 \mathrm{Ma}$ (b) D-D' cross-sections across the Timedouine ridge showing the paleomagnetic sites used in the restoration. (c) Paleomagnetic directions with their respective small circles used in this work. (d) Easternmost end of the Timedouine ridge, showing Triassic red-shales and Jurassic gabbros in the core, and Bajocian limestones as the overburden. (e) Local sedimentary unconformities in the Aalenian-Bajocian marls.

\section{Interpretation}

Recent research works (Saura et al., 2014; Moragas et al., 2016; Martín-Martín et al., 2017; Teixell et al., 2017; Vergés et al., 2017) evidence the major role of salt tectonics in the development of sedimentary basins during the Early-Middle Jurassic in the CHA. Jurassic subsidence was conditioned mainly by extensional tectonics, but with a significant contribution of salt migration (Moragas et al., 2016). During the Cenozoic compression these salt-walls accommodated the shortening and some of them were strongly tightened (e.g. Teixell et al., 2017), erasing the evidence of salt-tectonics and extension-related processes. Exceptions are the salt-walls that contain more competent rocks (Jurassic hooks, Triassic basalts and Jurassic gabbros) or structures having a post-compressional halokinetic activity. Following this line, the ridge linked to the Toumliline diapir (its prolongation towards the NE) could be a priori interpreted as a welded Jurassic salt-wall, since its present shape shows upright limbs limited by a tectonic contact (Fig. 8e). Although its present-day geometry is similar to the Ikkou ridge (in this case without Triassic basalt between both limbs), the ca. $100 \mathrm{Ma}$ restoration indicates that most of the tilting associated with the Toumliline ridge is Cenozoic in age. This is an example of how paleomagnetic results and quantification of the paleo-dips can help to achieve a more accurate interpretation about the evolution of this kind of structures.

The comparison between the pre- and post- compressional structure (ca. 100 Ma restored and present day, respectively) sheds light into the meaning of diapiric processes as generators of the CHA ridges and into the mechanisms by which the inherited extensional structures 


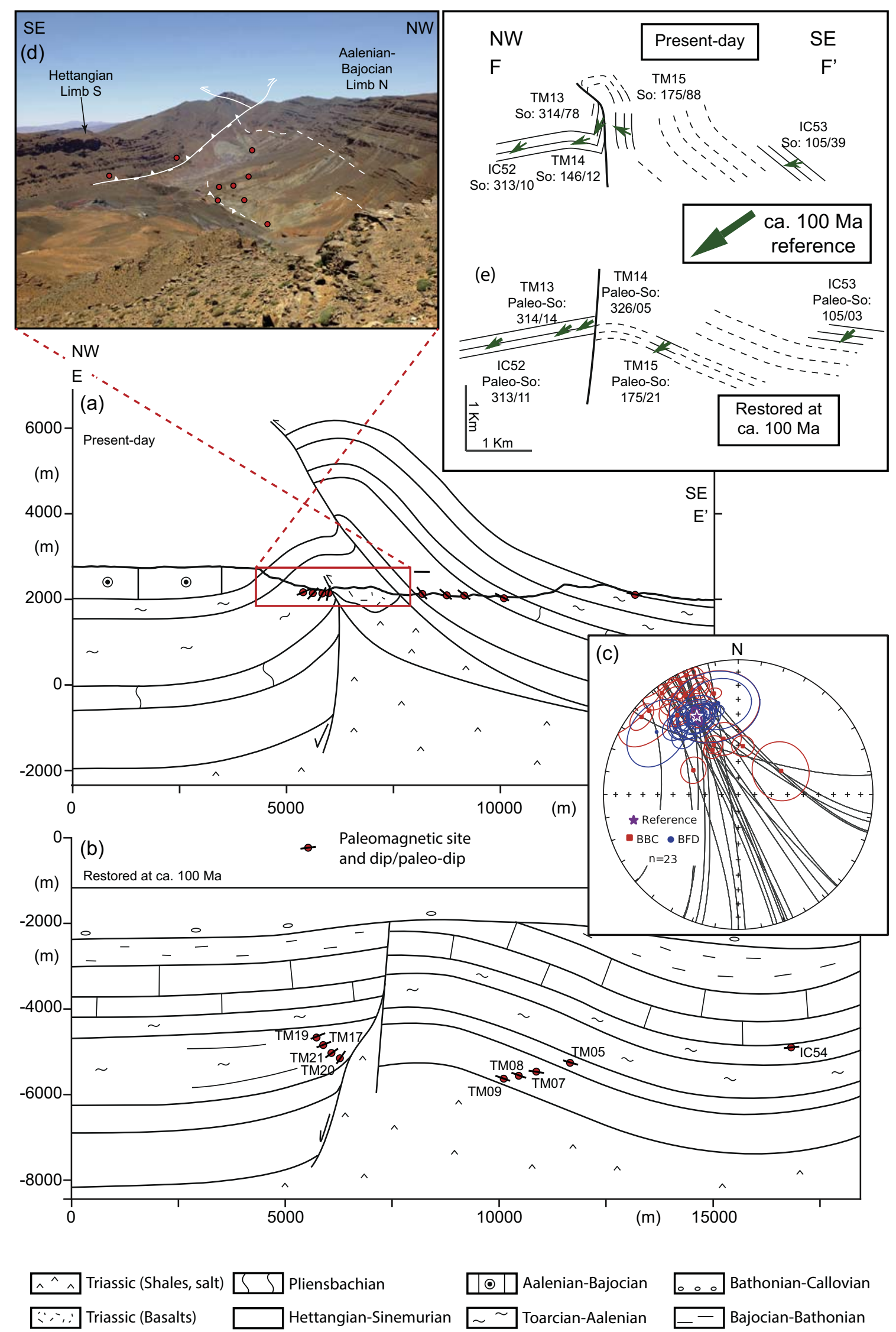

Fig. 8. Present-day (a) and ca. $100 \mathrm{Ma}$ (b) E-E' cross-sections across the Toumliline ridge showing the paleomagnetic sites used in the restoration. (c) Paleomagnetic directions with their respective small circles used in this work. (d) The Toumliline diapir, showing Triassic shales and basalts in its core, and the Hettangian in its southern limb thrusting over the Aalenian-Bajocian in its northern limb. (e) Present-day and ca. 100 Ma F-F' cross-section showing that most part of the present-day deformation is related to Cenozoic thrusting. 

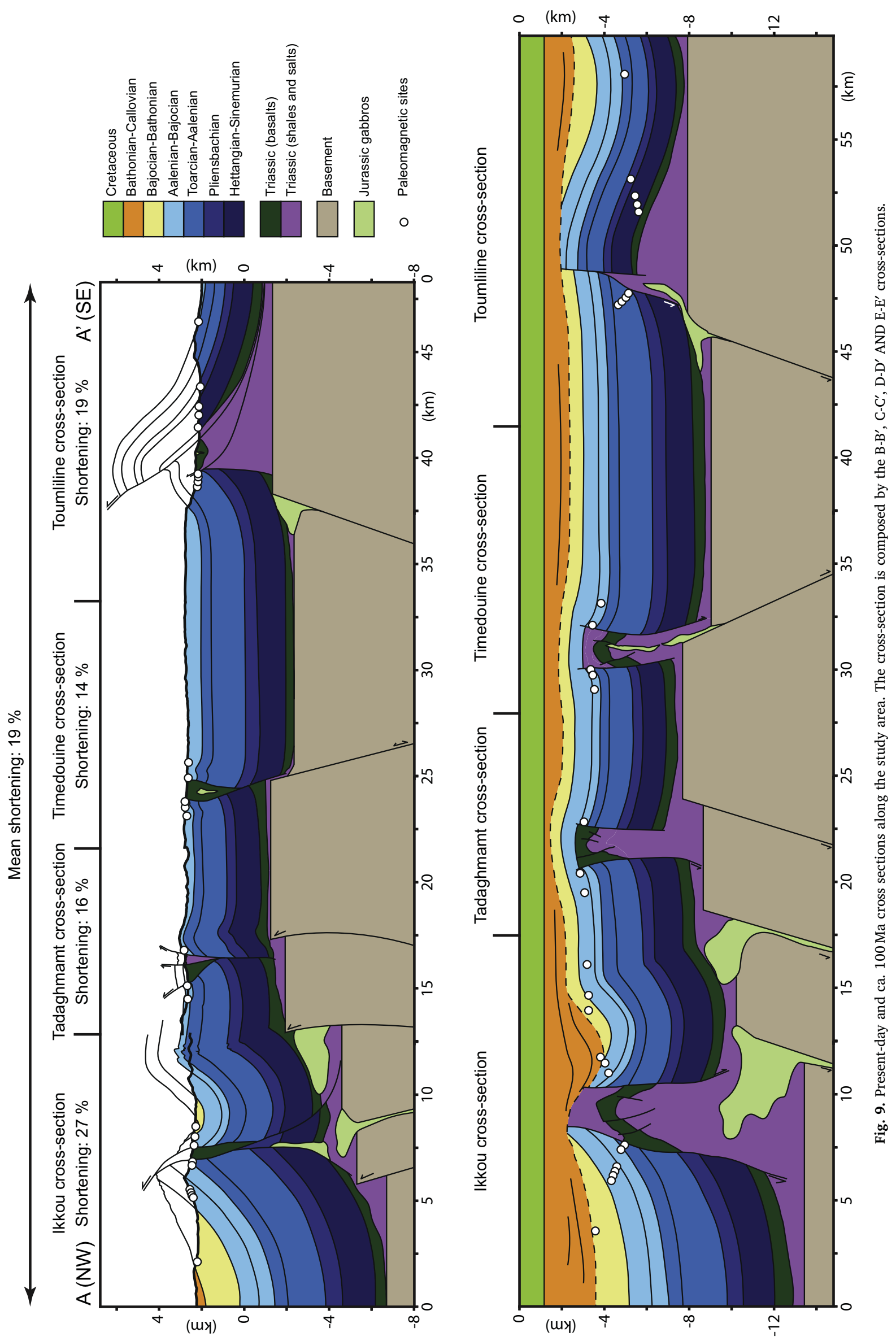
conditioned their compressional geometry. The analyzed structures show differences regarding the two stages of development related to their evolution (Fig. 9).

\subsection{Implications for ridges development}

Although in a simplistic view the ridges found in the CHA can be interpreted as welded salt-walls limiting minibasins, a detailed analysis of the four structures that crop out between the localities of Imilchil and Toumliline indicates strong differences regarding both their presentday geometry and their pre-compressional structure. This indicates contrasting evolutions during the extensional and compressional stages.

The Ikkou ridge shows similar geometry of the Jurassic sedimentary cover before and after the Cenozoic compression, with steeply-dipping Jurassic beds at both stages. The Cenozoic deformation in this ridge is restricted to tightening of the salt-wall (as much as allowed by the presence of competent rocks, such as basalts or gabbros in its core) together with north-verging thrusting, development of cleavage in both limbs (especially in the southern one) and minor, north-verging folds in the footwall of the thrust (Figs. 5 and 9). The Mesozoic deformation (Fig. 9b) consisted in the uplift of the core and outwards, centrifuges tilting in the first $1-2 \mathrm{~km}$ away from it at the limbs, with a quick decrease of the paleo-dip towards the synclines. This scenario agrees with the presence of a salt-wall limiting sedimentary depocenters during the Jurassic. The Mesozoic salt-wall cuts the sedimentary pile up to the Bathonian-Callovian redbeds, whose shallow dips in the NW limb of the Ikkou syncline and their basal unconformity point to a decreasing rate of salt migration in the salt-wall during the sedimentation of the redbeds. This can suggest that this unit could have fossilized the salt-wall. On the other hand, the Tadaghmamt and Timedouine salt-walls share similar features that differ from the Ikkou and Toumliline structures. In this central sector, the structure is characterized by flat-lying beds of Bajocian limestones that top the Triassic basalts and shales in the core of the Tadaghmamt ridge. Close to the ridge axes, the limbs are complicated by minor, decameter- to hectometer-scale folds as a consequence of buttresing towards the ridge during the Cenozoic compression. Conversely, their Mesozoic attitude was characterized by tilting of the limbs away from the ridge affecting only the area adjacent to the salt-walls (Fig. 9). This small tilting and the fact that the saltwalls do not completely cut through the Bajocian limestones seem to indicate lower extensional activity and consequently lower salt migration in the Tadaghmamt and Timedouine ridges.

The Jurassic cover of the Toumliline ridge shows shallow dips in the restored section, with exception of sites located in the hanging wall of the normal fault (Figs. 8 and 9). Furthermore, shortening of the Toumliline diapir during the Cenozoic was important, generating thrust-related folds. The cross-section of the ridge towards the $\mathrm{W}$ of the diapir depicts similar features, showing shallow dips in the pre-compressional restoration. Therefore, this structure can be interpreted as a Mesozoic salt-roller related to the normal fault, without imposing major controls on the sedimentary conditions with exception of the accommodation space generated by migration of salt from the hanging wall to the footwall. During the Cenozoic, both the presence of the normal fault and salt accumulation along the structure would favor the nucleation of deformation, generating folds and thrusts and the partial extrusion of salts forming the Toumliline diapir. Otherwise, the weaker development of Jurassic halokinetic processes in this structure can be responsible for the presence, at present, of a large amount of salt below the diapir, almost absent in other structures (e.g. the Ikkou salt-wall).

According to the comparison between the pre- and post-compressional structure, it is remarkable how the overburden and the saltbodies themselves responded differently to the Cenozoic compression, a behavior that depends in its turn on the geometries inherited from the extensional stage, that we can summarize in three categories: (i) The Ikkou salt-wall is a well-developed Mesozoic structure whose limbs tend to show moderate to steep dips; during shortening, accommodation of the deformation occurred mainly by squeezing of the salt core accompanied by north-directed thrusting and secondary steepening of its limbs (Fig. 9). (ii) When Mesozoic deformation was gentler (as in the case of the Tadaghmamt and Timedouine structures) and only consisted in the development of a salt-wall with minor vertical movements between limbs, the development of major compressional structures during the Cenozoic stage could be difficult due to the thickness of the sedimentary series. In this case, deformation was limited to the squeezing of salt-walls and development of folds close to the ridge by buttresing (Fig. 9). (iii) Finally, the Toumliline diapir shows a different compressional style in which the development of a main thrust was favored by the pre-compressional geometry, consisting of (a) a normal fault imposing a strong throw between the future fold limbs (note that this is the only sector where the Hettangian beds crop out) and (b) a significant accumulation of salts below the hanging wall of the Cenozoic thrust. Both conditioners are related to the existence of a Mesozoic saltroller.

\subsection{Subsidence implications}

Another interesting issue concerns the differences in thickness of the sedimentary pile observed between the limbs of the Ikkou and the Toumliline ridges, both related to north-dipping basement normal faults (Fig. 9). This favored higher subsidence and accumulation of sediments in the hanging wall during the Early-Middle Jurassic, evident in the Toarcian-Aalenian beds of the Toumliline ridge and the AalenianBajocian beds of the Ikkou structure (Figs. 5, 8 and 9). Tectonic subsidence during this early stage, according to Moragas et al. (2016), would be complemented by salt migration from the hanging wall to the footwall.

This scenario changed during the Bathonian-Callovian redbeds deposition, contemporary with decreasing extensional activity and salt migration from the hanging wall. At this moment, the beginning of migration of the salt in the footwall favored a stronger subsidence in the $\mathrm{S}$ limb of the Ikkou ridge, with the generation of syncline which acted as depocenter for the redbeds (Fig. 9b). The unconformity below the redbeds could be conditioned by this change in the subsidence behavior. Furthermore, the first stage of subsidence, controlled by basement normal faults, is more continuous along strike, whereas the second stage is restricted to small areas (e.g. the Ikkou syncline), because they depended on the amount of salt (or salt migration) below the ridge, which could be heterogeneously distributed. This is evident in the western end of the Ikkou syncline; towards the $\mathrm{W}$, the Jurassic shows a subhorizontal attitude, indicating the pinchout of the depocenter. Although there are not outcrops of red-beds in the Toumliline diapir to confirm this issue, following the observations of the Ikkou ridge, the syncline located in the footwall of the Toumliline ridge could have been structured during the same time.

\subsection{General structure}

The minimum width that ridges must have had before the compressional stage is related to the dip of the limbs in each structure: the higher the extensional tilting and the distance of affection to the limbs, the greater must be the minimum original width of the ridges. This allows to estimate the minimum shortening recorded by each individual structure during the Cenozoic compression (Fig. 9).

Tadaghmamt and Timedouine salt-walls show the lowest shortening values, around $15 \%$ that agree with the shallow dips observed around these structures. This is also consistent with the interpretation of ridge squeezing and the development of folds in the areas adjacent to the core. The Toumliline structure shows about $20 \%$ of minimum shortening but this figure strongly depends on the amount of displacement accommodated by the thrust, which is poorly constrained and could be higher than interpreted in this cross-section. Finally, the minimum width is greater for the Ikkou salt-wall than for the other structures and 
therefore it shows the highest shortening value, which is mainly accommodated by the squeezing of the salt-wall. In an overall view, the mean estimated shortening is around $19 \%$, what agrees with average shortening values proposed for the entire chain along this cross-section (Teixell et al., 2003).

An interesting issue is the accommodation of deformation at deeper levels, within the Paleozoic basement. Although geometry of structures at this level is conjectural, its present-day envelope agrees with the one adjusted by means of a gravimetric section (Ayarza et al., 2005). This envelope is characterized in the study area by two well differentiated structural highs, whose limit is the monocline south of the Ikkou syncline. Considering only the present-day dips, it is reasonable to interpret this geometry as a consequence of a north-verging basement thrust, with an associated hanging wall fold represented by the observed monocline. In fact, these variations in structural depth of the top of the basement have been previously interpreted as an evidence of the in volvement of the basement in the compressional structure (Teixell et al., 2003). However, the restored cross-section shows that these variations are inherited from the basinal stage. This implies that vertical movements of the basement were important during the extension, whereas during the inversion the shortening would be probably limited to folding and steepening of previous normal faults and/or cleavage development.

\section{Conclusions}

The carbonate rocks that crop out between the Imilchil and Toumliline villages (Central High Atlas) show a chemical remagnetization, carried by magnetite. This paleomagnetic signal shows features similar to those observed in close areas of the CHA (TorresLópez et al., 2014; Calvín et al., 2017a): maximum unblocking temperatures around $450-500{ }^{\circ} \mathrm{C}$, site-mean paleomagnetic directions with systematically northwestwards, positive inclinations, and scattering both before and after total bedding correction. This remagnetization was dated as ca. $100 \mathrm{Ma}$ (Torres-López et al., 2014) from comparison with the apparent polar wander path of North Africa (Torsvik et al., 2012).

By means of the small circle method, the geometry of the overburden of four salt-related structures has been quantitatively restored to the moment of the acquisition of the remagnetization (ca. $100 \mathrm{Ma}$, i.e. a tectonic quiescence period predating the Cenozoic compression). This methodology appears to be promisingly useful in the study of diapiric salt structures because allows to analyze the structure derived directly from the halokinetic processes generated during the basinal stage, without the subsequent compressional imprint.

Specifically, the application of paleomagnetic methodology in four structures of the CHA returns the following conclusions:

Most of the paleomagnetic directions, once they are restored at the remagnetization time, are close to the reference direction. This is indicative of the absence of significant and generalized vertical axis rotations and/or non-coaxial deformation during the pre- and postremagnetization deformation stages.

- The Ikkou salt-wall was almost totally developed during the extensional stage; the ca. 100 Ma restored geometry shows moderate to steep dips of the cover rocks, subparallel to the salt-wall, and similar attitude to the present-day structure. Cenozoic compression resulted in the squeezing and extrusion of its saline core (only Triassic basalts remain at present) together with north-directed thrusting, cleavage development and folding.

In the Timedouine and Tadaghmamt ridges only Bajocian limestones crop out; in the case of the Timedouine ridge, they do not allow to reconstruct the pre-compressional evolution of the salt-walls. However, the extensional geometries of both ridges show moderate dips away from their cores, indicating that the salt-walls were already developed before the remagnetization acquisition. In these ridges, the Jurassic deformation was minor, confined to the areas adjacent to the structure; the Cenozoic compression only generated the welding of the salt-walls and buttressing of the overburden towards the structures, with the generation of folds verging towards the ridges.

The ca. 100 Ma structure of the Toumliline diapir was mainly conditioned by normal faulting; the hanging wall is deformed close to the fault, showing growth strata or a drag fold, whereas the rocks of the footwall are deformed by a salt-roller. Most of the present-day structure developed during the Cenozoic compression, whit the development of a north-verging thrust and associated folds.

\section{Acknowledgements}

Special thanks to B. Oliva, E. Sánchez, Á. Herrejón and T. Mochales for their kind help during field work. The authors are grateful for their comments and suggestion to two anonymous reviewers as well as to the editor Rob Govers.

\section{Funding}

This study was supported by the MINECO (Spanish Ministry of Economy and Competitiveness) cofinanced by the ERDF (European Union) (research projects CGL2012-38481 and CGL2016-77560). PC also acknowledges the MINECO (F.P.I. research grant BES-2013062988).

\section{Appendix A. Supplementary data}

Supplementary data with this article can be found in the online version at https://doi.org/10.1016/j.tecto.2018.04.007. These data include the Google map of the most important areas described in this article.

\section{References}

Armando, G., 1999. Intracontinental alkaline magmatism: geology, petrography, mineralogy and geochemistry of the Jebel Hayim Massif (Central High Atlas-Morocco). In: Mémories de Géologie de l'Université de Lausanne. vol. 31. pp. 106.

Aubourg, C., Pozzi, J., Kars, M., 2012. Burial, claystones remagnetization and some consequences for magnetostratigraphy. Geol. Soc. Lond., Spec. Publ. 371, 181-188. http://dx.doi.org/10.1144/SP371.4.

Ayarza, P., Alvarez-Lobato, F., Teixell, A., Arboleya, M.L., Tesón, E., Julivert, M., Charroud, M., 2005. Crustal structure under the central High Atlas Mountains (Morocco) from geological and gravity data. Tectonophysics 400, 67-84. http://dx. doi.org/10.1016/j.tecto.2005.02.009.

Barbero, L., Teixell, A., Arboleya, M.-L., Del Río, P., Reiners, P.W., Bougadir, B., 2007 Jurassic-to-present thermal history of the central High Atlas (Morocco) assessed by low-temperature thermochronology. Terra Nova 19, 58-64. http://dx.doi.org/10. 1111/j.1365-3121.2006.00715.x.

Beauchamp, W., Allmendinger, R.W., Barazangi, M., Demnati, A., El-Alji, M., Dahmani, M., 1999. Inversion tectonics and the evolution of hte High Atlas Mountains, Morocco, based on a geological-geophysical transect. Tectonics 18, 163-184.

Bensalah, M.K., Youbi, N., Mata, J., Madeira, J., Martins, L., El Hachimi, H., Bertrand, H., Marzoli, A., Bellieni, G., Doblas, M., Font, E., Medina, F., Mahmoudi, A., Beraâouz, E.H., Miranda, R., Verati, C., De Min, A., Ben Abbou, M., Zayane, R., 2013. The Jurassic-Cretaceous basaltic magmatism of the Oued El-Abid syncline (High Atlas, Morocco): physical volcanology, geochemistry and geodynamic implications. J. African Earth Sci. 81, 60-81. http://dx.doi.org/10.1016/j.jafrearsci.2013.01.004.

Bouchouata, A., Canérot, J., Souhel, A., Gharib, A., 1995. Stratigraphie séquentielle et évolution géodynamique du Jurassique de la région Talmest-Tazoult (Haut Atlas central, Maroc). In: Comptes Rendus L'Academie Des Sci. Paris. vol. 320. pp. 749-756.

Casas, A.M., Villalaín, J.J., Soto, R., Gil-Imaz, A., del Río, P., Fernández, G., 2009. Multidisciplinary approach to an extensional syncline model for the Mesozoic Cameros Basin (N Spain). Tectonophysics 470, 3-20. http://dx.doi.org/10.1016/j. tecto.2008.04.020.

Chadima, M., Hrouda, F., 2006. Remasoft 3.0 a user-friendly paleomagnetic data browser and analyzer. Trav. Géophysiques 27, 20-21.

Channell, J.E.T., McCabe, C., 1994. Comparison of magnetic hysteresis parameters of unremagnetized and remagnetized limestones. J. Geophys. Res. Solid Earth 99, 4613-4623. http://dx.doi.org/10.1029/93JB02578.

Charrière, A., 1990. Héritage hercynien et évolution géodynamique alpine d'une chaîne intracontinentale: le Moyen Atlas au SE de Fès (Maroc). Univ. Paul-Sabatier Toulouse. Charrière, A., Haddoumi, H., Mojon, P.-O., Ferrière, J., Cuche, D., Zili, L., 2009. Mise en 
évidence par charophytes et ostracodes de l'âge Paléocène des dépôts discordants sur les rides anticlinales de la région d'Imilchil (Haut Atlas, Maroc) : conséquences paléogéographiques et structurales. Comptes Rendus Palevol 8, 9-19. http://dx.doi. org/10.1016/j.crpv.2008.11.006.

Costa, E., Vendeville, B.C., 2002. Experimental insights on the geometry and kinematics of fold-and-thrust belts above weak, viscous evaporitic décollement. J. Struct. Geol. 24, 1729-1739. http://dx.doi.org/10.1016/S0191-8141(01)00169-9.

Calvín, P., Casas-Sainz, A.M., Villalaín, J.J., Moussaid, B., 2017a. Diachronous folding and cleavage in an intraplate setting (Central High Atlas, Morocco) determined through the study of remagnetizations. J. Struct. Geol. 97, 144-160. http://dx.doi org/10.1016/j.jsg.2017.02.009.

Calvín, P., Ruiz-Martínez, V.C., Villalaín, J.J., Casas-Sainz, A.M., Moussaid, B., 2017b. Emplacement and deformation of Mesozoic Gabbros of the High Atlas (Morocco): paleomagnetism and magnetic fabrics. Tectonics 36, 3012-3037. http://dx.doi.org/ 10.1002/2017TC004578.

Calvín, P., Villalaín, J.J., Casas-Sainz, A.M., Tauxe, L., Torres-López, S., 2017c. pySCu: a new python code for analyzing remagnetizations directions by means of Small Circle utilities. Comput. Geosci. 109. http://dx.doi.org/10.1016/j.cageo.2017.07.002.

Davis, D.M., Engelder, T., 1985. The role of salt in fold-and-thrust belts. Tectonophysics 119, 67-88. http://dx.doi.org/10.1016/0040-1951(85)90033-2.

Domènech, M., Teixell, A., Babault, J., Arboleya, M.-L., 2015. The inverted Triassic rift of the Marrakech High Atlas: a reappraisal of basin geometries and faulting histories. Tectonophysics. http://dx.doi.org/10.1016/j.tecto.2015.03.017.

Dunlop, D.J., 2002. Theory and application of the Day plot (Mrs/Ms versus Hcr/Hc) 2. Application to data for rocks, sediments, and soils. J. Geophys. Res. 107, 2057. http://dx.doi.org/10.1029/2001JB000487.

Elmore, R.D., Muxworthy, A.R., Aldana, M., 2012. Remagnetization and chemical alteration of sedimentary rocks. Geol. Soc. Lond., Spec. Publ. 371, 1-21. http://dx.doi. org/10.1144/SP371.15.

Ettaki, M., Ibouh, H., Chellaï, E.H., Milhi, 2007. Les structures "diapiriques" liasiques du Haut-Atlas central, Maroc: example de la ride d'Ikerzi. Africa Geosci. Rev. 14, 79-93.

Fadile, A., 2003. Carte géologique du Maroc à 1/100 000, feuille Imilchil. Notes Mém. Serv. géol. Maroc 397

Ferrer, O., Jackson, M.P.A., Roca, E., Rubinat, M., 2012. Evolution of salt structures during extension and inversion of the Offshore Parentis Basin (Eastern Bay of Biscay) Geol. Soc. Lond., Spec. Publ. 363, 361-379. http://dx.doi.org/10.1144/SP363.16.

Fisher, R., 1953. Dispersion on a sphere. Proc. R. Soc. A Math. Phys. Eng. Sci. 217, 295-305. http://dx.doi.org/10.1098/rspa.1953.0064.

Frizon de Lamotte, D., Zizi, M., Missenard, Y., Hadif, M., El Azzouzi, M., Maury, R.C., Charrière, A., Taki, Z., Benammi, M., Michard, A., Hafid, M., El Azzouzi, M., Maury, R.C., Charrière, A., Taki, Z., Benammi, M., Michard, A., 2008. The Atlas System. In: Michard, A., Saddiqi, O., Chalouan, A., Lamotte, D. de F. (Eds.), Continental Evolution: The Geology of Morocco. Lecture Notes in Earth Sciences, vol. 116. Springer, Berlin, Heidelberg, pp. 133-202. http://dx.doi.org/10.1007/978-3-54077076-3 4.

Fletcher, R.C., 1974. Wavelength selection in the folding of a single layer with power-law rheology. Am. J. Sci. 274, 1029-1043. http://dx.doi.org/10.2475/ajs.274.9.1029.

García-Lasanta, C., Casas-Sainz, A., Villalaín, J.J., Oliva-Urcia, B., Mochales, T., Speranza, F., 2017. Remagnetizations used to unravel large-scale fold kinematics: a case study in the Cameros basin (N Spain). Tectonics. http://dx.doi.org/10.1002/ 2016TC004459.

Giles, K.A., Lawton, T.F., 2002. Halokinetic sequence stratigraphy adjacent to the E Papalote diapir, Northeastern Mexico. Am. Assoc. Pet. Geol. Bull. 86, 823-840. http://dx.doi.org/10.1306/61EEDBAC-173E-11D7-8645000102C1865D.

Gomez, F., Beauchamp, W., Barazangi, M., 2000. Role of the Atlas Mountains (northwest Africa) within the African-Eurasian plate-boundary zone. Geology 28, 775. http://dx. doi.org/10.1130/0091-7613(2000)28<775:ROTAMN > 2.0.CO;2.

Hadri, M., 1997. Carte géologique du Maroc à 1/100 000, feuille Tinejdad. Notes Mém. Serv. géol. Maroc1 385.

Hailwood, E.a., Mitchell, J.G., 1971. Palaeomagnetic and radiometric dating results from Jurassic intrusions in South Morocco. Geophys. J. Int. 24, 351-364. http://dx.doi. org/10.1111/j.1365-246X.1971.tb02183.x.

Heitzmann, P., Stüder, M.A., 1990. Carte géologique du Maroc au 1/100000, feuille Tounfite. Notes Mém. Serv. géol. Maroc 357.

Henry, B., Rouvier, H., Le Goff, M., Smati, A., Hatira, N., Laatar, E., Mansouri, A., Perthuisot, V., 2000. Paleomagnetism as a structural polarity criterion: application to Tunisian diapirs. J. Struct. Geol. 22, 323-334. http://dx.doi.org/10.1016/S01918141(99)00155-8.

Henry, B., Rouvier, H., Le Goff, M., 2004. Using syntectonic remagnetizations for fold geometry and vertical axis rotation: the example of the Cévennes border (France) Geophys. J. Int. 157, 1061-1070. http://dx.doi.org/10.1111/j.1365-246X.2004. 02277.x.

Jackson, C.A.L., Lewis, M.M., 2016. Structural style and evolution of a salt-influenced rift basin margin; the impact of variations in salt composition and the role of polyphase extension. Basin Res. 28, 81-102. http://dx.doi.org/10.1111/bre.12099.

Jackson, M., Swanson-Hysell, N.L., 2012. Rock magnetism of remagnetized carbonate rocks: another look. Geol. Soc. Lond., Spec. Publ. 371, 229-251. http://dx.doi.org/ 10.1144/sp371.3.

Joussiane, R., 2016. Les relations entre diapirisme et sédimentation: Exemple du Jurassique moyen de la région d'Imilchil, Haut-Atlas central, Maroc. Université Bordeaux Montaigne.

Katz, B., Elmore, R.D., Cogoini, M., Engel, M.H., Ferry, S., 2000. Associations between burial diagenesis of smectite, chemical remagnetization, and magnetite authigenesis in the Vocontian trough, SE France. J. Geophys. Res. Solid Earth 105, 851-868. http://dx.doi.org/10.1029/1999JB900309.

Kent, J.T., 1982. The Fisher-Bingham distribution on the sphere. J. R. Stat. Soc. Ser. B 44
$71-80$.

Kirschvink, J.L. 1980. The least-squares line and plane and the analysis of paleomagnetic data. Geophys. J. R. Astron. Soc. 62, 699-718. http://dx.doi.org/10.1111/j.1365246X.1980.tb02601.x.

Knight, K.B., Nomade, S., Renne, P.R., Marzoli, A., Bertrand, H., Youbi, N., 2004. The Central Atlantic Magmatic Province at the Triassic-Jurassic boundary: paleomagnetic and ${ }^{40} \mathrm{Ar} /{ }^{39} \mathrm{Ar}$ evidence from Morocco for brief, episodic volcanism. Earth Planet. Sci. Lett. 228, 1-2.

Kocher, T., Schmalholz, S.M., Mancktelow, N.S., 2006. Impact of mechanical anisotropy and power-law rheology on single layer folding. Tectonophysics 421, 71-87. http:// dx.doi.org/10.1016/j.tecto.2006.04.014.

Laville, E., Piqué, A., 1992. Jurassic penetrative deformation and Cenozoic uplift in the Central High Atlas (Morocco): a tectonic model. Structural and orogenic inversions. Geol. Rundsch. 81, 157-170. http://dx.doi.org/10.1007/BF01764546.

Leonhardt, R., 2006. Analyzing rock magnetic measurements: the RockMagAnalyzer 1.0 software. Comput. Geosci. 32, 1420-1431.

Martín-Martín, J.D., Vergés, J., Saura, E., Moragas, M., Messager, G., Baqués, V., Razin, P., Grélaud, C., Malaval, M., Joussiaume, R., Casciello, E., Cruz-Orosa, I., Hunt, D.W., 2017. Diapiric growth within an Early Jurassic rift basin: the Tazoult salt wall (central High Atlas, Morocco). Tectonics 36, 2-32. http://dx.doi.org/10.1002/ 2016 TC004300.

Mattauer, M., Tapponnier, P., Proust, F., 1977. Sur les mecanismes de formation des chaines intracontinentales; l'exemple des chaines atlasiques du Maroc. Bull. Soc. Geol. Fr. S7-XIX, 521-526. http://dx.doi.org/10.2113/gssgfbull.S7-XIX.3.521.

Malaval, M., 2016. Enregistrement sédimentaire de l'activité diapirique associée à la ride du Jbel Azourki. Haut-Atlas Central, Maroc. In: Enregistrement sédimentaire de l'activité diapirique associée à la ride du Jbel Azourki. Haut-Atlas Central, Maroc.

Michard, A., 1976. Eléments de gélogie marocaine. Notes Mém. Serv. Géol. Maroc 252 (408 pp.).

Michard, A., Ibouh, H., Charrière, A., 2011. Syncline-topped anticlinal ridges from the High Atlas: a Moroccan conundrum, and inspiring structures from the Syrian Arc. Israel. Terra Nov. 23, 314-323. http://dx.doi.org/10.1111/j.1365-3121.2011. 01016.x.

Milhi, A., 1997. Carte géologique du Maroc à 1/100 000, feuille Tinghir. Notes Mém. Serv. géol. Maroc 377.

Moragas, M., Vergés, J., Saura, E., Martín-Martín, J.-D., Messager, G., Merino-Tomé, Ó. Suárez-Ruiz, I., Razin, P., Grélaud, C., Malaval, M., Joussiaume, R., Hunt, D.W., 2016. Jurassic rifting to post-rift subsidence analysis in the Central High Atlas and its relation to salt diapirism. Basin Res. 1-27. http://dx.doi.org/10.1111/bre.12223.

Moussaid, B., Villalaín, J.J., Casas-Sainz, A., El Ouardi, H., Oliva-Urcia, B., Soto, R, Román-Berdiel, T., Torres-López, S., 2015. Primary vs. secondary curved fold axes: deciphering the origin of the Ait Attab syncline (Moroccan High Atlas) using paleomagnetic data. J. Struct. Geol. 70, 65-77. http://dx.doi.org/10.1016/j.jsg.2014.11. 004.

Roca, E., Beamud, E., Rubinat, M., Soto, R., Ferrer, O., 2013. Paleomagnetic and inner diapiric structural constraints on the kinematic evolution of a salt-wall: the BicorbQuesa and northern Navarrés salt-wall segments case (Prebetic Zone, SE Iberia). J. Struct. Geol. 52, 80-95. http://dx.doi.org/10.1016/j.jsg.2013.04.003.

Santolaria, P., Vendeville, B.C., Graveleau, F., Soto, R., Casas-Sainz, A., 2015. Double evaporitic décollements: influence of pinch-out overlapping in experimental thrust wedges. J. Struct. Geol. 76, 35-51. http://dx.doi.org/10.1016/j.jsg.2015.04.002.

Saura, E., Vergés, J., Martín-Martín, J.D., Messager, G., Moragas, M., Razin, P., Grélaud, C., Joussiaume, R., Malaval, M., Homke, S., Hunt, D.W., 2014. Syn- to post-rift diapirism and minibasins of the Central High Atlas (Morocco): the changing face of a mountain belt. J. Geol. Soc. Lond. 171, 97-105. http://dx.doi.org/10.1144/jgs2013079 .

Schaer, J.P., 1987. Evolution and structure of the High Atlas of Morocco. In: Schaer, J.P., Rodgers, J. (Eds.), The Anatomy of Mountain Ranges. Princeton University Press, pp. $107-128$.

Shipunov, S.V., 1997. Synfolding magnetization: detection, testing and geological applications. Geophys. J. Int. 130, 405-410. http://dx.doi.org/10.1111/j.1365-246X. 1997.tb05656.x.

Soto, R., Villalaín, J.J., Casas-Sainz, A.M., 2008. Remagnetizations as a tool to analyze the tectonic history of inverted sedimentary basins: a case study from the BasqueCantabrian basin (north Spain). Tectonics 27, TC1017. http://dx.doi.org/10.1029/ 2007TC002208.

Soto, R., Casas-Sainz, A.M., Villalain, J.J., 2011. Widespread Cretaceous inversion event in northern Spain: evidence from subsurface and palaeomagnetic data. J. Geol. Soc. Lond. 168, 899-912. http://dx.doi.org/10.1144/0016-76492010-072.

Tauxe, L., Watson, G.S., 1994. The fold test: an eigen analysis approach. Earth Planet. Sci. Lett. 122, 331-341. http://dx.doi.org/10.1016/0012-821X(94)90006-X.

Tauxe, L., Shaar, R., Jonestrask, L., Swanson-Hysell, N.L., Minnett, R., Koppers, A.A.P., Constable, C.G., Jarboe, N., Gaastra, K., Fairchild, L., 2016. PmagPy: software package for paleomagnetic data analysis and a bridge to the Magnetics Information Consortium (MagIC) Database. Geochem. Geophys. Geosyst. 17, 2450-2463. http:// dx.doi.org/10.1002/2016GC006307.

Teixell, A., Arboleya, M.-L., Julivert, M., Charroud, M., 2003. Tectonic shortening and topography in the central High Atlas (Morocco). Tectonics 22, 1051. http://dx.doi. org $/ 10.1029 / 2002$ TC001460.

Teixell, A., Barnolas, A., Rosales, I., Arboleya, M.-L., 2017. Structural and facies architecture of a diapir-related carbonate minibasin (lower and middle Jurassic, High Atlas, Morocco). Mar. Pet. Geol. 81, 334-360. http://dx.doi.org/10.1016/j. marpetgeo.2017.01.003.

Torres-López, S., Villalaín, J.J., Casas, A.M., EL Ouardi, H., Moussaid, B., Ruiz-Martínez, V.C., 2014. Widespread Cretaceous secondary magnetization in the High Atlas (Morocco). A common origin for the Cretaceous remagnetizations in the western 
Tethys? J. Geol. Soc. Lond. 171, 673-687. http://dx.doi.org/10.1144/jgs2013-107. Torres-López, S., Casas, A.M., Villalaín, J.J., El Ouardi, H., Moussaid, B., 2016. PreCenomanian vs. Cenozoic folding in the High Atlas revealed by palaeomagnetic data. Terra Nova 28, 110-119. http://dx.doi.org/10.1111/ter.12197.

Torsvik, T.H., Van der Voo, R., Preeden, U., Niocaill, C. Mac, Steinberger, B., Doubrovine, P.V., van Hinsbergen, D.J.J., Domeier, M., Gaina, C., Tohver, E., Meert, J.G.,

McCausland, P.J. a, Cocks, L.R.M., 2012. Phanerozoic polar wander, palaeogeography and dynamics. Earth-Sci. Rev. 114, 325-368. http://dx.doi.org/10.1016/j. earscirev. 2012.06.002

Vendeville, B.C., Jackson, M.P.A., 1992. The rise of diapirs during thin-skinned extension $\backslash$ rSpecial issue; salt tectonics. Mar. Pet. Geol. 9, 331-353. http://dx.doi.org/10 1016/0264-8172(92)90047-I.

Vergés, J., Moragas, M., Martín-Martín, J.D., Saura, E., Casciello, E., Razin, P., Grelaud, C., Malaval, M., Joussiame, R., Messager, G., Sharp, I., Hunt, D.W., 2017. Salt tectonics in the Atlas mountains of Morocco. Permo-Triassic Salt Prov. Eur. North Africa
Atl. Margins 563-579. http://dx.doi.org/10.1016/B978-0-12-809417-4.00027-6. Villalaín, J., Fernández-González, G., Casas, A.M., Gil-Imaz, A., 2003. Evidence of a Cretaceous remagnetization in the Cameros Basin (North Spain): implications for basin geometry. Tectonophysics 377, 101-117. http://dx.doi.org/10.1016/j.tecto. 2003.08.024

Villalaín, J.J., Casas-Sainz, A.M., Soto, R., 2016. Reconstruction of inverted sedimentary basins from syn-tectonic remagnetizations. A methodological proposal. Geol. Soc. Lond., Spec. Publ. 425, 233-246. http://dx.doi.org/10.1144/SP425.10.

Waldhör, M., Appel, E., 2006. Intersections of remanence small circles: new tools to improve data processing and interpretation in palaeomagnetism. Geophys. J. Int. 166, 33-45. http://dx.doi.org/10.1111/j.1365-246X.2006.02898.x.

Weinberger, R., Agnon, A., Ron, H., 1997. Paleomagnetic reconstruction of a diapir emplacement: a case study from Sedom diapir, the Dead Sea Rift. J. Geophys. Res. 102, 5173-5192. 


\section{Paleomagnetic and magnetic fabric study of the Jurassic gabbros from the Central High Atlas}

7.1 Restitución estructural por medio de direcciones paleomagnéticas en un cuerpo de gabro (macizo de Tirrhist, Alto Atlas Central, Marruecos) / Structural restoration using paleomagnetic directions in a gabro body (Tirrhist Massif, Central High Atlas, Morocco).

7.2 Emplacement and Deformation of Mesozoic Gabbros of the High Atlas (Morocco): Paleomagnetism and Magnetic Fabrics 

In the core of most of the anticlines of the Central High Atlas crop out Jurassic gabbros in different proportions with Triassic rocks (both basalts and evaporites and shales). The amount of gabbros is specially important in the structures located between Tasraft, Imilchil and Anemzi, limiting by the south the depocenter of the basin.

The first and only paleomagnetic work focused in the Jurassic gabbros was carried by Hailwood and Mitchell (1971), who tried to obtain paleopoles from the NE of Africa. However, the scatter that they observed in the paleomagnetic directions did not allow their use for that purpose. Here, gabbros from five anticlines are studied analyzing the scatter in the paleomagnetic directions and trying to understand the deformational event responsible for it. After that, once the rotation path followed by the original to the present day paleomagnetic directions is known, the magnetic fabrics are also restored. Then, paleomagnetic directions are used to analyze the deformation events recorded in the core of the anticlines and the magnetic fabrics can give clues about the emplacement mechanism of the gabbros and therefore their influence in the formation of the anticlines. 



\title{
Restitución estructural por medio de direcciones paleomagnéticas en un cuerpo de gabro (macizo de Tirrhist, Alto Atlas central, Marruecos)
}

\author{
Structural restoration using paleomagnetic directions in a gabbro body (Tirrhist Massif, Central High Atlas, Morocco) \\ Pablo Calvín ${ }^{1}$, Vicente C. Ruíz-Martínez², Juan J. Villalaín ${ }^{1}$, Bennacer Moussaid ${ }^{3}$ y Hmidou El Ouardi \\ ${ }^{1}$ Departamento de Física, Escuela Politécnica Superior, Universidad de Burgos. Avda. Cantabria s/n, 09006 Burgos, España. pcalvin@ubu.es, villa@ubu.es \\ 2 Departamento de Geofísica y Meteorología, Facultad de Física, Universidad Complutense de Madrid. Avda. Complutense s/n, 28040 Madrid, España. vcarlos@fis.ucm.es \\ ${ }^{3}$ Département de Géologie, Faculté des Sciences, Université Moulay Ismail, BP. 11201 Zitoune, Meknès, Marruecos. bnmous@hotmail.fr, hmidouelouardi@yahoo.fr
}

\begin{abstract}
The origin of the anticlines of the Central High Atlas (Morocco) is still debated due to the different processes involved in their formation. We show a paleomagnetic study in the Tirrhist anticline developed in Middle Jurassic gabbro bodies (8 sites). Principal component analysis led to the isolation of the characteristic remanent magnetization (ChRM) that shows low to intermediate coercivities and unblocking temperatures of $565^{\circ} \mathrm{C}$ and is carried by magnetite. The corresponding site-mean directions (with statistical parameters useful for tectonic purposes in most of the sites) are dispersed according to a small circle around an E-W trending axis. Therefore, the ChRM is used to restore the structure of the anticline at the time of blocking of the magnetization, shedding light on post-emplacement tectonic processes and allowing us conclude that some of the actual deformation was originated before the moment of blocking the magnetization.
\end{abstract}

Key-words: Paleomagnetism, horizontal-axis rotations, Central High Atlas, gabbro, Jurassic.

\section{RESUMEN}

La estructuración de los anticlinales del Alto Atlas Central es todavía materia de debate, debido principalmente a que son resultado de diferentes procesos. En este trabajo presentamos un estudio paleomagnético en el anticlinal de Tirrhist, desarrollado en gabros emplazados durante el Jurásico Medio (8 estaciones). El análisis de componentes principales ha permitido aislar la magnetización remanente característica en 5 de las 8 estaciones, que muestran coercitividades bajas a intermedias y temperaturas máximas de bloqueo de $565^{\circ} \mathrm{C}$, siendo portada por magnetita. Las direcciones medias obtenidas de cada estación muestran una distribución a lo largo de un círculo menor de eje horizontal y de dirección E-W. Dicha distribución se interpreta en términos estructurales, usando dichas direcciones para restituir la estructura del anticlinal al momento del bloqueo de la magnetización estudiada y permitiéndonos concluir que parte de la deformación que se observa en la actualidad es previa al bloqueo de la magnetización.

Palabras clave: Paleomagnetismo, rotación de eje horizontal, Alto Atlas central, gabro, Jurásico.

\section{Introducción}

La evolución tectónica de la cordillera del Alto Atlas Central (Marruecos; Fig. 1) es compleja y ampliamente discutida. La estructura de esta cadena está caracterizada por una serie de anticlinales apretados ENE-WSW que limitan amplios sinclinales. Clásicamente, la cordillera del Atlas se considera resultado de la inversión tectónica durante el Cenozoico de una cuenca mesozoica intraplaca (Mattauer et al. 1977; Frizon de Lamotte et al., 2008 y referencias allí incluidas). Sin embargo, Torres-López et al. (2012) han puesto de manifiesto, mediante la restitución de una remagnetización cretácica que afecta a las rocas jurásicas del Alto Atlas (Torres-López et al., 2014, 2015), que los anticlinales que surcan la cordillera se encontraban estructura- dos al menos hace $100 \mathrm{Ma}$. Saura et al. (2014) observan relaciones tectono-sedimentarias en los materiales del Jurásico inferior y proponen la actividad de una tectónica salina que comenzaría a generar dichos anticlinales, produciendo altos sedimentarios que limitaban sub-cuencas. Por otro lado, Laville y Piqué (1992) proponen un evento de deformación temprana de carácter transpresivo, simultáneo a la intrusión de gran cantidad de rocas ígneas situadas en la actualidad en el núcleo de algunos de los anticlinales de la zona central de la cordillera. Este evento transpresivo sería el causante principal de la estructuración de los anticlinales, con desarrollo de foliación, asociada y limitada al entorno de dichos anticlinales con intrusiones ígneas. Por último, Michard et al. (2011) indican también la existencia de un diapirismo tardío, coetáneo a la deformación Cenozoica.

Mediante un análisis paleomagnético de los gabros situados en el núcleo de uno de estos anticlinales (Macizo de Tirrhist), tratamos de aportar nueva información que ayude a valorar la importancia de los diferentes procesos generadores de dichas estructuras.

\section{Contexto geológico del macizo de Tirrhist}

El magmatismo alcalino del Jurásico Medio está caracterizado por complejos intrusivos y flujos de lava basálticos (Frizon de Lamotte et al., 2008 y referencias allí incluidas). El magma intruyó a través de fracturas verticales y finalmente se emplazó a presiones aproximadas de 1,5 Kbar (Lhachmi et al., 

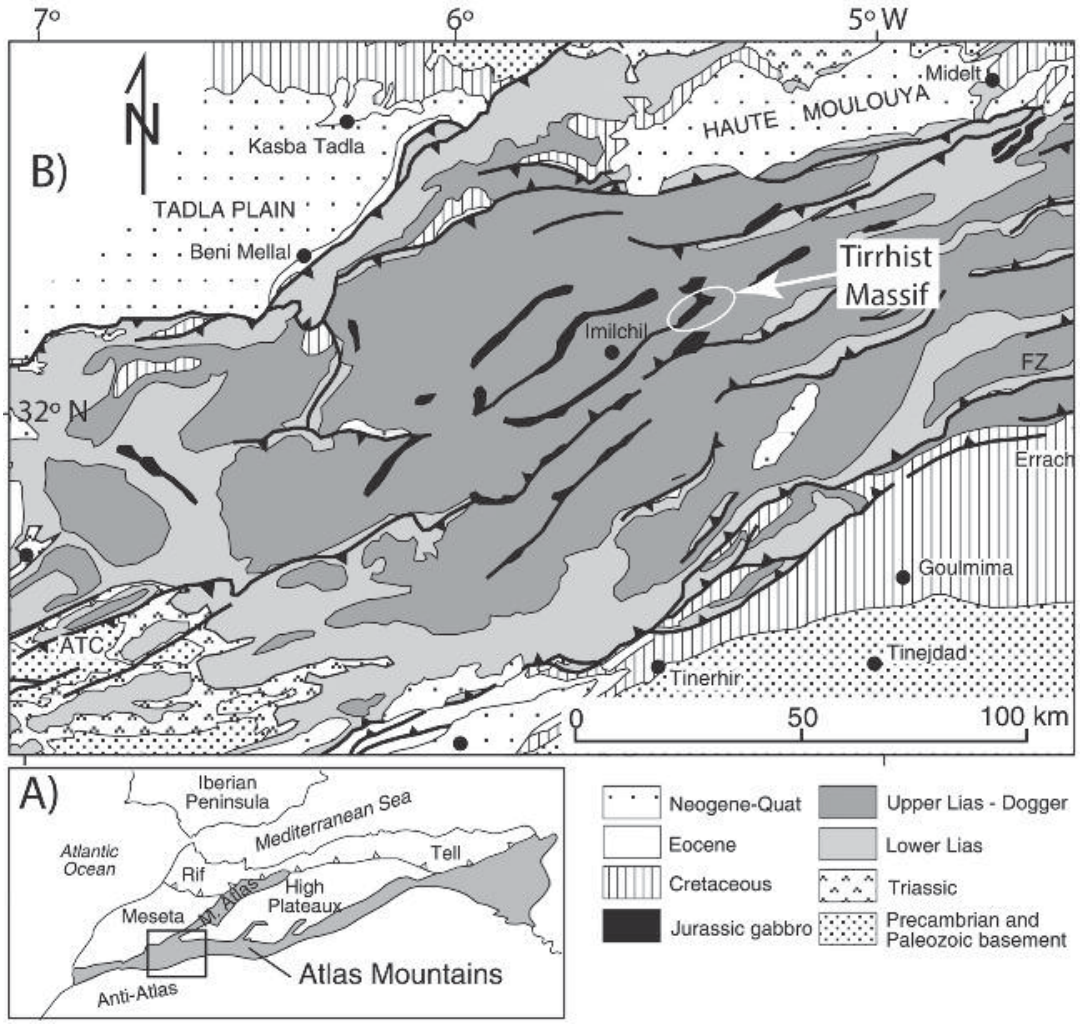

Fig. 1.- A) Situación del Alto Atlas Central. B) Mapa geológico del Alto Atlas Central mostrando la situación de los anticlinales NE-SW, en cuyo núcleo aparecen los cuerpos de gabros jurásicos. Modificado de Teixell et al. (2003).

Fig. 1.- A) Location of the Central High Atlas. B) Geological map of the Central High Atlas showing the NE-SW anticlines with Jurassic gabbro bodies in their core. Modified from Teixell et al. (2003).

2001), hace 145-160 Ma según dataciones K-Ar y Ar-Ar (Hailwood y Michael, 1971; Armando, 1999).

Actualmente, las rocas ígneas asociadas a este evento magmático, y concretamente los gabros que forman parte de la suite magmática (junto con otras rocas intermedias y ácidas), se encuentran en los núcleos de dichos anticlinales junto con materiales lutíticos y evaporíticos triásicos (Fig. 1). Es común el metamorfismo de contacto afectando a la roca encajante (Lhachmi et al., 2001).

Por otro lado, es interesante destacar un trabajo paleomagnético pionero realizado en los gabros, desarrollado con la finalidad de obtener un polo paleomagnético para el Jurásico en África (Hailwood y Michael, 1971). Además de las dataciones K-Ar de los gabros antes mencionadas, estos autores consideraban que los gabros estudiados portaban una magnetización primaria asociada a su enfriamiento. Dichas rocas habrían sufrido deformación como bloques rígidos debido a la tectónica que generó variaciones en la inclinación de las direcciones obtenidas en los cuerpos de gabros con respecto a las provenientes de los diques asociados. Las direcciones de los gabros fueron incluidas en el cálculo del polo jurásico tras una corrección tectónica de variaciones en la dirección de cada uno de los flancos del anticlinal. El flanco $S$ tiene orientación principalmente $\mathrm{E}-\mathrm{W}$, mientras que la parte occidental del flanco N es NE-SW y la oriental ESE-WNW (Fig. 2). El núcleo del anticlinal presenta una dirección principal NE-SW, paralelo al flanco NW, con cierta geometría sigmoidal. Dentro del núcleo se observan estructuras compresivas menores que pliegan las calizas triásico-jurásicas en dirección E-W o que superponen mediante fallas inversas diversos materiales contenidos en el núcleo. Las rocas ígneas intruyen rocas del Jurásico medio (Aaleniense-Bajociense) y están compuestas por un complejo máfico (troctolitas y gabros), que a su vez es intruido por rocas intermedias y ácidas tardías, emplazadas con posterioridad al complejo máfico pero siendo respuesta al mismo evento ígneo (Beraâouz y Bonin, 1993).

\section{Muestreo y análisis paleomagnéti- CO}

Para este trabajo se han muestreado 8 estaciones paleomagnéticas (Fig. 2) y en cada una de ellas se han obtenido 8 muestras mediante una perforadora de gasolina. Las muestras fueron orientadas in situ mediante un orientador solar y magnético y la desmagnetización de las mismas se llevó a cabo en el Laboratorio de Paleomagnetismo de la Universidad de Burgos usando el magnetómetro criogénico 2G 755 .

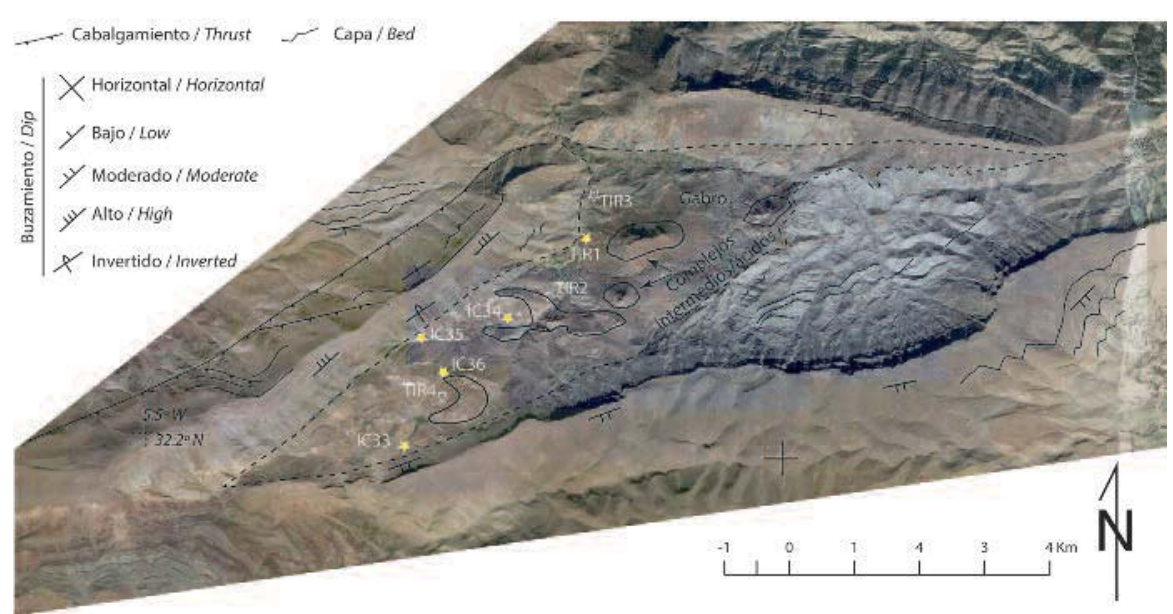

Fig. 2.- Imagen de satélite del anticlinal de Tirrhist mostrando la situación de las estaciones paleomagnéticas (estrellas rellenas representan las estaciones de las que se ha obtenido la dirección paleomagnética estable). Las líneas discontinuas indican el contacto entre el complejo ígneo y las calizas del Jurásico Medio; las líneas continuas indican el contacto entre las rocas intermedias/ácidas y los gabros. Nótese la presencia de tres flancos, y la orientación NE-SW del cuerpo ígneo, paralelo al flanco NW.

Fig. 2.- Satellite image of the Tirrhist anticline and location of the paleomagnetic sites (solid stars show the sites with a stable paleomagnetic component). The dashed lines are the contact between the igneous rocks and the Middle Jurassic limestones and the solid lines the contact between the intermediate/acid suite and the gabbro. Note the three limbs of the anticline, and the igneous body NESW parallel to NW limb. 


\section{IC34-08}
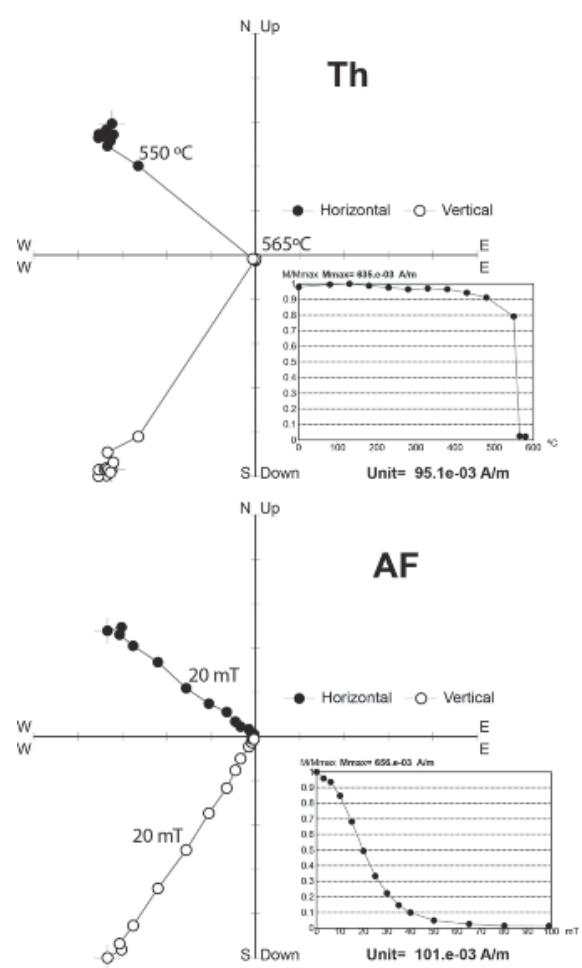

Fig. 3.- Diagramas de desmagnetización térmica (TH) y por campos alternos (AF) de la NRM de la muestra IC34-08.

Fig. 3.- Thermal (Th) and alternating field (AF) demagnetization of the IC34-08 sample.

Las muestras fueron sometidas a desmagnetización térmica y/o por campos alternos decrecientes (según el comportamiento de cada una de ellas). Tras el análisis magnético las componentes paleomagnéticas fueron calculadas usando técnicas de regresión lineal y la distribución de las direcciones fue determinada usando la estadística propuesta por Fisher (1953).

La desmagnetización progresiva de las muestras (Fig. 3) indica la presencia de una componente característica estable de alta temperatura de desbloqueo $\left(565^{\circ} \mathrm{C}\right.$ máximo) y de coercitividad baja/intermedia (20-100 mT). Además, se han realizado diversos experimentos de magnetismo de rocas (curvas termomagnéticas, ciclos de histéresis, adquisición progresiva de remanencia isotermal y curvas de back-fied), indicando de manera general la presencia de magnetita como mineral magnético dominante. Sin embargo, en algunas muestras, el comportamiento de las curvas de desmagnetización, así como los experimentos de magnetismo de rocas, parecen indicar la presencia de fases de óxido de hierro con cierto contenido de titanio, lo cual es esperable en este tipo de rocas con mineralogía magnética compleja. Según el estudio mineralógico de Beraâouz y Bonin (1993), el macizo plutónico de Tirrhist refleja diferentes fases evolutivas, con óxidos magmáticos como espinelas cromíferas, ilmenita y magnetita (y hematites en la paragénesis oxidada tardía). No obstante, la componente característica estable ha podido ser aislada en 5 de las 8 estaciones estudiadas.

Las direcciones calculadas para cada estación (Fig. 4A) muestran dispersión entre ellas y no coinciden con la dirección paleomagnética de referencia para el noroeste de África para el Mesozoico (obtenida a partir de Torsvik et al., 2012).

Las tres estaciones de las que no se ha podido aislar la componente característica muestran comportamientos heterogéneos y diferentes a los que muestran aquellas en las que sí ha sido posible aislarla. TIR3 se desmagnetiza completamente a $450^{\circ} \mathrm{C}$ y la componente calculada hasta ese valor de temperatura presenta valores de error elevados. TIR2 y TIR4 presentan una componente de alta temperatura, pero con gran dispersión entre las direcciones calculadas para las distintas muestras. Por tanto, estas diferencias en el comportamiento impiden que puedan usarse dado que no es posible asegurar que se trate de la misma magnetización.

\section{Interpretación de la componente característica}

Las direcciones paleomagnéticas muestran una notable dispersión, debida probablemente a deformación tectónica post-emplazamiento de las rocas ígneas, que presumiblemente también afecte a las rocas encajantes. Sin embargo, no han podido ser observadas relaciones claras entre los materiales ígneos muestreados y las rocas mesozoicas intruidas que aporten información sobre cómo restituir las direcciones paleomagnéticas halladas en los gabros, es decir, no conocemos el eje y la magnitud de rotación que han sufrido cada una de las estaciones analizadas. Sin embargo, cuando observamos la distribución de las direcciones paleomagnéticas in situ (Fig. 4A), podemos apreciar que ésta no es caótica, sino que se ajusta a un círculo menor con eje horizontal E-W en proyección estereográfica, que es la dispersión cónica que genera un vector cuando es rotado en torno a un eje (Villalaín et al., 2015). Así mismo, observamos que dicho círculo menor engloba la dirección paleomagnética del noroeste de África para 150 Ma (Fig. 4B), apoyando la hipótesis de que se trata de una componente primaria rotada según un eje horizontal de dirección E-W.

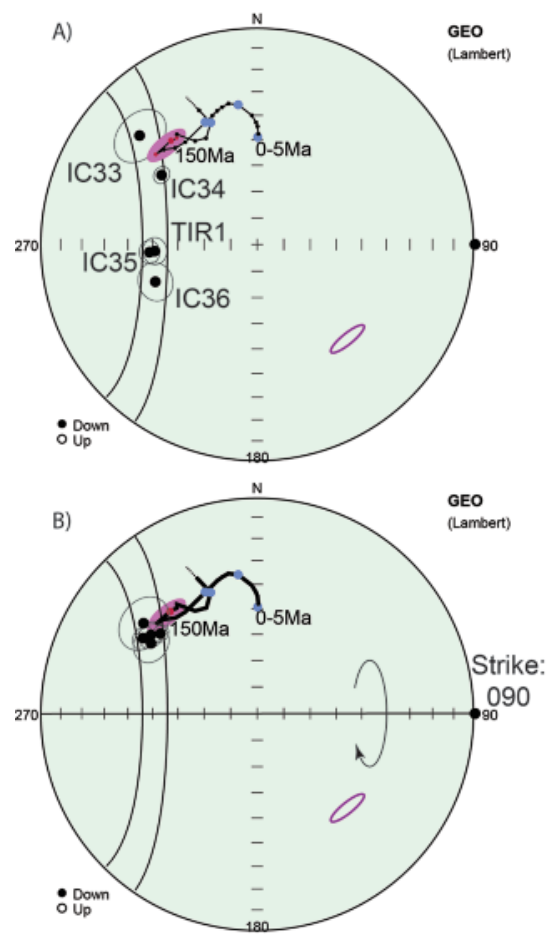

Fig. 4.- A) Proyección de las direcciones paleomagnéticas (puntos negros) y su error asociado. Se indican además las direcciones esperadas (puntos grises) para el Mesozoico y Cenozoico en el noroeste de África obtenidas a partir de la curva global de deriva polar aparente en coordenadas del NW de África (Torsvik et al., 2012). La elipse muestra la dirección esperada para la edad de la intrusión de los gabros en crones de polaridad normal (relleno) e inversa (sin relleno). Podemos observar que las cinco direcciones paleomagnéticas, así como la dirección esperada para el Jurásico medio, se encuentran agrupados en torno a un círculo menor de eje EW. B) Direcciones paleomagnéticas después de rotarlas mediante un eje horizontal E-W hasta la dirección de referencia jurásica. Nótese que todas las direcciones han de rotarse en sentido horario (mirando hacia el E) excepto IC33 que ha de rotarse en sentido anti-horario.

Fig. 4.- A) Stereoplot with the paleomagnetic directions (black points) and their associated errors. The expected directions (grey points) are also indicated for NW Africa according to the global apparent wander path in NW African coordinates (Torsvik et al., 2012). The ellipse shows the expected direction for the gabbro intrusion ages with normal (filled) and reversed (hollow) polarities. Note that the five sites directions and the Middle Jurassic expected direction lie on a small circle. B) Paleomagnetic directions after rotation along horizontal E-W axis to the Jurassic reference direction. Note that all directions were rotated in clockwise sense (looking to the E) except IC33, which was rotated in counterclockwise sense.

\section{Aplicación a la estructura y discu- sión}

Por tanto, a pesar de no conocer de manera directa la rotación que han sufrido los bloques de gabro después del registro de la mag- 
netización característica que estudiamos, podemos inferir a través del patrón de dispersión dicha deformación rotacional. Asimismo, vemos que es coherente con la dirección de la estructura del núcleo del anticlinal, así como con el flanco $S$ y la parte oriental del flanco N. Debido a la cercanía de las estaciones IC35 e IC33 a los flancos NW y S, respectivamente (Fig. 2), podemos rotar dichos flancos usando el eje y magnitud de rotación usados para sendas estaciones $\left(45^{\circ}\right.$ en sentido horario y $10^{\circ}$ en sentido anti-horario respectivamente). La estratificación del flanco N junto a IC35 presenta una orientación [241, 124] (acimut y buzamiento de la capa, según la regla de la mano derecha, es decir invertidas buzando $66^{\circ}$ al S), y tras realizar la rotación correspondiente a los gabros muestra una orientación [246,83]. Aplicando el mismo proceso al flanco $\mathrm{S}$, que presenta en la actualidad una menor inclinación, este pasa de presentar una orientación actual de $[081,37]$ a una paleo-orientación $[078,27]$. Si asumimos que los gabros y los materiales de los flancos se han movido de manera conjunta, podemos inferir la paleo-estructura del anticlinal para el momento de la fijación de la magnetización remanente en los gabros, es decir, poco después de su emplazamiento y enfriamiento. Dicha paleo-estructura, claramente asimétrica, presentaría un flanco NW en posición subvertical y dirección NE-SW, paralela al afloramiento actual de las rocas ígneas en el núcleo del anticlinal, y el flanco $S$ con valores de buzamiento inferiores a $30^{\circ}$. Extrapolando al flanco NE y dadas sus similitudes con el flanco $S$ en cuanto orientación e inclinación, posiblemente se encontraría también con buzamientos bajos.

La similitud en orientación entre el flanco NW, su elevado paleo-buzamiento y la disposición paralela con los afloramientos de rocas ígneas, apoyan que parte de dicha deformación sea simultánea al emplazamiento de los cuerpos ígneos; la clara directriz estructural NE-SW tanto del flanco NW como del afloramiento de rocas ígneas, sugieren que el ascenso de las rocas ígneas se favoreciese por medio de una falla de basamento de la misma dirección. Sin embargo, tal y como evidencian Saura et al. (2014), las relaciones tectono-sedimentarias presentes alrededor de estos anticlinales (onlaps, abanicos de capas, etc.) afectando a los materiales del Jurásico inferior, evidencian que parte de la deformación es previa al emplazamiento de las rocas ígneas, siendo originada por procesos halocinéticos que elevaron las zonas centrales de los anticlinales. Sin embargo, en la actualidad no nos es posible determinar la importancia de cada proceso en la deformación de las rocas encajantes. En todo caso, dado que tanto los flan$\cos S$ y NE, como las estructuras encontradas en el núcleo y la rotación de los gabros indican una directriz estructural E-W, la disposición del flanco NW según la dirección NE-SW es heredada. Por todo ello, y asumiendo que las rocas encajantes del NW y las rocas ígneas se han movido de manera conjunta, puede excluirse que el elevado buzamiento de dicho flanco sea debido a un basculamiento posterior a la adquisición de la magnetización y probablemente también a la intrusión.

No obstante, para corroborar que las rocas ígneas se han movido de manera conjunta a las rocas sedimentarias que conforman el anticlinal, es necesario realizar un análisis paleomagnético en las rocas encajantes como el realizado por Torres-López et al. (2012), en el que se restituye la remagnetización cretácica que también podría afectar a esta área.

\section{Conclusiones}

El análisis paleomagnético de los gabros situados en el núcleo del anticlinal de Tirrhist ha permitido aislar una componente característica en 5 de las 8 estaciones estudiadas. Estas cinco estaciones paleomagnéticas muestran un comportamiento magnético homogéneo, y la señal paleomagnética es portada por magnetita.

Las direcciones muestran una distribución que se agrupa en un círculo menor, indicando la rotación diferencial de las mismas en torno a un eje horizontal de dirección E-W. La comparación de las direcciones con la dirección esperada para el Jurásico Medio-Superior en esta región de África permite valorar la magnitud de la rotación que han sufrido los distintos afloramientos. La dirección del eje de rotación, E-W, es coherente con las direcciones estructurales encontradas en el núcleo del anticlinal; por el contrario, la disposición oblicua del flanco NW se debe a una dirección heredada, formada con anterioridad a que las rocas ígneas se enfriasen por debajo de la temperatura de bloqueo de la magnetita.

\section{Agradecimientos}

Este trabajo de investigación ha sido financiado mediante el proyecto CGL201238481 de la Dirección General de Investigación Científica y Técnica, Ministerio de Economía y Competitividad y fondos FEDER de la Unión Europea. Pablo Calvín disfruta de una beca FPI del Ministerio de Economía y Competitividad del Gobierno de España. Agradecemos encarecidamente el trabajo aportado por Antonio Casas Sainz, ayudando a la maduración de este trabajo. Así mismo, agradecemos los comentarios de dos revisores anónimos, que han enriquecido este trabajo.

\section{Referencias}

Armando, G. (1999). Intracontinental alkaline magmatism: geology, mineralogy and geochemistry of the Jbel Hayim massif (central High Atlas-Morocco). Mémories Geologiques Lausanne 31, $108 \mathrm{p}$.

Beraâouz, E.H. y Bonin, B. (1993). Comptes Rendus Académie des Sciences 317, 647-653.

Fisher, R.A. (1953). Society of London, Series A, 217, 295-305.

Frizon de Lamotte, Zizi, M., Missenard, Y., Hafid, M., El Azzouzi, M., Maury, R.C., Charrière, A., Taki, Z., Benami, M. y Michard, A. (2008). En: Continental evolution: The Geology of Morocco (A. Michard, O. Saddiqui, A. Chalouan, D. Frizon de Lamotte, Eds.). Lecture Notes in Earth Sciences 116, 133-202.

Hailwood, E.A. y Mitchell, J.C. (1991). Geophysics Journal Royal Astrophysics Society 24, 351364.

Laville, E. y Piqué, A. (1992). Geologische Rundshau 81, 157-170.

Lhachmi, A., Lorand, J.P. y Fabries, J. (2001). Journal of African Earth Sciences 32, 741-764.

Mattauer, M., Tapponier, P. y Proust, F. (1977). Bulletin de la Societé Géologique de France 19, 521-526.

Michard, A., Ibouh, H. y Charrière, A. (2011). Terra Nova 23, 314-323.

Saura, E., Vergés, J., Martín-Martín, J.D., Messager, G., Moragas, M., Razin, P., Grélaud, C., Joussiaume, R., Malaval, M., Hornke, S. y Hunt, D.W. (2014). Journal of the Geological Society, London 171, 97-105.

Teixell, A., Arboleya, M.L. y Julivert, M. (2003). Tectonics 22, 1051.

Torres-López, S., Villalaín, J.J., Casas, A., El Ouardi, H., Moussaid, B. y Ruíz-Martínez, V.C. (2012). En: Contributions to Geophysics and Geodesy, Special Issue, 116-117.

Torres-López S., Villalaín, J.J., Casas, A., El Ouardi, H., Moussaid B. y Ruiz-Martínez V.C. (2014). Journal of the Geological Society, London 171, 673-687.

Torres-López, S., Villalaín, J.J., Casas, A., El Ouardi, H., Moussaid, B. y Ruíz-Martínez, V.C. (2015). Geogaceta 57, 23-26.

Torsvick, T.H., Van der Voo, R., Preeden, U., Mac Niocaill, C., Steinberger, Doubrovine, P.V., van Hinsbergen, D.J.J., Domeier, M., Gaina, C., Tohver, R., Meert, J.G., McCausland, P.J.A. y Cocks, L.R.M. (2012). Earth-Science Reviews 114, 325-368.

Villalaín, J.J., Casas-Sainz, A.M. y Soto, R. (2015). En: Paleomagnetism in Fold and Thrust Belts: New Perspectives (E.L. Pueyo, F. Cifelli, A.J. Sussman, B. Oliva-Urcía, Eds.). London, Geological Society, Special Publications, 425. 


\section{QAGUPUBLICATIONS}

\section{Tectonics}

\section{RESEARCH ARTICLE \\ 10.1002/2017TC004578 \\ Key Points: \\ - A novel approach to restore paleomagnetic data from deformed igneous rocks is described \\ - New paleomagnetic and magnetic fabric data from Jurassic gabbros of NW Africa are provided \\ - This study allows a better and more complete constraint of the deformational history of the central High Atlas}

Supporting Information:

- Supporting Information S1

- Table S1

- Table S2

- Table S3

- Table S4

- Table S5

- Table S6

Correspondence to:

P. Calvín,

calvinballester@gmail.com

\section{Citation:}

Calvín, P., Ruiz-Martínez, V. C., Villalaín J. J., Casas-Sainz, A. M., \& Moussaid, B. (2017). Emplacement and deformation of Mesozoic gabbros of the High Atlas (Morocco): Paleomagnetism and magnetic fabrics. Tectonics, 36. https:// doi.org/10.1002/2017TC004578

Received 22 MAR 2017

Accepted 20 NOV 2017

Accepted article online 24 NOV 2017

(2)17. American Geophysical Union. All Rights Reserved.

\section{Emplacement and Deformation of Mesozoic Gabbros of the High Atlas (Morocco): Paleomagnetism and Magnetic Fabrics}

\author{
P. Calvín ${ }^{1}$, V. C. Ruiz-Martínez ${ }^{2}$ (D, J. J. Villalaín ${ }^{1}$ (D, A. M. Casas-Sainz ${ }^{3}$ (D), and B. Moussaid ${ }^{4}$ \\ ${ }^{1}$ Departamento de Física, Universidad de Burgos, Burgos, Spain, ${ }^{2}$ Departamento de Física de la Tierra, Astronomía y \\ Astrofísica, Universidad Complutense de Madrid, Madrid, Spain, ${ }^{3}$ Geotransfer, IUCA, Universidad de Zaragoza, Zaragoza, \\ Spain, ${ }^{4}$ Lab. «BGIM», Ecole Normale Supérieure, Université Hassan II, Casablanca, Morocco
}

\begin{abstract}
A paleomagnetic and magnetic fabric study is performed in Upper Jurassic gabbros of the central High Atlas (Morocco). These gabbros were emplaced in the core of preexisting structures developed during the extensional stage and linked to basement faults. These structures were reactivated as anticlines during the Cenozoic compressional inversion. Gabbros from 19 out of the 33 sampled sites show a stable characteristic magnetization, carried by magnetite, which has been interpreted as a primary component. This component shows an important dispersion due to postemplacement tectonic movements. The absence of paleoposition markers in these igneous rocks precludes direct restorations. A novel approach analyzing the orientation of the primary magnetization is used here to restore the magmatic bodies and to understand the deformational history recorded by these rocks. Paleomagnetic vectors are distributed along small circles with horizontal axes, indicating horizontal axis rotations of the gabbro bodies. These rotations are higher when the ratio between shales and gabbros in the core of the anticlines increases. Due to the uncertainties inherent to this work (the igneous bodies recording strong rotations), interpretations must be qualitative. The magnetic fabric is carried by ferromagnetic (s.s.) minerals mimicking the magmatic fabric. Anisotropy of magnetic susceptibility (AMS) axes, using the rotation routine inferred from paleomagnetic results, result in more tightly clustered magnetic lineations, which also become horizontal and are considered in terms of magma flow trend during its emplacement: NW-SE (parallel to the general extensional direction) in the western sector and NE-SW (parallel to the main faults) in the easternmost structures.
\end{abstract}

\section{Introduction}

Paleomagnetism has been extensively applied in gabbros and other related mafic rocks because the primary, stable characteristic magnetization (Denyszyn et al., 2013; Feinberg et al., 2005; Renne et al., 2002) carried by these rocks can be complemented with reliable absolute dating. Different studies have been focused on obtaining paleopoles (Brown \& McEnroe, 2015; Denyszyn et al., 2013; Dunlop et al., 1985; Evans \& McElhinny, 1966; McEnroe, 1996; Osete et al., 1997; Van der Voo, 1967, 1969 among others), paleointensities (Granot et al., 2007; Muxworthy et al., 2013), and magnetic properties characterizing the stability of the magnetic remanence (Usui \& Yamazaki, 2010). In the last years, detailed magnetic studies have targeted on magnetite included within silicate crystals (mainly pyroxene and plagioclase), generated during the solidification of magma and preserving the primary magnetization acquired when magnetite is cooled below its Curie temperature (Evans et al., 1968; Feinberg et al., 2005, 2006; Muxworthy \& Evans, 2013; Renne et al., 2002; Usui et al., 2014; Wenk et al., 2011).

Magnetic fabrics have also been analyzed in order to explore in a quick and reliable manner the petrofabric of plutonic rocks for determining (i) the strain regime at the time of magma emplacement or during subsequent stages after magma solidification or (ii) the flow pattern in magmatic chambers (Archanjo et al., 2012; Bouchez, 1997, 2000; Bouchez \& Gleizes, 1995; Gil et al., 2002; McNulty et al., 2000; Román-Berdiel et al., 2004, and references therein). Petrofabric and magnetomineralogic studies include typically room temperature anisotropy of the magnetic susceptibility (RT-AMS=, low-temperature anisotropy of the magnetic susceptibility (LT-AMS), anisotropy of the anhysteretic remanent magnetization (AARM), and anisotropy of the isothermal remanent magnetization (AIRM). The combined used of these techniques supports the interpretation of magnetic fabrics (Izquierdo-Llavall et al., 2012; Oliva-Urcia et al., 2012; Schöpa et al., 2015; Usui et al., 2006, and references therein). 


\section{QAGU Tectonics}

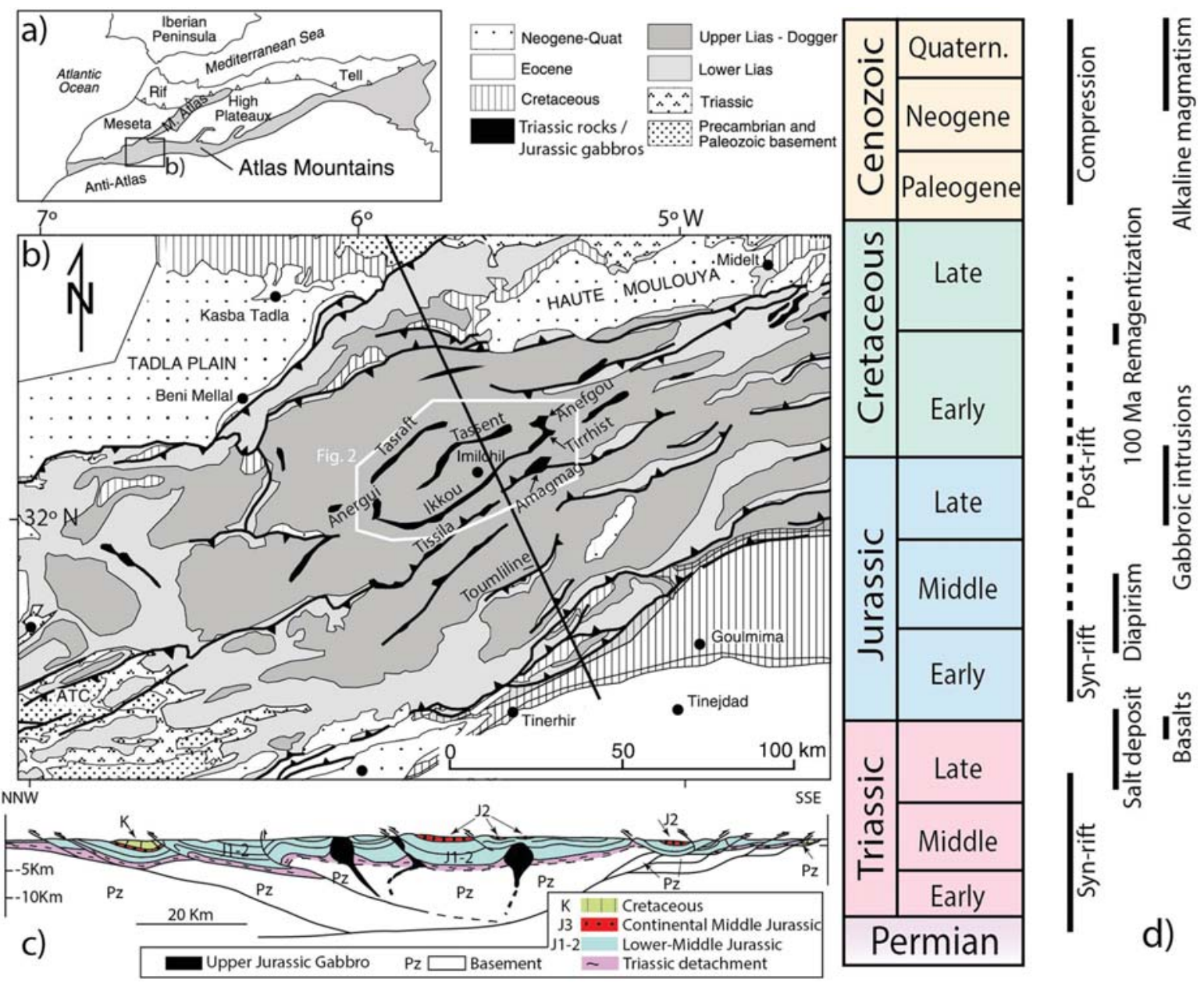

Figure 1. (a) Location sketch map of the Atlas Mountains in the Western Mediterranean framework and (b) geological map of the central High Atlas showing the position of the study area (Figure 2) and the main structures of the region. (c) Geological cross section of the central High Atlas showing the Jurassic gabbro intrusions. Figures $1 \mathrm{a}$ and $1 \mathrm{~b}$ were modified from Teixell et al. (2003), and Figure 1c was modified from Poisson et al. (1998). (d) Simplified temporal evolution of the main geological events occurred in the CHA.

In spite of their spectacular outcrops, the gabbros of the central High Atlas (CHA) have not been yet explored from the paleomagnetic point of view, apart from a pioneering work in the early seventies (Hailwood \& Mitchell, 1971).

The Atlas System (Figure 1a) has been classically considered as an intracontinental chain, resulting from the Cenozoic inversion of Mesozoic extensional basins (Frizon de Lamotte et al., 2008; Mattauer et al., 1977, and references therein). Its main structural features are tight anticlines (named classically as "ridges" in the literature) with steeply dipping limbs limiting wide, gentle synclines (Figure 1b). In the core of some of these ridges, Upper Jurassic gabbros crop out. Changes in the general trend of the structures, from ENE-WSW to NE-SW, define sigmoidal shapes in map view (e.g., Tassent ridge, Figures $1 \mathrm{~b}$ and 2). This fact has generated controversies about the timing and mechanism of formation of the anticlines. The three main mechanisms proposed are (i) superposition of different tectonic phases with different stress axes (de Sitter, 1952), (ii) sinistral transpression during the Jurassic (Laville \& Piqué, 1992), and (iii) tectonic control from inherited extensional faults (Beauchamp, 2004). In the last years, further studies have helped to clarify the origin of the ridges. Ettaki et al. (2007), Michard et al. (2011), and Saura et al. (2014) evidenced the occurrence of an early diapirism during the Jurassic that individualized sedimentary depocenters between narrow thresholds (the present-day ridges). By means of detailed paleomagnetic studies performed in Jurassic remagnetized limestones at the limbs of the anticlines, Torres-López et al. (2016) demonstrated that these anticlines were already structured before the Late Cretaceous. Regarding the superposition of different 


\section{QAGU Tectonics}
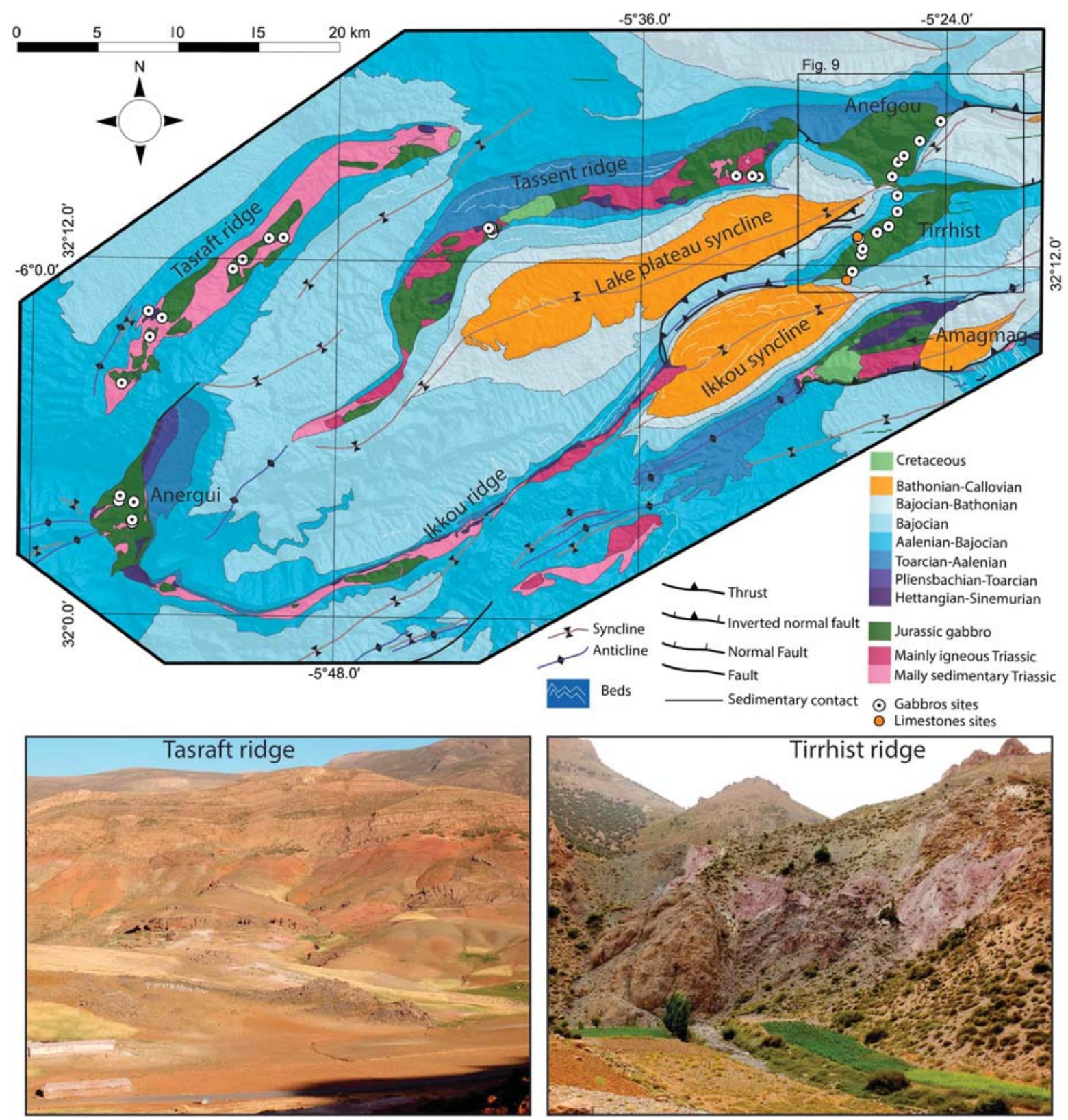

Figure 2. Detailed geological map of the study area showing the gabbro outcrops and the paleomagnetic sites. Datum WGS84 (EPSG: 4326$)$. Pictures of the general outcrops in Tasraft and Tirrhist ridges. The Tasraft picture shows in the foreground the core of the ridge, with the gabbros (the dark rocks in the middle of the picture) and the Triassic shales and basalts (with reddish and greenish tones, respectively); in the background appears the Jurassic limestones. In the Tirrhist picture can be observed the tectonic relationship between the gabbros (the dark rocks in the middle of the picture), the Triassic shales, and the Jurassic limestones.

sets of folds during the Cenozoic compression, Moussaid et al. (2015) showed through a paleomagnetic study that the curvature of the Ait Attab syncline is primary, probably related to the orientation of Mesozoic extensional structures. Michard et al. (2011) indicate the presence of a late diapiric phase (Cenozoic) affecting the core of the anticlines.

In summary, the CHA ridges are structures inherited from the Mesozoic extensional stage, initially formed as straight, long diapirs (salt walls) and conditioned by the structural pattern of the basement (Charrière, 1990; Mattauer et al., 1977). These salt walls acted as sedimentary highs between Jurassic sedimentary depocenters (Ettaki et al., 2007; Saura et al., 2014), and some of these anticlines already presented steeply dipping limbs during the Cenomanian age (Torres-López et al., 2016). 
In this paper, paleomagnetic, magnetic fabrics, and rock magnetism studies are presented in order to decipher the processes occurring at the core of the ridges of the CHA. On one hand, (1) directional analysis of paleomagnetic vectors can give information about the postemplacement rotations of the igneous bodies. On the other hand (2), magnetic fabrics can allow to characterize the tectonic regime under which the gabbros were emplaced and/or the processes related to magma ascent.

\section{The Ridges of the Central High Atlas}

\subsection{Geological Setting}

Detailed syntheses about the Mesozoic evolution of the CHA can be found in Frizon de Lamotte et al. (2008), Ibouh et al. (2014), and Saura et al. (2014, and references therein). Mesozoic sedimentation began with Triassic continental clastic sediments and evaporites during the first rifting stage, in a horst-graben system controlled by NE-SW normal faults. These series are topped by Triassic-Jurassic basalts. During the second rifting stage (Early-Middle Jurassic) faults were reactivated, and more than 5,000 $\mathrm{m}$ of Jurassic marine sediments accumulated in the depocenters until the end of Bajocian times (Frizon de Lamotte et al., 2008, and references therein). The NW-SE extension was oblique to the main trend of the CHA, and NE-SW normal faults were generated in addition to ENE-WSW faults. Diapiric processes began at this stage, favored by extensional tectonics. Salt walls formed at the footwall of normal faults, bounding minibasins (Saura et al., 2014). The Bathonian is characterized by lacustrine and fluvial red beds. During the Late Jurassic-Early Cretaceous the CHA eventually emerged (Charrière \& Haddoumi, 2016). Cretaceous sedimentation is characterized by red beds followed by expansive tabular limestones corresponding with postrift sediments.

During the Late Jurassic an extensive magmatic event, characterized by mafic intrusions (troctolites and gabbros) during the main phase, and intermediate (diorites and monzodiorites) and felsic rocks (syenites), resulting mainly from fractional crystallization processes (Zayane et al., 2002), occurred. Subsequently, more felsic rocks intruded the mafic rocks. In this study, dealing with gabbros s.s. and troctolites, the "gabbro" term refers to the whole set of intrusive mafic rocks. The cooling ages of these rocks were dated in the Tassent ridge with K-Ar in biotite at $160 \pm 3 \mathrm{Ma}$ to $152 \pm 3 \mathrm{Ma}$ (Hailwood \& Mitchell, 1971) and in the Anefgou ridge with $\mathrm{Ar}$-Ar in biotite at $151.3 \pm 0.5 \mathrm{Ma}$ to $146 \pm 0.5 \mathrm{Ma}$ (Armando, 1999). Moreover, mafic dikes intruded during the Early Cretaceous, between $119 \pm 3 \mathrm{Ma}$ and $134 \pm 3 \mathrm{Ma}$ according to ages obtained from K-Ar in biotite (Hailwood \& Mitchell, 1971).

Late Cretaceous-Cenozoic Alpine compression was relatively weak in the Atlas, with a $15 \%$ to $24 \%$ of shortening in the CHA (Teixell et al., 2003). The deformation is accommodated by the squeezing of previous extensional and diapiric structures, giving the current ridges (e.g., Torres-López et al., 2014) and double vergence angular folds with different degree of cleavage development (Calvín et al., 2017).

\subsection{Structure of the Studied Ridges}

Gabbros crop out in five ridges (Figures 1 and 2) whose structure can be summarized, from west to east, as follows:

The Anergui ridge shows a core of Triassic sedimentary rocks and Jurassic gabbros. It shows a main NNE-SSW trend, which turns to ESE-WNW toward the south, joining the lkkou ridge. The structure of its limbs shows different patterns. Toward the east, Lower Jurassic limestones dip moderately toward the SE, connecting with the SE limb of the Tasraft anticline. In the western limb, E-W trending, north vergent folds affect the Middle Jurassic rocks.

The Tasraft ridge is a NE-SW trending, $25 \mathrm{~km}$ long anticline whose core is formed by Triassic rocks including several gabbro outcrops. Its limbs are defined by Middle Jurassic limestones with moderate to steep dips close to its core, rapidly decreasing to subhorizontal with increasing distance to the core. The contacts between the shales at its core and the limestones at its limbs are mainly diapiric.

The Tassent ridge is a $45 \mathrm{~km}$ long antiform, whose trend changes from ENE-WSW to NE-SW. Its core is dominated by igneous rocks, with scarce, isolated outcrops of Triassic shales. The width of Triassic outcrops varies along strike, from less than $1 \mathrm{~km}$ along the eastern to $3.5 \mathrm{~km}$ along the western sampled sections, the wider outcrop coinciding with the major exposures of igneous rocks. Along the fold limbs the Jurassic limestones 


\section{QAGU Tectonics}

are faulted against the Upper Triassic shales at the core, showing steep dips that decrease with the distance to the core.

The Anefgou and Tirrhist ridges are the eastern continuations of the Tassent and Ikkou ridges, respectively. Unlike their western counterparts, these structures are much shorter along trend. Tirrhist is around $17 \mathrm{~km}$ long and $5 \mathrm{~km}$ wide, and Anefgou is around $10 \mathrm{~km}$ long and $4 \mathrm{~km}$ wide. Their general trend is ENE-WSW, although in detail they are defined by three limbs with different strikes, enclosing triangular areas. The two outcrops of gabbro at their cores have a rough sigmoidal shape in map view. The cores of both anticlines show large amounts of igneous rocks (mainly gabbros intruded by intermediate to acid igneous rocks) and a few outcrops of Triassic shales. The limbs are constituted by Middle Jurassic limestones.

In summary, Tasraft and Tassent are long structures with varying trends (NE-SW and ENE-WSW). In their cores an apparent chaotic mix of Triassic gypsiferous red shales, Triassic basalts, slivers of Liassic carbonates, and Middle-Upper Jurassic plutonic igneous rocks crops out (Figure 2). Conversely, the Tirrhist, Anefgou, and Anergui massifs (Figure 2) are short structures, whose cores are largely occupied by gabbro outcrops with minor presence of Triassic shales. Independently of the amount of gabbro and according to outcrop observations (Figures 1e and 1f), common points between the different ridge cores are the heterogeneity of outcrops of igneous rocks, showing different alteration degrees, the strong Cenozoic tectonic imprint resulting in faults between rigid blocks, and the scarcity of primary contacts between the gabbros and the host rocks.

\section{Previous Paleomagnetic Works in the Study Area}

In addition to Hailwood and Mitchell (1971) pioneering work in the Jurassic igneous rocks (whose aim was to obtain Jurassic paleomagnetic poles from South Morocco), paleomagnetic work has been focused on both sedimentary and igneous rocks from the CHA. Torres-López et al. (2014) presented a paleomagnetic and rock magnetism work on the Jurassic limestones. These authors found a regional, pervasive, and widespread chemical remagnetization (CRM), which affects to all the Jurassic limestones of the CHA. The interpreted age for this remagnetization is circa $100 \mathrm{Ma}$, by comparison between its orientation and the global apparent polar wander path (GAPWP) in African coordinates. Torres-López et al. (2016) used this remagnetization to restore the actual geometry of three ridges (Tassent and Tasraft ridges between them) to the remagnetization time, and Calvín et al. (2017) also restored folds with axial-plane cleavage to the preremagnetization stage, interpreting a Cenozoic age for cleavage formation.

Other paleomagnetic work is related to Mesozoic magmatic events such as the Early Cretaceous dikes and their relationship with the host rocks (Villalaín, Casas-Sainz, \& Soto, 2016; Villalaín, Ruiz, et al., 2016). These authors analyzed the relationship between dikes, limestones, and the circa $100 \mathrm{Ma}$ remagnetization described by Torres-López et al. (2014), by means of baked contact tests. Limestones affected by contact metamorphism show two remagnetization vectors: one component is carried by pyrrhotite, with a paleomagnetic direction similar to the dikes and consistent with the age of the igneous rocks (Late JurassicEarly (retaceous). The other component is carried by magnetite and presents a more northward direction, corresponding to the circa $100 \mathrm{Ma}$ regional remagnetization. Therefore, and according to the above cited work, limestones are capable of recording two remagnetizations, whereas the igneous rocks are not affected by the regional remagnetization, carrying only the primary component.

\section{Methodology}

A total of 33 sites was sampled (Figure 2) along five structures. Eight cores were taken at each site, with a portable gas-powered drill. Orientations were measured with a magnetic compass (and a solar one when possible). The sampling was conditioned by the quality of the gabbro outcrops and the neighboring roads. Furthermore, two limestone sites were sampled in two of the three limbs of the Tirrhist anticline, close to gabbro sites, in order to restore the limbs of the structure to the age of the magnetization in the way shown by Villalaín, Casas-Sainz, and Soto (2016), Villalaín, Ruiz, et al. (2016), and Torres-López et al. (2016).

Paleomagnetic analyses were conducted on 303 specimens using a $2 \mathrm{G}$ cryogenic magnetometer, which integrates alternating field (AF) coils, at the Paleomagnetic Laboratory of the University of Burgos (Spain). After $\mathrm{AF}$ and thermal (Th) pilot demagnetization, 9 sites were demagnetized by AF and 24 by Th according to the behavior of the different samples in order to isolate the paleomagnetic components. Nevertheless, 
most of the sites showed similar behavior under both demagnetization techniques (see section 5.1). Stepwise thermal demagnetization from room temperature up to $580-600^{\circ} \mathrm{C}$ was conducted using a TD48-DC thermal demagnetizer in 10 to 17 steps and a stepwise AF demagnetization from $0 \mathrm{mT}$ to $100 \mathrm{mT}$. Magnetic susceptibility was monitored during thermal demagnetization in order to detect mineralogical changes. Paleomagnetic directional components were calculated by principal component analysis (orientation and maximum angular deviation error (MAD) of the component; Kirschvink, 1980) on orthogonal demagnetization diagrams using Remasoft 3.0 software (Chadima \& Hrouda, 2006). Then, the site mean directions and related statistical parameters were calculated (Fisher, 1953).

The internal structure of the gabbro bodies was studied by petrofabric and magnetic fabric analysis in order to understand the meaning of the magnetic fabrics (by comparison with the petrofabric) and to avoid possible problems with anomalous fabrics (Potter \& Stephenson, 1988; Schöbel \& de Wall, 2014 for review). Anisotropy of magnetic susceptibility at room temperature (RT-AMS) was measured using a KLY4 Kappabridge (Agico). Between 6 and 23 specimens per site were measured, with a total of 434 measured specimens. The magnitudes and orientations of the three axes $\left(k_{1}, k_{2}\right.$, and $\left.k_{3}\right)$ of the AMS ellipsoid were obtained according to the statistical procedure based on Jelínek (1978). The relationship between the magnetic axes was analyzed by means of the normalized parameters (Jelinek, 1981) Pj (corrected anisotropy degree) and $T$ (shape parameter), which show the eccentricity and shape of the ellipsoid (from -1, prolate, to 1 , oblate), respectively.

In addition, the AMS at low temperature (LT-AMS) was measured in order to discriminate the contribution of the paramagnetic phases (Oliva-Urcia et al., 2011, and references therein), because under pure paramagnetic behavior and following the Curie-Weiss law, the bulk susceptibility shows an increase of about 3.8 times of susceptibility at 77 K (e.g., Lüneburg et al., 1999; Morrish, 1965). Sixteen specimens from nine sites were measured after being immersed in liquid nitrogen (at $77 \mathrm{~K}$ ) during 45 min before the initial measurement and $15 \mathrm{~min}$ before each measured position.

The anisotropy of the anhysteretic remanent magnetization (AARM) (McCabe et al., 1985) was used to obtain the magnetic fabric of the ferromagnetic s.s. minerals with coercivities below $90 \mathrm{mT}$. Sixteen specimens from 15 sites were measured following a standard protocol. (i) After demagnetization of the sample with an AF peak of $100 \mathrm{mT}$, (ii) an ARM is imparted in a decreasing AF with a peak of $90 \mathrm{mT}$ and a coaxial direct field of $50 \mu \mathrm{T}$, along a specific axis of the specimen; (iii) then, the remanence along this axis is measured in a cryogenic magnetometer and (iv) the ARM is removed with an AF peak of $100 \mathrm{mT}$ along the same axis. The operation is repeated imparting and measuring the ARM along nine different axes (Girdler, 1961) to calculate the AARM magnetic tensor.

The foliation observable at sample scale and defined by tabular crystals (mainly plagioclase) was measured and compared with the magnetic fabric. Thin sections were made perpendicular to the magnetic foliation and observed under a polarizing microscope. By doing so, it was possible to compare magnetic and petrological fabric of 18 samples.

Regarding the magnetic mineralogy, several rock magnetic experiments were performed in representative samples of each site. Acquisition of isothermal remanent magnetization (IRM), temperature-dependent induced magnetization and backfield curves, and hysteresis loops were performed by means of a magnetic variable field translation balance. Hysteresis parameters of silicate crystal (plagioclase, pyroxene, and amphibole) were measured using the Alternating Gradient Force Magnetometer of the Institute for Rock Magnetism (University of Minnesota, USA). In addition, temperature-dependent susceptibility curves were performed using a KLY4 Kappabridge susceptometer with a CS3 furnace (temperature range between 25 and $710^{\circ} \mathrm{C}$ ) and a CSL cryostat (from -195 to $0^{\circ} \mathrm{C}$ ). Susceptibility curves were measured under argon atmosphere in order to avoid mineral oxidations. With the exception of the measurements on silicate crystals, the rock magnetic measurements were performed in the Paleomagnetic Laboratory of the University of Burgos (Spain).

\section{Results}

\subsection{NRM and Paleomagnetic Components}

Site mean intensities of natural remanent magnetization (NRM) are in the order of $200-500 \mathrm{~mA} / \mathrm{m}$, with extreme values of $2,500 \mathrm{~mA} / \mathrm{m}$ (around $16,000 \mathrm{~mA} / \mathrm{m}$ in TIR4, probably affected by lightning 


\section{QAGU Tectonics}

$10.1002 / 2017$ TC004578

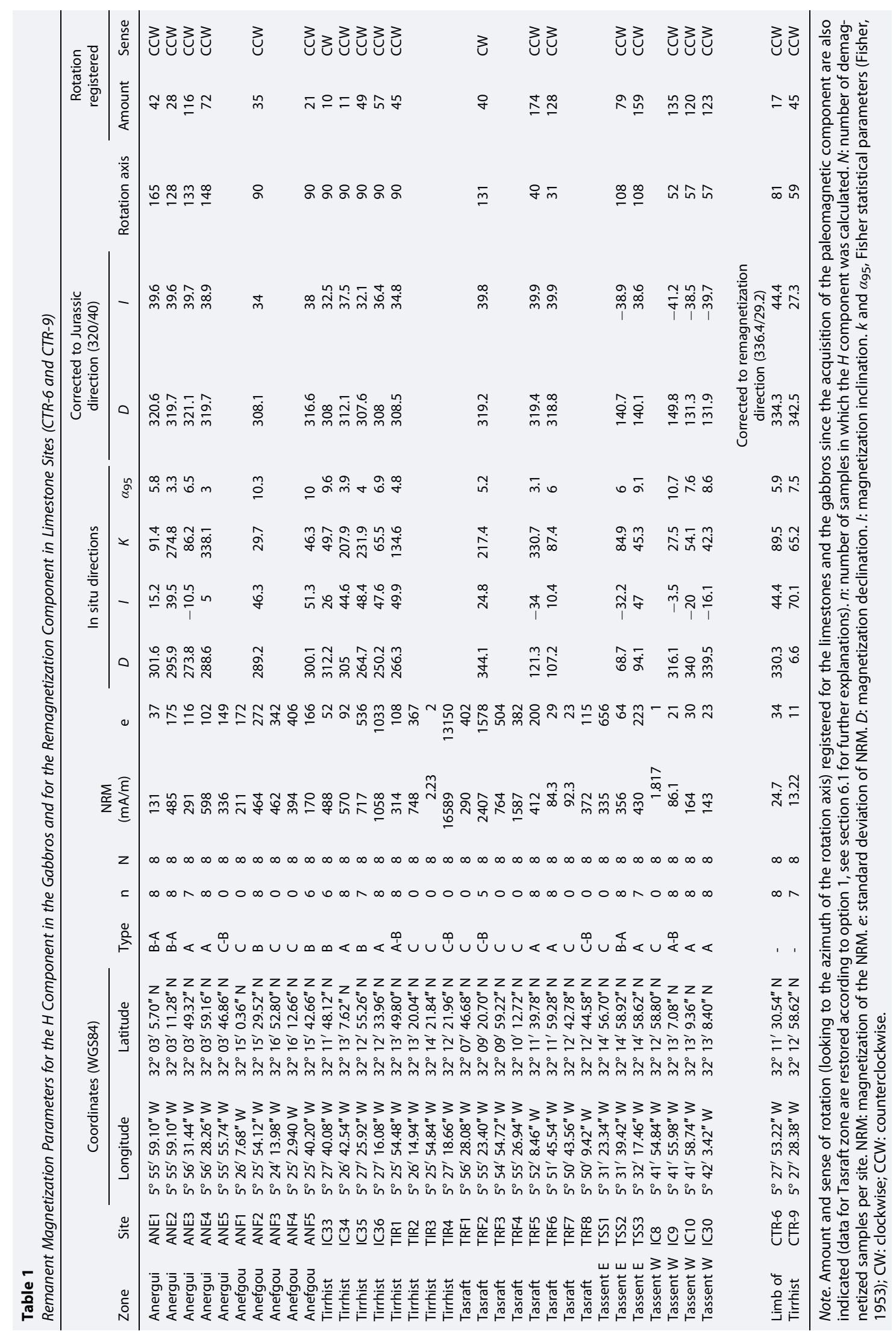


remagnetization) and $2 \mathrm{~mA} / \mathrm{m}$ (Table 1). Magnetic susceptibility values range between $0.3 \times 10^{-3}$ and $165 \times 10^{-3} \mathrm{SI}$, with a mean value of $18 \times 10^{-3} \mathrm{SI}$ (Table 2 ).

The NRM shows different behaviors, in both AF and Th demagnetization diagrams, attending to the observed directional components (named A, B and C, Figure 3). Behavior A is mainly unidirectional (Figure 3a), characterized by a high-temperature component ( $H$ component) that is destroyed between 500 and $565^{\circ} \mathrm{C}$; it is the carrier of $90 \%$ of the magnetization. When submitted to $\mathrm{AF}$ demagnetization, samples of this group show two different behaviors: (i) mean destructive field (MDF) around 20-30 mT (e.g., IC34-08A and TSS2-4B, Figure 3a) and (ii) MDF around $70 \mathrm{mT}$ (e.g., ANE4-5A, Figure 3a). In spite of this difference, all samples are unidirectional, going to the origin, and with the same direction. On the other hand, their behavior under thermal demagnetization is indistinguishable.

Type B (Figure 3b) shows two clear components $(H$ and $L$ ) in different proportions. In ANF5-2, component $L$ is the carrier of $80 \%$ of the total magnetization (destroyed at $100-325^{\circ} \mathrm{C}$ and $4-40 \mathrm{mT}$ ) and component $\mathrm{H}$ of $20 \%$ (from 500 to $575^{\circ} \mathrm{C}$ ). However, in ANE1-6 and ANE1-4, component $L$ carries $30 \%\left(100-300^{\circ} \mathrm{C}\right.$ ) in Th demagnetization and $10 \%(0-12 \mathrm{mT})$ in $\mathrm{AF}$, whereas $\mathrm{H}$ component carries $50 \%\left(500-585^{\circ} \mathrm{C}\right)$ or $70 \%$ in $\mathrm{AF}$ (from 35 to more than $100 \mathrm{mT}$ ) of the total magnetization. In AF demagnetization, these components show overlaps, being either possible (ANE1-4) or not (ANE2-9) to differentiate them. Intermediate terms between these two end-member behaviors can be observed (e.g., Th demagnetization of ANE2-9).

Finally, in Type $C$ behavior, $H$ component cannot be defined (Figure $3 c$ ). In some of these samples, $L$ component is clearly present (ANF1-6; Figure 3c) and in others there exists a high-temperature component but with greater dispersion at site level (TRF3; Figure 3c), perhaps because of overlapping. Consequently, samples that show erratic behavior, overlapping components, major behavior differences in the same site and/or generating large error in the site means were not used for paleomagnetic interpretation.

$L$ component was calculated in 7 out of the 33 sites, in Anergui, Anefgou, and Tirrhist massifs. This component shows minor dispersion, with a mean direction overlapping the expected directions between $20 \mathrm{Ma}$ and the present day (Figure 4). The characteristic component, $H$, appears in 22 sites, with mean directions (Figure 4 and Table 1) showing a significant dispersion for each sample.

\subsection{Magnetic Mineralogy}

Temperature-dependent induced magnetization curves (Figure 5a) show a good correspondence with Types $A$ and $B$ coming from the NRM behavior. Rocks of Type $A$, with only $H$ paleomagnetic component, show a magnetic phase with $580^{\circ} \mathrm{C}$ Curie temperature. Rocks of Type $\mathrm{B}$, with $L$ and $H$ paleomagnetic components, show two magnetic phases; one of them is the $580^{\circ} \mathrm{C}$ temperature phase and the other presents lower Curie temperatures $\left(330-580^{\circ} \mathrm{C}\right.$ ) (Figure $5 \mathrm{a}$ ). This latter phase is not present in the cooling loop, indicating that it is destroyed during heating probably because of oxidation to hematite. Samples have low saturation fields (around 200-250 mT) in the IRM acquisition, higher in general when the low-temperature phase is more developed (Figure 5a).

Susceptibility temperature curves (Figure $5 \mathrm{~b}$ ) also evidence a drop of the magnetic susceptibility at $580^{\circ} \mathrm{C}$ and show the typical signature at $-150^{\circ} \mathrm{C}$ related to the Verwey transition (Verwey, 1939; Walz, 2002). Homogeneous magnetic susceptibility in the heating loops between $-100^{\circ} \mathrm{C}$ and $400^{\circ} \mathrm{C}$ evidences a minimum contribution of paramagnetic minerals to the total susceptibility since paramagnetic minerals show hyperbolic decreases with the increase of the temperature. This is in agreement with the similar bulk susceptibilities obtained at room and low temperature $\left(-195^{\circ} \mathrm{C}\right.$, Figure $\left.5 \mathrm{C}\right)$.

Day plot (Day et al., 1977; Dunlop, 2002) for different samples shows a mixing between single domain (SD) and multidomain (MD) magnetite (Figure $5 \mathrm{~d}$ ), independently of the NRM classification. The same experiment made for the whole rock and extracts of silicates of a hand sample of ANF2 site evidences the presence of magnetic minerals inside the silicate crystals, with magnetic properties similar to the whole rock, and clustered in the pseudo single domain (PSD) (Figure 5e).

Therefore, rock magnetic experiments show good correspondence with Types A and B coming from the NRM behavior. Rocks with low-temperature paleomagnetic component $(L)$ show low to intermediate Curie temperature phase, which is absent for samples lacking the $L$ component. 


\section{QAGU Tectonics}

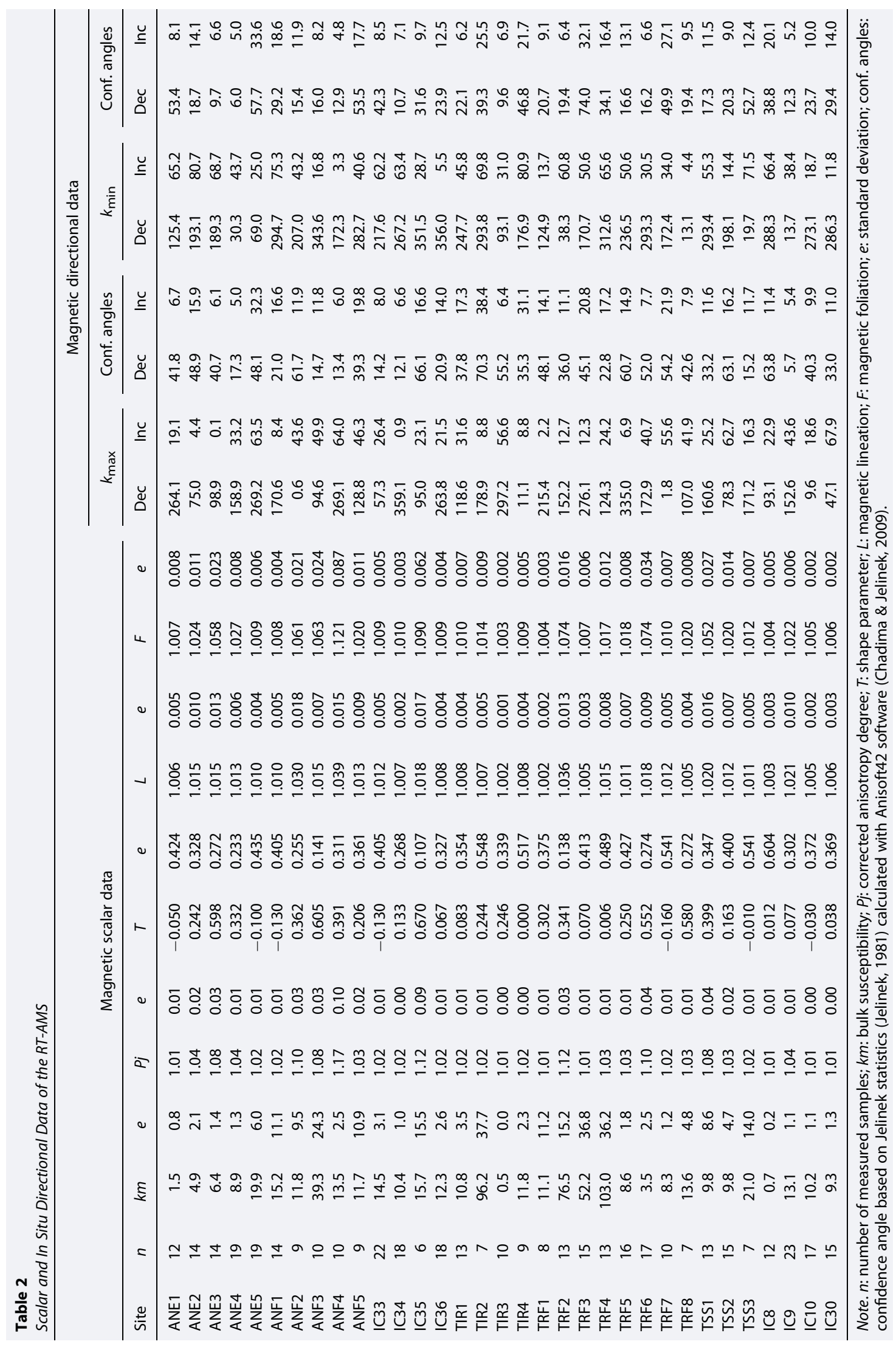




\section{QAGU Tectonics}

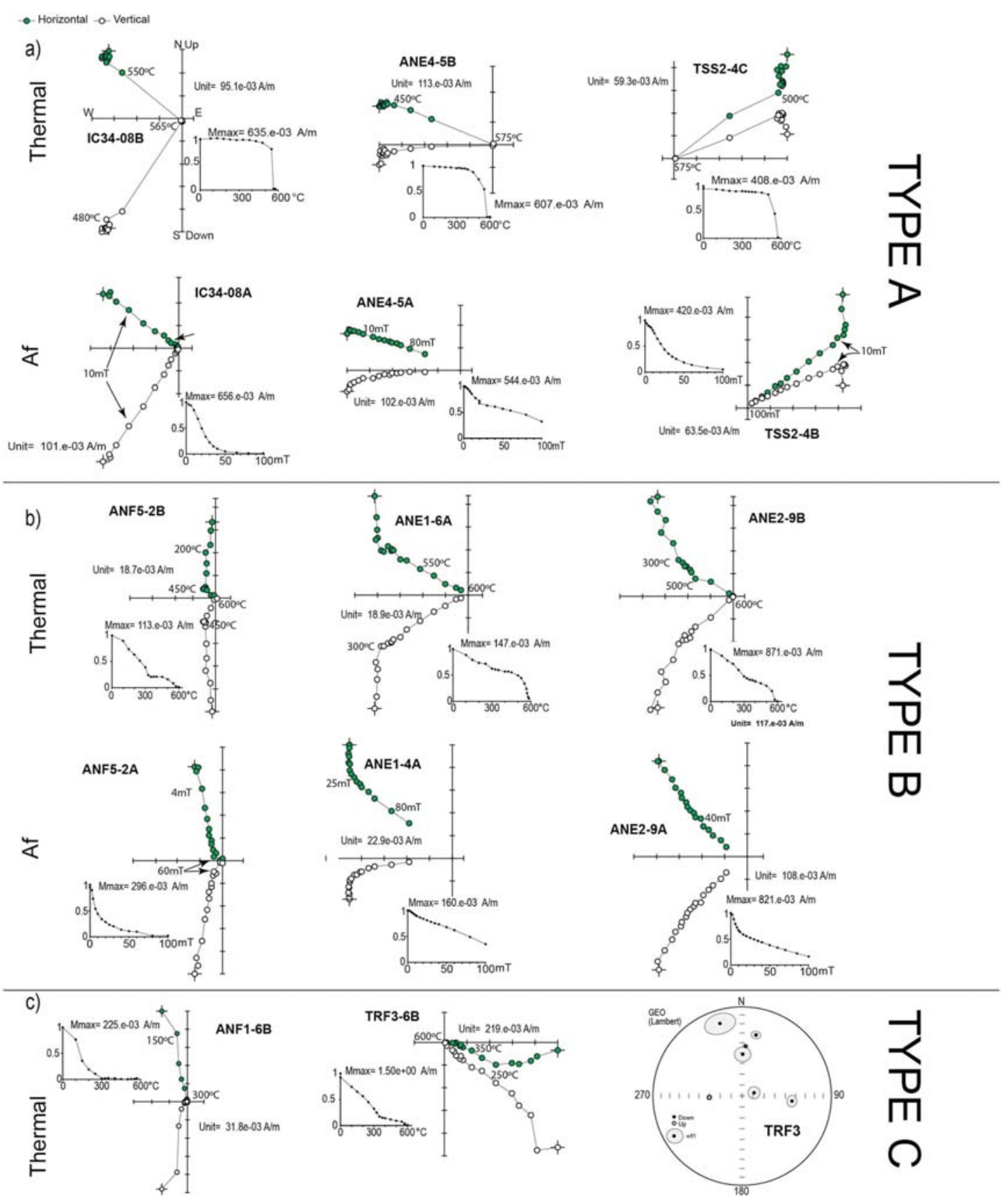

Figure 3. Orthogonal plots of NRM thermal and alternating field demagnetizations of representative samples, plotted in in situ coordinates. Filled symbols are projections onto the horizontal plane (north toward the up and east toward the right) and open symbols on the vertical east-west plane. Normalized NRM intensity is also shown. (a) Type A, characterized by unidirectional vectors that define the $H$ component. (b) Type B, characterized by different development of $L$ and $H$ components. (c) Type $C$ includes different behaviors with the common point of the absence of a reliable $H$ component. ANF1- 6 only presents the $L$ component, and TRF3 shows a high-temperature component but with high dispersion at site level. Note that in Figures $2 \mathrm{a}$ and $2 \mathrm{~b}$, examples are shown in pairs of AF and Th demagnetizations, corresponding to two specimens from the same core.

\subsection{Magnetic Fabrics}

The gabbros show moderate to high magnetic susceptibility values, ranging between $0.3 \times 10^{-3}$ and $165 \times 10^{-3} \mathrm{SI}$. These values are distributed mainly from 1 to $20 \times 10^{-3} \mathrm{SI}$, with more than $75 \%$ of the samples in this range and an average value of $18.54 \times 10^{-3} \mathrm{SI}$ (Table 2). These values are consistent with the presence of variable portions of magnetite, as indicated by the rock magnetic experiments. The mean ratio between 


\section{QAGU Tectonics}
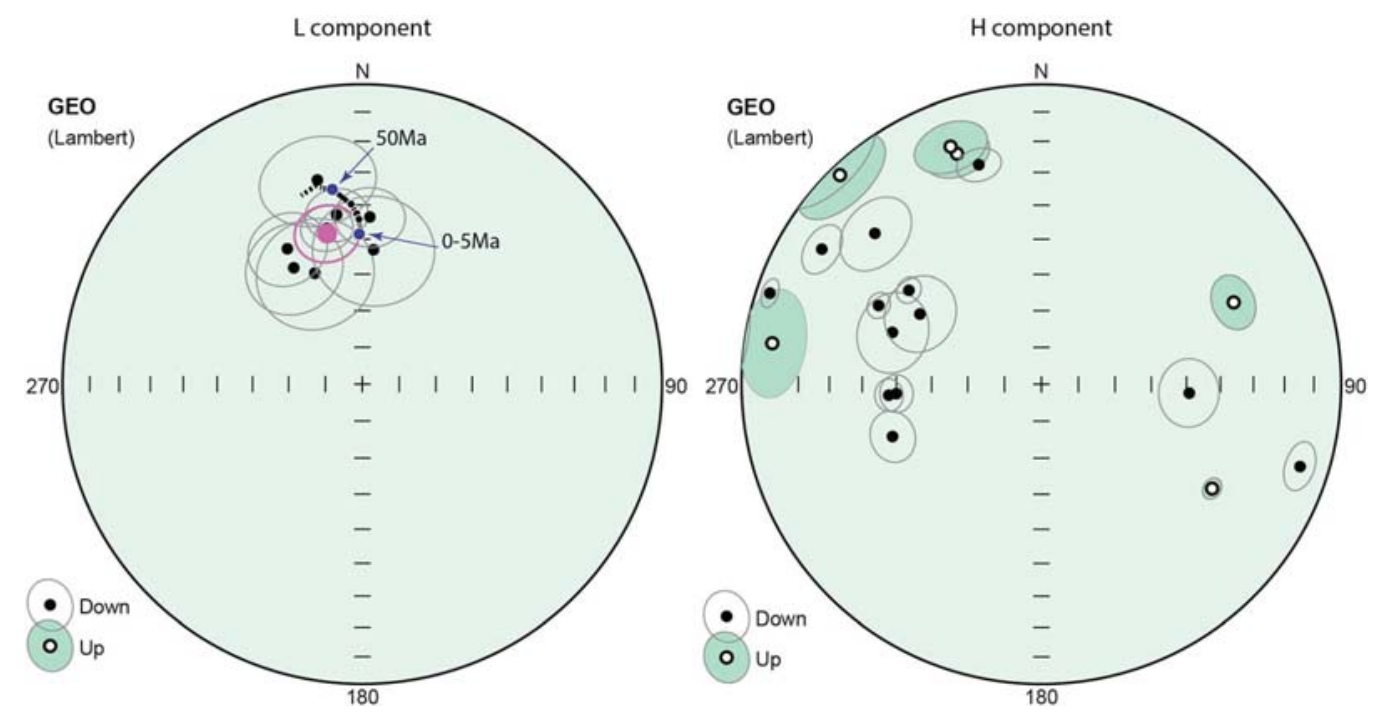

Figure 4. Equal-area projections showing the site mean directions of $L$ and $H$ components. Expected directions for NW of Africa between 50 and $0 \mathrm{Ma}$, obtained through the global apparent polar wander path (GAPWAP) (Torsvik et al., 2012), are also represented.

the bulk susceptibility at low and room temperature (Figure $5 \mathrm{c}$ ) is 1.14 , with values always very close to 1 , indicative of the dominance of ferromagnetic minerals (s.l.).

Table 2 summarizes the scalar parameters for sites. Site means $P j$ values range from 1.002 to 1.407 ; high values of $P j$ dominate in Anefgou, western Tassent, and Tasraft (Figure 6). These values of $P j$ can be related to an igneous fabric (Tarling \& Hrouda, 1993). Magnetic axes are well defined in most of the sites (Figure 6), regardless of the anisotropy degree. Overall, the magnetic foliation $\left(F\right.$, plane whose pole is $\left.k_{3}\right)$ is better defined than the magnetic lineation ( $L$, coinciding with $k_{1}$ ) and in most sites $k_{3}$ is well clustered and $k_{1}$ appears either well clustered or scattered, together with $k_{2}$ along a girdle defining the $F$ plane. Maximum mean values of $F$ and $L$ factors are 1.121 and 1.039, and their mean values are 1.027 and 1.013, respectively. Few sites (e.g., IC33, Figure 6) show markedly prolate ellipsoids with clustered $k_{1}$ axes and a girdled distribution of $k_{2}$ and $k_{3}$. Although in each site the orientation of axes for different samples is consistent at the site scale, a noteworthy point is the strong difference in orientation between sites, even if located along the same structure.

In order to check the distribution of the RT-AMS axes and because of the possibility of finding intermediate and inverse magnetic fabric due to SD magnetite (Potter \& Stephenson, 1988), RT-AMS has been compared with LT-AMS and AARM measurements. Most sites show normal geometry of the AMS because of the coincidence of the minimum axes of RT-AMS, LT-AMS, and AARM (Figure 6); maximum axes are not so well defined because fabrics are mainly oblate. However, some sites show intermediate fabrics. In IC10, LT-AMS and AARM are similar but different to RT-AMS (minimum and intermediate axes switching), indicating that the SD effect disappears at low temperature because of the enhancement of the paramagnetic signal; coincidence between RT and LT-AMS also agrees with magnetite and paramagnetic minerals carrying a similar magnetic fabric. IC34 shows similar distribution in RT-AMS and LT-AMS but different in AARM, indicating that both RT-AMS and LT-AMS are carried by SD magnetite. Finally, TIR1, TSS2, and TSS3 show slight deviations between the three magnetic fabrics. In summary, comparison between RT-AMS, LT-AMS, and AARM supports that RT-AMS generally shows normal magnetic fabrics carried by MD magnetite, but in some sites, both RTAMS and LT-AMS reveal intermediate or inverse fabrics indicating a main contribution of SD magnetite to the magnetic fabric.

Furthermore, the significance of the magnetic fabric in relation to the petrofabric has been checked by comparison with 18 thin sections analyzed under the petrographic microscope. Thin sections (Figure 7) are perpendicular either to the observed foliation (when it was observable in hand samples or outcrops) or to the magnetic foliation. In general, the thin sections show a clear preferred orientation of tabular crystals of 


\section{QAGU Tectonics}

a) Type $\mathrm{A}$

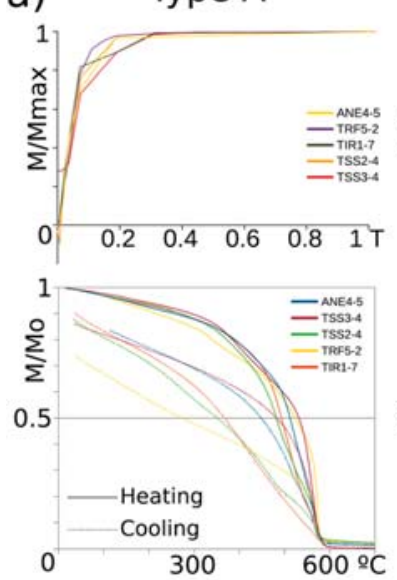

b)

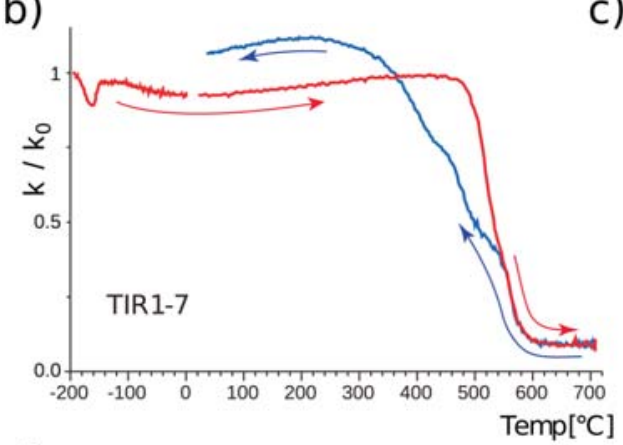

d)

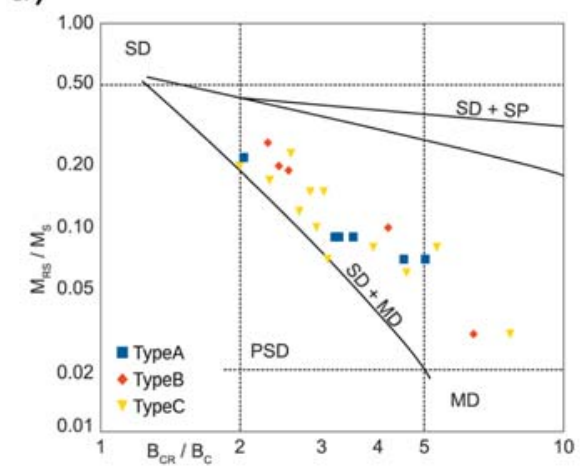

Type B
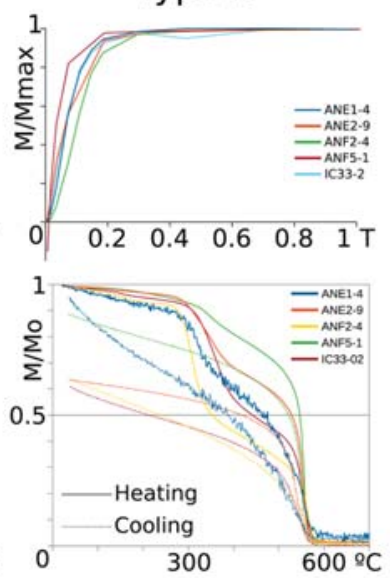

C)

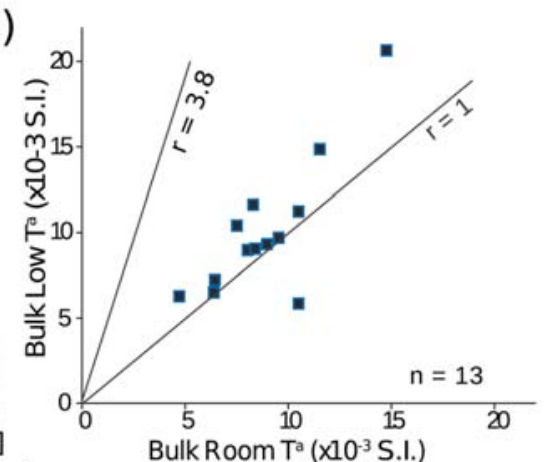

e)

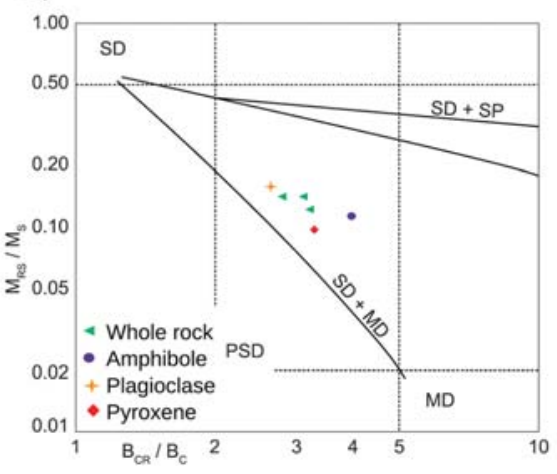

Figure 5. (a) Isothermal remanent magnetization (IRM) acquisition curves and temperature-dependent induced magnetization curves of the different behavior observed in the NRM analysis (Types A, B, and C). (b) Temperature-dependent susceptibility curve from liquid nitrogen temperatures corresponding to sample TIR1-7 (Type A in the NRM behavior). (c) Susceptibility at low (77 K) and room temperature (295 K) showing 1 and 3.8 ratios. (d) Day plot (Day et al., 1977) showing the hysteresis parameters for representative samples of different gabbro outcrops and (e) for the whole rock and extracts of silicates of sample ANF2-4. Classic areas of single domain (SD), pseudo single domain (PSD) and multidomain (MD) are plotted. Theoretical mixing curves (Dunlop, 2002) are also shown (SP, superparamagnetic).

plagioclase, coincident with the magnetic fabric (with deviations lower than $10^{\circ}$ ). In some sections, plagioclase crystals define two or more orientation maxima, but a dominant trend can be normally determined. The coincidence between large crystals orientation and the magnetic fabric agrees with models (Tarling \& Hrouda, 1993; Usui et al., 2006, and references therein) stating that ferromagnetic minerals (s.l.) are usually aligned with large crystals whose orientation was acquired at high temperatures due to hydrodynamic forces during fluid or plastic magmatic flow. This has also been observed, for instance, by O'Driscoll et al. (2008) and Pueyo Anchuela et al. (2014). 


\section{QAGU Tectonics}

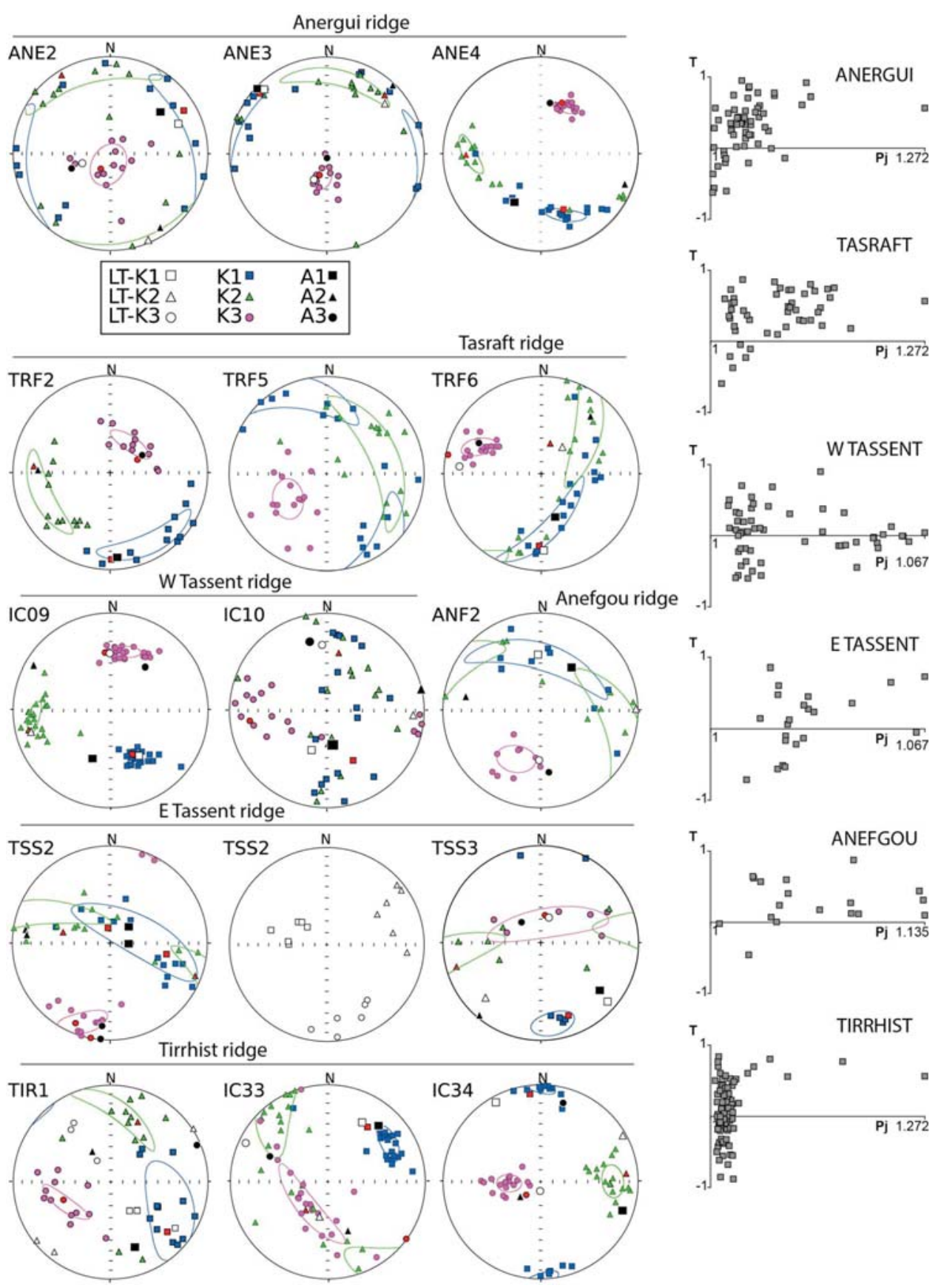

Figure 6. Equal-area projection of in situ magnetic fabrics (RT-AMS in colors, LT-AMS in white, and AARM in black) and Pj-T diagrams of the different gabbro massifs.

\section{Interpretation of the Paleomagnetic Components}

\subsection{Magnetic Carriers}

There exists a correlation between $L$ and $H$ paleomagnetic components, on one side and the magnetic phases with low and high Curie temperature observed in the thermomagnetic curves, on the other. The paleomagnetic direction of the $L$ component is similar in the different sites and close to the present-day magnetic field (Figure 4), indicating that it is a secondary component generated after the Cenozoic compression 


\section{QAGU Tectonics}
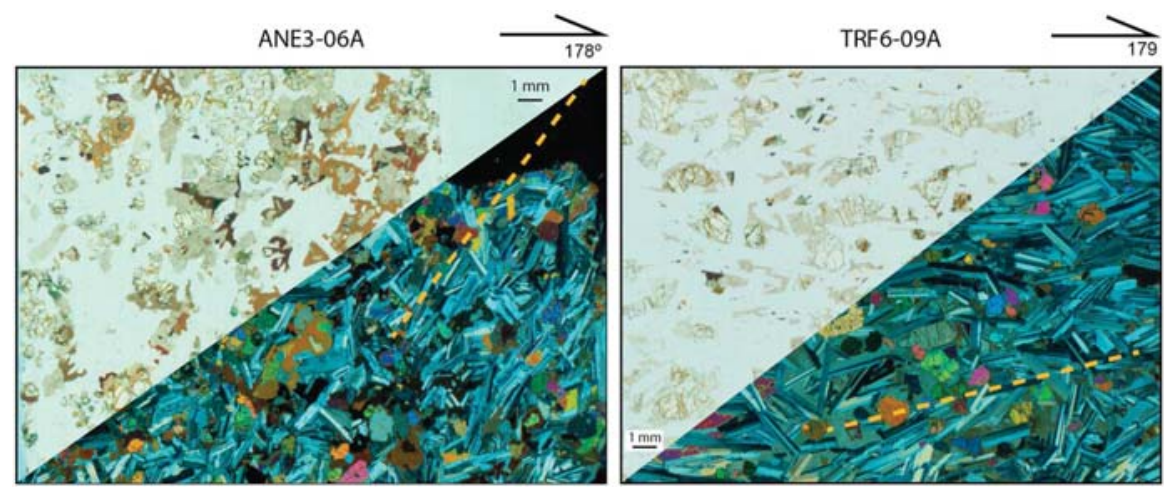

Figure 7. Microscopic images (parallel nicols at the top and crossed nicols at the bottom) of two selected samples. The thin section is perpendicular to the petrofabric foliation so the lineation defined by plagioclases in the thin section is the foliation of the rock. In orange, projection of the magnetic foliation onto the thin section plane.

(it does not record any rotation); this component could be related to alteration during the exhumation of the chain or with weathering. Curie temperatures of the low-temperature phase could be related to titanomagnetite; gradual variations of the Curie temperature between samples can be related to changes in Ti-Fe ratio and different degree of oxidation. Because of the slightly higher coercivity observed in the IRM acquisition curves, in the samples with this magnetic phase, changes on the Curie temperature could be rather related to different degree of oxidation.

Regarding the $H$ component, NRM demagnetization diagrams (Figure 3) show a typical behavior of almost pure magnetite, coinciding with results from rock magnetic experiments (Figure 5). Noteworthy, this magnetite shows medium to high coercivity in AF experiments in some samples (e.g., ANE4 and ANE1; Figure 3). This behavior was observed in gabbros having inclusions of exsolved magnetite in silicate crystals (Ebert et al., 2010; Evans et al., 1968; Feinberg et al., 2005), and this is in agreement with rock magnetism experiments carried on silicate extracts (Figure $5 \mathrm{~d}$ ). However, the presence of additional fine-grained magnetite outside the silicate crystals cannot be discarded.

\subsection{Origin of the $H$ Component}

Ensuring the primary character of a paleomagnetic component is a difficult matter in paleomagnetism. The lack of paleohorizontal reference on the gabbros, the high dispersion of the paleomagnetic mean directions, and the absence of baked contact tests makes this matter even more complex. In these points we analyze and justify the possible primary origin of $H$ component:

1. The site mean directions of $H$ component (Figure 4) show strong dispersion due to block rotations presumably during the Cenozoic inversion of the basin. Therefore, the $H$ component was acquired before the Cenozoic.

2. There exists evidence about the presence of SD magnetite, such as inclusions in silicates that usually carry a very stable primary thermoremanence (Ebert et al., 2010; Evans et al., 1968; Feinberg et al., 2005).

3. Magnetic properties, that is, the medium to high coercivity $(>100 \mathrm{mT}$ ) of a fraction of the $H$ component, indicate a probable origin of the carrier (magnetite) related to high-temperature exsolution processes. These processes usually happen at temperatures above the Curie temperature of magnetite (Ebert et al., 2010).

4. Baked contact tests carried on Upper Jurassic-Lower Cretaceous dykes with carbonates as host rocks in the CHA (Villalaín, Casas-Sainz, \& Soto, 2016; Villalaín, Ruiz, et al., 2016) show that dikes are not affected by the Cretaceous CRM observed in limestones. This agrees with results from other works that indicate that the primary component is preserved in gabbro bodies even after reheating due to younger intrusions (Denyszyn et al., 2013; Evans \& McElhinny, 1966) or after metamorphism/metasomatism (Pariso et al., 1996).

Considering all these facts, and in light of previous works in similar materials, we can reasonably assume that the magnetite generated by high-temperature exsolution processes and/or appearing as inclusions within 


\section{QAGU Tectonics}

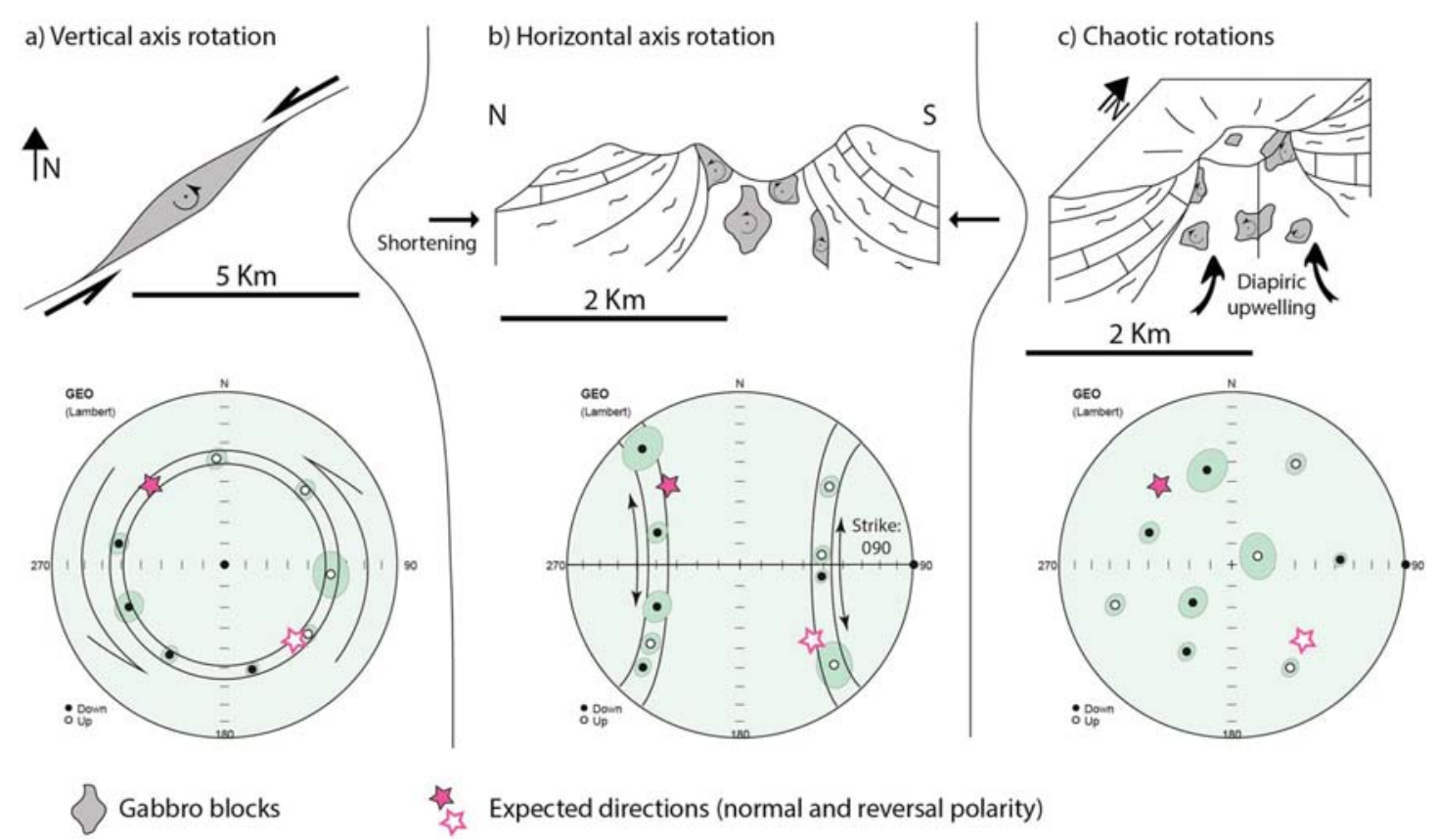

Figure 8. Equal-area projections showing hypothetical dispersion of paleomagnetic directions due to: (a) vertical axis rotations in a strike-slip context, (b) horizontal axis rotations for folding, or (c) chaotic rotations due to diapiric upwelling. In Figures $8 \mathrm{a}$ and $8 \mathrm{~b}$ the small circles along which the paleomagnetic directions are expected are also shown. 
anticline ridges (Figure 8): (i) According to Laville and Piqué (1992), Jurassic igneous rocks were emplaced under a left lateral transpressional tectonic regime; if the $H$ component were blocked before the end of these tectonic movements, the latter would generate a dispersion of the paleomagnetic component along a small circle with vertical axis (vertical axis rotation, Figure 8a). (ii) If the gabbros were rotated during, and consistently with, the Cenozoic folding of the anticlines, the dispersion should be in accord with a small circle with horizontal axis parallel to the tectonic structures (Figure 8b). (iii) Finally, if this dispersion is due to late diapiric upwelling without tectonic control, a chaotic dispersion of paleomagnetic directions is expected (Figure 8c). A chaotic dispersion could also result from the superposition of processes (i) and (ii) (horizontal and vertical axis rotations).

Although these models are oversimplified, their correlation with data can help to define the postemplacement history of these rocks, closely related to the tectonic evolution of the area. In the next subsection we analyze individually the paleomagnetic vectors obtained in each of the studied structures.

\subsection{The Tirrhist-Anefgou Setting}

The massifs of Tirrhist and Anefgou (Figure 9a) provide the key to elucidate the processes involved in the structuring of the gabbroic bodies and therefore in the scattering of the paleofield vector ( $H$ component). In equal-area projection (Figure 9b), these directions are scattered along a small circle with horizontal axis, whose trend is E-W. This small circle contains the expected paleomagnetic direction for this area during Jurassic times, obtained from the global apparent polar wander path (GAPWP) (Torsvik et al., 2012) in local coordinates. Therefore, variable clockwise $(\mathrm{CW})$ rotations along this small circle and looking to $\mathrm{N} 90^{\circ} \mathrm{E}$ are necessary to adjust the obtained paleomagnetic vectors to the Jurassic direction (except for IC33, which needs a minor counterclockwise, $\mathrm{CCW}$, rotation, around $10^{\circ}$; this direction can be considered as indistinguishable from the expected direction and practically in situ). Therefore, the gabbros and their primary paleomagnetic directions have been affected by a CCW rotation after cooling (Table 1). The rotation around an E-W axis is consistent with the tectonic structures observed in the core of the anticline (E-W folds involving the limestones, Figure $9 \mathrm{c}$, and minor thrust affecting both sedimentary and igneous rocks) and the CCW rotations agree with the NNW vergence of the Tirrhist anticline.

Following the works by Villalaín et al. (2003) and Villalaín, Casas-Sainz, and Soto (2016), the limbs of the Tirrhist anticline, where limestones affected by the circa 100 Ma remagnetization crop out, can be restored to the moment of the remagnetization acquisition. There, it is possible to obtain the paleodip of beds and to make a comparison between the deformational history of these limbs and the closest igneous rocks sites (IC33 and IC35). Paleomagnetic directions obtained from limestones at the limbs of the Tirrhist anticline (Figure 9d and Table 1) show that (i) its NW limb (CTR9) was affected by a strong CCW rotation ( $45^{\circ}$ looking to the azimuth of the bed, $\mathrm{N} 059^{\circ} \mathrm{E}$ ) after the remagnetization stage, and (ii) its SE limb is affected by a smaller CCW rotation (about $17^{\circ}$ looking to $\mathrm{N} 081^{\circ} \mathrm{E}$ ). After this procedure the NW limb showed a steep dip at circa $100 \mathrm{Ma}(329,79)$ (bedding as dip direction and dip) and the attitude of its SE limb was similar to its present-day position $(171,54)$ (Figure $9 \mathrm{~d}$ ). Therefore, the rotation axes and the amount of rotations are similar in limestones and gabbros (Figure 9d). However, note that IC35 shows a rotation axis slightly different from the closest limestone site (CTR9; see Figure 9d), thus indicating that there exists a small decoupling between the limbs and the core of the anticline.

\subsection{Defining Criteria for Paleomagnetic Restoration}

In the Tirrhist-Anefgou case, only one horizontal axis was used to restore the paleomagnetic directions (the simplest solution). However, there is more than one solution (i.e., axis trend) to restore the paleomagnetic vector to a feasible direction because two polarities, normal and reverse, are possible. In this way, there are two different solutions (horizontal axes and their corresponding small circles) to restore paleomagnetic directions. Note that the emplacement age of the gabbros circa $150 \mathrm{Ma}$ is characterized by a high reversal rate of magnetic polarity (Gradstein et al., 2012) and both solutions could be right. These two axes have necessarily different direction, and the one having a better match with the geological features (trend of the main and minor structures at the core of the anticlines) was chosen. Moreover, AMS axes can be restored in the same way that the paleomagnetic directions (considering that blocking of the characteristic paleomagnetic component and the magnetic fabric acquisition is geologically coeval). Therefore, coherence between 


\section{QAGU Tectonics}

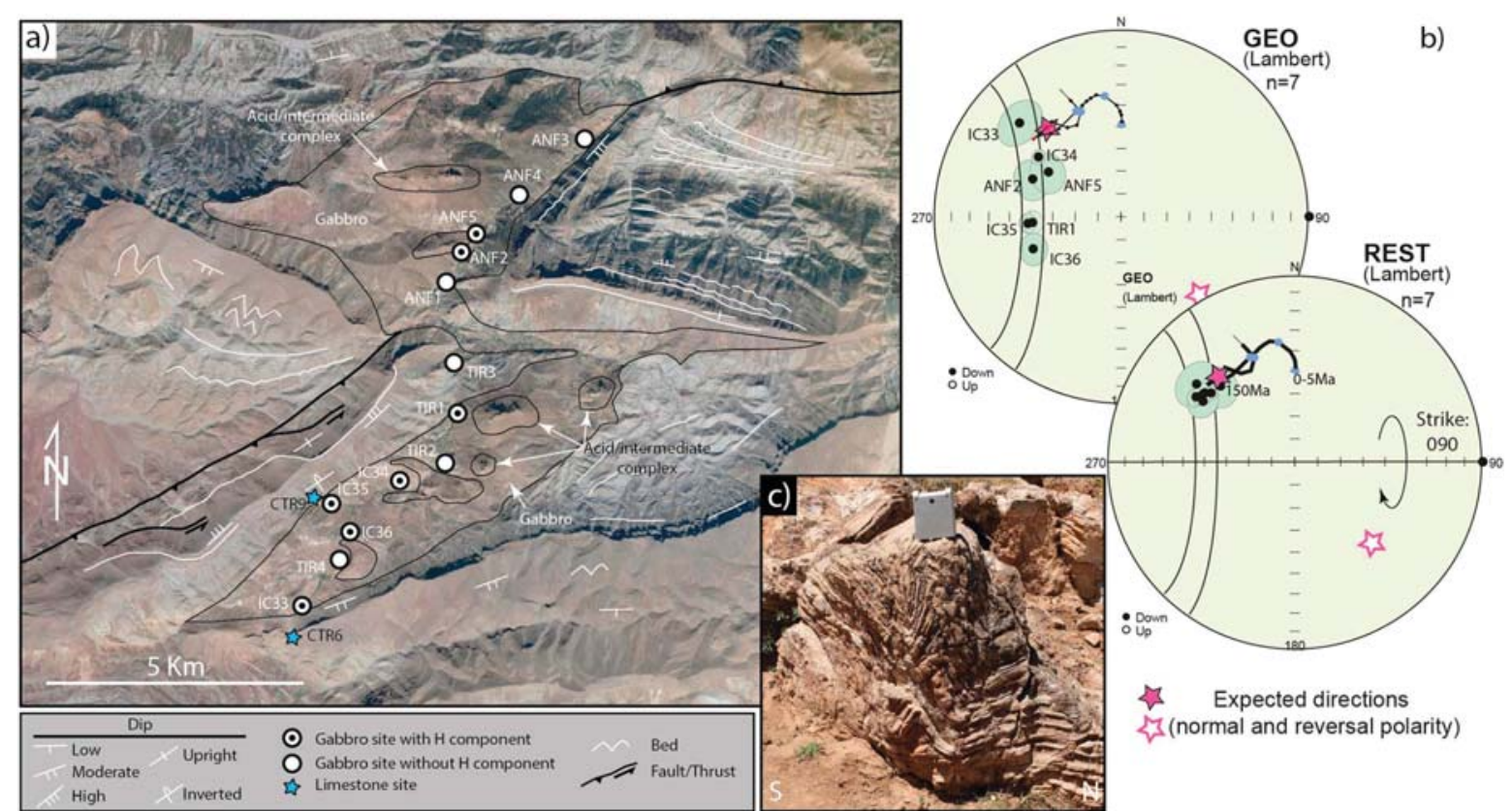

d)

d) $\begin{aligned} & \text { ca. } 100 \mathrm{Ma} \\ & \text { reference }\end{aligned} \quad \begin{aligned} & \text { Late Jurassic } \\ & \text { reference }\end{aligned}$
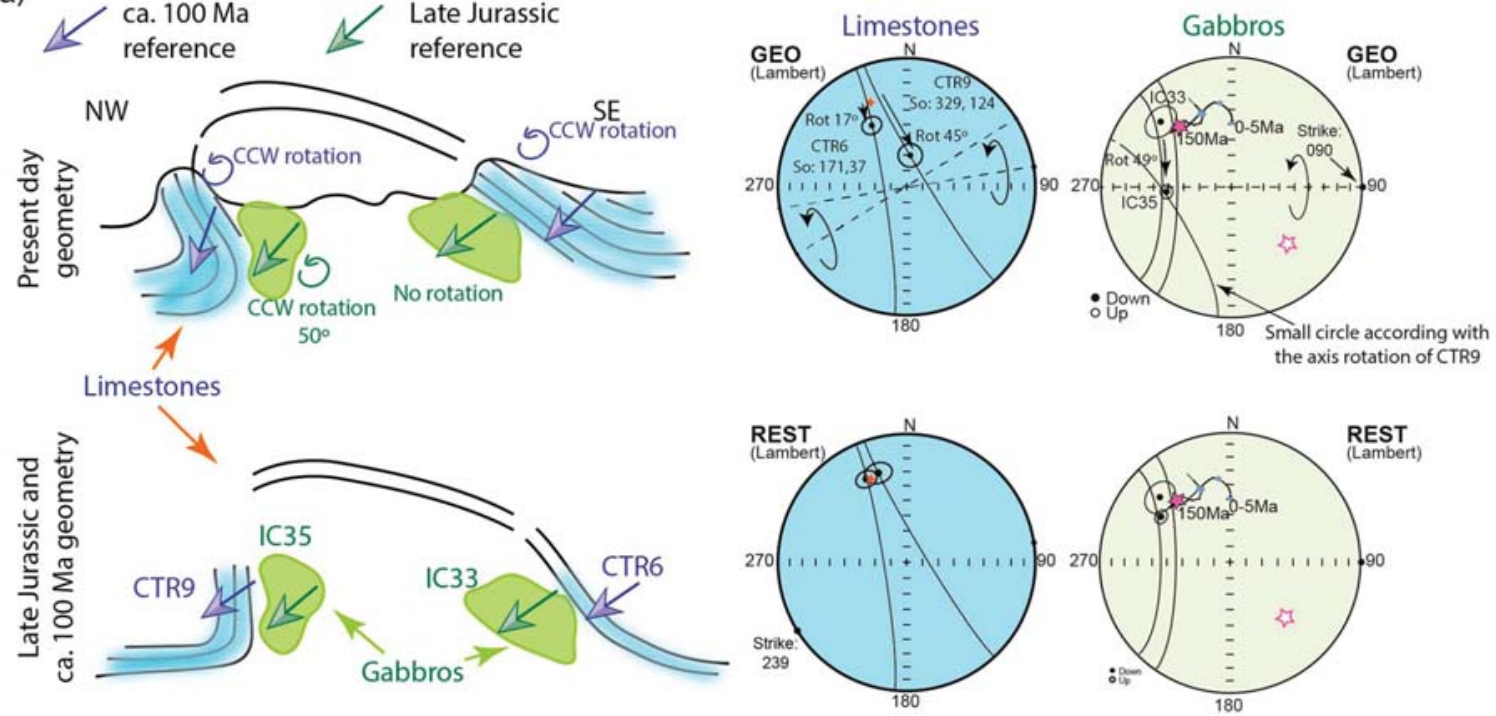

Figure 9. (a) Google Earth image of the Tirrhist-Anefgou massif with the location of the paleomagnetic sites and some geological features. (b) Equal-area projections showing the mean directions for the characteristic magnetization ( $H$ component) and 95\% confidence circle obtained in Tirrhist and Anefgou gabbros, before (GEO coordinates) and after (REST (Restored) coordinates) the rotation correction toward the Middle-Late Jurassic reference. The seven paleomagnetic directions show dispersion along a small circle with E-W horizontal axis. Mesozoic-Cenozoic expected directions for NW of Africa obtained through the global apparent polar wander path (GAPWAP) (Torsvik et al., 2012) are also represented. Violet star shows the expected direction for the gabbros cooling age. (c) E-W syncline affecting a Triassic-Jurassic limestone site in the core of the Tirrhist anticline. (d) Current geometry of south and NW limbs of the Tirrhist anticline (CTR6 and CTR9 sites) and the closest gabbro sites (IC33 and IC35, respectively) and reconstruction to the paleogeometry at the time of the magnetization acquisition (note that this time is different for the gabbros and for the limestones). Equal-area projections showing mean paleomagnetic directions for CTR6, CTR9, IC33, and IC35, in in situ coordinates (GEO) and after restoration to the expected direction of the remagnetization (REST). The optimal directions, close to circa $100 \mathrm{Ma}$ and circa $150 \mathrm{Ma}$ directions for limestones and gabbros, respectively, and the disposition of the limb for this age are also represented.

AMS data from the different sites for each structure was also checked according to the two different rotation routines for normal and inverse polarities

Finally, once the axis of rotation has been chosen, it is possible to perform the restoration in CW or CCW sense, for $360^{\circ}$ as sum of the two angles. When the two angles were very different, the smaller angle 


\section{QAGU Tectonics}

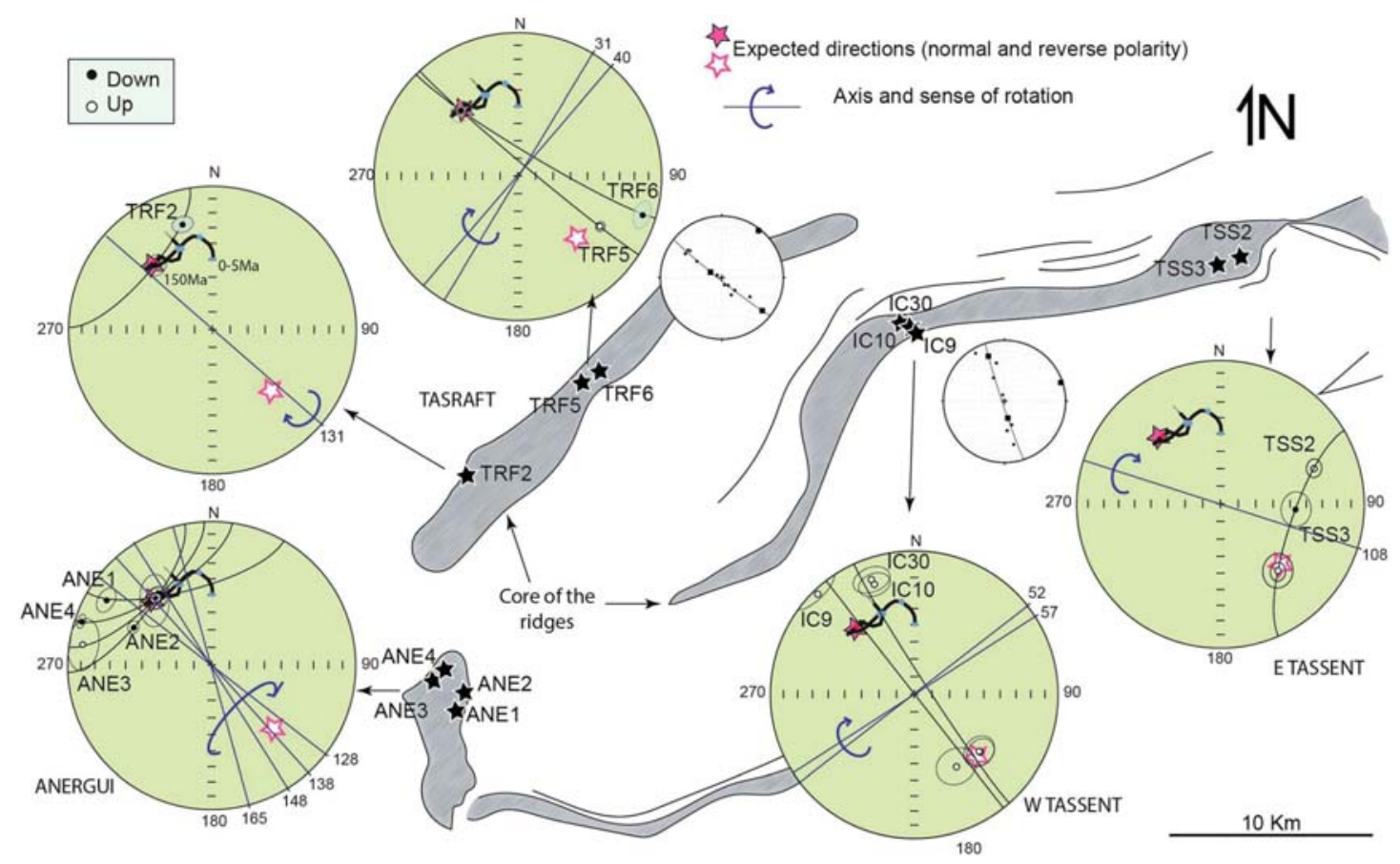

Figure 10. Paleomagnetic restoration of Anergui, Tasraft, and Tassent sites. The mean site directions of the $H$ component are represented in equal-area projections. Each diagram shows the in situ paleomagnetic direction of the different sites and the restored direction to the Jurassic position (see Figure 9). Each diagram has the corresponding small circle, which joins the in situ with the Jurassic paleomagnetic directions as well as the orientation of the axes of rotation underwent by the bodies. Available bedding data and their cylindrical best fit are also represented in equal-area projection (white stereoplots).

was chosen. However, there is a higher uncertainty when both solutions are similar (amount of rotation close to $180^{\circ}$ ).

Hence, although there can be different paths to restore paleomagnetic vectors, throughout this process we have chosen the simplest (only one axis of rotation following the smaller rotation) and geologically more reasonable (structural trends and minimum rotation angles) path to restore the paleomagnetic directions.

On the other hand, it is important to remark that the goal of this work is to analyze the deformational patterns of the core of ridges instead of a detailed reconstruction of the rotational history of the gabbros (perhaps an impossible task at this time). This is the reason that we use some simplifications that allow us to define some common patterns. As an example, uncertainties linked to mean paleomagnetic directions (i.e., $\alpha_{95}$ ) have not been quantitatively considered because they do not contribute to obtain more accurate results and are another error source, increasing the complexity of the problem. All in all, this restoration method was used to obtain qualitative but not quantitative (i.e., paleopoles) results and restored paleomagnetic directions of the ridges were obtained (Figure 10 and Table 1), as we describe in the following subsections.

\subsection{Paleomagnetic Restoration}

In the Tassent ridge, the $H$ component was clearly isolated in five out of seven sites (two in the eastern sector and three in the western one). The directions from the two sites of the eastern sector (TSS2 and TSS3) lie in a small circle (with ESE axis), which also includes the expected reverse polarity direction for Jurassic times at the study area. Rotations necessary to restore the calculated paleomagnetic directions to this Jurassic direction are high but consistent with the main structural trend and local folds. Nevertheless, the western sites need a NE rotation axis, different from the eastern sector but consistent with the main trend of the ridge (bedding data agree with the rotation axis). In comparison with the Anefgou-Tirrhist massif, Tassent gabbros record important rotations. In both eastern and western areas, the sense of rotations registered in the gabbros (finite rotation since their emplacement until present) is CCW looking to the east. 
Only in three out of the eight sites of the Tasraft ridge the $H$ component has been isolated (Figure 10). Taking into account the same magnetic polarity for all sites, two restoring options are available.

1. Considering a normal polarity for the paleomagnetic direction (Figure 10), TRF5 and TRF6 show dispersion along a NE-SW small circle and TRF2 along a NW-SE one. The NE-SW axis (for TRF5 and TRF6 sites), but not the NW-SE axis necessary in TRF2, is consistent with the main trend of Tasraft antiform.

2. Considering the reverse magnetic polarity, TRF5 and TRF6 paleomagnetic directions and the reverse polarity direction for the Jurassic lie within a small circle with NW-SE axis. On the other hand, TRF2 needs a strong rotation along a NE-SW axis, parallel to the structural trend. Either of the two options implies two perpendicular rotations. Finally, Anergui paleomagnetic directions show CW moderate rotations along axes with NW-SE to NNW-SSE directions.

\subsection{Interpretation of the Paleomagnetic Restoration}

From the obtained results, paleomagnetic directions obtained from $H$ component show an important dispersion that can be explained by horizontal axis rotations of the gabbro bodies. In Tassent, Tasraft, Anefgou, and Tirrhist (independently of the restoring option chosen for Tasraft), paleomagnetic directions record CCW rotations (looking to the NE-E) around axes parallel to the structures (E-W to NE-SW). This agrees with a tectonic control of rotation consistent with reverse, top-to-the-N-NW shear, in relation with overthrusting. However, diapiric processes can also be involved in the rotation of the gabbro bodies (mainly in Tasraft, where there is a high proportion of plastic rocks) generating rotations around other axes. Differences between rotation axes according to variations in the structural trend agree with a main control from the inherited extensional structures.

Tasraft and Tassent show stronger rotations of the gabbro bodies than Anefgou and Tirrhist ridges. This can be related to differential proportion between igneous and Triassic sedimentary rocks (mainly shales) at the core of the ridges. In Anefgou and Tirrhist, igneous rocks dominate with minor presence of shales; conversely, Tasraft and Tassent show important amount of shales in their cores. Dominance of sedimentary rocks (shales and evaporites) versus igneous rocks can allow stronger rotations of gabbro bodies or even differential rotations between close sites (e.g., TSS2 and TSS3).

The Anergui ridge shows a different pattern. In this case, block tilting driven by halokinetic processes is probably the cause for the dispersion in the paleomagnetic directions.

Finally, further discussion is necessary regarding the Tasraft ridge and the two proposed restoration options. There is evidence to support the option shown in Figure 10. First, the restoration of the AMS agrees better with this option. Besides, there is a differential rotation between TRF5 and TRF6 (Figure 10), in spite of being close sites; this could be more easily explainable by rotations related to tectonic processes (with rotation axis parallel to the structural trend) rather than only by a strong rotation of TRF6 (TRF5 would not record any rotation since it approaches the reverse polarity direction) due to diapiric processes (around an axis perpendicular to the structural trend). However, this does not have implications in the interpretations since the same rotation axes are necessary in both options. Nevertheless, it is true that the proximity of TRF2 and TRF5 paleomagnetic directions to normal and reverse polarity references, respectively (Figure 10), could indicate a different scenario in which the igneous rocks of this ridge could show different polarities.

In summary, restoration of the paleomagnetic directions indicates that tectonic structures imposed a major control on the rotation of gabbro units. Rotation axes are grouped into two main sets, NE-SW and E-W, coincident with the structural trend in each sector. This is indicative of the control of inherited geometry on the trend of the Cenozoic structures, generated under a NNW-SSE shortening (Ait-Brahim et al., 2002; Mattauer et al., 1977). Major rotations are observed in the structures with higher proportion of Triassic shales and smaller gabbro blocks (massifs of Tassent and Tasraft). This also clearly indicates the decoupling between the core and the limbs of the ridges since the limbs did not register rotations higher than $70^{\circ}$ after remagnetization (Torres-López et al., 2016) and $90-100^{\circ}$ in total. However, in the anticlines whose core is mainly composed by igneous rocks (Tirrhist and Anefgou), the rotations of the gabbro units are more limited and on the same order than recorded by the limestones. In either case, CCW sense of rotation in most sites can indicate reverse shear toward the north or NW, not readily apparent due to the strong symmetry of the Mesozoic structures (salt walls). On the other hand, moderate rotations in the southwesternmost sites (Anergui and south of Tasraft) may be related to block tilting associated with diapiric processes. 


\section{QAGU Tectonics}

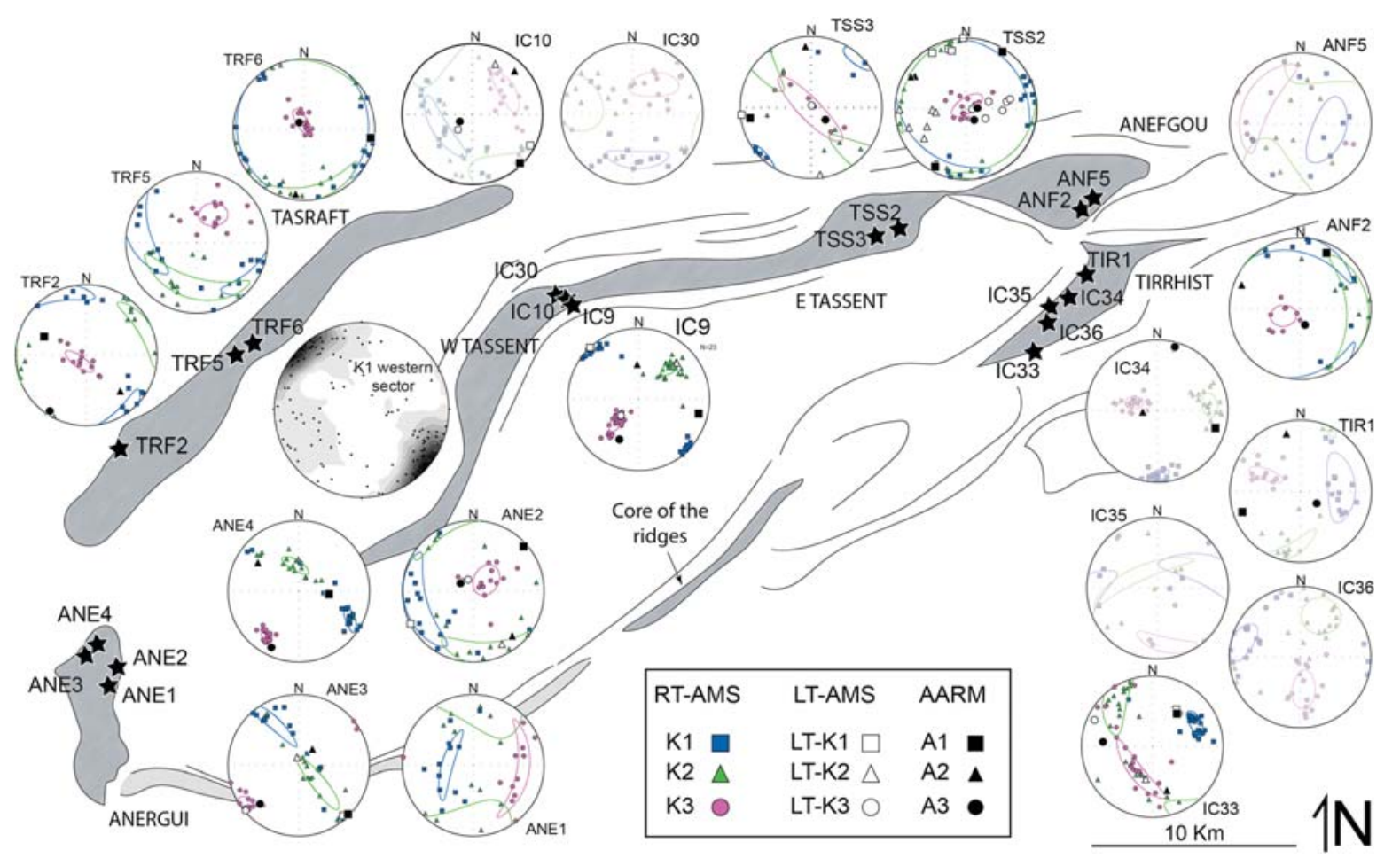

Figure 11. Equal-area projection of restored magnetic fabrics (RT-AMS, LT-AMS, and AARM). Only the sites in which paleomagnetic restoration is available are represented. Sites without confidence on normal carrier fabrics are represented with transparency. Contour plot of $k_{1}$ is represented for the western sector.

\section{AMS Results and an Emplacement Model for the Gabbros}

The gabbro bodies are characterized by brittle deformation; these processes did not modify the original magnetic fabric, since no indication for solid-state deformation was detected under the microscope (Figure 7), where texture and mineral arrangement are clearly primary generated during the solidification of the magma. Low Pj values of the AMS also are in agreement with a primary petrofabric rather than with solidstate deformation.

Gabbro bodies only crop out in the core of the ridges because of the presence of Triassic shales and evaporites, whose ductile behavior favored their emplacement; this unit is the main décollement, several hundreds of meters thick (Calvín et al., 2017; Saura et al., 2014), located at the bottom of the Jurassic carbonate sequence. When the magma reaches the ductile level during its ascent, expansion and replacing of the ductile level occurs, forming laccolith-shaped bodies, as shown in analogue models of sand-silicone systems (Román-Berdiel, 1999; Roman-Berdiel et al., 1995, 1997). The magnetic fabric acquired during magma solidification, blocked around $800^{\circ} \mathrm{C}$ when the plastic flow ceases (Tarling \& Hrouda, 1993), can respond to (i) external tectonic control, determining the strain field in the region during magma emplacement and the kinematic framework controlled by its structural setting (Antolín-Tomás et al., 2009; Aranguren et al., 2003; Bouchez \& Gleizes, 1995; Bouchez et al., 1990; Izquierdo-Llavall et al., 2012; Liodas et al., 2013; RománBerdiel et al., 2006) and (ii) internal flow mechanisms not directly related to the strain conditions but rather to the behavior of magma within the magmatic chamber (Archanjo et al., 2012; Ferré et al., 2002; Maes et al., 2007).

Axes and angles of rotations obtained from paleomagnetic restoration can be used to restore the magnetic fabric directional data to the prerotation stage (Table 1). With the exception of ANE1 and ANE2, all sites from the western sector (Anergui, Tasraft, and western Tassent) show consistent directions after restoration (Figure 11). Magnetic lineation is subhorizontal with a main NW-SE direction independently on the trend of the ridge (e.g., compare IC09 and TRF sites). The magnetic foliation is subhorizontal in Tasraft and show 


\section{QAGU Tectonics}

steep dips, with a NW-SE trend, in ANE-3 and ANE-4. Intermediate dips appear in other sites. Note that IC10 has intermediate RT-AMS (and probably also IC30 that shows similar RT-AMS properties), but AARM and LT-AMS follow the general trend for this sector.

Magnetic fabrics in the eastern sector (eastern Tassent, Anefgou, and Tirrhist) show a strong heterogeneity. Eastern Tassent sites show horizontal foliation and lineation; however, lineations show a high variability in trend. TSS2 shows both ENE-WSW and N-S trending lineations, but all prolate samples (negative $T$ parameter) have ENE-WSW lineation, in agreement with the NE-SW lineation observed in TSS3. Horizontal foliation also dominates in Anefgou and Tirrhist, but the lineation is not well defined and only a weak pattern of E-W to N-S trend can be observed. Note that several samples of this area (those with transparency in Figure 11) show intermediate fabrics in AMS.

There are nearby sites (ANE3 and ANE4; TRF and TSS sites; Figure 11) that show a better clustering, even after applying the corresponding different rotations for each site. This is a complementary test supporting the correct restoration of the paleomagnetic and AMS data and also of the relative chronology of AMS and the blocking of magnetic fabric (i.e., magma solidification) that must predate solid-state rotation of igneous bodies. However, Tirrhist and Anefgou sites, where the paleomagnetic restoration is well constrained, show very different patterns and directions of their magnetic fabrics (Figure 11). This can be related to the internal conditioning of magmatic systems, such as differential magma fluxes.

In summary, western sites (western Tassent, Tasraft, and Anergui) are characterized by a NW-SE magnetic lineation. In both Tasraft and western Tassent ridges, the gabbro bodies are small and embedded within Triassic ductile rocks. In these cases, the magma was free to expand during its ascent and emplacement because the Triassic salts and shales acted as an isotropic medium. However, the pervasive NW-SE magnetic lineation indicates a preferred flow direction that can be related to the regional trend of extension; a NW-SE extensional stress favoring a magma expansion (and therefore a main flow direction) roughly parallel with it. This is consistent with the NW-SE to NNW-SSE extensional regime proposed for the Jurassic in this sector (Ait-Brahim et al., 2002). Magnetic foliation could be related either to lithostratigraphic pressure of the overburden or to ballooning during expansion of the intrusion.

The eastern bodies show a more heterogeneous magnetic fabric. This can be a response to the lack of available space for the intrusion. During magma ascent, the cooling magma would not be free to move laterally, thus conditioning the petrofabric. The roughly E-W to N-S lineation could be related to the shape of the bodies, which in turn were controlled by the geometry of the ridge and the fault system channeling magma upward to the emplacement levels.

\section{Evolutionary Models of the Gabbros}

Attending to the volume portion of gabbros in the core of the ridges and the subsequent behavior of the gabbro bodies during the evolution of the ridges, two kinds of structures can be distinguished (Figure 12). Tasraft type is characterized by small Jurassic igneous bodies embedded in a large amount of Triassic rocks, registering high rotations and the core is totally decoupled from the limbs; in Tirrhist type the core of the ridge is occupied mainly by Jurassic igneous rocks, and rotations are lower and similar for limbs and core (although a weak decoupling can also be interpreted). The ridges of the $\mathrm{CHA}$ and the rotations of the gabbro bodies are the result of three main stages (Figure 12):

1. Tilting of the bedding due to an early diapiric stage (Early-Middle Jurassic, Saura et al., 2014), mainly generating salt walls along inherited basement faults during basin formation, linked to extensional tectonics (Figure 12a).

2. Emplacement of igneous rocks during the Middle-Late Jurassic, partially using the gaps generated by the earlier diapiric processes, replacing the Triassic evaporites, and generating new structures of the host rocks, mainly in Anefgou and Tirrhist ridges. Diapiric processes were probably reactivated due to the activity of hydrothermal fluids that circulated along the ridges (Figure 12b) (Schofield et al., 2014). According to AMS, main flow direction in the Tasraft type is NW-SE, probably conditioned by the main NW-SE extensional tectonic regime, whereas in the Tirrhist type the main flow direction is roughly NE-SW, parallel to the main faults.

3. Basin inversion during Cenozoic shortening (Figure 12c) triggered an important erosion of Mesozoic sediments and exhumation of gabbros. Diapiric processes (Michard et al., 2011) affected the core of 


\section{QAGU Tectonics}

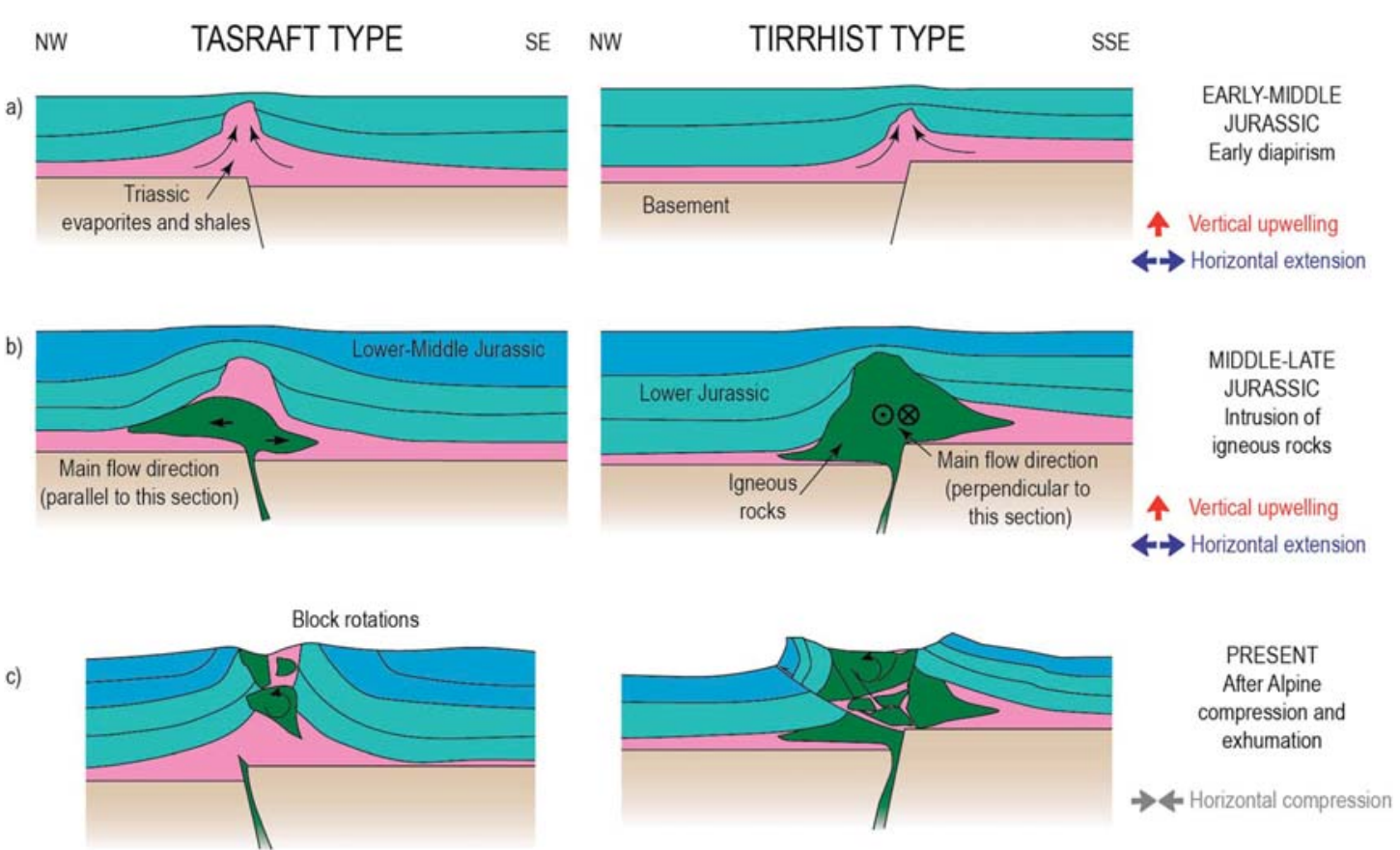

Figure 12. Evolutionary model of the two main kinds of structures found in the studied area, showing the main processes generating the ridges: (a) early diapirism predating the igneous intrusion, (b) igneous intrusion with deformation and reactivation of the diapiric processes due to the activity of hydrothermal fluids, and (c) Cenozoic shortening, exhumation and late diapirism (the latter intervening mainly in the Tasraft structure).

the ridges, especially in Tasraft and Tassent, where paleomagnetic analysis indicates strong rotations probably linked to a higher proportion of Triassic shales. However, according with the rotation pattern, these diapiric processes were conditioned by the trend of the structures and by the compressive tectonic regime, because rotations follow a systematic pattern and the scatter recorded by the paleomagnetic $H$ component cannot be considered as random. Therefore, the Cenozoic rotation of the gabbros is interpreted as a consequence of compression and north verging thrusting instead of late diapiric processes.

Considering everything, two kinds of structures can be distinguished. On one hand, Anefgou and Tirrhist (Figure 12) are short structures with large amounts of igneous rocks in their cores and practically absence of Triassic shales. These structures are actually similar to eastern Tassent gabbro. Both the Tirrhist and Anefgou gabbros show minor to moderate horizontal axes rotations; gabbros close to the host rocks recorded similar Cenozoic rotations. This can suggest that these gabbros were emplaced in contact with the limestones, generating tilting of beds. However, absence of rocks younger than the Lower Liassic as roof pendants embedded in the igneous rocks (Armando, 1999) in Tirrhist-Anefgou massifs indicates that the gabbros were emplaced below the Lower Liassic limestones and that during the Cenozoic shortening they were uplifted (about 3-4 km in the Tirrhist-Anefgou massifs) undergoing only minor block rotations.

On the other hand, the gabbros of Tassent and Tasraft (Figure 12) show significant rotations related to abundant shales and consequently more freedom of movement within them. Finally, Anergui structure cannot be interpreted as a true ridge but as a significant accumulation of igneous rocks whose ascent was favored by fractures at the intersection between the Tassent and Ikkou ridges.

\section{Conclusions}

The paleomagnetic study in the central High Atlas gabbros allows to isolate the characteristic component in 19 paleomagnetic sites. This is interpreted as a primary thermal magnetization (i.e., a thermal remanence acquired by these igneous rocks during their cooling ages) carried by SD to PSD magnetite. At least part of this magnetite is forming inclusions in silicate crystals (pyroxene, amphibole, and plagioclase). 


\section{QAGU Tectonics}

Distribution analysis of the paleomagnetic directions allows inferring horizontal axes rotations of the gabbro bodies in the Tirrhist-Anefgou massif and extrapolating this deformational model to other studied massifs. Two kinds of structures were differentiated according to both the rotation pattern (amount of rotation and orientation of rotation axis) and the outcrop pattern of each ridge. (i) Tirrhist type is characterized by wide, dome-shaped structures, with a large amount of Jurassic igneous rocks in their cores; small rotations $\left(<50^{\circ}\right)$ are registered, similar and coherent with the ones obtained in host rocks. (ii) Tasraft type is characterized by long structures with relatively small Jurassic igneous bodies embedded in a matrix of Triassic rocks.

Horizontal rotation axes used for restoration are E-W to NE-SW, parallel to each structure and indicating a tectonic control on the rotations. Strong rotations ( $>90^{\circ}$ in some sites) are recorded, much bigger than the ones registered by the host rock, indicating a decoupling between core and limbs due to the Cenozoic inversion. All sites record counterclockwise rotations (looking to the east and to the NE), indicating that they can be related to NW to north verging thrusting.

This study shows that this methodological approach can be a useful tool to restore igneous bodies lacking position markers.

Results from paleomagnetic analysis were used to restore the magnetic fabric to its prerotational stage. Magnetic fabric analysis (RT-AMS, LT-AMS, and AARM) combined with petrofabric studies infers normal fabrics in most of the sites, although in several cases intermediate to inverse fabrics (mainly in the eastern sector) occur. AMS is carried by magnetite that mimics the distribution of plagioclase crystals. Magnetic fabrics on the western sector show a prevailing NW-SE horizontal lineation that can be related to tectonic extension during the emplacement of igneous rocks. The eastern sector shows a more heterogeneous distribution in orientations, the direction of the prevailing lineations trending NE-SW, parallel to the main faults.

Acknowledgments

This study was financed by the research projects CGL2012-38481 and CGL201677560 of the MINECO (Spanish Ministry of Economy and Competitiveness) with also FEDER funding (European Union). P. C. also acknowledges the MINECO for the F.P.I. research grant BES-2013062988. The authors acknowledge Abdelkader Mahmoudi and Hmidou El Ouardi for helping in field work and Carlos Rossi for carrying out the extracts of the silicate crystals. Institute for Rock Magnetism (University of Minnesota, USA) and specifically Mike Jackson are thanked for rock magnetic measurement support. The authors also acknowledge the constructive revisions, comments, and suggestion from Helga de Wall and three anonymous reviewers. Raw data are in the supporting information.

\section{References}

Ait-Brahim, L., Chotin, P., Hinaj, S., Abdelouafi, A., El Adraoui, A., Nakcha, C., ... Chaouni, A. (2002). Paleostress evolution in the Moroccan African margin from Triassic to present. Tectonophysics, 357(1-4), 187-205. https://doi.org/10.1016/S0040-1951(02)00368-2

Antolín-Tomás, B., Román-Berdiel, T., Casas-Sainz, A., Gil-Peña, I., Oliva, B., \& Soto, R. (2009). Structural and magnetic fabric study of the Marimanha granite (axial zone of the Pyrenees). International Journal of Earth Sciences, 98(2), 427-441. https://doi.org/10.1007/ s00531-007-0248-1

Aranguren, A., Cuevas, J., Tubía, J. M., Román-Berdiel, T., Casas-Sainz, A., \& Casas-Ponsati, A. (2003). Granite laccolith emplacement in the Iberian arc: AMS and gravity study of the La Tojiza pluton (NW Spain). Journal of the Geological Society, 160(3), 435-445. https://doi.org/ 10.1144/0016-764902-079

Archanjo, C. J., Campanha, G. A. C., Salazar, C. A., \& Launeau, P. (2012). Using AMS combined with mineral shape preferred orientation analysis to understand the emplacement fabrics of the Apiaí gabbro-norite (Ribeira Belt, SE Brazil). International Journal of Earth Sciences, 101(3), 731-745. https://doi.org/10.1007/s00531-011-0659-x

Armando, G. (1999). Intracontinental alkaline magmatism: Geology, petrography, mineralogy and geochemistry of the Jebel Hayim Massif (central High Atlas-Morocco). Mémories de Géologie de l'Université de Lausanne, 31, 106.

Beauchamp, W. (2004). Superposed folding resulting from inversion of a synrift accommodation zone, Atlas Mountains, Morocco. In K. R. McClay (Ed.), Thrust tectonics and hydrocarbon systems, AAPG Memoir (Vol. 82, pp. 635-646). AAPG, American Association of Petroleum Geologists.

Biggin, A. J., van Hinsbergen, D. J. J., Langereis, C. G., Straathof, G. B., \& Deenen, M. H. L. (2008). Geomagnetic secular variation in the Cretaceous normal superchron and in the Jurassic. Physics of the Earth and Planetary Interiors, 169(1-4), 3-19. https://doi.org/10.1016/ j.pepi.2008.07.004

Bouchez, J. L. (1997). Granite is never isotropic: An introduction to AMS studies of granitic rocks. In J. L. Bouchez, D. H. W. Hutton, \& W. E. Stephens (Eds.), Granite: From segregation of melt to emplacement fabrics (Vol. 8, pp. 95-112). Dordrecht, Netherlands: Springer. https://doi.org/10.1007/978-94-017-1717-5

Bouchez, J.-L. (2000). Anisotropie de susceptibilité magnétique et fabrique des granites. Comptes Rendus de l'Académie des Sciences Series IIA - Earth and Planetary Science, 330(1), 1-14. https://doi.org/10.1016/S1251-8050(00)00120-8

Bouchez, J. L., \& Gleizes, G. (1995). Two-stage deformation of the Mont-Louis-Andorra granite pluton (Variscan Pyrenees) inferred from magnetic susceptibility anisotropy. Journal of the Geological Society, 152(4), 669-679. https://doi.org/10.1144/gsjgs.152.4.0669

Bouchez, J. L., Gleizes, G., Djouadi, T., \& Rochette, P. (1990). Microstructure and magnetic susceptibility applied to emplacement kinematics of granites: The example of the Foix pluton (French pyrenees). Tectonophysics, 184(2), 157-171. https://doi.org/10.1016/ 0040-1951(90)90051-9

Brown, L. L., \& McEnroe, S. A. (2015). 916 Ma pole for southwestern Baltica: Palaeomagnetism of the Bjerkreim-Sokndal layered intrusion, Rogaland igneous complex, southern Norway. Geophysical Journal International, 203(1), 567-587. https://doi.org/10.1093/ gji/ggv299

Calvín, P., Casas-Sainz, A. M., Villalaín, J. J., \& Moussaid, B. (2017). Diachronous folding and cleavage in an intraplate setting (central High Atlas, Morocco) determined through the study of remagnetizations. Journal of Structural Geology, 97, 144-160. https://doi.org/10.1016/ j.jsg.2017.02.009

Chadima, M., \& Hrouda, F. (2006). Remasoft 3.0 a user-friendly paleomagnetic data browser and analyzer. Travaux Géophysiques, $27,20-21$.

Chadima, M., \& Jelinek, V. (2009). Anisoft data browser, 4.2, AGICO inc.

Charrière, A. (1990). Héritage hercynien et évolution géodynamique alpine d'une chaîne intracontinentale: Le Moyen Atlas au SE de Fès (Maroc). Toulouse: Université Paul-Sabatier. 
Charrière, A., \& Haddoumi, H. (2016). Les <<Couches rouges $>>$ continentales jurassico-crétacées des Atlas marocains (Moyen Atlas, Haut Atlas central et oriental): bilan stratigraphique, paléogéographies successives et cadre géodynamique. Boletín Geológico y Minero, $127(2-3), 407-430$.

Day, R., Fuller, M., \& Schmidt, V. A. (1977). Hysteresis properties of titanomagnetites: Grain-size and compositional dependence. Physics of the Earth and Planetary Interiors, 13(4), 260-267. https://doi.org/10.1016/0031-9201(77)90108-X

de Sitter, L. U. (1952). Plissement croisé dans le Haut Atlas. Geologie en Mijnbouw, 14, 277-282.

Denyszyn, S. W., Feinberg, J. M., Renne, P. R., \& Scott, G. R. (2013). Revisiting the age and paleomagnetism of the Modipe Gabbro of South Africa. Precambrian Research, 238, 176-185. https://doi.org/10.1016/j.precamres.2013.10.002

Dunlop, D. J. (2002). Theory and application of the Day plot (Mrs/Ms versus $\mathrm{Hcr} / \mathrm{Hc}$ ) 1. Theoretical curves and tests using titanomagnetite data. Journal of Geophysical Research, 107(B3), 20562. https://doi.org/10.1029/2001JB000486

Dunlop, D. J., Hyodo, H., Knight, T., \& Steele, A. G. (1985). Palaeomagnetism of the Tudor gabbro, Ontario: Evidence for divergence between Grenvillia and interior Laurentia. Geophysical Journal International, 83(3), 699-720. https://doi.org/10.1111/j.1365-246X.1985.tb04333.x

Ebert, Y., Kessel, R., Shaar, R., Agnon, A., \& Ron, H. (2010). Petrology and rock magnetism of the gabbro of Troodos ophiolite. Physics of the Earth and Planetary Interiors, 183(3-4), 413-420. https://doi.org/10.1016/j.pepi.2010.09.006

Ettaki, M., Ibouh, H., Chellaï, E. H., \& Milhi (2007). Les structures "diapiriques" liasiques du Haut-Atlas central, Maroc: Example de la ride d'Ikerzi. Africa Geosciences Review, 14(1), 79-93.

Evans, M. E., \& McElhinny, M. W. (1966). The paleomagnetism of the Modipe Gabbro. Journal of Geophysical Research, 71(24), 6053-6063. https://doi.org/10.1029/JZ071i024p06053

Evans, M. E., McElhinny, M. W., \& Gifford, A. C. (1968). Single domain magnetite and high coercivities in a gabbroic intrusion. Earth and Planetary Science Letters, 4(2), 142-146. https://doi.org/10.1016/0012-821X(68)90008-3

Feinberg, J. M., Harrison, R. J., Kasama, T., Dunin-Borkowski, R. E., Scott, G. R., \& Renne, P. R. (2006). Effects of internal mineral structures on the magnetic remanence of silicate-hosted titanomagnetite inclusions: An electron holography study. Journal of Geophysical Research, 111 , B12S15. https://doi.org/10.1029/2006JB004498.

Feinberg, J. M., Scott, G. R., Renne, P. R., \& Wenk, H. R. (2005). Exsolved magnetite inclusions in silicates: Features determining their remanence behavior. Geology, 33(6), 513-516. https://doi.org/10.1130/G21290.1

Ferré, E. C., Bordarier, C., \& Marsh, J. S. (2002). Magma flow inferred from AMS fabrics in a layered mafic sill, Insizwa, South Africa. Tectonophysics, 354(1-2), 1-23. https://doi.org/10.1016/S0040-1951(02)00273-1

Fisher, R. (1953). Dispersion on a sphere. Proceedings of the Royal Society A: Mathematical, Physical and Engineering Sciences, 217(1130), 295-305. https://doi.org/10.1098/rspa.1953.0064

Frizon de Lamotte, D., Zizi, M., Missenard, Y., Hadif, M., El Azzouzi, M., Maury, R. C., ... Michard, A. (2008). The atlas system. In A. Michard, et al. (Eds.), Continental evolution: The geology of Morocco. Lecture notes in Earth sciences 116, (pp. 133-202). Berlin: Springer. https://doi.org/10.1007/978-3-540-77076-3_4

Gil, A., Lago, M., Galé, C., Pocoví, A., \& Arranz, E. (2002). Magnetic fabric in folded sills and lava flows. A case study in the Permian basalts of the Anayet Massif (Pyrenean axial zone, Spain). Tectonophysics, 350(1), 1-15. https://doi.org/10.1016/S0040-1951(02)00078-1

Girdler, R. W. (1961). The measurement and computation of anisotropy of magnetic susceptibility of rocks. Geophysical Journal International, 5(1), 34-44. https://doi.org/10.1111/j.1365-246X.1961.tb02927.x

Gradstein, F. M., Ogg, J. G., Schmitz, M. D., \& Ogg, G. M. (2012). The geologic time scale. Boston: Elsevier.

Granot, R., Tauxe, L., Gee, J., \& Ron, H. (2007). A view into the Cretaceous geomagnetic field from analysis of gabbros and submarine glasses. Earth and Planetary Science Letters, 256(1-2), 1-11. https://doi.org/10.1016/j.epsl.2006.12.028

Hailwood, E. A., \& Mitchell, J. G. (1971). Palaeomagnetic and radiometric dating results from Jurassic intrusions in South Morocco. Geophysical Journal International, 24(4), 351-364. https://doi.org/10.1111/j.1365-246X.1971.tb02183.x

Hurst, S. D., Verosub, K. L., \& Moores, E. M. (1992). Paleomagnetic constraints on the formation of the Solea graben, Troodos ophiolite, Cyprus. Tectonophysics, 208(4), 431-445. https://doi.org/10.1016/0040-1951(92)90439-D

Ibouh, H., Michard, A., Charrière, A., Benkaddour, A., \& Rhoujjati, A. (2014). Tectonic-karstic origin of the alleged "impact crater" of Lake Isli (Imilchil district, High Atlas, Morocco). Comptes Rendus Geoscience, 346(3-4), 82-89. https://doi.org/10.1016/j.crte.2014.03.005

Izquierdo-Llavall, E., Román-Berdiel, T., Casas, A. M., Oliva-Urcia, B., Gil-Peña, l., Soto, R., \& Jabaloy, A. (2012). Magnetic and structural study of the Eaux-Chaudes intrusion: Understanding the Variscan deformation in the western axial zone (Pyrenees). International Journal of Earth Sciences, 101(7), 1817-1834. https://doi.org/10.1007/s00531-012-0760-9

Jelínek, V. (1978). Statistical processing of anisotropy of magnetic susceptibility measured on groups of specimens. Studia Geophysica et Geodaetica, 22(1), 50-62. https://doi.org/10.1007/BF01613632

Jelinek, V. (1981). Characterization of the magnetic fabric of rocks. Tectonophysics, 79(3-4), 63-67. https://doi.org/10.1016/ 0040-1951(81)90110-4

Kirschvink, J. L. (1980). The least-squares line and plane and the analysis of paleomagnetic data. Geophysical Journal of the Royal Astronomical Society, 62(3), 699-718. https://doi.org/10.1111/j.1365-246X.1980.tb02601.x

Laville, E., \& Piqué, A. (1992). Jurassic penetrative deformation and Cenozoic uplift in the central High Atlas (Morocco): A tectonic model. Structural and orogenic inversions. Geologische Rundschau, 81(1), 157-170. https://doi.org/10.1007/BF01764546

Liodas, N. T., Gébelin, A., Ferré, E. C., \& Misgna, G. M. (2013). Deformation coupling between the Archean Pukaskwa intrusive complex and the Hemlo shear zone, Superior Province, Canada. Tectonophysics, 608, 1226-1237. https://doi.org/10.1016/j.tecto.2013.06.022

Lüneburg, C. M., Lampert, S. A., Lebit, H. D., Hirt, A. M., Casey, M., \& Lowrie, W. (1999). Magnetic anisotropy, rock fabrics and finite strain in deformed sediments of SW Sardinia (Italy). Tectonophysics, 307(1-2), 51-74. https://doi.org/10.1016/S0040-1951(99)00118-3

Maes, S. M., Tikoff, B., Ferré, E. C., Brown, P. E., \& Miller, J. D. Jr. (2007). The Sonju Lake layered intrusion, northeast Minnesota: Internal structure and emplacement history inferred from magnetic fabrics. Precambrian Research, 157(1-4), 269-288. https://doi.org/10.1016/ j.precamres.2007.02.021

Mattauer, M., Tapponnier, P., \& Proust, F. (1977). Sur les mecanismes de formation des chaines intracontinentales; l'exemple des chaines atlasiques du Maroc. Bulletin de la Societe Geologique de France, S7-XIX(3), 521-526. https://doi.org/10.2113/gssgfbull.S7-XIX.3.521

McCabe, C., Jackson, M., \& Ellwood, B. B. (1985). Magnetic anisotropy in the Trenton limestone: Results of a new technique, anisotropy of anhysteretic susceptibility. Geophysical Research Letters, 12(6), 333-336. https://doi.org/10.1029/GL012i006p00333

McEnroe, S. A. (1996). A Barremian-Aptian (Early Cretaceous) North American paleomagnetic reference pole. Journal of Geophysical Research: Solid Earth, 101(B7), 15,819-15,835. https://doi.org/10.1029/96JB00652

McNulty, B. A., Tobisch, O. T., Cruden, A. R., \& Gilder, S. (2000). Multistage emplacement of the Mount Givens pluton, central Sierra Nevada batholith, California. Geological Society of America Bulletin, 112(1), 119-135. https://doi.org/10.1130/0016-7606(2000)112\%3C119: MEOTMG\%3E2.0.CO;2 
Michard, A., Ibouh, H., \& Charrière, A. (2011). Syncline-topped anticlinal ridges from the High Atlas: A Moroccan conundrum, and inspiring structures from the Syrian Arc, Israel. Terra Nova, 23(5), 314-323. https://doi.org/10.1111/j.1365-3121.2011.01016.x

Morrish, A. H. (1965). The physical principles of magnetism. Hoboken, NJ: John Wiley.

Moussaid, B., Villalaín, J. J., Casas-Sainz, A., El Ouardi, H., Oliva-Urcia, B., Soto, R., ... Torres-López, S. (2015). Primary vs. secondary curved fold axes: Deciphering the origin of the Ait Attab syncline (Moroccan High Atlas) using paleomagnetic data. Journal of Structural Geology, 70 , 65-77. https://doi.org/10.1016/j.jsg.2014.11.004

Muxworthy, A. R., \& Evans, M. E. (2013). Micromagnetics and magnetomineralogy of ultrafine magnetite inclusions in the Modipe Gabbro. Geochemistry, Geophysics, Geosystems, 14, 921-928. https://doi.org/10.1029/2012GC004445

Muxworthy, A. R., Evans, M. E., Scourfield, S. J., \& King, J. G. (2013). Paleointensity results from the late-Archaean Modipe Gabbro of Botswana. Geochemistry, Geophysics, Geosystems, 14, 2198-2205. https://doi.org/10.1002/ggge.20142

O'Driscoll, B., Stevenson, C. E. T. E., Troll, V. R., Trolly, V. R., \& Troll, V. R. (2008). Mineral lamination development in layered gabbros of the British Palaeogene igneous province: A combined anisotropy of magnetic susceptibility, quantitative textural and mineral chemistry study. Journal of Petrology, 49(6), 1187-1221. https://doi.org/10.1093/petrology/egn022

Oliva-Urcia, B., Casas, A. M., Pueyo, E. L., Juan, A., Oliva-Urcía, B., Pueyo, E. L., ... Pocovi-Juan, A. (2012). Paleomagnetic evidence for non-rotational kinematics of the South Pyrenean Frontal Thrust at the western termination of the External Sierras southwestern central. Geologica Acta, 10, 125-144. https://doi.org/10.1344/105.000001704

Oliva-Urcia, B., Casas, A. M., Soto, R., Villalaín, J. J., \& Kodama, K. (2011). A transtensional basin model for the Organyà basin (central southern Pyrenees) based on magnetic fabric and brittle structures. Geophysical Journal International, 184(1), 111-130. https://doi.org/10.1111/ j.1365-246X.2010.04865.x

Osete, M. L., Rey, D., Villalaín, J. J., \& Juárez, M. (1997). The Late Carboniferous to Late Triassic segment of the apparent polar wander path of Iberia. Geologie En Mijnbouw (Geology and Mining), 76(1/2), 105-119. https://doi.org/10.1023/A:1003197500052

Pariso, J. E., Kelso, P., \& Richter, C. (1996). Paleomagnetism and rock magnetic properties of gabbro from Hole 894G, Hess Deep. Proceedings of the Ocean Drilling. Program, 147 Scientific Results. Ocean Drilling Program. https://doi.org/10.2973/odp.proc. sr.147.023.1996

Poisson, A., Hadri, M., Milhi, A., Julien, M., \& Andrieux, J. (1998). The Central High-Atlas (Morocco). Litho- and chrono-stratigraphic correlations during Jurassic times between Tinjdad and Tounfite. Origin of subsidence. In S. Crasquin-Soleau \& E. Barrier (Eds.), Peri-Tethys memoir 4: Epicratonic basins of Peri-Tethyan platforms (pp. 237-256). Paris: Mémoires du Muséum National d'Histoire Naturelle.

Potter, D. K., \& Stephenson, A. (1988). Single-domain particles in rocks and magnetic fabric analysis. Geophysical Research Letters, 15(10), 1097-1100. https://doi.org/10.1029/GL015i010p01097

Pueyo Anchuela, Ó., Gil Imaz, A., Gil-Peña, I., Maestro, A., Galindo-Zaldivar, J., López-Martínez, J., ... Oliva-Urcia, B. (2014). Application of AMS for reconstruction of the geological evolution of recent volcanic systems: Case of Deception Island (South Shetland Islands, Antarctica) Tectonophysics, 626, 69-85. https://doi.org/10.1016/j.tecto.2014.03.032

Renne, P. R., Scott, G. R., Glen, J. M. G., \& Feinberg, J. M. (2002). Oriented inclusions of magnetite in clinopyroxene: Source of stable remanent magnetization in gabbros of the Messum Complex, Namibia. Geochemistry, Geophysics, Geosystems, 3(12), 1079. https://doi.org/10.1029/ 2002 GC000319

Román-Berdiel, T. (1999). Geometry of granite emplacement in the upper crust: Contributions of analogue modelling. Geological Society, London, Special Publications, 168(1), 77-94. https://doi.org/10.1144/GSL.SP.1999.168.01.06

Román-Berdiel, T., Casas, A., Oliva-Urcia, B., Pueyo, E., \& Rillo, C. (2004). The main Variscan deformation event in the Pyrenees: New data from the structural study of the Bielsa granite. Journal of Structural Geology, 26(4), 659-677. https://doi.org/10.1016/j.jsg.2003.09.001

Román-Berdiel, T., Casas, A. M., Oliva-Urcia, B., Pueyo, E. L., Liesa, C., \& Soto, R. (2006). The Variscan Millares granite (central Pyrenees): Pluton emplacement in a T fracture of a dextral shear zone. Geodinamica Acta, 19(3-4), 197-211. https://doi.org/10.3166/ ga.19.197-211

Roman-Berdiel, T., Gapais, D., \& Brun, J. P. (1995). Analogue models of laccolith formation. Journal of Structural Geology, 17(9), $1337-1346$. https://doi.org/10.1016/0191-8141(95)00012-3

Roman-Berdiel, T., Gapais, D., \& Brun, J.-P. (1997). Granite intrusion along strike-slip zones in experiment and nature. American Journal of Science, 297(6), 651-678. https://doi.org/10.2475/ajs.297.6.651

Saura, E., Vergés, J., Martín-Martín, J. D., Messager, G., Moragas, M., Razin, P., ... Hunt, D. W. (2014). Syn- to post-rift diapirism and minibasins of the central High Atlas (Morocco): The changing face of a mountain belt. Journal of the Geological Society, 171(1), 97-105. https://doi.org/ $10.1144 /$ jgs 2013-079

Schöbel, S., \& de Wall, H. (2014). AMS-NRM interferences in the Deccan basalts: Toward an improved understanding of magnetic fabrics in flood basalts. Journal of Geophysical Research: Solid Earth, 119, 2651-2678. https://doi.org/10.1002/2013JB010660

Schofield, N., Alsop, I., Warren, J., Underhill, J. R., Lehne, R., Beer, W., \& Lukas, V. (2014). Mobilizing salt: Magma-salt interactions. Geology, 42(7), 599-602. https://doi.org/10.1130/G35406.1

Schöpa, A., Floess, D., Blanquat, M., Saint, D., Annen, C., \& Launeau, P. (2015). The relation between magnetite and silicate fabric in granitoids of the Adamello batholith. Tectonophysics, 642, 1-15. https://doi.org/10.1016/j.tecto.2014.11.022

Spera, F. (1980). Thermal evolution of plutons: A parameterized approach. Science (New York, N.Y.), 207(4428), 299-301. https://doi.org/ $10.1126 /$ science.207.4428.299

Tarling, D. H., \& Hrouda, F. (1993). The magnetic anisotropy of rocks. London: Chapman \& Hall.

Teixell, A., Arboleya, M.-L., Julivert, M., \& Charroud, M. (2003). Tectonic shortening and topography in the central High Atlas (Morocco). Tectonics, 22(5), 1051. https://doi.org/10.1029/2002TC001460

Torres-López, S., Casas, A. M., Villalaín, J. J., El Ouardi, H., \& Moussaid, B. (2016). Pre-Cenomanian vs. Cenozoic folding in the High Atlas revealed by palaeomagnetic data. Terra Nova, 28(2), 110-119. https://doi.org/10.1111/ter.12197

Torres-López, S., Villalaín, J. J., Casas, A. M., El Ouardi, H., Moussaid, B., \& Ruiz-Martínez, V. C. (2014). Widespread Cretaceous secondary magnetization in the High Atlas (Morocco). A common origin for the Cretaceous remagnetizations in the western Tethys? Journal of the Geological Society, 171(5), 673-687. https://doi.org/10.1144/jgs2013-107

Torsvik, T. H., Van der Voo, R., Preeden, U., Niocaill, C. M., Steinberger, B., Doubrovine, P. V., ... Cocks, L. R. M. (2012). Phanerozoic polar wander, palaeogeography and dynamics. Earth-Science Reviews, 114(3-4), 195-217. https://doi.org/10.1016/j.earscirev.2012.06.002

Usui, Y., Nakamura, N., \& Yoshida, T. (2006). Magnetite microexsolutions in silicate and magmatic flow fabric of the Goyozan granitoid (NE Japan): Significance of partial remanence anisotropy. Journal of Geophysical Research, 111, B11101. https://doi.org/10.1029/ $2005 J$ JB004183

Usui, Y., Shibuya, T., Sawaki, Y., \& Komiya, T. (2014). Rock magnetism of tiny exsolved magnetite in plagioclase from a Paleoarchean granitoid in the Pilbara craton. Geochemistry, Geophysics, Geosystems, 16, 112-125. https://doi.org/10.1002/2014GC005508 
Usui, Y., \& Yamazaki, S. (2010). Salvaging primary remanence from hydrothermally altered oceanic gabbros in the Oman ophiolite: A selective destructive demagnetization approach. Physics of the Earth and Planetary Interiors, 181(1-2), 1-11. https://doi.org/10.1016/ j.pepi.2010.04.008

Van der Voo, R. (1967). The rotation of Spain: Palaeomagnetic evidence from the Spanish meseta. Palaeogeography, Palaeoclimatology, Palaeoecology, 3, 393-416. https://doi.org/10.1016/0031-0182(67)90027-2

Van der Voo, R. (1969). Paleomagnetic evidence for the rotation of the Iberian Peninsula. Tectonophysics, 7(1), 5-56. https://doi.org/10.1016/ 0040-1951(69)90063-8

Verwey, E. J. (1939). Electronic conduction of magnetite $\left(\mathrm{Fe}_{3} \mathrm{O}_{4}\right)$ and its transition point at low temperatures. Nature (London), 144(3642), 327-328. https://doi.org/10.1038/144327b0

Villalaín, J., Fernández-González, G., Casas, A. M., \& Gil-Imaz, A. (2003). Evidence of a cretaceous remagnetization in the Cameros Basin (North Spain): Implications for basin geometry. Tectonophysics, 377(1-2), 101-117. https://doi.org/10.1016/j.tecto.2003.08.024

Villalaín, J. J., Casas-Sainz, A. M., \& Soto, R. (2016). Reconstruction of inverted sedimentary basins from syn-tectonic remagnetizations. A methodological proposal. Geological Society, London, Special Publications, 425(1), 233-246. https://doi.org/10.1144/SP425.10

Villalaín, J. J., Ruiz, V. C., Torres-López, S., Casas-Sainz, A., Moussaid, B., \& Calvín, P. (2016). Estudio paleomagnético preliminar de diques mesozoicos del Alto Atlas. Control térmico en la generación de pirrotina en calizas remagnetizadas con magnetita. In J. A. Morales-González, et al. (Eds.), IX Congreso Geológico de España (Vol. 16, pp. 901-904). Huelva, Spain: Sociedad Geológica de España.

Walz, F. (2002). The Verwey transition-A topical review. Journal of Physics: Condensed Matter, 14(12), R285-R340. https://doi.org/10.1088/ 0953-8984/14/12/203

Wenk, H.-R., Chen, K., \& Smith, R. (2011). Morphology and microstructure of magnetite and ilmenite inclusions in plagioclase from Adirondack anorthositic gneiss. American Mineralogist, 96(8-9), 1316-1324. https://doi.org/10.2138/am.2011.3760

Zayane, R., Essaifi, A., Maury, R. C., Piqué, A., Laville, E., \& Bouabdelli, M. (2002). Cristallisation fractionnée et contamination crustale dans la série magmatique jurassique transitionnelle du Haut Atlas central (Maroc). Comptes Rendus Geoscience, 334(2), 97-104. https://doi.org/ $10.1016 /$ S1631-0713(02)01716-9 


\section{Magnetic fabrics in remagnetized carbonates}

8.1 Anisotropic magnetite growth in remagnetized limestones: Tectonic constrains and implications for basin history.

8.2 The carriers of AMS in remagnetized carbonates. Insights for remagnetization mechanism and basin evolution. 

A usual procedure working with magnetic fabrics is the comparison between the magnetic ellipsoid before and after the total bedding correction. Then, it is possible to know if the magnetic fabric was developed before or after the tilting of the bedding. However, a partial bedding correction according the paleodip data can be applied, which can be compared with the other stages. Then, a best cluster of the magnetic fabric when different sites are considered can indicate that the magnetic fabric was developed at the same time that the acquisition of the remagnetization.

In this chapter we present (i) AARM (anisotropy of the anhysteretic remanent magnetization) data to analyze the magnetic fabric carried by the SSD magnetite that also carries the remagnetization. After the magnetic fabric of the magnetite is constrained, (ii) the RT-AMS (room temperature anisotropy of the magnetic susceptibility), which is compared with subfabrics is analyzed. Then, and supported by rock magnetic data, the carriers of the RT-AMS in remagnetized limestones can be evaluated. 



\title{
Anisotropic magnetite growth in remagnetized limestones: Tectonic constraints and implications for basin history
}

\author{
Pablo Calvín', Juan J. Villalaín', and Antonio M. Casas-Sainz² \\ 1Departamento de Física, Universidad de Burgos, Av/ Cantabria s/n, 9006 Burgos, Spain \\ ${ }^{2}$ Geotransfer Research Group (IUCA), Universidad de Zaragoza, C/ Pedro Cerbuna 12, 50009 Zaragoza, Spain
}

\begin{abstract}
Magnetic properties of sedimentary rocks have been commonly exploited to determine the tectonic and chemical evolution of sedimentary basins. We here propose the use of the anisotropy of the anhysteretic remanent magnetization (ARM) to infer the orientation of magnetite grains formed during remagnetization stages, and hence to obtain the tectonic regime during the magnetization period, whose age can also be constrained by paleomagnetic methods. The anisotropy of ARM technique is here applied to remagnetized Jurassic limestones from the Central High Atlas (North Africa). These rocks were remagnetized at ca. 100 Ma during the Cretaceous Normal Superchron in an extensional tectonic setting. The magnetic fabric carried by authigenic magnetite (which is also the carrier of the remagnetization) shows a consistent orientation after a partial bedding correction, which precisely corresponds with the attitude of strata at the time of remagnetization. The anisotropy of the ARM tensor shows a well-defined horizontal lineation parallel to the Mesozoic regional extension, and a horizontal magnetic foliation perpendicular to the lithostatic maximum stress axis. Therefore, our results demonstrate that (1) the magnetite grain growth was consistent with the stress conditions and did not follow any preexisting fabric of the rock, and (2) these grains did not rotate during the subsequent compressional events.
\end{abstract}

\section{INTRODUCTION}

Magnetic methods commonly applied in basin analysis include the analysis of the anisotropy of magnetic susceptibility (AMS) that results from the contribution of ferro-, para-, and dia-magnetic minerals (see García-Lasanta et al., 2014, and references therein) and more specific methods (Hirt and Almqvist, 2012; see below) that are able to isolate the ferromagnetic contribution to the magnetic fabric of the sedimentary rock. Particularly, analysis of the anisotropy of remanent magnetization is a tool to infer the orientation of ferromagnetic (sensu lato, s.l.) grains. Previous studies (McCabe et al., 1985; Jackson et al., 1989; Jackson, 1990) have used the anisotropy of the anhysteretic remanent magnetization (ARM) to understand the behavior of neoformed magnetite under compressional tectonic regimes; specifically, its applicability for estimating strain in weakly deformed rocks. Because remagnetization processes can be linked to magnetite neoformation, whose age and relationship with geometrical features within sedimentary basins can be controlled (pre-, syn- or post-folding), the fabric defined by these crystals can provide information about basin history. However, in the described example (the Appalachian Mountains of the United States; e.g., Jackson, 1990), remagnetization and compression occurred simultaneously, and therefore it remains unclear whether the compressional magnetic fabric carried by magnetite is due to (1) growth of the magnetic grains according to the tectonic strain field or, alternatively, (2) compressional modification of an initially isotropic fabric (Sun et al., 1993).

The Central High Atlas chain (North Africa; Fig. 1) shows a distinct and well-defined temporal relationship between remagnetization and tectonics, which can help to clarify the tectonic significance of anisotropy of the ARM. Its regional geological history is summarized as follows. During the Triassic and the Jurassic, a thick sedimentary sequence was deposited under a northwest-southeast extensional tectonic regime (e.g., Ait-Brahim et al., 2002). Jurassic sedimentation produced a thick sedimentary pile ( $>5 \mathrm{~km}$ in the depocenters) composed almost entirely of carbonates, which was subsequently deformed by extensional and halokinetic processes during the Jurassic (e.g., Ettaki et al., 2007). During the Cretaceous, these rocks were affected by a widespread interfolding remagnetization carried by magnetite, dated to ca. $100 \mathrm{Ma}$ by comparison with the global apparent polar wander path (Torres-López et al., 2014). Using this remagnetization, it is possible to restore the attitude of the beds (for each paleomagnetic site) at the moment of remagnetization (e.g., Calvín et al., 2017); in other words, we can determine the paleodip of the bedding during the precompressional stage (Fig. 2). Note that the interfolding behavior of this remagnetization means that it is temporally bracketed between two different folding stages (Jurassic extension and Cenozoic compression). After the extensional stage and remagnetization event, the basin was inverted during the Cenozoic (Mattauer et al., 1977). Compression was accompanied by the development of an ESE-WNW-trending pressure-solution cleavage associated both with layer-parallel shortening and flattening derived from folding (Calvín et al., 2017). In this setting, we analyze the magnetic fabric of the magnetite that carries the ca. 100 Ma remagnetization by means of the
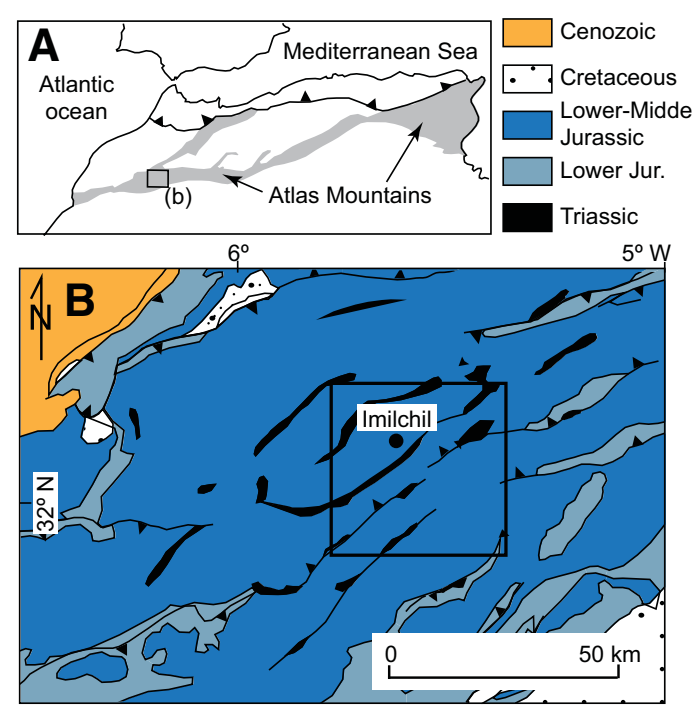

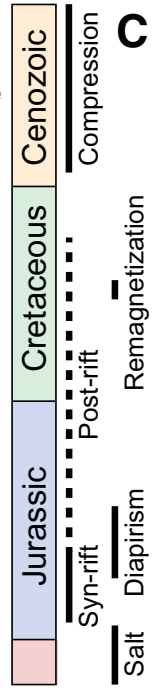

Figure 1. A: Location of the Central High Atlas in North Africa. B: Geological sketch showing the study area (highlighted by the box in A). C: Remagnetization in the context of the main tectonic events. 


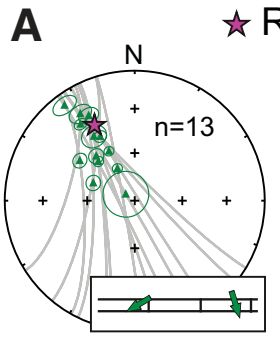

After total bedding correction
Remagnetization reference

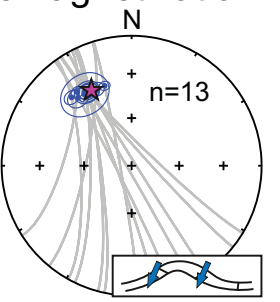

After partial bedding correction

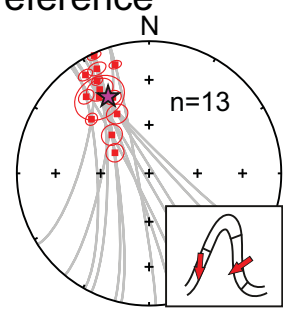

Before bedding correction

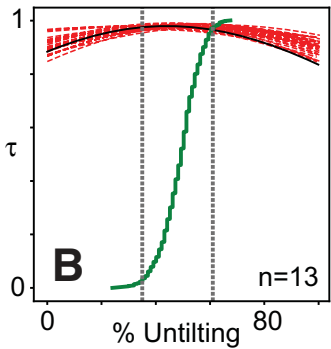

Figure 2. A: Mean paleomagnetic directions of the 13 study sites (from the Atlas Mountains of Morocco) represented in an equal area projection (lower hemisphere), with different bedding corrections. B: Bootstrap fold-test (Tauxe and Watson, 1994) showing the synfolding behavior of the remagnetization. $\tau$-largest eigenvalue of the orientation matrix.

ARM anisotropy. By comparing the ARM magnetic ellipsoid before bedding correction, after partial bedding correction (i.e., restoring to the paleodip at the remagnetization time), and after total bedding correction, we infer the controls on the growth of magnetite grains and the effects of the subsequent cleavage development on their magnetic fabrics.

\section{METHODS}

The anisotropy of the ARM was measured in 62 standard paleomagnetic specimens of Jurassic limestones from 13 different sites in the Atlas Mountains of Morocco (4-5 specimens per site) (see Table DR1 in the GSA Data Repository ${ }^{1}$ ). The measurement procedure of the ARM tensor was performed according to the method of McCabe et al. (1985), using a direct field of $0.05 \mathrm{mT}$ coupled with a coaxial alternating field with a peak of $90 \mathrm{mT}$. After each ARM step, the specimens were demagnetized in a peak alternating field of $100 \mathrm{mT}$, and this measurement was used as a baseline for each position to remove the contribution of grains with coercivities over $100 \mathrm{mT}$. This process was performed at the University of Burgos (Spain) using a 2G 755 cryogenic magnetometer with integrated direct- and alternating-field coils. The symmetric secondcalculated with the least squares method from the nine measured positions, according to Girdler's (1961) procedure.

Twin specimens from the 13 analyzed sites were previously demagnetized and paleomagnetically analyzed (Calvín et al., 2017). Using the Small Circle methods (Fig. DR1 in the Data Repository), we calculated the remagnetization direction (declination, D: $330.9^{\circ}$; inclination, I: $35.1^{\circ}$ ) and the paleodips of the beds at the remagnetization time. Present-day dips and paleodips

${ }^{1}$ GSA Data Repository item 2018275, the Small Circle method and bedding restorations, rock magnetism of the remagnetized limestones, and Tables DR1 and DR2 and Figures DR1-DR3, is available online at http://www.geosociety.org/datarepository/2018/ or on request from editing@ geosociety.org. vary between $14^{\circ}-64^{\circ}$ and $5^{\circ}-49^{\circ}$, respectively (Table DR1). These data were used to restore the ARM principal axes. After both restorations of the ARM tensor (i.e., according to the dip and the paleodip of the bedding), we obtained a fresh view of the principal axes (1) in their present-day position, (2) after total bedding correction, i.e., in stratigraphic coordinates, and (3) after partial bedding correction, which represents the orientation of the ARM ellipsoid after restoring bedding geometry to the remagnetization time (Fig. 3).

\section{RESULTS}

Rock magnetic experiments (Figs. DR2 and DR3) point to stable single-domain (SSD) tion; BBC—before bedding correction. rank tensor that defines the ARM ellipsoid was magnetite as the carrier of the remagnetization, which covers the coercivity spectra (0-90 mT) used in the ARM acquisition (Fig. DR3b). Negligible differences between the magnetization applied along both the $z$ and $-z$ axis directions (Fig. DR3f; Mitra et al., 2011) are indicative of uniaxial particles.

The directional data of the ARM tensor (Fig. 3) show different degrees of clustering in the different coordinate systems, with significantly better clustering after applying the partial bedding correction. The maximum ellipsoid axes tend to be horizontal with a NNW-SSE trend, and the minimum axes are nearly vertical and contained within an ENE-WSW vertical plane. Dispersion of both the minimum and the maximum axes before and after total vertical plane, perpendicular to the average bedding strike. Directional data show a well-defined cluster of maximum axes and a girdle between the minimum and intermediate axes. However, it is possible to statistically define a horizontal magnetic foliation (with a vertical minimum axis). At specimen level, the shape parameter $\mathrm{T}$ (Table DR2) shows a dominance of negatives values (mean: -0.17 ). The anisotropy degree (Pj) presents low values, i.e., between 1.02 and 1.07 for most samples (mean: $1.04 \pm 0.02$ ), very similar to other remagnetized limestones (e.g., McCabe et al., 1985; Jackson, 1990; Lu and McCabe, 1993). bedding correction occurs within a NNW-SSE
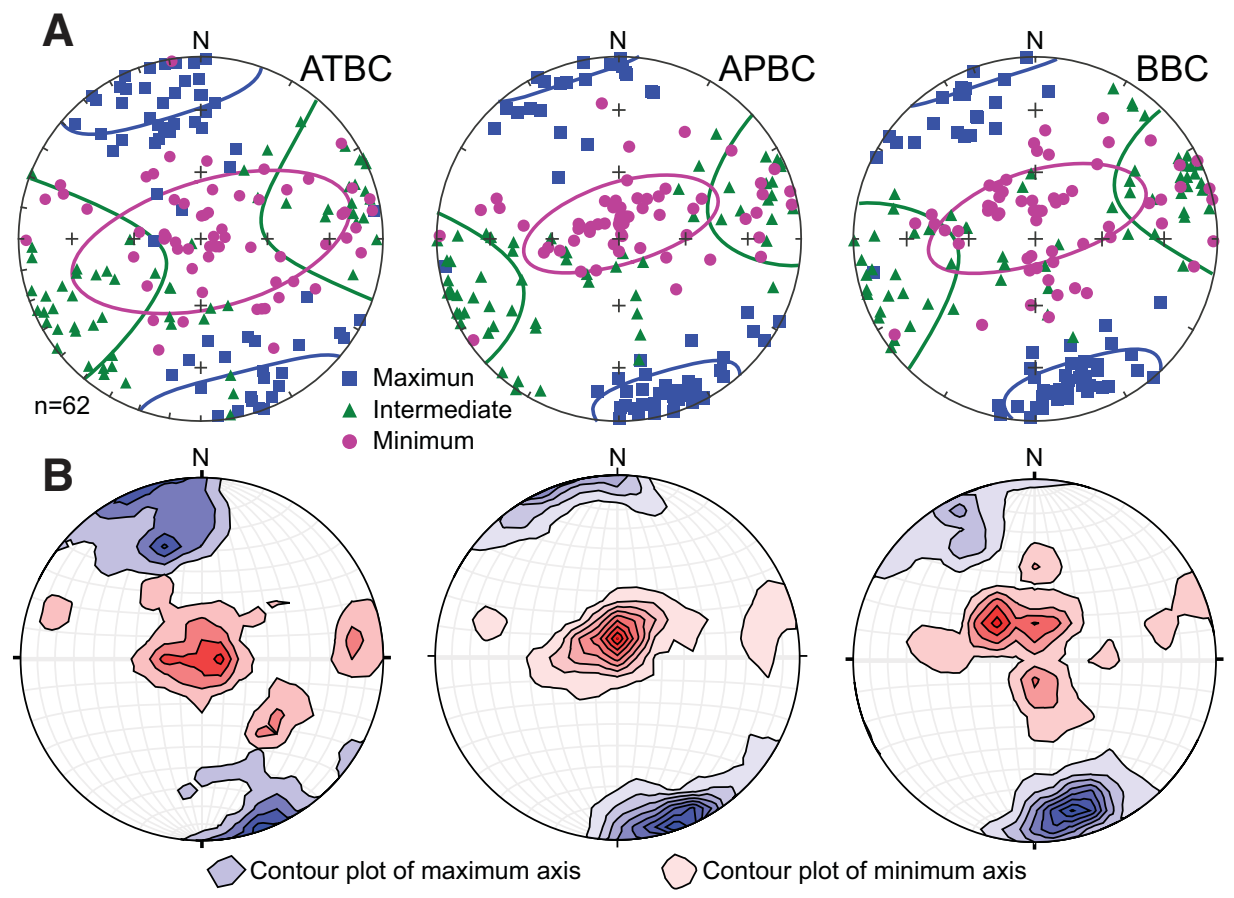

Figure 3. A: Orientation of the principal axis of anhysteretic remanent magnetization (ARM) and Hext (1963) ellipses. B: Contour plots (interval $4 \%$ per $1 \%$ area) of the maximum and minimum axes. The results from 62 specimens (13 paleomagnetic sites in the Atlas Mountains, Morocco) are represented. The contour interval is $3 \%$. The raw data are shown in Table DR2 (see footnote 1). ATBC-after total bedding correction; APBC-after partial bedding correc- 


\section{DISCUSSION}

The rock magnetic and paleomagnetic analyses indicate that the ARM is carried by uni-axial SSD magnetite grains, also responsible for the remagnetization. The directional data from the ARM ellipsoid show the best clustering after applying the partial bedding corrections. Therefore, a clear link exists between the structure at the remagnetization time and the magnetic fabric defined by the carriers of the remagnetization. In addition, the ferromagnetic fabric can be interpreted to have formed under an extensional tectonic regime because a well-defined cluster of the maximum axes is in a horizontal position aligned with the NW-SE to NNW-SSE extension dominant during the Mesozoic (e.g., Ait-Brahim et al., 2002), and the horizontal magnetic foliation is perpendicular to the lithostatic stress (the maximum stress axis in an extensional regime).

Three main conclusions can be inferred from these results. (1) The growth of magnetite grains was not conditioned by preexisting sedimentary or mineralogical structures, such as laminations. (2) Additionally, these grains did not define an isotropic fabric during their growth. Conversely, the magnetite grains grew following the extensional tectonic constraints present in the Atlas Mountains, producing a weak but welldefined magnetic fabric (Fig. 4A). (3) The postremagnetization compression, which involved the development of pressure-solution cleavage, was not capable of modifying the orientation of the magnetite grains since no evidence of the influence of north-south compression is present in the ARM ellipsoid (an east-west magnetic lineation, parallel to the intersection lineation, could be expected).

These points seem to be interrelated with the growth mechanism of the magnetite grains. Clay transformations and pyrite oxidation are the main possible remagnetization mechanisms in carbonates (see Elmore et al., 2012). If magnetite is related to clay transformations, authigenic grains are expected to follow preexisting structures defined by clays. Furthermore, magnetite grains should have been affected by compression since phyllosilicates are rotated according to cleavage formation (Calvín et al., 2017) However, pyrite oxidation imposes a completely different scenario. Pyrite crystals are isotropic and the grains themselves are not affected by preexisting sedimentary fabrics. Then, nanometric magnetite grains can grow within an isotropic space (inside the pyrite grains) being conditioned only by the infinitesimal strain (equivalent to the stress conditions) during their growth. Finally, during compression, pyrite grains are competent enough to deflect cleavage surfaces, and shield magnetite grains from the effects of compression.

These results are applicable to ARM anisotropy studies performed in the Appalachian Mountains of the United States, where remagnetization is related to compression (e.g., Jackson, 1990). Similar to this work, several studies on magnetic fabrics (McCabe et al., 1985, and references therein; Jackson et al., 1989; Sun et al., 1993) documented a ferromagnetic fabric whose maximum principal axis tends to be horizontal and perpendicular to the compression, and the minimum and intermediate axes are distributed in a girdle within the vertical plane that contains the compression direction. Sun at el. (1993) sug gested that this ARM ellipsoid reflects either (1) neoformation or growth of SSD magnetite during remagnetization according to layer-parallel compression, or (2) reorientation during compression of a previous isotropic fabric defined by SSD grains. In light of the results shown in this work, the growth of magnetic grains is more likely to directly mimic the compression (Fig. 4B), corresponding to the first hypothesis. Thus, the ARM magnetic ellipsoid can be considered a primary fabric because it is fixed during the growth of the grains.

In summary, the ARM anisotropy is capable of recording the stress conditions in limestones (even under weak deformation) during the growth of the remagnetization carriers (Fig. 4). When remagnetization occurs in an extensional setting (Fig. 4A), the maximum principal axis of the ARM tensor tends to be parallel to the minimum (horizontal) stress, whereas the minimum principal axis tends to parallelize the maximum (vertical) stress. On the other hand, when remagnetization occurs under compression, the maximum horizontal axis is horizontal and perpendicular to the compression direction (i.e., parallel to the intersection lineation), and minimum and intermediate axes lie in a vertical plane parallel to compression (Fig. 4B). This arrangement results from the interaction between the lithostatic pressure and the horizontal compression.

This novel approach for working with magnetic fabrics can be extended to other sedimentary basins. Classically, the (para-)magnetic fabric carried by phyllosilicates is used to infer the tectonic evolution of sedimentary basins (e.g., Cifelli et al., 2004; García-Lasanta et al., 2014, and references therein) because the phyllosilicates are aligned with the stretching direction during early diagenesis. Several of these basins are affected by widespread remagnetizations (e.g., García-Lasanta et al., 2014), and therefore the evolutionary knowledge of the basins can be complemented with the application of the anisotropy of the ARM and its restoration to the remagnetization time.

\section{CONCLUSIONS}

Rock magnetism experiments carried out in chemically remagnetized limestones of the Central High Atlas (North Africa) show that the remanence is mainly carried by uni-axial SSD magnetite grains. The anisotropy of the
A Atlasic case: Remagnetization for magnetite growth under extensional setting

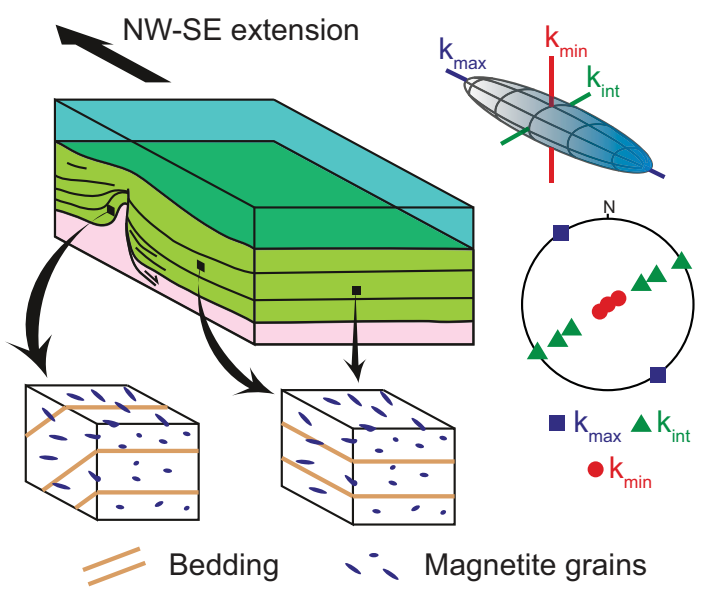

B Appalachian case: Remagnetization for magnetite growth under compression

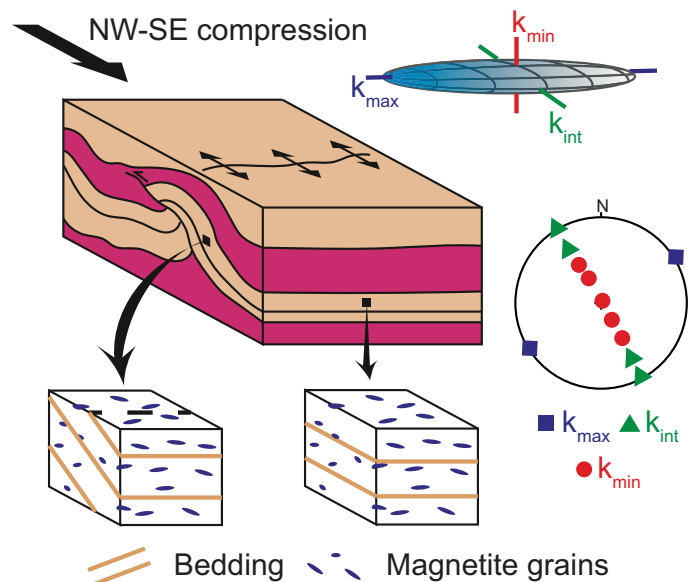

Figure 4. Model for the growth of magnetite in limestones during remagnetization events under $(A)$ extensional and (B) compressional settings. Note that, independently of the bedding attitude, magnetite grains define a prolate ellipsoid with a horizontal maximum anisotropy axis $\left(k_{\max }\right)$ that is parallel to extension or perpendicular to compression in the different settings, and a girdle between the minimum (min) and intermediate (int) axes. Atlasic-Atlas Mountains, Morocco; AppalachianAppalachian Mountains, eastern USA. 
ARM can be interpreted as an extensional fabric, and the best clustering of the magnetic axes is observed after partial restoration of bedding (to its position at the remagnetization acquisition time). Therefore, the magnetic fabric was developed during growth of the magnetite grains without following a preexisting fabric, and was not modified during subsequent compression and cleavage development. The anisotropy degree is low, but a defined fabric reflects the stress conditions during growth of magnetic grains. When a remagnetization occurs in an extensional tectonic context, the maximum magnetic axis is horizontal and parallel to the stretching direction, whereas the minimum axis is vertical and controlled by lithostatic pressure. The fact that the magnetic fabric does not follow preexisting fabrics and is not affected by subsequent compression can be explained if magnetite grains grew inside bigger, undeformed pyrite grains: magnetite grew in an isotropic framework, and magnetite grains were protected from compression by the pyrite grains. A comparison of our results with those of studies on limestones that were remagnetized in compressional settings seems to indicate that, in this context, the growth of the authigenic grains is also constrained by tectonics: the maximum axis of the magnetic ellipsoid is parallel to the bedding-cleavage intersection lineation, and the minimum axis is contained within a vertical plane with a strike that is parallel to the compression direction.

\section{ACKNOWLEDGMENTS}

ARM tensors were calculated with an MSExcel spreadsheet developed by Mike Jackson (Institute for Rock Magnetism, University of Minnesota, USA). This study was supported by the MINECO (Spanish Ministry of Economy and Competitiveness), together with ERDF funding (European Regional Development Fund, European Union) (research projects CGL2012-38481 and CGL2016-77560). Calvin also acknowledges the MINECO (F.P.I. research grant BES-2013-062988) and the Institute for Rock Magnetism (University of Minnesota, USA) for the use of the IRM laboratory. Mike Jackson, Bjarne Almqvist, and an anonymous reviewer are thanked for their constructive comments that help to improve the manuscript.

\section{REFERENCES CITED}

Ait-Brahim, L., et al., 2002, Paleostress evolution in the Moroccan African margin from Triassic to Present: Tectonophysics, v. 357, p. 187-205 https://doi.org/10.1016/S0040-1951(02)00368-2.

Calvín, P., Casas-Sainz, A.M., Villalaín, J.J., and Moussaid, B., 2017, Diachronous folding and cleavage in an intraplate setting (Central High Atlas, Morocco) determined through the study of remagnetizations: Journal of Structural Geology, v. 97, p. 144-160, https://doi.org/10.1016/j .jsg.2017.02.009.

Cifelli, F., Mattei, M., Hirt, A.M., and Günther, A., 2004, The origin of tectonic fabrics in "undeformed" clays: The early stages of deformation in extensional sedimentary basins: Geophysical Research Letters, v. 31, L09604, https://doi.org /10.1029/2004GL019609.

Elmore, R.D., Muxworthy, A.R., and Aldana, M., 2012 , Remagnetization and chemical alteration of sedimentary rocks, in Elmore, R.D., et al., eds., Remagnetization and Chemical Alteration of Sedimentary Rocks: Geological Society of London Special Publications, v. 371, p. 1-21, https://doi .org/10.1144/SP371.15.

Ettaki, M., Ibouh, H., Chellaï, E.H., and Milhi, A., 2007, Les structures “diapiriques" liasiques du Haut-Atlas central, Maroc: Example de la ride d'Ikerzi: Africa Geoscience Review, v. 14, p. 79-93.

García-Lasanta, C., Oliva-Urcia, B., Román-Berdiel, T., Casas, A.M., and Hirt, A.M., 2014, Understanding the Mesozoic kinematic evolution in the Cameros basin (Iberian Range, NE Spain) from magnetic subfabrics and mesostructures: Journal of Structural Geology, v. 66, p. 84-101, https:// doi.org/10.1016/j.jsg.2014.05.013.

Girdler, R.W., 1961, The measurement and computation of anisotropy of magnetic susceptibility of rocks: Geophysical Journal International, v. 5, p. 34-44, https://doi.org/10.1111/j.1365-246X .1961.tb02927.x.

Hext, G.R., 1963, The estimation of second-order tensors, with related tests and designs: Biometrika v. 50, p. 353-373, https://doi.org/10.1093/biomet /50.3-4.353.

Hirt, A.M., and Almqvist, B.S.G., 2012, Unraveling magnetic fabrics: International Journal of Earth Sciences, v. 101, p. 613-624, https://doi.org /10.1007/s00531-011-0664-0.
Jackson, M., 1990, Magnetic anisotropy of the Trenton limestone revisited: Geophysical Research Letters, v. 17, p. 1121-1124, https://doi.org/10.1029 /GL017i008p01121.

Jackson, M., Craddock, J.P., Ballard, M., Van Der Voo, R., and McCabe, C., 1989, Anhysteretic remanent magnetic anisotropy and calcite strains in Devonian carbonates from the Appalachian Plateau, New York: Tectonophysics, v. 161, p. 43-53, https://doi.org/10.1016/0040-1951(89)90300-4.

Lu, G., and McCabe, C., 1993, Magnetic fabric determined from ARM and IRM anisotropies in $\mathrm{Pa}$ leozoic carbonates, Southern Appalachian Basin: Geophysical Research Letters, v. 20, p. 10991102, https://doi.org/10.1029/93GL00986.

Mattauer, M., Tapponnier, P., and Proust, F., 1977, Sur les mecanismes de formation des chaines intracontinentales; l'Exemple des chaines atlasiques du Maroc: Bulletin de la Societe Geologique de France, v. S7, XIX, p. 521-526, doi:10.2113 /gssgfbull.S7-XIX.3.521.

McCabe, C., Jackson, M., and Ellwood, B.B., 1985, Magnetic anisotropy in the Trenton Limestone: Results of a new technique, anisotropy of anhysteretic susceptibility: Geophysical Research Letters, v. 12, p. 333-336, https://doi.org/10.1029 /GL012i006p00333.

Mitra, R., Tauxe, L., and Gee, J.S., 2011, Detecting uniaxial single domain grains with a modified IRM technique: Geophysical Journal International, v. 187, p. 1250-1258, https://doi.org/10.1111/j .1365-246X.2011.05224.x.

Sun, W., Jackson, M., and Craddock, J.P., 1993, Relationship between remagnetization, magnetic fabric and deformation in Paleozoic carbonates: Tectonophysics, v. 221, p. 361-366, https://doi .org/10.1016/0040-1951(93)90167-I.

Tauxe, L., and Watson, G.S., 1994, The fold test: An Eigen analysis approach: Earth and Planetary Science Letters, v. 122, p. 331-341, https://doi.org /10.1016/0012-821X(94)90006-X.

Torres-López, S., Villalaín, J.J., Casas, A.M., El Ouardi, H., Moussaid, B., and Ruiz-Martínez, V.C., 2014, Widespread Cretaceous secondary magnetization in the High Atlas (Morocco): A common origin for the Cretaceous remagnetizations in the western Tethys?: Journal of the Geological Society, v. 171, p. 673-687, https://doi.org/10.1144/jgs2013-107.

Manuscript received 17 May 2018

Revised manuscript received 10 July 2018

Manuscript accepted 12 July 2018

Printed in USA 


\begin{abstract}
Anisotropic magnetite growth in remagnetized limestones: tectonic constraints and implications for basin history

Pablo Calvín ${ }^{1}$, Juan J. Villalaín ${ }^{1}$, and Antonio M. Casas-Sainz ${ }^{2}$

${ }^{1}$ Laboratorio de Paleomagnetismo, Universidad de Burgos, Av/Cantabria s/n, 9006 Burgos, Spain.

${ }^{2}$ Geotransfer Research Group (IUCA), Universidad de Zaragoza, C/ Pedro Cerbuna 12, 50009

Zaragoza, Spain.
\end{abstract}

\title{
Table of Contents
}

A1. List of supplementary tables and figures

A2. The Small Circle method and the bedding restorations

A3. Rock magnetism of the remagnetized limestones 


\section{A1. List of supplementary tables and figures}

Figure DR1. Charts illustrating the analysis of remagnetization directions using the small circle intersection (SCI) method and bedding restoration at the remagnetization acquisition time. (a) The cone defined by a paleomagnetic direction rotated around the bedding strike defines a small circle (SC) in equal area projection. (b) The remagnetization direction is common to all sites and therefore it must be the intersection direction of the SCs. (c) One the remagnetization direction is known, it is used as a reference to calculate the best fit $(\mathrm{BF})$ direction and their corresponding paleodip. (d) Small circles and mean-site paleomagnetic direction before bedding correction (BBC) and after total bedding correction (ATBC) of data from the study area (Calvín et al., 2017a). (e) The calculated remagnetization direction (the reference) and the minimum $A / n$ values are coincident with the ca. 100 Ma directions for NW of Africa obtained through the global apparent polar wander path (Torsvik et al., 2012). The remagnetization direction is calculated as the closest direction to a set of small circles, i.e. the direction that minimize A/n. (f) Calculated best fit directions (BFD) used to obtain the paleodips. (g) Bootstrap fold-test (Tauxe and Watson, 1994; Tauxe et al., 2010) of the study area showing a synfolding behavior of the remagnetization.

Figure DR2. Orthogonal plots of alternating field (Af) and thermal (Th) NRM demagnetization of representative samples in geographic coordinates. Open symbols are projected onto the vertical $E$ - $W$ plane and solid ones in the horizontal plane with $N$ towards the left and $W$ downwards.

Figure DR3. (a) SK19-6 hysteresis loops (original and after subtracting the paramagnetic fraction) and backfield demagnetization curve (b) Hysteresis parameters plot and mixing curves for magnetite (Dunlop, 2002) showing a mixture between SP and SSD. (c) Alternating field demagnetization curves of the NRM and the ARM. (d) ARM/SIRM ratio as function of the strength of the direct biasing field interpreted as SSD magnetite. (e) IRM/SIRM ratio during IRM acquisition and AF demagnetization of the SIRM. Acquisition-demagnetization pairs of curves cross around 0.4. (f) Double IRM acquisition (Mitra et al., 2011), consisting of a double progressive acquisition of IRM. The inset shows the IRAT values $(M(\mathrm{z}) / \mathrm{M}(-\mathrm{z}))$ for each step.

Table DR1. Summary of location, age of the rocks, attitude of the in situ bedding (So) and the remagnetization time bedding (Paleo-So).

Table DR2. Dataset. 


\section{A2. The Small Circle method and the bedding restorations}

In the same way that the bedding can be restored according to paleomagnetic data, it is possible to do the same with the geometric features that can be referred to its reference frame inside the rocks, here including sedimentary or tectonic structures. In this work we restore magnetic fabric ellipsoids and we compare them in three different stages: in the present-day attitude, after applying total bedding correction (i.e. restoring the bedding to the horizontal) and after partial bedding correction (i.e. restoring to the paleodip, which is the bedding attitude at the ca. $100 \mathrm{Ma}$ remagnetization time). The used paleodip data were previously obtained (Calvín et al., 2017a) by means of Small Circle (SC) methods.

SC methods (McClelland-Brown, 1983; Surmont et al., 1990; Shipunov, 1997; Waldhör, 1999; Henry et al., 2004; Waldhör and Appel, 2006; Villalaín et al., 1992; 2003, 2016; Calvín et al. 2017b) provide useful workflows with which to analyze secondary synfolding magnetizations, i.e. remagnetizations: (i) the remagnetization direction can be calculated and (ii) the paleodips of the beds (i.e. the bedding attitude at the remagnetization time) can be known.

A small circle (SC) is the projection, in an equal area plot, of the cone defined by a paleomagnetic direction when it is rotated around its bedding strike (Fig. DR1a); in absence of rotation axes other than along the bedding strike, the SC provides the boundaries for the possible directions that the paleomagnetic direction could have presented in previous stages. A set of paleomagnetic sites affected by the same remagnetization must share this paleomagnetic direction, but if they were differentially folded they would show different in situ paleomagnetic directions (Fig. DR1b). However, the SCs of all sites must intersect in the paleomagnetic direction that is common to all of them (Fig. DR1b), i.e. the remagnetization direction (e.g., Villalaín et al., 2016; for review).

The previous statement is true when some initial assumptions are fulfilled: (i) the analyzed sites were remagnetized simultaneously at geological scale, and (ii) only tilting around the bedding strike is responsible for the dispersion of the paleomagnetic directions. Previous works (Torres-López et al., 2014; 2016; Moussaid et al., 2015; Calvín et al., 2017a, 2018) proved the fulfillment of this initial assumptions in the study area.

Once the remagnetization direction is calculated, it becomes in the reference for paleodip calculations. The necessary rotation around the bedding strike to place the paleomagnetic directions in the closest directions (upon their respective SC) to the reference is calculated and therefore the paleodip of the bedding can be obtained (Fig. DR1c). 

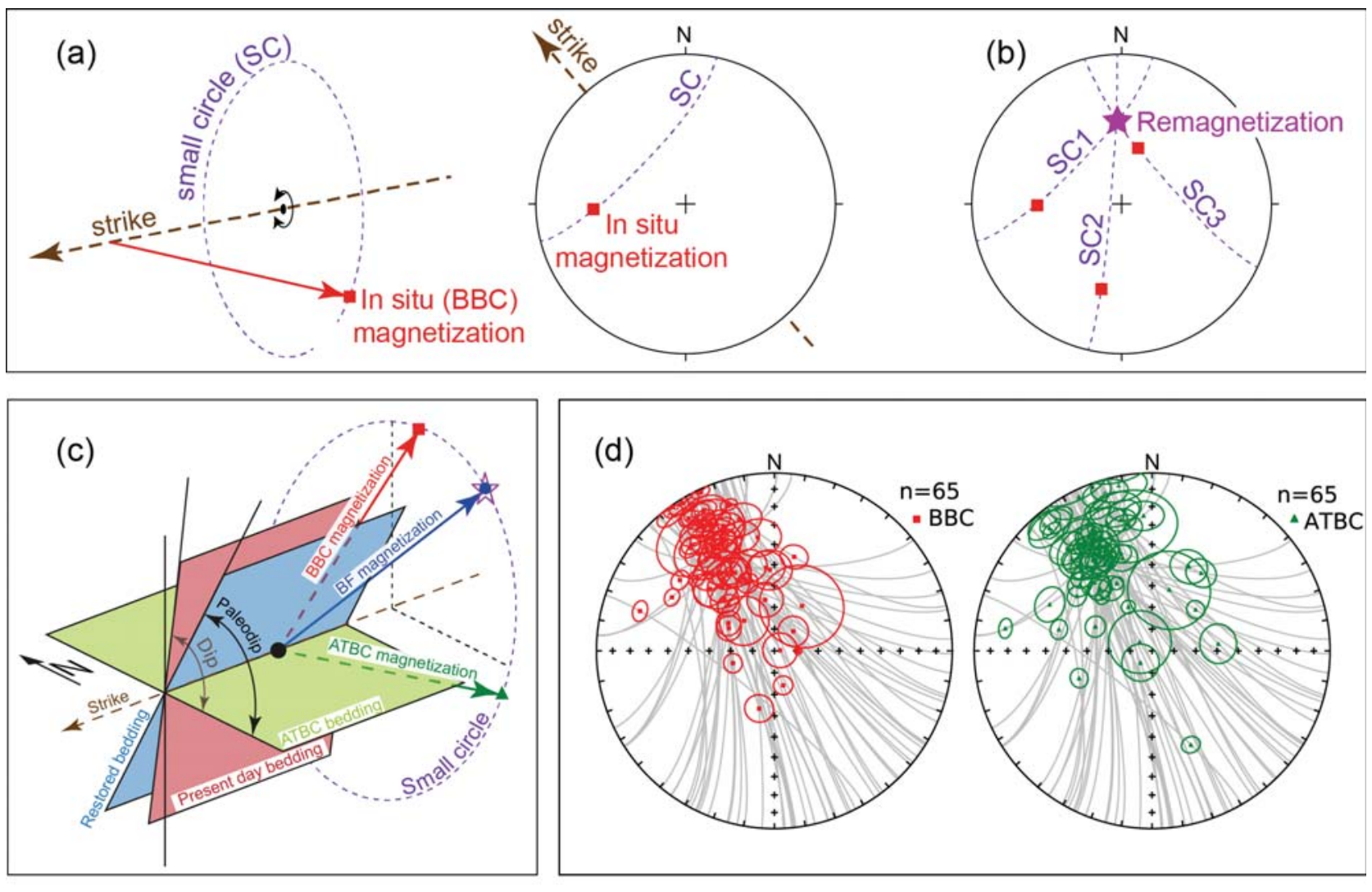

(g)
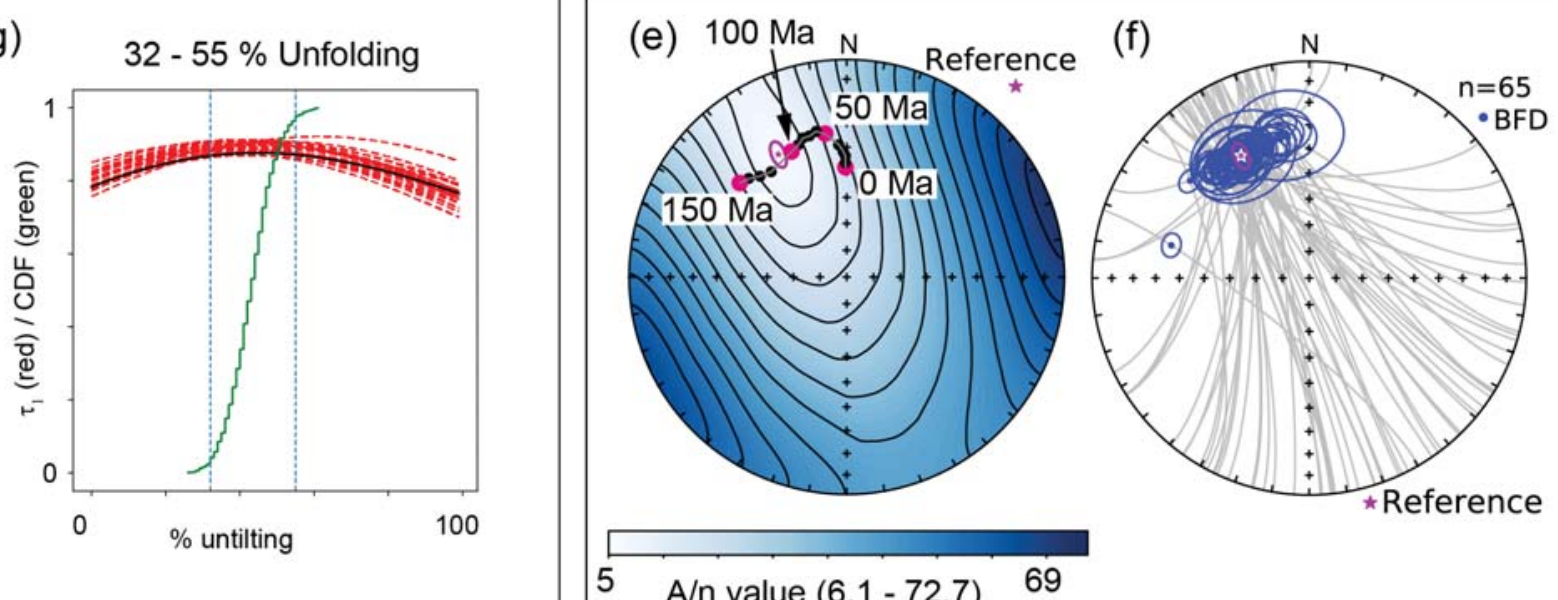

$5 \quad$ A/n value $(6.1-72.7) \quad 69$

Figure DR1. Charts illustrating the analysis of remagnetization directions using the small circle intersection (SCI) method and bedding restoration at the remagnetization acquisition time. (a) The cone defined by a paleomagnetic direction rotated around the bedding strike defines a small circle (SC) in equal area projection. (b) The remagnetization direction is common to all sites and therefore it must be the intersection direction of the SCs. (c) One the remagnetization direction is known, it is used as a reference to calculate the best fit (BF) direction and their corresponding paleodip. (d) Small circles and meansite paleomagnetic direction before bedding correction (BBC) and after total bedding correction (ATBC) of data from the study area (Calvín et al., 2017a). (e) The calculated remagnetization direction (the reference) and the minimum A/n values are coincident with the ca. 100 Ma directions for NW of Africa obtained through the global apparent polar wander path (Torsvik et al., 2012). The remagnetization direction is calculated as the closest direction to a set of small circles, i.e. the direction that minimize A/n. (f) Calculated best fit directions (BFD) used to obtain the paleodips. (g) Bootstrap fold-test (Tauxe and Watson, 1994; Tauxe et al., 2010) of the study area showing a syn-folding behavior of the remagnetization. 
Twin specimens from the used in this work had been previously analyzed (from a paleomagnetic point of view) by Calvín et al. (2017a). They observed that the limestones carry the regional remagnetization described by Torres-López et al. (2014). It presents the following directional characteristic: site-mean paleomagnetic directions with systematically northwestwards, positive inclinations and scattering both before and after total bedding correction (Fig. DR1d). The remagnetization direction obtained as the SC intersection was calculated (n: 65, Dec: $330.9^{\circ}$, Inc: $35.7^{\circ}$, $\eta: 5.7^{\circ}, \xi: 2.3^{\circ}, \mathrm{A} / \mathrm{n}: 6.12^{\circ}$ ) using pySCu software (Calvín et al., 2017b) and it is coincident with the ca. $100 \mathrm{Ma}$. directions for NW of Africa obtained through the global apparent polar wander path (Torsvik et al., 2012) (Fig. DR1e), which was evidenced by Torres-López et al. (2014). The uncertainty in the remagnetization direction is given by the $95 \%$ confidence ellipse (Kent, 1982), whose long axis trends NNW-SSE. This agrees with the A/n contour plot (Waldhör and Appel, 2006) (Fig. DR1e), which represents the sum of the angular distances $(\alpha)$ between each direction in the space and the set of SCs $\left(A=\sum \alpha / n\right)$ and also shows that the uncertainty in the calculation of the remagnetization direction trends NNW-SSE, parallel to the path followed by the SC. Using the remagnetization direction as a reference, the best fit directions (Fig. DR1f), which represent the closest directions to the reference upon each SC are calculated. The necessary rotations around the corresponding bedding strikes from the in situ to the best fit paleomagnetic directions are used to calculate the paleodips.

Furthermore, the synfolding behavior of the remagnetization is also evidenced by the bootstrap fold-test (Tauxe and Watson, 1994) (Fig. DR1g). It is necessary to point out that the synfolding behavior of this remagnetization should not be understood in its classical sense. This remagnetization was not acquired during a folding event, it was acquired during a tectonic quiescence period temporally bracketed between two folding stages (Jurassic extension and Cenozoic compression, respectively) under which the bedding were coaxially folded (e.g. Calvín et al., 2018). Then, in this paper, we refer to it as an interfolding remagnetization.

\section{A3. Rock magnetism of the remagnetized limestones}

Previous rock magnetic experiments carried out in the remagnetized limestones of the Central High Atlas (CHA) point out that a mix of superparamagnetic (SP) and stable single domain (SSD) magnetite are the main ferromagnetic s.l. phases present in these rocks (e.g., Torres-López et al., 2014; Calvín et al., 2017a; 2018), being the SSD grains the carriers of the remagnetization.

To complement this information and to characterize the carriers of the ARM several rock magnetic experiment were performed. The natural remanent magnetization (NRM) of twin specimens from those previously treated by thermal demagnetization (Calvín et al., 2017a) were progressively demagnetized by alternating field (AF) using a 755 cryogenic magnetometer (2G) that integrates alternating and direct field coils. Besides, the anhysteretic remanent magnetization (ARM), imparted in 
the same samples using a coaxial field of $0.05 \mathrm{mT}$ coupled with a peak alternating field of $90 \mathrm{mT}$, was also progressively demagnetized by AF. The field window (0-90 mT) in which the ARM was applied (both in the ARM demagnetization and in the measure of the anisotropy of the ARM) is coincident with the coercivity spectra of the neoformed magnetite grains that grew during the remagnetization event. Hysteresis loops and backfield demagnetization curves were measured using a variable field translation balance MMVFTB (Magnetic Measurements) and these data were analyzed with Analyzer 1.1 software (Leonhardt, 2006). The anisotropy of the individual grains of magnetite (multiaxial vs. uniaxial) was tested using the experiment procedures described by Mitra et al. (2011) consisting in the acquisition of a double isothermal remanent magnetization (IRM). For this a double progressive acquisition of IRM is measured, taking two measurements at each field after applying the magnetization along the same axis in opposite directions (i.e. along $\mathrm{z}$ and $-\mathrm{z}$ ). The pair of values are compared with the IRAT parameter, which is the ratio between the magnetization in the second position $\mathrm{M}(-\mathrm{z})$ and in the first position $\mathrm{M}(\mathrm{z})$. Similar values (i.e. IRAT values close to 1 ) indicate a dominance of uniaxial grains whereas big differences indicate predominance of multiaxial grains. All of these experiments were performed in the Paleomagnetic Laboratory of Burgos University (Spain). Besides, the progressive acquisition of the ARM was performed at the Institute of Rock Magnetism at the University of Minnesota (USA). Progressive direct fields were imparted in a peak AF of $160 \mathrm{mT}$ with an alternating-field demagnetizer
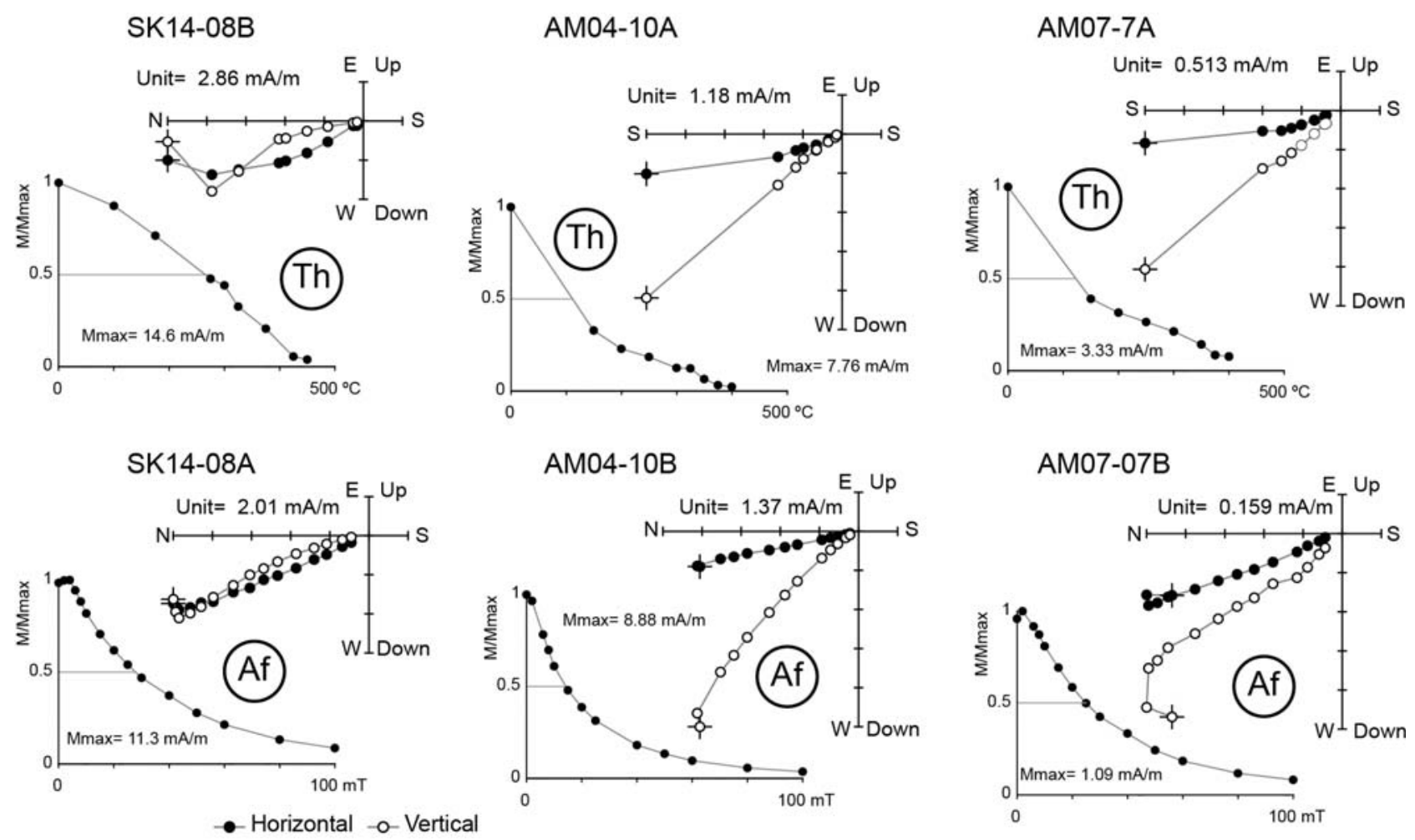

Figure DR2. Orthogonal plots of alternating field (Af) and thermal (Th) NRM demagnetization of representative samples in geographic coordinates. Open symbols are projected onto the vertical $E$ - $W$ plane and solid ones in the horizontal plane with $N$ towards the left and $W$ downwards. 
with an ARM device (Schonstedt alternating-field demagnetizer) and measured with a cryogenic 2G magnetometer.

Under thermal demagnetization the NRM shows the remagnetized component with unblocking temperatures between 300 and $450^{\circ} \mathrm{C}$ (Fig. DR2). This component is coincident with those observed under AF demagnetization with coercivities between 40-60 and $100 \mathrm{mT}$. At low coercivities an overlapping can be observed, probably between the remagnetization component and a viscous component. Given the grain distribution typical of remagnetized limestones (e.g., Jackson and Swanson-Hysell, 2012) we interpret that this viscous component is carried by finer magnetite grains (close to the SP behavior) with low relaxation times and therefore genetically related to the SSD magnetite grains that carry the remagnetization.

The SP and SSD mix in remagnetized limestones is evidenced by wasp-waisted hysteresis loops (Fig. DR3a). The hysteresis parameters plot (Fig. DR3b) shows high $\mathrm{H}_{\mathrm{cr}} / \mathrm{H}_{\mathrm{c}}$ ratios (between 5 and 20) that place the measured samples over the SP-SSD experimental curves (Dunlop, 2002). Previous works (e.g. Channel and McCabe, 1994; Jackson and Swanson-Hysell, 2012) in authigenic magnetite-bearing remagnetized limestones reported the same behavior, which is typical of this kind of rocks. Both AF demagnetization curves of NRM and ARM show progressive decays of the magnetization but with different medium destructive fields, with values around 15-20 mT and 25-35 mT respectively. ARM acquisition curves show a nonlinear behavior, reaching over $15 \%$ and $25 \%$ of SIRM for a direct field of $0.2 \mathrm{mT}$ (Fig. DR3d). Similar curves have been interpreted previously as indicative of non-interacting SSD grains (Sugiura, 1979; Jackson and Swanson-Hysell, 2012). This agrees with the cross-point around 0.4 between pairs of IRM acquisition and subsequent AF demagnetization curves (Fig. DR3e) (Cisowski, 1981). Attending to the IRM demagnetization curve (Fig. DR3e), between 10-30\% of the initial intensity remains after the AF step of $100 \mathrm{mT}$, indicating that a minor contribution of high coercivity minerals (probably pyrrhotite and/or goethite) are activate during IRM acquisition. Regarding the shape of the magnetic grains, the forward and reverse isothermal remanent magnetization acquisitions (Fig. DR3f) show negligible differences between the magnetization applied along both z-axis directions, i.e., $\mathrm{M}_{\mathrm{r}}(\mathrm{z})$ and $\mathrm{M}_{\mathrm{r}}(-\mathrm{z})$, and the ratios between these values (IRAT parameter in the figure) are between 0.9 and 1, indicative of uniaxial particles (Mitra et al., 2011).

In summary, the main magnetic phase of the studied limestones is single domain magnetite distributed in a wide range of size (from SP to SSD), consequence of authigenic growth. Magnetite grains are uniaxial and mostly non-interacting. 
8
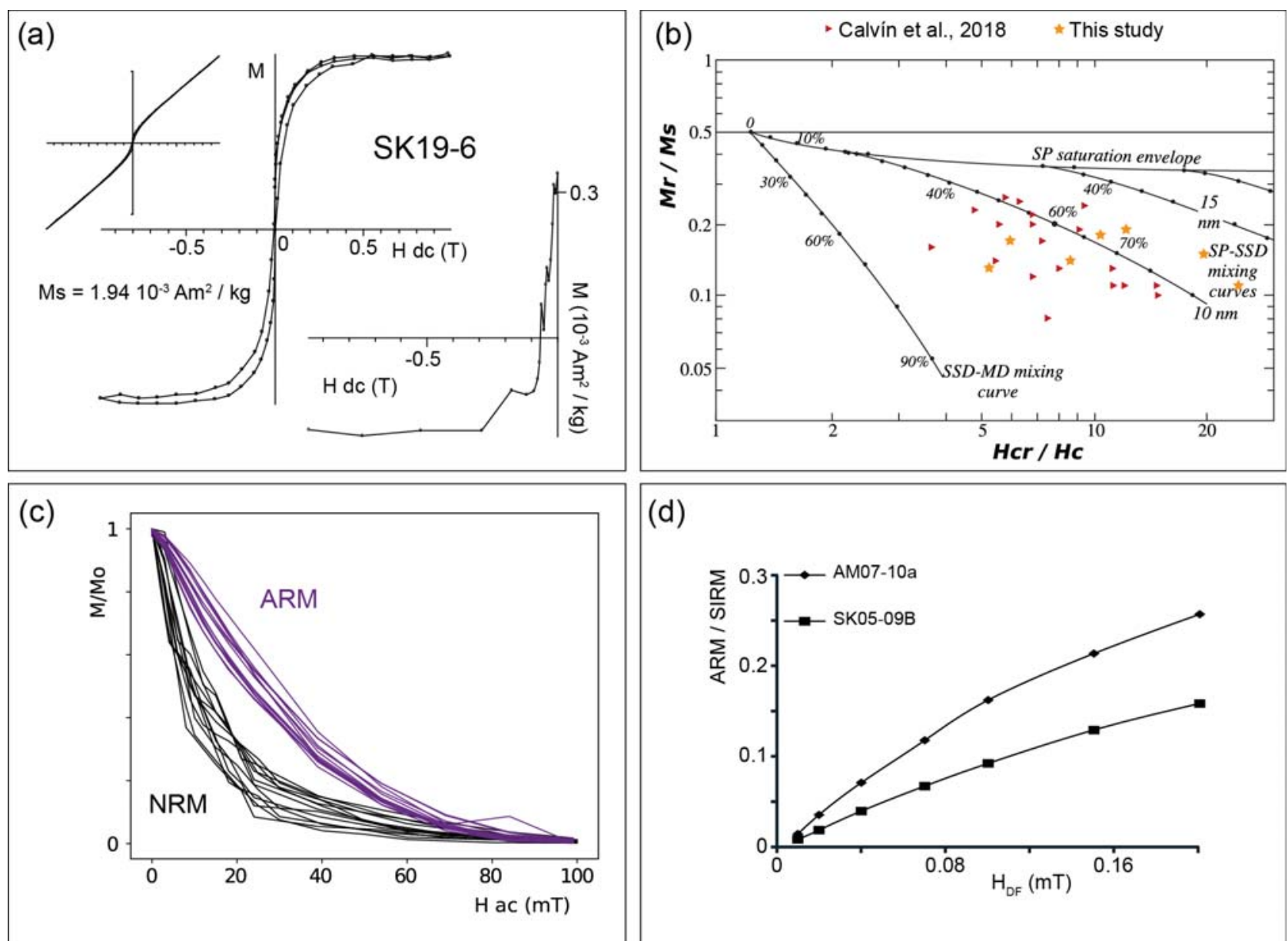

(d)

(e)

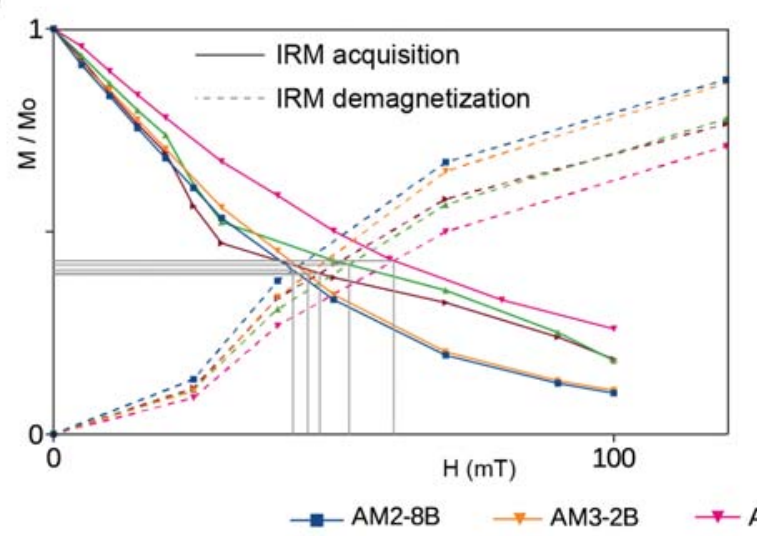

(f)
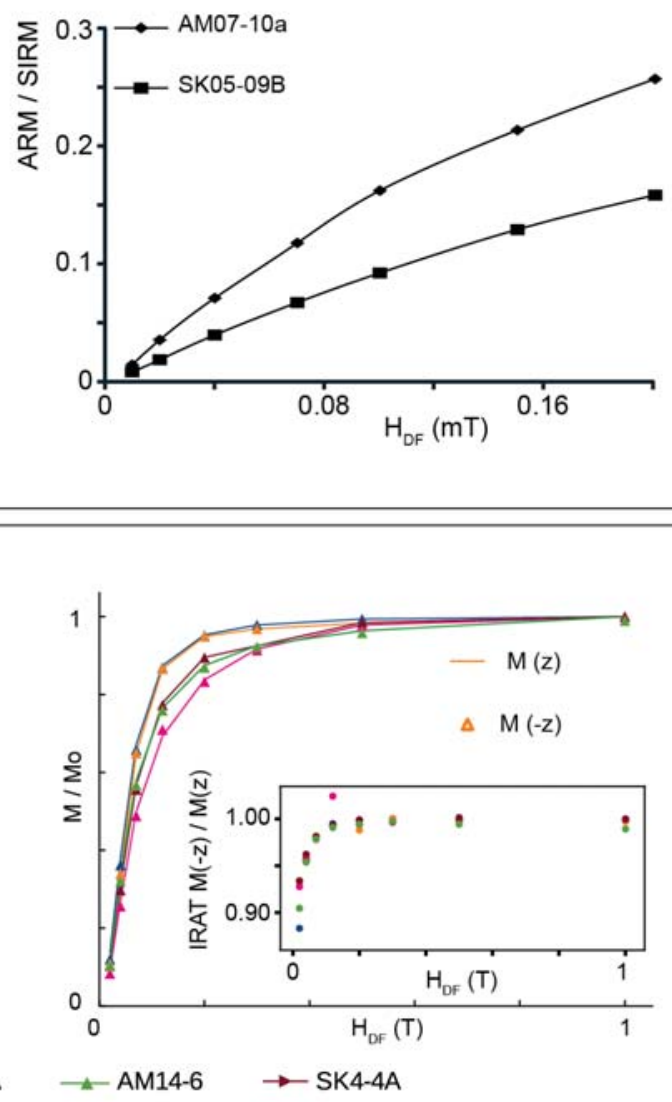

Figure DR3. (a) SK19-6 hysteresis loops (original and after subtracting the paramagnetic fraction) and backfield demagnetization curve (b) Hysteresis parameters plot and mixing curves for magnetite (Dunlop, 2002) showing a mixture between SP and SSD. (c) Alternating field demagnetization curves of the NRM and the ARM. (d) ARM/SIRM ratio as function of the strength of the direct biasing field interpreted as SSD magnetite. (e) IRM/SIRM ratio during IRM acquisition and AF demagnetization of the SIRM. Acquisition-demagnetization pairs of curves cross around 0.4. ( $f$ ) Double IRM acquisition (Mitra et al., 2011), consisting of a double progressive acquisition of IRM. The inset shows the IRAT values $(M(\mathrm{z}) / M(-\mathrm{z}))$ for each step. 


\section{A4. References}

Calvín, P., Casas-Sainz, A.M., Villalaín, J.J., and Moussaid, B., 2017a, Diachronous folding and cleavage in an intraplate setting (Central High Atlas, Morocco) determined through the study of remagnetizations: Journal of Structural Geology, v. 97, p. 144-160, doi: 10.1016/j.jsg.2017.02.009.

Calvín, P., Villalaín, J.J., Casas-Sainz, A.M., Tauxe, L., and Torres-López, S., 2017b, pySCu: A new python code for analyzing remagnetizations directions by means of small circle utilities: Computers \& Geosciences, v. 109, p. 32-42, doi: 10.1016/j.cageo.2017.07.002.

Calvín, P., Casas-Sainz, A.M., Villalaín, J.J., and Moussaid, B., 2018, Extensional vs. compressional deformation in the Central High Atlas salt province: A paleomagnetic approach: Tectonophysics, doi: 10.1016/j.tecto.2018.04.007.

Channell, J.E.T., and McCabe, C., 1994, Comparison of magnetic hysteresis parameters of unremagnetized and remagnetized limestones: Journal of Geophysical Research: Solid Earth, v. 99, p. 4613-4623, doi: 10.1029/93JB02578.

Cisowski, S., 1981, Interacting vs. non-interacting single domain behavior in natural and synthetic samples: Physics of the Earth and Planetary Interiors, v. 26, p. 56-62, doi: 10.1016/00319201(81)90097-2.

Dunlop, D.J., 2002, Theory and application of the Day plot ( M rs / M s versus H cr / H c ) 2. Application to data for rocks, sediments, and soils: Journal of Geophysical Research, v. 107, p. 2057, doi: 10.1029/2001JB000487.

Henry, B., Rouvier, H., and Le Goff, M., 2004, Using syntectonic remagnetizations for fold geometry and vertical axis rotation: the example of the Cévennes border (France): Geophysical Journal International, v. 157, p. 1061-1070, doi: 10.1111/j.1365-246X.2004.02277.x.

Jackson, M., and Swanson-Hysell, N.L., 2012, Rock magnetism of remagnetized carbonate rocks: another look: Geological Society, London, Special Publications, v. 371, p. 229-251, doi: 10.1144/sp371.3.

Kent, J.T., 1982, The Fisher-Bingham distribution on the sphere: Journal of the Royal Statistical Society. Series B, v. 44, p. 71-80, http://www.jstor.org/stable/2984712.

Leonhardt, R., 2006, Analyzing rock magnetic measurements: The RockMagAnalyzer 1.0 software: Computers and Geosciences, v. 32, p. 1420-1431.

McClelland-Brown, E., 1983, Palaeomagnetic studies of fold development and propagation in the Pembrokeshire old red Sandstone: Tectonophysics, v. 98, p. 131-149, doi: 10.1016/00401951(83)90214-7. 
Mitra, R., Tauxe, L., and Gee, J.S., 2011, Detecting uniaxial single domain grains with a modified IRM technique: Geophysical Journal International, v. 187, p. 1250-1258, doi: 10.1111/j.1365246X.2011.05224.x.

Moussaid, B., Villalaín, J.J., Casas-Sainz, A., El Ouardi, H., Oliva-Urcia, B., Soto, R., Román-Berdiel, T., and Torres-López, S., 2015, Primary vs. secondary curved fold axes: Deciphering the origin of the Aït Attab syncline (Moroccan High Atlas) using paleomagnetic data: Journal of Structural Geology, v. 70, p. 65-77, doi: 10.1016/j.jsg.2014.11.004.

Shipunov, S. V, 1997, Synfolding magnetization: detection, testing and geological applications: Geophysical Journal International, v. 130, p. 405-410, doi: 10.1111/j.1365-246X.1997.tb05656.x.

Sugiura, N., 1979, ARM, TRM and magnetic interactions: Concentration dependence: Earth and Planetary Science Letters, v. 42, p. 451-455, doi: 10.1016/0012-821X(79)90054-2.

Surmont, J., Sandulescu, M., and Bordea, S., 1990, Mise en évidence dúne réaimantation fini crétacée des séries mésozoïques de l'unité de Bihor (Monts Apuseni, Roumanie) et de sa rotation horarie ultériore: Comptes Rendus De L Academie Des Sciences Paris, v. 310, p. 213-219, http://linkinghub.elsevier.com/retrieve/pii/S1631073X12001926.

Tauxe, L., Shaar, R., Jonestrask, L., Swanson-Hysell, N.L., Minnett, R., Koppers, A.A.P., Constable, C.G., Jarboe, N., Gaastra, K., and Fairchild, L., 2016, PmagPy: Software package for paleomagnetic data analysis and a bridge to the Magnetics Information Consortium (MagIC) Database: Geochemistry, Geophysics, Geosystems, v. 17, p. 2450-2463, doi: 10.1002/2016GC006307.

Tauxe, L., and Watson, G.S., 1994, The fold test: an eigen analysis approach: Earth and Planetary Science Letters, v. 122, p. 331-341, doi: 10.1016/0012-821X(94)90006-X.

Torres-López, S., Villalaín, J.J., Casas, A.M., EL Ouardi, H., Moussaid, B., and Ruiz-Martínez, V.C., 2014, Widespread Cretaceous secondary magnetization in the High Atlas (Morocco). A common origin for the Cretaceous remagnetizations in the western Tethys? Journal of the Geological Society, v. 171, p. 673-687, doi: 10.1144/jgs2013-107.

Torres-López, S., Casas, A.M., Villalaín, J.J., El Ouardi, H., and Moussaid, B., 2016, Pre-Cenomanian vs. Cenozoic folding in the High Atlas revealed by palaeomagnetic data: Terra Nova, v. 28, p. 110119, doi: 10.1111/ter.12197.

Torsvik, T.H., Van der Voo, R., Preeden, U., Niocaill, C. Mac, Steinberger, B., Doubrovine, P. V., van Hinsbergen, D.J.J., Domeier, M., Gaina, C., Tohver, E., Meert, J.G., McCausland, P.J. a, and Cocks, L.R.M., 2012, Phanerozoic polar wander, palaeogeography and dynamics: Earth-Science Reviews, v. 114, p. 325-368, doi: 10.1016/j.earscirev.2012.06.002.

Villalaín, J.J., Osete, M.L., Vegas, R., and García-Dueñas, V., 1992, Evidencia de una reimanación terciaria en la Béticas Occidentales. Implicaciones tectónicas: Física de la Tierra, v. 4, p. 165-184. 
Villalaín, J., Fernández-González, G., Casas, A.M., and Gil-Imaz, A., 2003, Evidence of a Cretaceous remagnetization in the Cameros Basin (North Spain): implications for basin geometry: Tectonophysics, v. 377, p. 101-117, doi: 10.1016/j.tecto.2003.08.024.

Villalaín, J.J., Casas-Sainz, A.M., and Soto, R., 2016, Reconstruction of inverted sedimentary basins from syn-tectonic remagnetizations. A methodological proposal: Geological Society, London, Special Publications, v. 425, p. 233-246, doi: 10.1144/SP425.10.

Waldhör, M., 1999, The small-circle reconstruction in palaeomagnetism and its application to palaeomagnetic data from the pamirs: Tübingen University, 99 p.

Waldhör, M., and Appel, E., 2006, Intersections of remanence small circles: new tools to improve data processing and interpretation in palaeomagnetism: Geophysical Journal International, v. 166, p. 3345, doi: 10.1111/j.1365-246X.2006.02898.x. 
Table DR1. Summary of location, age of the rocks, attitude of the in situ bedding (So) and the remagnetization time bedding (Paleo-So). Bedding data as dip direction and dip. This data come from Calvín et al. (2017).

\begin{tabular}{|c|c|c|c|c|c|}
\hline Site & $\begin{array}{c}\text { Longitude } \\
\text { (WGS84) }\end{array}$ & Latitude (WGS84) & Age & So : DD/Dip & $\begin{array}{l}\text { Paleo-So: } \\
\text { DD/Dip }\end{array}$ \\
\hline AM02 & $5^{\circ} 03^{\prime} 14.2934^{\prime \prime} \mathrm{W}$ & $32^{\circ} 13^{\prime} 48.5580^{\prime \prime} \mathrm{N}$ & Bajocian & $175 / 60$ & $175 / 24$ \\
\hline AM03 & $5^{\circ} 01^{\prime} 44.8230 " \mathrm{~W}$ & $32^{\circ} 14^{\prime} 5.4535^{\prime \prime} \mathrm{N}$ & Bajocian & $170 / 53$ & $170 / 31$ \\
\hline AM04 & $5^{\circ} 01^{\prime} 55.5442^{\prime \prime} \mathrm{W}$ & $32^{\circ} 16^{\prime} 22.3799^{\prime \prime} \mathrm{N}$ & Aalenian-Bajocian & $191 / 22$ & $191 / 22$ \\
\hline AM06 & $4^{\circ} 57^{\prime} 39.8714^{\prime \prime} \mathrm{W}$ & $32^{\circ} 17^{\prime} 45.8084^{\prime \prime} \mathrm{N}$ & Toarcian-Aalenian & $134 / 32$ & $134 / 08$ \\
\hline AM07 & $4^{\circ} 45^{\prime} 19.9271^{\prime \prime} \mathrm{W}$ & $32^{\circ} 16^{\prime} 18.5563^{\prime \prime} \mathrm{N}$ & Bajocian & $318 / 26$ & $318 / 13$ \\
\hline AM08 & $4^{\circ} 48^{\prime} 34.0337^{\prime \prime} \mathrm{W}$ & $32^{\circ} 15^{\prime} 54.8597^{\prime \prime} \mathrm{N}$ & Aalenian-Bajocian & $150 / 52$ & $150 / 49$ \\
\hline AM13 & $4^{\circ} 49^{\prime} 11.5072^{\prime \prime} \mathrm{W}$ & $32^{\circ} 16^{\prime} 19.0200^{\prime \prime} \mathrm{N}$ & Bajocian & $148 / 34$ & $148 / 20$ \\
\hline AM14 & $5^{\circ} 06^{\prime} 7.0200^{\prime \prime} \mathrm{W}$ & $32^{\circ} 16^{\prime} 34.1400^{\prime \prime} \mathrm{N}$ & Aalenian-Bajocian & $353 / 46$ & $353 / 09$ \\
\hline SK04 & $5^{\circ} 28^{\prime} 44.4918^{\prime \prime} \mathrm{W}$ & $32^{\circ} 04^{\prime} 32.8883^{\prime \prime} \mathrm{N}$ & Aalenian-Bajocian & $015 / 20$ & 015/05 \\
\hline SK05 & $5^{\circ} 28^{\prime} 5.5963^{\prime \prime} \mathrm{W}$ & $32^{\circ} 02^{\prime} 37.0194^{\prime \prime} \mathrm{N}$ & Aalenian-Bajocian & $333 / 48$ & $333 / 26$ \\
\hline SK07 & $5^{\circ} 28^{\prime} 7.6602 " \mathrm{~W}$ & $32^{\circ} 02^{\prime} 19.0704^{\prime \prime} \mathrm{N}$ & Aalenian-Bajocian & $160 / 14$ & $160 / 05$ \\
\hline SK14 & $5^{\circ} 19^{\prime} 31.1365^{\prime \prime} \mathrm{W}$ & $32^{\circ} 08^{\prime} 53.5823^{\prime \prime} \mathrm{N}$ & Toarcian-Aalenian & $180 / 64$ & $180 / 38$ \\
\hline SK19 & $5^{\circ} 22^{\prime} 48.4997 " \mathrm{~W}$ & $32^{\circ} 07^{\prime} 49.3291^{\prime \prime} \mathrm{N}$ & Aalenian-Bajocian & $177 / 28$ & $177 / 20$ \\
\hline
\end{tabular}




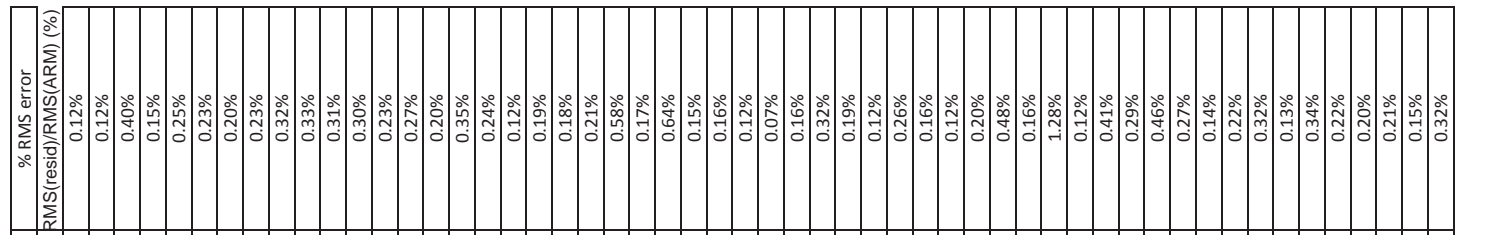

जิ

言

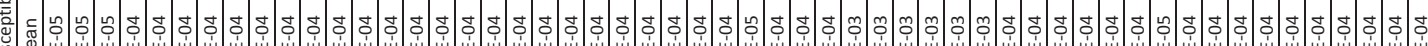

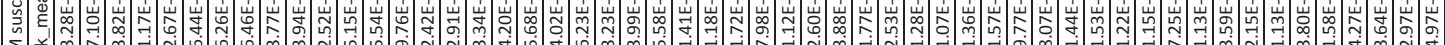

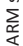

言

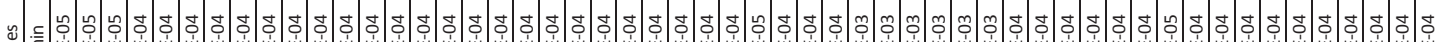

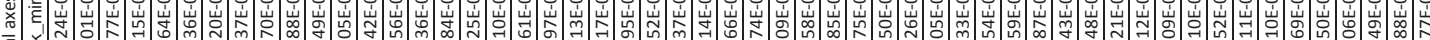

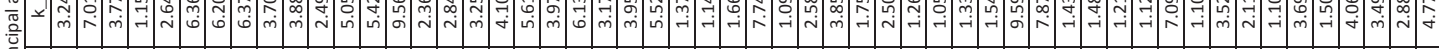

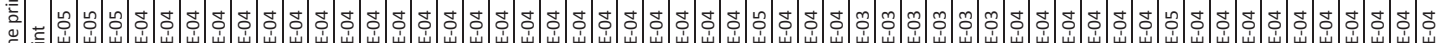

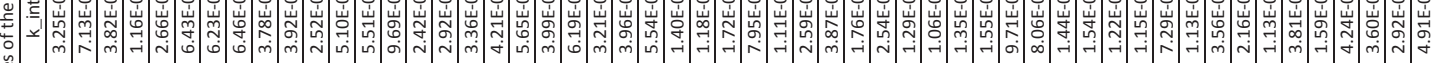

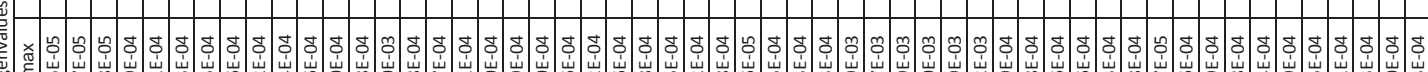

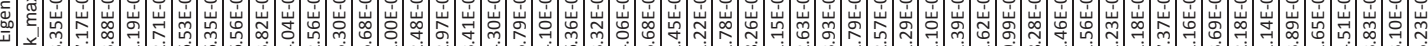

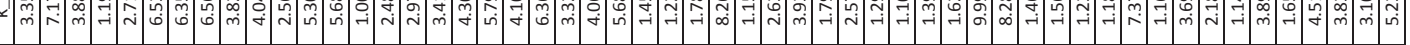

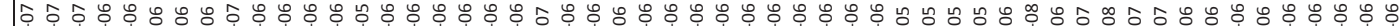

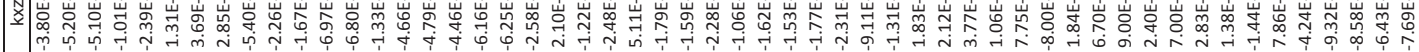

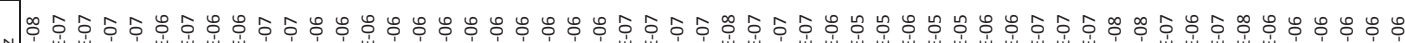

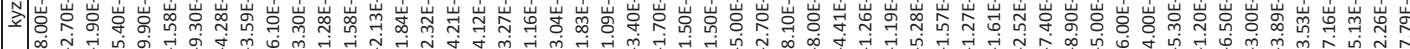

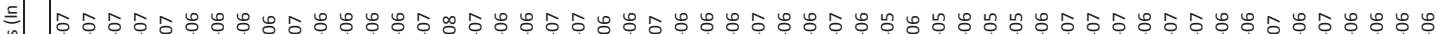

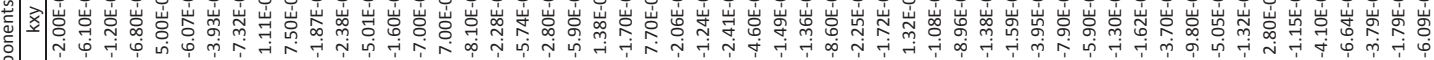
है-

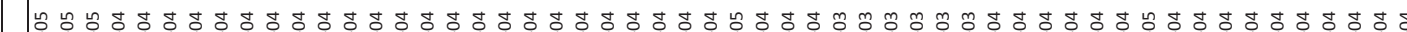

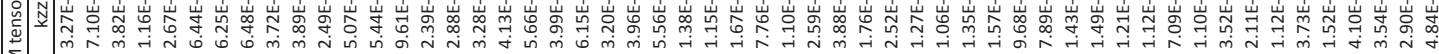
$\sum_{\substack{\alpha \\ \mathbb{4}}}$

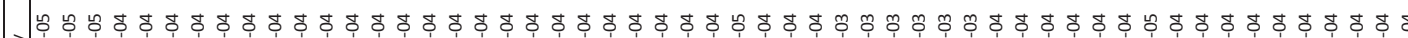

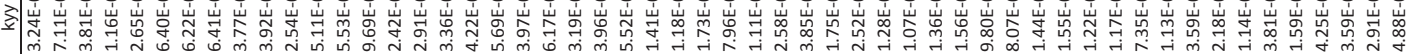

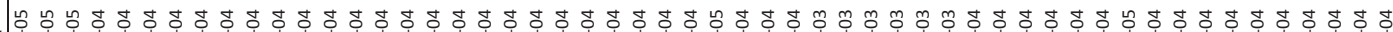

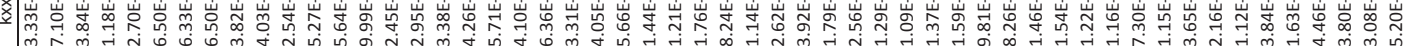

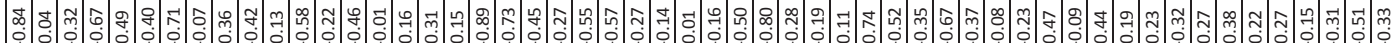
言

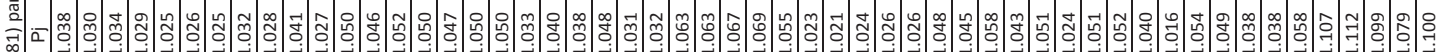

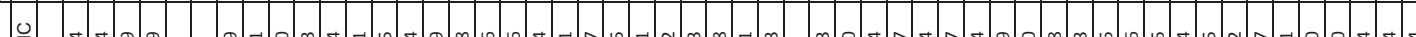

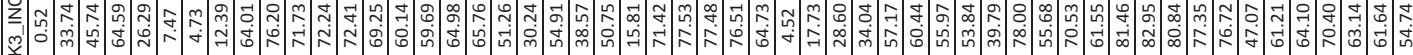

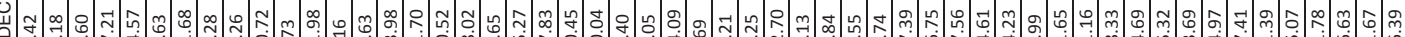

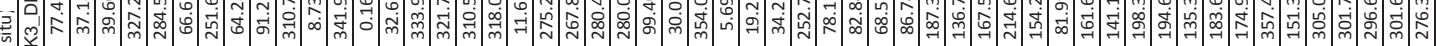

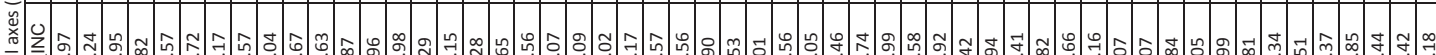

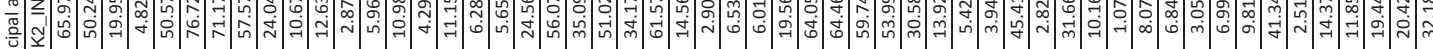

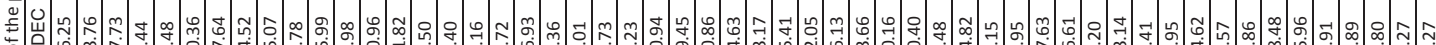

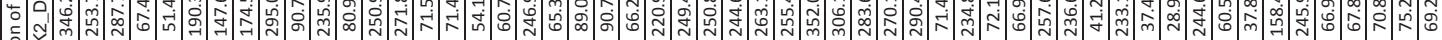

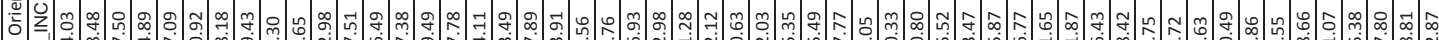

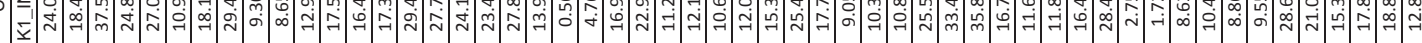

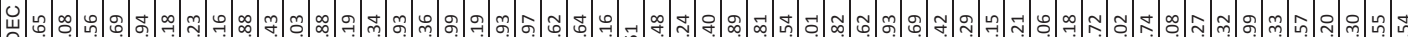

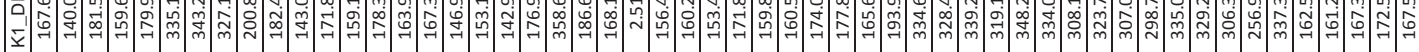

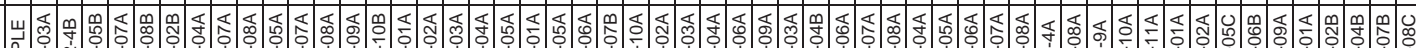

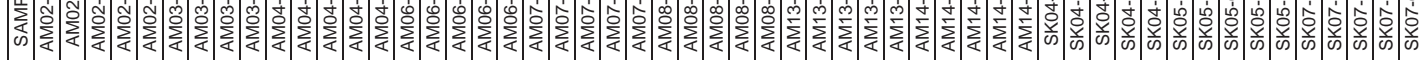




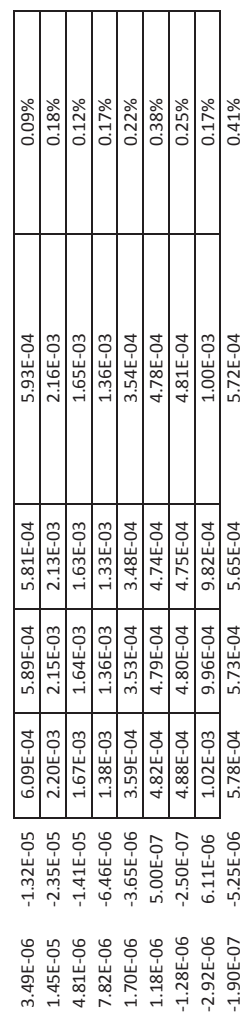

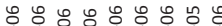

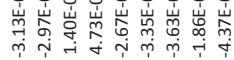

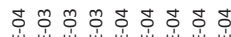

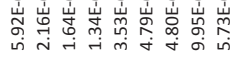

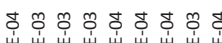

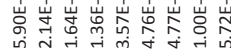

ఫ

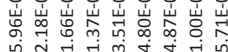

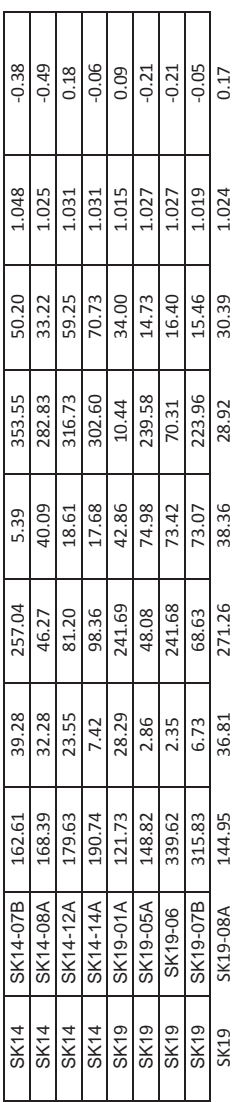




\title{
The carriers of AMS in remagnetized carbonates. Insights for remagnetization mechanism and basin evolution
}

\author{
Pablo Calvín $^{\mathrm{a}, *, 1}$, Juan J. Villalaín ${ }^{\mathrm{a}, 2}$, Antonio M. Casas-Sainz ${ }^{\mathrm{b}, 3}$ \\ ${ }^{a}$ Departamento de Física, Universidad de Burgos. Escuela Politécnica Superior, Av. Cantabria s/n, 09001 Burgos, Spain \\ ${ }^{\mathrm{b}}$ Geotransfer Research Group (IUCA), Universidad de Zaragoza, C/ San Pedro Cerbuna 12, 50009 Zaragoza, Spain
}

\section{A R T I C L E I N F O}

\section{Keywords:}

Magnetic fabrics

Magnetic subfabrics

Superparamagnetic fabric

Limestone fabric

Remagnetization

Central High Atlas

\begin{abstract}
A B S T R A C T
Magnetic fabrics are usually studied to unravel the evolution of sedimentary basins, mainly focusing the attention in paramagnetic minerals. However, since basins are sometimes affected by burial-related chemical remagnetizations, magnetic fabrics can also be carried by authigenic ferromagnetic minerals related to remagnetization processes. Consequently, the study of the different types of fabrics can give complementary and valuable information about the evolution of sedimentary basins. Here, we explore, in the Jurassic carbonates of the Central High Atlas (Morocco), the role in magnetic fabrics of authigenic magnetite that grew during the Cretaceous (ca. $100 \mathrm{Ma}$ ) widespread remagnetization event.

Magnetic fabrics are studied in 53 sites using the anisotropy of the magnetic susceptibility measured at room temperature (RT-AMS) and comparing results with sub-fabrics that alternatively enhance the paramagnetic and the ferromagnetic signal. Furthermore, an innovative analysis is proposed, comparing the magnetic fabrics before and after bedding correction (the common procedure) with fabric orientation after partial bedding correction. We use the paleomagnetic information to reconstruct the attitude of bedding at the remagnetization time and to restore the magnetic fabrics at this time.

The performed analysis allows interpreting RT-AMS in terms of the contribution of different subfabrics, and the relationship between these, tectonic processes and the magnetic mineralogy. Four RT-AMS types are defined: $\mathrm{T} 1$ is carried by superparamagnetic magnetite that grew during the remagnetization stage and shows a horizontal lineation parallel to the extension direction at this time; T3 and T4 are carried by paramagnetic minerals and show compressive fabrics with the magnetic lineation parallel to intersection (bedding-cleavage) lineation; finally, T2 shows a mix between ferrimagnetic and paramagnetic fabrics.
\end{abstract}

\section{Introduction}

Since the first works by Graham $(1954,1966)$ evaluating the petrofabric of sedimentary rocks through the anisotropy of low field induced magnetization (i.e. the anisotropy of the magnetic susceptibility, AMS), this tool has been widely used to infer the petrofabric in a quick and reliable way (Borradaile and Tarling, 1981, Hrouda, 1982; Rochette and Vialon, 1984; Borradaile, 1988; Tarling and Hrouda, 1993; among others), even when other textural indicators are weakly developed. The measurement of AMS at room temperature (RT-AMS) gives the bulk information of the whole mineral assemblage in the rock (i.e. diamagnetic, paramagnetic and ferromagnetic s.l. minerals). Its application in phyllosilicate-rich sedimentary rocks lead to relatively straightforward inferences about the tectonic regime responsible for deformation in sedimentary units (see Parés 2004, 2015 for review). Therefore, AMS provides information about (i) the tectonic frame under which sediments were deposited and subsequently deformed (e.g. Aubourg et al., 2004, 2010; Borradaile and Hamilton, 2004; Caricchi et al., 2016; Cifelli et al., 2004, 2005; García-Lasanta et al., 2014, 2015; Kissel et al., 1986; Lee and Angelier, 2000; Mattei et al., 1997, 1999; Moussaid et al., 2013; Oliva-Urcia et al., 2009, 2011; Parés et al., 1999; Pueyo-Anchuela et al., 2011; Soto et al., 2009, 2012), (ii) subsequent tectonic imprints (e.g. Debacker et al., 2004; Dudzisz et al., 2018; OlivaUrcia et al., 2013; Oliva-Urcia et al., 2018; Izquierdo-Llavall et al., 2013), or (iii) other common geological processes, such as the diapiric evolution both under compressional and extensional settings

\footnotetext{
* Corresponding author.

E-mail addresses: calvinballester@gmail.com, pcalvin@ubu.es (P. Calvín).

${ }^{1}$ P.C. http://orcid.org/0000-0002-4485-213.

2 J.V. http://orcid.org/0000-0001-9948-0953.

${ }^{3}$ A.C.S. http://orcid.org/0000-0003-3652-3527. 
(Santolaria et al., 2015; Soto et al., 2017). This has led to refinement of evolutionary basin models and of fault activity during basin evolution.

However, a fundamental previous step before interpreting AMS is to determine the magnetic mineralogy that gives rise to the magnetic fabric, for a number of reasons: (i) different minerals can have a different origin and formation time; (ii) different minerals present different rheology and therefore their response to deformation can be variable; (iii) dia- para- and ferromagnetic s.l. fabrics can record and, therefore contribute, with different information, allowing a wider vision about the tectonic evolution experienced by rocks. There are different approaches that allow to assess which are the carriers of the RTAMS, as for example: (i) sub-fabrics measurements, either by means of AMS measured at liquid nitrogen temperature (LT-AMS) (Richter and van der Pluijm, 1994; Pares and van der Pluijm, 2002, Parés et al., 2014; Issachar et al., 2016), through high-field and low-field measurements (e.g., Hrouda and Jelínek, 1990; Rochette and Fillion, 1988; Schmidt et al., 2007) or through the anisotropy of the remanence measured by different ways (e.g. McCabe et al., 1985; Jackson., 1991; Martín-Hernández and Ferré, 2007; Potter, 2004; Bilardello and Jackson, 2014); (ii) comparison between magnetic fabrics and petrographic observations (both under optical and electronic microscopes) or (iii) X-ray and neutron goniometry (e.g. Chadima et al., 2004; MartínHernández and Ferré, 2007; Cifelli et al., 2009; Schmidt et al., 2009; Oliva-Urcia et al., 2012). Usually the coincidence of axes orientations between RT-AMS and LT-AMS indicates that the carriers of the RT-AMS are paramagnetic minerals when the diamagnetic fabrics are excluded (or at least that the RT-AMS is equivalent to the paramagnetic petrofabric). Conversely, the coincidence in orientation between RT-AMS and anisotropy of the remanence indicates that the RT-AMS shows the petrofabric of the ferromagnetic s.l. minerals. It goes without saying that RT-AMS, LT-AMS and anisotropy of the remanence can all show similar orientations, thus indicating a coincidence between the petrofabric of paramagnetic and ferromagnetic minerals.

One of the first tests when working with magnetic fabric is to establish its relationship with bedding. The clustering degree between ellipsoids from different sites before and after bedding correction is probably the quickest and most reliable way to determine this relationship. Paleomagnetic analysis provides a new element for comparing with the magnetic fabric: paleomagnetic directions of synfolding remagnetizations allow to know the attitude of beds (i.e. the paleo-bedding) at the moment of remagnetization occurrence (e.g. Villalaín et al., 2003, 2016; Soto et al., 2008; Torres-López et al., 2014; García-Lasanta et al., 2017). Beyond the comparison before and after total bedding correction, it is possible to analyse the magnetic fabric after partial bedding correction (i.e. restoring strata to their paleobedding) and, in this way, to understand possible relationships between remagnetization and magnetic fabric acquisition.

Because of (i) the abundance of ferromagnetic fabrics, and the scarcity of phyllosilicates, and hence paramagnetic fabrics, in some rock types (namely marine limestones and dolostones), and (ii) the extent to which remagnetizations in sedimentary basins are found, the unravelling of the significance of the different types of magnetic fabrics in remagnetized rocks is of primary importance. This is especially significant if a thorough application of the AMS technique to sedimentary rocks is intended. In this work, we explore how the characteristic mineralogy of remagnetized limestones, containing significant amounts of superparamagnetic (SP) and stable single domain (SSD) magnetite (e.g. Jackson and Swanson-Hysell, 2012, for review) affects the RT-AMS. For that purpose, on one hand (i) magnetic sub-fabrics (LT-AMS and anisotropy of the anhysteretic remanent magnetization -AARM) are compared with RT-AMS, and on the other hand, (ii) we propose the complementary test of comparing the magnetic fabric with the paleobedding in addition to the usual comparison with bedding, to understand the timing of acquisition of the RT-AMS. The results obtained are of interest for the study of other marine and non-marine sedimentary basins and widens the range of applicability of AMS as a reliable marker in basin analysis.

\section{Geological setting}

The Atlas system is an ENE-WSW intracontinental chain located in the foreland of the southernmost sector of the Mediterranean Alpine System, in NW Africa (Fig. 1a). The chain is the result of the Cenozoic convergence between African and European plates, which generated the inversion of a system of Mesozoic extensional basins (Mattauer et al., 1977; Gomez et al., 2000; Frizon de Lamotte et al., 2008).

Because of its intrinsic geological and paleomagnetic features, the Central High Atlas (CHA; Fig. 1b) provides an outstanding location for the study of AMS linked to remagnetized limestones because of (i) the widespread remagnetization that involves $80 \%$ of the width of the mountain chain and extends at least from the Atlantic coast to the Saharan Atlas, affecting different types of rocks and (ii) the thickness and lithological variety of the Jurassic calcareous sequences. The tectonic evolution of the High Atlas and the stress directions at each stage are relatively well known (e.g. Ait-Brahim et al., 2002) and magnetic properties of limestones have also been the target of several paleomagnetic works (Torres-López et al., 2014, 2016; Calvín et al., 2017a). Mesozoic extension, especially during the Triassic and the Jurassic (Fig. 2), was responsible for (i) the deposition of several thousand meters of red beds and marine limestones in overall, and (ii) a complex thermal history that included the deposition of intercalated lava flows and the intrusion of basic rocks in several episodes (Hailwood and Mitchel, 1971; Armando, 1999; Haddoumi et al., 2002; Zayane et al., 2002; Bensalah et al., 2013; Calvín et al., 2017b and references therein), including gabbroic bodies and dyke complexes. Furthermore, the basinal stage, and also probably the inversion stage, were characterized by diapiric processes, favoured by the presence of a thick evaporitic unit at the bottom of the Jurassic sequence and triggered by tectonic movements and igneous activity (Michard et al., 2011; TorresLópez et al., 2016). Structures formed as a consequence of salt tectonics, and triggered by regional deformation developed at one time with folds, thrusts and alternatively normal faulting.

The Mesozoic extensional stage is related to the opening of the Central Atlantic (especially in the western part of the Atlasic realm) and the evolution of the Western Tethys (Oliva-Urcia et al., 2016). Orientations of stress axes during the Mesozoic and Cenozoic in the Moroccan High-Atlas are relatively well established: WNW-ESE extension in Triassic times was succeeded by NW-SE extension, at least until Middle Jurassic times. From this time onwards, sedimentation rate dramatically diminished and other indicators, such as magmatic products, must be used to understand the tectonic frame. Late Jurassic to Early Cretaceous dykes provide a N-S extension direction, and probably re-used older structures (Ait-Brahim et al., 2002). N-S compression prevailed during the Eocene (with a previous weaker episode of E-W shortening) to finally change to a NW-SE direction in recent times (Fig. 2).

\section{The ca. 100 Ma remagnetization in the Central High Atlas}

Previous paleomagnetic studies carried out in the CHA (e.g. TorresLópez et al., 2014; Moussaid et al., 2015; Calvín et al., 2018) divide the Mesozoic deformational history in three main stages: pre, syn and post ca. 100 Ma remagnetization (Fig. 2). This remagnetization has an interfolding behaviour (Fig. 2) because it was acquired between two deformational stages (the Mesozoic extension and the Cenozoic compression), both responsible for the ENE-WSW structure of the CHA. 


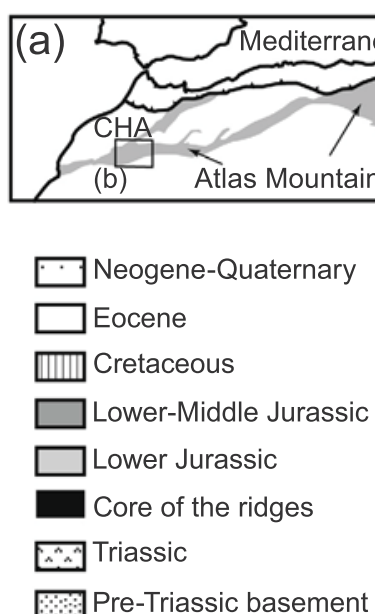

(c)
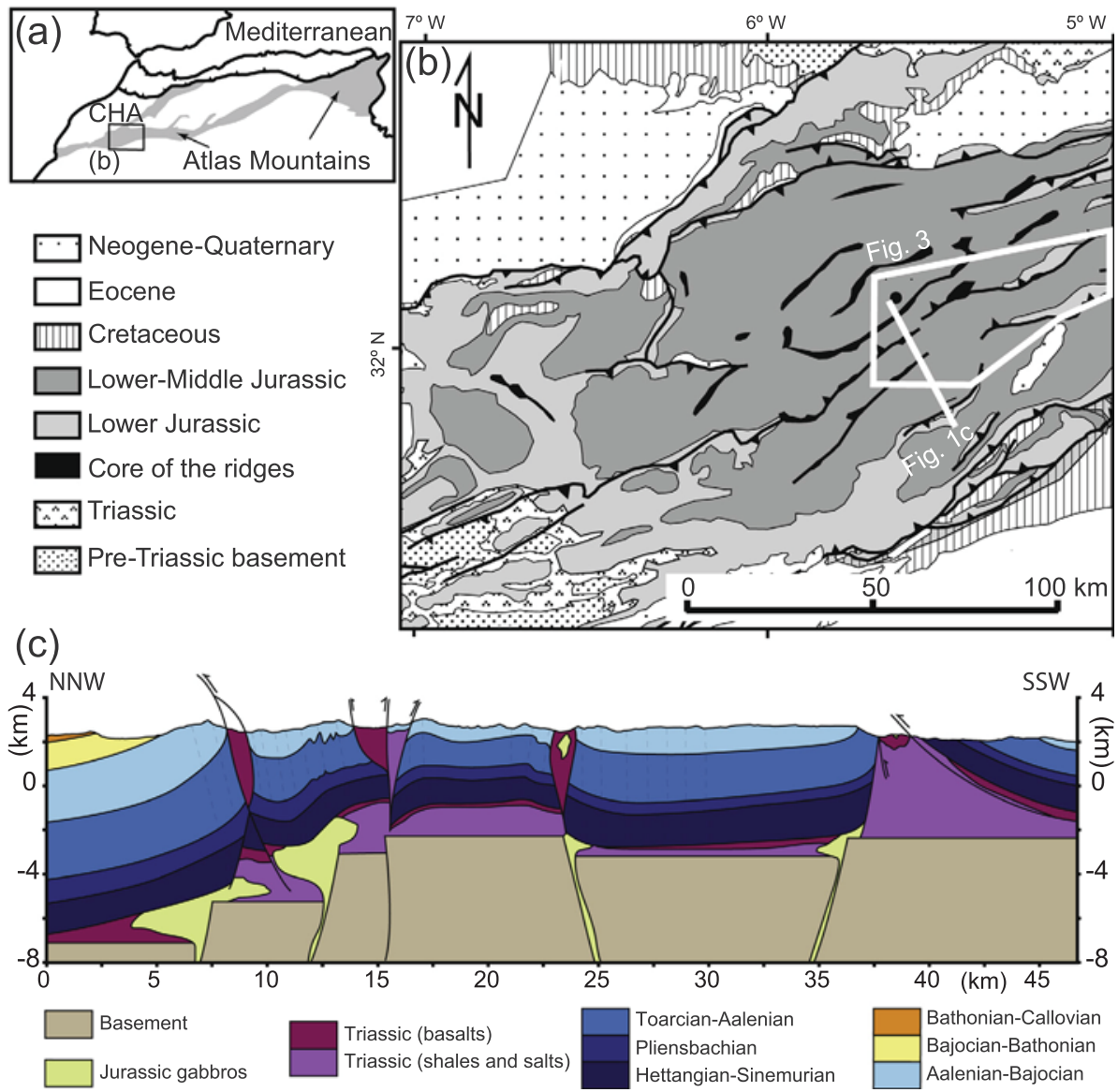

Fig. 1. (a) Location of the Central High Atlas (CHA) in the westernmost Mediterranean area. Synthetic geological map of the CHA and location of the study area (Fig. 3). Modified after Teixell et al. (2003). (c) Cross-section of the study area.

From the analysis of the paleomagnetic vectors after the calculation of the remagnetization direction, it is possible to make a restoration of the attitude of beds at $c a .100$ Ma (Torres-López et al., 2016; Villalaín et al., 2016; Calvín et al., 2017c). The AMS sites studied in this work were previously analysed paleomagnetically by Calvín et al. (2017a) and therefore we can use the paleo-dip (i.e. the $c a .100$ Ma bedding orientation) to restore the magnetic fabrics at the remagnetization acquisition moment. Then, three orientations of AMS can be compared: before bedding correction (BBC), after partial bedding correction
(APBC, i.e. restoring at the paleo-dip) and after total bedding correction (ATBP, i.e. restoring the bedding at the horizontal).

Another important point when analysing the magnetic fabrics in remagnetized limestones is their specific magnetic mineralogy. Chemical remagnetizations carried by magnetite are characterized by large amounts of superparamagnetic (SP) and stable single domain (SSD) grains (see Jackson and Swanson-Hysell, 2012 for review) that show shape anisotropy (Calvin et al., submitted). Comparing the AARM in the three stages, Calvin et al. (submitted) observed that the

\begin{tabular}{c|c|c|c|c|c|c|c|c|}
\hline \multirow{2}{*}{} & \multicolumn{3}{|c|}{ Jurassic } & \multicolumn{2}{c|}{ Cretaceous } & \multicolumn{3}{c|}{ Cenozoic } \\
\cline { 2 - 7 } & Lower & Middle & Upper & Lower & Upper & Paleogene & Neogene & Quaternary \\
\hline
\end{tabular}

Sedimentation

Extensional deformation (NW-SE extension)

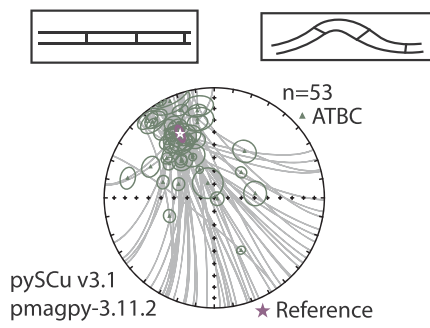

ca. 100 Ma remagnetization

paleomagnetic vector

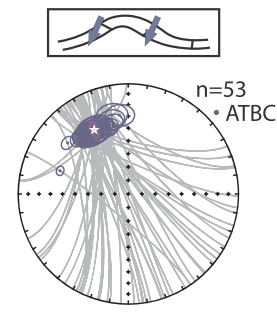

Atlasic N-S compression
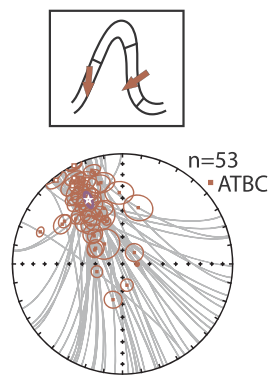

Fig. 2. Synthesis of the main geological events occurred in the CHA with noticeable imprint in the magnetic fabric and paleomagnetic directions of the studied sites (data from Calvín et al., 2017a). Equal-area projections with the small circles and the remagnetization site mean directions before bedding correction (BBC), after partial bedding correction (APBC) and after total bedding correction (ATBC) are also shown. 

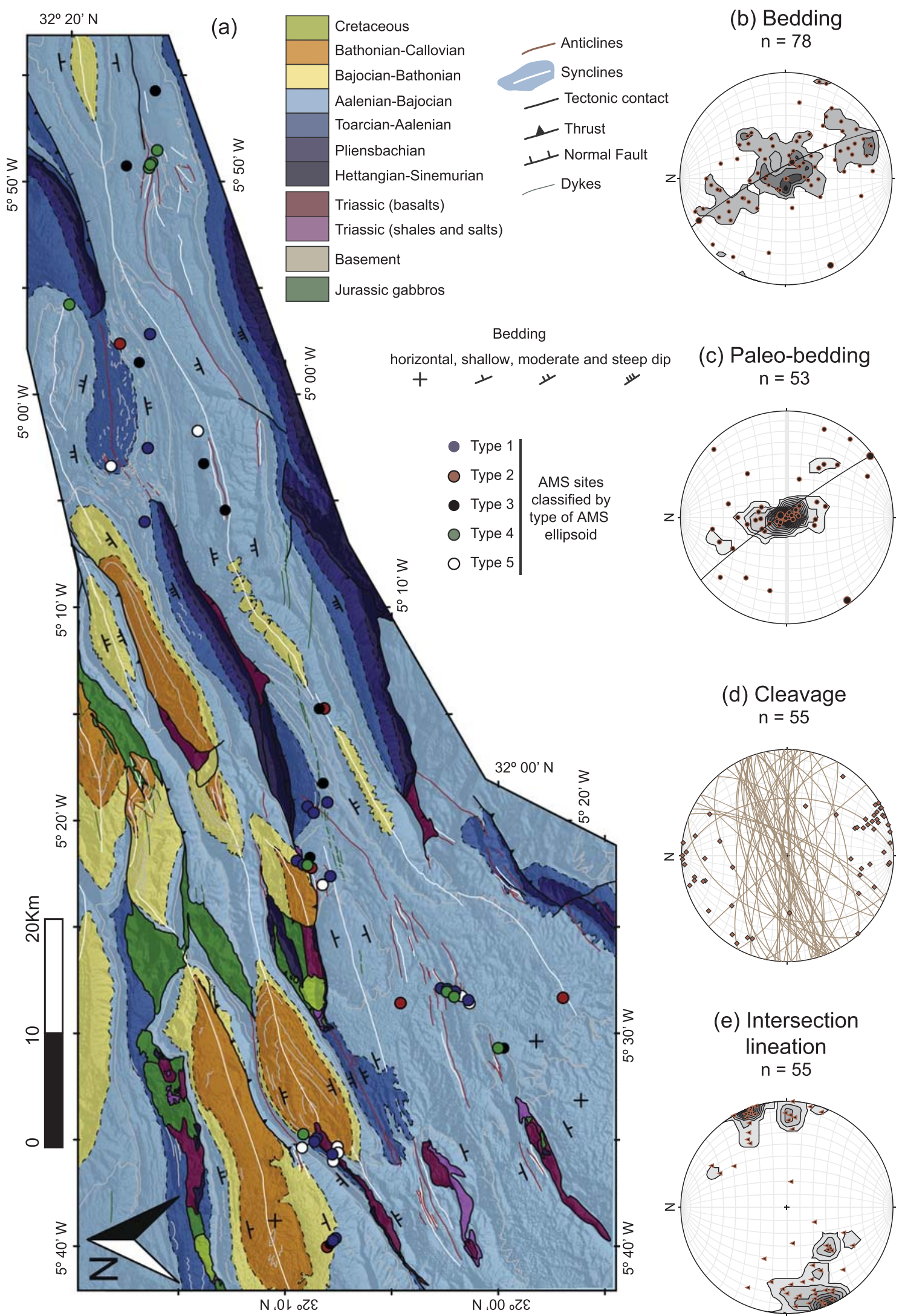

(c) Paleo-bedding
$n=53$

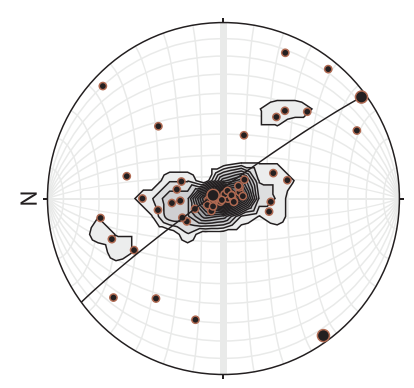

(d) Cleavage $n=55$

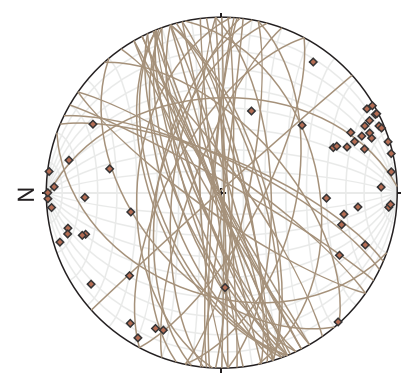

(e) Intersection lineation $\mathrm{n}=55$

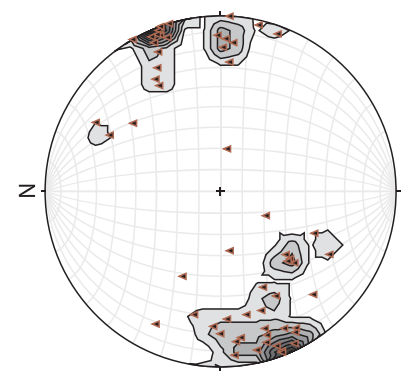

Fig. 3. (a) Geological map of the study area showing the sites classified according to the observed type of RT-AMS. Lower hemisphere, equal area projections showing (b) the poles to bedding and (c) the paleo-bedding with their associated cylindrical best-fit and the density isolines, (d) the great circles and poles to cleavage and (e) the intersection lineation between bedding and cleavage. 
ferrimagnetic fabric of the limestones in the CHA is carried by the diagenetic magnetite responsible for the Cretaceous remagnetization. This fabric shows the best cluster APBC, with a horizontal cluster of the magnetic lineation in a NNE-SSW direction, which is interpreted as the extension direction at the remagnetization time.

\section{Applied techniques}

The magnetic fabric of cylindrical standard specimens was assessed by means of three techniques: anisotropy of the magnetic susceptibility measured at room and low temperature (liquid nitrogen temperature; $\sim 77 \mathrm{~K}$ ) (RT-AMS and LT-AMS respectively) and through the anisotropy of the anhysteretic remanent remagnetization (AARM). RT-AMS is an approximation to the petrofabric of the rock in which all minerals contribute to the bulk signal (diamagnetic, paramagnetic and ferromagnetic s.l. minerals). LT-AMS amplifies the paramagnetic contribution to the AMS signature (Richter and van der Pluijm, 1994; Pares and van der Pluijm, 2002) according to the Curie-Weiss law (the paramagnetic susceptibility at $77 \mathrm{~K}$ is 3.8 times greater than at room temperature). Finally, AARM (McCabe et al., 1985) indicates the magnetic anisotropy of ferromagnetic s.l. grains with coercivities in the range between 0 and $90 \mathrm{mT}$, i.e., mainly ferrimagnetic minerals.

The AMS is a symmetric, second rank tensor, whose eigenvalues and eigenvectors can be used to define an ellipsoid with orthogonal principal axes, $\mathrm{k}_{\max }>\mathrm{k}_{\mathrm{int}}>\mathrm{k}_{\min }$. The shape and the anisotropy degree defined by the ellipsoid are determined using the $\mathrm{T}$ and $\mathrm{Pj}$ parameters (Jelinek, 1981) respectively, and the bulk susceptibility is defined by $\mathrm{k}_{\mathrm{m}}=\left[\left(\mathrm{k}_{\max }+\mathrm{k}_{\mathrm{int}}+\mathrm{k}_{\min }\right) / 3\right]$ (Nagata, 1961). AMS experiments were carried out with a KLY4-S Kappabridge (AGICO) $(875 \mathrm{~Hz}$ and $300 \mathrm{~A} / \mathrm{m}$ ). For measurements at low temperature (LT-AMS), specimens were submerged into liquid nitrogen about $45 \mathrm{~min}$ before starting the experiments, and 10-15 min between measurements.

The AARM was measured in 17 specimens from four sites (four to five specimens per site) and were evaluated together with previous AARM results from the same sites (presented in Calvín et al., 2018), totalling 63 specimens from 13 sites. The procedure for AARM analysis consists in the measurement of nine different positions of the sample, previously demagnetized, after the acquisition of an anhysteretic field along the axis of measurement (see McCabe et al., 1985). The magnetic second-rank tensor is calculated following Girdler's (1961) procedure. AARM measurements were made with a $2 \mathrm{G}$ cryogenic magnetometer with integrated alternating field (AF) and direct field (DF) coils. We used a DF of $0.05 \mathrm{mT}$ imparted coaxially with an AF between 90 and $0 \mathrm{mT}$. Anhysteretic magnetization was demagnetized after each measurement in a peak alternating field of $100 \mathrm{mT}$ and this measurement was used as a baseline to each position to remove the contribution of higher coercivity minerals.

The studied sites have been previously analysed paleomagnetically (Calvín et al., 2017a), giving information about the paleo-dip of bedding at the age of remagnetization ( $c a .100 \mathrm{Ma}$ ). This information allows applying a double restoration to the magnetic ellipsoid. In addition to the magnetic ellipsoid before bedding correction (BBC; i.e. in situ), we can analyse it after partial bedding correction (APBC; i.e. after untilting the beds to their $\mathrm{ca}$. $100 \mathrm{Ma}$ attitude) and after total bedding correction (ATBC; i.e. after restoring the bedding to the horizontal). In this way, we can observe the coherence at the different evolutionary stages.

In addition, several rock-magnetic experiments were made in order to understand the link between the magnetic minerals present in the specimens and the magnetic fabrics. Temperature-dependent susceptibility curves were carried out using a KLY4 Kappabridge (AGICO) with a CS3 furnace (temperature range between 25 and $700{ }^{\circ} \mathrm{C}$ ) and a CSL cryostat (from -195 to $0{ }^{\circ} \mathrm{C}$ ) under argon atmosphere. The variation of the bulk susceptibility with the frequency, expressed as the percentage of frequency-dependent susceptibility parameter ( $\% \chi \mathrm{fd}$; Dearing et al., 1996), was used to assess the contribution of the superparamagnetic fraction to the bulk susceptibility.

\section{Lithological and textural characterization}

The present day ENE-WSW structure of the CHA (Fig. 3) is the consequence of the mainly NW-SE directed extension that generated ENE-WSW basins during the Mesozoic (especially during the Jurassic) and the subsequent N-S Cenozoic compression (e.g. Frizon de Lamotte et al., 2008). The study area presents a particular deformation style (Fig. 1c) that is strongly conditioned by (i) the thick sedimentary sequences and (ii) the inherited extensional geometry, consisting of wide, flat areas separated by antiforms related to halokinetic and igneous activity, many of them already configured at the remagnetization time (Torres-López et al., 2016) (Fig. 3c).

These structures were reactivated under compression, and the antiforms were squeezed and thrusted during the Cenozoic, accommodating part of the deformation. The areas between antiforms are folded, generally by angular folds, and show development of axialplane cleavage (Calvín et al., 2017a) (Figs. 3d and 4). At outcrop scale (Fig. 4) this cleavage appears as fracture (e.g. AM01) or pressure-solution (e.g. SK05) cleavage with different degrees of development depending on the lithology involved and its location within the basin, ranging from nodular limestones without evidence of cleavage (e.g. DP01) to moderate (e.g., AM06, AM08, SK14) and penetrative cleavage (e.g. SK01, AM09) that can obliterate the bedding to some extent (e.g. OU01). Pencil structures (e.g. AM01) can be observed in some outcrops and the bedding-cleavage angle is variable, ranging from almost perpendicular (e.g. SK05) to sub-parallel (e.g. SK14).

Observations under the petrographical microscope (Fig. 5) also show a variety of features concerning both lithology and deformation degree, which is not always evident at outcrop scale. One common feature of all observed samples is the presence of bedding-parallel, platy pyrite grains or laminae, often formed by aggregates of crystals with cubic or framboidal shape. Many of these grains probably have been partially altered to magnetite during the remagnetization process. AG02 is a bioclastic limestone without cleavage and presenting stratiform stylolites. SK14, SK05 and AM01 are micritic limestones with some contribution of detrital grains (quartz and phyllosilicates) showing different degrees of cleavage development. In these samples the bedding is defined by oriented phyllosilicates and subtle changes in grain size. Cleavage is defined by faint pressure-solution surfaces and grain orientation in SK14, better defined in SK05 by the accumulation of opaque minerals. SK01 shows the better-defined solution surfaces with accumulation of opaque minerals; probably most of the opaque minerals correspond to iron oxides, but also to very fine-grained shales that can be present in all samples although individual minerals are not visible at this scale.

\section{AMS results (RT-AMS, LT-AMS, AARM)}

Measured specimens show a mean low-field susceptibility ( $\kappa)$ at room temperature (RT-AMS) of $234 \times 10^{-6}$ SI $\left(\sigma=245 \times 10^{-6} \mathrm{SI}\right.$ ), with a range of $37 \times 10^{-6} \mathrm{SI}$ and $1596 \times 10^{-6} \mathrm{SI}$ (Fig. 6a). The anisotropy degree reflected by the $\mathrm{Pj}$ parameter has a mean of 1.027 $(\sigma=0.016)$ ranging between 1.004 and 1.099. Finally, the shape parameter T is variable, with a mean value of $-0.008(\sigma=0.461)$, with a range of -0.959 and 0.917 (Fig. 5; Table 1) indicating similar number of samples with prolate and oblate ellipsoids. LT-AMS (Fig. 6b) 

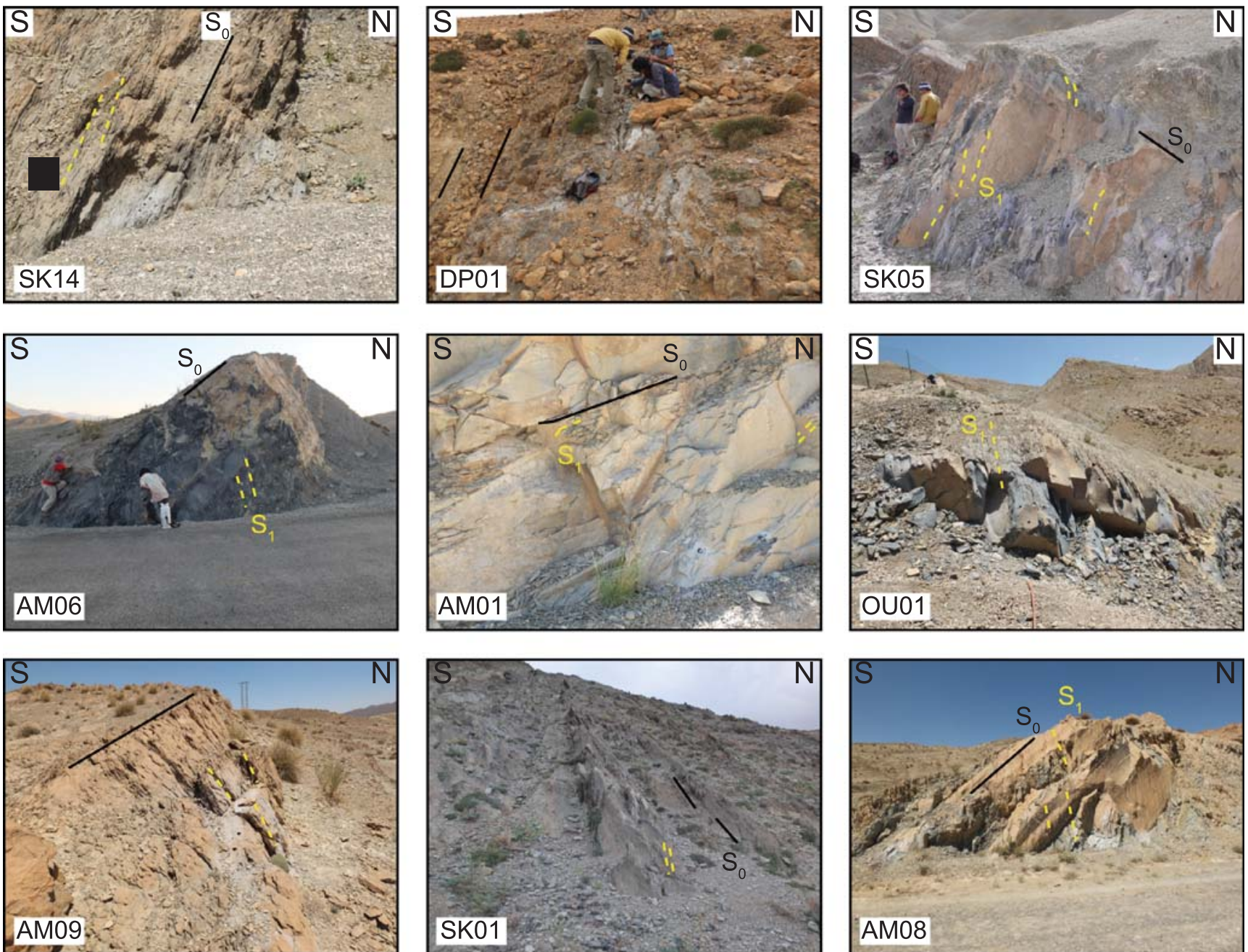

Fig. 4. Pictures of outcrops showing different attitudes and deformation degrees of the sampled limestones. Solid lines mark the bedding $\left(\mathrm{S}_{0}\right)$ and dashed lines the cleavage $\left(\mathrm{S}_{1}\right)$

shows similar parameters, with the exception of the $\mathrm{T}$ parameter, showing mainly oblate ellipsoids (positive $\mathrm{T}$ values), contrasting with AARM, which shows prolate ellipsoids (negative T values).

A visual inspection of the principal axes of the RT-AMS of the set of 53 measured sites (Fig. 6a) shows a roughly horizontal foliation. This is better defined (confidence angles are lower) both APBC and ATBC rather than BBC. The maximum axis $\mathrm{k}_{\max }$ is scattered in the horizontal plane (preferably APBC and ATBC). However, none of the projections shows a clean, clustered distribution of the RT-AMS axes, probably due to a mix of different magnetic fabrics.

Sub-fabrics determined from LT-AMS (enhanced paramagnetic fabric) and the AARM (ferrimagnetic fabric), although defined from a lower number of samples, are in general better clustered than the RTAMS (Fig. 6b, c). LT-AMS is more scattered BBC and APBC compared to ATBC, which shows a horizontal magnetic foliation (indicating a sedimentary origin for most of the paramagnetic foliation) and a scattered ESE-WNW horizontal magnetic lineation. Nevertheless, in AARM the best clustering is APBC, indicating that the ferrimagnetic fabric was acquired coeval with the remagnetization (Calvin et al., submitted).

A site-by-site detailed comparison of the different sub-fabrics
(Figs. 7 and 8) allows differentiating four different types of RT-AMS, according to the geometry and orientation of the magnetic ellipsoids and the distribution of their axes. Forty-four out of the 53 sites are included in one or another of these groups, whereas nine sites cannot be classified because of the dispersion of AMS axes at site scale or their anomalous orientation with respect to the deformation axes (labelled as 'unclassified' at Table 2).

Type 1 RT-AMS (Fig. 7a) is defined by a well clustered NNW-SSW lineation that becomes horizontal APBC, and a girdle between $\mathrm{k}_{\min }$ and $\mathrm{k}_{\text {int }}$, with a dominantly vertical $\mathrm{k}_{\min }$. The RT-AMS fabric is similar to the ferromagnetic fabric defined by the AARM. The prolate geometry of both ellipsoids is also consistent with the prolate behaviour at specimen level (negative values of $\mathrm{T}$ parameter). The opposite happens when the paramagnetic fabric is enhanced through the LT-AMS: the mean, as well as the specimen ellipsoids, become triaxial (positive values of $\mathrm{T}$ parameter); the orientation of the principal axes is almost equal to RT-AMS, but the magnetic foliation becomes horizontal ATBC instead of APBC. Although this difference is subtle for low paleo-dips, it is significant because this is one of the major differential facts between fabric types 1 and 2 . 

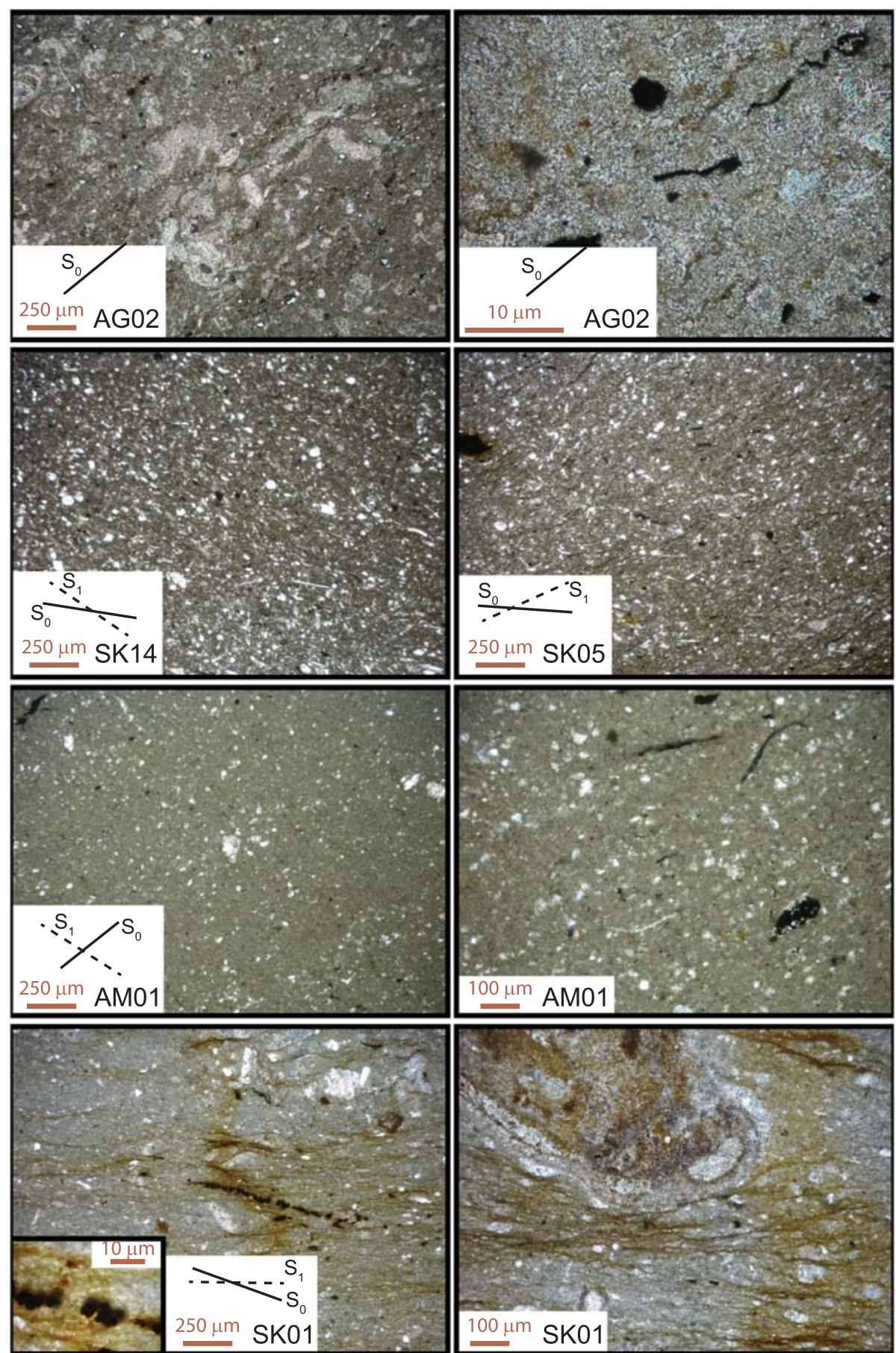

Fig. 5. Thin-sections photomicrographs showing different aspects of deformational structures in the analysed limestones. AG02: bioclastic limestones without cleavage. SK14, SK05 and AM01: micritic limestones with contribution of detrital grains, with pressure-solution cleavage $\left(\mathrm{S}_{1}\right)$. SK01: bioclastic limestones with a well-defined pressure-solution cleavage with concentration of oxides (and probably also phyllosilicates) in the cleavage surfaces. Note the presence in all samples of bedding-parallel pyrite grains showing framboidal morphologies in some cases (see the inset in SK01).

Type 2 RT-AMS (Fig. 7b) is characterized by a triaxial to oblate ellipsoid, with a well-defined magnetic foliation. RT-AMS foliation is coincident with LT-AMS but slightly different from AARM, which shows more dispersion of $\mathrm{k}_{\mathrm{min}}$. Besides, in both magnetic susceptibility fabrics, magnetic foliation is horizontal ATBC whereas in the AARM this happens in the APBC orientation. Regarding the lineation, it is noteworthy that $\mathrm{k}_{\max }$ at LT-AMS progressively approaches the intersection lineation between bedding and cleavage $\left(\mathrm{L}_{1}\right)$. Conversely, $\mathrm{k}_{\max }$ for RT-AMS and AARM ellipsoids tends to be parallel to the general NNW-SSW trend observed in type 1 fabrics (Fig. 7a).

Type 3 RT-AMS (Fig. 8a) is defined by the coincidence between $k_{\max }$ and $\mathrm{L}_{1}$, but keeping the magnetic foliation parallel to the bedding. LT- 


\section{ATBC}

\section{APBC}
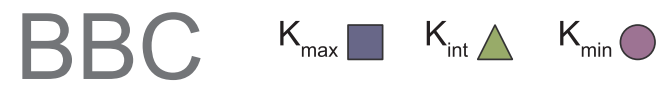

(a) RT-AMS (53 sites; 484 specimens)
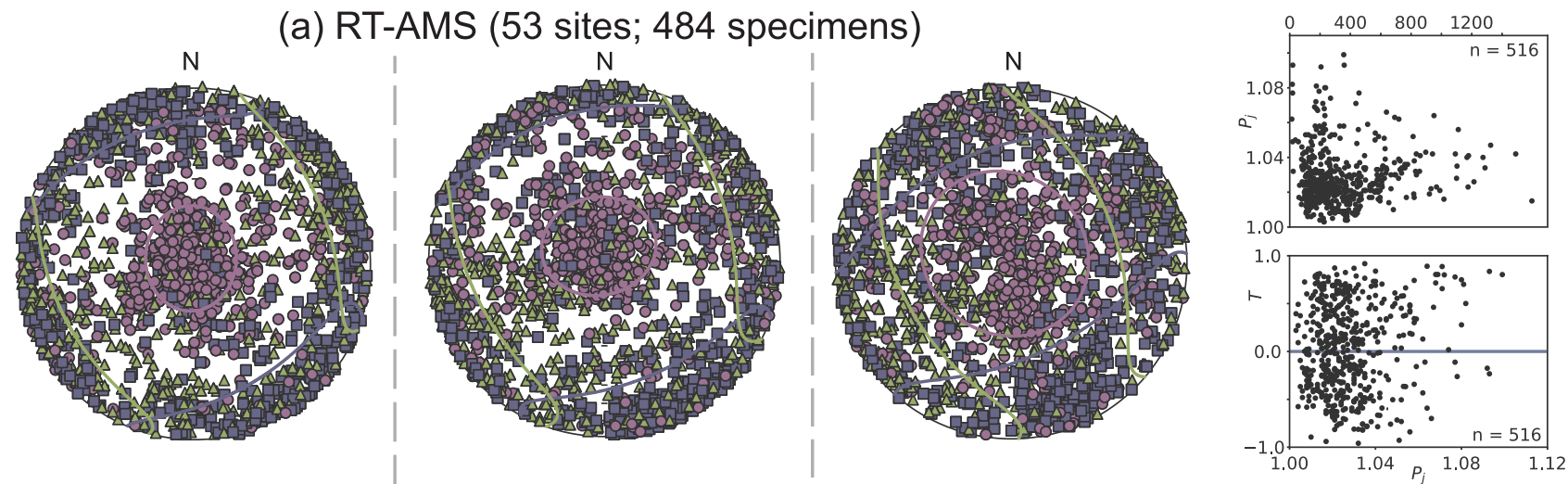

(b) LT-AMS (11 sites; 41 specimens)
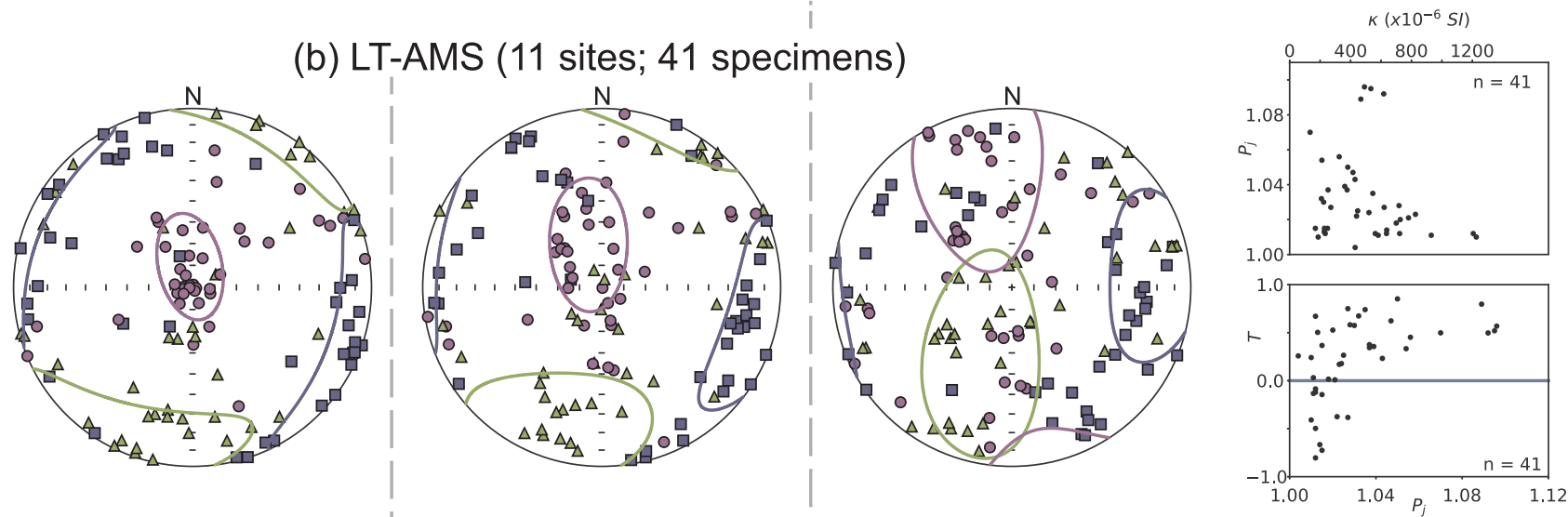

(c) AARM (13 sites; 62 specimens)
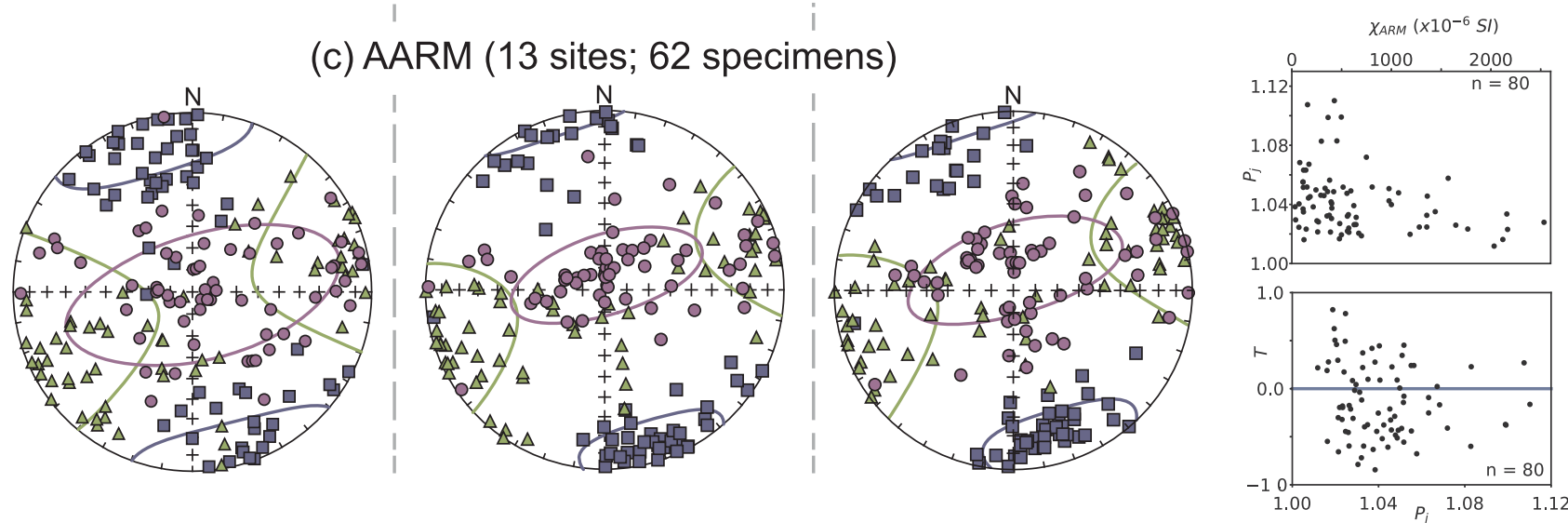

Fig. 6. Lower hemisphere, equal area projection of the principal axes of (a) RT-AMS, (b) LT-AMS and (c) AARM, for all studied sites, showing the corrected anisotropy degree $\left(\mathrm{P}_{\mathrm{j}}\right)$ versus bulk susceptibility $\left(\kappa_{\mathrm{RT}}\right)$ and shape parameter $(\mathrm{T})$, as well. BBC: before bedding correction; APBC: after partial bedding correction; ATBC: after total bedding correction.

AMS behaviour is similar to RT-AMS and both show triaxial ellipsoids. Conversely AARM is similar to type1; the axes show a girdle between $\mathrm{k}_{\max }$ and $\mathrm{k}_{\mathrm{int}}$ (thus forming a prolate ellipsoid); however, at specimen level this difference is not evident, since triaxial to oblate behaviour was observed in most samples with independence of the type of sub- fabric.

Finally, type 4 RT-AMS (Fig. 8b) is clearly related to cleavage, showing oblate ellipsoids with $\mathrm{k}_{\max }$ parallel to $\mathrm{L}_{1}$, and a clustered $\mathrm{k}_{\min }$ perpendicular to cleavage planes, both in RT- and LT-AMS. As in type 3, AARM does not show evidence for being affected by the tectonic 
Table 1

Location of the studied sites, type of ellipsoid defined by the RT-AMS, and scalar parameters of the RT-AMS. N/n: number of total data vs. number of used data; km: bulk susceptibility; L: magnetic lineation; F: magnetic foliation; $P_{j}$ : corrected anisotropy degree; T: shape parameter; $\sigma$ : standard deviation; U: unclassified type.

\begin{tabular}{|c|c|c|c|c|c|c|c|c|c|c|c|c|c|c|}
\hline \multirow[t]{2}{*}{ Site } & \multicolumn{2}{|c|}{ Coordinates (WGS86) } & \multirow{2}{*}{$\begin{array}{l}\text { Type of } \\
\text { Ellipsoid }\end{array}$} & \multirow[t]{2}{*}{$\mathrm{N} / \mathrm{n}$} & \multirow{2}{*}{$\frac{\mathrm{km}}{\mathrm{X} 10^{-6} \mathrm{SI}}$} & \multirow[t]{2}{*}{$\sigma$} & \multirow[t]{2}{*}{$\mathrm{L}$} & \multirow[t]{2}{*}{$\sigma$} & \multirow[t]{2}{*}{$\mathrm{F}$} & \multirow[t]{2}{*}{$\sigma$} & \multirow[t]{2}{*}{$P_{j}$} & \multirow[t]{2}{*}{$\sigma$} & \multirow[t]{2}{*}{$\mathrm{T}$} & \multirow[t]{2}{*}{$\sigma$} \\
\hline & Longitude & Latitude & & & & & & & & & & & & \\
\hline AG02 & -5.4775792563 & 32.0222007889 & 1 & $7 / 7$ & 756 & 459 & 1.022 & 0.008 & 1.01 & 0.005 & 1.033 & 0.01 & -0.374 & 0.277 \\
\hline AM04 & -5.0439580000 & 32.2736890000 & 1 & $12 / 12$ & 619 & 176 & 1.023 & 0.006 & 1.007 & 0.003 & 1.031 & 0.005 & -0.526 & 0.251 \\
\hline AM13 & -4.9543220000 & 32.2719410000 & 1 & $12 / 12$ & 603 & 331 & 1.009 & 0.004 & 1.012 & 0.007 & 1.022 & 0.006 & 0.076 & 0.434 \\
\hline AM14 & -5.1019540000 & 32.2761530000 & 1 & $13 / 13$ & 530 & 102 & 1.021 & 0.005 & 1.01 & 0.003 & 1.032 & 0.004 & -0.335 & 0.211 \\
\hline DP01 & -5.6653333333 & 32.1274666667 & 1 & $8 / 8$ & 287 & 56.6 & 1.019 & 0.013 & 1.01 & 0.007 & 1.03 & 0.011 & -0.178 & 0.636 \\
\hline DP02 & -5.6653333333 & 32.1274666667 & 1 & $8 / 8$ & 173 & 167 & 1.018 & 0.012 & 1.066 & 0.004 & 1.026 & 0.013 & -0.38 & 0.49 \\
\hline DP05 & -5.5874166667 & 32.1423666667 & 1 & $8 / 8$ & 373 & 610 & 1.003 & 0.001 & 1.002 & 0.001 & 1.006 & 0.002 & -0.166 & 0.347 \\
\hline DP06 & -5.5888333333 & 32.1428415000 & 1 & $11 / 11$ & 458 & 49 & 1.007 & 0.005 & 1.005 & 0.002 & 1.012 & 0.005 & -0.057 & 0.53 \\
\hline DP10 & -5.5987000000 & 32.1288333333 & 1 & $10 / 10$ & 189 & 37.3 & 1.011 & 0.006 & 1.006 & 0.003 & 1.017 & 0.005 & -0.22 & 0.488 \\
\hline OU02 & -5.3680260000 & 32.1566960000 & 1 & $12 / 12$ & 226 & 120 & 1.008 & 0.003 & 1.008 & 0.005 & 1.017 & 0.006 & -0.016 & 0.38 \\
\hline OU03 & -5.3710290000 & 32.1502090000 & 1 & $10 / 10$ & 181 & 90.6 & 1.022 & 0.01 & 1.021 & 0.014 & 1.043 & 0.022 & -0.058 & 0.263 \\
\hline OU06 & -5.3220820000 & 32.1325970000 & 1 & $12 / 12$ & 315 & 147 & 1.014 & 0.004 & 1.007 & 0.003 & 1.022 & 0.005 & -0.361 & 0.219 \\
\hline SK05 & -5.4682166667 & 32.0436165000 & 1 & $17 / 17$ & 230 & 198 & 1.014 & 0.012 & 1.014 & 0.008 & 1.028 & 0.018 & 0.106 & 0.397 \\
\hline SK07 & -5.4688000000 & 32.0386306667 & 1 & $13 / 13$ & 1.72 & 40.6 & 1.01 & 0.006 & 1.013 & 0.014 & 1.024 & 0.013 & -0.045 & 0.564 \\
\hline SK09 & -5.4708093899 & 32.0326174154 & 1 & $7 / 7$ & 790 & 169 & 1.029 & 0.01 & 1.01 & 0.003 & 1.041 & 0.011 & -0.442 & 0.227 \\
\hline SK14 & -5.3253166667 & 32.1482173333 & 1 & $12 / 12$ & 478 & 142 & 1.015 & 0.005 & 1.007 & 0.004 & 1.024 & 0.004 & -0.327 & 0.358 \\
\hline SK15 & -5.3301000000 & 32.1434253000 & 1 & $11 / 11$ & 169 & 31.7 & 1.007 & 0.004 & 1.008 & 0.003 & 1.016 & 0.003 & 0.102 & 0.422 \\
\hline SK19 & -5.3801388333 & 32.1303691667 & 1 & $15 / 15$ & 274 & 89 & 1.018 & 0.01 & 1.009 & 0.004 & 1.029 & 0.013 & -0.263 & 0.305 \\
\hline AM06 & -4.9612480000 & 32.2959210000 & 2 & $13 / 13$ & 227 & 31 & 1.015 & 0.005 & 1.016 & 0.005 & 1.031 & 0.003 & 0.039 & 0.291 \\
\hline DP04 & -5.6679666667 & 32.1295166667 & 2 & $7 / 7$ & 197 & 32.8 & 1.006 & 0.003 & 1.016 & 0.007 & 1.023 & 0.006 & 0.411 & 0.389 \\
\hline OU04 & -5.3701710000 & 32.1495530000 & 2 & $10 / 10$ & 315 & 40.8 & 1.004 & 0.002 & 1.018 & 0.007 & 1.024 & 0.008 & 0.584 & 0.18 \\
\hline SK04 & -5.4790333333 & 32.0758023333 & 2 & $12 / 12$ & 124 & 256 & 1.005 & 0.004 & 1.018 & 0.009 & 1.025 & 0.012 & 0.577 & 0.25 \\
\hline SK12 & -5.4748666667 & 31.9483000000 & 2 & $11 / 11$ & 301 & 113 & 1.008 & 0.004 & 1.06 & 0.011 & 1.075 & 0.013 & 0.757 & 0.134 \\
\hline SK16 & -5.2474666667 & 32.1355240000 & 2 & $7 / 7$ & 479 & 159 & 1.015 & 0.007 & 1.011 & 0.005 & 1.026 & 0.008 & -0.117 & 0.464 \\
\hline AM01 & -5.0903890000 & 32.2135470000 & 3 & $7 / 7$ & 323 & 110 & 1.015 & 0.004 & 1.019 & 0.006 & 1.035 & 0.006 & 0.137 & 0.247 \\
\hline AM02 & -5.0537886044 & 32.2303715708 & 3 & $12 / 12$ & 112 & 34.8 & 1.009 & 0.004 & 1.024 & 0.009 & 1.035 & 0.012 & 0.433 & 0.171 \\
\hline AM07 & -4.7608470004 & 32.2683762996 & 3 & $13 / 13$ & 234 & 49.9 & 1.005 & 0.002 & 1.016 & 0.002 & 1.023 & 0.003 & 0.543 & 0.17 \\
\hline AM12 & -4.8198670000 & 32.2909960000 & 3 & $8 / 8$ & 310 & 98.7 & 1.011 & 0.003 & 1.011 & 0.005 & 1.023 & 0.006 & -0.068 & 0.388 \\
\hline AM16 & -4.9743190000 & 32.2809610000 & 3 & $8 / 8$ & 722 & 914 & 1.019 & 0.005 & 1.011 & 0.005 & 1.032 & 0.003 & -0.27 & 0.322 \\
\hline DP03 & -5.6653333333 & 32.1274666667 & 3 & $7 / 7$ & 818 & 496 & 1.099 & 0.007 & 1.022 & 0.007 & 1.032 & 0.011 & 0.478 & 0.309 \\
\hline OU01 & -5.3626490000 & 32.1470260000 & 3 & $8 / 8$ & 372 & 51.3 & 1.008 & 0.005 & 1.01 & 0.002 & 1.019 & 0.004 & 0.18 & 0.349 \\
\hline OU07 & -5.3044540000 & 32.1367200000 & 3 & $10 / 10$ & 247 & 52.5 & 1.007 & 0.003 & 1.01 & 0.005 & 1.018 & 0.005 & 0.097 & 0.434 \\
\hline SK10 & -5.5125000000 & 31.9963333333 & 3 & $6 / 6$ & 167 & 142 & 1.019 & 0.014 & 1.007 & 0.004 & 1.028 & 0.017 & -0.26 & 0.514 \\
\hline SK17 & -5.2458833333 & 32.1371576667 & 3 & $7 / 7$ & 323 & 97.3 & 1.018 & 0.011 & 1.023 & 0.012 & 1.043 & 0.016 & 0.145 & 0.416 \\
\hline AM05 & -4.9305720000 & 32.3343230000 & 4 & $8 / 8$ & 370 & 56 & 1.005 & 0.003 & 1.013 & 0.003 & 1.019 & 0.003 & 0.415 & 0.315 \\
\hline AM08 & -4.8096290000 & 32.2655130000 & 4 & $10 / 10$ & 197 & 26.4 & 1.014 & 0.003 & 1.038 & 0.004 & 1.055 & 0.006 & 0.458 & 0.102 \\
\hline AM09 & -4.8208030000 & 32.2706410000 & 4 & $6 / 6$ & 259 & 23 & 1.008 & 0.001 & 1.015 & 0.003 & 1.024 & 0.004 & 0.286 & 0.124 \\
\hline AM10 & -4.8205335533 & 32.2708180885 & 4 & $3 / 3$ & 253 & 15.6 & 1.005 & 0.004 & 1.013 & 0.004 & 1.02 & 0.006 & 0.439 & 0.267 \\
\hline AM11 & -4.8207239530 & 32.2709996914 & 4 & $5 / 5$ & 283 & 12.3 & 1.004 & 0.002 & 1.004 & 0.002 & 1.008 & 0.002 & -0.087 & 0.436 \\
\hline OU05 & -5.3701360000 & 32.1477500000 & 4 & $8 / 4$ & 336 & 55 & 1.009 & 0.003 & 1.012 & 0.004 & 1.021 & 0.006 & 0.136 & 0.165 \\
\hline SK01 & -5.5812961667 & 32.1510336667 & 4 & $10 / 10$ & 171 & 47 & 1.006 & 0.002 & 1.025 & 0.018 & 1.033 & 0.021 & 0.558 & 0.16 \\
\hline SK06 & -5.4695500000 & 32.0398310000 & 4 & $6 / 6$ & 189 & 44.8 & 1.011 & 0.004 & 1.014 & 0.007 & 1.025 & 0.011 & 0.104 & 0.237 \\
\hline SK08 & -5.4708479598 & 32.0328691962 & 4 & $6 / 6$ & 334 & 68.8 & 1.015 & 0.003 & 1.006 & 0.002 & 1.022 & 0.003 & -0.409 & 0.171 \\
\hline SK11 & -5.51376666667 & 31.9958123333 & 4 & $7 / 7$ & 584 & 57.5 & 1.027 & 0.013 & 1.016 & 0.01 & 1.044 & 0.016 & -0.28 & 0.339 \\
\hline AG01 & -5.4775860517 & 32.0223116547 & $\mathrm{U}$ & $13 / 12$ & 164 & 48.7 & 1.005 & 0.003 & 1.01 & 0.006 & 1.016 & 0.007 & 0.186 & 0.403 \\
\hline AM03 & -5.0290900000 & 32.2349690000 & $\mathrm{U}$ & $12 / 12$ & 513 & 107 & 1.012 & 0.004 & 1.007 & 0.003 & 1.019 & 0.005 & -0.293 & 0.235 \\
\hline AM15 & -5.0567310000 & 32.3029890000 & $\mathrm{U}$ & $8 / 8$ & 344 & 197 & 1.006 & 0.001 & 1.003 & 0.001 & 1.009 & 0 & -0.315 & 0.155 \\
\hline DP07 & -5.5909000000 & 32.1534241667 & $\mathrm{U}$ & $6 / 6$ & 139 & 21.3 & 1.01 & 0.004 & 1.024 & 0.007 & 1.036 & 0.007 & 0.385 & 0.263 \\
\hline DP08 & -5.5902166667 & 32.1256740000 & $\mathrm{U}$ & $4 / 4$ & 150 & 10.2 & 1.02 & 0.006 & 1.028 & 0.008 & 1.049 & 0.005 & 0.159 & 0.281 \\
\hline DP09 & -5.5948833333 & 32.1251833333 & $\mathrm{U}$ & $8 / 8$ & 240 & 33.7 & 1.027 & 0.015 & 1.019 & 0.012 & 1.048 & 0.024 & -0.19 & 0.338 \\
\hline DP11 & -5.60156666667 & 32.1289411667 & $\mathrm{U}$ & $8 / 8$ & 99.7 & 41.2 & 1.023 & 0.013 & 1.011 & 0.006 & 1.036 & 0.016 & -0.34 & 0.278 \\
\hline SK13 & -5.4719666667 & 32.0284786667 & $\mathrm{U}$ & $7 / 7$ & 811 & 282 & 1.012 & 0.01 & 1.015 & 0.011 & 1.028 & 0.014 & 0.099 & 0.589 \\
\hline SK18 & -5.3846790000 & 32.1373333333 & $\mathrm{U}$ & $8 / 8$ & 555 & 117 & 1.01 & 0.004 & 1.009 & 0.005 & 1.02 & 0.005 & -0.067 & 0.348 \\
\hline
\end{tabular}

cleavage, showing the same behaviour to that observed in type 1 . In this case, differences can be observed at specimen level, showing oblate ellipsoids in AMS (with higher anisotropy in LT-AMS) and prolate ellipsoids in AARM.

These observations are enhanced in the projection of the RT-AMS of all sites classified by behaviour types (Fig. 9). Types 1 and 2 are similar, but magnetic lineation is better defined in type 1 (Fig. 9a) and magnetic foliation in type 2 (Fig. 9b), in agreement with the existence of more prolate specimens $(T<1)$ for type 1 and oblate ones $(T>1)$ for type
2. The best clustering in type 1 takes place APBC whereas in type 2 this arrangement is met ATBC, with vertical $\mathrm{k}_{\min }$ and $\mathrm{k}_{\max }$ oriented NNESSW. On the other hand, type 3 (Fig. 9c) shows the best clustering ATBC and the more scattered distribution BBC, as in type 2. However, the magnetic lineation is roughly NE-SW, parallel to the NE-SW regional trend of compressional structures. Type 4 (Fig. 9d) does not show a good clustering for any of the bedding corrections. At site level (Table 2) $k_{\min }$ is normal to cleavage and $k_{\max }$ is parallel to $L_{1}$. Finally, the 9 sites showing unclassified behaviour (Fig. 9e) are characterized 


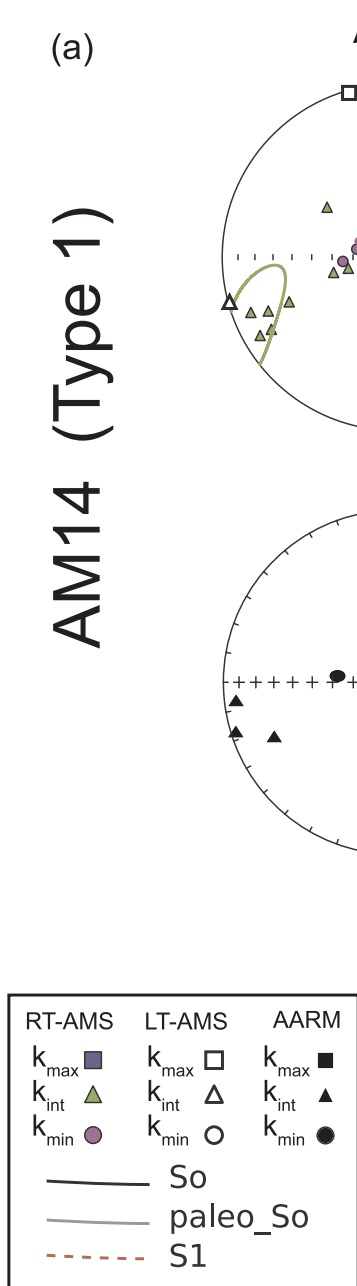

ATBC

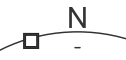

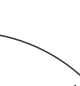

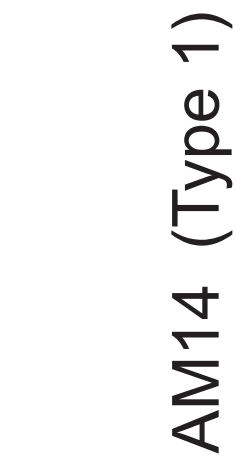
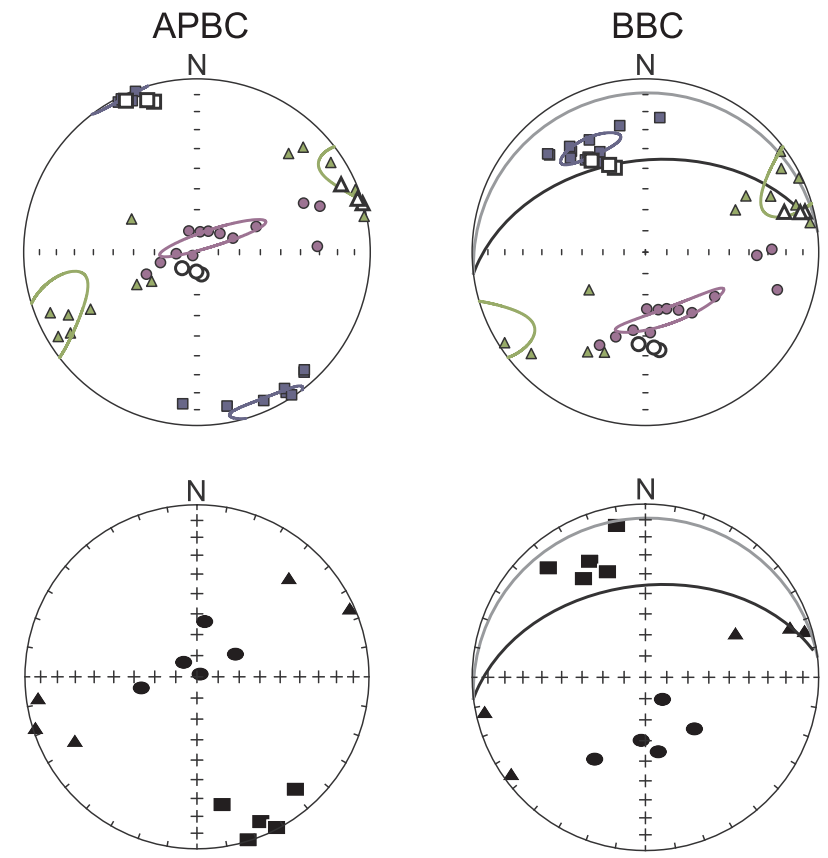

(b)

ATBC

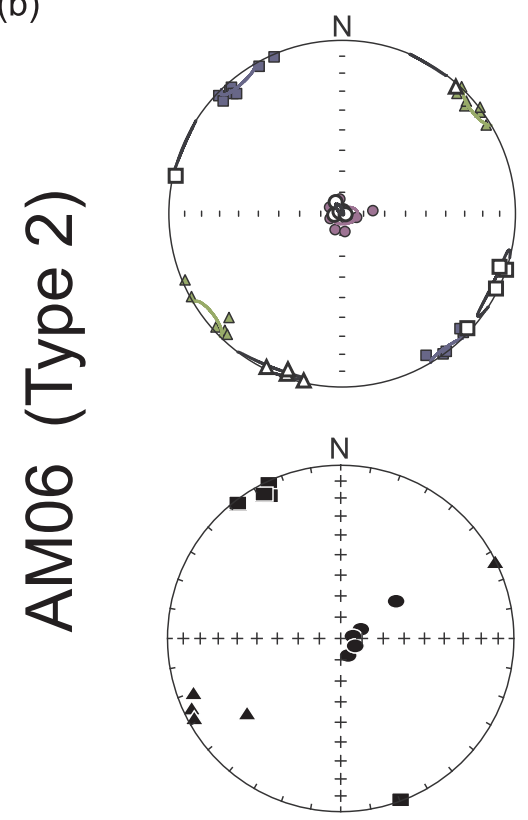

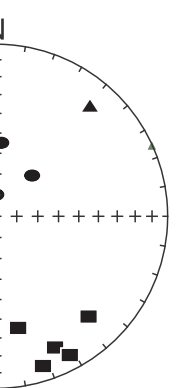
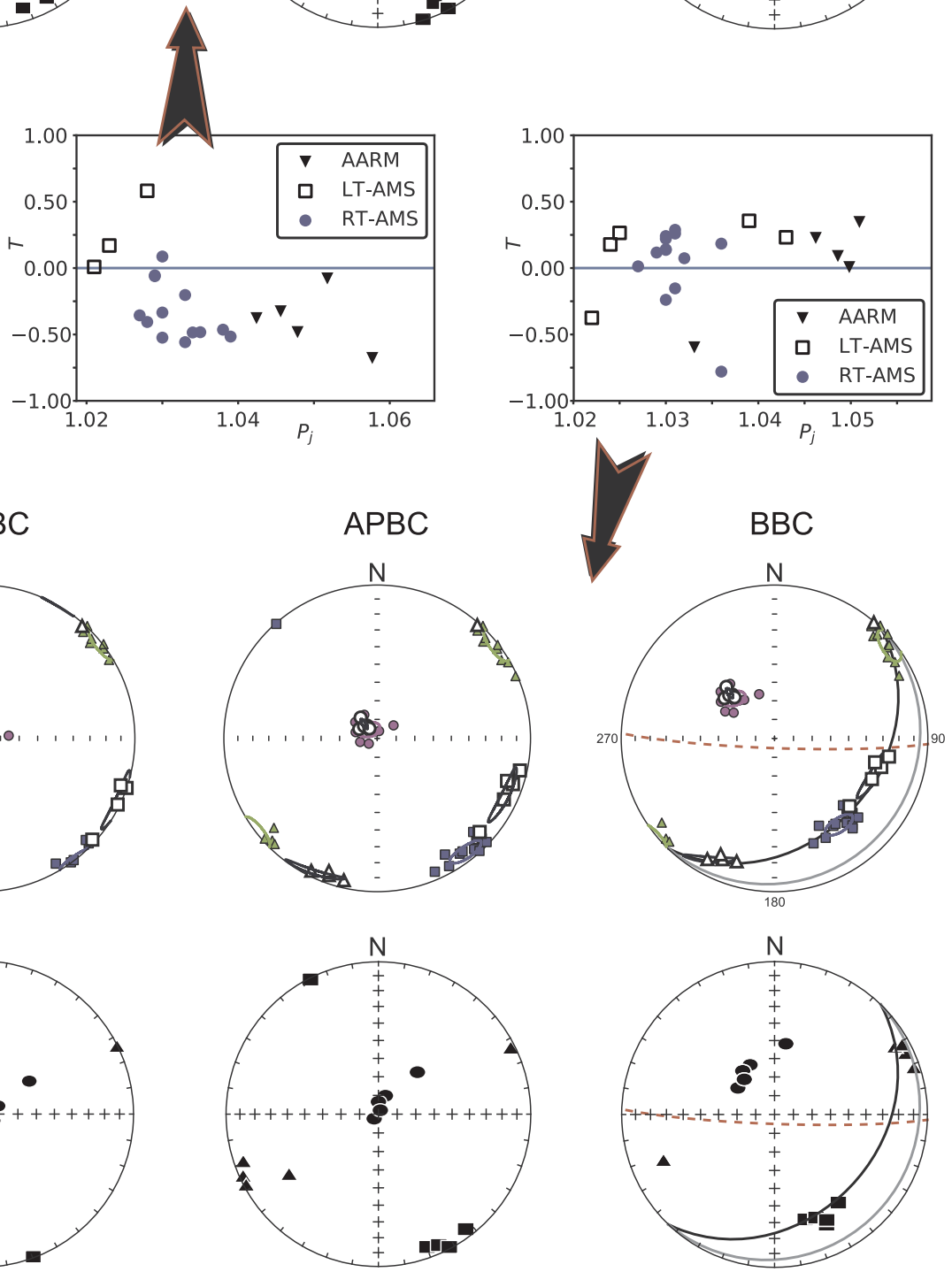

Fig. 7. Equal-area projection of the different fabrics (RT-AMS, LT-AMS and AARM) for two selected sites representative of types (a) 1 and (b) 2 together with the corresponding $\mathrm{P}_{\mathrm{j}}$-T plot. 

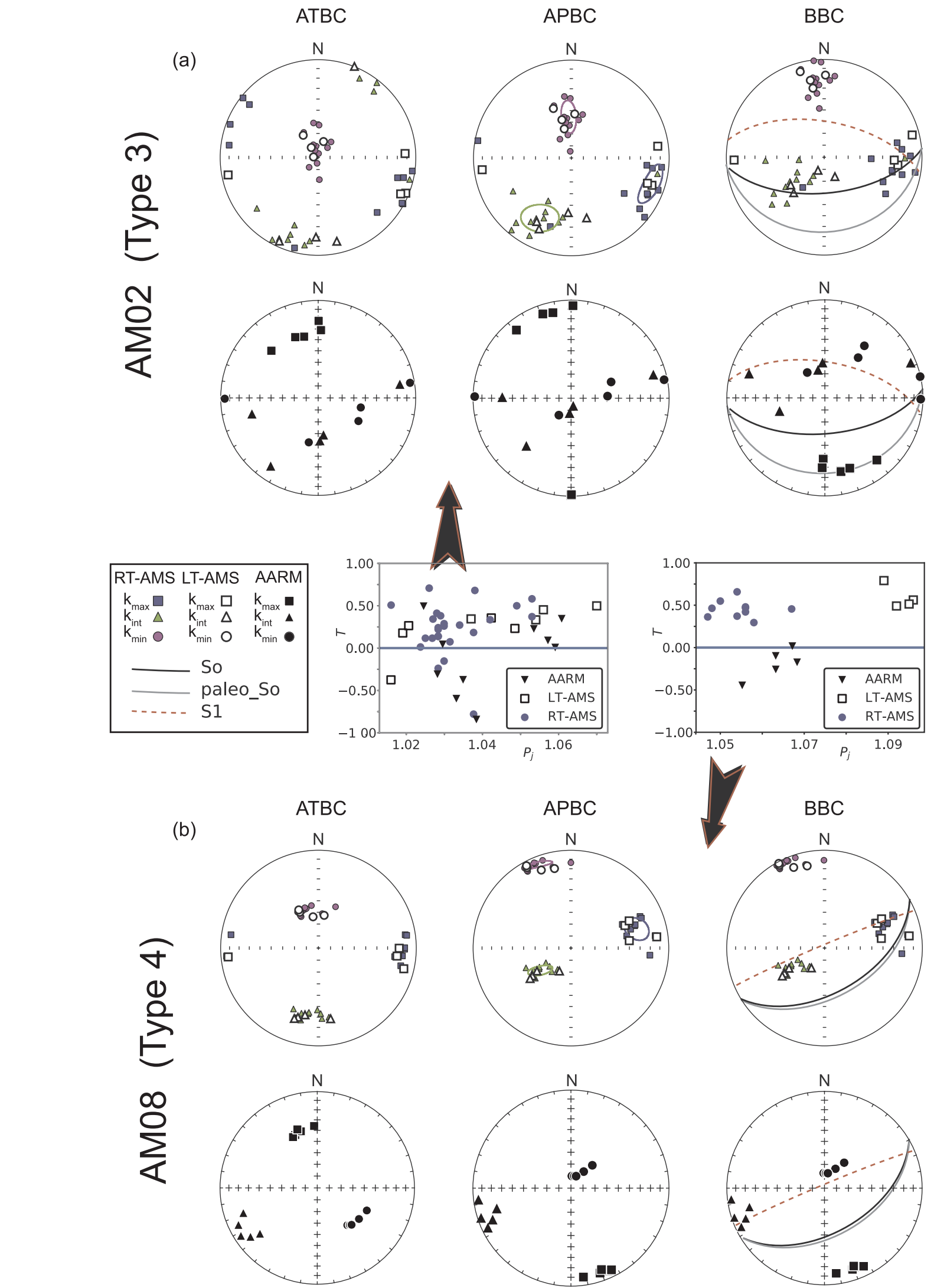

Fig. 8. Equal area projection of the different fabrics (RT-AMS, LT-AMS and AARM) for two selected sites representative of types (a) 3 and T(b) 4 together with the corresponding $\mathrm{P}_{\mathrm{j}}$-T plot. 
Table 2

Structural and RT-AMS directional data. Bedding, paleo-bedding and cleavage, as dip direction and dip of the maximum dip direction; $\mathrm{L}_{1}$ (lineation of intersection) as trend and plunge (calculated from bedding and cleavage data). Principal axis of the RT-AMS direction are given as trend and plunge before bedding correction (BBC), after partial bedding correction (APBC) and after total bedding correction (ATBC), with the corresponding angles of confidence (e1 and e2); U: unclassified type.

\begin{tabular}{|c|c|c|c|c|c|c|c|c|c|c|c|c|c|c|c|c|c|}
\hline \multirow[t]{2}{*}{ Site } & \multirow[t]{2}{*}{ Bedding } & \multirow{2}{*}{$\begin{array}{l}\text { Paleo- } \\
\text { Bedding }\end{array}$} & \multirow[t]{2}{*}{ Cleavage } & \multirow[t]{2}{*}{$\mathrm{L}_{1}$} & \multirow{2}{*}{$\frac{\text { Type of }}{\text { Ellipsoid }}$} & \multicolumn{4}{|l|}{$\operatorname{kmax}$} & \multicolumn{4}{|l|}{ kint } & \multicolumn{4}{|l|}{$\mathrm{kmin}$} \\
\hline & & & & & & BBC & APBC & АТВС & $\mathrm{e} 1 / \mathrm{e} 2$ & BBC & APBC & АТВС & $\mathrm{e} 1 / \mathrm{e} 2$ & BBC & АРBC & АТВС & $\mathrm{e} 1 / \mathrm{e} 2$ \\
\hline AG02 & $001 / 00$ & $001 / 02$ & $-1-$ & $-1-$ & 1 & $340 / 08$ & $340 / 08$ & $340 / 07$ & $19 / 2$ & $072 / 14$ & $072 / 14$ & $072 / 14$ & $35 / 15$ & $223 / 74$ & $223 / 74$ & $225 / 75$ & $33 / 3$ \\
\hline AM04 & $191 / 22$ & $191 / 22$ & $208 / 72$ & $201 / 22$ & 1 & $160 / 14$ & $160 / 14$ & $341 / 05$ & $8 / 4$ & $070 / 02$ & $070 / 02$ & $072 / 13$ & $12 / 8$ & $331 / 76$ & $331 / 76$ & $232 / 76$ & $11 / 4$ \\
\hline AM13 & $148 / 34$ & $148 / 20$ & $-1-$ & $-1-$ & 1 & $167 / 22$ & $166 / 09$ & $345 / 10$ & $8 / 6$ & $076 / 02$ & $256 / 01$ & $254 / 08$ & $33 / 6$ & $341 / 68$ & $355 / 81$ & $126 / 77$ & $34 / 3$ \\
\hline AM14 & $353 / 46$ & $353 / 09$ & $-1-$ & $-1-$ & 1 & $332 / 32$ & $155 / 03$ & $155 / 12$ & $14 / 5$ & $064 / 02$ & $246 / 10$ & $248 / 12$ & $27 / 10$ & $157 / 58$ & $048 / 80$ & $023 / 73$ & $26 / 4$ \\
\hline DP01 & $355 / 71$ & $175 / 07$ & $-1-$ & $-1-$ & 1 & $323 / 68$ & $163 / 07$ & $344 / 00$ & $15 / 12$ & 077/09 & $254 / 06$ & $254 / 05$ & $35 / 12$ & $170 / 20$ & $025 / 81$ & $075 / 85$ & $35 / 15$ \\
\hline DP02 & $350 / 60$ & $350 / 04$ & $-1-$ & $-1-$ & 1 & $330 / 52$ & $158 / 03$ & $158 / 07$ & $9 / 7$ & $067 / 05$ & $248 / 08$ & $249 / 09$ & $62 / 7$ & $161 / 38$ & $049 / 82$ & $030 / 79$ & $62 / 8$ \\
\hline DP05 & $293 / 87$ & $293 / 79$ & $-1-$ & $-1-$ & 1 & $007 / 20$ & $005 / 17$ & $182 / 14$ & $12 / 6$ & $257 / 45$ & $261 / 38$ & $083 / 32$ & $40 / 10$ & $114 / 39$ & $114 / 47$ & $392 / 54$ & $40 / 6$ \\
\hline DP06 & $303 / 59$ & $303 / 46$ & $-1-$ & $-1-$ & 1 & $141 / 07$ & $142 / 20$ & $162 / 61$ & $19 / 9$ & $234 / 22$ & $238 / 17$ & $062 / 05$ & $29 / 7$ & $033 / 67$ & $006 / 64$ & $330 / 38$ & $28 / 9$ \\
\hline DP10 & $333 / 71$ & $333 / 74$ & $-1-$ & $-1-$ & 1 & $158 / 23$ & $158 / 20$ & $284 / 84$ & $31 / 6$ & $067 / 02$ & 068/02 & $062 / 05$ & $35 / 17$ & $332 / 67$ & $332 / 70$ & $153 / 04$ & $26 / 10$ \\
\hline OU02 & $298 / 39$ & $298 / 04$ & $-1-$ & $-1-$ & 1 & $318 / 23$ & $136 / 10$ & $137 / 14$ & $57 / 10$ & $225 / 05$ & 045/05 & $045 / 07$ & $57 / 21$ & $123 / 66$ & $287 / 79$ & $290 / 75$ & $21 / 9$ \\
\hline OU03 & $314 / 64$ & $314 / 58$ & $-/-$ & $-1-$ & 1 & $321 / 09$ & $321 / 03$ & $145 / 55$ & $17 / 7$ & $132 / 81$ & $128 / 87$ & $314 / 35$ & $19 / 14$ & $230 / 01$ & $230 / 01$ & $048 / 05$ & $16 / 6$ \\
\hline OU06 & $188 / 15$ & $188 / 03$ & $192 / 78$ & $102 / 01$ & 1 & $186 / 08$ & $007 / 04$ & $007 / 07$ & $29 / 9$ & $279 / 19$ & $275 / 19$ & $274 / 18$ & $29 / 18$ & $075 / 70$ & $109 / 71$ & $117 / 70$ & $18 / 8$ \\
\hline SK05 & $333 / 48$ & $333 / 26$ & $163 / 70$ & $250 / 08$ & 1 & $324 / 17$ & $144 / 05$ & $143 / 31$ & $13 / 12$ & 056/07 & $054 / 04$ & $233 / 00$ & $16 / 9$ & $169 / 72$ & $285 / 83$ & $323 / 59$ & $14 / 12$ \\
\hline SK07 & $160 / 14$ & $160 / 05$ & $-1-$ & $-1-$ & 1 & $163 / 09$ & $163 / 00$ & $343 / 05$ & $14 / 6$ & 073/01 & $071 / 00$ & $253 / 00$ & $12 / 9$ & $339 / 81$ & $318 / 90$ & $162 / 85$ & $11 / 8$ \\
\hline SK09 & $180 / 16$ & $180 / 04$ & $-/-$ & $-1-$ & 1 & $178 / 01$ & $358 / 11$ & $358 / 15$ & $8 / 4$ & $087 / 17$ & $091 / 18$ & $092 / 17$ & $25 / 6$ & $270 / 73$ & $237 / 69$ & $229 / 67$ & $25 / 5$ \\
\hline SK14 & $180 / 64$ & $180 / 38$ & $192 / 55$ & $248 / 39$ & 1 & $170 / 32$ & $171 / 08$ & $350 / 31$ & $8 / 6$ & $263 / 04$ & $262 / 01$ & 083/05 & $19 / 8$ & $358 / 58$ & $356 / 82$ & $182 / 58$ & $19 / 6$ \\
\hline SK15 & $202 / 41$ & $202 / 21$ & $290 / 41$ & $246 / 32$ & 1 & $159 / 20$ & $162 / 05$ & $341 / 11$ & $14 / 6$ & $259 / 27$ & $253 / 15$ & $250 / 02$ & $25 / 12$ & $038 / 56$ & $055 / 74$ & $52 / 79$ & $24 / 7$ \\
\hline SK19 & $177 / 28$ & $177 / 20$ & $330 / 85$ & $241 / 13$ & 1 & $150 / 12$ & $150 / 05$ & $329 / 13$ & $8 / 6$ & $308 / 77$ & $269 / 81$ & $204 / 68$ & $24 / 7$ & $059 / 05$ & $059 / 08$ & $064 / 17$ & $24 / 7$ \\
\hline AM06 & $134 / 32$ & $134 / 08$ & $182 / 85$ & $294 / 26$ & 2 & $143 / 30$ & $142 / 06$ & $322 / 02$ & $7 / 4$ & 051/04 & $052 / 01$ & $232 / 01$ & $7 / 6$ & $315 / 60$ & $317 / 84$ & $123 / 88$ & $6 / 4$ \\
\hline DP04 & $355 / 14$ & $175 / 06$ & $-1-$ & $-1-$ & 2 & $329 / 11$ & $329 / 04$ & $149 / 02$ & $21 / 7$ & $061 / 11$ & $060 / 08$ & $059 / 05$ & $21 / 6$ & $196 / 74$ & $214 / 81$ & $256 / 84$ & $11 / 4$ \\
\hline OU04 & $129 / 110$ & $129 / 96$ & $-1-$ & $-1-$ & 2 & $313 / 59$ & $316 / 73$ & $127 / 11$ & $31 / 6$ & $197 / 15$ & $195 / 09$ & $032 / 25$ & $31 / 5$ & $100 / 27$ & $102 / 14$ & $238 / 62$ & $6 / 4$ \\
\hline SK04 & $015 / 20$ & 015/05 & $088 / 45$ & $020 / 20$ & 2 & $298 / 8$ & $300 / 04$ & $300 / 03$ & $21 / 7$ & $031 / 20$ & 030/05 & $030 / 00$ & $22 / 6$ & $188 / 69$ & $172 / 83$ & $128 / 87$ & $9 / 6$ \\
\hline SK12 & 018/01 & 018/05 & $-1-$ & $-1-$ & 2 & $005 / 02$ & $005 / 01$ & $005 / 01$ & $45 / 5$ & $095 / 01$ & $095 / 01$ & $095 / 01$ & $45 / 3$ & $202 / 88$ & $227 / 89$ & $227 / 89$ & $5 / 3$ \\
\hline SK16 & $318 / 18$ & $138 / 01$ & $-1-$ & $-1-$ & 2 & $298 / 17$ & $299 / 02$ & $299 / 00$ & $15 / 9$ & $208 / 00$ & $208 / 06$ & $209 / 07$ & $19 / 15$ & $117 / 73$ & $047 / 84$ & $029 / 84$ & $19 / 10$ \\
\hline AM01 & $004 / 17$ & $004 / 22$ & $003 / 50$ & 093/00 & 3 & $117 / 07$ & $118 / 05$ & $114 / 13$ & $13 / 4$ & $209 / 13$ & $208 / 09$ & $212 / 29$ & $12 / 7$ & $000 / 75$ & $358 / 80$ & $002 / 58$ & $9 / 7$ \\
\hline AM02 & $175 / 60$ & $175 / 24$ & $010 / 60$ & $092 / 13$ & 3 & $095 / 26$ & $109 / 15$ & $112 / 04$ & $15 / 8$ & $233 / 57$ & $208 / 31$ & $203 / 10$ & $16 / 12$ & $356 / 19$ & $357 / 55$ & $360 / 79$ & $14 / 6$ \\
\hline AM07 & $318 / 26$ & $318 / 13$ & $175 / 87$ & $264 / 16$ & 3 & $258 / 06$ & $079 / 01$ & 078/07 & $40 / 8$ & $349 / 07$ & $169 / 04$ & $170 / 15$ & $40 / 3$ & $129 / 81$ & $340 / 86$ & $323 / 73$ & $8 / 4$ \\
\hline AM12 & $338 / 24$ & $338 / 8$ & $005 / 85$ & $276 / 12$ & 3 & $315 / 19$ & $316 / 05$ & $136 / 03$ & $18 / 7$ & $049 / 11$ & 047/05 & $046 / 02$ & $18 / 4$ & $167 / 68$ & $186 / 83$ & $278 / 86$ & $7 / 4$ \\
\hline AM16 & $155 / 36$ & $155 / 21$ & $-1-$ & $-1-$ & 3 & $209 / 18$ & $206 / 09$ & $026 / 05$ & $12 / 6$ & $115 / 12$ & $116 / 00$ & $295 / 16$ & $15 / 7$ & $354 / 69$ & $26 / 81$ & $131 / 73$ & $15 / 11$ \\
\hline DP03 & $001 / 25$ & $181 / 04$ & $-1-$ & $-1-$ & 3 & $065 / 11$ & $243 / 03$ & $242 / 01$ & $13 / 2$ & $034 / 20$ & $152 / 06$ & $152 / 03$ & $14 / 4$ & $183 / 67$ & $356 / 84$ & $346 / 88$ & $7 / 3$ \\
\hline OU01 & $228 / 30$ & $228 / 46$ & $138 / 60$ & $210 / 29$ & 3 & $247 / 48$ & $256 / 63$ & $241 / 19$ & $20 / 8$ & $341 / 05$ & $162 / 02$ & $336 / 15$ & $21 / 6$ & $075 / 42$ & $071 / 27$ & $103 / 65$ & $10 / 7$ \\
\hline OU07 & $160 / 80$ & $160 / 57$ & $187 / 89$ & $100 / 70$ & 3 & $112 / 52$ & $130 / 37$ & $140 / 01$ & $16 / 5$ & $230 / 20$ & $225 / 07$ & $050 / 19$ & $26 / 13$ & $333 / 31$ & $325 / 52$ & $232 / 71$ & $25 / 4$ \\
\hline SK10 & $320 / 59$ & $320 / 9$ & $113 / 74$ & $031 / 28$ & 3 & $042 / 12$ & $039 / 08$ & $037 / 06$ & $10 / 9$ & $311 / 07$ & $131 / 14$ & $130 / 23$ & $15 / 10$ & $192 / 76$ & $279 / 74$ & $293 / 66$ & $15 / 9$ \\
\hline SK17 & $143 / 55$ & $43 / 06$ & $-1-$ & $-/-$ & 3 & $062 / 12$ & $068 / 01$ & $248 / 01$ & $20 / 7$ & $162 / 38$ & $338 / 09$ & $338 / 15$ & $20 / 10$ & $318 / 49$ & $164 / 81$ & $338 / 15$ & $10 / 7$ \\
\hline AM05 & $334 / 55$ & $334 / 04$ & $320 / 50$ & $291 / 46$ & 4 & $035 / 18$ & $212 / 10$ & $212 / 12$ & $38 / 12$ & $392 / 35$ & $120 / 07$ & $120 / 10$ & $38 / 10$ & $147 / 50$ & $356 / 78$ & $351 / 75$ & $14 / 8$ \\
\hline AM08 & $150 / 52$ & $50 / 49$ & $337 / 87$ & $066 / 08$ & 4 & $311 / 72$ & $074 / 30$ & $092 / 10$ & $12 / 8$ & $239 / 58$ & $234 / 58$ & $188 / 31$ & $11 / 4$ & $338 / 06$ & $339 / 09$ & $346 / 57$ & $10 / 3$ \\
\hline AM09 & $315 / 13$ & $135 / 02$ & $178 / 67$ & $265 / 08$ & 4 & $127 / 43$ & $126 / 54$ & $125 / 56$ & $16 / 6$ & $260 / 36$ & $266 / 29$ & $267 / 28$ & $17 / 8$ & $011 / 26$ & $007 / 19$ & $006 / 18$ & $8 / 6$ \\
\hline AM10 & $288 / 34$ & $288 / 31$ & $167 / 79$ & $27 / 246$ & 4 & $-1-$ & $-1-$ & $-1-$ & $-1-$ & $-1-$ & $-1-$ & $-1-$ & $-1-$ & $-1-$ & $-1-$ & $-1-$ & $-1-$ \\
\hline AM11 & $193 / 53$ & $193 / 47$ & $338 / 75$ & $257 / 30$ & 4 & $075 / 34$ & $049 / 37$ & $120 / 41$ & $67 / 10$ & $296 / 48$ & $290 / 49$ & $246 / 35$ & $67 / 12$ & $181 / 21$ & $181 / 16$ & $360 / 30$ & $16 / 6$ \\
\hline OU05 & $223 / 40$ & $223 / 83$ & $305 / 80$ & $224 / 40$ & 4 & $-1-$ & $-1-$ & $-1-$ & $-1-$ & $-1-$ & $-1-$ & $-1-$ & $-1-$ & $-1-$ & $-1-$ & $-1-$ & $-1-$ \\
\hline SK01 & $103 / 61$ & & $116 / 75$ & $038 / 37$ & 4 & & & & & & & & & & & $328 / 77$ & $9 / 5$ \\
\hline SK06 & $160 / 72$ & $160 / 14$ & $338 / 58$ & $249 / 02$ & 4 & $067 / 09$ & $076 / 07$ & $077 /$ & $19 / 9$ & $252 / 81$ & $170 / 32$ & $169 / 18$ & $28 / 14$ & $157 / 01$ & $335 / 57$ & $331 / 71$ & $27 / 15$ \\
\hline SK08 & $158 / 49$ & $158 / 08$ & $340 / 65$ & $069 / 01$ & 4 & 088/04 & $266 / 09$ & $264 / 12$ & $34 / 26$ & $178 / 01$ & $003 / 37$ & $006 / 44$ & $72 / 29$ & $281 / 86$ & $164 / 51$ & $163 / 43$ & $72 / 26$ \\
\hline SK11 & $338 / 74$ & $338 / 04$ & $145 / 80$ & $066 / 09$ & 4 & $058 / 22$ & $224 / 02$ & $224 / 03$ & $14 / 9$ & $152 / 09$ & $128 / 77$ & $115 / 81$ & $27 / 11$ & $263 / 66$ & $315 / 13$ & $315 / 09$ & $26 / 8$ \\
\hline AG01 & $344 / 68$ & $344 / 31$ & $334 / 83$ & $060 / 31$ & $\mathrm{U}$ & $068 / 04$ & $067 / 00$ & $248 / 04$ & $53 / 22$ & $336 / 28$ & $157 / 09$ & $155 / 39$ & $53 / 32$ & $166 / 62$ & $337 / 81$ & $342 / 50$ & $34 / 18$ \\
\hline AM03 & $170 / 53$ & $170 / 31$ & $178 / 89$ & $088 / 10$ & $\mathrm{U}$ & $329 / 28$ & $321 / 48$ & $282 / 70$ & $12 / 5$ & $159 / 62$ & $163 / 40$ & $165 / 10$ & $34 / 11$ & $061 / 04$ & $064 / 11$ & $072 / 18$ & $34 / 6$ \\
\hline AM15 & $285 / 22$ & $285 / 02$ & $180 / 89$ & $270 / 21$ & $\mathrm{U}$ & $174 / 03$ & $176 / 10$ & $177 / 11$ & $8 / 4$ & $079 / 58$ & $051 / 73$ & $045 / 75$ & $9 / 7$ & $266 / 32$ & $269 / 13$ & $269 / 11$ & $9 / 5$ \\
\hline DP07 & $325 / 70$ & $325 / 09$ & $-1-$ & $-1-$ & $\mathrm{U}$ & $018 / 04$ & $211 / 30$ & $216 / 33$ & $77 / 16$ & $285 / 34$ & $112 / 16$ & $110 / 24$ & $77 / 3$ & $113 / 56$ & $357 / 55$ & $351 / 47$ & $17 / 6$ \\
\hline DP08 & $138 / 82$ & $138 / 73$ & $-1-$ & $-1-$ & $\mathrm{U}$ & $-1-$ & $-1-$ & $-1-$ & $-1-$ & $-1-$ & $-1-$ & $-1-$ & $-1-$ & $-1-$ & $-1-$ & $-1-$ & $-1-$ \\
\hline DP09 & $124 / 78$ & $124 / 58$ & $-1-$ & $-1-$ & $\mathrm{U}$ & $144 / 19$ & $143 / 01$ & & $48 / 19$ & $249 / 37$ & & $177 / 35$ & $55 / 25$ & $032 / 47$ & $053 / 44$ & $080 / 10$ & $45 / 19$ \\
\hline DP11 & $305 / 51$ & $305 / 51$ & $-1-$ & $-1-$ & $\mathrm{U}$ & $186 / 26$ & $186 / 26$ & $220 / 38$ & $48 / 26$ & $090 / 12$ & $090 / 12$ & $067 / 49$ & $48 / 38$ & $338 / 60$ & $338 / 61$ & $321 / 13$ & $41 / 21$ \\
\hline SK13 & $013 / 62$ & $016 / 22$ & $168 / 44$ & $094 / 16$ & $\mathrm{U}$ & $329 / 01$ & $142 / 27$ & $130 / 39$ & $43 / 18$ & $239 / 27$ & $266 / 48$ & $292 / 50$ & $45 / 17$ & $061 / 63$ & $036 / 29$ & $033 / 09$ & $27 / 18$ \\
\hline SK18 & $171 / 55$ & $171 / 60$ & $165 / 80$ & $253 / 11$ & $\mathrm{U}$ & $279 / 23$ & $282 / 22$ & $251 / 28$ & $25 / 14$ & $170 / 38$ & $170 / 43$ & $351 / 17$ & $21 / 14$ & $034 / 43$ & $031 / 40$ & $005 / 56$ & $21 / 12$ \\
\hline
\end{tabular}

mainly by strong dispersion at site level. A dominant NW-SE trend for the magnetic lineation can be observed before any correction in these sites.

\section{Origin of the different RT-AMS types and implications}

\subsection{Magnetic mineralogy}

The correspondence between the RT-AMS and the sub-fabrics indicates that the magnetic mineralogy (together with the deformation degree) is one of the principal factors that control the different types of RT-AMS observed. Whereas the ferrimagnetic fabric expressed by the AARM is always of type 1, the enhanced paramagnetic fabric (LT-AMS) tends to fit types 3 and 4 . The ratio between the bulk susceptibility measured at low and room temperature $\left(\kappa_{\mathrm{LT}} / \kappa_{\mathrm{RT}}\right.$; Fig. 10a) is in agreement with directional observations: ratios between 1 and 2 (presumably indicating a minor contribution of paramagnetic minerals) are typical of type 1 fabrics, ratios around 2 are mostly found in type 2 and 

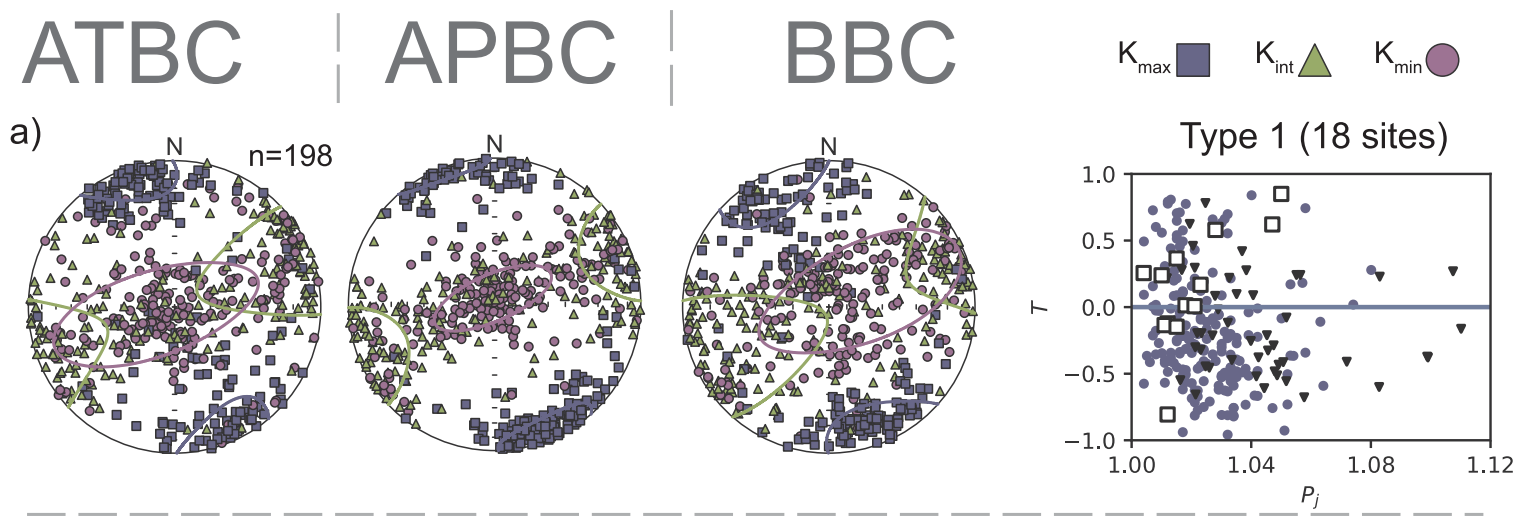

b)
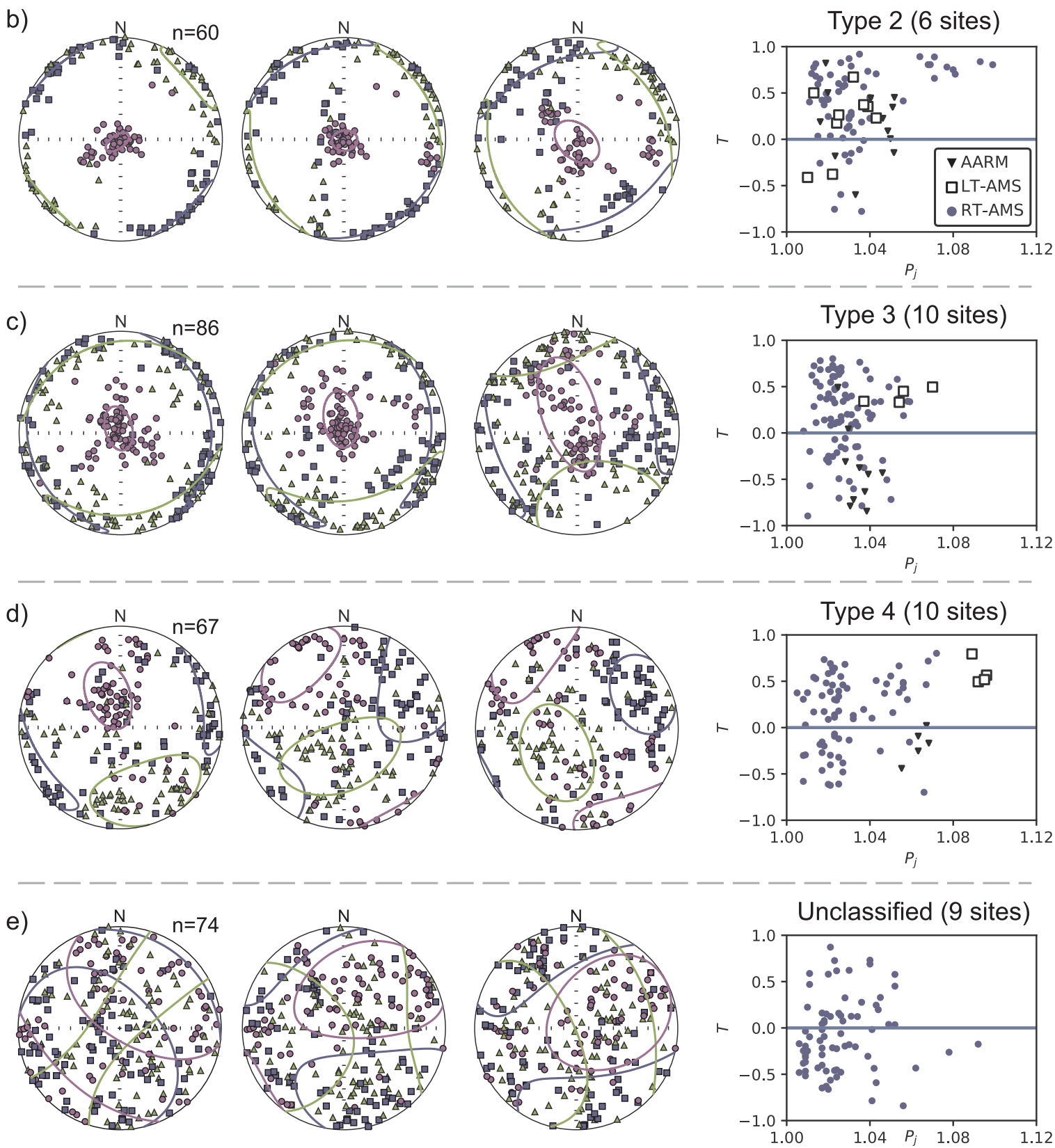

Fig. 9. RT-AMS for all samples, classified according to the five different groups. 


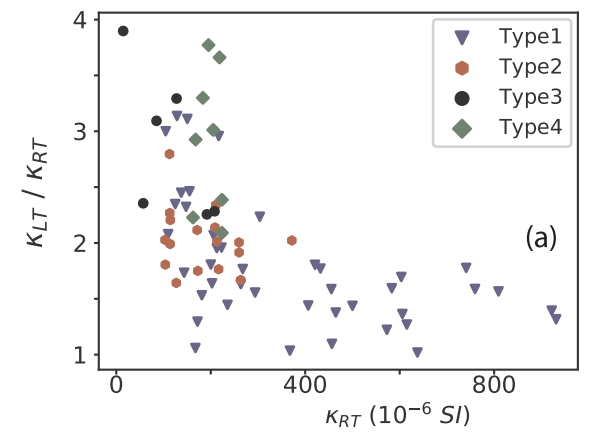

(b)
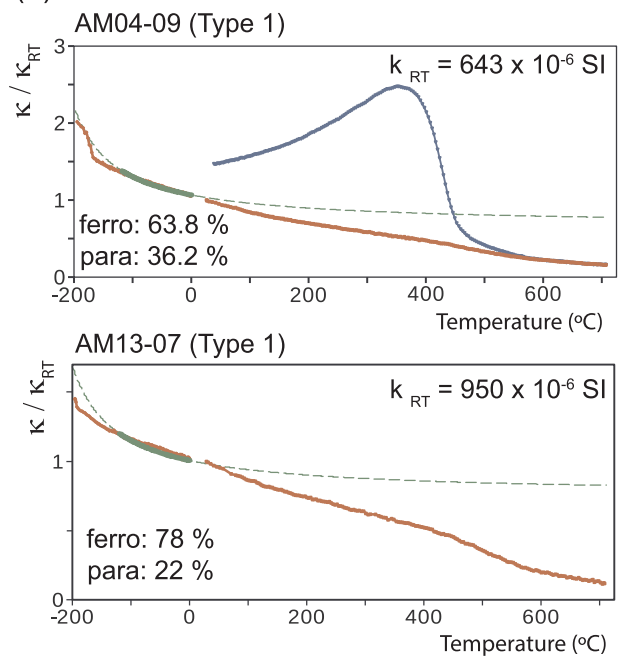
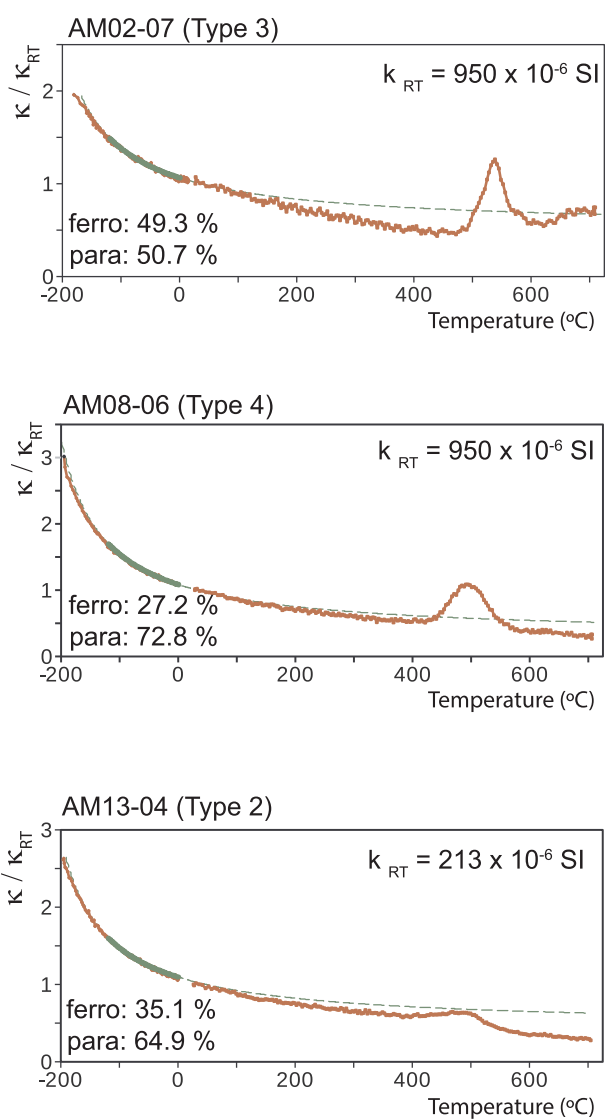

(c)
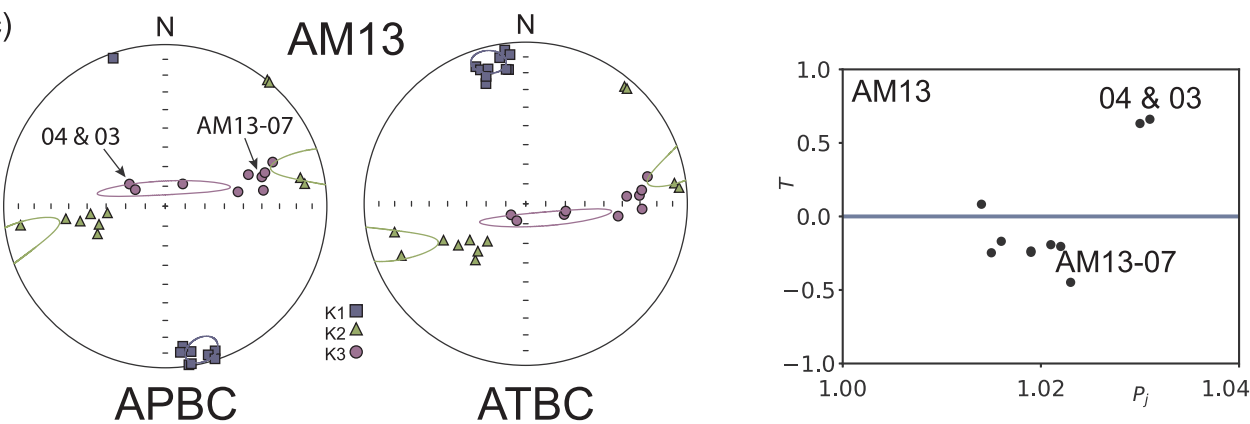

Fig. 10. a) $\kappa_{\mathrm{LT}} / \kappa_{\mathrm{RT}}$ ratio vs. $\kappa_{\mathrm{RT}}$ showing in different colours the different groups. b) Heating $\kappa$-T curves from liquid nitrogen temperature $\left(\sim-196{ }^{\circ} \mathrm{C}\right)$ to $700^{\circ} \mathrm{C}$, showing the paramagnetic fit calculated with the Cureval software (Chadima and Hrouda, 2009) following Hrouda (1994) and Hrouda et al. (1997); the calculated ferromagnetic (ferro) and paramagnetic (para) ratios are indicated. c) Equal area projection of the principal axes of the RT-AMS for site AM13, showing specimens with type 2 behaviour ( -03 and -04 ) and the type 1 behaviour.

ratios between 2 and 4 are found in types 3 and 4 . Besides, comparing this ratio with $\kappa_{\mathrm{RT}}$ (Fig. 10a), we find a correspondence between 'ferromagnetic' $\kappa_{\mathrm{LT}} / \kappa_{\mathrm{RT}}$ ratios (lower than 2 ) and high $\kappa_{\mathrm{RT}}$ values, indicating that samples with predominance of paramagnetic phases present $\kappa_{\mathrm{RT}}$ values up to $250 \times 10^{-6} \mathrm{SI}$, and higher $\kappa_{\mathrm{RT}}$ values indicate dominance of ferromagnetic phases.

Susceptibility-temperature ( $\kappa-\mathrm{T}$ ) heating curves (Fig. 10b) for type 1 fabrics show a major contribution of ferromagnetic s.l. minerals, with a progressive decay of the susceptibility during heating without following the typical hyperbolic behaviour indicated by the Curie-Weiss law of paramagnetic minerals. According to previous paleomagnetic works in these rocks (Torres-López et al., 2014; Calvín et al., 2017a), the main ferromagnetic phase is magnetite, with a dominance of the superparamagnetic (SP) and stable single domain (SSD) states. Although not so clearly, AM13-07 sample shows a sharp fall between 500 and $600{ }^{\circ} \mathrm{C}$. It is noteworthy the main decay at low temperature (between -200 and $-150{ }^{\circ} \mathrm{C}$ ) in type 1 samples that is not present in the other types. This decay could correspond with the Verwey transition (Verwey, 1939; Walz, 2002) or could be related to the presence of SP magnetite (Worm, 1998; Worm and Jackson, 1999; Zhao and Liu, 2010) or titanomagnetite (Radhakrishnamurty and Likhite, 1993; Moskowitz et al., 1998); absence of clear Verwey transitions in samples with dominance of magnetite can be explained if the magnetite is not perfectly stoichiometric or if it is partially oxidized (e.g., Özemir et al., 1993). On the 
a)
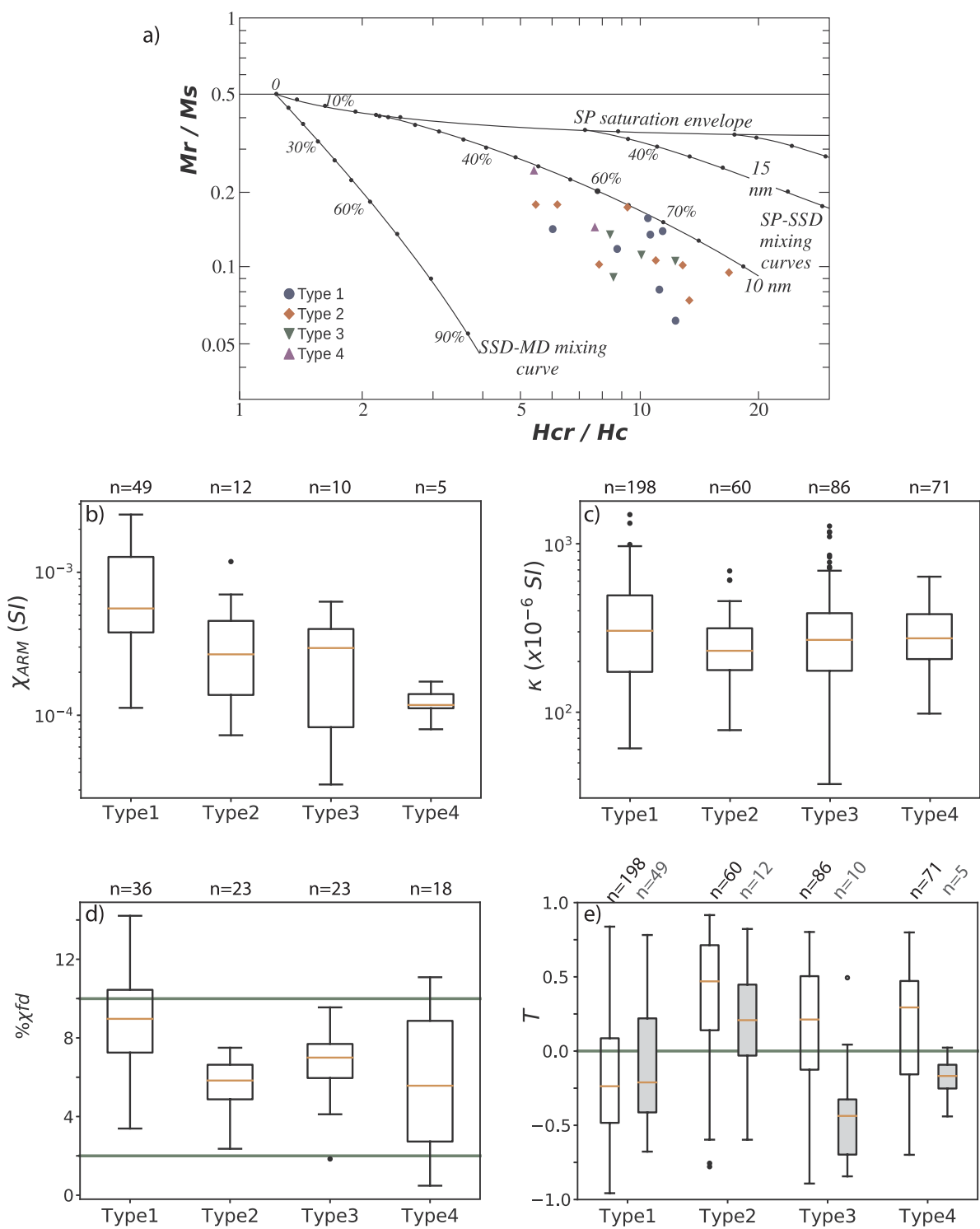

Fig. 11. a) Hysteresis parameters plot and mixing curves for magnetite (Dunlop, 2002). Measured specimens are in the SP-SSD mixing zone, independently of the observed RT-AMS type. b-e) Box and whisker plot showing the median and the quartiles of the different parameters measured in specimens. b) susceptibility of the $\operatorname{ARM}\left(\chi_{\text {ARM }}\right)$. c) Bulk susceptibility at room temperature $\left(\kappa_{\mathrm{RT}}\right)$. d) Percentage of frequency-dependent susceptibility measured at room temperature $\left(\% \chi_{\mathrm{fd}}\right)$. e) Shape parameter (T) of the RT-AMS (white boxes) and AARM (grey boxes).

other hand, paramagnetic phases dominate $\mathrm{\kappa}$-T curves in types 2,3 , and 4 , with hyperbolic shapes of the curves. Between 400 and $600{ }^{\circ} \mathrm{C}$, susceptibility increases and falls again due to neoformation of ferromagnetic minerals. In all cases, neoformation of different ferromagnetic phases is important, resulting in irreversible curves (cooling curves show evident increase of the susceptibility), as in AM04-09. These neoformed ferromagnetic phases have Curie temperatures between 450 and $600{ }^{\circ} \mathrm{C}$, probably indicating the formation of non-stoichiometric magnetite.

Site AM13 (Fig. 10c) shows a mixed of behaviour between types 1 and 2 in correspondence with the $\mathrm{k}$-T curves. Specimens AM13-03 and AM13-04 of this site show a dominant paramagnetic behaviour in $\mathrm{k}-\mathrm{T}$ curves and type 2 RT-AMS behaviour, with an oblate ellipsoid and $\mathrm{k}_{\min }$ becoming vertical ATBC. Conversely, ferromagnetic phases are dominant in AM13-07 and, as the rest of specimens, it shows a prolate ellipsoid whose $\mathrm{k}_{\max }$ becomes horizontal APBC, indicating a type 1 RTAMS. It is noteworthy that $\mathrm{k}_{\max }$ shows similar orientations in all the above-described specimens and differences only arise in the orientation of the magnetic foliation. The results obtained for AM13 site are similar to the example illustrated in site AM06 (Fig. 7b), which shows in an overall view a type 2 behaviour. However, whereas $k_{\min }$ axes of RT- and LT-AMS are equal, $\mathrm{k}_{\max }$ axes are different; in this case, $\mathrm{k}_{\max }$ axes of RTAMS are similar to the ones representing the AARM. This can be interpreted as a superposed magnetic fabric in the RT-AMS, in which magnetic foliation is defined by paramagnetic minerals and magnetic lineation by ferromagnetic s.l. minerals.

Fig. 11 illustrates different magnetic properties of samples for the defined RT-AMS types. The ratios between the hysteresis parameters (Day plot; Fig. 10a) show dispersion along the SP-SSD mixing curves, typical of remagnetized limestones (Channel and McCabe, 1994; 
Jackson and Swanson-Hysell, 2012), without differences between samples belonging to the different groups. This behaviour discards mineralogical grain-size differences of magnetite between fabric types.

ARM susceptibility ( $\chi_{\text {ARM }}$; Fig. $11 b$ ) in remagnetized limestones is indicative of the amount of SSD magnetite. Despite of the overlapping present in the box and whisker plots, type 1 shows higher values than the others. $\kappa_{\mathrm{RT}}$ (Fig. 11c) does not show major differences despite the observations made comparing the $\kappa_{\mathrm{LT} /} \kappa_{\mathrm{RT}}$ vs. $\kappa_{\mathrm{RT}}$ plot (Fig. 10a), where types 2,3 and 4 showed similar $\kappa_{\mathrm{RT}}$ values (between 50 and $300 \times 10^{-6} \mathrm{SI}$ ) while type 1 specimens showed higher values (note the difference of measured samples between both plots). It is interesting to compare the percentage of variation in the susceptibility measured at low $(470 \mathrm{~Hz})$ and high frequencies $(4700 \mathrm{~Hz})\left(\% \chi_{\mathrm{fd}}\right.$; Fig. 11d). This ratio is indicative of the contribution of SP grains to the bulk susceptibility. Type 1 specimens show high ratios (median of $9 \% \chi_{\mathrm{fd}}$ ), indicating a strong contribution from SP grains, whereas the other types show medians around 5 and $7 \% \chi_{\mathrm{fd}}$, indicating mixing of SP and non-SP contributions to the bulk susceptibility. Finally, a comparison of the shape parameter T (Fig. 11e) both of the RT-AMS and the AARM between different types show dominantly negative values (prolate ellipsoid) of AARM in all types except for type 2 , whereas T values for the RT-AMS are mostly positive with the exception of type 1 . Therefore, $\mathrm{T}$ values are similar both for AARM and RT-AMS in types 1 and 2 (although dominantly negative in the first case and positive in the second) and conversely, types 3 and 4 show different behaviour, and therefore different carriers, between AARM and RT-AMS.

It is remarkable the fact that inverse fabrics (Stephenson et al., 1986; Potter and Stephenson, 1988; Rochette et al., 1992) are mostly absent. The presence of this kind of fabric could be a priori expected due to (i) the high contribution of ferrimagnetic grains to the overall susceptibility (especially in type 1) and (ii) the uniaxial anisotropy of the SSD magnetites present in these rocks (Calvin et al., submitted). However, in addition to SSD magnetite grains, remagnetized limestones show a high amount of SP magnetite (Jackson and Swanson-Hysell, 2012), which presents higher values of susceptibility than SSD, especially in the SP-SSD threshold (Worm, 1998; Hrouda and Ježek, 2014; Lanci and Zanella, 2016). A similar tendency in the $\chi_{\text {ARM }}$ and the $\% \chi_{\mathrm{fd}}$ (Fig. 10) indicates a direct relation between the amount of SSD and SP magnetite (indicative for the first and the second parameters respectively). Furthermore, SSD and SP magnetic fabrics should have ellipsoids with equal orientation but with an interchange of the principal axes. The sum of the two ellipsoids results in an increase of the isotropy of the observed ellipsoid but without modification of its orientation (Ferré, 2002). All of this can explain the absence of inverse magnetic fabrics in RT-AMS or deviation in the orientation of the principal axes because specimens with high contribution of SSD also present high contribution of SP grains, which are dominant in the bulk susceptibility and without the capability of showing inverse fabrics.

Although most of these parameters allow separating type 1 (ferrimagnetic RT-AMS), type 2 (combined RT-AMS) and types 3 and 4 (paramagnetic RT-AMS), there is overlapping of the different indicators between the defined groups (e.g. in the $\kappa_{\mathrm{LT}} / \kappa_{\mathrm{RT}}$ ratios, the $\chi \mathrm{ARM}$ or the $\% \chi_{\mathrm{fd}}$ ). This can be explained in two non-exclusionary ways. (i) These parameters measure the bulk contribution to the susceptibility without considering the anisotropy of the carriers of the susceptibility. As an example, samples without phyllosilicates but containing large amounts of pyrite (both are paramagnetic minerals) and a minor contribution of magnetite to the bulk susceptibility, can show a paramagnetic behaviour according to the bulk parameters. This can occur at the same time that the RT-AMS is carried by the magnetite grains if magnetite is more anisotropic than pyrite. (ii) The second explanation, exemplified by site AM13, is the heterogeneity within sites. The types of RT-AMS have been defined observing the directional behaviour at site level and differences between specimens can exist even if they are not obvious.

In any case, it seems evident that in type 1 the ferrimagnetic phases are dominant, showing low $\kappa_{\mathrm{LT}} / \kappa_{\mathrm{RT}}$ ratios (mostly between 1 and 2), ferromagnetic-shaped $\kappa$-T curves, and an important contribution of SP grains. Conversely, types 3 and 4 show that the paramagnetic phases are dominant, with $\kappa_{\mathrm{LT}} / \kappa_{\mathrm{RT}}$ ratios between 2 and 4 and hyperbolic $\kappa-\mathrm{T}$ curves. Type 2 shows intermediate behaviour, but with a dominance of the paramagnetic phases in $\kappa$ - $\mathrm{T}$ curves.

\subsection{Tectonic meaning of AMS in relation to basin evolution}

A summary of the main geological processes probably having an imprint on the magnetic fabrics are the following: (i) sedimentation of carbonates during the Jurassic in a NW-SE extensional setting; (ii) synsedimentary deformation due to extensional tectonics and subsequent diapirism generating paleo-dips; (iii) $c a$. 100 Ma widespread chemical remagnetization due to the neoformation of SP and SSD magnetite grains; (iv) Cenozoic N-S compression developing folding and regional cleavage.

According to observations in other extensional basins (e.g., Cifelli et al., 2005; García-Lasanta et al., 2014), phyllosilicates usually define a RT-AMS characterized by horizontal $\mathrm{k}_{\max }$ axes perpendicular to the strike of normal faults and parallel to the stretching direction and $\mathrm{k}_{\mathrm{min}}$ axes perpendicular to bedding. On the other hand, Calvin et al. (submitted) observed in the same rocks involved in this study, that the AARM defines a horizontal NW-SE magnetic lineation and its $k_{\min }$ is vertical defining a girdle together with $\mathrm{k}_{\text {int }}$; this AARM is considered to be carried by the authigenic grains that grew during the $c a .100 \mathrm{Ma}$ chemical remagnetization process, and aligning according to the general extension direction during this stage. Several works (Sagnotti et al., 1998; Parés, 2004; Pueyo-Anchuela et al., 2010; Dudzisz et al., 2018, among others) have indicated a relationship between phyllosilicaterelated RT-AMS and compression in weakly deformed rocks, with the development of a RT-AMS defined by $k_{\max }$ parallel to the strike of compressional structures and to the intersection lineation, keeping their $\mathrm{k}_{\min }$ perpendicular to bedding. The increase of flattening develops a transition to tectonic magnetic fabrics in which $\mathrm{k}_{\min }$ becomes perpendicular to cleavage planes.

Similar extensional and compressional directional features can be observed in the different types of RT-AMS described in this work (Fig. 12). Type 1 fabric is carried by mostly ferrimagnetic grains that also carry the AARM, corresponding to the authigenic grains of magnetite related to remagnetization. As discussed in the previous subsection, the orientation of the principal axes in the RT-AMS reflects the orientation of SP instead SSD magnetite grains, because of the absence of generalized inverse fabrics Since the growth of the SP and SSD is coeval, they show the same orientation despite differences in size, and the contribution of SSD grains should be limited to the increase in the isotropy of the resultant ellipsoid (Ferré, 2002). In any case, type 1 fabric reflects the extension direction during the remagnetization time.

RT-AMS types 3 and 4 have a good correspondence with compressional fabrics carried by phyllosilicates. Type 3 is indicative of lower degree of deformation, with the $\mathrm{k}_{\min }$ still normal to bedding (and therefore compaction-related), and the $\mathrm{k}_{\max }$ parallel to the intersection lineation, whereas type 4 shows the same relation between $k_{\max }$ and the intersection lineation, but the $\mathrm{k}_{\min }$ is normal to cleavage.

Finally, the case of type 2 is more difficult to analyse. In first instance, it is possible to consider this RT-AMS type as carried by phyllosilicates and defining an extensional fabric, with its $\mathrm{k}_{\min }$ axis perpendicular to bedding and the $\mathrm{k}_{\max }$ parallel to the Jurassic stretching direction at the basinal scale. However, the analysed parameters indicate an intermediate behaviour between paramagnetic and ferromagnetic minerals. Besides, when LT-AMS is available, its $k_{\min }$ is 


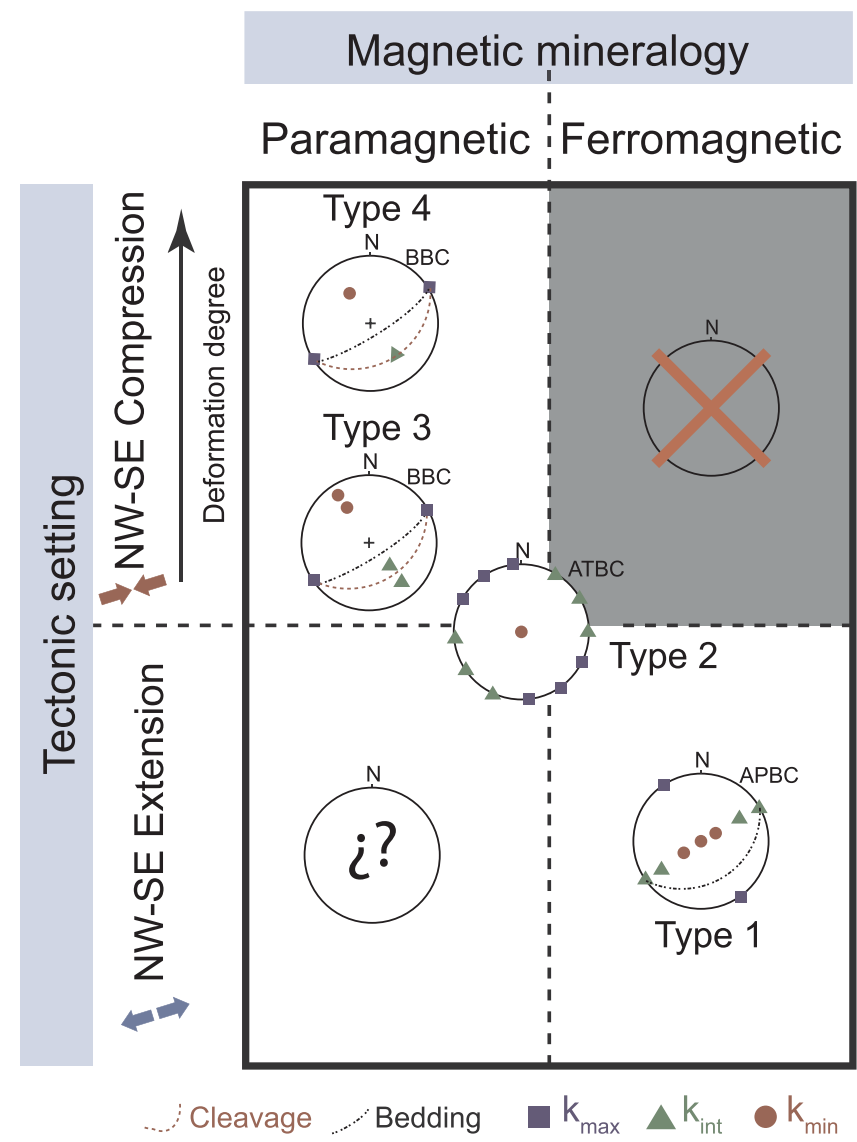

Fig. 12. Sketch showing the relationship between magnetic mineralogy, tectonic processes and observed RT-AMS. Type 1 is pure ferrimagnetic interpreted as related to extensional features whereas type 3 and 4 are paramagnetic fabrics related to compression. Type 2 shows intermediate attitudes, showing extensional and ferrimagnetic lineation and paramagnetic and compaction foliation. Compressional ferrimagnetic fabrics have not been observed in the study area.

coincident with RT-AMS but not its $\mathrm{k}_{\max }$. LT-AMS shows the magnetic lineation parallel to the intersection lineation $\mathrm{L}_{1}$, being coincident the lineations of RT-AMS and AARM. This can be interpreted as a mix between types 1 and 3: the more prolate ferrimagnetic fabric defines the lineation and the more oblate paramagnetic fabric defines the foliation. Since there are not LT-AMS data for all sites classified as type 2, the presence of some kind of extensional fabrics within this type cannot be excluded. In any case, most sites with paramagnetic fabric only present compressional RT-AMS, indicating that possible paramagnetic extensional fabrics in this area were overprinted during the Cenozoic compression.

\subsection{The behaviour of the authigenic magnetite grains under deformation}

The analysed samples do not show syn-compressional RT-AMS fabrics of ferrimagnetic origin (Fig. 11). Site AM08 shows how the ferrimagnetic fabric (by means of the AARM in this site) preserves the original extensional fabric in spite of the well developed pressure-solution cleavage in this site, which leads to define a type 4 RT-AMS carried by phyllosilicates, that reflects the compression. This fact implies that phyllosilicates and magnetite are not related. The growth of magnetite grains during remagnetizations can be related to smectiteillite transformations associated with the increase in temperature during burial and the generation of magnetite during the diagenetic process (McCabe and Elmore, 1989; Katz et al., 1998) and/or with oxidation of pyrite during burial (Suk et al., 1990; Banerjee et al., 1997). Since phyllosilicates and magnetite define very different magnetic fabrics, authigenic magnetite did not grow mimetically with phyllosilicates and this could indicate that the smectite-illite transformation is not the process (or at least not the main process) that triggers the remagnetization. Conversely, the oxidation of pyrite can explain our observations in the different magnetic sub-fabrics and therefore this could correspond with the remagnetization mechanism in the studied carbonates. The isotropic shape of pyrite grains does not seem to be affected by flattening, if small grains of magnetite (nanometre grains) grew inside the pyrite grains as external rims (this has been observed in several remagnetized rocks; e.g., Suk, 1993; Blumstein et al., 2004; Oliva-Urcia et al., 2009; Kars et al., 2014), non-deformed pyrite grains could have prevented deformation of magnetite grains, as well. Following this line of logic, pyrite grains provide an isotropic medium in which magnetite grains can grow without following previous sedimentary or tectonic structures (e.g. sedimentary lamination). Therefore, their growth is only constrained by contemporary dynamic factors, such as strain conditions. This reinforces the value of the study of magnetic fabric in remagnetized limestones (with low amounts of phyllosilicates) to characterize the tectonic setting under which this process occurs, either extensional or compressional (Sun et al., 1993; Calvin et al., submitted).

\subsection{Applicability to basin evolution}

New experiments to characterize the ferrimagnetic contribution in limestones, and the use of the partial restoration of the magnetic fabrics as shown here, could be useful in basins to understand if the magnetic lineation appearing in remagnetized limestones associated with RTAMS prolate ellipsoids is related either to (i) paramagnetic minerals and extension during their deposition or, conversely, (ii) to remagnetization-carrier magnetite, following the stretching direction at remagnetization times. This can give a picture of the tectonic setting under which the remagnetizations occurred in the different basins, and can shed light into some question not totally resolved at this time: e.g. are these remagnetization triggered by a change in the tectonic regime? Are the remagnetizations, and thus their associated AMS, synchronous? Which was the tectonic setting in the different basins during the postrift stage? And ultimately, are the Iberian remagnetizations related to the Cretaceous rotation?

In summary, we have shown the possibilities of the analysis of ferrimagnetic fabrics in sedimentary basins, either using AARM or RTAMS, or both, in remagnetized limestones not containing significant amounts of phyllosilicates. The application of the partial bedding correction (restoring beds to the remagnetization time) technique, can offer a unique view of the tectonic context under which the remagnetizations happened. The magnetic lineation carried by the ferrimagnetic minerals is demonstrated to be a good indicator of the stretching direction at the remagnetization time.

\section{Conclusions}

The magnetic fabrics of the carbonates that crop out in the Central High Atlas are analysed in 53 sites. For this purpose, the RT-AMS is measured systematically and compared with sub-fabrics (LT-AMS and AARM) to enhance the paramagnetic and the ferromagnetic signal, respectively.

The studied rocks are affected by a basin-scale chemical remagnetization carried by SSD magnetite. This remagnetization has an inter-folding behaviour because it was acquired during the Cretaceous (ca. $100 \mathrm{Ma}$ ), between the Jurassic extension and the Cenozoic compression. By means of previously published paleomagnetic results, the attitude of beds at the remagnetization time (i.e. the paleodip) can be known. We present here a new procedure that consists in applying a partial restoration to the magnetic fabrics (i.e. to restore according to the paleo-dip); the comparison between fabrics before bedding correction (BBC), after partial bedding correction (APBC), and after total 
bedding correction (ATBC), has provided key clues to unravel the magnetic fabrics carried by these rocks.

Four types of magnetic fabrics have been differentiated according to their directional behaviour:

- Type 1 RT-AMS shows prolate ellipsoids, with a clustered NNW-SSE lineation that becomes horizontal APBC. RT-AMS is coincident with AARM but not with LT-AMS. Comparing different sites, the best grouping of magnetic anisotropy axes is reached after this partial bedding correction.

- Type 2 RT-AMS shows intermediate directional behaviour between AARM and LT-AMS, magnetic foliation approaching LT-AMS results, and the magnetic lineation similar to the one obtained by means of AARM.

- Type 3 RT-AMS is coincident with LT-AMS but not with AARM. The magnetic foliation is normal to bedding and the magnetic lineation is normal to the intersection lineation between cleavage and bedding.

- Type 4 RT-AMS is also coincident with LT-AMS, with the magnetic foliation parallel to cleavage and the magnetic lineation parallel to the intersection lineation.

Furthermore, magnetic properties were measured in specimens from the different groups to determine differences that separate the established types. No differences were observed in the hysteresis parameters (indicating similar ferromagnetic mineralogy) or in the bulk susceptibility. However, type 1 shows high values in susceptibility of the ARM and dependence on the frequency of the susceptibility, indicating that this group presents more ferromagnetic minerals than the others in both magnetic states, SSD and SP magnetite. Therefore, we conclude that type 1 RT-AMS fabrics are carried by SP magnetite, with the same orientation than the SSD magnetite that carries the Cretaceous remagnetization and the AARM. This fabric is interpreted as extensional, showing the stretching at the remagnetization time. Type 3 and 4 RTAMS fabrics are compressive fabrics, carried by phyllosilicates, with different degrees of deformation. Finally, type 2 is an intermediate member between the extensional ferromagnetic fabric and the compressional paramagnetic fabric.

The last remarkable point is the difference in the response of magnetite and phyllosilicates to compression in the CHA. Magnetite grains are not affected by compression and thus they are capable to record an extensional secondary magnetic fabric fixed during the growth of the authigenic magnetite grains, whereas paramagnetic fabrics carried by phyllosilicates record secondary, compressional fabrics.

\section{Acknowledgments}

AMS plots and $\kappa$-T curves have been analyzed with Anisoft 42 (Chadima and Jelinek, 2009) and Cureval 8.0 software (Chadima and Hrouda, 2009). Warm thanks to B Moussaid for help with field work. This study was funded by the MINECO (Spanish Ministry of Economy and Competitiveness) cofinanced by the ERDF (European Union) (research projects CGL2012-38481 and CGL2016-77560). PC acknowledges the MINECO (F.P.I. research grant BES-2013-062988). The authors sincerely thank the reviewers Bjarne Almqvist and Pedro Silva for their carefully and constructive comments, which have helped to improve the original manuscript. Raw ASM data can be found in the repository.

\section{Appendix A. Supplementary data}

Supplementary data associated with this article can be found, in the online version, at http://dx.doi.org/10.1016/j.pepi.2018.06.003. These data include Google maps of the most important areas described in this article.

\section{References}

Ait-Brahim, L., Chotin, P., Hinaj, S., Abdelouafi, A., El Adraoui, A., Nakcha, C., Dhont, D., Charroud, M., Sossey Alaoui, F., Amrhar, M., Bouaza, A., Tabyaoui, H., Chaouni, A., 2002. Paleostress evolution in the Moroccan African margin from Triassic to Present. Tectonophysics 357, 187-205. http://dx.doi.org/10.1016/S0040-1951(02)00368-2.

Armando, G., 1999. Intracontinental alkaline magmatism: geology, petrography, mineralogy and geochemistry of the Jebel Hayim Massif (Central High Atlas-Morocco). Mémories de Géologie de l'Université de Lausanne 31, 106.

Aubourg, C., Klootwijk, C., Korsch, R.J., 2004. Magnetic fabric constraints on oroclinal bending of the Texas and Coffs Harbour blocks: new England Orogen, eastern Australia. In: Geol. Soc. London. Spec. Publ., pp. 421-445. http://dx.doi.org/10. 1144/GSL.SP.2004.238.01.22.

Aubourg, C., Smith, B., Eshraghi, A., Lacombe, O., Authemayou, C., Amrouch, K., Bellier, O., Mouthereau, F., 2010. New magnetic fabric data and their comparison with palaeostress markers in the Western Fars Arc (Zagros, Iran): tectonic implications. In: Geol. Soc. London. Spec. Publ., pp. 97-120. http://dx.doi.org/10.1144/SP330.6.

Banerjee, S., Elmore, R.D., Engel, M.H., 1997. Chemical remagnetization and burial diagenesis: Testing the hypothesis in the Pennsylvanian Belden Formation Colorado. J. Geophys. Res. Solid Earth 102, 24825-24842. http://dx.doi.org/10.1029/ 97JB01893.

Bensalah, M.K., Youbi, N., Mata, J., Madeira, J., Martins, L., El Hachimi, H., Bertrand, H., Marzoli, A., Bellieni, G., Doblas, M., Font, E., Medina, F., Mahmoudi, A., Beraâouz, E.H., Miranda, R., Verati, C., De Min, A., Ben Abbou, M., Zayane, R., 2013. The Jurassic-Cretaceous basaltic magmatism of the Oued El-Abid syncline (High Atlas, Morocco): physical volcanology, geochemistry and geodynamic implications. J. Afr. Earth Sci. 81, 60-81. http://dx.doi.org/10.1016/j.jafrearsci.2013.01.004.

Bilardello, D., Jackson, M.J., 2014. A comparative study of magnetic anisotropy measurement techniques in relation to rock-magnetic properties. Tectonophysics 629 , 39-54. http://dx.doi.org/10.1016/j.tecto.2014.01.026.

Blumstein, A.M., Elmore, R.D., Engel, M.H., Elliot, C., Basu, A., 2004. Paleomagnetic dating of burial diagenesis in Mississippian carbonates Utah. J. Geophys. Res. 109, $1-16$.

Borradaile, G.J., Hamilton, T., 2004. Magnetic fabrics may proxy as neotectonic stress trajectories, Polis rift, Cyprus. Tectonics 23, 278-7407.

Borradaile, G.J., Tarling, D.H., 1981. The influence of deformation mechanisms on magnetic fabrics in weakly deformed rocks. Tectonophysics 77, 151-168.

Borradaile, G.J., 1988. Magnetic susceptibility, petrofabrics and strain. Tectonophysics 156, 1-20. http://dx.doi.org/10.1016/0040-1951(88)90279-X.

Calvín, P., Casas-Sainz, A.M., Villalaín, J.J., Moussaid, B., 2018. Extensional vs. compressional deformation in the Central High Atlas salt province: a paleomagnetic approach. Tectonophysics 734-735, 130-147. http://dx.doi.org/10.1016/j.tecto.2018. 04.007.

Calvín, P., Casas-Sainz, A.M., Villalaín, J.J., Moussaid, B., 2017a. Diachronous folding and cleavage in an intraplate setting (Central High Atlas, Morocco) determined through the study of remagnetizations. J. Struct. Geol. 97, 144-160. http://dx.doi org/10.1016/j.jsg.2017.02.009.

Calvín, P., Ruiz-Martínez, V.C., Villalaín, J.J., Casas-Sainz, A.M., Moussaid, B., 2017b. Emplacement and Deformation of Mesozoic Gabbros of the High Atlas (Morocco): paleomagnetism and magnetic fabrics. Tectonics. http://dx.doi.org/10.1002/ 2017 TC004578.

Calvín, P., Villalaín, J.J., Casas-Sainz, A.M., Tauxe, L., Torres-López, S., 2017c. pySCu: a new python code for analyzing remagnetizations directions by means of Small Circle utilities. Comput. Geosci. 109. http://dx.doi.org/10.1016/j.cageo.2017.07.002.

Calvín, P., Villalaín, J.J., Casas-Sainz, A.M. Anisotropic magnetite growth in remagnetized limestones. Tectonic constraints and implications in basin history. Geology. submitted.

Caricchi, C., Cifelli, F., Kissel, C., Sagnotti, L., Mattei, M., 2016. Distinct magnetic fabric in weakly deformed sediments from extensional basins and fold-and-thrust structures in the Northern Apennine orogenic belt (Italy). Tectonics 35, 238-256. http://dx.doi. org $/ 10.1002 / 2015$ TC003940.

Chadima, M., Hansen, A., Hirt, A.M., Hrouda, F., Siemes, H., 2004. Phyllosilicate preferred orientation as a control of magnetic fabric: evidence from neutron texture goniometry and low and high-field magnetic anisotropy (SE Rhenohercynian Zone of Bohemian Massif). In: Geol. Soc. London. Spec. Publ., pp. 361-380. http://dx.doi. org/10.1144/GSL.SP.2004.238.01.19.

Chadima, M., Hrouda, F., 2009. Cureval 8.0: Thermomagnetic Curve Browser for Windows. Agico Inc., Brno.

Chadima, M., Jelinek, V., 2009. Anisoft data browser.Version 4.2. Agico, Brno.

Channell, J.E.T., McCabe, C., 1994. Comparison of magnetic hysteresis parameters of unremagnetized and remagnetized limestones. J. Geophys. Res. Solid Earth 99, 4613-4623. http://dx.doi.org/10.1029/93JB02578.

Cifelli, F., Mattei, M., Chadima, M., Lenser, S., Hirt, A.M., 2009. The magnetic fabric in "undeformed clays": AMS and neutron texture analyses from the Rif Chain (Morocco). Tectonophysics 466, 79-88. http://dx.doi.org/10.1016/j.tecto.2008.08. 008.

Cifelli, F., Mattei, M., Chadima, M., Hirt, A., Hansen, A., 2005. The origin of tectonic lineation in extensional basins: combined neutron texture and magnetic analyses on "undeformed" clays. Earth Planet. Sci. Lett. 235, 62-78. http://dx.doi.org/10.1016/j. epsl.2005.02.042.

Cifelli, F., Mattei, M., Hirt, A.M., Günther, A., 2004. The origin of tectonic fabrics in "undeformed" clays: the early stages of deformation in extensional sedimentary basins. Geophys. Res. Lett. 31. http://dx.doi.org/10.1029/2004GL019609.

Dearing, J.A., Hay, K.L., Baban, S.M.J., Huddleston, A.S., Wellington, E.M.H., Loveland, P.J., 1996. Magnetic susceptibility of soil: an evaluation of conflicting theories using 
a national data set. Geophys. J. Int. 127, 728-734. http://dx.doi.org/10.1111/j. 1365-246X.1996.tb04051.x.

Debacker, T.N., Robion, P., Sintubin, M., 2004. The anisotropy of magnetic susceptibility (AMS) in low-grade, cleaved pelitic rocks: influence of cleavage/bedding angle and type and relative orientation of magnetic carriers. Geol. Soc., London, Spec. Publ. 238, 77-107.

Dudzisz, K., Szaniawski, R., Michalski, K., Chadima, M., 2018. Rock magnetism and magnetic fabric of the Triassic rocks from the West Spitsbergen Fold-and-Thrust Belt and its foreland. Tectonophysics 728-729, 104-118. http://dx.doi.org/10.1016/j. tecto.2018.02.007.

Dunlop, D.J., 2002. Theory and application of the Day plot (Mrs/Ms versus Hcr/Hc) 2 . Application to data for rocks, sediments, and soils. J. Geophys. Res. 107 (B3). http:/ dx.doi.org/10.1029/2001JB000487.

Ferré, E.C., 2002. Theoretical models of intermediate and inverse AMS fabrics. Geophys. Res. Lett. 29, 1127. http://dx.doi.org/10.1029/2001GL014367.

Frizon de Lamotte, D., Zizi, M., Missenard, Y, Hadif, M., El Azzouzi, M., Maury, R.C., Charrière, A., Taki, Z., Benammi, M., Michard, A., Hafid, M., Azzouzi, M El, Maury, R.C., Charrière, A., Taki, Z., Benammi, M., Michard, A., 2008. The Atlas system. In: Michard, A., Saddiqi, O., Chalouan, A., Lamotte, D. de F. (Eds.), Continental Evolution: The Geology of Morocco. Lecture Notes in Earth Sciences 116. Springer, Berlin, Heidelberg, pp. 133-202. http://dx.doi.org/10.1007/978-3-540-77076-3 4.

García-Lasanta, C., Casas-Sainz, A., Villalaín, J.J., Oliva-Urcia, B., Mochales, T., Speranza, F., 2017. Remagnetizations used to unravel large-scale fold kinematics: a case study in the Cameros basin (N Spain). Tectonics. http://dx.doi.org/10.1002/ 2016TC004459.

García-Lasanta, C., Román-Berdiel, T., Oliva-Urcia, B., Casas, A.M., Gil-Peña, I., Speranza, F., Mochales, T., 2015. Tethyan versus Iberian extension during the Cretaceous period in the eastern Iberian Peninsula: insights from magnetic fabrics. J. Geol. Soc. London 2015-68. http://dx.doi.org/10.1144/jgs2015-068.

García-Lasanta, C., Oliva-Urcia, B., Román-Berdiel, T., Casas, A.M.A.M., Hirt, A.M.A.M., 2014. Understanding the Mesozoic kinematic evolution in the Cameros basin (Iberian Range, NE Spain) from magnetic subfabrics and mesostructures. J. Struct. Geol. 66, 84-101. http://dx.doi.org/10.1016/j.jsg.2014.05.013.

Girdler, R.W., 1961. The measurement and computation of anisotropy of magnetic susceptibility of rocks. Geophys. J. Int. 5, 34-44. http://dx.doi.org/10.1111/j.1365246X.1961.tb02927.

Gomez, F., Beauchamp, W., Barazangi, M., 2000. Role of the Atlas Mountains (northwest Africa) within the African-Eurasian plate-boundary zone. Geology 28, 775. http://dx. doi.org/10.1130/0091-7613(2000) $28<775:$ ROTAMN $>2.0$.CO;2

Graham, J.W., 1966. Significance of magnetic anisotropy in appalachian sedimentary rocks. In: Steinhart, J.S., Smith, T.J. (Eds.), The Earth Beneath the Continents. American Geophysical Union. Geophysical Monograph Series, Washington, pp. 627-648. http://dx.doi.org/10.1029/GM010p0627.

Graham, J.W., 1954. Magnetic susceptibility anisotropy, an unexploited petrofabric element. Geol. Soc. Am. Bull. 65, 1257-1258.

Haddoumi, H., Charrière, A., Feist, M., Andreu, B., 2002. Nouvelles datation (Hauterivien supérieur-Barrémien inférieur) dans les «Couches rouges» continentales du Haut Atlas central marocain; conséquences sur l'âge du magmatisme et des structurations mésozoïques de la chaîne Atlasique. Comptes Rendus - Palevol 1 , 259-266. http://dx.doi.org/10.1016/S1631-0683(02)00039-8.

Hailwood, E.A., Mitchell, J.G., 1971. Palaeomagnetic and radiometric dating results from Jurassic Intrusions in South Morocco. Geophys. J. Int. 24, 351-364. http://dx.doi. org/10.1111/j.1365-246X.1971.tb02183.x.

Hrouda, F., Jelínek, V., Zapletal, K., 1997. Refined technique for susceptibility resolution into ferromagnetic and paramagnetic components based on susceptibility temperature-variation measurement. Geophys. J. Int. 129, 715-719. http://dx.doi.org/10. 1111/j.1365-246X.1997.tb04506.x.

Hrouda, F., 1994. A technique for the measurement of thermal changes of magnetic susceptibility of weakly magnetic rocks by the CS-2 apparatus and KLY-2 Kappabridge. Geophys. J. Int. 118, 604-612. http://dx.doi.org/10.1111/j.1365246X.1994.tb03987.x.

Hrouda, F., Jelínek, V., 1990. Resolution of ferrimagnetic and paramagnetic anisotropies in rocks, using combined low-field and high-field measurements. Geophys. J. Int. 103, 75-84. http://dx.doi.org/10.1111/j.1365-246X.1990.tb01753.x.

Hrouda, F., Ježek, J., 2014. Frequency-dependent AMSof rocks: A tool for the investigation of the fabric of ultrafine magnetic particles. Tectonophysics $629,27-38$ http://dx.doi.org/10.1016/j.tecto.2014.01.040.

Hrouda, F., 1982. Magnetic anisotropy of rocks and its application in geology and geophysics. Geophys. Surv. 5, 37-82. http://dx.doi.org/10.1007/BF01450244.

Issachar, R., Levi, T., Lyakhovsky, V., Marco, S., Weinberger, R., 2016. Improving themethod of low-temperature anisotropy of magnetic susceptibility (LT-AMS) measurements in air. Geochem. Geophys. Geosyst. 2940-2950. http://dx.doi.org/10. 1002/2016GC006339.

Izquierdo-Llavall, E., Casas-Sainz, A.M., Oliva-Urcia, B., 2013. Heterogeneous deformation recorded by magnetic fabrics in the Pyrenean Axial Zone. J. Struct. Geol. 57, 97-113. http://www.sciencedirect.com/science/article/pii/S0191814113001764.

Jackson, M.J., 1991. Anisotropy of magnetic remanence: a brief review of mineralogical sources, physical origins, and geological applications, and comparison with susceptibility anisotropy. Pure Appl. Geophys. PAGEOPH 136, 1-28. http://dx.doi.org/ 10.1007/BF00878885.

Jackson, M., Swanson-Hysell, N.L., 2012. Rock magnetism of remagnetized carbonate rocks: another look. In: Geol. Soc. London. Spec. Publ., pp. 229-251. http://dx.doi. org $/ 10.1144 / \mathrm{sp} 371.3$

Jelinek, V., 1981. Characterization of the magnetic fabric of rocks. Tectonophysics 79, T63-T67. http://dx.doi.org/10.1016/0040-1951(81)90110-4.

Kars, M., Aubourg, C., Labaume, P., Berquó, T., Cavailhes, T., 2014. Burial diagenesis of magnetic minerals: new insights from the Grès d'Annot Transect (SE France). Minerals 4, 667-689. http://dx.doi.org/10.3390/min4030667.

Katz, B., Elmore, R.D., Cogoini, M., Ferry, S., 1998. Widespread chemical remagnetization: orogenic fluids or burial diagenesis of clays? Geology 26, 603-606. http://dx doi.org/10.1130/0091-7613(1998) 026<0603:WCROFO > 2.3.CO

Kissel, C., Barrier, E., Laj, C., Lee, T.-Q., 1986. Magnetic fabric in "undeformed" marine clays from compressional zones. Tectonics 5, 769-781. http://dx.doi.org/10.1029/ TC005i005p00769.

Lanci, L., Zanella, E., 2016. The anisotropy of magnetic susceptibility of uniaxial superparamagnetic particles: consequences for its interpretation in magnetite and maghemite bearing rocks. J. Geophys. Res. B Solid Earth 121, 27-37. http://dx.doi.org/ 10.1002/2015JB012255.

Lee, T.-Q., Angelier, J., 2000. Tectonic significance of magnetic susceptibility fabrics in Plio-Quaternary mudstones of southwestern foothills Taiwan. Earth, Planets Sp. 52, 527-538. http://dx.doi.org/10.1186/BF03351660.

Martín-Hernández, F., Ferré, E.C., 2007. Separation of paramagnetic and ferrimagnetic anisotropies: a review. J. Geophys. Res. Solid Earth 112. http://dx.doi.org/10.1029/ 2006JB004340.

Mattauer, M., Tapponnier, P., Proust, F., 1977. Sur les mecanismes de formation des chaines intracontinentales; l'exemple des chaines atlasiques du Maroc. Bull. la Soc Geol. Fr. S7 (XIX), 521-526. http://dx.doi.org/10.2113/gssgfbull.S7-XIX.3.521.

Mattei, M., Sagnotti, L., Faccenna, C., Funiciello, R., 1997. Magnetic fabric of weakly deformed clay-rich sediments in the Italian peninsula: relationship with compressional and extensional tectonics. Tectonophysics 271, 107-122. http://dx.doi.org/10. 1016/S0040-1951(96)00244-2

Mattei, M., Speranza, F., Argentieri, A., Rossetti, F., Sagnotti, L., Funiciello, R., 1999. Extensional tectonics in the Amatea basin (Calabria, Italy): a comparison between structural and magnetic anisotropy data. Tectonophysics 307, 33-49.

McCabe, C., Elmore, R.D., 1989. The occurrence and origin of Late Paleozoic remagnetization in the sedimentary rocks of North America. Rev. Geophys. 27, 471-494. http://dx.doi.org/10.1029/RG027i004p00471.

McCabe, C., Jackson, M., Ellwood, B.B., 1985. Magnetic anisotropy in the Trenton Limestone: results of a new technique, anisotropy of anhysteretic susceptibility. Geophys. Res. Lett. 12, 333-336. http://dx.doi.org/10.1029/GL012i006p00333.

Michard, A., Ibouh, H., Charrière, A., 2011. Syncline-topped anticlinal ridges from the High Atlas: a Moroccan conundrum, and inspiring structures from the Syrian Arc Israel. Terra Nova 23, 314-323. http://dx.doi.org/10.1111/j.1365-3121.2011. 01016.x.

Moskowitz, B.M., Jackson, M., Kissel, C., Moskowitz, B.M., Moskowitz, J.M.K.C., Jackson, B.M., Kissel, M.C., 1998. Low-temperature magnetic behavior of titanomagnetites. Earth Planet. Sci. Lett. 157, 141-149. http://dx.doi.org/10.1016/S0012-821X(98) 00033-8.

Moussaid, B., El Ouardi, H., Casas-Sainz, A., Villalaín, J.J., Román-Berdiel, T., OlivaUrcia, B., Soto, R., Torres-López, S., 2013. Magnetic fabrics in the Jurassic-Cretaceous continental basins of the northern part of the Central High Atlas (Morocco): geodynamic implications. J. Afr. Earth Sci. 87, 13-32. http://dx.doi.org/10.1016/j. jafrearsci.2013.07.001.

Moussaid, B., Villalaín, J.J., Casas-Sainz, A., El Ouardi, H., Oliva-Urcia, B., Soto, R., Román-Berdiel, T., Torres-López, S., 2015. Primary vs. secondary curved fold axes: deciphering the origin of the Ait Attab syncline (Moroccan High Atlas) using paleomagnetic data. J. Struct. Geol. 70, 65-77. http://dx.doi.org/10.1016/j.jsg.2014.11. magn

Nagata, T., 1961. Rock Magnetism,, 2nd edition ed. Maruzen, Tokyo.

Oliva-Urcia, B., Gil-Peña, I., Soto, R., Samsó, J.M., Antolín, B., Pueyo, E.L., 2018. New insights into asymmetric folding by means of the anisotropy of magnetic susceptibility, Variscan and Pyrenean folds (SW Pyrenees). Stud. Geophys. Geod. 62. http:// dx.doi.org/10.1007/s11200-017-0143-6.

Oliva-Urcia, B., Casas, A.M., Moussaid, B., Villalaín, J.J., El Ouardi, H., Soto, R., TorresLópez, S., Román-Berdiel, T., 2016. Tectonic fabrics vs. mineralogical artifacts in AMS analysis: a case study of the Western Morocco extensional Triassic basins. J. Geodyn. 94-95, 13-33. http://dx.doi.org/10.1016/j.jog.2016.01.004.

Oliva-Urcia, B., Casas, a. M., Ramón, M.J., Leiss, B., Mariani, E., Román-Berdiel, T., 2012. On the reliability of AMS in ilmenite-type granites: An insight from the Marimanha pluton, central Pyrenees. Geophys. J. Int. 189, 187-203. doi:10.1111/j.1365-246X. 2011.05355.x.

Oliva-Urcia, B., Casas, A.M., Soto, R., Villalaín, J.J., Kodama, K., 2011. A transtensional basin model for the Organyà basin (central southern Pyrenees) based on magnetic fabric and brittle structures. Geophys. J. Int. 184, 111-130. http://dx.doi.org/10, 1111/j.1365-246X.2010.04865.x.

Oliva-Urcia, B., Larrasoaña, J.C., Pueyo, E.L., Gil, A., Mata, P., Parés, J.M., Schleicher, A.M., Pueyo, O., 2009. Disentangling magnetic subfabrics and their link to deformation processes in cleaved sedimentary rocks from the Internal Sierras (west central Pyrenees, Spain). J. Struct. Geol. 31, 163-176. http://dx.doi.org/10.1016/j. jsg.2008.11.002.

Oliva-Urcia, B., Román-Berdiel, T., Casas, Bógalo, M.F., Osácar, M.C., García-Lasanta, C., 2013. Transition from extensional to compressional magnetic fabrics in the Cretaceous Cabuérniga basin (NorthSpain). J. Struct. Geol. 46, 220-234.

Özdemir, Ö., Dunlop, D.J., Moskowitz, B.M., 1993. The effect of oxidation on the Verwey transition in magnetite. Geophys. Res. Lett. 20, 1671-1674. http://dx.doi.org/10. 1029/93GL01483.

Parés, J.M., 2015. Sixty years of anisotropy of magnetic susceptibility in deformed sedimentary rocks. Front. Earth Sci. 3, 1-13. http://dx.doi.org/10.3389/feart.2015. 00004

Parés, J.M., 2004. How deformed are weakly deformed mudrocks? Insights from magnetic anisotropy. In: Geol. Soc. London. Spec. Publ., pp. 191-203. http://dx.doi.org/ 10.1144/GSL.SP.2004.238.01.13. 
Parés, J.M., van der Pluijm a, B., 2014. Low-temperature AMS and the quantification of subfabrics in deformed rocks. Tectonophysics $629,55-62$. http://dx.doi.org/10. 1016/j.tecto.2014.03.005.

Parés, J.M., van der Pluijm, B.A., Dinarès-Turell, J., 1999. Evolution of magnetic fabrics during incipient deformation of mudrocks (Pyrenees, northern Spain). Tectonophysics 307, 1-14. http://dx.doi.org/10.1016/S0040-1951(99)00115-8.

Parés, J.M., van der Pluijm, B.A., 2002. Phyllosilicate fabric characterization by lowtemperature anisotropy of magnetic susceptibility (LT-AMS). Geophys. Res. Lett. 29. http://dx.doi.org/10.1029/2002GL015459.

Potter, D.K., 2004. A comparison of anisotropy of magnetic remanence methods - a user's guide for application to palaeomagnetism and magnetic fabric studies. In: MartinHernández, F., Lüneburg, C.M., Aubourg, C., Jackson, M. (Eds.), Magnetic Fabric: Methods and Applications. Geological Society Special Publications. The Geological Society of London, London, pp. 21-36. http://dx.doi.org/10.1144/GSL.SP.2004.238. 01.03 .

Potter, D.K., Stephenson, A., 1988. Single-domain particles in rocks and magnetic fabric analysis. Geophys. Res. Lett. 15, 1097-1100. http://dx.doi.org/10.1029/ GL015i010p01097.

Pueyo Anchuela, Ó., Gil Imaz, A., Pocoví Juan, A., 2010. Significance of AMS in multilayer systems in fold-and-thrust belts. A case study from the Eocene turbidites in the Southern Pyrenees (Spain). Geol. J. 45, 544-561. http://dx.doi.org/10.1002/gj. 1194.

Pueyo Anchuela, Ó., María Casas-Sainz, A., Pocoví Juan, A., Gil Imaz, A., 2011. Lithologydependent reliability of AMS analysis: a case study of the Eocene turbidities in the southern Pyrenees (Aragón, Spain). Comptes Rendus Geosci. 343, 11-19. http://dx. doi.org/10.1016/j.crte.2010.11.003.

Radhakrishnamurty, C., Likhite, S.D., 1993. Frequency dependence of low-temperature susceptibility peak in some titanomagnetites. Phys. Earth Planet. Inter. 76, 131-135.

Richter, C., van der Pluijm, B.A., 1994. Separation of paramagnetic and ferrimagnetic susceptibilities using low temperature magnetic susceptibilities and comparison with high field methods. Phys. Earth Planet. Inter. 82, 111-121.

Rochette, P., Jackson, M., Aubourg, C., 1992. Rock magnetism and the interpretation of anisotropy of magnetic susceptibility. Rev. Geophys. 30, 209-226. http://dx.doi.org/ 10.1029/92RG00733.

Rochette, P., Fillion, G., 1988. Identification of multicomponent anisotropies in rocks using various field and temperature values in a cryogenic magnetometer. Phys. Earth Planet. Inter. 51, 379-386. http://dx.doi.org/10.1016/0031-9201(88)90079-9.

Rochette, P., Vialon, P., 1984. Development of planar and linear fabrics in Dauphinois shales and slates (French Alps) studied by magnetic anisotropy and its mineralogical control. J. Struct. Geol. 6, 33-38. http://dx.doi.org/10.1016/0191-8141(84) 90081-6.

Sagnotti, L., Speranza, F., Winkler, A., Mattei, M., Funiciello, R., 1998. Magnetic fabric of clay sediments from the external northern Apennines (Italy). Phys. Earth Planet. Inter. 105, 73-93.

Santolaria, P., Casas, A.M., Soto, R., 2015. Anisotropy of magnetic susceptibility as a proxy to assess internal deformation in diapirs: case study of the Naval salt wall (Southern Pyrenees). Geophys. J. Int. 202, 1207-1222. http://dx.doi.org/10.1093/ gji/ggv231.

Schmidt, V., Hirt, A.M., Leiss, B., Burlini, L., Walter, J.M., 2009. Quantitative correlation of texture and magnetic anisotropy of compacted calcite-muscovite aggregates. J. Struct. Geol. 31, 1062-1073. http://dx.doi.org/10.1016/j.jsg.2008.11.012.

Schmidt, V., Hirt, A.M., Rosselli, P., Martín-Hernández, F., 2007. Separation of diamagnetic and paramagnetic anisotropy by high-field, low-temperature torque measurements. Geophys. J. Int. 168, 40-47. http://dx.doi.org/10.1111/j.1365-246X.2006. 03202.x.

Soto, R., Beamud, E., Roca, E., Carola, E., Almar, Y., 2017. Distinguishing the effect of diapir growth on magnetic fabrics of syn-diapiric overburden rocks: Basque-
Cantabrian basin Northern Spain. Terra Nova 38, 42-49. http://dx.doi.org/10.1111/ ter.12262.

Soto, R., Kullberg, J.C., Oliva-Urcia, B., Casas-Sainz, A.M., Villalaín, J.J., 2012. Switch of Mesozoic extensional tectonic style in the Lusitanian basin (Portugal): Insights from magnetic fabrics. Tectonophysics 536-537, 122-135. http://dx.doi.org/10.1016/j. tecto.2012.03.010.

Soto, R., Larrasoaña, J.C., Arlegui, L.E., Beamud, E., Oliva-Urcia, B., Simón, J.L., 2009. Reliability of magnetic fabric of weakly deformed mudrocks as a palaeostress indicator in compressive settings. J. Struct. Geol. 31, 512-522. http://dx.doi.org/10. 1016/j.jsg.2009.03.006.

Soto, R., Villalaín, J.J., Casas-Sainz, A.M., 2008. Remagnetizations as a tool to analyze the tectonic history of inverted sedimentary basins: a case study from the BasqueCantabrian basin (north Spain). Tectonics 27. http://dx.doi.org/10.1029/ 2007TC002208.

Stephenson, A., Sadikun, S., Potter, D.K., 1986. A theoretical and experimental comparison of the anisotropies of magnetic susceptibility and remanence in rocks and minerals. Geophys. J. R. Astron. Soc. 84, 185-200.

Suk, D.-W., der Voo, R., Peacor, D.R., 1993. Origin of magnetite responsible for remagnetization of early Paleozoic limestones of New York State. J. Geophys. Res. B Solid Earth 98, 419-434.

Suk, D., Peacor, D.R., Van Der Voo, R., 1990. Replacement of pyrite framboids by magnetite in limestone and implications for palaeomagnetism. Nature 345, 611-613.

Sun, W., Jackson, M., Craddock, J.P., 1993. Relationship between remagnetization, magnetic fabric and deformation in Paleozoic carbonates. Tectonophysics 221, 361-366. http://dx.doi.org/10.1016/0040-1951(93)90167-I.

Tarling, D.H., Hrouda, F., 1993. The Magnetic Anisotropy of Rocks. Chapman \& Hall, London.

Torres-López, S., Villalaín, J.J., Casas, A.M., EL Ouardi, H., Moussaid, B., Ruiz-Martínez, V.C., 2014. Widespread Cretaceous secondary magnetization in the High Atlas (Morocco). A common origin for the Cretaceous remagnetizations in the western Tethys? J. Geol. Soc. London 171, 673-687. http://dx.doi.org/10.1144/jgs2013-107.

Torres-López, S., Casas, A.M., Villalaín, J.J., El Ouardi, H., Moussaid, B., 2016. PreCenomanian vs. Cenozoic folding in the High Atlas revealed by palaeomagnetic data. Terra Nova 28, 110-119. http://dx.doi.org/10.1111/ter.12197.

Villalaín, J., Fernández-González, G., Casas, A.M., Gil-Imaz, A., 2003. Evidence of a Cretaceous remagnetization in the Cameros Basin (North Spain): implications for basin geometry. Tectonophysics 377, 101-117. http://dx.doi.org/10.1016/j.tecto. 2003.08.024.

Villalaín, J.J., Casas-Sainz, A.M., Soto, R., 2016. Reconstruction of inverted sedimentary basins from syn-tectonic remagnetizations. A methodological proposal. In: Geol. Soc. London. Spec. Publ., pp. 233-246. http://dx.doi.org/10.1144/SP425.10.

Verwey, E.J., 1939. Electronic conduction of magnetite $\left(\mathrm{Fe}_{3} \mathrm{O}_{4}\right)$ and its transition point at low temperatures. Nature 144, 327-328. http://dx.doi.org/10.1038/144327b0.

Walz, F., 2002. The Verwey transition - a topical review. J. Phys. Condens. Matter 14 R285-R340. http://dx.doi.org/10.1088/0953-8984/14/12/203.

Worm, H.U., 1998. On the superparamagnetic-stable single domain transition for mag netite, and frequency dependence of susceptibility. Geophys. J. Int. 133, 201-206.

Worm, H.U., Jackson, M., 1999. The superparamagnetism of Yucca Mountain Tuff. J. Geophys. Res. B Solid Earth 104 (25), 415-425 425

Zayane, R., Essaifi, A., Maury, R.C., Piqué, A., Laville, E., Bouabdelli, M., 2002. Cristallisation fractionnée et contamination crustale dans la série magmatique jurassique transitionnelle du Haut Atlas central (Maroc). Comptes Rendus Geosci. 334, 97-104. http://dx.doi.org/10.1016/S1631-0713(02)01716-9.

Zhao, X., Liu, Q., 2010. Effects of the grain size distribution on the temperature-dependent magnetic susceptibility of magnetite nanoparticles. Sci. China Earth Sci. 53, 1071-1078. http://dx.doi.org/10.1007/s11430-010-4015-y. 


\section{Discusión}

9.1 La remagnetización cretácica del Alto Atlas Central................................ 235

9.2 Aportaciones a la metodología basada en círculos menores.......................... 245

9.3 Aportaciones a la geología regional....................................... 257 



\subsection{La remagnetización cretácica del Alto Atlas Central}

\subsubsection{Características de la magnetita autigénica}

Los carbonatos afectados por remagnetizaciones químicas, cuyo portador es la magnetita, presentan una serie de características magnéticas que son reconocibles en materiales de diferente edad a lo largo del planeta (por ej., Jackson \& Swanson-Hysell, 2012; Van der Voo \& Torsvik, 2012). Dichas propiedades magnéticas están controladas por una población de magnetita autigénica, con tamaños de superparamagnético (SP) a monodominio estable (SSD), consecuencia del proceso remagnetizador (Channel \& McCabe, 1994).

En la figura 9.1 se pueden observar algunas de estas características en muestras jurásicas del Alto Atlas Central (AAC), como por ejemplo los ciclos de histéresis en cintura de avispa (Tauxe et al., 1996) consecuencia de dos fases magnéticas con distinta coercitividad (SP y SSD) que generan altas ratios de coercitividad remanente frente a coercitividad (Figs. 9.1a, b). La alta dependencia de la susceptibilidad con respecto a la frecuencia (Fig. 9.1c) es indicativa de la presencia de una importante cantidad de granos en estado SP (Dearing et al., 1996); el aumento de la susceptibilidad con la temperatura (en el rango de $60 \mathrm{~K}$ a $100 \mathrm{~K}$ ), así como el aumento de la dependencia susceptibilidad-frecuencia, es indicativo del desbloqueo de granos SSD que se convierten en SP al aumentar la temperatura. Esto se observa más claramente en las curvas de desmagnetización de la remanencia a baja temperatura (Fig. 9.1d), donde la disminución progresiva de la intensidad de la magnetización se relaciona con el desbloqueo de granos ferrimagnéticos que pasan de SSD a SP; a partir de estas curvas, Jackson \& Swanson-Hysell (2012) estiman la distribución de volúmenes de grano (Worm \& Jackson, 1999) en calizas remagnetizadas de los Apalaches, observando una importante contribución de granos SP. Finalmente, es indicativa la ausencia mayoritaria de transiciones a baja temperatura, que puede estar relacionada con una composición no estequiométrica de magnetita o que ésta esté parcialmente oxidada.

Lo anterior es indicativo de que las calizas del AAC han sido afectadas por una remagnetización química en la que se ha generado gran cantidad de magnetita autigénica, de similares características a las observadas en otras zonas. Otra de las aportaciones realizadas en el transcurso de esta tesis doctoral ha derivado del estudio de las fábricas magnéticas de las calizas y los experimentos de magnetismo de rocas asociados a dicho estudio (ver apartado 8).

El estudio de la AARM ha permitido analizar la fábrica magnética de los granos de magnetita autigénicos que fue fijada en el momento de la remagnetización, tal y como se deriva del mayor agrupamiento de los ejes magnéticos principales tras la corrección de las capas a su posición en el momento de la adquisición de la remagnetización. Además, su comparación con la ASM indica que, a pesar de que los filosilicatos sean afectados por la foliación tectónica cenozoica, la fábrica definida por los granos de magnetita no es alterada (Fig. 9.2a). 
(a)

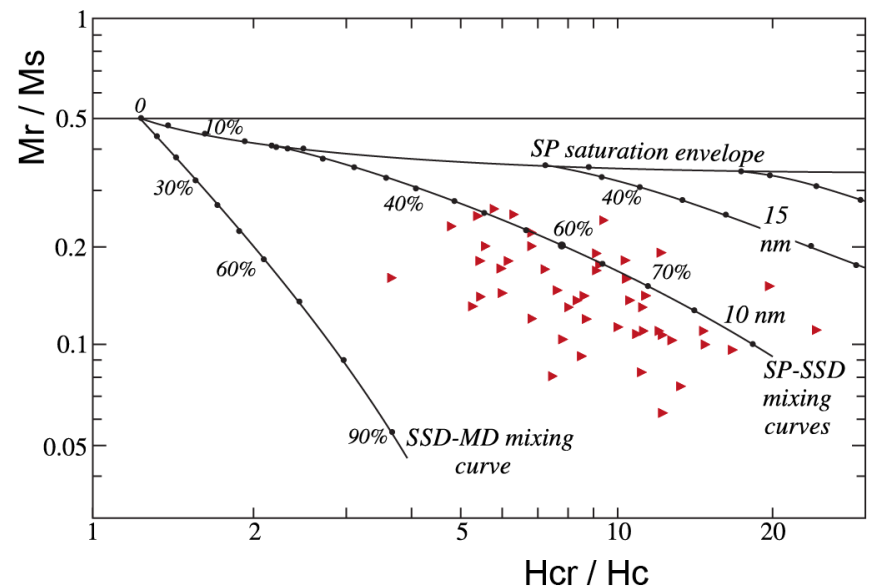

(b)

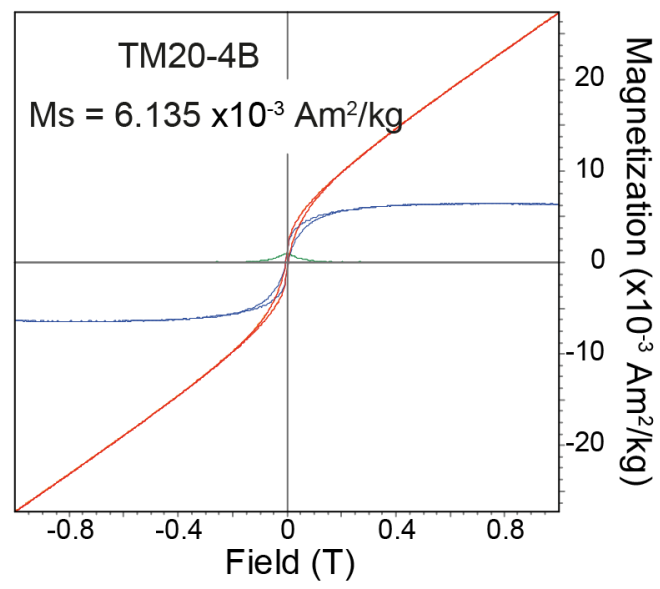

(d)
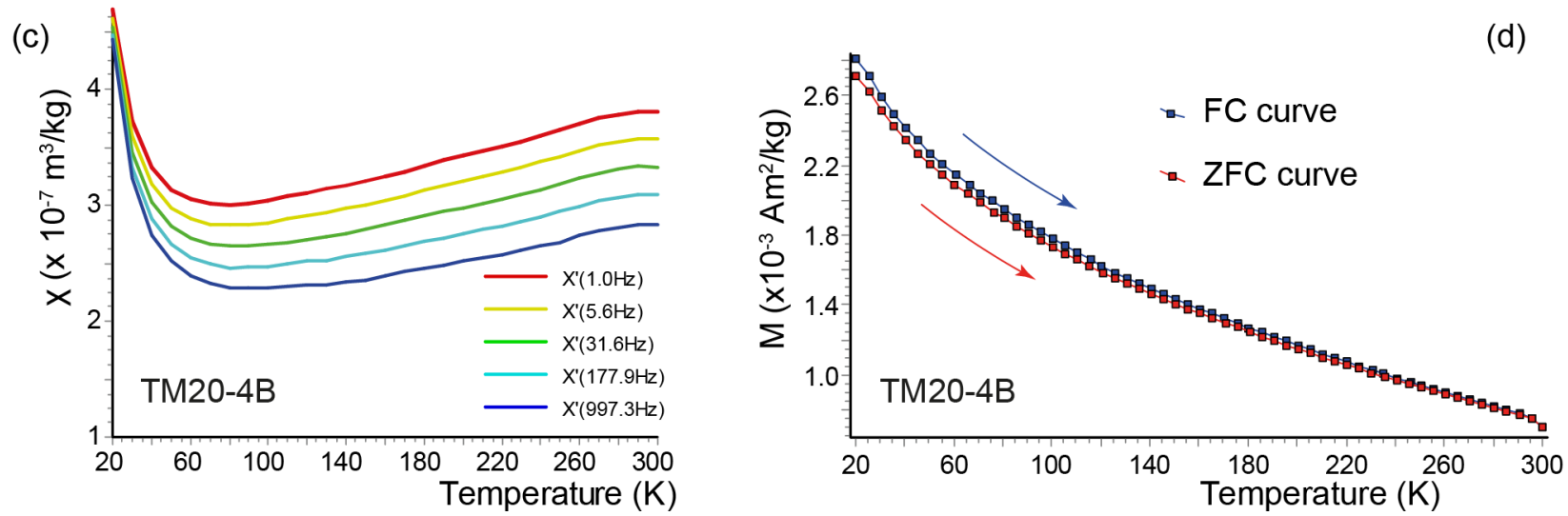

Figura 9.1 (a) Gráfica con los parámetros de la histéresis y las curvas de mezcla para magnetita (Dunlop, 2002) de muestras del Alto Atlas Central. (b) Curva de histéresis, con y sin corrección de la fracción paramagnética, de la muestra TM20-4B. (c) Curvas mostrado la dependencia de la susceptibilidad con la temperatura para cinco frecuencias diferentes. La disminución de la susceptibilidad entre 20 y $60 \mathrm{~K}$ puede estar relacionada con la presencia de minerales paramagnéticos; el aumento de la susceptibilidad, así como el aumento de la variación de la susceptibilidad con la temperatura entre 60 y $300 \mathrm{~K}$ está relacionado con la transición de manera progresiva de magnetitas SSD a SP. (d) Curvas de desmagnetización de la remanencia a baja temperatura. La remanencia en la curva FC fue adquirida durante el enfriamiento entre 300-20 K bajo un campo de 2,5 T, y en la curva ZFC fue adquirida a $20 \mathrm{~K}$ bajo un campo de 2,5 T. La disminución de la remanencia al aumentar la temperatura está relacionada con el desbloqueo de granos de magnetita SSD que se convierten en magnetita SP.

Figure 9.1 (a) Hysteresis parameters plot and mixing curves for magnetite (Dunlop, 2002) for samples from the Central High Atlas. (b) Hysteresis loops, before and after paramagnetic fraction correction, for TM20-4B specimen. (c) Susceptibility-temperature dependence curves at five frequencies measured from 20 to $300 \mathrm{~K}$. The decrease of susceptibility between 20 to $60 \mathrm{~K}$ can be related to the presence of paramagnetic minerals; the increase of susceptibility as well as the increment of the dependence with the frequency is related to the progressive transition from SSD to SP magnetite. (d) Thermal demagnetization of low-temperature remanence. FC remanence was imprinted by cooling from 300 to $20 \mathrm{~K}$ in a $2.5 \mathrm{~T}$ field, and ZFC remanence was acquired at $20 \mathrm{~K}$ in a $2.5 \mathrm{~T}$ field. The progressive decrease of the remanence is related with the unblocking of SSD magnetite that become in SP magnetite. 
Entre los mecanismos clásicos de remagnetizaciones en calizas (Elmore et al., 2012), uno es debido a transformaciones esmectita-illita (por. ej., Hirt et al., 1993; Katz et al., 1998, 2000; ), proceso durante el que se libera hierro que se oxida para formar magnetita, y el otro es debido a la oxidación de sulfuros en relación con la maduración de la materia orgánica (por ej., Fruit et al., 1995, Brothers et al., 1996; Kars et al., 2014). Tal y como indican Elmore et al. (2012), ambos procesos no son excluyentes entre sí, y pueden actuar simultáneamente durante la diagénesis.

El hecho de que la fábrica portada por la magnetita no sea afectada por la foliación tectónica, mientras que sí lo hacen los filosilicatos (cuando están presentes), lo interpretamos como indicativo de que la oxidación de la pirita es el proceso principal por el cuál se genera magnetita. Si la magnetita hubiera crecido a expensas del hierro liberado en el proceso de illitización, es de suponer que los granos se encontrarían entre las láminas de los filosilicatos y habrían sido rotados solidariamente con ellos. Por el contrario, la oxidación de la pirita permite que parte de la misma sea reemplazada por magnetita, formando parte del grano de pirita original (i.e., cubos o framboides originales de pirita); observaciones mediante microscopía electrónica han permitido ver cristales de pirita con el anillo exterior oxidado a magnetita (Suk et al., 1990; 1993). Durante la compresión estos granos no son deformados (como mucho pueden sufrir rotaciones) al ser más resistentes que el material carbonatado o los filosilicatos, permitiendo que la fábrica original, adquirida durante la
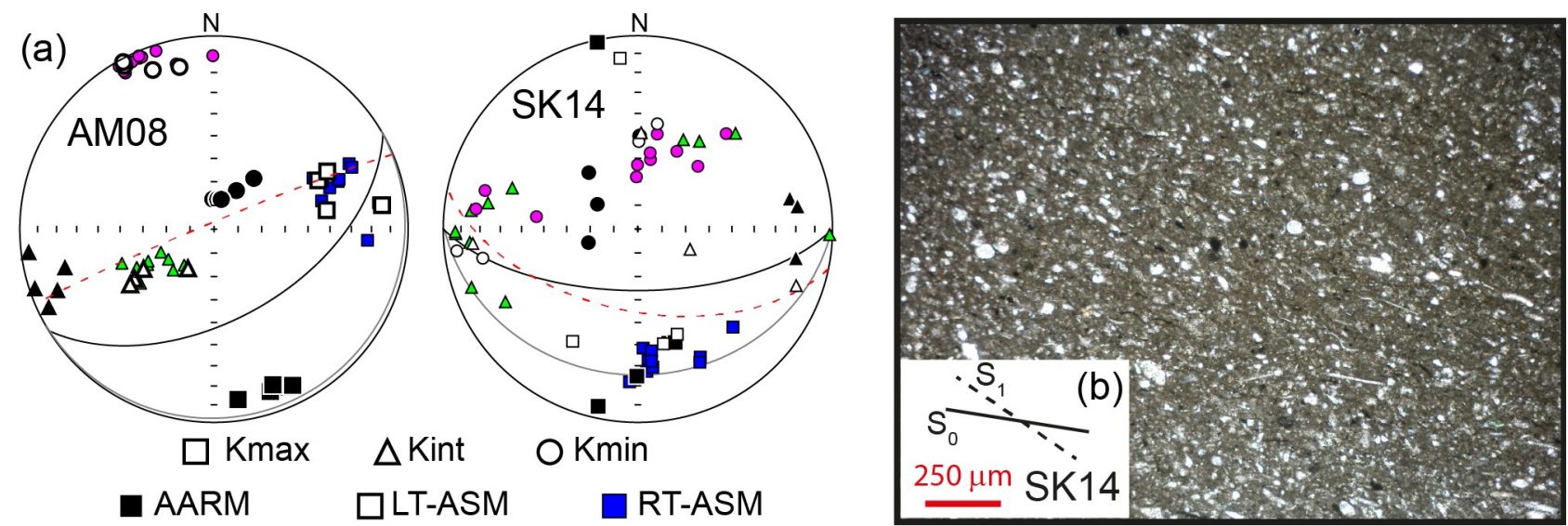

Figura 9.2 (a) Proyecciones de igual área mostrando la fábrica magnética (AARM, RT-AMS y LTAMS) de las estaciones AM08 y SK14. Círculo mayor negro: estratificación; círculo mayor gris: paleo-estratificación; círculo menor naranja: foliación tectónica. En AM08, la RT-AMS y la LTAMS son coincidentes, mostrando la foliación magnética perpendicular a la foliación tectónica, mientras que la misma en la AARM es perpendicular a la paleo-estratificación. Por el contrario, SK14 muestra homogeneidad entre los diferentes tipos de fábricas con una lineación bien definida contenida en la paleo-estratificación y mayor dispersión de los ejes intermedio y mínimo. (b) Caliza bioclástica de la estación SK14 mostrando la relación entre la estratificación y la foliación tectónica, así como numerosos granos de pirita.

Figure 9.2 (a) Equal area projections showing the magnetic fabric (AARM, RT-AMS y LT-AMS) of AM08 and SK14 sites. Black great circle: bedding; gray great circle: paleo-bedding; orange great circle: cleavage. In AM08 the RT-AMS and the LT-AMS magnetic foliation is coincident with the cleavage whereas the AARM magnetic foliation is parallel to the paleo-bedding. Opposite, in SK14 all magnetic fabrics are almost coincident with the magnetic lineation contained in the paleobedding and bigger dispersion of the minimum and intermediate axes. (b) SK14 bioclastic limestone showing the bedding-cleavage relationship as well as several pyrite grains. 
remagnetización, sea preservada. Por tanto, consideramos que la oxidación de la pirita ha sido el principal mecanismo de generación de granos autigénicos en los materiales muestreados que, por otra parte, son selectivamente pobres en filosilicatos, dominando las calizas y margocalizas en las que se pueden observar importantes cantidades de granos de pirita (o pseudomorfos de ella) (Fig. 9.2d).

Sin embargo, lo anterior parece contradecirse parcialmente con los resultados obtenidos de la realización de extractos magnéticos. En las observaciones mediante microscopía electrónica se han observado granos de magnetita de tamaño micrométrico (multidominio -MD-) con morfologías prismáticas y esféricas, framboides de pirita y filosilicatos (ver apartado 5). A priori estas observaciones pueden explicarse por la pérdida progresiva de material magnético durante el proceso de extracción magnética. Esta pérdida se produce tanto durante el proceso de disolución con ácido acético como durante la separación magnética usando el imán de neodimio. Además, esta pérdida es selectiva, afectando predominantemente a los granos de magnetita más finos (SP y SSD). Resultados similares fueron observados en experimentos con extractos magnéticos previos en calizas remagnetizadas (Sun \& Jackson 1994). No obstante, si se observan framboides de pirita, y los granos de magnetita autigénica están reemplazando parcialmente dichos granos, ¿por qué no se aprecian en los experimentos de magnetismo de rocas? Una posible explicación es que durante el proceso de disolución y extracción magnética se hayan perdido de manera selectiva gran cantidad de granos de pirita, bien por disolución de los mismos por el ácido acético (Marenco et al., 2008), bien porque dichos granos son predominantemente paramagnéticos y no se han adherido al imán de neodimio. Ambos procesos pueden generar un aumento en la proporción de granos de magnetita MD, de probable origen detrítico; este cambio en la proporción entre las diferentes familias de magnetita genera las variaciones en las propiedades magnéticas observadas.

\subsubsection{Desencadenantes y datación del proceso de remagnetización}

En la evolución de las cuencas sedimentarias y como consecuencia del enterramiento, durante la diagénesis se produce un aumento de la temperatura a la que son sometidos los materiales sedimentarios. La temperatura alcanzada tiene relación con la profundidad alcanzada por los sedimentos y con el gradiente térmico. Mediante el estudio de la cristalinidad de la illita a lo largo de la serie jurásica en el área de Tounfite (correspondiente con el sector oriental de nuestra área de estudio) Studer (1980) estimó un gradiente térmico de $30{ }^{\circ} \mathrm{C} / \mathrm{km}$. Analizando sistemáticamente la cristalinidad de la illita en las margas pertenecientes al Toarciense Inferior a lo largo del perfil N-S en la transversal de Rich, Brechbühler et al. (1988) observaron que la zona central de la cuenca pasó por unas condiciones diagenéticas relativamente homogéneas, dentro de la diagénesis profunda y la anquizona, de modo que los sedimentos habrían alcanzado temperaturas entre 150 y $300{ }^{\circ} \mathrm{C}$ (Fig. 8.3). Además, es destacable la presencia de un salto brusco en el grado de diagénesis alcanzado hacia sendos márgenes de la cuenca, que deben de estar relacionados con importantes fallas de basamento que controlarían la subsidencia de la misma. Estos datos son consistentes con las observaciones de Torres-López et al. (2014); en un estudio paleomagnético en la transversal de Imilchil ( 90 km al OSO de la transversal de Rich) observan que los materiales carbonatados 
jurásicos están afectados por la remagnetización cretácica, a excepción de los dos bordes de la cuenca.

De acuerdo a los índices de la cristalinidad de la illita, y el gradiente térmico estimado, las margas analizadas debieron de estar enterradas aproximadamente a siete u ocho kilómetros de profundidad, lo que es coherente con nuestros cortes geológicos.

En los últimos años se han realizado diferentes estudios en los que se observa una fuerte correlación entre la mineralogía magnética presente entre carbonatos y lutitas (según Kars et al., 2014, los modelos son globales) y la temperatura alcanzada por los mismos. Aubourg et al. (2012) proponen un modelo de evolución de la mineralogía magnética en función del aumento de la temperatura. Hasta $50{ }^{\circ} \mathrm{C}$, el mineral magnético dominante es greigita, que a partir de esta temperatura comienza a oxidarse para formar magnetita. Hasta los $200{ }^{\circ} \mathrm{C}$ la magnetita es el mineral magnético dominante, momento en el que empieza a reaccionar con pirita para generar pirrotina. Magnetita y pirrotina coexisten entre 200 y $300{ }^{\circ} \mathrm{C}$, temperatura a partir de la cuál la pirrotina es la única fase ferromagnética. Estos valores de temperatura son consistentes con la presencia de magnetita como principal fase magnética en los carbonatos estudiados, dadas las paleo-temperaturas estimadas a partir de la cristalinidad de la illita.

Por tanto, el proceso de enterramiento, dadas las importantes potencias sedimentadas en el área de estudio, es suficiente para explicar el aumento de temperatura y el consecuente crecimiento de magnetita autigénica.

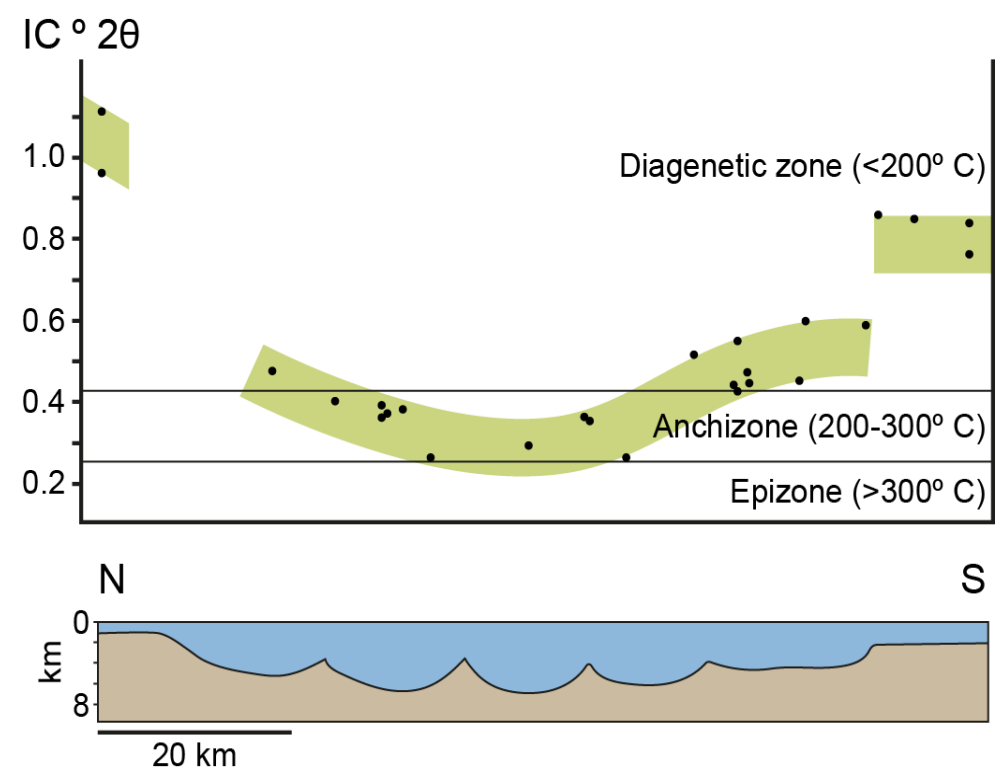

Figura 9.3 Cristalinidad de la illita en margas del inicio del Toarciense, a lo largo del corte N-S realizado en la transversal de Rich. En la base, la reconstrucción propuesta para el enterramiento sufrido por las muestras analizadas. Dibujado a partir de Brechbühler et al. (1988).

Figure 9.3 Illite crystallinity in the marls of the base of the Toarcian through a N-S section along the Rich transect. At the bottom, proposed reconstruction of the post-early Toarcian burial. Redraw from Brechbühler et al. (1988). 


\subsubsection{Momento de adquisición de la remagnetización}

La datación absoluta de magnetizaciones secundarias no es un asunto trivial, y presenta una incertidumbre mayor que cuando se trabaja con magnetizaciones primarias. El primer acercamiento a su edad se realiza mediante los llamados test de campo de estabilidad paleomagnética (por ej. test del pliegue), que permiten una datación relativa de la misma. En ocasiones la remagnetización

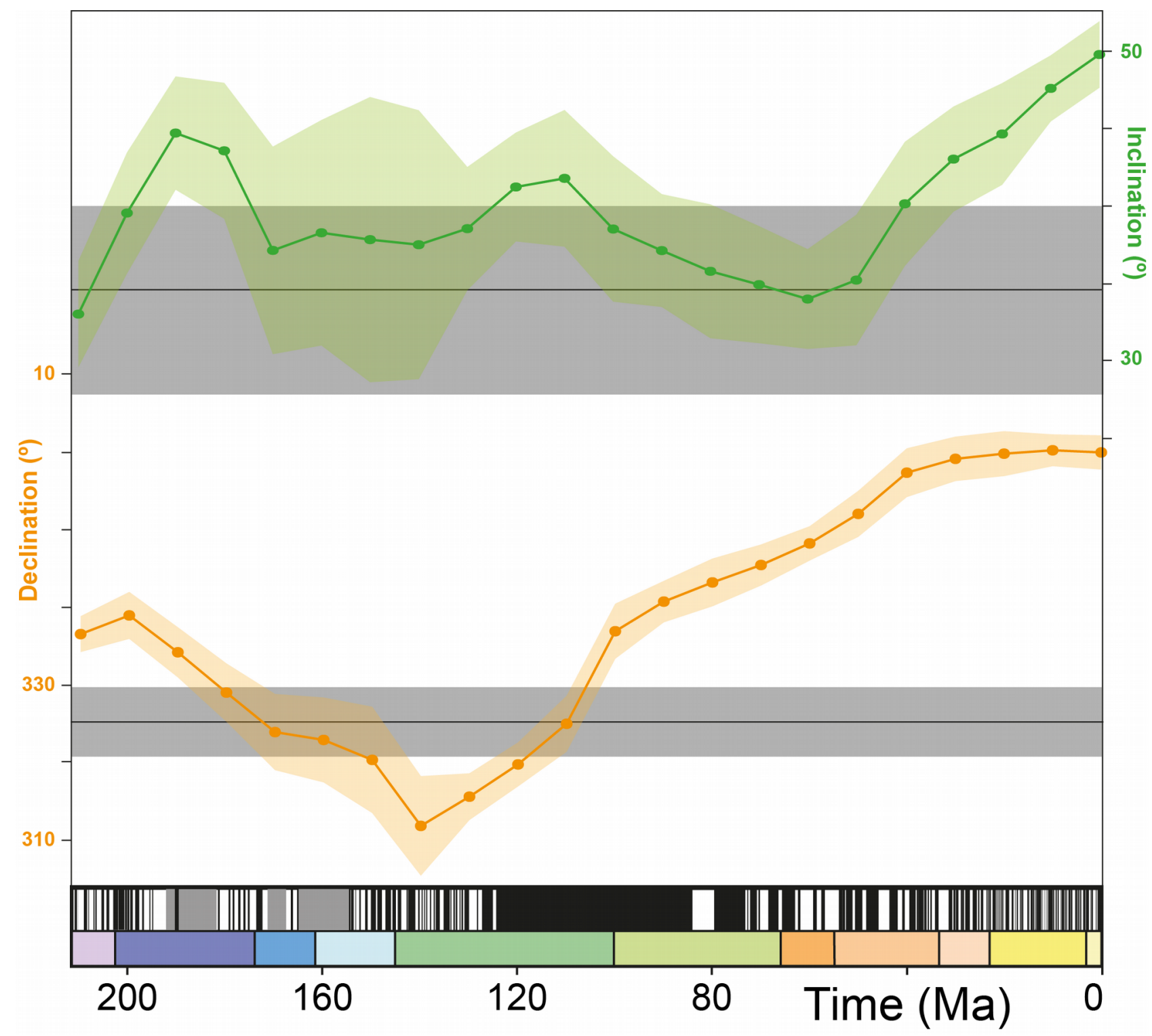

Figura 9.4 Curvas de declinación e inclinación esperada en coordenadas del área de estudio calculadas a partir de la curva de deriva polar aparente (Torsvik et al., 2012). Las líneas horizontales negras indican la dirección media de la remagnetización, y el área gris su intervalo de confianza al 95\%. Las curvas se han obtenido usando el software Paleomagnetism.org (Koymans et al., 2016).

Figure 9.4 Expected declination and inclination curves in coordinates of the study area calculated from the apparent polar wonder path (Torsvik et al., 2012). Gray areas correspond with the declination and inclination of the calculated remagnetization. The horizontal black lines correspond with the mean calculated remagnetization direction and the gray areas are the 95\% confidence areas. Curves obtained using Paleomagnetism.org software (Koymans et al., 2016). 
puede relacionarse con otros procesos geoquímicos que sí pueden ser datados, como es el proceso de illitización (Tohver et al., 2008). Sin embargo, la relación entre la adquisición de la remagnetización y el proceso geoquímico en cuestión debe ser analizado en detalle para no llevar a equívocos. Por ejemplo, observar procesos de illitización no implica que la magnetita que porta una remagnetización haya sido generada a consecuencia de tal proceso (Elliot et al., 2006; Osborn et al., 2014). Otro método usado habitualmente para datar remagnetizaciones es comparar la dirección de la misma con la esperada a partir de paleopolos o de la curva de deriva polar aparente para la placa que corresponda (por ej., Dinarès-Turell y García-Senz, 2000; Henry et al., 2001; Blumstein et al., 2004; Soto et al., 2008; Gong et al., 2009; Weil et al., 2010; Meijers et al., 2011; Torres-López et al., 2014; Zhang et al., 2016). Este método está limitado por la calidad de la curva, las características de la misma (i.e., que presente importantes variaciones en declinación y/o inclinación a lo largo del tiempo) y las características del área de estudio (i.e., que no se encuentre despegada de la placa estable, no haya sufrido rotaciones de eje vertical, etc.).

Las curvas de declinación e inclinación esperadas para el área de estudio (Fig. 9.4) se han obtenido a partir de la curva global de deriva polar aparente en coordenadas africanas (Torsvik et al., 2012). La inclinación muestra poca variación, indicando que esta región de la placa africana se ha mantenido en una paleolatitud estable durante el Mesozoico. Sin embargo, la declinación presenta mayor variación debido a la rotación del continente alrededor de un polo euleriano próximo a la región de estudio, horaria durante el Jurásico, y antihoraria desde el Cretácico Inferior hasta Eoceno. Comparando la curva de declinación con la dirección obtenida para la remagnetización observamos coincidencia de declinaciones durante el Jurásico Medio-Superior y durante el Cretácico Inferior. Dada la sistemática polaridad normal observada en las muestras consideramos más probable que la remagnetización sea de edad cretácica, de acuerdo a lo establecido previamente por Torres-López et al. (2014), con una edad media entre 100-105 Ma. Si bien puede existir cierta incertidumbre en la edad debida a la larga duración del Supercron de
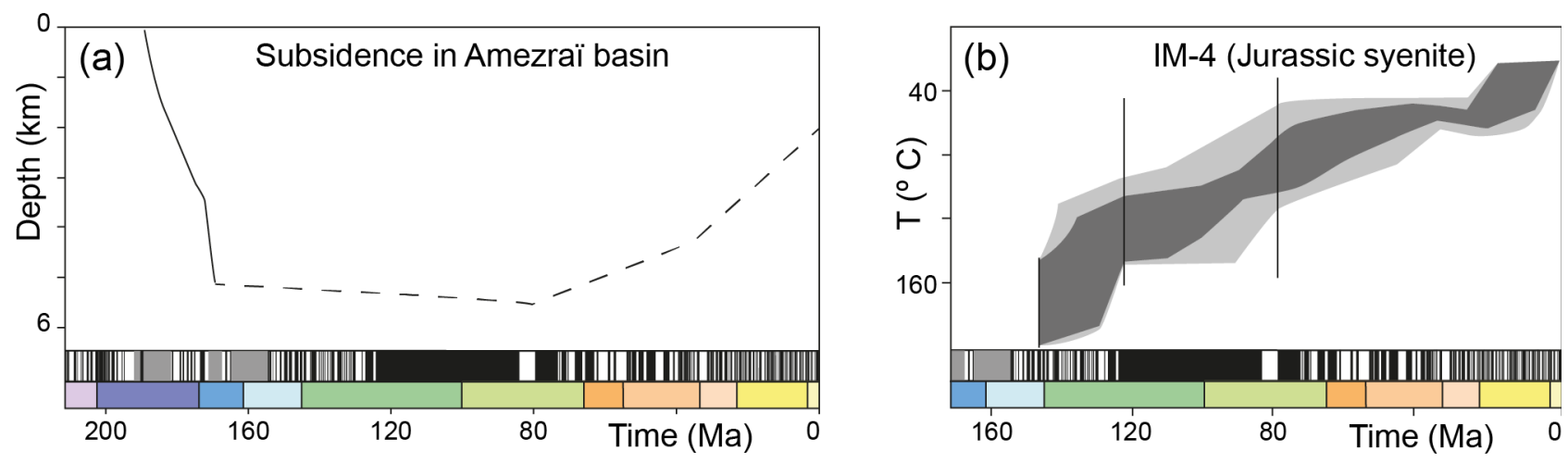

Figura 9.5 (a) Curva de subsidencia total para la cuenca de Amezraï (Alto Atlas Central) según Moragas et al. (2016) a partir de datos de reflectancia de la vitrinita. (b) Modelos térmicos realizados para una sienita jurásica proveniente del anticlinal de Tassent, según Barbero et al. (2007). Escala temporal y magnética a partir de Gradstein et al. (2012).

Figure 9.5 (a) Subsidence curve of the Amezraï basin (Central High Atlas) from Moragas et al. (2016) using vitrinite reflectance data.(b) Thermal model for a Jurassic syenite coming from Tassent massif, from Barbero et al. (2007). Time and magnetic scale according to Gradstein et al. (2012). 
Polaridad Normal del Cretácico. Sin embargo, dada la amplia separación temporal entre los dos eventos de deformación en el AAC (Jurásico Inferior-Medio y Cretácico Superior-Cenozoico), dicha incertidumbre en la edad no supone un inconveniente en el uso de la remagnetización para la restitución de la estructura previa a la compresión.

(a) Tectonic subsidence curve (Moragas et al., 2016)

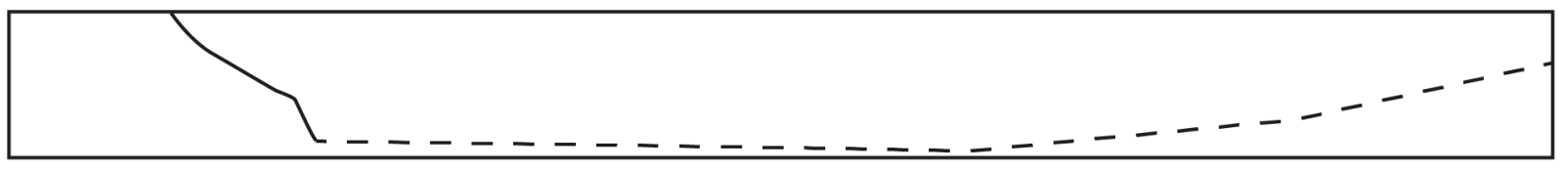

(b) Progressive magnetite growth model

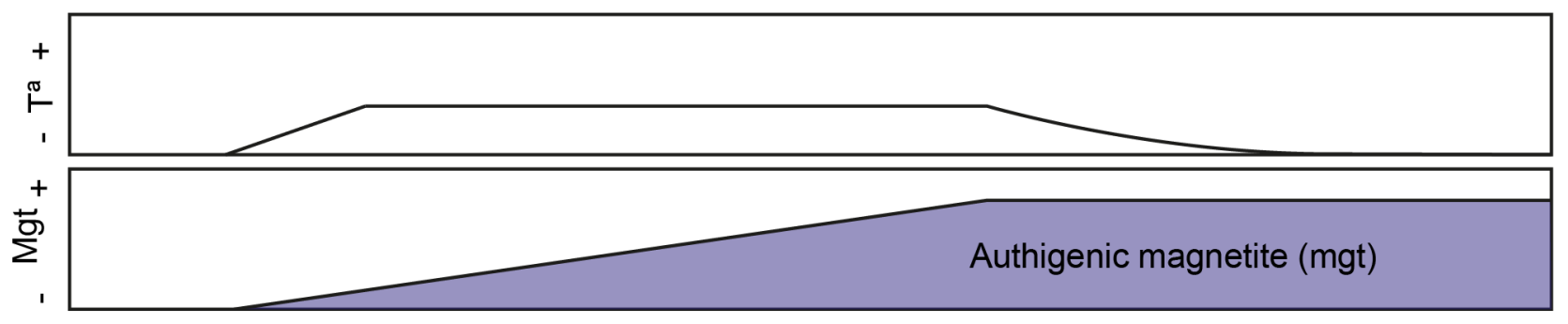

(c) Punctual magnetite growth model

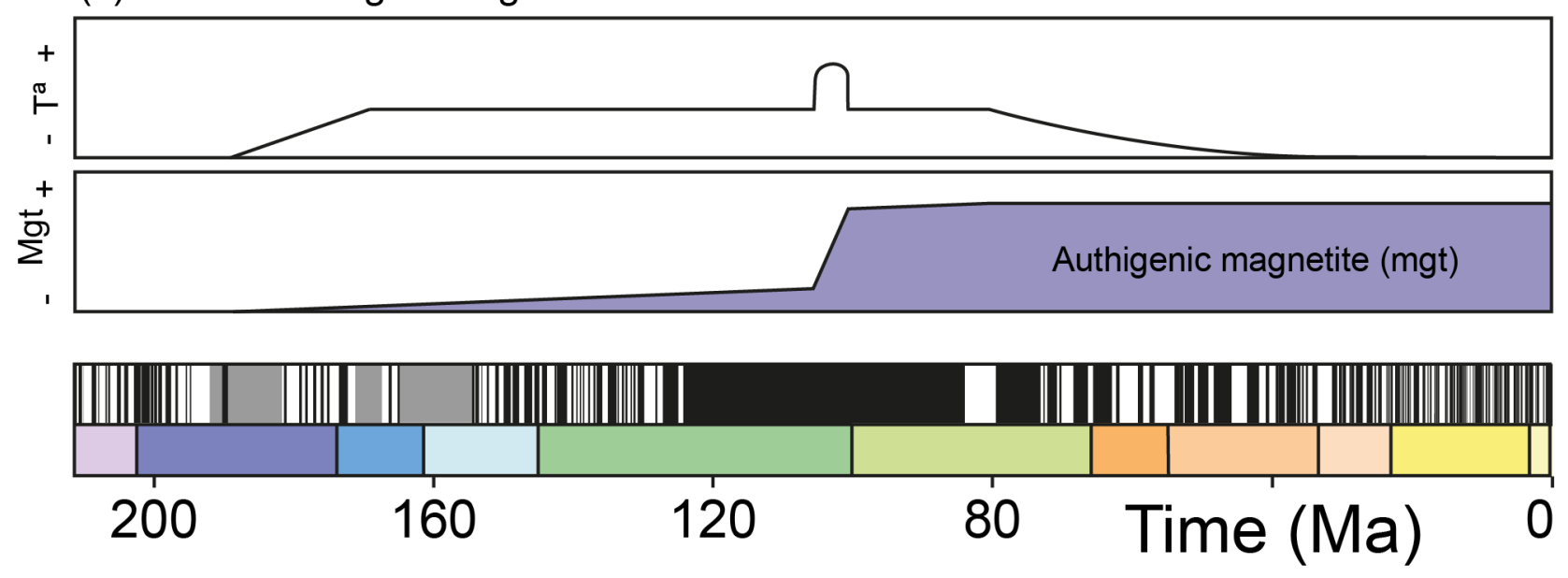

Figura 9.6 (a) Curva de subsidencia total para la cuenca de Amezraï (Alto Atlas Central) según Moragas et al. (2016). (b, c) Modelos de evolución de la temperatura y consiguiente crecimiento de magnetita considerando el mismo como un evento progresivo desde el Jurásico Medio al Cretácico Superior (b) o sumado a lo anterior la presencia de un evento térmico centrado en 100-105 Ma (c).

Figure 9.6 (a) Subsidence curve of the Amezraï basin (Central High Atlas) from Moragas et al. (2016). (b, c) Models of temperature evolution and consequent magnetite growth according the progressive growth from the Middle Jurassic to the Late Cretaceous (b) or considering a peak thermal event in 100-105 Ma (c).

Un último aspecto por discutir es el siguiente. ¿Por qué tiene dicha edad la remagnetización? Las curvas de subsidencia realizadas en la cuenca de Amezraï (Moragas et al., 2016), cercana al área de estudio, muestran que durante el Jurásico se alcanzan valores de subsidencia superiores a los $5 \mathrm{~km}$ (Fig. 9.5a), suficientes para que se alcancen las temperaturas necesarias que desencadenen la 
formación de magnetita autigénica. Por otro lado, datos termocronológicos provenientes de las rocas ígneas jurásicas presentes en la estructura de Tassent (Barbero et al., 2007) muestran que la exhumación de los mismos se produjo durante el Cretácico Superior y el Cenozoico (Fig. 9.5b). Por tanto, la generación de magnetita autigénica pudo comenzar en el Jurásico Medio-Superior y prolongarse hasta el Cretácico Superior (Fig. 9.6b). En este sentido, a medida que los granos neoformados de magnetita alcanzaban un volumen crítico bloqueaban su momento magnético con la polaridad que correspondiese en cada determinado momento. La magnetización remanente natural es la suma vectorial de todos los momentos magnéticos que portan cada uno de los granos por unidad de volumen. Los constantes cambios de polaridad durante el Jurásico (que harían que se anulasen progresivamente los momentos magnéticos bloqueados en las diferentes crones de polaridad), y la presencia del supercron cretácico (periodo en el que todos los granos que alcanzasen el volumen crítico registrarían la misma polaridad normal), favorecerían el resultado de una polaridad normal, con dirección media centrada en la mitad del supercron. Otro posible escenario que permite explicar una dirección tan constante a lo largo del Atlas, tanto en calizas (Torres-López et al., 2014) como en capas rojas (Moussaid et al., 2015), seria la presencia de un evento centrado en 100-105 Ma, que favoreciese un mayor crecimiento de granos en dicho momento. De este modo, la formación de granos autigénicos de magnetita sería constante desde el Jurásico Medio hasta el Cretácico Superior, con excepción del periodo anómalo en 100-105 Ma, en el que se formaría una mayor cantidad de magnetita (Fig. 9.6c). Este evento anómalo podría corresponder con una anomalía térmica, o quizá con un aumento de la migración de fluidos debido a un cambio del régimen tectónico en relación con el movimiento relativo entre África e Iberia. Sin embargo, si se debió a un evento térmico, ¿por qué no se produjo durante el Jurásico Superior o el Cretácico Inferior, momento coincidente con la intrusión de las rocas ígneas básicas? Por otro lado, el cambio

(a)

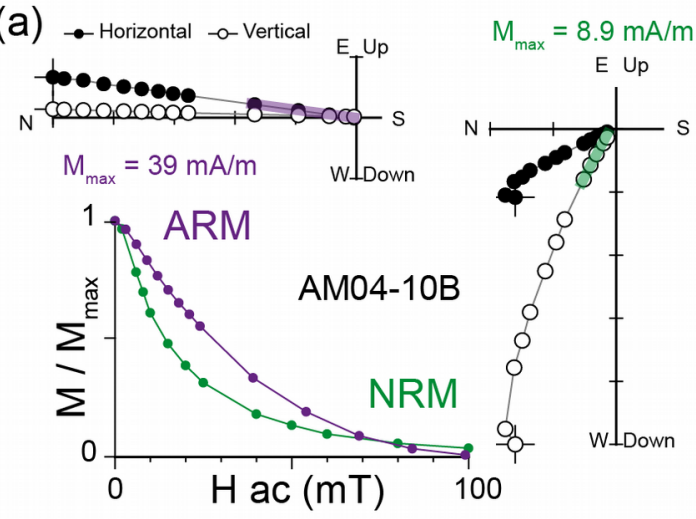

(b)

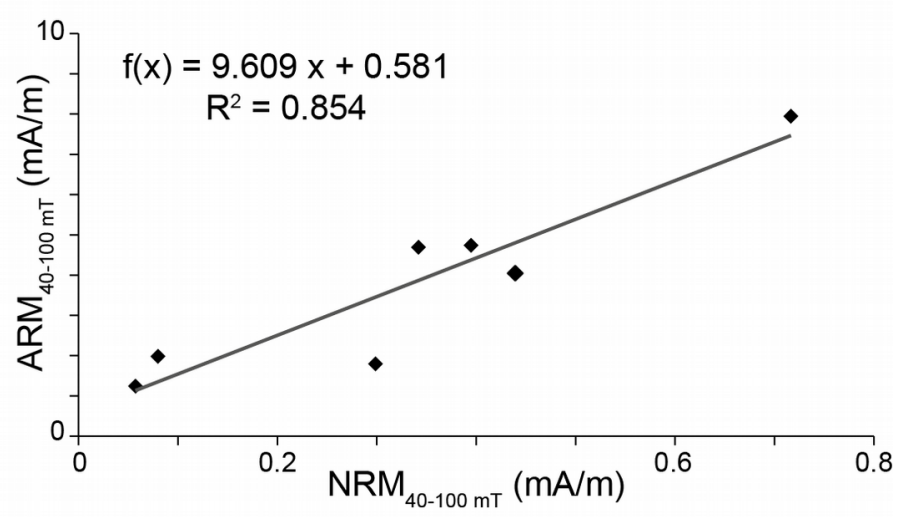

Figura 9.7 (a) Diagramas ortogonales de desmagnetización de la NRM y la ARM por campos alternos, y gráfica de intensidad. (b) Relación entre la intensidad de la NRM y la ARM entre 40 y $100 \mathrm{mT}$ (coercitividades en las que se desbloquea la componente remagnetizada), en la que se observa una correlación entre ambas. todas las muestras pertenecen al área de estudio y presentan una edad Aaleniense-Bajociense.

Figure 9.7 (a) Alternating field demagnetization orthogonal plots both of the NRM and the ARM, and intensity chart. (b) NRM vs. ARM intensity between 40 and $100 \mathrm{mT}$ (the coercivity window in which the remagnetized component is unblocked) showing a good correlation. The samples are all of them Aalenian-Bajocian limestones from the study area. 
de régimen tectónico no sería acorde con nuestra interpretación de las fábricas magnéticas portadas por la magnetita (Fig. 9.2, apartado 8) que relacionamos con una extensión NNO-SSE durante el crecimiento de los granos ferrimagnéticos. Aunque también es posible otra interpretación considerando que la lineación preferente NNO-SSE de la magnetita sea debida a una alineación preferente de los granos magnéticos paralela a la declinación del campo magnético en el momento de su crecimiento (la foliación horizontal estaría constreñida por la carga litostática).

Hasta el momento todo lo anterior son conjeturas (que sin embargo proporcionan un marco para el desarrollo de trabajos futuros) y son necesarios trabajos sistemáticos y minuciosos a lo largo de la serie jurásica para valorar estos procesos. Futuros trabajos podrían ir en la línea del análisis detallado a lo largo de la serie jurásica de varios parámetros: i) variación de las direcciones de la remagnetización (materiales más antiguos mostrarían tendencia en las declinaciones más al oeste), ii) variaciones en las propiedades magnéticas (mayor tamaño de grano dentro del espectro SSD, y consecuentemente mayores temperaturas de desbloqueo en profundidad), iii) análisis de las relaciones entre la ARM y la NRM (Fig. 9.7), que permitirían valorar la variación a lo largo de la serie jurásica del porcentaje de granos de magnetita que portan señal magnética efectiva a la NRM. 


\subsection{Aportaciones a la metodología basada en círculos menores}

\subsubsection{La incertidumbre inherente a los datos de entrada}

Un círculo menor (SC) está definido por el azimut de la estratificación y la dirección paleomagnética media. Por tanto, la incertidumbre de estos dos elementos genera incertidumbre en los círculos menores. Henry et al. (2004), mediante un proceso de bootstrap similar al descrito en el apartado 4.1, definían áreas de confianza (para distintos porcentajes) de la dirección calculada. Por otro lado, Waldhör y Appel (2006) proponían la matriz A/n como herramienta para estimar la incertidumbre asociada a la dirección calculada.

El nuevo software pySCu utiliza ambas aproximaciones para calcular la incertidumbre de la dirección calculada. Concretamente, respecto al proceso de bootstrap, para cada estación paleomagnética se crea un set artificial de 30 datos de estratificación y de 30 direcciones paleomagnéticas, que comparten orientación y el parámetro estadístico к (Fisher, 1953) con los datos originales. Tras ello, calcula 500 posibles direcciones usando diferentes círculos menores definidos por combinación aleatoria de los datos de estratificación y dirección paleomagnética creados por el proceso de bootstrap. Las soluciones calculadas son usadas para calcular la dirección media y su correspondiente elipse de confianza (Kent, 1982).

Una de las ventajas del nuevo software es que es fácilmente accesible por la comunidad científica (https://github.com/pablitolito/pySCu3) y de código abierto, de modo que puede ser implementado en cualquier otro software de paleomagnetismo como Remasoft 3.0 (Chadima y Hrouda, 2006), Paleomagnetism.org (Koymans et al., 2016) o VPD (Ramón et al., 2017).

Por otro lado, la elipse de confianza es una herramienta que puede ser usada con significado estadístico. La matriz A/n es visual, ayuda a entender cómo se distribuye la incertidumbre asociada al cálculo, pero no proporciona un límite estadístico que permita la comparación con otras direcciones. La elipse, por el contrario, sí que permite comparar la dirección calculada con la curva de deriva polar aparente, o comparar diferentes direcciones calculadas en distintas zonas.

Hasta la fecha en varios trabajos (Casas et al., 2009; Gong et al., 2009; Soto et al., 2011; Torres-López et al., 2014; García-Lasanta et al., 2017) se ha utilizado como medida de la incertidumbre el $\alpha_{95}$ asociado a la población de las direcciones sobre cada SC más próximas a la referencia calculada (BFD por sus siglas en inglés, best fit direction). Sin embargo, como se ha indicado en el capítulo 4.1, esta aproximación no tiene ningún significado dado que por definición la distribución de las BFD es artificial: están forzadas a situarse sobre el correspondiente SC. En la figura 9.8 se valora la variación de la incertidumbre en la dirección calculada según el mayor o menor paralelismo de los círculos menores analizados. En el primer caso tanto la elipse de confianza como el mapa de contornos de la variable $\mathrm{A} / \mathrm{n}$ son redondeadas, estableciendo un área bien definida para la dirección de referencia. Sin embargo, a medida que aumenta el paralelismo de los círculos menores aumenta la incertidumbre de la dirección calculada, que se evidencia porque tanto los mapas de contornos como las elipses son más alargadas. Por tanto, vemos que la variable $\mathrm{A} / \mathrm{n}$ y la elipse de confianza muestras comportamientos análogos. Por el contrario, observamos que el $\alpha_{95}$ de las BFD no sufre apenas cambios, aumentando ligeramente la incertidumbre en el último 
estadio. Además el círculo de confianza $\alpha_{95}$ no expande su incertidumbre en la dirección de los SC cuando son más paralelos, proporcionando un margen irreal. Concluyendo, tanto la elipse de confianza asociada a la dirección calculada mediante bootstrap, como la variable A/n, muestran de manera realista un rango de incertidumbre de la dirección de remagnetización, no así el $\alpha_{95}$ de las BFD. Además, la elipse de confianza tiene significado estadístico que permite que sea comparada con otras direcciones.

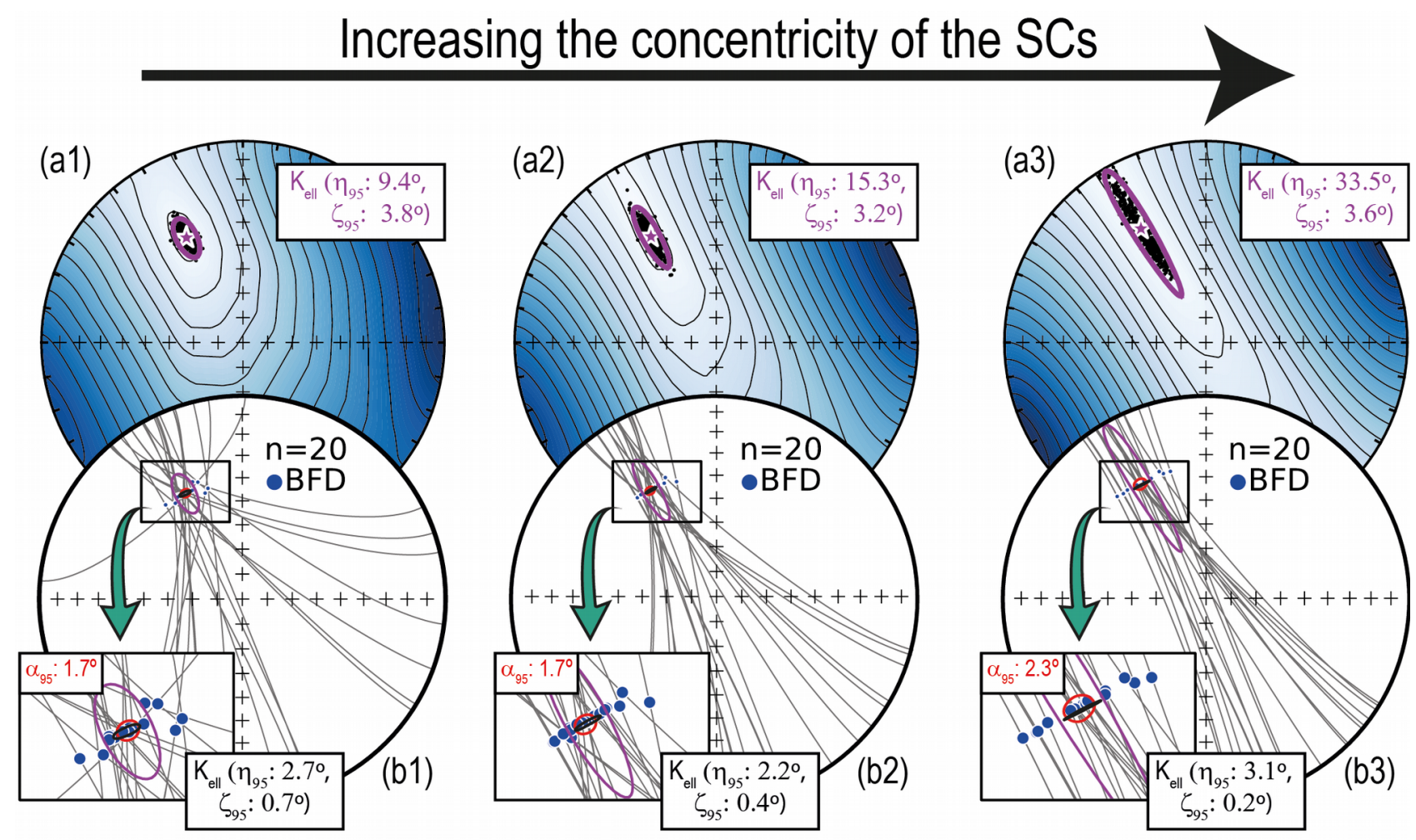

Figura 9.8 (a) Mapas de contornos de la variable $\mathrm{A} / \mathrm{n}$, dirección de remagnetización calculada (estrella) y elipse de confianza para tres poblaciones de 20 círculos menores con diferente grado de paralelismo. Los puntos negros son cada una de las 500 soluciones calculadas. (b) Proyección de igual área mostrando los correspondientes círculos menores, las elipses de confianza con sus correspondientes parámetros (Kent, 1982), y los conos de confianza (Fisher, 1953) de las BFD. Tomado de Calvín et al. (2017a).

Figure 9.8 (a) A/n contour plots obtained from three examples, calculated remagnetization direction (star) and corresponding 95\% confidence ellipse. Black points are the 500 calculated solutions. (b) Equal area projections showing the three corresponding SC distributions and the best fit directions (BFD). 95\% confidence circle (Fisher, 1953) and 95\% confidence ellipse (Kent, 1982) corresponding to the 20 BFDs are depicted for comparison. From Calvín et al. (2017a).

\subsubsection{La incertidumbre en los datos del Atlas}

Los círculos menores del Atlas (Fig. 9.9) presentan ángulos apicales grandes ( $\left.>60^{\circ}\right)$ debido a que la dirección de la remagnetización cretácica (NO) forma un ángulo elevado con la estructura general (ENE-OSO). Además, existe una distribución de las orientaciones de la estratificación suficientemente holgada como para que los círculos menores no sean extremadamente paralelos entre sí, permitiendo definir la dirección de remagnetización con bastante precisión. Aun así, se puede apreciar en el mapa de contornos de A/n (Fig. 9.9) que la propagación de la incertidumbre se 
produce en la dirección NO-SE, perpendicular a la directriz estructural y conteniendo los círculos menores.

En los trabajos desarrollados en el transcurso de esta tesis doctoral las direcciones de referencia se han obtenido sin aplicar un filtrado sistemático de los datos por su calidad. Esto se ha realizado así dado que, cuando se han calculado las direcciones de referencia aplicando o sin aplicar filtros, no se han obtenido diferencias significativas, y se ha considerado que, si es posible, es preferible no sesgar los datos de entrada. La ausencia de diferencias significativas puede deberse al número de datos utilizado (64 en Calvín et al., 2017b y 100 en Calvín et al. 2018). Sin embargo, puede darse el caso, sobretodo para poblaciones más pequeñas, de que haya datos que afecten negativamente al cálculo de la dirección de la remagnetización, siendo necesario aplicar diferentes filtros, tal y como realiza Torres-López et al. (2014). Los filtros básicos que pueden aplicarse son los siguientes:

- Eliminar estaciones con gran incertidumbre (por ej. $\alpha_{95}>10^{\circ}$ ) de sus direcciones paleomagnéticas medias (Fig. 9.9b).

- Eliminar estaciones con bajo buzamiento (por ej. $<15^{\circ}$ ), dado que la incertidumbre en la medida de la dirección de la estratificación es mayor (Fig. 9.9c).

(a)

Main dataset
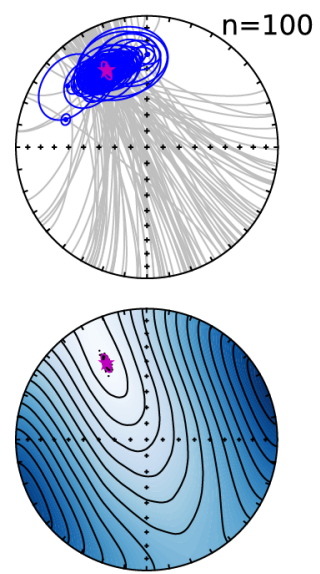

Dec: $332.2^{\circ}$ Inc: $34.3^{\circ}$ (b) $\alpha 95<10^{\circ}$
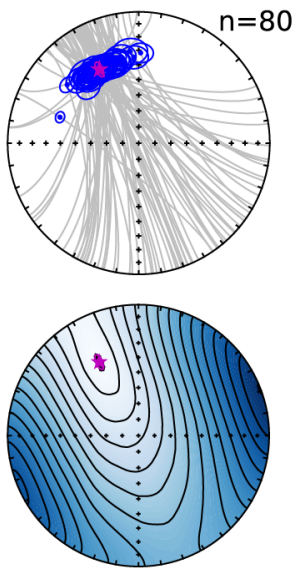

Dec: $331.9^{\circ}$ Inc: $36.5^{\circ}$ (c) $\operatorname{dip}>15^{\circ}$
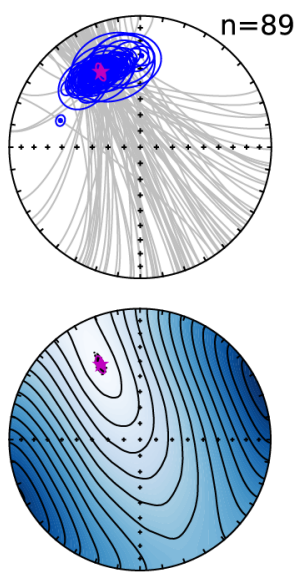

Dec: $332.2^{\circ}$ Inc: $35.5^{\circ}$ (d) $\alpha 95<10^{\circ}$
$\operatorname{dip}>15^{\circ}$
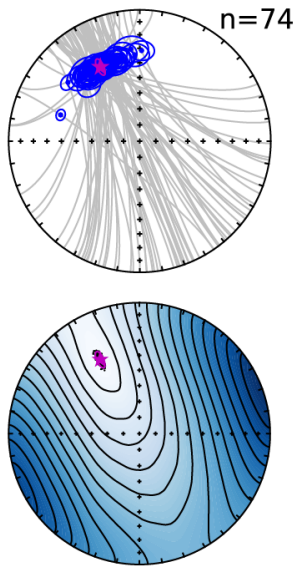

Dec: $332.0^{\circ}$ Inc: $36.2^{\circ}$ (e) Angle BFD-ref $<10^{\circ}$
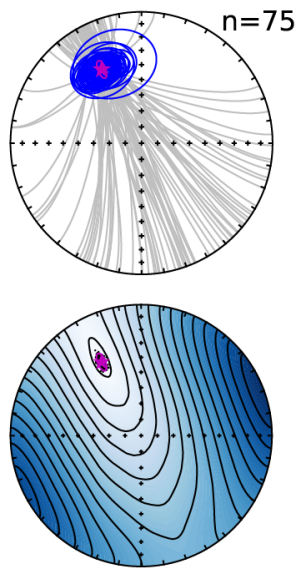

Dec: $331.6^{\circ}$ Inc: $36.3^{\circ}$

\section{Calculated reference \\ ○ Best fit direction}

Figura 9.9 Proyecciones de igual área (hemisferio inferior) mostrando los círculos menores, las BFD, el mapa de contornos de $\mathrm{A} / \mathrm{n}$ y la dirección calculada para distintos set de datos provenientes del Atlas. (a) Datos de partida, sin aplicar ningún filtro, provenientes de Calvín et al., 2018. (b) Tras eliminar aquellas estaciones cuya dirección paleomagnética media presenta valores de $\alpha_{95}$ superiores a $10^{\circ}$. (c) eliminando las estaciones cuyo buzamiento es inferior a $15^{\circ}$. (d) Eliminando las de los dos puntos anteriores. (e) Tras eliminar aquellas estaciones cuyo BFD tenía un ángulo con la referencia calculada mayor que $10^{\circ}$.

Figure 9.9 Equal area projections (lower hemisphere) showing the small circles, the BFD, the A/n contours and the calculated direction for different data sets from the Atlas. (a) Unfiltered main data coming from Calvín et al. (2018). (b) After removing those sites whose paleomagnetic mean direction have $\alpha_{95}$ over $10^{\circ}$. (c) After to remove sites with dip under $10^{\circ}$. (d) Removing the sites from the previous two points. (e) After removing the sites whose BFD have angles respect to the calculated reference bigger than $10^{\circ}$. 
- El ángulo entre la dirección calculada y cada círculo menor (i.e., el ángulo entre la BFD y la referencia) es un indicativo de la calidad de la estación paleomagnética. Se puede realizar un primer cálculo con todos los datos, y volver calcular la dirección tras eliminar aquellas estaciones con altos valores del mismo (por. ej. $>10^{\circ}$ ) (Fig. 9.9e).

En el caso del Atlas, tras aplicar todos los filtros de manera individual o combinados (Fig. 9.9), la dirección obtenida, así como su elipse de confianza, es muy similar. Esto es debido a que, por un lado, al menos el $75 \%$ de los datos pasa dichos filtros, generando un modelo robusto para el cálculo de la referencia. Además, los dos primeros filtros son contemplados por el proceso de bootstrap (si bien en el Atlas la incertidumbre proveniente de la estratificación no se ha utilizado, usando un balor de $\mathrm{\kappa}$ constante); este proceso le otorga más peso tanto a las direcciones paleomagnéticas como a los datos de estratificación con menos incertidumbre, puesto que los 500 círculos menores generados para cada cálculo serán más similares entre sí.

\section{Inclination $=45^{\circ}$}

\section{$\mathrm{CCW}$}

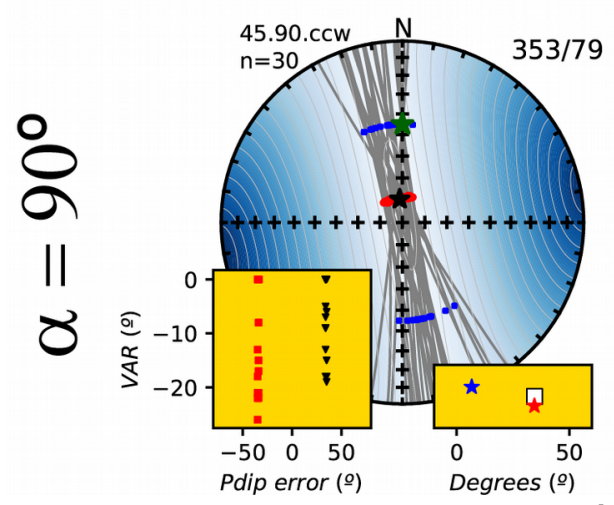

Sym.

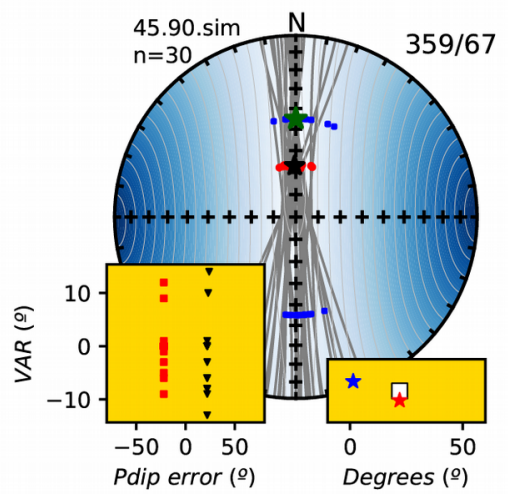

CW

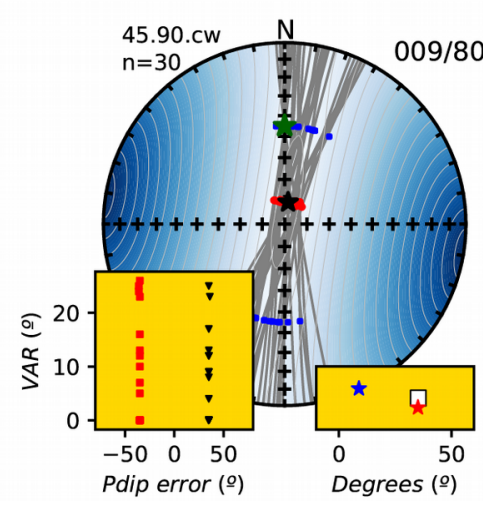

Figura 9.10 Proyecciones de igual área mostrando tres poblaciones de 30 datos en los que se han aplicado rotaciones de eje vertical diferenciales en sentido antihorario (CCW), simétrico (Sym) y horario (CW) para un caso similar al Atlas, en el que la declinación de la remagnetización y la estructura general forman $90^{\circ}(\alpha)$ e inclinación intermedia $\left(45^{\circ}\right)$ de la remagnetización original. En los gráficos menores, situados abajo a la izquierda, se muestra el error en paleobuzamiento para cada uno de los flancos, en el situado abajo a la derecha, el error cometido en el cálculo de la dirección de remagnetización (cuadro blanco), así como en su declinación (estrella azul) e inclinación (estrella roja). Ésta es parte de la figura 3 del apartado 4.2.

Figure 9.10 Equal area projections showing three data sets with 30 data affected by differential vertical axis rotations in counter-clockwise (CCW), symmetric (Sym) and clockwise (CW) sense. Both the angle between the original remagnetization declination and the general structural trend ( $\alpha$ $=90^{\circ}$ ) and the inclination of the remagnetization $\left(45^{\circ}\right)$ are similar to the Atlas. The left insets shows the error in paleodip for each limb and the right insets shows the error in the calculated remagnetization direction in overall (white square), in declination (blue star) and inclination (red star). This is a section of the figure 3 of the section 4.2 . 


\subsubsection{Sobre las rotaciones de eje vertical en el Atlas}

La variabilidad en la orientación de la estratificación en el Atlas puede tener diferentes orígenes, entre ellos que hayan sido afectadas por rotaciones diferenciales de eje vertical (VAR) antes o después de la remagnetización. Si las VARs fueran previas a la adquisición de la remagnetización no afectarían ni al cálculo de la referencia ni a la restitución de la estructura, y podrían corresponder con los círculos menores con diferente dirección de su eje, pero que contienen (o son cercanos) a la dirección de referencia. Sin embargo sí tendrían notable influencia si fueran posteriores a la adquisición de la remagnetización, y podrían ser responsables de los 25 datos eliminados en el último filtro aplicado en la figura 9.9, cuyos círculos menores están alejados de la referencia. En el apartado 4.2 se han tratado una serie de modelos en los que se analizaba cómo afectan las VAR

(a)
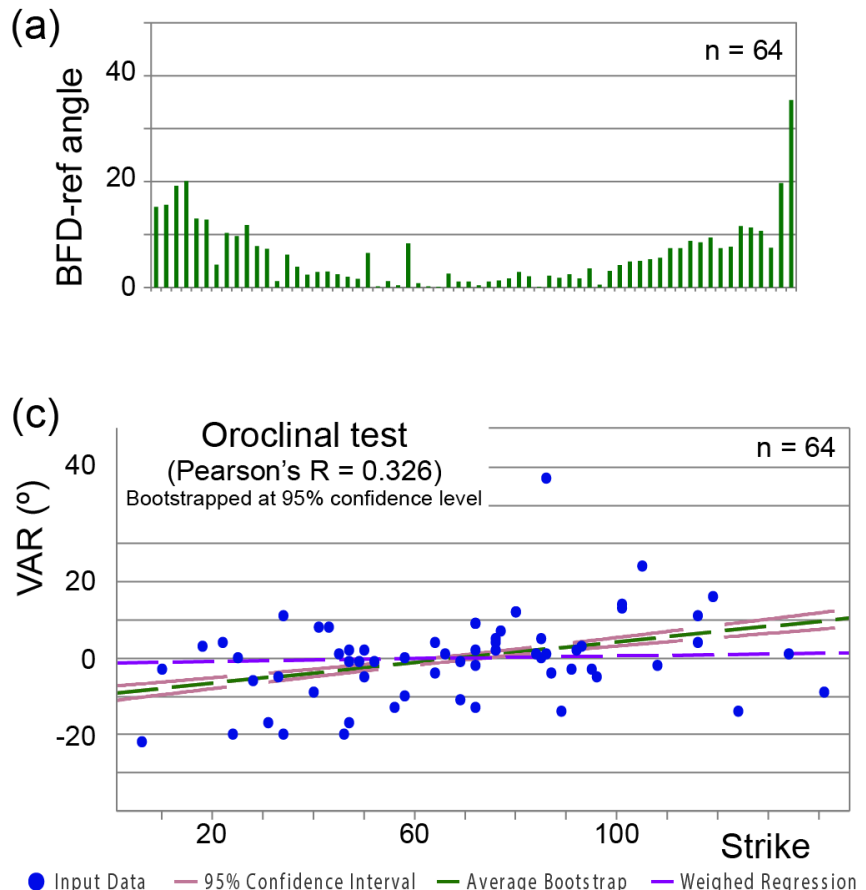

(b)

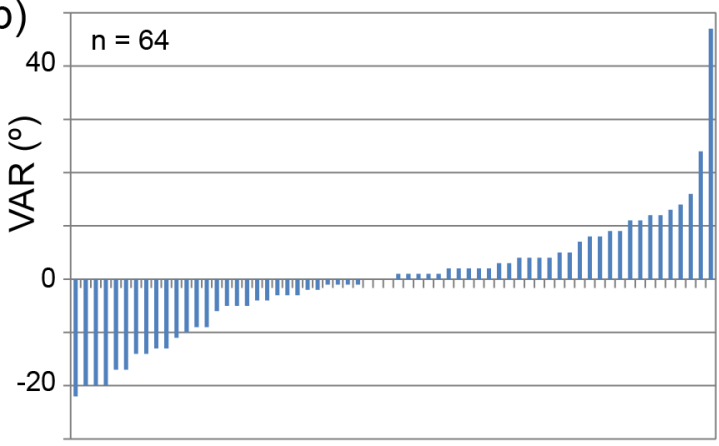

(d)

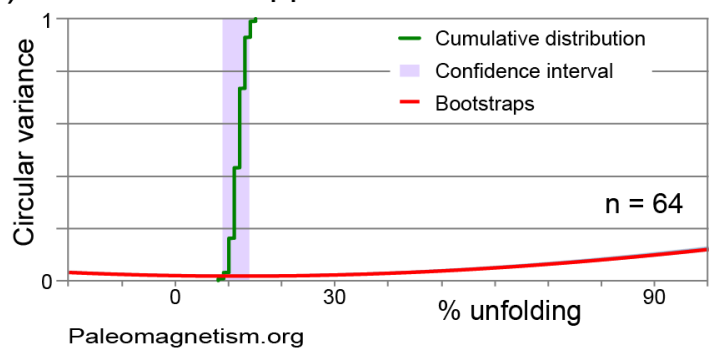

Figura 9.11 Histogramas mostrando (a) el ángulo mínimo entre la dirección de referencia calculada y cada círculo menor, (b) el valor de rotación de eje vertical (VAR) aplicado sobre cada estación paleomagnética necesario para que cada círculo menor contenga la dirección de referencia calculada; los valores positivos corresponden con VAR de sentido horario y los negativos con sentido antihorario. El orden de las estaciones paleomagnéticas y la escala en sendos histogramas es coincidente. (c) Test del oroclinal realizado sobre los mismos datos, en los que no se observa una relación entre la variación de la orientación de la estratificación y los valores de VAR. (d) Test del pliegue del oroclinal mostrando la varianza circular con respecto al ángulo de despliegue. Si bien los valores son bajos para todo el progreso de despliegue (lo que hace poco significativo al test), su mínimo en torno al $10 \%$ indica que la variación de orientación de las capas es previa a las hipotéticas rotaciones de eje vertical. Los datos usados provienen de Calvín et al. (2017b).

Figure 9.11 Histogram charts showing (a) the minimum angle between the calculated reference and each small circle, (b) the vertical axis rotation (VAR) necessary in each paleomagnetic site in order that al small circles intersect with the calculated reference; positive VARs are clockwise and the negatives are counter-clockwise. Position of the paleomagnetic sites between charts is coincident. (c) Oroclinal test with the same data showing non-correlation between strike and VAR. (d) Oroclinal fold-test showing the circular variance as a function of unfolding. The low values of all unfolding stages indicates that the test is non-significant, but the minimum values around $10 \%$ could be meaning that the strikes differences are previous to the hypothetical vertical axis rotations. Used data are from Calvín et al. (2017b). 
posteriores a la adquisición de la remagnetización en el uso de los círculos menores para diferentes contextos. Si seleccionamos aquellos que comparten características con los datos del Atlas (ángulo entre la declinación de la remagnetización y la dirección estructural general cercano a $90^{\circ}$, e inclinación de la remagnetización intermedia, $45^{\circ}$ ) (Fig. 9.10) observamos que la presencia de VAR tiene importantes consecuencias tanto en el cálculo de la dirección de remagnetización como en el paleobuzamiento. Quizá la más significativa es el aumento sistemático de la inclinación en la dirección calculada (entre $60^{\circ}$ y $80^{\circ}$ ) frente a la esperada $\left(45^{\circ}\right)$.

En el caso de los datos del Atlas, por el contrario, observamos que la dirección calculada presenta una inclinación acorde con la esperada según la curva de deriva polar aparente. Esto es indicativo de la ausencia de VARs diferenciales posteriores a la remagnetización, que pudieran afectar de manera generalizada a los afloramientos estudiados. Sin embargo, las 25 estaciones cuyos círculos menores están desviados respecto de la referencia, sí podrían haber sufrido estos procesos sin que afecte al cálculo de la dirección, dado que sólo representan el 25\% de los datos. Finalmente, una inclinación correcta no indica que toda el área de estudio no haya sido afectada por una rotación de eje vertical en bloque (misma magnitud de rotación afectando a todas las estaciones paleomagnéticas), ya que la curva de deriva polar aparente para el NO de África muestra inclinaciones similares desde el Jurásico Superior al final del Cretácico (y por tanto no permitiría apreciar tal proceso). Si el área estuviera afectada por este proceso, tendríamos un problema para el cálculo de la edad estimada de la remagnetización, dado que ésta se ha determinado por comparación con dicha curva. Sin embargo, no hay ningún indicio geológico de que se haya producido este proceso.

El nuevo programa VPD (Ramón et al., 2017; Pueyo et al., en preparación) propone el cálculo de la VAR necesaria para cada estación, para que cada SC contenga la dirección de referencia calculada. Este parámetro es parecido a la medida del ángulo entre la BFD y la dirección de referencia (Calvín et al., 2017a), solo que en el primer caso el ángulo se mide sobre un círculo menor de eje vertical que contiene la referencia (asumiendo que dicha desviación se debe exclusivamente a una VAR), y en el segundo se mide sobre el círculo mayor que une ambas direcciones. La comparación mediante un histograma de ambas variables (Fig. 9.11a, b) muestra una buena correlación entre su magnitud (los valores positivos indican VAR de sentido horario y las negativas sentido antihorario). Aunque los valores de VAR siempre son mayores, ambos ángulos son inferiores a $10^{\circ}$ en más del $50 \%$ de los casos.

Usando estos valores de VAR se ha realizado de manera tentativa un test del oroclinal (Fig. 9.11c) y un test del pliegue del oroclinal (Fig. 9.11d) usando el programa Paleomagnetism.org (Koymans et al., 2016). En el primero se observa que no existe correlación entre la variación del azimut de las capas y los valores calculados de VAR (valores bajos de la variable de correlación R), indicando que no existen VAR posteriores a la adquisición de la remagnetización. Respecto al test del pliegue del oroclinal, éste es poco significativo, con valores inferiores a 0.2 en la varianza circular (ver por ejemplo Pastor-Galán et al., 2017); aun así, la interpretación derivada del mismo es que la dispersión en la orientación de la estratificación es previa a la adquisición de la remagnetización.

No obstante, es necesario indicar que si bien estos test se pueden realizar de manera tentativa sobre nuestros datos con el fin de obtener una idea superficial de su relación con las VAR, los 
resultados podrían no ser correctos. Esto se debe a que los valores de VAR estimados son bajos, posiblemente del orden de la dispersión de la dirección de la estratificación esperable en una cuenca extensional. Por tanto, aunque los datos hubieran registrado VARs reales, éstas podrían no ser evidentes tras la aplicación de sendos test.

\subsubsection{Sobre el grado de coaxialidad en el Alto Atlas}

Otro mecanismo que puede generar dispersión en los datos de estratificación es la no coaxialidad entre los ejes de rotación horizontales previos y posteriores a la adquisición de la remagnetización. Según los modelos expuestos en el apartado 4.2, este proceso genera variación en la distribución de los círculos menores, pero afecta muy poco tanto al cálculo de la dirección de referencia como a los paleobuzamientos (Fig. 9.12). La poca afección en los datos de salida es la parte positiva, mientras que la negativa es que hace difícil de detectar la no coaxialidad.

Un método útil para detectar la no coaxialidad es el propuesto por Torres-López et al. (2016), en el que comparan la distribución de los polos de la estratificación y la paleoestratificación

\section{Inclination $=45^{\circ}$}
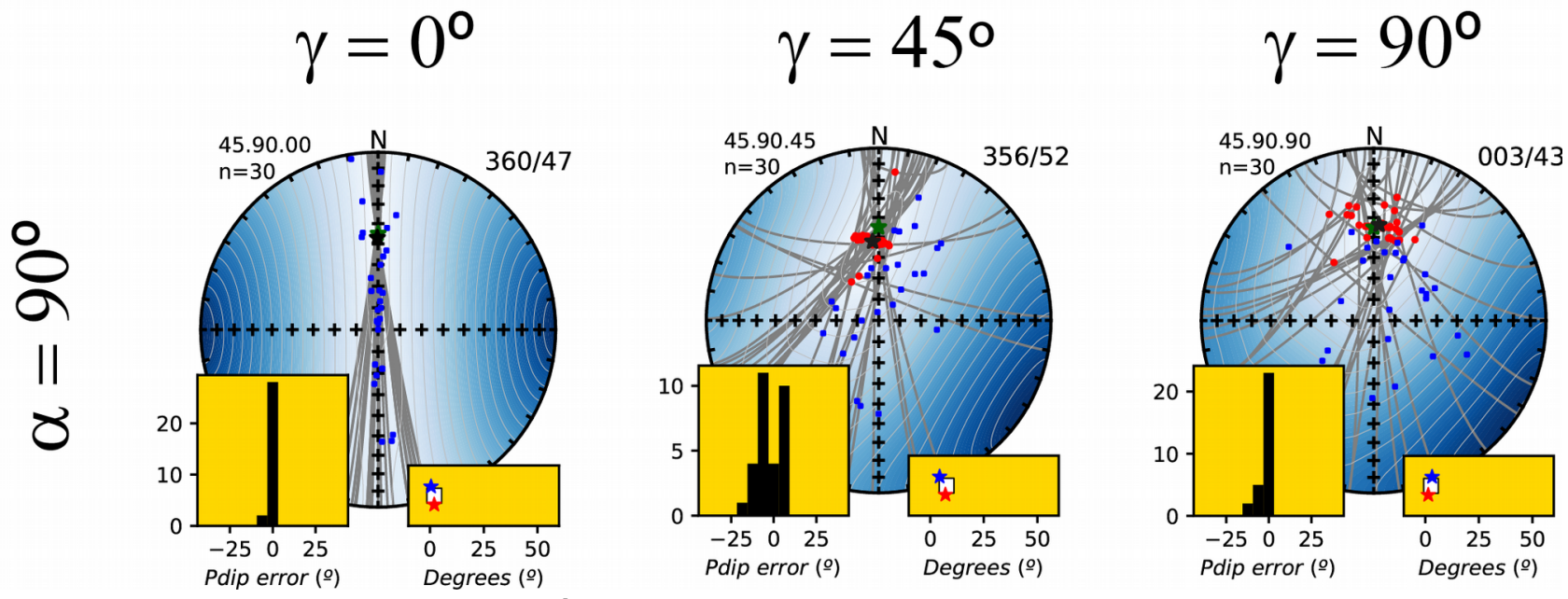

Figura 9.12 Proyecciones de igual área mostrando tres poblaciones de 30 datos en los que los ejes horizontales de rotación, previos y posteriores a la remagnetización, forman diferentes ángulos ( $\mathrm{\gamma}$ ). Se ha considerado un caso similar al Atlas, en el que la declinación de la remagnetización y la estructura general forman $90^{\circ}(\alpha)$ e inclinación intermedia $\left(45^{\circ}\right)$ de la remagnetización original. En los gráficos menores, situados abajo a la izquierda, se muestra el error en paleobuzamiento, en el situado abajo a la derecha, el error cometido en el cálculo de la dirección de remagnetización (cuadro blanco), así como en su declinación (estrella azul) e inclinación (estrella roja). Ésta es parte de la figura 5 del apartado 4.2.

Figure 9.12 Equal area projections showing three data sets with 30 data in which the horizontal axes of rotation pre- and post-remagnetization have different angles $(\gamma)$. Both the angle between the original remagnetization declination and the general structural trend $\left(\alpha=90^{\circ}\right)$ and the inclination of the remagnetization $\left(45^{\circ}\right)$ are similar to the Atlas. The left insets show the error in paleodip and the right insets show the error in the calculated remagnetization direction in overall (white square), in declination (blue star) and inclination (red star). This is a section of the figure 5 of the section 4.2. 
de las estaciones que presentan deformación predominante posterior (paleobuzamiento $<30 \%$ buzamiento actual) y previa (paleobuzamiento > 70\% buzamiento actual) a la remagnetización, respectivamente (Fig. 9.13). En nuestro caso, encontramos que los datos en ambos casos son acordes a un plegamiento NE-SO a ENE-OSO de eje horizontal. Si bien existe una ligera diferencia entre ambos ejes $\left(\sim 10^{\circ}\right)$, no es significativa, y la posible no coaxialidad entre los ejes de rotación previos y posteriores a la remagnetización parece que no superaría dicho valor.
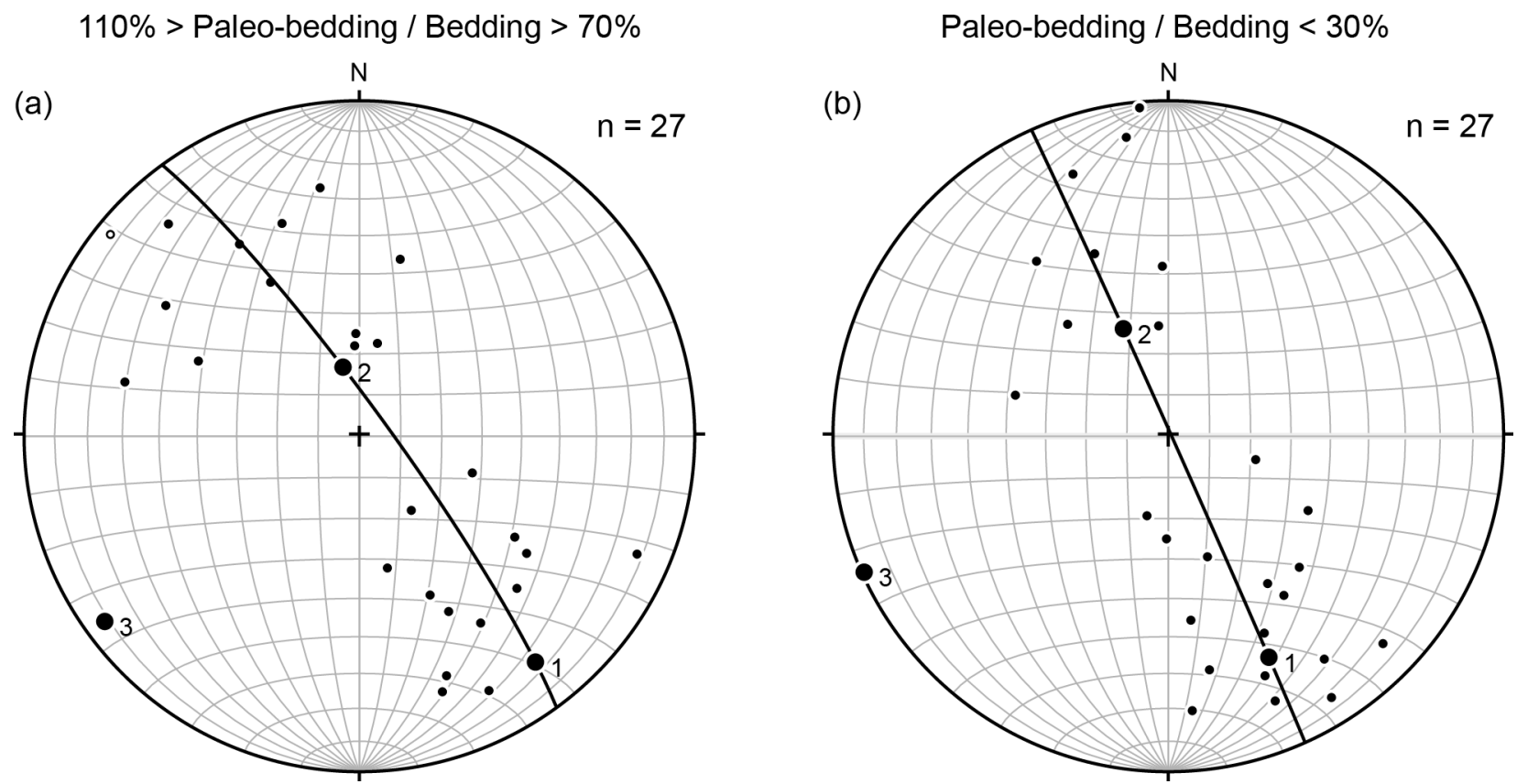

Figura 9.13 Proyecciones de igual área mostrando (a) los polos de la paleo-estratificación de las estaciones que han sido deformadas principalmente durante la etapa previa a la remagnetización, es decir, el paleobuzamiento es similar al buzamiento actual, y (b) los polos de la estratificación de las estaciones cuya deformación es principalmente posterior a la remagnetización, es decir, el paleobuzamiento es próximo a la horizontal. Se muestra en ambos casos el mejor ajuste cilíndrico a los datos.

Figure 9.13 Equal area projections showing (a) the pole of the paleo-bedding of sites whose deformation was generated mainly during the pre-remagnetization stage and (b) the pole of the bedding for sites deformed mainly during the post-remagnetizacion stage. In both case the cylindrical best fit is showed.

\subsubsection{Propagación de la incertidumbre de las direcciones paleomagnéticas al paleobuzamiento}

Considerando la restitución de una estación paleomagnética cuyo círculo menor contiene la dirección de referencia calculada, la influencia que la incertidumbre de la dirección paleomagnética $\left(\alpha_{95}\right)$ tiene en el paleobuzamiento depende del ángulo apical del círculo menor.

Pongamos un ejemplo: consideremos dos direcciones paleomagnéticas con igual incertidumbre $\left(\alpha_{95}=10^{\circ}\right)$ y diferentes ángulos apicales de sus respectivos círculos menores $\left(\mathrm{Ap}_{1}=\right.$ $65^{\circ} ; \mathrm{Ap}_{2}=25^{\circ}$ ) (Fig. 9.14a). Cuando variamos el buzamiento de una capa, el polo de la misma se desplaza a lo largo del plano- $\pi$, es decir, del círculo mayor (Ap $=90^{\circ}$ ) vertical perpendicular a la capa (el plano de movimiento del polo de la capa), mientras que la dirección paleomagnética se desplaza a lo largo de un círculo menor $\left(\mathrm{Ap} \leq 90^{\circ}\right)$. Aunque la rotación sufrida por ambos vectores 
es la misma, la traslación absoluta que sufren es distinta dado que forman ángulos diferentes con el eje de rotación. En otras palabras, la rotación necesaria (variación de buzamiento) para que una dirección paleomagnética rote un ángulo equivalente a su cono de confianza depende del Ap del círculo menor que la contiene, cuyo eje es la dirección de estratificación. La figura 9.14 nos ayuda a ver esto de la siguiente manera: si trazamos dos círculos mayores, uno que pase por la dirección paleomagnética media, y otro por el borde del cono de confianza (círculos mayores en líneas discontinuas), el ángulo que existe entre ellos (medido sobre el plano- $\pi$ ) representa la propagación de la incertidumbre en la magnetización dada por el semi-ángulo del cono de confianza sobre el dato de buzamiento de la capa. Podemos observar que dicho ángulo $(\varepsilon)$ es distinto para los dos casos propuestos. Cuando se realiza la restitución de una capa, todo el intervalo de paleobuzamientos en los que la dirección de referencia está contenida por el cono de confianza $\alpha_{95}$ de la dirección paleomagnética, son igualmente válidos. Este intervalo es el ángulo $\varepsilon$, que nos indica la incertidumbre que presenta un paleobuzamiento, es decir, el error de paleobuzamiento.

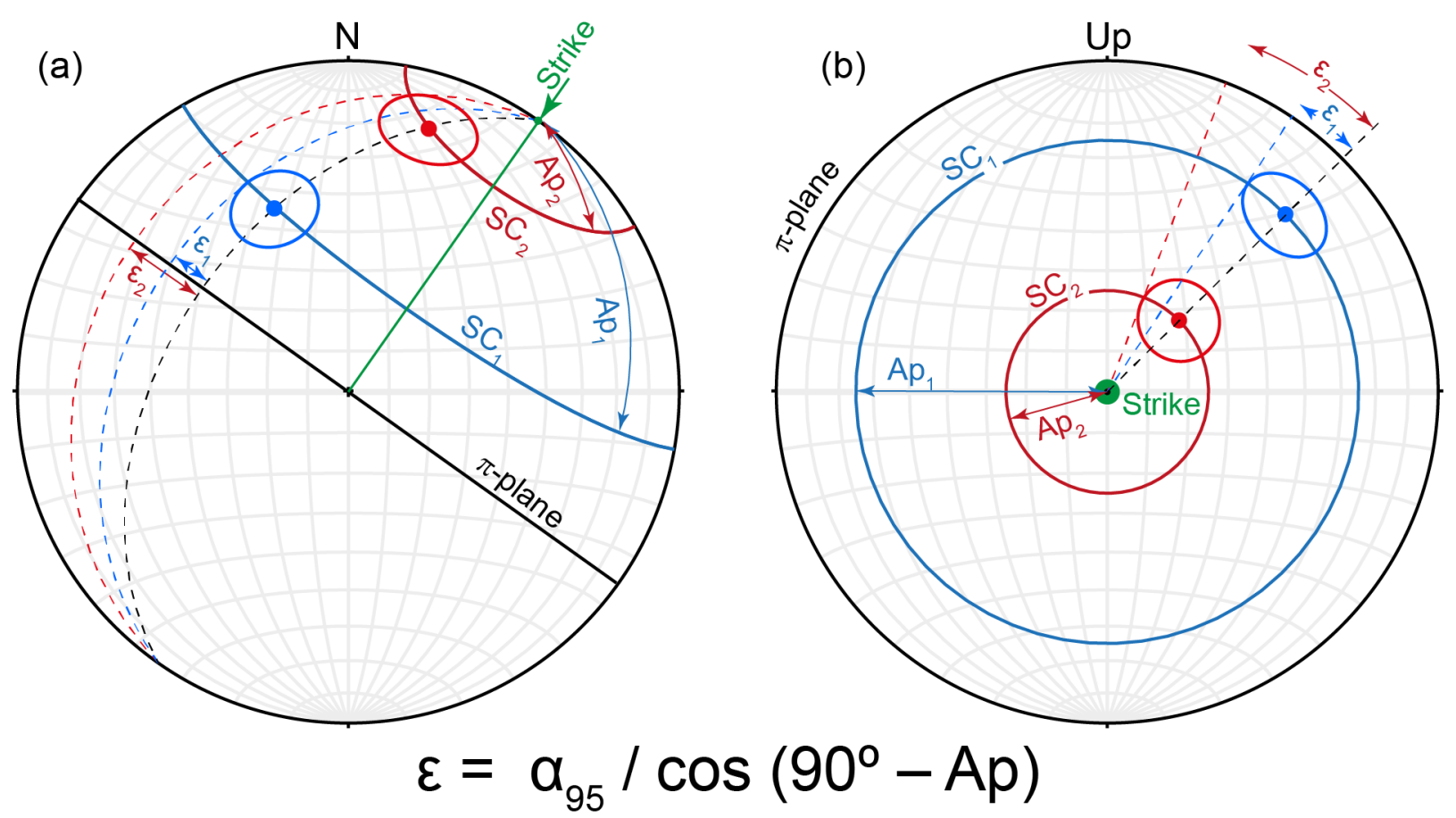

Figura 9.14 Proyecciones de igual área mostrando (a) el hemisferio superior y (b) proyección perpendicular a la dirección de la estratificación de la misma configuración de círculos menores y direcciones paleomagnéticas. Los colores azules y rojos muestran dos ejemplos similares pero con círculos menores de diferente ángulo apical (Ap), que se traduce en diferentes valores del error en el paleobuzamiento $(\varepsilon)$ para un mismo error en la dirección paleomagnética $\left(\alpha_{95}\right)$. La relación entre $\varepsilon$, Ap, y $\alpha_{95}$ viene dado por la ecuación mostrada. El plano- $\pi$ es el plano de movimiento del polo la estratificación cuando se varía el buzamiento de la capa (i.e., la capa es rotada a lo largo de su dirección).

Figure 9.14 Equal-area projections showing (a) the upper hemisphere (b) and view perpendicular to strike of the same configuration of small circles and paleomagnetic directions. Blue and red colors correspond with two similar examples with different apical angle (Ap). Different Ap values imply different paleodip errors $(\varepsilon)$ for equal errors of the paleomagnetic direction $\left(\alpha_{95}\right)$. $\varepsilon$, Ap, and $\alpha_{95}$ are related by the showed equation. $\pi$-plane corresponds with the movement plane of the pole bedding during tilting. 
Siguiendo la misma línea, del mismo modo que el cono de confianza asociado a las direcciones paleomagnéticas tiene influencia en $\varepsilon$, también la tiene la elipse de confianza asociada a la dirección de referencia. Además, en este caso, no será homogénea en todas las direcciones del espacio, sino que será variable dependiendo de la relación entre la orientación de los semi-ejes de la elipse y el círculo menor definido en cada estación.

La proyección de las incertidumbres provenientes de las direcciones paleomagnéticas, la dirección de confianza, así como de la orientación de la estratificación, podrían definir el error del paleobuzamiento. Sin embargo, esto solamente sería cierto si se trabajase solo con círculos menores que contuvieran la dirección de referencia, o al menos los conos de confianza de las direcciones paleomagnéticas intersecaran con la elipse de confianza asociada a la dirección de referencia. Sin embargo, cuando se trabaja con datos reales y en base a la experiencia obtenida de esta tesis doctoral así como la proveniente de trabajos previos, indican que los datos pueden ser igualmente válidos.

En cualquier caso, utilizar este intervalo de incertidumbre podría ser interesante. Quizá un posible procedimiento de trabajo futuro sería dar diferentes calidades a las estaciones paleomagnéticas, por ejemplo calidad A a aquellas en las que existe intersección entre el cono y la elipse y calidad B para las que no, y a las primeras adjudicarles un error que proviniese de las tres incertidumbres comentadas anteriormente. Este planteamiento de trabajo podría ser útil y objetivo a priori, y permitiría ofrecer un criterio de calidad potencialmente importante para posibles usuarios no familiarizados con los métodos de restitución por círculos menores. Sin embargo, habría que analizar todas las posibles causalidades para evitar ofrecer una falsa confianza de los datos. Un ejemplo de esto puede ser el siguiente. Imaginemos una dirección paleomagnética con alta incertidumbre (por ej. $\alpha_{95}=15^{\circ}$ ), cuyo cono de confianza interseca con la elipse de la dirección de referencia, definiendo una horquilla para el paleobuzamiento de $5^{\circ}$ y calidad A. Imaginemos ahora la misma dirección, con una menor incertidumbre (por ej. $\alpha_{95}=7^{\circ}$ ); en este caso no habrá intersección entre ambas y la calidad de la estación será B. Pero, ¿ofrece mayor garantías el primer caso que el segundo? Claramente no. Desde mi punto de vista y por el momento, los criterios de calidad subjetivos (ver siguiente subapartado) son de máxima importancia, y deben valorarse estación a estación. Hasta que la estimación del error en el paleobuzamiento no esté bien refinada y constreñida, es mejor cualificar que cuantificar. 


\subsubsection{Consideraciones sobre el uso de los SC para restituir estructuras}

A continuación se indican brevemente algunos aspectos que es conveniente considerar cuando se utilizan los círculos menores para el cálculo de la dirección de remagnetizaciones, así como para la restitución de las estructuras.

En relación al proceso de remagnetización.

- Es posible que se trate de una remagnetización regional, sincrónica a escala geológica o, por el contrario, la remagnetización puede responder a diferentes eventos (por ej. emplazamiento de diferentes láminas de cabalgamiento). Para poder aplicar los métodos basados en los círculos menores, la remagnetización debe ser sincrónica a escala geológica. Esta condición de sincronía a escala geológica es también aplicable cuando no hay actividad tectónica durante el proceso de adquisición y el polo paleomagnético virtual tiene un desplazamiento despreciable.

Sobre la calidad de la dirección de referencia calculada.

- ¿ ¿Está bien definida la dirección de referencia calculada? La elipse de confianza y la matriz $\mathrm{A} / \mathrm{n}$ nos ayudan a valorar este punto.

- ¿Existen indicios geológicos en el área de estudio de no coaxialidad o rotaciones diferenciales de eje vertical? La distribución de los círculos menores puede ser útil, dado que es posible que estos dos procesos puedan dar patrones característicos.

- Las rotaciones de eje vertical y los basculamientos regionales post-remagnetización pueden no afectar a la distribución de los círculos menores, la elipse de confianza y la matriz A/n. Sin embargo, la dirección obtenida puede ser errónea también en estos casos.

- Comparar la dirección obtenida con la proveniente de estaciones horizontales y, si está disponible, la curva de deriva polar aparente para el área de estudio, es útil a la hora de analizar la validez de la solución calculada. Como ya se ha indicado, la dirección calculada con un set de datos que ha sufrido rotaciones de eje vertical diferenciales tiende a ser mayor que la esperada. Dependiendo de la orientación de la elipse, y la trayectoria de la curva de deriva polar aparente, puede ser útil tratar de fijar la declinación o la inclinación de la dirección que se va a calcular.

- Hay que recordar que en el proceso de cálculo de la remagnetización, no todos los datos provenientes de las distintas estaciones tienen el mismo efecto. Los círculos menores que más intersecciones producen tienen más peso en la solución final (por ej., aquellos que son definidos por orientaciones de la estratificación perpendiculares a la estructura general). Calcular la dirección con y sin dichos datos ayuda a valorar la importancia de los mismos en el cálculo final, así como tratar de estimar si la dirección calculada está demasiado influenciada por los mismos. 
De cara a la restitución de la estructura.

- ¿Cómo es la distribución de los círculos menores? ¿Cuál es la precisión que puedo esperar en la restitución de la paleo-estructura? Debido al propio proceso del cálculo de la dirección de remagnetización, la elongación de la elipse asociada a ésta suele presentar un alto grado de paralelismo con los círculos menores. Esto aumenta la incertidumbre en el cálculo del paleobuzamiento y debe ser tenido en cuenta, sobretodo cuando no se cuenta con una referencia externa de la dirección esperada (por. ej. la curva de deriva polar aparente de la placa).

- Para cada estación en particular, ¿la dirección de referencia está cerca del círculo menor (pequeños valores del ángulo entre el círculo menor y la referencia)? ¿Cuál es el valor del $\alpha_{95}$ ? ¿Se observó alguna anomalía en el campo en esta estación? Valores por encima de la media en los dos ángulos indicados deben desecharse sistemáticamente; posiblemente dicha estación paleomagnética está sujeta a errores en los datos de entrada (estratificación y/o dirección paleomagnética), han sufrido procesos locales de no coaxialidad, etc.

- Por otro lado, analizar la coherencia estructural de la geometría restituida suele ser un buen indicador sobre la calidad de los datos de paleobuzamiento obtenidos. Un ejemplo de ello es el flanco norte del anticlinal de Ikkou, donde se observa un tren de pliegues que al ser restituidos presenta un paleobuzamiento uniforme en todo el flanco (Fig. 9.15). La coherencia geológica puede ser un indicador del buen funcionamiento del método.

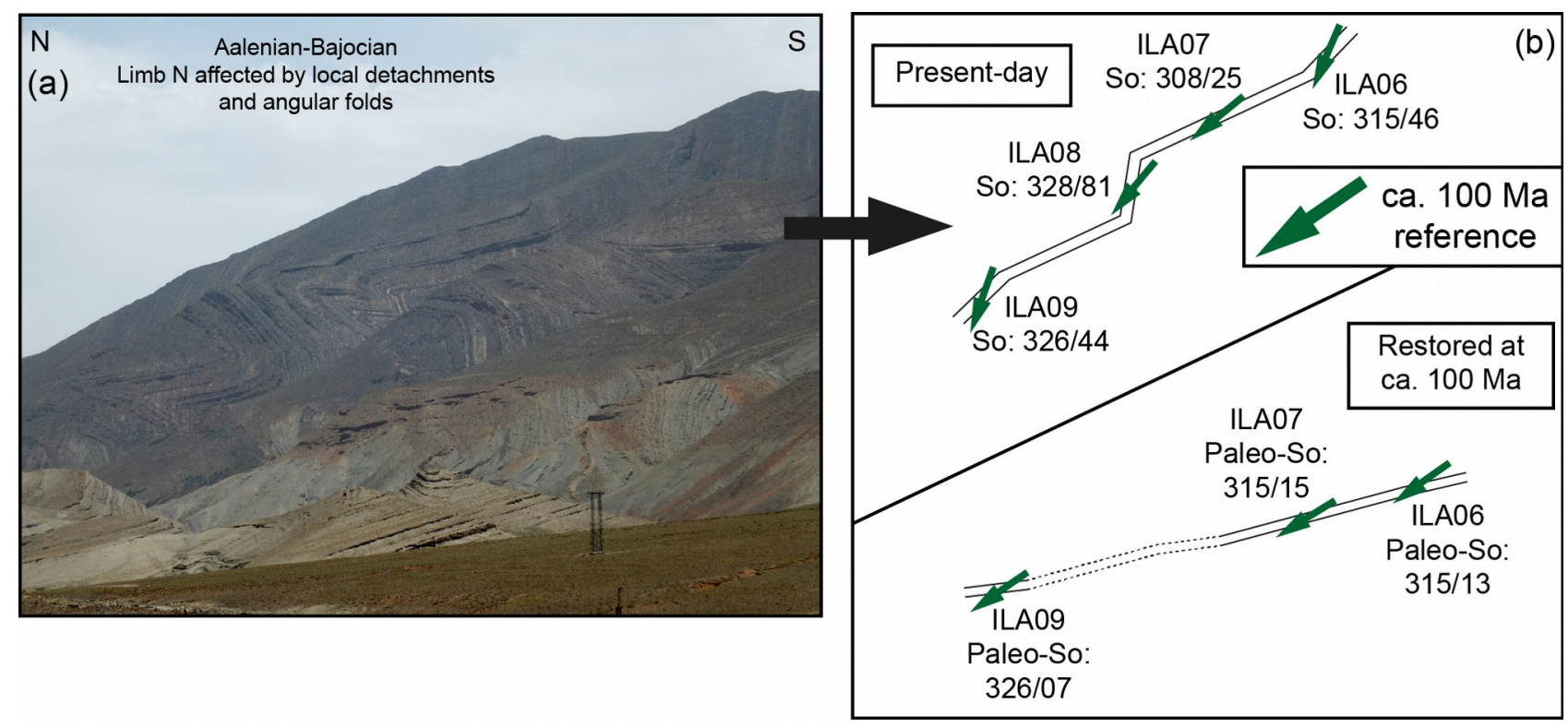

Figura 9.15 Ejemplo de la restitución del flanco N del anticlinal de Ikkou en el que se observa un tren de pliegues en su disposición actual (a). Cuando se restituye uno de estos trenes de pliegues (b), el paleobuzamiento es similar en todas las estaciones con independencia del buzamiento actual, indicando coherencia en la plaeo-estructura.

Figure 9.15 Example of restoration of the $N$ limb of the Ikkou anticline where can be observed angular folds in the present-day geometry (a). When the limb is restored (b) the paleodips are similar independently of the present-day dip, indicating a coherence of the paleo-structure. 


\subsection{Aportaciones a la geología regional}

Actualmente el modelo evolutivo del Alto Atlas Central (AAC) más consensuado es el descrito por Frizon de Lamotte et al. (2009), que se resume en: (i) primera etapa de rifting durante el Triásico con sedimentación continental dominante y actividad ígnea subaérea, (ii) consiguiente etapa postrift durante el inicio del Jurásico Inferior, (iii) segunda etapa de rift durante el Jurásico Inferior (Toarciense-Aaleniense) (iv) y subsecuente etapa de post-rift desde el Jurásico Medio al Cretácico. Durante esta segunda etapa de post-rift se produce un nuevo evento ígneo (intrusión de rocas esencialmente básicas, diques y coladas basálticas) y se eleva el Arco Marroquí Occidental (AMO) (ambos procesos parecen estar relacionados y podrían ser consecuencia de una anomalía térmica en el manto); los materiales depositados son predominantemente continentales. (v) Inversión tectónica de la cuenca durante el Cenozoico debido a la convergencia N-S entre África e Iberia y Eurasia, con dos etapas principales de deformación durante el Eoceno Superior y el Pleistoceno.

Si bien este modelo modelo evolutivo general es ampliamente aceptado, el estudio de la estructura del AAC, en su estadio actual, y la comparación del mismo con el estadio precompresivo (i.e., momento de la adquisición de la remagnetización albiense-cenomaniense), permite realizar significantes valoraciones sobre la evolución de esta cadena intraplaca. Concretamente, el uso de las técnicas de restitución nos permite cuantificar el basculamiento generado durante la etapa extensiva, esencialmente durante el Jurásico, y compresiva, durante el Cenozoico. Además, aplicadas a estructuras concretas, como los pliegues con foliación de plano axial asociada, nos permiten datar dichas estructuras de manera relativa con respecto a la remagnetización.

No menos relevante es la información proveniente del estudio de los gabros jurásicos que afloran en los núcleos anticlinales. El análisis de las direcciones paleomagnéticas nos permite conocer cómo han sido las rotaciones posteriores al emplazamiento y enfriamiento de dichos cuerpos. Por otro lado, las fábricas magnéticas aportan información sobre las condiciones de emplazamiento de los mismos.

\subsubsection{Origen de la deformación mesozoica}

Ya desde los primeros trabajos modernos realizados en el AAC, la propuesta de una fase de estructuración jurásica (p. ej., Schaer y Persoz, 1976; Mattauer et al., 1977; Studer y du Dresnay, 1980) surge como consecuencia de diferentes observaciones geológicas. Concretamente, la presencia de (i) discordancias dentro de la serie jurásica en los flancos de los anticlinales, (ii) de gabros jurásicos ${ }^{1}$ en el núcleo de estos y (iii) de foliación tectónica regional que en las cercanías de los cuerpos de gabros parece estar relacionada con la intrusión de los mismos (Schaer y Persoz, 1976) y (iv) que es fosilizada por materiales que fueron considerados pertenecientes al cretácico inferior (Mattauer et al., 1977).

1 Si bien la suite ígnea jurásica está compuesta por troctolitas, gabros s.s., monzonitas y sienitas, las rocas estudiadas paleomagnéticamente, y también la más abundantes, son las dos primeras. Por simplicidad, de ahora en adelante nos referiremos a la suite completa como gabros. 
Por otro lado, las diferentes direcciones estructurales presentes en el AAC (N45 $\mathrm{E}$ y $\mathrm{N} 70^{\circ} \mathrm{E}$ ) que generan áreas limitadas por fallas con geometría romboidal (Studer y du Dresnay, 1980) ha sido explicada como (i) superposición de plegamiento cenozoico (de Sitter, 1952, 1964), (ii) influencia de las estructuras heredades del basamento (Beauchamp, 2004; Ibouh, 2004) o (iii) diferentes modelos transcurrentes (Mattauer et al., 1977; Laville y Harmand, 1982; Jenny, 1984) con áreas transtensivas y transpresivas durante el jurásico.

Finalmente, diversos trabajos recientes (Saura et al., 2014; Teixell et al., 2017; Vergés et al., 2017) han postulado a los procesos diapíricos (relacionados con la migración de sales triásicas) como los principales estructuradores de los anticlinales del AAC. Si bien estos procesos ya habían sido propuestos (Ovtracht, 1980) y observados (Ettaki et al., 2007), la ausencia casi generalizada de potentes series de sales y arcillas triásicas en el AAC, así como posiblemente la coincidencia con las tendencias globales en el pensamiento científico y los modelos tectónicos, ha evitado que los procesos halocinéticos no se hayan postulado hasta la última década de manera generalizada como principales agentes en la estructuración del Atlas.

A continuación se discuten los puntos descritos anteriormente con la finalidad de esclarecer qué procesos y en qué grado han actuado en la formación de las características ridges del AAC.

\subsubsection{La compresión jurásica en el Alto Atlas Central}

La compresión jurásica en el AAC surge para explicar distintas observaciones geológicas realizadas durante los años 70 a 90, que pueden ser enumeradas de la siguiente manera:

- Presencia de metamorfismo y pliegues con foliación asociada en las inmediaciones del gabro de Amouguer (estructura cercana a Rich) (Schaer y Persoz, 1976).

- Presencia de foliación tectónica en las inmediaciones de otros afloramientos de gabros jurásicos en el área de Imilchil, con rellenos de minerales hidrotermales asociados a las intrusiones ígneas (Laville y Piqué, 1992). Relación entre los minerales metamórficos y la foliación (Laville et al., 1994).

- Materiales sedimentarios (capas rojas, margas y calizas) atribuidos inicialmente al Cretácico Inferior discordantes sobre los núcleos de los anticlinales (en contacto en ocasiones con los gabros), fosilizando la foliación tectónica (Mattauer et al., 1977).

- El grado de desarrollo de la foliación, así como sus trayectorias, son variables según la distancia a los núcleos gabroicos (Laville y Piqué, 1992), hecho que puede ser interpretado como una relación genética entre metamorfismo e intrusión de los gabros y desarrollo de la foliación (Laville et al., 1994).

- Cambio en la naturaleza de los materiales jurásicos (paso de materiales marinos a continentales) durante el Jurásico Medio, que es interpretado como una elevación del AAC debido a la compresión jurásica (Laville y Piqué, 1992). 
Estas observaciones han favorecido que la posible compresión jurásica en el Atlas se haya considerado de manera recurrente en diferentes trabajos (Laville et al., 2004, y referencias allí incluidas), ya sea considerando a la etapa jurásica el principal evento de estructuración de la cadena, o de entidad menor con respecto a la compresión cenozoica.

Un cambio importante en la línea de pensamiento sobre la evolución del Atlas lo proporcionaron los datos termocronológicos proporcionados por Barbero et al. (2007), quien por medio de datos de huellas de fisión en las rocas plutónicas jurásicas establecen que la exhumación de las mismas se produjo de manera posterior a ca. 50 Ma. Por otro lado, Charrière et al. (2009) realizaron un estudio bioestratigráfico (análisis de carofitas y ostrácodos) en los materiales discordantes sobre los anticlinales que fosilizan la foliación, datando a estos como paleocenos.

Estas dos observaciones favorecieron el cambio de modelo hacia la prolongación del periodo extensivo durante todo el Mesozoico (Frizon de Lamotte et al., 2008; 2009), hasta la inversión cenozoica de la cuenca. Los dos trabajos anteriores evidencian que no se produjo una exhumación total de las rocas ígneas (y por tanto de los anticlinales) hasta el Cenozoico. Si bien la nueva edad propuesta para los materiales discordantes elimina la principal base en que se asentaba la hipótesis de que la foliación se hubiese desarrollado en el jurásico, no indica que no pudiese desarrollarse en dicho momento; que dichos materiales se depositaron durante el paleoceno únicamente indica que la foliación es pre-paleocena. Un hipotético escenario compresivo con desarrollo de foliación e inversión parcial de la cadena es posible, sin que ello tenga que conllevar una exhumación total de los gabros y los anticlinales (recordemos que los materiales afectados por la foliación, así como los gabros, se encontraban a varios kilómetros de profundidad).

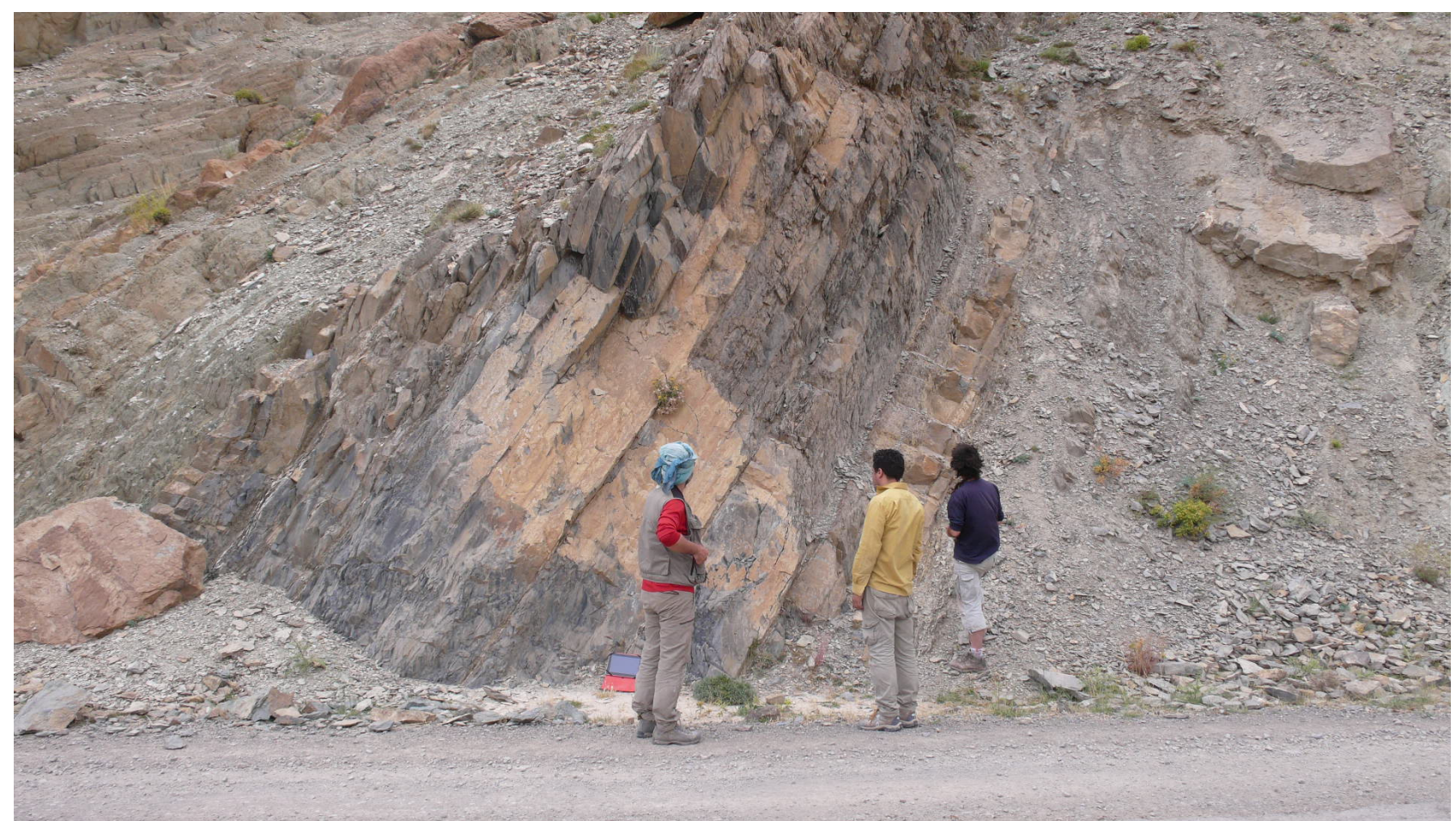

Figura 9.16 Afloramiento de margas y calizas bajocienses en el flanco S del sinclinal de Ikkou, con desarrollo de foliación subvertical. El norte se encuentra a la izquierda.

Figure 9.16 Bajocian marls and limestones at the S limb of the Ikkou syncline with development of sub-vertical cleavage. 
El uso de la reimanación cretácica para la datación relativa de estructuras tectónicas ha permitido constatar que el desarrollo de los pliegues con foliación de plano axial es posterior a la adquisición de la remagnetización (ca. 100 Ma), y debe atribuirse por tanto a la inversión cenozoica. Las observaciones realizadas por diferentes autores que observaban relaciones entre el metamorfismo asociado a la intrusión de los gabros y la foliación (Schaer y Persoz, 1976; Laville y Piqué, 1992; Laville et al., 1994) no son contradictorias con lo anterior. Es probable que, durante la intrusión de los gabros y favorecido por el aumento de la temperatura de los materiales encajantes, se produjera el desarrollo local de foliación asociada a la intrusión de los mismos. Pero el origen de dicha foliación, de carácter local, no puede generalizarse a la foliación regional observada en el área de estudio (Fig. 9.16). Por otro lado, las trayectorias de la foliación y su aparente relación con los cuerpos ígneos (Laville y Piqué, 1992) puede ser consecuencia de las diferencias de competencia entre los materiales carbonatados e ígneos, que pudo favorecer procesos de buttressing y desviación de la trayectoria de la foliación en torno a los cuerpos ígneos.

Finalmente y como se comentará en el subapartado 9.3.1.3, la fábrica magnética registrada por los gabros jurásicos también evidencia que estos materiales fueron emplazados en un contexto extensivo. Los afloramientos occidentales (Anergui, Tasraft y Tassent oriental) muestran una lineación magnética horizontal NO-SE y foliación horizontal; ésta ha sido interpretada como la dirección de extensión durante el emplazamiento de los gabros.

\subsubsection{Los procesos halocinéticos}

Los procesos halocinéticos como principales estructuradores de las ridges han sido considerados desde los primeros trabajos realizados en el AAC (Ovtracht, 1980). Sin embargo, la ausencia casi generalizada de potentes series de sales y arcillas triásicas quizá haya sido la causa de que estos procesos hayan sido considerado secundarios, limitados a la migración local de sales debido a la circulación hidrotermal inducida por el metamorfismo durante la intrusión de los gabros jurásicos (Schaer, 1987).

La importancia de estos procesos en la deformación jurásica ha recobrado fuerza en los últimos años. Trabajos de investigación recientes en el AAC (Saura et al., 2014; Moragas et al., 2016; Martín-Martín et al., 2017; Teixell et al., 2017; Vergés et al., 2017) han evidenciado que los procesos diapíricos (tanto por movilización de sales triásicas como posiblemente por la presencia de arcillas sobre-presurizadas) han jugado un papel importante en el desarrollo de los característicos anticlinales del AAC. Además, la subsidencia jurásica no sólo estuvo controlada por la tectónica extensional, sino también por la movilización de sales (Moragas et al., 2016). Estos trabajos prueban que (i) los procesos halocinéticos y la generación de estructuras salinas han sido una de las fuentes principales de deformación jurásica (p. ej., Martín-Martín et al., 2017) y (ii) la migración de sales ha contribuido de manera significativa a la subsidencia total registrada en la cuenca (Moragas et al., 2016). 
En la actualidad estas estructuras diapíricas presentan morfología alargada, con extensiones de varios kilómetros, y anchuras mucho más reducidas (cuando no se ha producido un cierre total de las mismas suelen presentar desde decenas a centenas de metros), características que permiten clasificarlas como salt-walls o muros de sal. En ocasiones, como en el caso del anticlinal de Ikkou, se observan variaciones de espesor en la serie jurásica entre sendos flancos de las estructuras. Lateralmente, algunas de estas estructuras conectan con anticlinales cuyo núcleo está compuesto esencialmente por gabros: este es el caso de Tassent, donde se relevan zonas con dominio de gabros y otras donde dominan los materiales triásicos, o el caso de Ikkou-Tirrhist, que originalmente debieron ser la misma estructura. Lo anterior permite relacionar los muros de sal con fallas generadas en la etapa extensional, que conectan en profundidad con fallas de basamento a favor de las cuales fue intruido el material ígneo.

Esta estructura actual es fruto de la interacción de la estructuración jurásica con la generada durante la compresión cenozoica, momento en el que las estructuras diapíricas acomodaron gran parte de la deformación, acortándose de manera importante (Teixell et al., 2017) y eliminando evidencias de la etapa extensional. La gran cantidad de material ígneo embebido en las arcillas y sales triásicas (basaltos triásicos y gabros jurásicos) han evitado que algunas de estas estructuras se cierren completamente y se pueda intuir la estructura precompresiva. En otras ocasiones, como en el

(a) Present-day structure

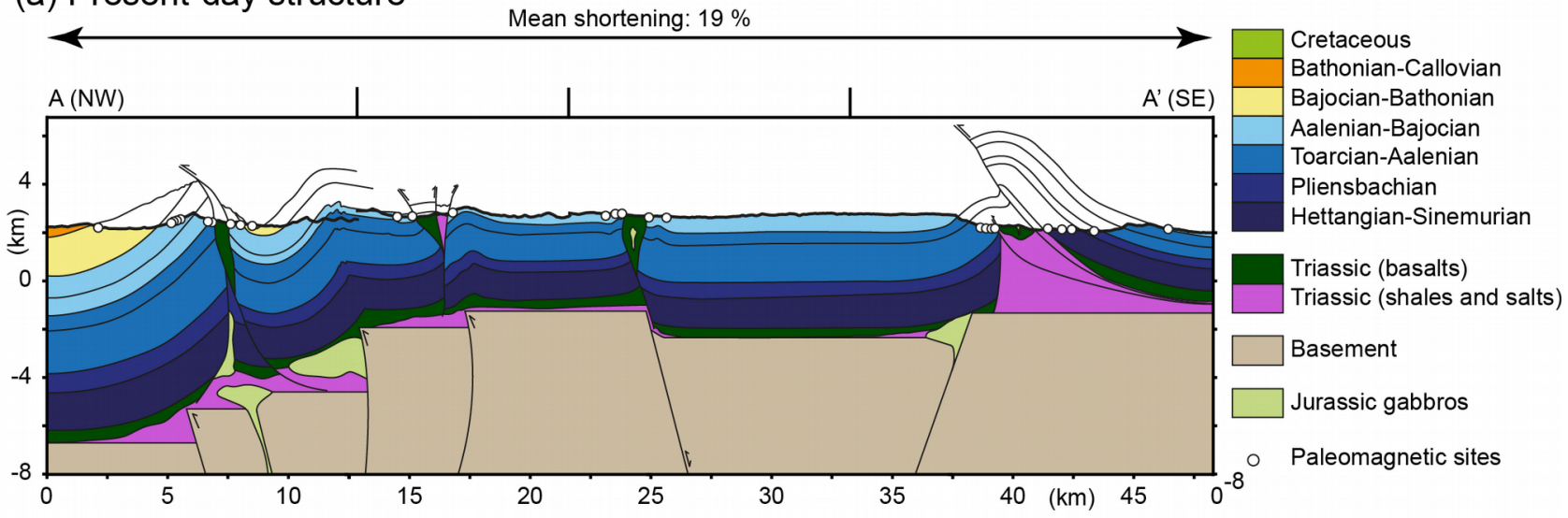

(b) ca. 100 Ma structure

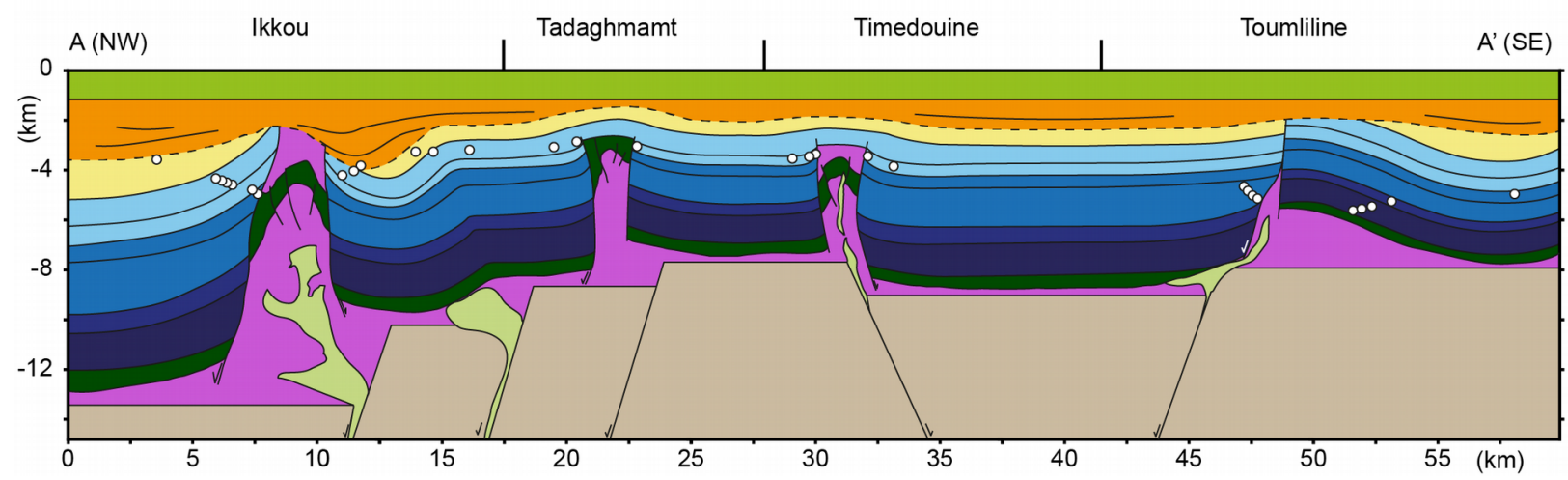

Figura 9.17 Cortes geológicos en su disposición actual (a) y tras la restitución a ca. 100 Ma (b) de las estructuras presentes entre Imilchil y Toumliline. El corte es una composición de los cuatro cortes geológicos presentados en el apartado 6.2

Figure 9.17 Present-day (a) and ca. 100 Ma (b) cross-sections of the structures present between Imilchil and Toumliline villages. The cross-section is composed by the four cross-sections showed in the 6.2. section. 
caso de Tasraft, no se ha producido un acortamiento importante de la misma (posiblemente por su dirección NE-SO, ligeramente oblicua a la compresión predominante N-S) y es posible apreciar arcillas triásicas en su núcleo. Sin embargo, y a pesar de que el acercamiento tectono-estratigráfico permite realizar inferencias cualitativas, queda por responder el grado de desarrollo de las diferentes estructuras durante sendos eventos de deformación. Es decir, ¿̇todas las ridges presentaban el mismo grado de desarrollo jurásico? La comparación entre la estructura actual y la restituida (Fig. 9.17), realizada a lo largo de las cuatro estructuras presentes entre las localidades de Imilchil y Toumliline, permiten observar diferentes grados de estructuración jurásica en las diferentes estructuras.

El anticlinal de Ikkou presenta una geometría actual muy similar a la que presentaba en la etapa precompresiva (Fig. 9.17), con buzamientos moderados a altos en ambos flancos. Esto es indicativo que la estructura de la misma es consecuencia principalmente de la extensión y la actividad halocinética generada durante el Jurásico. Como se ha indicado en la sección 7.3, la deformación cenozoica estaría limitada al apretamiento de la estructura (todo lo que la presencia de basaltos triásicos permitió), desarrollo de foliación y pliegues vergentes al norte. La deformación mesozoica consistió en el levantamiento del núcleo de la estructura que generó el basculamiento de los flancos en las proximidades del núcleo (1-2 km de núcleo). La continuidad lateral de la estructura, y las variaciones de espesor dentro de la serie jurásica muestran a esta estructura como un muro de sal (salt-wall) relacionado con una falla extensional; la diferencia de carga litostática entre ambos bloques fue posiblemente el desencadenante de la migración de sales.

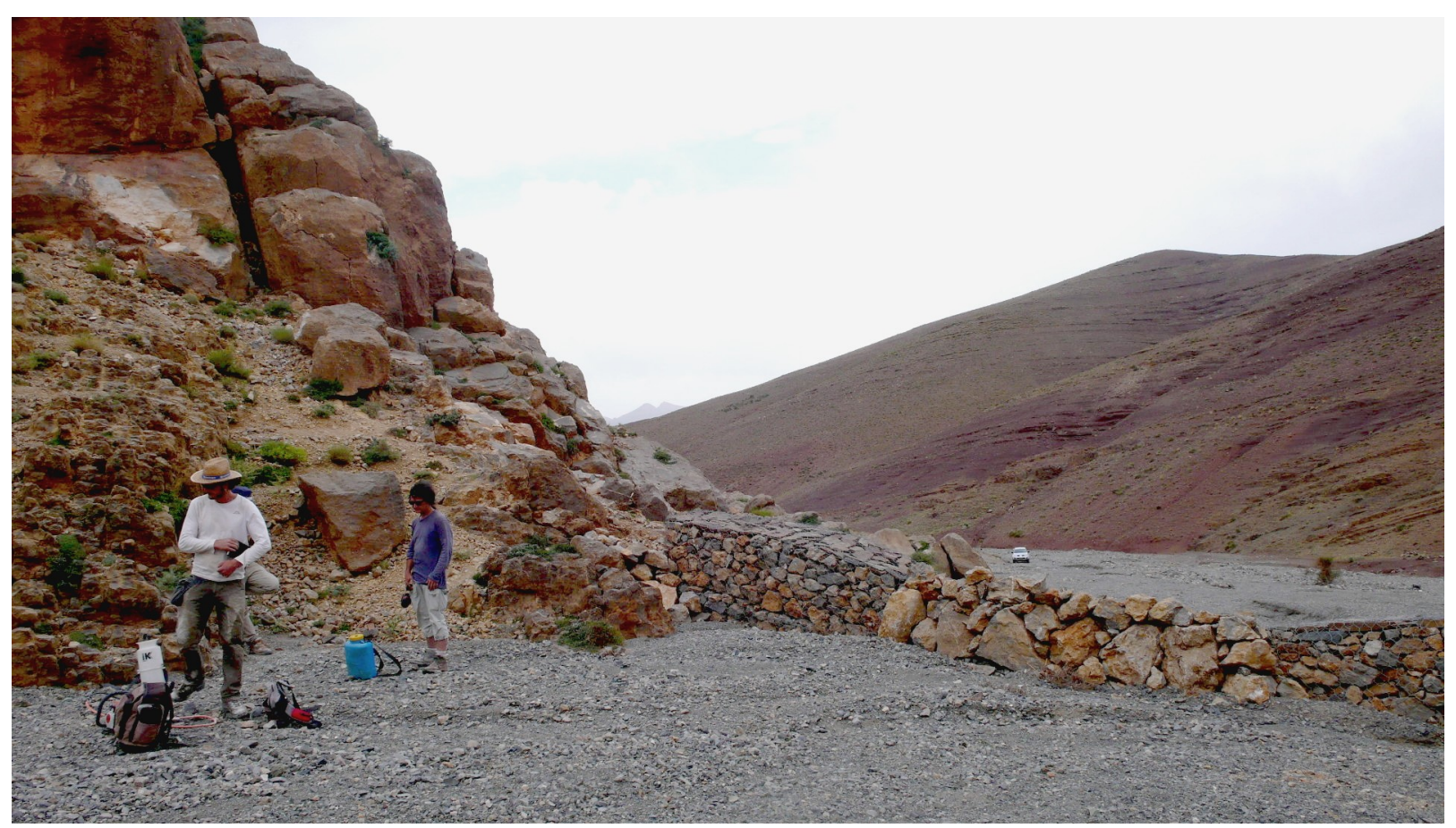

Figura 9.18 Fotografía del flanco sur del anticlinal de Ikkou. A la izquierda (norte), calizas bajocienses subverticales; a la derecha (sur), capas rojas bathonienses subhorizontales. El contacto entre ambas unidades se produce por medio de una discordancia angular.

Figure 9.18 Picture shows the south limb of the Ikkou anticline. In the left (north) appears the Bajocian limestones with sub-vertical attitude; in the right (south) crops out sub-horizontal Bathonian red-beds. The contact between both units is through and angular unconformity. 
Una importante discordancia se observa entre las calizas bajocienses y las capas rojas bathonienses (Fig. 9.18), con altos y bajos buzamientos respectivamente. De hecho, la estructura diapírica corta de manera franca toda la serie jurásica hasta llegar a las capas rojas, que podrían marcar un descenso en la actividad halocinética. De hecho, el análisis de las variaciones de espesor a lo largo de la serie jurásica muestra potencias mayores de carbonatos en el bloque $\mathrm{N}$ que en el sur, que corresponden con los bloques hundidos y levantados respectivamente. Sin embargo, si bien la deformación registrada por las capas bathonienses es inferior, el paleo-sinclinal que se observa en el bloque levantado muestra una importante subsidencia en el mismo durante la sedimentación de las capas rojas (Fig. 9.17). Interpretamos esto como un cambio en la subsidencia: (i) durante el Toarciense-Bajociense, la subsidencia es mayor en el bloque norte debido tanto a causas tectónicas como a una mayor migración de sales desde este bloque dada su mayor carga litostática (Fig. 9.19a). (ii) Posteriormente, durante el Bathoniense, la subsidencia tectónica es prácticamente nula, y la migración de sales es mayor en el bloque levantado dada la mayor disponibilidad de sales que presentaba dicho bloque (Fig. 9.19b). Este segundo evento de migración de sales podrías haber estado parcialmente inducido por la intrusión de las rocas ígneas jurásicas.

\section{(a) Salt deposition}

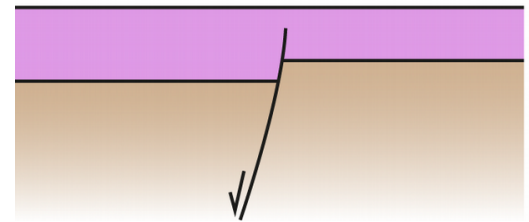

(b) Tectonic subsidence and salt migration I

\section{(c) Salt migration II}

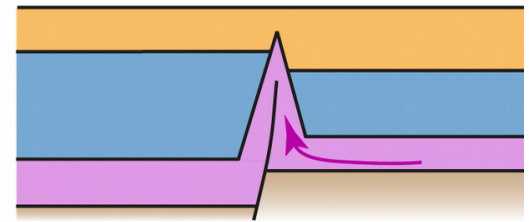

Figura 9.19 Modelo de variación de subsidencia en relación a la actividad tectónica y la migración de sales. (a) Depósito del material salino, con mayor espesor en el bloque hundido. (b) Durante la segunda etapa de sedimentación, la serie es más potente en el bloque hundido debido a la actividad tectónica, y a la mayor migración de sales desde este bloque. (c) En la tercera etapa, la subsidencia tectónica es mínima, y el espacio de acomodación diferencial se genera por migración de sales desde el bloque levantado, que presenta mayor disponibilidad de las mismas.

Figure 9.19 Model illustrating the variations in subsidence according tectonic activity and salt mobilization. (a) Deposition of salt, thicker in the down-throw block. (b) During the first stage the serie is thicker in the hanging-wall block due to the tectonic activity and higher salt migration because of the bigger lithostatic charge. (c) In the thirst stage, tectonic subsidence in minimum and the accommodation space is bigger in the foot-wall block because of bigger salt mobilization.

Un aspecto muy diferente muestra la geometría previa a la remagnetización de las estructuras de Tadaghmamt y Timedouine (Fig. 9.17). La restitución de la estructura muestra que las capas estaban inclinadas de manera contraria a la posición del núcleo, con buzamientos bajos que pasan a ser horizontales hacia los sinclinales. La principal diferencia con la estructura actual es que algunos buzamientos han cambiado de sentido debido al apretamiento y cierre de las estructuras jurásicas. A lo largo de estas estructuras sólo aflora la parte superior de la serie aaleniense y las calizas bajocienses, sin poderse observar discordancias importantes o variaciones de espesor. Además, las calizas bajocienses se disponen en algunos puntos sobre el material triásico que aparece en los núcleos anticlinales, tanto basaltos como arcillas (Fig. 9.20). Esto puede ser indicativo de que la fase principal de la actividad diapírica es previa a estas calizas que fosilizan la 
estructura. En las terminaciones laterales se observan cabalgamientos vergentes al norte generados durante la compresión cenozoica.

Finalmente, la estructura precompresiva de Toumliline es acorde con un salt-roller generado por la presencia de una falla normal con importante salto vertical y migración de sales que generan la deformación del bloque levantado (Fig. 9.17). En el bloque hundido la deformación jurásica es pequeña, estando limitada a las proximidades de la estructura diapírica y la falla normal. En el bloque levantado, la cobertera jurásica muestra buzamientos suaves generando un sinclinal, que puede ser interpretado de manera análoga al sinclinal de Ikkou, por migración de sales durante la sedimentación de las capas bathonienses (Fig. 9.19). El importante salto vertical y la acumulación de sales bajo el jurásico del bloque levantado pudieron favorecer el cabalgamiento de éste último sobre el bloque hundido.

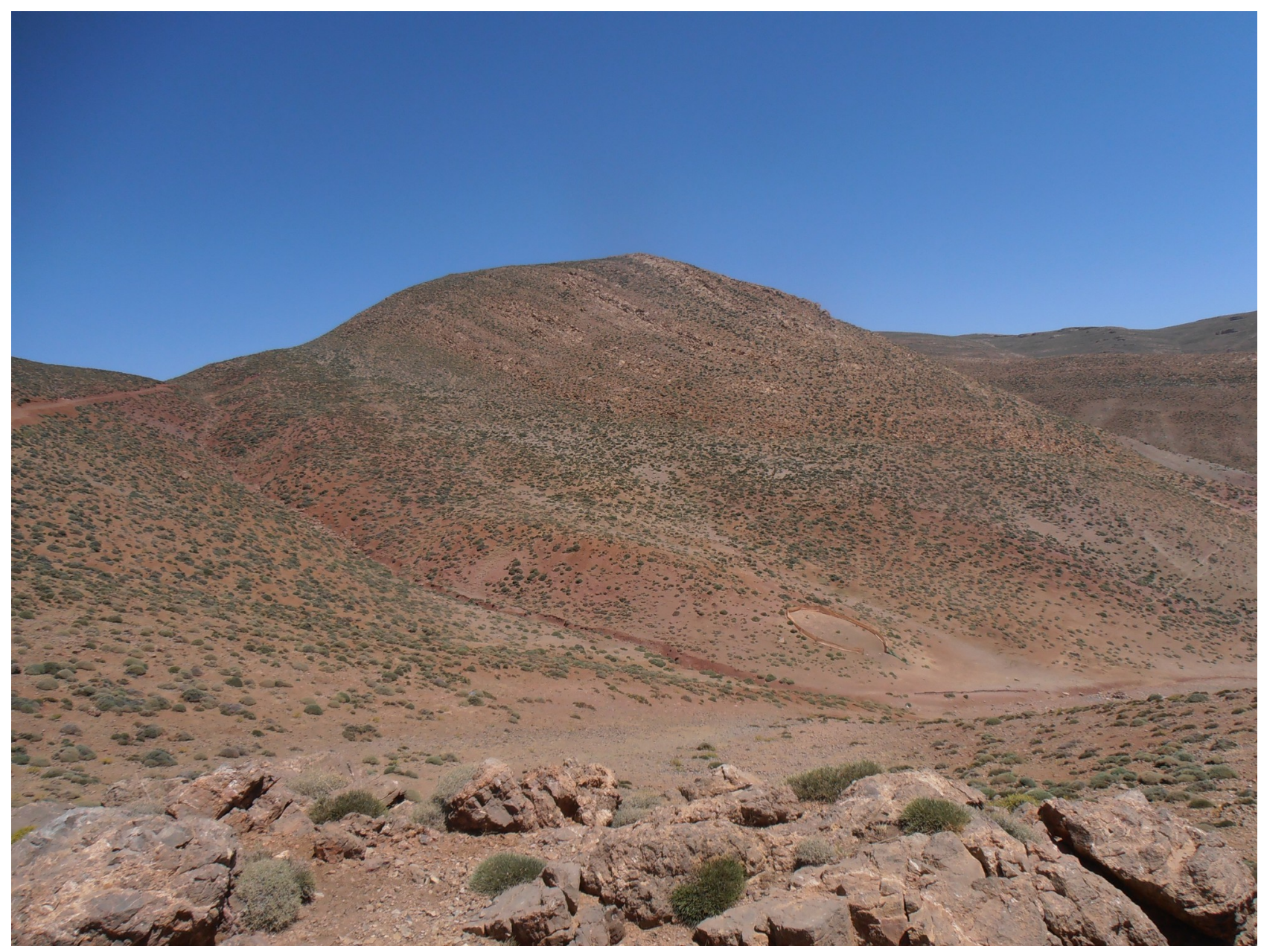

Figura 9.20 Calizas bajocienses dispuestas sobre las arcillas triásicas en el núcleo de la estructura de Tadaghmamt. Norte a la izquierda de la fotografía.

Figure 9.20 Bajocian limestones over the Triassic shales in the core of Tadaghmamt structure. 


\subsubsection{La intrusión de los gabros jurásicos}

La pregunta sobre si existe relación entre la deformación mesozoica y la intrusión de los gabros surge de manera casi automática al observar la relación directa entre grado de estructuración precompresiva y la cantidad de gabros en el núcleo de ciertas estructuras (Fig. 9.21). Sin embargo, valorar ambas expresiones es complicado en el área de estudio debido principalmente a que (i) los gabros y su encajante se encuentran desacoplados; el contacto entre ellos es de tipo mecánico generado en una etapa posterior a la intrusión, y a que (ii) la deformación jurásica registrada por el encajante responde a diferentes procesos, no únicamente a la intrusión de los gabros.

La comparación del grado de deformación entre las estructuras con y sin gabros no es un método válido para tal efecto, dado que la deformación previa a la intrusión no tiene por qué ser homogénea. De hecho, otra explicación válida para la correlación entre grado de deformación jurásica y cantidad de material gabroico puede ser que estos se encuentran en la zona central de la cuenca, donde los procesos halocinéticos pudieron ser más intensos, por ejemplo.

TASRAFT

(a) Present day structure

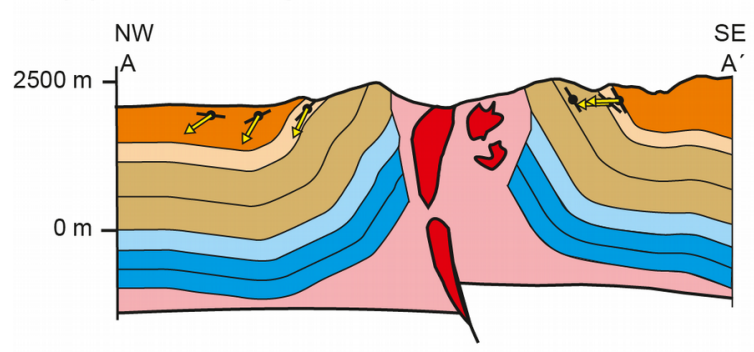

$5000 \mathrm{~m}$
TASSENT

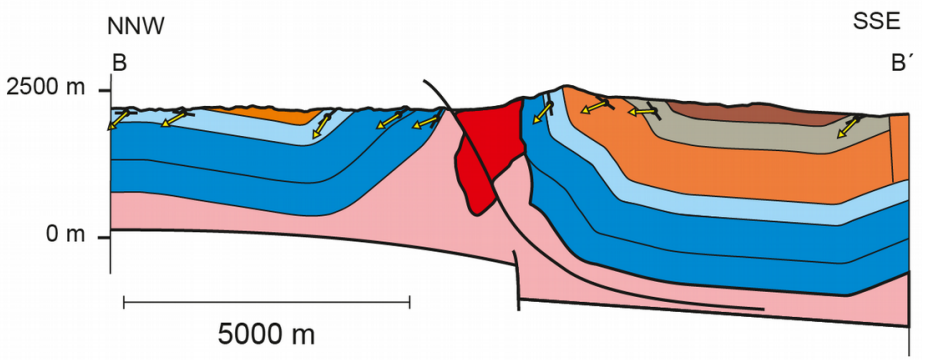

(b) ca. 100 Ma restored structure

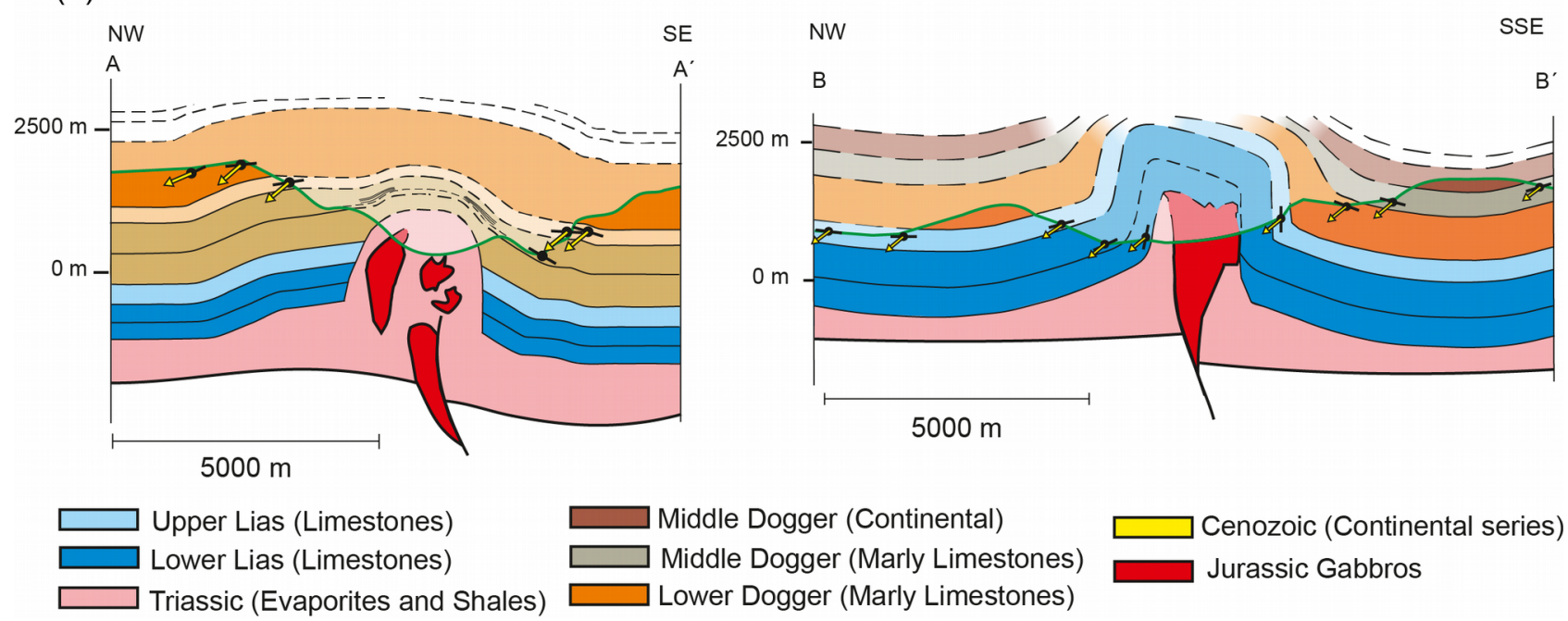

Figura 9.21 Cortes geológicos de los anticlinales de Tasraft y Tassent en su disposición actual (a) y tras la restitución a ca. 100 Ma (b). El anticlinal de Tassent presenta mayor cantidad de material gabroico en el núcleo, y mayor grado de deformación mesozoica. Tomado de Torres-López et al., (2016).

Figure 9.21 Present-day (a) and ca. 100 Ma (b) cross-sections of the Tasraft and Tassent anticlines. Tassent anticline shows larger amount of Jurassic gabbro in its core and also bigger Mesozoic deformation. From Torres-López et al., (2016). 
Finalmente, el análisis de las series syn-compresivas podrían ayudar a valorar el grado de deformación derivado de la intrusión de los gabros durante el Jurásico Superior. Sin embargo, estos se intruyeron en profundidad y pudieron deformar la roca encajante sin tener ninguna expresión en superficie que fuera registrada por los materiales syn-intrusivos, y en caso de hacerlo, responderían más bien a una reactivación de los procesos halocinéticos como consecuencia del aumento de temperatura y la actividad hidrotermal durante la actividad ígnea (Schofield et al., 2014)

Según lo expuesto en el apartado 7.2, los anticlinales con presencia de gabros en el núcleo pueden dividirse en dos tipos de estructuras. Por un lado, las estructuras occidentales (Tipo A; Tasraft y Tassent occidental) presentan núcleos con mayor proporción de rocas triásicas (basaltos y arcillas rojas) que de gabros (Fig. 9.21a), mientras que el núcleo de las estructuras orientales (Tipo B; Tassent oriental, Anefgou y Tirrhist) está compuesto casi en su totalidad por gabros (Fig. 9.21b). Estas diferencias no solo radican en la relación entre las rocas aflorantes en el núcleo, sino que hay más variaciones entre ellos que podemos resumir en los diferentes puntos:

(1) Menor tamaño de los cuerpos de gabro en el tipo A, que se encuentran más fragmentados y limitados por material triásico (Fig. 9.22a). En los afloramientos tipo B (Fig. 9.22b) se observan fracturas que limitan bloques, pero siempre presentando un aspecto compacto.

(2) Mayor alteración en los afloramientos tipo A, que se traduce en menor estabilidad de la señal paleomagnética. En Tasraft, por ejemplo, la componente característica sólo ha podido aislarse en 3 de las 8 estaciones paleomagnéticas.

(3) La componente característica analizada en ambos tipos de gabros indican que han sufrido rotaciones post-emplazamiento según ejes horizontales paralelos a cada estructura, de sentido antihorario (mirando hacia el NE o ENE). Esto es coherente con la vergencia dominante hacia el norte observada en las estructuras (Fig. 9.23).

(4) Las rotaciones anteriores son mayores en las estructuras tipo A que en las de tipo B. Esto pudo ser favorecido por la mayor libertad de rotación de bloques pequeños embebidos en material dúctil triásico (tipo A) que la que presentarían bloques de mayor tamaño (tipo B).

(5) Las rotaciones post-emplazamiento y post-remagnetización inferidas por medio del paleomagnetismo en gabros y calizas, respectivamente, indican diferencias respecto a los ejes y las magnitudes de rotación. Por un lado, esto implica un desacoplamiento entre ambos, al menos durante la compresión cenozoica. Por otro, como es el caso de las estructuras de Tirrhist y Anefgou, estas diferencias son leves y los valores de rotación son bajos $\left(<50^{\circ}\right)$, indicando probablemente que la situación actual de los gabros es similar a la de su emplazamiento.

(6) Los afloramientos de tipo B son sistemáticos ensanchamientos de los anticlinales. Dichos ensanchamientos pudieron generarse bien durante el emplazamiento de los gabros, por empuje lateral y consecuente deformación de la roca encajante (debido a las mencionadas limitaciones de espacio), o durante el cierre de las estructuras en el cenozoico (las zonas con predominio de rocas dúctiles triásicas permitirían mayor acomodación del acortamiento). 
Por otro lado, la fábrica magnética refleja la petrofábrica de los gabros generada durante su emplazamiento, aportando valiosa información sobre los procesos que se dieron lugar en dicho momento. En las estructuras tipo A presenta una lineación horizontal NO-SE (perpendicular a las estructuras) y foliación horizontal, mientras que en aquellos de tipo B la lineación es NE-SO (paralela a las estructuras). Cabe decir que, de acuerdo a diferentes estudios petrológicos y geoquímicos (Essaifi y Zayane, 2018; y referencias allí incluidas), los gabros y resto de rocas ígneas jurásicas son consecuencia de un proceso de cristalización fraccionada a baja presión (10-15 km), y un posterior proceso de ascenso diapírico durante el enfriamiento. Esto sitúa las cámaras magmáticas aproximadamente en los niveles dúctiles del Triásico Superior, bajo la cobertera jurásica. Es fácil pensar que el magma pudo reemplazar dichos materiales plásticos formando lacolitos, tal y como se observa en los modelos analógicos (Román-Berdiel et al., 1995).

De acuerdo a la fábrica magnética observada, las observaciones previas, y la profundidad de emplazamiento, interpretamos ambos tipos de distinta manera. El primer tipo de fábrica se interpreta como tectónica, reflejo de la dirección de extensión NO-SE en el momento de intrusión de los gabros; estos se emplazarían sin limitaciones de espacio, reemplazando a los materiales dúctiles triásicos. Por el contrario, la fábrica tipo B es interpretada consecuencia del emplazamiento de los gabros en núcleos anticlinales, con limitaciones de espacio por la presencia de materiales rígidos carbonatados, de modo que el flujo de magma sería paralelo a las estructuras previas.

Respecto a la deformación que pudieron generar en la roca encajante, por un lado parece que ésta estaría limitada a las calizas del Jurásico Inferior, dada la profundidad estimada a la que se emplazaron las cámaras magmáticas. Por otro, sólo en las estructuras tipo B es esperable que el emplazamiento de los gabros pudiera deformar las rocas encajantes, dada la fábrica magnética de ambos tipos de estructuras

(a) Type A Tasraft

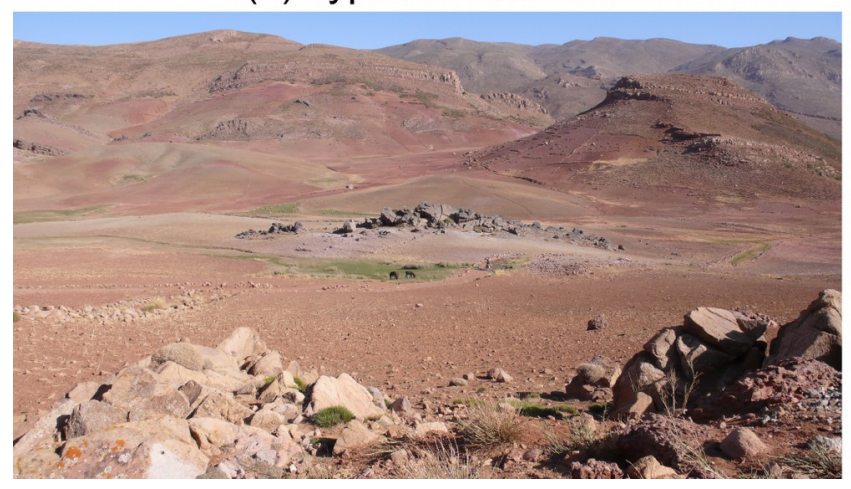

(b) Type B Tirrhist

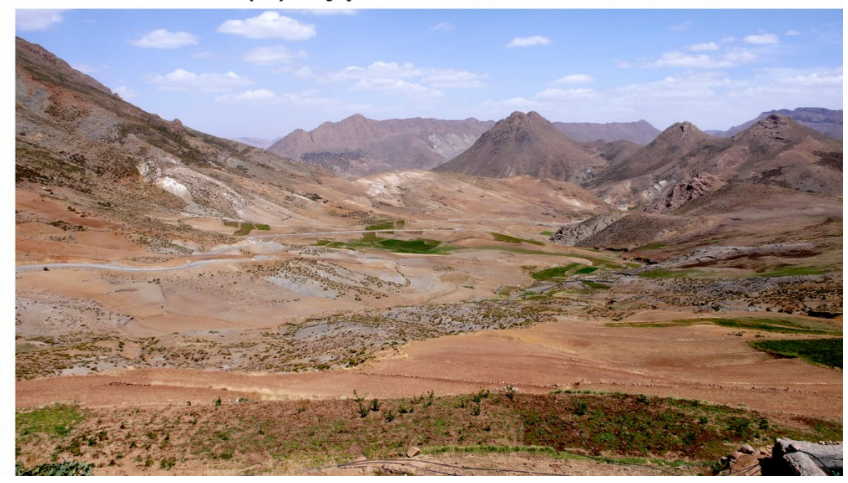

Figura 9.22 Fotografías del núcleo de los anticlinales de Tasraft y Tirrhist. Los afloramientos tipo A (a) presentan baja proporción de gabros jurásicos (colores marrones en primer plano) con respecto arcillas y basaltos triásicos, predominando los colores rojos y negros. Por el contrario, en los afloramientos tipo B (b) los gabros jurásicos son lo materiales dominantes en el núcleo, dando tonalidades marrones a los mismos.

Figure 9.22 Pictures of the core of Tasraft and Tirrhist anticlines. Type A outcrops (a) are characterized by large amounts of Triassic shales and basalts regarding Jurassic gabbros, dominating reddish colors. On the other hand, in type B outcrops (b) gabbros and brownish colors are dominating. 


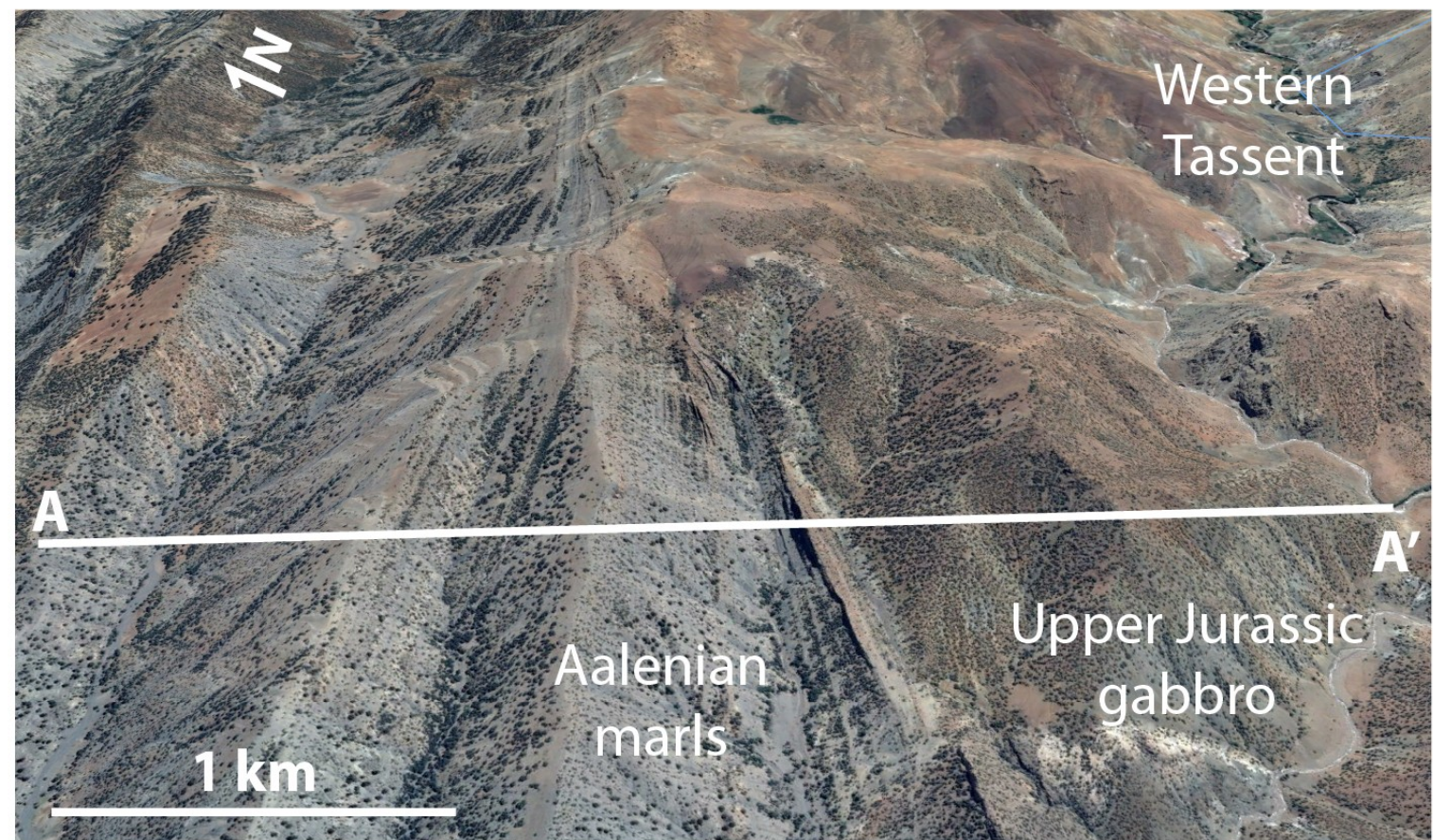

A

$A^{\prime}$

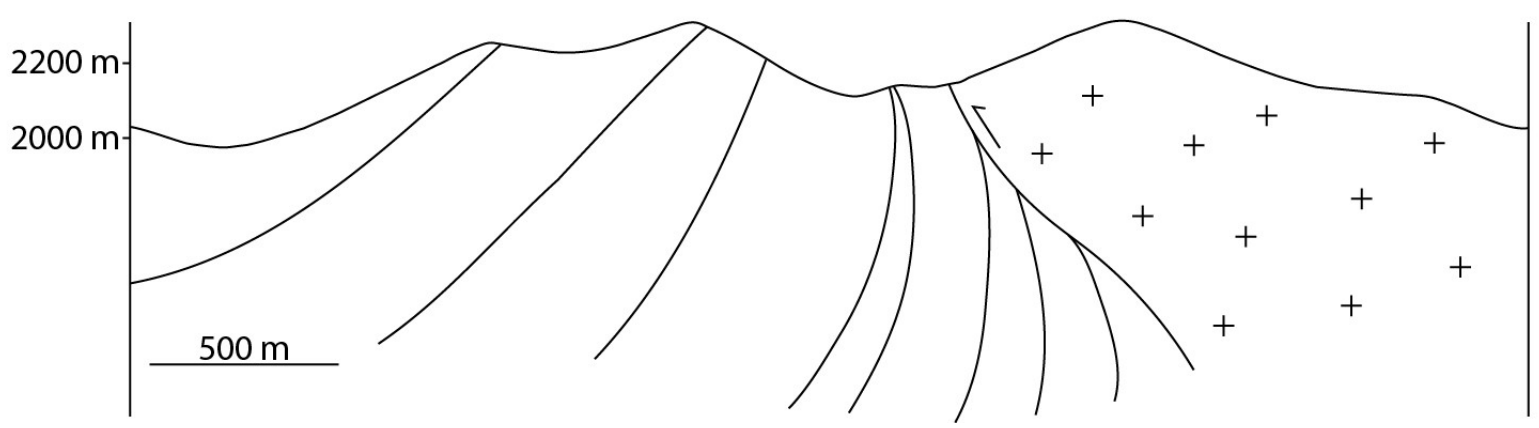

Figura 9.23 Imagen del Google Earth y corte geológico mostrando los gabros de Tassent oriental cabalgando hacia norte sobre las margas aalenienses. Las capas invertidas de margas muestran aumento de espesor hacia el norte.

Figure 9.23 Google Earth image and cross-section showing the western Tassent gabro overthrusting the Aalenian marls. Overturned Aalenian beds show a thickening towards the north.

\subsubsection{Estilo de deformación}

La estructura actual del AAC se caracteriza por anticlinales apretados (Fig. 9.24a), bastante simétricos pero con ligera vergencia norte y alto buzamiento de sus flancos. Estas estructuras limitan sinclinales amplios con bajo buzamiento de sus capas de manera general (Fig. 9.24c); en ocasiones se observan sinclinales angulares con buzamientos más elevados. Una pauta bastante generalizada es la homogeneidad de materiales aflorantes en el área de estudio, que está limitada principalmente a los carbonatos y capas rojas del Jurásico Inferior terminal y el Jurásico Medio. Sólo en algunos de los anticlinales afloran materiales más antiguos del Jurásico Inferior, como es el caso de Toumliline. A continuación se exponen distintos puntos de interés para la comprensión del estilo de deformación en el área de estudio. 
(1) Teixell et al. (2003) estiman casi $30 \mathrm{~km}$ (18\%) de acortamiento en la transversal de Imilchil, acomodado principalmente en los bordes del Atlas donde la serie es menos potente y se favorece el desarrollo de láminas de cabalgamiento despegadas de la serie triásica. En la zona de estudio, el acortamiento medio de las estructuras es del 19\%, mínimo en las estructuras de Timedouine y Tadaghmamt (14\% y 16\% respectivamente) y máximo en la estructura de Ikkou (27\%); estas variaciones de acortamiento están controladas por el grado de estructuración previa: Ikkou, más desarrollado durante el Jurásico, presenta un mayor acortamiento, y lo contrario para las otras dos estructuras. A los valores de acortamiento previo habría que sumar el acomodado por la generación de foliación tectónica.

(2) Los anticlinales forman estrechas bandas donde se acumula la deformación, que interrumpen áreas tabulares más amplias, con poca deformación. Por otro lado, la serie jurásica es potente (6-12 km), preservándose actualmente al menos $4 \mathrm{~km}$ de material jurásico bajo la
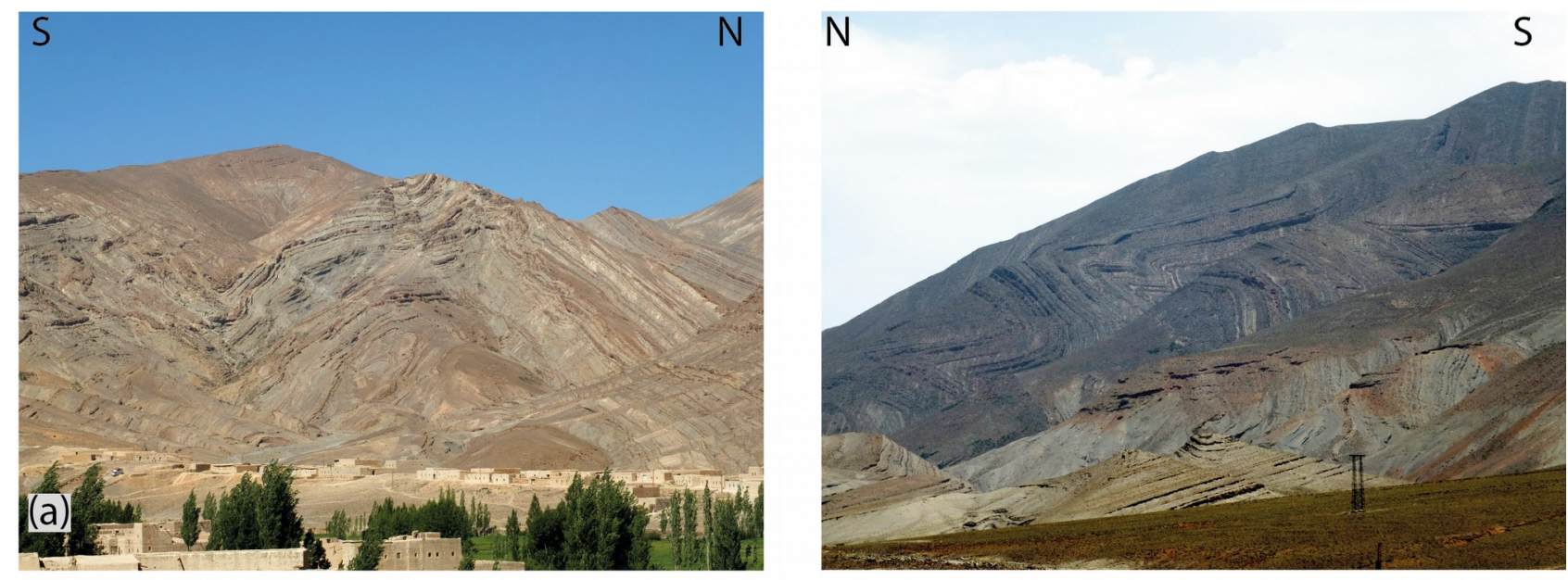

S

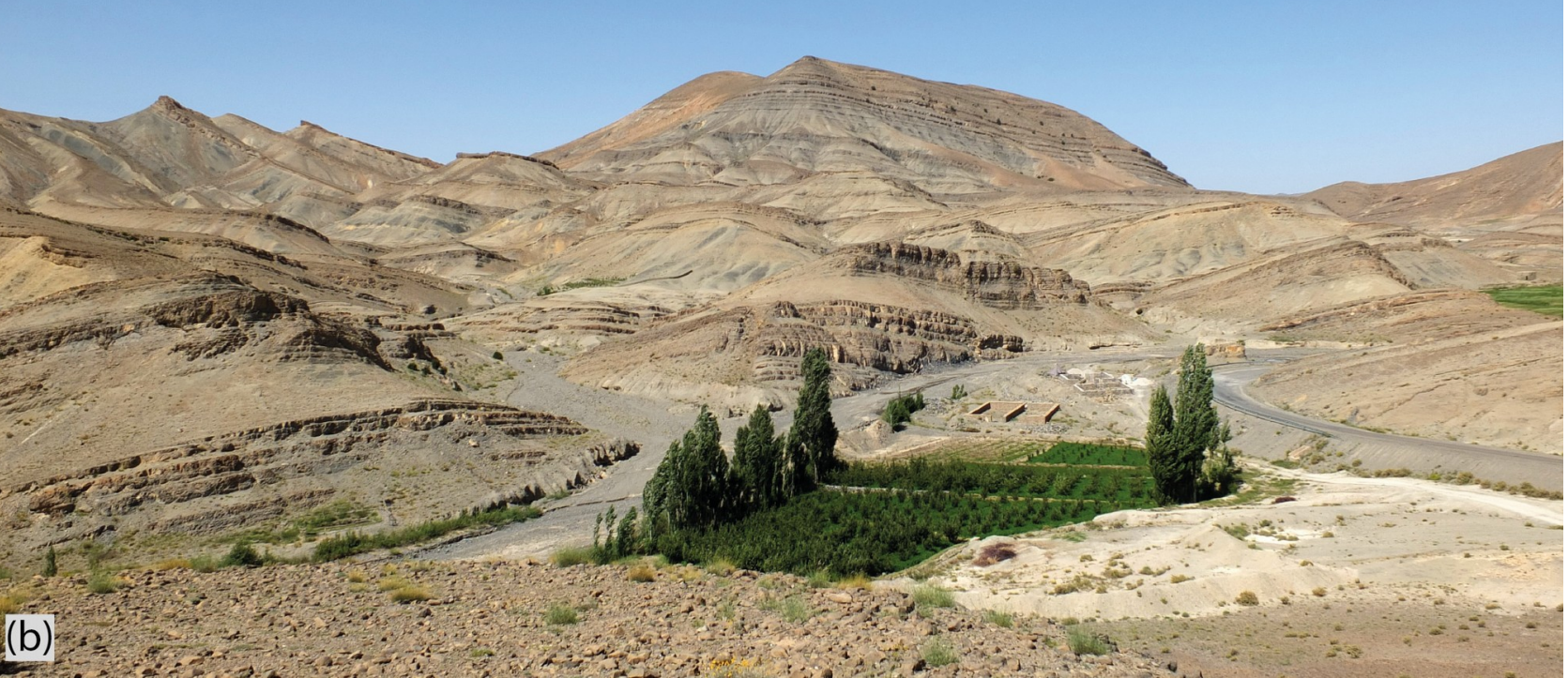

Figura 9.24 Fotografías mostrando el aspecto estructural del área de estudio. (a) Anticlinal de Tissila. (b) Pliegues angulosos vergentes al norte en el flanco norte del anticlinal de Ikkou. (c) Sinclinal laxo con desarrollo de foliación subvertical.

Figure 9.24 Pictures showing the general structural face of the study area. (a) Tissila anticline. (b) North verging angular folds in the $N$ limb of the Ikkou anticline. (c) Gently syncline with cleavage development. 
superficie. Si bien existen diferentes unidades que podrían haber actuado como niveles de despegue (sales y arcillas triásicas y margas jurásicas), no parecen haber jugado un papel importante en la deformación. Únicamente se observan cabalgamientos despegados de los niveles triásicos en las inmediaciones de las estructuras diapíricas, o en zonas como el anticlinal de Toumliline donde el levantamiento de la cobertera jurásica en el bloque inferior durante la extensión favorece el cabalgamiento de éste hacia el norte.

(3) Los dos puntos anteriores parecen estar relacionados. Por un lado, la disposición tabular de la serie y su gran potencia dificultan mecánicamente la formación de láminas de cabalgamiento que acomoden el acortamiento. Además, dado el bajo acortamiento en el AAC, el acortamiento puede ser acomodado únicamente mediante el apretamiento de las zonas de debilidad (las estructuras salinas previas), que se ve reflejado en el plegamiento y amplificación de las estructuras heredadas de la extensión. Además, parte del acortamiento se acomoda con la generación de pliegues principalmente angulosos, con desarrollo de foliación de presión-disolución.

(4) El área de estudio no es propicia para conocer cómo el basamento se involucra en la inversión y deformación de la cadena, dado que no aflora y se encuentra al menos a 5 km de profundidad. Hacia el este y el oeste, donde sí aflora, se observa que se encuentra involucrado en la estructura compresiva, si bien puede ser esperable un desacople entre el mismo y la cobertera jurásica canalizado en las sales y arcillas triásicas. Este desacoplamiento no tiene por qué ser homogéneo a lo largo de la cadena y puede estar sujeto a la cantidad de material triásico preservada tras los procesos halocinéticos. Por ejemplo, el anticlinal de Toumliline está asociado a un despegue desde el triásico y no hay evidencias de que siga una estructura de basamento.

(5) En relación al punto anterior, existen saltos en el nivel estructural en el área de estudio (por ejemplo entre los sectores $\mathrm{N}$ y S del anticlinal de Tissila) que parecen estar relacionadas con fallas normales generadas durante la extensión y no con fallas inversas de basamento. Por tanto, si existe cierta inversión de las fallas de basamento, no se evidencia de manera clara en la estructura de la cobertera. De hecho, el anticlinal de Tissila y el sinclinal de Ikkou están relacionados con una falla normal de basamento con bloque hundido al N. La estructura compresiva de dicho anticlinal presenta un predominio de vergencia norte, contraria a lo esperado si la falla de basamento hubiera sufrido una reactivación importante. Esto lo vemos repetido en diversas estructuras, donde el bloque levantado durante la extensión es el que cabalga sobre el bloque hundido. Esto indica que, independientemente de cómo acomode el acortamiento el basamento (inversión de fallas previas, plegamiento, generación de nuevas estructuras, etc.), la deformación y vergencia de las estructuras de la cobertera están condicionadas por la estructuración jurásica de la cobertera.

Dicho lo anterior, y como observábamos previamente al comparar la estructura actual y la derivada de la etapa de cuenca (Fig. 9.17), la estructura del área de estudio está caracterizada por un acortamiento moderado ( $19 \%)$ que se acomoda principalmente en las estructuras diapíricas formadas durante el jurásico, que actúan como áreas de debilidad. En las áreas tabulares que son limitadas por las anteriores la deformación es pequeña, limitada al desarrollo de foliación 
subvertical y pliegues angulosos acompañados por pequeños cabalgamientos despegados en niveles internos de la serie jurásica.

\subsubsection{Modelo de evolución}

A continuación se propone un modelo evolutivo para el área de estudio. Esta propuesta se basa en los modelos evolutivos regionales presentes en la literatura (p. ej. Frizon de Lamotte et al., 2009), en los que integramos la información derivada de esta tesis doctoral.

El origen de la cuenca del Atlas se remonta al Pérmico-Triásico, con la fracturación de Pangea a lo largo del actual Atlántico Central (p. ej. Frizon de Lamotte et al., 2015, y referencias allí incluidas), con un importante control estructural del orógeno varisco. Las principales evidencias sobre la estructuración de las cuencas y el inicio del rift en el Alto Atlas viene dado por las observaciones realizadas en el área de Marrakech, donde se observan afloramientos de rocas triásicas limitados por fallas que se depositaron en semigrabens. En dicha área las cuencas estaban controladas por fallas normales $\mathrm{N}^{\circ} 0^{\circ} \mathrm{E}$, con principal componente normal, siendo los movimientos direccionales, de carácter sinistro, limitados a estructuras locales (p. ej. Beauchamp, 1988; Domènech et al., 2015). La apertura de la cuenca se produjo bajo un campo de esfuerzos radial, con una dirección de extensión dominante NO-SE. Inicialmente, la sedimentación es esencialmente continental, dominada por areniscas rojas. Durante el Triásico Superior la influencia marina es más importante, depositándose arcillas y sales de manera más extensiva que los anteriores (Fig. 9.25a). En el tránsito Triásico-Jurásico tiene lugar un evento ígneo importante en todo el área atlántica, con la extrusión de gran cantidad de material basáltico datado en ca. 200 Ma (Verati et al., 2007); en el área de Marrakech se observan series de coladas de 100 a 300 m de espesor (Knight et al., 2004). Tras la primera etapa de rift, durante el inicio del Jurásico Inferior se implanta una plataforma carbonatada somera; en este momento la actividad tectónica fue menor, y el espacio de acomodación es generado principalmente por subsidencia térmica (Fig. 9.25a).

El segundo evento de rift (Fig. 9.25c) se produce durante el Jurásico Inferior-Medio con el depósito de potentes series carbonatadas bajo una extensión NO-SE. La actividad extensional y las variaciones de espesor entre los diferentes bloques desencadenan la migración de sales que ascienden a favor de las discontinuidades tectónicas, generando muros de sal. La migración de sales también tiene su aportación en la subsidencia total. La segunda etapa de post-rift (Fig. 9.25c) está dominada por subsidencia térmica, pero también posiblemente por migración de sales, predominantemente en los bloques levantados de las fallas normales. La sedimentación pasa a presentar carácter continental con facies transicionales al inicio y posteriormente arcillas y areniscas, de manera más o menos discontinua (Charrière y Haddoumi, 2016; y referencias allí incluidas). El paso de la sedimentación marina a continental la explican algunos autores (Frizon de Lamotte et al., 2008; para su revisión) con un levantamiento térmico del Arco Marroquí Occidental (AMO), situado al oeste del área de estudio, y que estaría relacionado con una anomalía mantélica. Durante este periodo de tiempo se produce la intrusión de rocas ígneas de procedencia mantélica en dos eventos principales, el primero durante el Jurásico Superior y el segundo durante el Cretácico inferior. Al primer evento corresponden los gabros observados en el área de estudio, datados en torno a 160-146 Ma (Hailwood y Mitchell, 1971; Armando, 1999) y que tienen correlación con el 
NNW

(a) Triassic: tectonic subsidence (sub). 1st rift stage

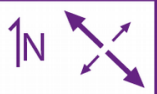

Continental sedimentation (sandstones, shales and salts). Igneous activity

(2)

(b) Early Liassic: thermal sub. Post-rift stage

Marine sedimentation (limestones)

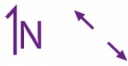

Sea level

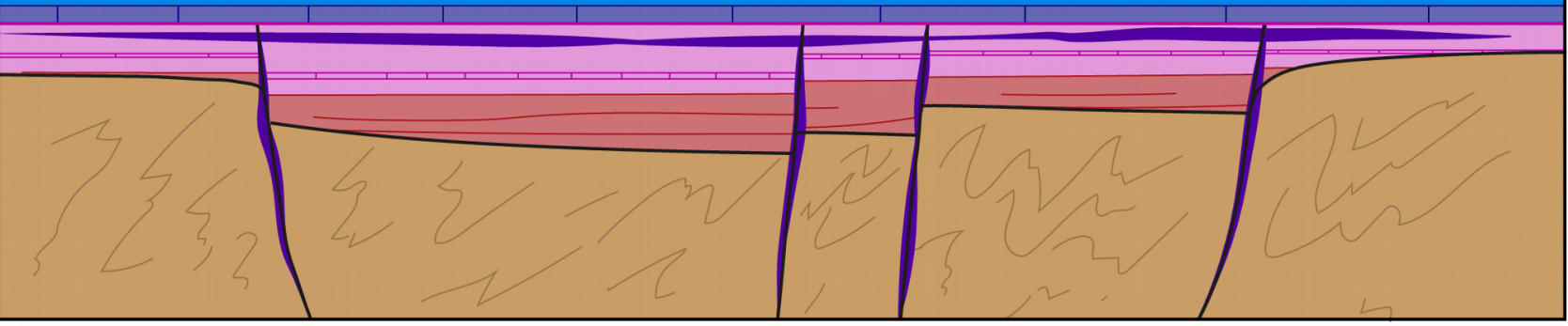

(c) Late Liassic - Early Dogger: tectonic sub. + salt migration. 2nd rift stage Marine sedimentation (marls and limestones)

Sea level
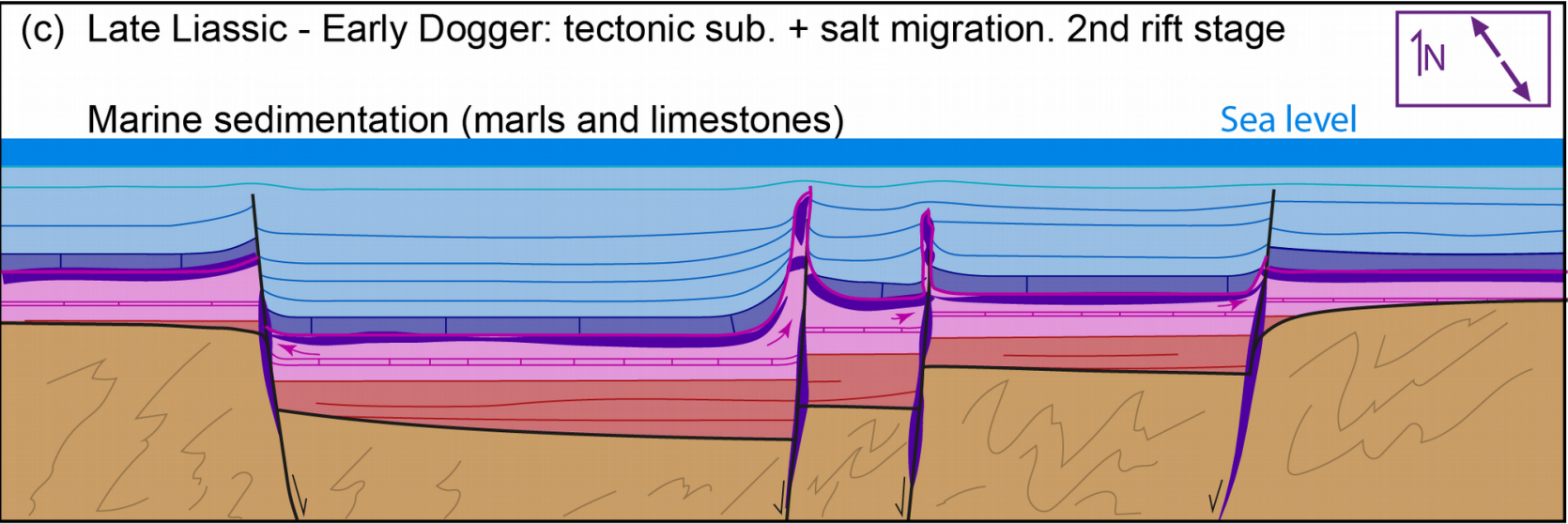

(d) Bathonian-Barremian: thermal subs. + local salt migration.

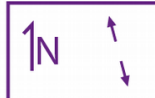

Continental sedimentation (sandstones). Igneous activity (gabbros and basalts)

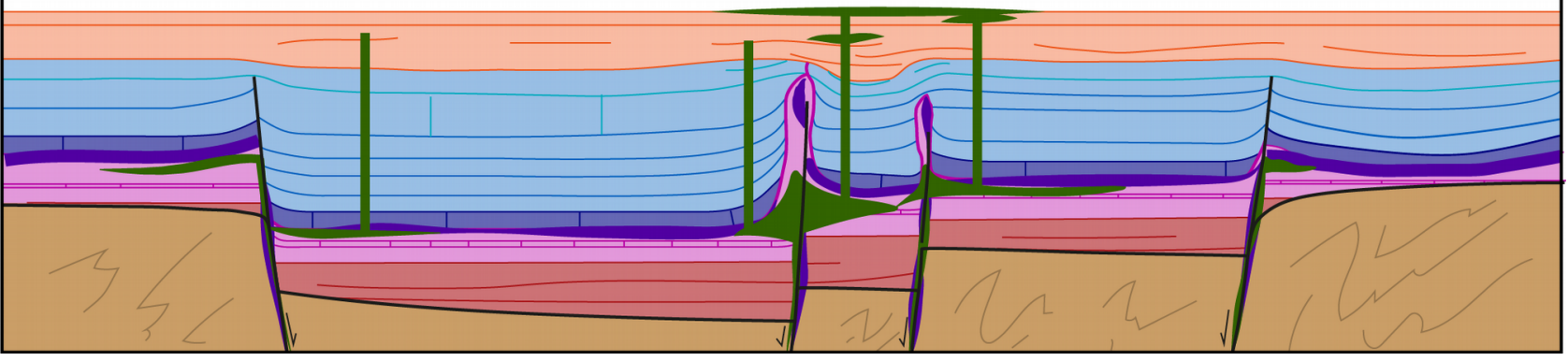




(e) Albian-Cenomanian (ca. $100 \mathrm{Ma}$ ): remagnetization acquisition
Marine sedimentation?
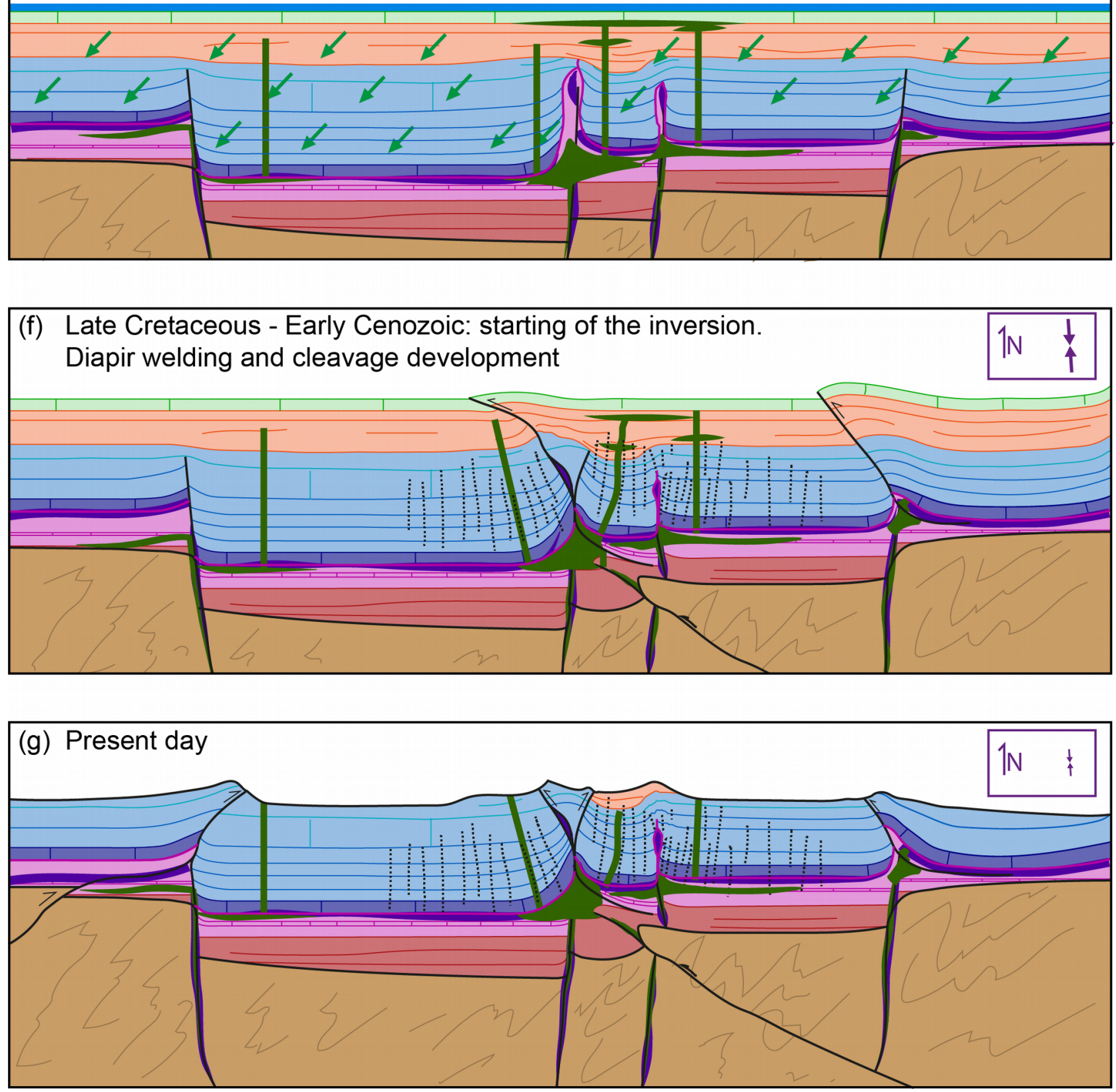

Figura 9.25 Esquemas mostrando la evolución del área de estudio. Los pequeños recuadros situados en la esquina superior derecha de cada esquema muestran la dirección del eje de esfuerzos horizontal máximo.

Figure 9.25 Sketch showing the evolution of the study area. The upper-right insets shows the maximum horizontal stress axis. 
primer grupo de coladas basálticas observadas en las cuencas del norte, cuyas edades K-Ar son 175-

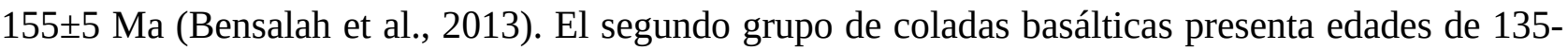
110 \pm 5 Ma (Bensalah et al., 2013) en la cuenca de Aït Attab, si bien no se han encontrado sus correspondientes rocas intrusivas. Durante estos eventos ígneos es esperable una reactivación de los procesos diapíricos. De acuerdo a la fábrica magnética observada en los gabros, el emplazamiento de estos se produjo en un contexto extensivo NO-SE.

Aproximadamente en el límite entre el Cretácico Inferior y Superior (ca. $100 \mathrm{Ma}$ ) se produce la remagnetización química de las rocas sedimentarias (Fig. 9.25e), datada por comparación de la dirección calculada con la curva de deriva polar aparente de África (Torres-López et al., 2014). Según la información aportada por la fabrica magnética portada por la magnetita, portadora también de la remagnetización, este proceso tendría lugar bajo una extensión NNO-SSE.

Durante el final del Cretácico y el inicio del Cenozoico se inicia la inversión de la cuenca consecuencia de la convergencia entre África y Eurasia e Iberia. En estos primeros estadios se debió producir la foliación tectónica y el inicio del cierre de las estructuras diapíricas. Posteriormente, a medida que la erosión fue más importante, eliminando carga litostática, se favorecería el desarrollo de pliegues y cabalgamientos hasta generar la estructura actual. 
10. Conclusions 



\section{Conclusions}

The analysis of rock magnetic experiments, paleomagnetism and magnetic fabrics in the carbonates and gabros of the Central High Atlas, and the analysis of the small circles (SC), allowed to obtain several conclusions, which are enumerated in the following paragraphs.

\section{About the remagnetization of the Central High Atlas}

1a) The Jurassic carbonates of the Central High Atlas (Morocco) record a widespread chemical remagnetization, carried by SSD magnetite. The magnetite grains grew generating a population of SP-SSD magnetite that imprint characteristic magnetic features in the carbonates, common of chemically remagnetized carbonates.

1b) According to the results of the anisotropy of the ARM and rock magnetic experiments, the SDD magnetite grains present uniaxial anisotropy, and during their growth they defined an anisotropic distribution: the magnetic fabric defined by the SDD magnetite grains was developed during the remagnetization process and was characterized at this time by horizontal magnetic foliation and horizontal NNW-SSE lineation. This fabric has been interpreted to reflect the extensional tectonics during the growth of the grains.

1c) The characteristic magnetization shows systematically northwestward declinations and positive inclinations indicating normal polarity. This shows an interfolding behavior since it is bracketed between two folding stages (the Jurassic extension and the Cenozoic compression). The remagnetization direction (n: 100, Dec: $332.2^{\circ}$, Inc: $34.5^{\circ}, \eta: 6.2^{\circ}, \xi: 2.0^{\circ}$, $\mathrm{A} / \mathrm{n}: 6.427^{\circ}$ ) calculated by means of the SC tools is coincident with the Albian-Cenomanian expected directions for NW Africa.

\section{About the SC restoration technique. Methodological contributions}

2a) The new PySCu software for applying the SC tools is presented. This is a cross-platform free application written in Python. One of the main novelties of this software is the implementation of bootstrap statistics to calculate the uncertainty in the remagnetization direction.

2b) Through the simulation of artificial data, the effect of the non-fulfillment of two of the starting hypotheses of the SC tools have been analyzed: the presence of vertical axis rotations (VARs) and the non-coaxiality between the pre- and post remagnetization deformation stages. The presence of VARs has a strong effect in the calculation of both the remagnetization direction and the paleodips. When VARs are considered, the inclination of the calculated remagnetization direction is always overestimated. On the other hand, the error in the paleodips is high (between 0 and $50^{\circ}$ ); however, the VARs affects with characteristic patterns in the calculation of the paleodip (over- and under-estimating 
symmetrically the paleodips in opposite limbs) that can help to detect the presence of VARs. On the other hand, the presence of non-coaxiality affects to a lesser degree both the remagnetization direction and the paleodip calculations.

2c) The comparison between the simulation and the real data of the Central High Atlas indicates that the area is not affected neither by VARs nor by non-coaxiality. Besides, the comparison between the bedding between sites in which deformation mostly predates remagnetization and sites in which deformation is mostly post-remagnetization shows similar cylindrical best fit, indicating the absence of significant non-coaxiality between the pre- and the postremagnetization deformational stages. These results indicate that the study area fulfills the starting hypotheses necessary for the application of the SC tools.

\section{About the paleomagnetic results in Jurassic carbonates and tectonic implications}

3a) The remagnetization has been dated as ca. 100 Ma. Paleodips at the remagnetization acquisition time have been calculated by SC methods for all paleomagnetic sites and from this information, different cross-sections showing the geometry of the area at ca. $100 \mathrm{Ma}$ have been elaborated.

3b) The comparison between present-day and restored at ca. 100 Ma geologic cross-sections resulted useful to unravel some geological topics of the study area.

3c) The folds with axial-plane cleavage developed after the remagnetization acquisition. Therefore, the cleavage development of the study area is related with the Cenozoic compression.

3d) The characteristic narrow anticlines (ridges) are inherited structures from the extensional stages. The different analyzed ridges showed different degrees of development in the precompressional stage, from ridges with moderate to steep dips of their limbs (the Ikkou ridge), ridges in which the basinal deformation is limited to the contact with the core (Tadaghmamt and Timedouine ridges), or structures forming salt-rollers (Toumliline diapir). These structures were generated mainly as consequence of halokinetic processes with the generation of diapirs and salt-walls that delimited sedimentary depocenters. The inherited extensional structure conditioned how the Cenozoic shortening was accommodated in the different structures: welding of the salt-walls in Ikkou, Tadaghmamt and Timedouine, and thrusting in Toumliline.

\section{About the magnetic fabric interpretation of remagnetized carbonates and its tectonic implications}

4a) It is common to compare the magnetic fabrics between their in situ orientation after the total restoration of the bedding (i.e., to restore the bedding to the horizontal). To compare these stages with the magnetic fabric after partial bedding restoration (i.e., to restore the bedding according the paleodip at the remagnetization acquisition time) has revealed itself as a useful procedure to unravel the meaning of magnetic fabrics in remagnetized carbonates. 
4b) The magnetite neoformed during the remagnetization stage plays a major role in the magnetic fabrics of the carbonates in the Central High Atlas. When the magnetic fabric of the SSD magnetite grains is considered by itself by means of the anisotropy of the ARM, it can be observed that the best clustering of the principal axes is achieved after the partial bedding correction (restoring the bedding to its attitude at the remagnetization time). This is probably because the magnetic fabric was developed during the growth of the magnetite grains and is interpreted to reflect of the extensional tectonic constraints at this moment. This property can be used to infer the tectonic context under which remagnetizations took place.

4c) The RT-AMS shows four different behaviors. Type 1 shows the same behavior than the observed in the anisotropy of the ARM and it is interpreted as carried by the SP magnetite grains neoformed during the remagnetization event, which define the same magnetic fabric than SSD grains. Otherwise, in type 3 and 4 the magnetic lineation is parallel to the intersection direction between bedding and cleavage and it is considered as a compressive tectonic fabric; the magnetic foliation in type 3 is parallel to bedding and in type 4 is parallel to cleavage. Both fabrics have been interpreted as carried by phyllosilicates. Type 2 shows an intermediate behavior between the previous.

4d) Magnetite and phyllosilicates show a distinct behavior under compression because the magnetic fabric carried by phyllosilicates agrees with the cleavage whereas the magnetic fabric carried by the neoformed magnetite reflects the stretching during the growth of grains. This can be due to the growth of the magnetite inside pyrite crystals that could deflect cleavage and prevent the deformation of the magnetite grains during the compression.

\section{About the paleomagnetic and magnetic anisotropy results in the gabro bodies of the Central High Atlas}

5a) The Jurassic gabbros present a characteristic paleomagnetic component, which has been isolated in 19 out of 33 sites. This paleomagnetic component is considered as a thermal magnetization (acquired during the cooling of the igneous rocks) carried by SSD to PSD magnetite. At least part of this magnetite is forming inclusions in silicate crystals.

5b) The characteristic component shows a strong scattering that has been interpreted as a consequence of the Cenozoic compression. When the different structures are analyzed separately, the scattering of the paleomagnetic directions defines small circles with horizontal axes parallel to each structure. This supports that the scatter is a consequence of horizontal rotations axes that are consistent with the main Cenozoic folding.

5c) The results derived from the paleomagnetic analysis can be used to restore the magnetic fabrics to their position at the moment of the emplacement of the igneous rocks. After this restoration, the magnetic fabrics for each site are coherent. In the western sector an extensional magnetic fabric whose magnetic foliation is horizontal and the magnetic lineation is horizontal and trends NNW-SSE is defined. This direction mimics the stretching during the emplacement of the igneous rocks. In the eastern sector the magnetic fabrics show a more complex pattern that can be derived from a lack of space during the emplacement. 



\section{References}

Ait Addi, A., Chafiki, D., 2013. Sedimentary evolution and palaeogeography of mid-Jurassic deposits of the Central High Atlas, Morocco. J. African Earth Sci. 84, 54-69. doi:10.1016/j.jafrearsci.2013.04.002

Ait Brahim, L., Chotin, P., Hinaj, S., Abdelouafi, A., El Adraoui, A., Nakcha, C., Dhont, D., Charroud, M., Sossey Alaoui, F., Amrhar, M., Bouaza, A., Tabyaoui, H., Chaouni, A., Ait-Brahim, L., Chotin, P., Hinaj, S., Abdelouafi, A., El Adraoui, A., Nakcha, C., Dhont, D., Charroud, M., Sossey Alaoui, F., Amrhar, M., Bouaza, A., Tabyaoui, H., Chaouni, A., 2002. Paleostress evolution in the Moroccan African margin from Triassic to Present. Tectonophysics 357, 187-205. doi:10.1016/S00401951(02)00368-2

Ait-Itto, F.Z., Martinez, M., Price, G.D., Ait Addi, A., 2018. Synchronization of the astronomical time scales in the Early Toarcian: A link between anoxia, carbon-cycle perturbation, mass extinction and volcanism. Earth Planet. Sci. Lett. 493, 1-11. doi:10.1016/j.epsl.2018.04.007

Allerton, S., 1998. Geometry and kinematics of vertical-axis rotations in fold and thrust belts. Tectonophysics 299, 15-30. doi:10.1016/S0040-1951(98)00196-6

Antolín, B., Schill, E., Grujic, D., Baule, S., Quidelleur, X., Appel, E., Waldhör, M., 2012. E-W extension and block rotation of the southeastern Tibet: Unravelling late deformation stages in the eastern Himalayas (NW Bhutan) by means of pyrrhotite remanences. J. Struct. Geol. 42, 19-33. doi:10.1016/j.jsg.2012.07.003

Antolín-Tomás, B., Román-Berdiel, T., Casas-Sainz, A., Gil-Peña, I., Oliva, B., Soto, R., 2009. Structural and magnetic fabric study of the Marimanha granite (Axial Zone of the Pyrenees). Int. J. Earth Sci. 98, 427-441. doi:10.1007/s00531-007-0248-1

Aranguren, A., Cuevas, J., Tubía, J.M., Román-Berdiel, T., Casas-Sainz, A., Casas-Ponsati, A., Tubía, J.M., Román-Berdiel, T., Casas-Sainz, A., Casas-Ponsati, A., 2003. Granite laccolith emplacement in the Iberian arc: AMS and gravity study of the La Tojiza pluton (NW Spain). J. Geol. Soc. London. 160, 435-445. doi:10.1144/0016-764902-079

Arboleya, M.L., Teixell, A., Charroud, M., Julivert, M., 2004. A structural transect through the High and Middle Atlas of Morocco. J. African Earth Sci. 39, 319-327. doi:10.1016/j.jafrearsci.2004.07.036

Archanjo, C.J., Campanha, G.A.C., Salazar, C.A., Launeau, P., 2012. Using AMS combined with mineral shape preferred orientation analysis to understand the emplacement fabrics of the Apiaí gabbro-norite (Ribeira Belt, SE Brazil). Int. J. Earth Sci. 101, 731-745. doi:10.1007/s00531-011-0659-x

Armando, G., 1999. Intracontinental alkaline magmatism: Geology, Petrography, Mineralogy and Geochemistry of the Jebel Hayim Massif (Central High Atlas-Morocco). Mémories de Géologie de l’Université de Lausanne 31, 106.

Aubourg, C., Klootwijk, C., Korsch, R.J., 2004. Magnetic fabric constraints on oroclinal bending of the Texas and Coffs Harbour blocks: New England Orogen, eastern Australia. Geol. Soc. London, Spec. Publ. 238, 421-445. doi:10.1144/GSL.SP.2004.238.01.22

Aubourg, C., Smith, B., Eshraghi, A., Lacombe, O., Authemayou, C., Amrouch, K., Bellier, O., Mouthereau, F., 2010. New magnetic fabric data and their comparison with palaeostress markers in the Western Fars 
Arc (Zagros, Iran): tectonic implications. Geol. Soc. London, Spec. Publ. 330, 97-120. doi:10.1144/SP330.6

Aubourg, C., Pozzi, J., Kars, M., 2012. Burial, claystones remagnetization and some consequences for magnetostratigraphy. Geol. Soc. London, Spec. Publ. 371, 181-188. doi:10.1144/SP371.4

Ayarza, P., Alvarez-Lobato, F., Teixell, A., Arboleya, M.L., Tesón, E., Julivert, M., Charroud, M., 2005. Crustal structure under the central High Atlas Mountains (Morocco) from geological and gravity data. Tectonophysics 400, 67-84. doi:10.1016/j.tecto.2005.02.009

Babault, J., Teixell, A., Arboleya, M.L., Charroud, M., 2008. A Late Cenozoic age for long-wavelength surface uplift of the Atlas Mountains of Morocco. Terra Nov. 20, 102-107. doi:10.1111/j.13653121.2008.00794.x

Baidder, L., Michard, A., Soulaimani, A., Fekkak, A., Eddebbi, A., Rjimati, E.-C.C., Raddi, Y., 2016. Fold interference pattern in thick-skinned tectonics; a case study from the external Variscan belt of Eastern Anti-Atlas, Morocco. J. African Earth Sci. 119, 204-225. doi:10.1016/j.jafrearsci.2016.04.003

Banerjee, S., Elmore, R.D., Engel, M.H., 1997. Chemical remagnetization and burial diagenesis: Testing the hypothesis in the Pennsylvanian Belden Formation, Colorado. J. Geophys. Res. Solid Earth 102, 24825-24842. doi:10.1029/97JB01893

Barbero, L., Teixell, A., Arboleya, M.-L.L., Río, P. Del, Reiners, P.W., Bougadir, B., 2007. Jurassic-topresent thermal history of the central High Atlas (Morocco) assessed by low-temperature thermochronology. Terra Nov. 19, 58-64. doi:10.1111/j.1365-3121.2006.00715.x

Baudon, C., Fabuel-Perez, I., Redfern, J., 2009. Structural style and evolution of a Late Triassic rift basin in the Central High Atlas, Morocco: controls on sediment deposition. Geol. J. 44, 677-691. doi:10.1002/gj.1195

Bazhenov, M.L., Shipunov, S. V., 1991. Fold test in paleomagnetism: new approaches and reappraisal of data. Earth Planet. Sci. Lett. 104, 16-24. doi:10.1016/0012-821X(91)90233-8

Beauchamp, W., 1988. Triassic sedimentation and rifting in the High Atlas (Morocco), in: Developments in Geotectonics. Elsevier B.V., pp. 477-497. doi:10.1016/B978-0-444-42903-2.50025-7

Beauchamp, W., Barazangi, M., Demnati, A., El Alji, M., 1996. Inversion of synrift normal faults in the High Atlas Mountains, Morocco. AAPG Bull. 80, 1459-1482. doi:10.1190/1.1437760

Beauchamp, W., Allmendinger, R.W., Barazangi, M., Demnati, A., El Alji, M., Dahmani, M., 1999. Inversion tectonics and the evolution of the High Atlas Mountains, Morocco, based on a geological-geophysical transect. Tectonics 18, 163-184. doi:10.1029/1998TC900015

Beauchamp, W., 2004. Superposed folding resulting from inversion of a synrift accommodation zone, Atlas Mountains, Morocco, in: McClay, K.R. (Ed.), Thrust Tectonics and Hydrocarbon Systems. AAPG Memoir, pp. 635-646. doi:10.1306/M82813C33

Bensalah, M.K., Youbi, N., Mata, J., Madeira, J., Martins, L., El Hachimi, H., Bertrand, H., Marzoli, A., Bellieni, G., Doblas, M., Font, E., Medina, F., Mahmoudi, A., Beraâouz, E.H., Miranda, R., Verati, C., De Min, A., Ben Abbou, M., Zayane, R., 2013. The Jurassic-Cretaceous basaltic magmatism of the Oued El-Abid syncline (High Atlas, Morocco): Physical volcanology, geochemistry and geodynamic implications. J. African Earth Sci. 81, 60-81. doi:10.1016/j.jafrearsci.2013.01.004 
Beraâouz, E.H., Bonin, B., 1993. Magmatisme alcalin intra-continental en contexte de décrochement: le massif plutonique mésozoïque de Tirrhist, Haut-Atlas (Maroc). Comptes Comptes Rendus - Acad. des Sci. 317, 647-653.

Besse, J., Courtillot, V., 2002. Apparent and true polar wander and the geometry of the geomagnetic field over the last 200 Myr. J. Geophys. Res. Solid Earth 107, EPM 6-1-EPM 6-31. doi:10.1029/2000JB000050

Biedermann, A.R., Jackson, M., Bilardello, D., Feinberg, J.M., Brown, M.C., McEnroe, S.A., 2017. Influence of static alternating field demagnetization on anisotropy of magnetic susceptibility: Experiments and implications. Geochemistry, Geophys. Geosystems 18, 3292-3308. doi:10.1002/2017GC007073

Biggin, A.J., van Hinsbergen, D.J.J., Langereis, C.G., Straathof, G.B., Deenen, M.H.L., 2008. Geomagnetic secular variation in the Cretaceous Normal Superchron and in the Jurassic. Phys. Earth Planet. Inter. 169, 3-19. doi:10.1016/j.pepi.2008.07.004

Bilardello, D., Jackson, M.J., 2014. A comparative study of magnetic anisotropy measurement techniques in relation to rock-magnetic properties. Tectonophysics 629, 39-54. doi:10.1016/j.tecto.2014.01.026

Blumstein, A.M., Elmore, R.D., Engel, M.H., Elliot, C., Basu, A., 2004. Paleomagnetic dating of burial diagenesis in Mississippian carbonates, Utah. J. Geophys. Res. 109, 1-16.

Bodego, A., Iriarte, E., López-Horgue, M.A., Álvarez, I., 2018. Rift-margin extensional forced folds and salt tectonics in the eastern Basque-Cantabrian rift basin (western Pyrenees). Mar. Pet. Geol. 91, 667-682. doi:10.1016/j.marpetgeo.2018.02.007

Borradaile, G.J., 1988. Magnetic susceptibility, petrofabrics and strain. Tectonophysics 156, 1-20. doi:10.1016/0040-1951(88)90279-X

Borradaile, G.J., 1997. Deformation and paleomagnetism. Surv. Geophys. 18, 405-436. doi:10.1023/A:1006555906559

Borradaile, G.J., Tarling, D.H., 1981. The influence of deformation mechanisms on magnetic fabrics in weakly deformed rocks. Tectonophysics 77, 151-168.

Borradaile, G.J., Henry, B., 1997. Tectonic applications of magnetic susceptibility and its anisotropy. EarthScience Rev. 42, 49-93.

Borradaile, G.J., Hamilton, T., 2004. Magnetic fabrics may proxy as neotectonic stress trajectories, Polis rift, Cyprus. Tectonics 23, 278-7407.

Bouchez, J.L., Gleizes, G., 1995. Two-stage deformation of the Mont-Louis-Andorra granite pluton (Variscan Pyrenees) inferred from magnetic susceptibility anisotropy. J. Geol. Soc. London. 152, 669679. doi:10.1144/gsjgs.152.4.0669

Bouchez, J.L., Gleizes, G., Djouadi, T., Rochette, P., 1990. Microstructure and magnetic susceptibility applied to emplacement kinematics of granites: the example of the Foix pluton (French pyrenees). Tectonophysics 184, 157-171. doi:10.1016/0040-1951(90)90051-9

Bouchez, J.L., 1997. Granite is Never Isotropic: An Introduction to AMS Studies of Granitic Rocks, in: Bouchez, J.L., Hutton, D.H.W., Stephens, W.E. (Eds.), Granite: From Segregation of Melt to Emplacement Fabrics1, Petrology and Structural Geology. Springer, Dordrecht, Dordrecht, pp. 95-112. doi:10.1007/978-94-017-1717-5_6 
Bouchez, J.L., 2000. Anisotropie de susceptibilité magnétique et fabrique des granites. Comptes Rendus l’Académie des Sci. - Ser. IIA - Earth Planet. Sci. 330, 1-14. doi:10.1016/S1251-8050(00)00120-8

Bouchouata, A., Canérot, J., Souhel, A., Gharib, A., 1995. Stratigraphie séquentielle et évolution géodynamique du Jurassique de la région Talmest-Tazoult (Haut Atlas central, Maroc). Comptes Rendus L’Academie Des Sci. Paris 320, 749-756.

Brothers, L.A., Engel, M.H., Elmore, R.D., 1996. The late diagenetic conversion of pyrite to magnetite by organically complexed ferric iron. Chem. Geol. 130, 1-14. doi:10.1016/0009-2541(96)00007-1

Brown, L.L., McEnroe, S.A., 2015. 916 Ma Pole for southwestern Baltica: palaeomagnetism of the Bjerkreim-Sokndal layered intrusion, Rogaland Igneous Complex, southern Norway. Geophys. J. Int. 203, 567-587. doi:10.1093/gji/ggv299

Butler, R.F., 1992. Paleomagnetism: Magnetic Domains to Geologic Terranes. Blackwell Scientific Publications.

Cairanne, G., Aubourg, C., Pozzi, J.P., 2002. Syn-folding remagnetization and the significance of the small circle test examples from the Vocontian trough (SE France). Phys. Chem. Earth 27, 1151-1159. doi:10.1016/S1474-7065(02)00106-7

Calvín, P., VIllalaín, J.J., Mahmoudi, A., 2017. Evidencias de facies rojas remagnetizadas en el Atlas Medio (Marruecos). Geogaceta 61, 87-90.

Calvín, P., Villalaín, J.J., Casas-Sainz, A.M., Tauxe, L., Torres-López, S., 2017a. pySCu: A new python code for analyzing remagnetizations directions by means of small circle utilities. Comput. Geosci. 109, 3242. doi:10.1016/j.cageo.2017.07.002

Calvín, P., Casas-Sainz, A.M., Villalaín, J.J., Moussaid, B., 2017b. Diachronous folding and cleavage in an intraplate setting (Central High Atlas, Morocco) determined through the study of remagnetizations. J. Struct. Geol. 97, 144-160. doi:10.1016/j.jsg.2017.02.009

Calvín, P., Ruiz-Martínez, V.C., Villalaín, J.J., Casas-Sainz, A.M., Moussaid, B., 2017. Emplacement and Deformation of Mesozoic Gabbros of the High Atlas (Morocco): Paleomagnetism and Magnetic Fabrics. Tectonics 36, 3012-3037. doi:10.1002/2017TC004578

Calvín, P., Casas-Sainz, A.M., Villalaín, J.J., Moussaid, B., 2018. Extensional vs. compressional deformation in the Central High Atlas salt province: A paleomagnetic approach. Tectonophysics 734-735, 130-147. doi:10.1016/j.tecto.2018.04.007

Calvín, P., Villalaín, J.J., Casas-Sainz, A.M., 2018. Anisotropic magnetite growth in remagnetized limestones: Tectonic constraints and implications for basin history. Geology. doi:10.1130/G45158.1

Caricchi, C., Cifelli, F., Kissel, C., Sagnotti, L., Mattei, M., 2016. Distinct magnetic fabric in weakly deformed sediments from extensional basins and fold-and-thrust structures in the Northern Apennine orogenic belt (Italy). Tectonics 35, 238-256. doi:10.1002/2015TC003940

Casas, A.M., Villalaín, J.J., Soto, R., Gil-Imaz, A., del Río, P., Fernández, G., 2009. Multidisciplinary approach to an extensional syncline model for the Mesozoic Cameros Basin (N Spain). Tectonophysics 470, 3-20. doi:10.1016/j.tecto.2008.04.020

Casquet, C., Galindo, C., González-Casado, J.M., Alonso, A., Mas, J.R., Rodas, M., García, E., Barrenechea, J.F., 1992. El metamorfismo en la Cuenca de los Cameros. Geocronología e implicaciones tectónicas. Geogaceta 11, 22-25. 
Chadima, M., Hansen, A., Hirt, A.M., Hrouda, F., Siemes, H., 2004. Phyllosilicate preferred orientation as a control of magnetic fabric: evidence from neutron texture goniometry and low and high-field magnetic anisotropy (SE Rhenohercynian Zone of Bohemian Massif). Geol. Soc. London, Spec. Publ. 238, 361380. doi:10.1144/GSL.SP.2004.238.01.19

Chadima, M., Hrouda, F., 2006. Remasoft 3.0 a user-friendly paleomagnetic data browser and analyzer. Trav. Géophysiques 27, 20-21.

Chadima, M., Hrouda, F., 2009. Cureval 8.0: Thermomagnetic Curve Browser for Windows.

Chadima, M., Jelinek, V., 2009. Anisoft data browser.

Channell, J.E.T., McCabe, C., 1994. Comparison of magnetic hysteresis parameters of unremagnetized and remagnetized limestones. J. Geophys. Res. Solid Earth 99, 4613-4623. doi:10.1029/93JB02578

Charrière, A., 1990. Héritage hercynien et évolution géodynamique alpine d'une chaîne intracontinentale: le Moyen Atlas au SE de Fès (Maroc). Université de Touluse-3.

Charrière, A., Haddoumi, H., Mojon, P.-O., Ferrière, J., Cuche, D., Zili, L., 2009. Mise en évidence par charophytes et ostracodes de l'âge Paléocène des dépôts discordants sur les rides anticlinales de la région d'Imilchil (Haut Atlas, Maroc) : conséquences paléogéographiques et structurales. Comptes Rendus Palevol 8, 9-19. doi:10.1016/j.crpv.2008.11.006

Charrière, A., Haddoumi, H., 2016. Les <<Couches rouges >> continentales jurassico-crétacées des Atlas marocains (Moyen Atlas, Haut Atlas central et oriental): bilan stratigraphique, paléogéographies successives et cadre géodynamique. Boletín Geológico y Min. 127, 407-430.

Chevallier, R., 1925. L'aimantation des laves de l'Etna et l'orientation du champ terrestre en Sicile du XII e au XVII e siècle. Ann. Phys. (Paris). 10, 5-162. doi:10.1051/anphys/192510040005

Cifelli, F., Mattei, M., Hirt, A.M., Günther, A., 2004. The origin of tectonic fabrics in "undeformed" clays: The early stages of deformation in extensional sedimentary basins. Geophys. Res. Lett. 31. doi:10.1029/2004GL019609

Cifelli, F., Mattei, M., Chadima, M., Hirt, A., Hansen, A., 2005. The origin of tectonic lineation in extensional basins: Combined neutron texture and magnetic analyses on "undeformed" clays. Earth Planet. Sci. Lett. 235, 62-78. doi:10.1016/j.epsl.2005.02.042

Cifelli, F., Mattei, M., Chadima, M., Lenser, S., Hirt, A.M., 2009. The magnetic fabric in "undeformed clays": AMS and neutron texture analyses from the Rif Chain (Morocco). Tectonophysics 466, 79-88. doi:10.1016/j.tecto.2008.08.008

Cisowski, S., 1981. Interacting vs. non-interacting single domain behavior in natural and synthetic samples. Phys. Earth Planet. Inter. 26, 56-62. doi:10.1016/0031-9201(81)90097-2

Cloetingh, S., Burov, E., Poliakov, A., 1999. Lithosphere folding: Primary response to compression? (from central Asia to Paris basin). Tectonics 18, 1064-1083. doi:10.1029/1999TC900040

Cogné, J.P., Perroud, H., 1985. Strain removal applied to paleomagnetic directions in an orogenic belt: the Permian red slates of the Alpes Maritimes, France. Earth Planet. Sci. Lett. 72, 125-140. doi:10.1016/0012-821X(85)90122-0

Costa, E., Vendeville, B.C., 2002. Experimental insights on the geometry and kinematics of fold-and-thrust belts above weak, viscous evaporitic décollement. J. Struct. Geol. 24, 1729-1739. doi:10.1016/S01918141(01)00169-9 
Cox, A., Doell, R.R., 1960. Review of paleomagnetism. Bull. Geol. Soc. Am. 71, 645-768. doi:10.1130/0016-7606(1960)71[645:ROP]2.0.CO;2

Creer, K.M., 1964. A reconstruction of the continents for the Upper Paleozoic from paleomagnetic data. Nature 203, 1115-1120.

Creer, K.M., 1968. Palaeozoic Palaeomagnetism. Nature 219, 246-250. doi:10.1038/219246a0

Davis, D.M., Engelder, T., 1985. The role of salt in fold-and-thrust belts. Tectonophysics 119, 67-88. doi:10.1016/0040-1951(85)90033-2

Day, R., Fuller, M., Schmidt, V.A., 1977. Hysteresis properties of titanomagnetites: Grain-size and compositional dependence. Phys. Earth Planet. Inter. 13, 260-267. doi:10.1016/0031-9201(77)90108-X

de Sitter, L.U., 1952. Plissement croisé dans le Haut Atlas. Geol. en Mijnb. 14, 277-282.

de Sitter, L.U., 1964. Structural geology, 3rd editio. ed. McGraw-Hill, New York.

Dearing, J.A., Hay, K.L., Baban, S.M.J., Huddleston, A.S., Wellington, E.M.H., Loveland, P.J., 1996. Magnetic susceptibility of soil: an evaluation of conflicting theories using a national data set. Geophys. J. Int. 127, 728-734. doi:10.1111/j.1365-246X.1996.tb04051.x

Debacker, T.N., Robion, P., Sintubin, M., 2004. The anisotropy of magnetic susceptibility (AMS) in lowgrade, cleaved pelitic rocks; influence of cleavage/bedding angle and type and relative orientation of magnetic carriers, in: Martin-Hernández, F., Lüneburg, C.M., Aubourg, C., Jackson, M. (Eds.), Magnetic Fabric: Methods and Applications, Geological Society Special Publications. The Geological Society of London, London, pp. 77-107. doi:10.1144/gsl.sp.2004.238.01.08

DeFelipe, I., Pedreira, D., Pulgar, J.A., Iriarte, E., Mendia, M., 2017. Mantle exhumation and metamorphism in the Basque-Cantabrian Basin (NSpain): Stable and clumped isotope analysis in carbonates and comparison with ophicalcites in the North-Pyrenean Zone (Urdach and Lherz). Geochemistry, Geophys. Geosystems 18, 631-652. doi:10.1002/2016GC006690

Dekkers, M.J., 2012. End-member modelling as an aid to diagnose remagnetization: a brief review. Geol. Soc. London, Spec. Publ. 371, 253-269. doi:10.1144/SP371.12

Delaunay, S., Smith, B., Aubourg, C., 2002. Asymmetrical fold test in the case of overfolding: two examples from the Makran accretionary prism (Southern Iran). Phys. Chem. Earth, Parts A/B/C 27, 1195-1203. doi:10.1016/S1474-7065(02)00130-4

Deng, H., Koyi, H.A., Nilfouroushan, F., 2016. Superimposed folding and thrusting by two phases of mutually orthogonal or oblique shortening in analogue models. J. Struct. Geol. 83, 28-45. doi:10.1016/j.jsg.2015.08.005

Denyszyn, S.W., Feinberg, J.M., Renne, P.R., Scott, G.R., 2013. Revisiting the age and paleomagnetism of the Modipe Gabbro of South Africa. Precambrian Res. 238, 176-185. doi:10.1016/j.precamres.2013.10.002

Dias, R., Araújo, A., Terrinha, P., Kullberg, J.C., 2006. Geologia de Portugal no contexto da Ibéria. Universidade de Évora, Évora.

Dinarès-Turell, J., Garcia-Senz, J., 2000. Remagnetization of Lower Cretaceous limestones from the southern Pyrenees and relation to the Iberian plate geodynamic evolution. J. Geophys. Res. Solid Earth 105, 19405. doi:10.1029/2000JB900136 
Domènech, M., Teixell, A., Babault, J., Arboleya, M.-L., 2015. The inverted Triassic rift of the Marrakech High Atlas: A reappraisal of basin geometries and faulting histories. Tectonophysics. doi:10.1016/j.tecto.2015.03.017

Dudzisz, K., Szaniawski, R., Michalski, K., Chadima, M., 2018. Rock magnetism and magnetic fabric of the Triassic rocks from the West Spitsbergen Fold-and-Thrust Belt and its foreland. Tectonophysics 728729, 104-118. doi:10.1016/j.tecto.2018.02.007

Duggen, S., Hoernle, K.A., Hauff, F., Klügel, A., Bouabdellah, M., Thirlwall, M.F., 2009. Flow of Canary mantle plume material through a subcontinental lithospheric corridor beneath Africa to the Mediterranean. Geology 37, 283-286. doi:10.1130/G25426A.1

Dunlop, D.J.J., Hyodo, H., Knight, T., Steele, A.G.G., 1985. Palaeomagnetism of the Tudor gabbro, Ontario: evidence for divergence between Grenvillia and interior Laurentia. Geophys. J. Int. 83, 699-720. doi:10.1111/j.1365-246X.1985.tb04333.x

Dunlop, D.J., 2002a. Theory and application of the Day plot ( M rs / M s versus H cr / H c ) 2. Application to data for rocks, sediments, and soils. J. Geophys. Res. 107, 2057. doi:10.1029/2001JB000487

Dunlop, D.J., 2002. Theory and application of the Day plot ( M rs / M s versus H cr / H c ) 1. Theoretical curves and tests using titanomagnetite data. J. Geophys. Res. 107, 2056. doi:10.1029/2001JB000486

Ebert, Y., Kessel, R., Shaar, R., Agnon, A., Ron, H., 2010. Petrology and rock magnetism of the gabbro of Troodos ophiolite. Phys. Earth Planet. Inter. 183, 413-420. doi:10.1016/j.pepi.2010.09.006

El Arabi, E.H., 2007. La série permienne et triasique du rift haut-atlasique: nouvelles datations; évolution tectono-sédimentaire. Université Hassan II Casablanca.

Eldredge, S., Bachtadse, V., Van Der Voo, R., 1985. Paleomagnetism and the orocline hypothesis. Tectonophysics 119, 153-179. doi:10.1016/0040-1951(85)90037-X

Ellero, A., Ottria, G., Malusà, M.G., Ouanaimi, H., 2012. Structural Geological Analysis of the High Atlas (Morocco): Evidences of a Transpressional Fold-Thrust Belt. Tectonics - Recent Adv. 330. doi:10.5772/2620

Elmore, R.D., Muxworthy, A.R., Aldana, M., 2012. Remagnetization and chemical alteration of sedimentary rocks. Geol. Soc. London, Spec. Publ. 371, 1-21. doi:10.1144/SP371.15

Essaifi, A., Zayane, R., 2018. Petrogenesis and origin of the Upper Jurassic-Lower Cretaceous magmatism in Central High Atlas (Morocco): Major, trace element and isotopic (Sr-Nd) constraints. J. African Earth Sci. 137, 229-245. doi:10.1016/j.jafrearsci.2017.10.002

Ettaki, M., Chellaï, E.H., Milhi, A., Sadki, D., Boudchiche, L., 2000. Le passage Lias moyen-Lias supérieur dans la région de Todrha-Dadès : événements bio-sédimentaires et géodynamiques (Haut Atlas central, Maroc). Comptes Rendus l’Académie des Sci. - Ser. IIA - Earth Planet. Sci. 331, 667-674. doi:10.1016/S1251-8050(00)01458-0

Ettaki, M., Ibouh, H., Chellaï, E.H., Milhi, 2007. Les structures “diapiriques” liasiques du Haut-Atlas central, Maroc: example de la ride d’Ikerzi. Africa Geosci. Rev. 14, 79-93.

Evans, M.E., McElhinny, M.W., 1966. The paleomagnetism of the Modipe Gabbro. J. Geophys. Res. 71, 6053-6063. doi:10.1029/JZ071i024p06053

Evans, M.E., McElhinny, M.W., Gifford, A.C., 1968. Single domain magnetite and high coercivities in a gabbroic intrusion. Earth Planet. Sci. Lett. 4, 142-146. doi:10.1016/0012-821X(68)90008-3 
Faccenna, C., Becker, T.W., Auer, L., Billi, A., Boschi, L., Brun, J.P., Capitanio, F.A., Funiciello, F., Horvàth, F., Jolivet, L., Piromallo, C., Royden, L., Rossetti, F., Serpelloni, E., 2014. Mantle dynamics in the Mediterranean. Rev. Geophys. 52, 283-332. doi:10.1002/2013RG000444

Fadile, A., 2003. Carte géologique du Maroc à 1/100 000, feuille Imilchil. Notes Mém. Serv. géol. Maroc 397.

Feinberg, J.M., Scott, G.R., Renne, P.R., Wenk, H.R., 2005. Exsolved magnetite inclusions in silicates: Features determining their remanence behavior. Geology 33, 513-516. doi:10.1130/G21290.1

Feinberg, J.M., Harrison, R.J., Kasama, T., Dunin-Borkowski, R.E., Scott, G.R., Renne, P.R., 2006. Effects of internal mineral structures on the magnetic remanence of silicate-hosted titanomagnetite inclusions: An electron holography study. J. Geophys. Res. Solid Earth 111, B12S15. doi:10.1029/2006JB004498

Ferré, E.C., 2002. Theoretical models of intermediate and inverse AMS fabrics. Geophys. Res. Lett. 29, 1127. doi:10.1029/2001GL014367

Ferré, E.C., Bordarier, C., Marsh, J.S., 2002. Magma flow inferred from AMS fabrics in a layered mafic sill, Insizwa, South Africa. Tectonophysics 354, 1-23. doi:10.1016/S0040-1951(02)00273-1

Ferrer, O., Jackson, M.P.A., Roca, E., Rubinat, M., 2012. Evolution of salt structures during extension and inversion of the Offshore Parentis Basin (Eastern Bay of Biscay). Geol. Soc. London, Spec. Publ. 363, 361-379. doi:10.1144/SP363.16

Fisher, N.I., Lewis, T., Embleton, B.J.J., 1987. Statistical analysis of spherical data, Cambridge: Cambridge University Press. Cambridge University Press, Cambridge. doi:10.1017/CBO9780511623059

Fisher, R., 1953. Dispersion on a Sphere. Proc. R. Soc. A Math. Phys. Eng. Sci. 217, 295-305. doi:10.1098/rspa.1953.0064

Fitz-Diaz, E., Hudleston, P., Tolson, G., Van Der Pluijm, B., 2014. Progressive, episodic deformation in the Mexican Fold-Thrust Belt (central Mexico): Evidence from isotopic dating of folds and faults. Int. Geol. Rev. 56, 734-755. doi:10.1080/00206814.2014.896228

Fletcher, R.C., 1974. Wavelength selection in the folding of a single layer with power-law rheology. Am. J. Sci. 274, 1029-1043. doi:10.2475/ajs.274.9.1029

Frizon de Lamotte, D., Zizi, M., Missenard, Y., Hafid, M., El Azzouzi, M., Maury, R.C., Charrière, A., Taki, Z., Benammi, M., Michard, A., 2008. The Atlas System, in: Michard, A., Saddiqi, O., Chalouan, A., Frizon de Lamotte, D. (Eds.), Continental Evolution: The Geology of Morocco. Springer Berlin Heidelberg, Berlin, Heidelberg, pp. 133-202. doi:10.1007/978-3-540-77076-3_4

Frizon de Lamotte, D., Leturmy, P., Missenard, Y., Khomsi, S., Ruiz, G., Saddiqi, O., Guillocheau, F., Michard, A., 2009. Mesozoic and Cenozoic vertical movements in the Atlas system (Algeria, Morocco, Tunisia): An overview. Tectonophysics 475, 9-28. doi:10.1016/j.tecto.2008.10.024

Frizon De Lamotte, D., Fourdan, B., Leleu, S., Leparmentier, F., De Clarens, P., 2015. Style of rifting and the stages of Pangea breakup. Tectonics 34, 1009-1029. doi:10.1002/2014TC003760

Fullea, J., Fernàndez, M., Afonso, J.C., Vergés, J., Zeyen, H., 2010. The structure and evolution of the lithosphere-asthenosphere boundary beneath the Atlantic-Mediterranean Transition Region. Lithos 120, 74-95. doi:10.1016/j.lithos.2010.03.003

Galdeano, A., Moreau, M.G., Pozzi, J.P., Berthou, P.Y., Malod, J.A., 1989. New paleomagnetic results from Cretaceous sediments near Lisboa (Portugal) and implications for the rotation of Iberia. Earth Planet. Sci. Lett. 92, 95-106. doi:10.1016/0012-821X(89)90024-1 
García-Lasanta, C., 2016. Magnetic fabric analyses and paleomagnetism applied to study the mesozoic evolution of the Iberian Range. PhD thesis. Universidad de Zaragoza.

García-Lasanta, C., Oliva-Urcia, B., Román-Berdiel, T., Casas, A.M., Hirt, A.M., 2014. Understanding the Mesozoic kinematic evolution in the Cameros basin (Iberian Range, NE Spain) from magnetic subfabrics and mesostructures. J. Struct. Geol. 66, 84-101. doi:10.1016/j.jsg.2014.05.013

García-Lasanta, C., Oliva-Urcia, B., Román-Berdiel, T., Casas, A.M., Gil-Peña, I., Sánchez-Moya, Y., Sopeña, A., Hirt, A.M., Mattei, M., 2015. Evidence for the Permo-Triassic transtensional rifting in the Iberian Range (NE Spain) according to magnetic fabrics results. Tectonophysics 651, 216-231. doi:10.1016/j.tecto.2015.03.023

García-Lasanta, C., Román-Berdiel, T., Oliva-Urcia, B., Casas, A.M., Gil-Peña, I., Speranza, F., Mochales, T., 2016. Tethyan versus Iberian extension during the Cretaceous period in the eastern Iberian Peninsula: insights from magnetic fabrics. J. Geol. Soc. London. 173, 127-141. doi:10.1144/jgs2015068

García-Lasanta, C., Casas-Sainz, A., Villalaín, J.J., Oliva-Urcia, B., Mochales, T., Speranza, F., 2017. Remagnetizations used to unravel large-scale fold kinematics: a case study in the Cameros basin (N Spain). Tectonics. doi:10.1002/2016TC004459

Gautam, P., Ulak, P. Das, Paudayal, K.N., Gyawali, B.R., Bhandari, S., 2012. Magnetostratigraphic dating of the prime-time sedimentary record of Himalayan tectonics and climate: new age constraints (13-10 Ma) from the Siwaliks of the Tinau Khola north section, Nepal. Geophys. J. Int. 190, 1378-1392. doi:10.1111/j.1365-246X.2012.05568.X

Ghorbal, B., Bertotti, G., Foeken, J., Andriessen, P., 2008. Unexpected Jurassic to Neogene vertical movements in 'stable'parts of NW Africa revealed by low temperature geochronology. Terra Nov. 20, 355-363. doi:10.1111/j.1365-3121.2008.00828.x

Gil, A., Lago, M., Galé, C., Pocoví, A., Arranz, E., Pocoví, A., Arranz, E., Pocoví, A., Arranz, E., 2002. Magnetic fabric in folded sills and lava flows. A case study in the Permian basalts of the Anayet Massif (Pyrenean Axial Zone, Spain). Tectonophysics 350, 1-15. doi:10.1016/S0040-1951(02)00078-1

Giles, K.A., Lawton, T.F., 2002. Halokinetic sequence stratigraphy adjacent to the El Papalote diapir, Northeastern Mexico. Am. Assoc. Pet. Geol. Bull. 86, 823-840. doi:10.1306/61EEDBAC-173E-11D78645000102C1865D

Girdler, R.W., 1961. The Measurement and Computation of Anisotropy of Magnetic Susceptibility of Rocks. Geophys. J. Int. 5, 34-44. doi:10.1111/j.1365-246X.1961.tb02927.x

Goldberg, J.M., Guiraud, M., Maluski, H., Séguret, M., 1988. Caractères pétrologiques et âge du métamorphisme en contexte distensif du bassin sur décrochement de Soria (Crétacé inférieur Nord Espagnet). Comptes Rendus L Acad. Des Sci. Paris 307, 521-527.

Gomez, F., Beauchamp, W., Barazangi, M., 2000. Role of the Atlas Mountains (northwest Africa) within the African-Eurasian plate-boundary zone. Geology 28, 775-778. doi:10.1130/00917613(2000)28<775:ROTAMN $>2.0$. CO;2

Gong, Z., Langereis, C.G., Mullender, T. A.T., 2008. The rotation of Iberia during the Aptian and the opening of the Bay of Biscay. Earth Planet. Sci. Lett. 273, 80-93. doi:10.1016/j.epsl.2008.06.016

Gong, Z., Dekkers, M.J., Dinarès-Turell, J., Mullender, T.A.T., 2008. Remagnetization mechanism of Lower Cretaceous rocks from the Organyà Basin (Pyrenees, Spain). Stud. Geophys. Geod. 52, 187-210. doi:10.1007/s11200-008-0013-3 
Gong, Z., van Hinsbergen, D.J.J., Dekkers, M.J., 2009. Diachronous pervasive remagnetization in northern Iberian basins during Cretaceous rotation and extension. Earth Planet. Sci. Lett. 284, 292-301. doi:10.1016/j.epsl.2009.04.039

Gradstein, F.M., Ogg, J.G., Schmitz, M.D., Ogg, G.M., 2012. The Geologic Time Scale, The Geologic Time Scale 2012. Elsevier, Boston. doi:10.1016/C2011-1-08249-8

Graham, J.W., 1949. The stability and significance of magnetism in sedimentary rocks. J. Geophys. Res. 54, 131-167. doi:10.1029/JZ054i002p00131

Graham, J.W., 1954. Magnetic susceptibility anisotropy, an unexploited petrofabric element. Geol. Soc. Am. Bull. 65, 1257-1258.

Graham, J.W., 1966. Significance of Magnetic Anisotropy in Appalachian Sedimentary Rocks, in: Steinhart, J.S., Smith, T.J. (Eds.), The Earth Beneath the Continents. American Geophysical Union, Geophysical Monograph Series, Washington, pp. 627-648. doi:10.1029/GM010p0627

Granot, R., Tauxe, L., Gee, J.S., Ron, H., 2007. A view into the Cretaceous geomagnetic field from analysis of gabbros and submarine glasses. Earth Planet. Sci. Lett. 256, 1-11. doi:10.1016/j.epsl.2006.12.028

Haddoumi, H., Charrière, A., Feist, M., Andreu, B., 2002. Nouvelles datations (Hauterivien supérieurBarrémien inférieur) dans les «Couches rouges» continentales du Haut Atlas central marocain; conséquences sur l'âge du magmatisme et des structurations mésozoïques de la chaîne Atlasique. Comptes Rendus - Palevol 1, 259-266. doi:10.1016/S1631-0683(02)00039-8

Hadri, M., 1997. Carte géologique du Maroc à 1/100 000, feuille Tinejdad. Notes Mém. Serv. géol. Maroc1 385.

Hailwood, E.A., Mitchell, J.G., 1971. Palaeomagnetic and Radiometric Dating Results from Jurassic Intrusions in South Morocco. Geophys. J. Int. 24, 351-364. doi:10.1111/j.1365-246X.1971.tb02183.x

Hargraves, R.B., Johnson, D., Chan, C.Y., 1991. Distribution anisotropy: The cause of AMS in igneous rocks? Geophys. Res. Lett. 18, 2193-2196. doi:10.1029/91GL01777

Heitzmann, P., Stüder, M.A., 1990. Carte géologique du Maroc au 1/100000, feuille Tounfite. Notes Mém. Serv. géol. Maroc 357.

Henry, B., Rouvier, H., Le Goff, M., Smati, A., Hatira, N., Laatar, E., Mansouri, A., Perthuisot, V., 2000. Paleomagnetism as a structural polarity criterion: Application to Tunisian diapirs. J. Struct. Geol. 22, 323-334. doi:10.1016/S0191-8141(99)00155-8

Henry, B., Rouvier, H., le Goff, M., Leach, D., Macquar, J.-C., Thibieroz, J., Lewchuk, M.T., 2001. Palaeomagnetic dating of widespread remagnetization on the southeastern border of the French Massif Central and implications for fluid flow and Mississippi Valley-type mineralization. Geophys. J. Int. 145, 368-380. doi:10.1046/j.0956-540x.2001.01382.x

Henry, B., Rouvier, H., Le Goff, M., 2004. Using syntectonic remagnetizations for fold geometry and vertical axis rotation: the example of the Cévennes border (France). Geophys. J. Int. 157, 1061-1070. doi:10.1111/j.1365-246X.2004.02277.x

Hext, G.R., 1963. The estimation of second-order tensors, with related tests and designs. Biometrika 50, 353-373. doi:10.1093/biomet/50.3-4.353

Hirt, A.M., Lowrie, W., Pfiffner, O.A., 1986. A paleomagnetic study of tectonically deformed red beds of the Lower Glarus Nappe Complex, eastern Switzerland. Tectonics 5, 723-731. doi:10.1029/TC005i005p00723 
Hirt, A.M., Almqvist, B.S.G., 2012. Unraveling magnetic fabrics. Int. J. Earth Sci. 101, 613-624. doi:10.1007/s00531-011-0664-0

Holl, J.E., Anastasio, D.J., 1993. Paleomagnetically derived folding rates, southern Pyrenees, Spain. Geology 21, 271. doi:10.1130/0091-7613(1993)021<0271:PDFRSP>2.3.CO;2

Hospers, J., 1955. Rock Magnetism and Polar Wandering. J. Geol. 63, 59-74.

Hospers, J., Van Andel, S.I., 1969. Palaeomagnetism and tectonics, a review. Earth-Science Rev. 5, 5-44. doi:10.1016/0012-8252(69)90050-6

Hounslow, M.W., Maher, B.A., 1996. Quantitative extraction and analysis of carriers of magnetization in sediments. Geophys. J. Int. 124, 57-74.

Hrouda, F., 1982. Magnetic anisotropy of rocks and its application in geology and geophysics. Geophys. Surv. 5, 37-82. doi:10.1007/BF01450244

Hrouda, F., 1994. A technique for the measurement of thermal changes of magnetic susceptibility of weakly magnetic rocks by the CS-2 apparatus and KLY-2 Kappabridge. Geophys. J. Int. 118, 604-612. doi:10.1111/j.1365-246X.1994.tb03987.x

Hrouda, F., Jelínek, V., 1990. Resolution of ferrimagnetic and paramagnetic anisotropies in rocks, using combined low-field and high-field measurements. Geophys. J. Int. 103, 75-84. doi:10.1111/j.1365246X.1990.tb01753.x

Hrouda, F., Jelínek, V., Zapletal, K., 1997. Refined technique for susceptibility resolution into ferromagnetic and paramagnetic components based on susceptibility temperature-variation measurement. Geophys. J. Int. 129, 715-719. doi:10.1111/j.1365-246X.1997.tb04506.x

Hrouda, F., Ježek, J., 2014. Frequency-dependent AMS of rocks: A tool for the investigation of the fabric of ultrafine magnetic particles. Tectonophysics 629, 27-38. doi:10.1016/j.tecto.2014.01.040

Hurst, S. D., Verosub, K. L., Moores, E. M., 1992. Paleomagnetic constraints on the formation of the Solea graben, Troodos ophiolite, Cyprus. Tectonophysics 208, 431-445. doi: 10.1016/0040-1951(92)90439-D

Ibouh, H., 2004. Du rift avorté au bassin sur décrochement, contrôles tectonique et sédimentaire pendant le Jurassique (Haut Atlas Central, Maroc). PhD thesis. Université Cadi Ayyad, Marrakech.

Ibouh, H., Michard, A., Charrière, A., Benkaddour, A., Rhoujjati, A., 2014. Tectonic-karstic origin of the alleged "impact crater” of Lake Isli (Imilchil district, High Atlas, Morocco). Comptes Rendus Geosci. 2-9. doi:10.1016/j.crte.2014.03.005

Irving, E., 1958. Palaeogeographic Reconstruction from Palaeomagnetism. Geophys. J. R. Astron. Soc. 1, 224-237. doi:10.1111/j.1365-246X.1958.tb00056.x

Irving, E., 1959. Palaeomagnetic Pole Positions: A Survey and Analysis. Geophys. J. Int. 2, 51-79. doi:10.1111/j.1365-246X.1959.tb05781.x

Issachar, R., Levi, T., Lyakhovsky, V., Marco, S., Weinberger, R., 2016. Improving the method of lowtemperature anisotropy of magnetic susceptibility (LT-AMS) measurements in air. Geochemistry, Geophys. Geosystems 17, 2940-2950. doi:10.1002/2016GC006339

Izquierdo-Llavall, E., Román-Berdiel, T., Casas, A.M., Oliva-Urcia, B., Gil-Peña, I., Soto, R., Jabaloy, A., 2012. Magnetic and structural study of the Eaux-Chaudes intrusion: Understanding the Variscan deformation in the Western Axial Zone (Pyrenees). Int. J. Earth Sci. 101, 1817-1834. doi:10.1007/s00531-012-0760-9 
Izquierdo-Llavall, E., Aldega, L., Cantarelli, V., Corrado, S., Gil-Peña, I., Invernizzi, C., Casas, A.M., 2013. On the origin of cleavage in the Central Pyrenees: Structural and paleo-thermal study. Tectonophysics 608, 303-318. doi:10.1016/j.tecto.2013.09.027

Izquierdo-Llavall, E., Casas-Sainz, A.M., Oliva-Urcia, B., 2013. Heterogeneous deformation recorded by magnetic fabrics in the Pyrenean Axial Zone. J. Struct. Geol. 57, 97-113. doi:10.1016/j.jsg.2013.10.005

Izquierdo-Llavall, E., Sainz, A.C., Oliva-Urcia, B., Burmester, R., Pueyo, E.L., Housen, B., 2015. Multiepisodic remagnetization related to deformation in the Pyrenean Internal Sierras. Geophys. J. Int. 201, 891-914. doi:10.1093/gji/ggv042

Jackson, C.A.L., Lewis, M.M., 2016. Structural style and evolution of a salt-influenced rift basin margin; the impact of variations in salt composition and the role of polyphase extension. Basin Res. 28, 81-102. doi:10.1111/bre.12099

Jackson, M., 1990. Magnetic anisotropy of the Trenton limestone revisited. Geophys. Res. Lett. 17, 11211124. doi:10.1029/GL017i008p01121

Jackson, M.J., 1991. Anisotropy of magnetic remanence: A brief review of mineralogical sources, physical origins, and geological applications, and comparison with susceptibility anisotropy. Pure Appl. Geophys. PAGEOPH 136, 1-28. doi:10.1007/BF00878885

Jackson, M., Craddock, J.P., Ballard, M., Van Der Voo, R., McCabe, C., 1989. Anhysteretic remanent magnetic anisotropy and calcite strains in Devonian carbonates from the Appalachian Plateau, New York. Tectonophysics 161, 43-53. doi:10.1016/0040-1951(89)90300-4

Jackson, M., Swanson-Hysell, N.L., 2012. Rock magnetism of remagnetized carbonate rocks: another look. Geol. Soc. London, Spec. Publ. 371, 229-251. doi:10.1144/sp371.3

Jelínek, V., 1978. Statistical processing of anisotropy of magnetic susceptibility measured on groups of specimens. Stud. Geophys. Geod. 22, 50-62. doi:10.1007/BF01613632

Jelinek, V., 1981. Characterization of the magnetic fabric of rocks. Tectonophysics 79, T63-T67. doi:10.1016/0040-1951(81)90110-4

Jenny, J., 1984. Dynamique de la phase tectonique synsédimentaire du Jurassique moyen dans le Haut Atlas central ( Maroc ). Eclogae Geol. Helv. 77, 143-152.

Jordanova, N., Henry, B., Jordanova, D., Ivanov, Z., Dimov, D., Bergerat, F., 2001. Paleomagnetism in northwestern Bulgaria: geological implications of widespread remagnetization. Tectonophysics 343, 79-92. doi:10.1016/S0040-1951(01)00220-7

Joussiane, R., 2016. Les relations entre diapirisme et sédimentation: Exemple du Jurassique moyen de la région d’Imilchil, Haut-Atlas central, Maroc. PhD thesis. Université Bordeaux Montaigne.

Juárez, M.T., Osete, M.L., Meléndez, G., Langereis, C.G., Zijderveld, J.D.A., 1994. Oxfordian magnetostratigraphy of the Aguilón and Tosos sections (Iberian Range, Spain) and evidence of a preOligocene overprint. Phys. Earth Planet. Inter. 85, 195-211. doi:10.1016/0031-9201(94)90017-5

Juárez, M.., Lowrie, W., Osete, M.., Meléndez, G., 1998. Evidence of widespread Cretaceous remagnetisation in the Iberian Range and its relation with the rotation of Iberia. Earth Planet. Sci. Lett. 160, 729-743. doi:10.1016/S0012-821X(98)00124-1

Kamoun, F., Peybernès, B., Ciszak, R., Calzada, S., 2001. Triassic palaeogeography of Tunisia. Palaeogeogr. Palaeoclimatol. Palaeoecol. 172, 223-242. doi:10.1016/S0031-0182(01)00283-8 
Kars, M., Aubourg, C., Labaume, P., Berquó, T., Cavailhes, T., 2014. Burial Diagenesis of Magnetic Minerals: New Insights from the Grès d'Annot Transect (SE France). Minerals 4, 667-689. doi:10.3390/min4030667

Kars, M., Aubourg, C., Suarez-Ruiz, I., 2015. Neoformed magnetic minerals as an indicator of moderate burial: The key example of middle Paleozoic sedimentary rocks, West Virginia. Am. Assoc. Pet. Geol. Bull. 99, 389-401. doi:10.1306/06301413006

Katz, B., Elmore, R.D., Cogoini, M., Ferry, S., 1998. Widespread chemical remagnetization: orogenic fluids or burial diagenesis of clays? Geology 26, 603-606. doi:10.1130/00917613(1998)026<0603:WCROFO >2.3.CO

Katz, B., Elmore, R.D.D., Cogoini, M., Engel, M.H.M.H., Ferry, S., 2000. Associations between burial diagenesis of smectite, chemical remagnetization, and magnetite authigenesis in the Vocontian trough, SE France. J. Geophys. Res. Solid Earth 105, 851-868. doi:10.1029/1999JB900309

Kent, J.T., 1982. The Fisher-Bingham distribution on the sphere. J. R. Stat. Soc. Ser. B 44, 71-80.

Kirschvink, J.L., 1980. The least-squares line and plane and the analysis of paleomagnetic data. Geophys. J. R. Astron. Soc. 62, 699-718. doi:10.1111/j.1365-246X.1980.tb02601.x

Kissel, C., Barrier, E., Laj, C., Lee, T.-Q., 1986. Magnetic fabric in "undeformed" marine clays from compressional zones. Tectonics 5, 769-781. doi:10.1029/TC005i005p00769

Kligfield, R., Lowrie, W., Hirt, A., Siddans, A.W.B., 1983. Effect of progressive deformation on remanent magnetization of permian redbeds from the alpes maritimes (France). Tectonophysics 98, 59-85. doi:10.1016/0040-1951(83)90211-1

Knight, K.B., Nomade, S., Renne, P.R., Marzoli, A., Bertrand, H., Youbi, N., 2004. The Central Atlantic Magmatic Province at the Triassic-Jurassic boundary: paleomagnetic and 40Ar/39Ar evidence from Morocco for brief, episodic volcanism. Earth Planet. Sci. Lett. 228, 143-160. doi:10.1016/j.epsl.2004.09.022

Kocher, T., Schmalholz, S.M., Mancktelow, N.S., 2006. Impact of mechanical anisotropy and power-law rheology on single layer folding. Tectonophysics 421, 71-87. doi:10.1016/j.tecto.2006.04.014

Kodama, K.P., 1988. Remanence rotation due to rock strain during folding and the stepwise application of the fold test. J. Geophys. Res. B Solid Earth 93, 3357-3371. doi:10.1029/JB093iB04p03357

Koymans, M.R., Langereis, C.G., Pastor-Galán, D., van Hinsbergen, D.J.J., 2016. Paleomagnetism.org: An online multi-platform open source environment for paleomagnetic data analysis. Comput. Geosci. 93, 127-137. doi:10.1016/j.cageo.2016.05.007

Lanci, L., Zanella, E., 2016. The anisotropy of magnetic susceptibility of uniaxial superparamagnetic particles: Consequences for its interpretation in magnetite and maghemite bearing rocks. J. Geophys. Res. B Solid Earth 121, 27-37. doi:10.1002/2015JB012255

Laville, E., Harmand, C., 1982. Evolution magmatique et tectonique du bassin intracontinental mesozoique du Haut-Atlas (Maroc); un modele de mise en place synsedimentaire de massifs “anorogeniques” lies a des decrochements. Bull. la Soc. Geol. Fr. S7-XXIV, 213-227. doi:10.2113/gssgfbull.S7-XXIV.2.213

Laville, E., Piqué, A., 1992. Jurassic penetrative deformation and Cenozoic uplift in the Central High Atlas (Morocco): A tectonic model. structural and orogenic inversions. Geol. Rundschau 81, 157-170. doi:10.1007/BF01764546 
Laville, E., Zayane, R., Honnorez, J., Pique, A., 1994. The Jurassic metamorphism in the central High Atlas (Morocco): successive syntectonic and hydrothermal episodes | Le metamorphisme jurassique du Haut Atlas central (Maroc); episodes synschisteux et hydrothermaux. Comptes Rendus - Acad. des Sci. Ser. II Sci. la Terre des Planetes 318, 1349-1356.

Laville, E., Zayane, R., Honnorez, J., Piqué, A., 1994. Le métamorphisme jurassique du Haut Atlas central (Maroc) ; épisodes synschisteux et hydrothermaux. Comptes rendus l’Académie des Sci. Série 2. Sci. la terre des planètes 318, 1349-1356.

Laville, E., Pique, A., Amrhar, M., Charroud, M., 2004. A restatement of the Mesozoic Atlasic Rifting (Morocco). J. African Earth Sci. 38, 145-153. doi:10.1016/j.jafrearsci.2003.12.003

Le Roy, P., Guillocheau, F., Piqué, A., Morabet, A.M., 1998. Subsidence of the Atlantic Moroccan margin during the Mesozoic. Can. J. Earth Sci. 35, 476-493. doi:10.1139/e97-111

Le Roy, P., Piqué, A., 2001. Triassic-Liassic western Moroccan synrift basins in relation to the Central Atlantic opening. Mar. Geol. 172, 359-381. doi:10.1016/S0025-3227(00)00130-4

Lee, T.-Q., Angelier, J., 2000. Tectonic significance of magnetic susceptibility fabrics in Plio-Quaternary mudstones of southwestern foothills, Taiwan. Earth, Planets Sp. 52, 527-538. doi:10.1186/BF03351660

Leonhardt, R., 2006. Analyzing rock magnetic measurements: The RockMagAnalyzer 1.0 software. Comput. Geosci. 32, 1420-1431.

Lhachmi, A., Lorand, J.P., Fabries, J., 2001. Pétrologie de l'intrusion alcaline mésozoïque de la région d’Anemzi, Haut Atlas Central, Maroc. J. African Earth Sci. 32, 741-764. doi:10.1016/S08995362(02)00052-0

Liodas, N.T., Gébelin, A., Ferré, E.C., Misgna, G.M., 2013. Deformation coupling between the Archean Pukaskwa intrusive complex and the Hemlo shear zone, Superior Province, Canada. Tectonophysics 608, 1226-1237. doi:10.1016/j.tecto.2013.06.022

Lowrie, W., 1990. Identification of ferromagnetic minerals in a rock by coercivity and unblocking temperature properties. Geophys. Res. Lett. 17, 159-162. doi:10.1029/GL017i002p00159

Lu, G., McCabe, C., 1993. Magnetic fabric determined from ARM and IRM anisotropies in Paleozoic carbonates, Southern Appalachian Basin. Geophys. Res. Lett. 20, 1099-1102. doi:10.1029/93GL00986

Lu, H., Xiong, S., 2009. Magnetostratigraphy of the Dahonggou section, northern Qaidam Basin and its bearing on Cenozoic tectonic evolution of the Qilian Shan and Altyn Tagh Fault. Earth Planet. Sci. Lett. 288, 539-550. doi:10.1016/j.epsl.2009.10.016

Lüneburg, C.M., Lebit, H.D.W., 1998. The development of a single cleavage in an area of repeated folding. J. Struct. Geol. 20, 1531-1548. doi:10.1016/S0191-8141(98)00039-X

Lüneburg, C.M., Lampert, S.A., Lebit, H.D., Hirt, A.M., Casey, M., Lowrie, W., 1999. Magnetic anisotropy, rock fabrics and finite strain in deformed sediments of SW Sardinia (Italy). Tectonophysics 307, 51-74. doi:10.1016/S0040-1951(99)00118-3

MacDonald, W.D., 1980. Net tectonic rotation, apparent tectonic rotation, and the structural tilt correction in paleomagnetic studies. J. Geophys. Res. Solid Earth 85, 3659-3669. doi:10.1029/JB085iB07p03659

Maes, S.M., Tikoff, B., Ferré, E.C., Brown, P.E., Miller Jr., J.D., 2007. The Sonju Lake layered intrusion, northeast Minnesota: Internal structure and emplacement history inferred from magnetic fabrics. Precambrian Res. 157, 269-288. doi:10.1016/j.precamres.2007.02.021 
Malaval, M., 2016. Enregistrement sédimentaire de l'activité diapirique associée à la ride du Jbel Azourki. Haut-Atlas Central, Maroc. Enregistrement sédimentaire de l'activité diapirique associée à la ride du Jbel Azourki. Haut-Atlas Central, Maroc.

Marshak, S., Mitra, G., 1988. Basic methods of structural geology. Prentice-Hall.

Martín-Hernández, F., Hirt, A.M., 2004. A method for the separation of paramagnetic, ferrimagnetic and haematite magnetic subfabrics using high-field torque magnetometry. Geophys. J. Int. 157, 117-127.

Martín-Hernández, F., Ferré, E.C., 2007. Separation of paramagnetic and ferrimagnetic anisotropies: A review. J. Geophys. Res. Solid Earth 112. doi:10.1029/2006JB004340

Martín-Martín, J.D., Vergés, J., Saura, E., Moragas, M., Messager, G., Baqués, V., Razin, P., Grélaud, C., Malaval, M., Joussiaume, R., Casciello, E., Cruz-Orosa, I., Hunt, D.W., 2017. Diapiric growth within an Early Jurassic rift basin: The Tazoult salt wall (central High Atlas, Morocco). Tectonics 36, 2-32. doi:10.1002/2016TC004300

Masrouhi, A., Bellier, O., Koyi, H., Vila, J.M., Ghanmi, M., 2013. The evolution of the Lansarine-Baouala salt canopy in the North African Cretaceous passive margin in Tunisia. Geol. Mag. 150, 835-861. doi:10.1017/S0016756812000763

Mata, M.P., Casas, A.M., Canals, A., Gil, A., Pocovi, A., 2001. Thermal history during Mesozoic extension and tertiary uplift in the Cameros basin, Northern Spain. Basin Res. 13, 91-111. doi:10.1046/j.13652117.2001.00138.x

Mattauer, M., 1973. Les Déformations des Matériaux de l’Ecorce Terrestre. Hermann, Paris.

Mattauer, M., Tapponnier, P., Proust, F., 1977. Sur les mecanismes de formation des chaines intracontinentales; l'exemple des chaines atlasiques du Maroc. Bull. la Soc. Geol. Fr. S7-XIX, 521526. doi:10.2113/gssgfbull.S7-XIX.3.521

Mattei, M., Sagnotti, L., Faccenna, C., Funiciello, R., 1997. Magnetic fabric of weakly deformed clay-rich sediments in the Italian peninsula: Relationship with compressional and extensional tectonics. Tectonophysics 271, 107-122. doi:10.1016/S0040-1951(96)00244-2

Mattei, M., Speranza, F., Argentieri, A., Rossetti, F., Sagnotti, L., Funiciello, R., 1999. Extensional tectonics in the Amantea basin (Calabria, Italy): a comparison between structural and magnetic anisotropy data. Tectonophysics 307, 33-49. doi:10.1016/S0040-1951(99)00117-1

Matthews, K.J., Seton, M., Müller, R.D., 2012. A global-scale plate reorganization event at 105-100Ma. Earth Planet. Sci. Lett. 355-356, 283-298. doi:10.1016/j.epsl.2012.08.023

Matuyama, M., 1929. On the direction of magnetization of basalt in Japan, Tyôsen, and Manchuria. Japan Acad. Procedings 5, 203-205.

McCabe, C., Van der Voo, R., Peacor, D.R., Scotese, C.R., Freeman, R., 1983. Diagenetic magnetite carries ancient yet secondary remanence in some Paleozoic sedimentary carbonates. Geology 11, 221-223. doi:10.1130/0091-7613(1983)11<221

McCabe, C., Jackson, M., Ellwood, B.B., 1985. Magnetic anisotropy in the Trenton Limestone: Results of a new technique, anisotropy of anhysteretic susceptibility. Geophys. Res. Lett. 12, 333-336. doi:10.1029/GL012i006p00333

McCabe, C., Elmore, R.D., 1989. The occurrence and origin of Late Paleozoic remagnetization in the sedimentary rocks of North America. Rev. Geophys. 27, 471-494. doi:10.1029/RG027i004p00471 
McClelland-Brown, E., 1983. Palaeomagnetic studies of fold development and propagation in the Pembrokeshire old red Sandstone. Tectonophysics 98, 131-149. doi:10.1016/0040-1951(83)90214-7

McElhinny, M.W., Opdyke, N.D., 1973. Remagnetization Hypothesis Discounted: A Paleomagnetic Study of the Trenton Limestone, New York State. Geol. Soc. Am. Bull. 84, 3697. doi:10.1130/00167606(1973)84<3697:RHDAPS>2.0.CO;2

McElhinny, M.W., Brock, A., 1975. A new palaeomagnetic result from East Africa and estimates of the Mesozoic palaeoradius. Earth Planet. Sci. Lett. 27, 321-328. doi:10.1016/0012-821X(75)90044-8

McEnroe, S.A., 1996. A Barremian-Aptian (Early Cretaceous) North American paleomagnetic reference pole. J. Geophys. Res. Solid Earth 101, 15819-15835. doi:10.1029/96JB00652

McFadden, P.L., 1990. A new fold test for palaeomagnetic studies. Geophys. J. Int. 103, 163-169. doi:10.1111/j.1365-246X.1990.tb01761.x

McNulty, B.A., Tobisch, O.T., Cruden, A.R., Gilder, S., 2000. Multistage emplacement of the Mount Givens pluton, central Sierra Nevada batholith, California. Geol. Soc. Am. Bull. 112, 119-135. doi:10.1130/0016-7606(2000)112<119:MEOTMG>2.0.CO;2

Meijers, M.J.M., van Hinsbergen, D.J.J., Dekkers, M.J., Altıner, D., Kaymakcı, N., Langereis, C.G., 2011. Pervasive Palaeogene remagnetization of the central Taurides fold-and-thrust belt (southern Turkey) and implications for rotations in the Isparta Angle. Geophys. J. Int. 184, 1090-1112. doi:10.1111/j.1365-246X.2010.04919.x

Mercaton, P.L., 1926. Inversion de l'inclination magnétique terrestre aux âges geologique. Terr. Magn. Atmos. Electr. 31, 187-190.

Michard, A., 1976. Eléments de gélogie marocaine. Notes Mém. Serv. Géol. Maroc 252, 408 pp.

Michard, A., Ibouh, H., Charrière, A., 2011. Syncline-topped anticlinal ridges from the High Atlas: A Moroccan conundrum, and inspiring structures from the Syrian Arc, Israel. Terra Nov. 23, 314-323. doi:10.1111/j.1365-3121.2011.01016.x

Milhi, A., 1997. Carte géologique du Maroc à 1/100 000, feuille Tinghir. Notes Mém. Serv. géol. Maroc 377.

Missenard, Y., 2006. Le relif des Atlas marocains: contribution des processus asthénosphériques et du raccourcissement crustal, aspects chronologiques. $\mathrm{PhD}$ thesis. Université de Cergy-Pontoise.

Missenard, Y., Zeyen, H., Frizon de Lamotte, D., Leturmy, P., Petit, C., Sébrier, M., Saddiqi, O., 2006. Crustal versus asthenospheric origin of relief of the Atlas Mountains of Morocco. J. Geophys. Res. Solid Earth 111, B03401. doi:10.1029/2005JB003708

Missenard, Y., Saddiqi, O., Barbarand, J., Leturmy, P., Ruiz, G., El Haimer, F.Z., Frizon de Lamotte, D., 2008. Cenozoic denudation in the Marrakech High Atlas, Morocco: insight from apatite fission-track thermochronology. Terra Nov. 20, 221-228. doi:10.1111/j.1365-3121.2008.00810.x

Missenard, Y., Cadoux, A., 2012. Can Moroccan Atlas lithospheric thinning and volcanism be induced by Edge-Driven Convection? Terra Nov. 24, 27-33. doi:10.1111/j.1365-3121.2011.01033.x

Mitra, G., Adolph Yonkee, W., 1985. Relationship of spaced cleavage to folds and thrusts in the Idaho-UtahWyoming thrust belt. J. Struct. Geol. 7, 361-373. doi:10.1016/0191-8141(85)90041-0

Mitra, R., Tauxe, L., Gee, J.S., 2011. Detecting uniaxial single domain grains with a modified IRM technique. Geophys. J. Int. 187, 1250-1258. doi:10.1111/j.1365-246X.2011.05224.x 
Moragas, M., Vergés, J., Saura, E., Martín-Martín, J.-D., Messager, G., Merino-Tomé, Ó., Suárez-Ruiz, I., Razin, P., Grélaud, C., Malaval, M., Joussiaume, R., Hunt, D.W., 2016. Jurassic rifting to post-rift subsidence analysis in the Central High Atlas and its relation to salt diapirism. Basin Res. 1-27. doi:10.1111/bre.12223

Moreau, M.G., Canerot, J., Malod, J.A., 1992. Paleomagnetic study of Mesozoic sediments from the Iberian Chain (Spain); suggestions for Barremian remagnetization and implications for the rotation of Iberia. Bull. la Soc. Geol. Fr. 163, 393-402.

Moreau, M.G.G., Ader, M., Enkin, R.J.J., 2005. The magnetization of clay-rich rocks in sedimentary basins: low-temperature experimental formation of magnetic carriers in natural samples. Earth Planet. Sci. Lett. 230, 193-210. doi:10.1016/j.epsl.2004.11.013

Morrish, A.H., 1965. The Physical Principles of Magnetism. John Wiley, Hoboken, N. J.

Moskowitz, B.M., Jackson, M., Kissel, C., 1998. Low-temperature magnetic behavior of titanomagnetites. Earth Planet. Sci. Lett. 157, 141-149. doi:10.1016/S0012-821X(98)00033-8

Moussaid, B., El Ouardi, H., Casas-Sainz, A., Villalaín, J.J., Román-Berdiel, T., Oliva-Urcia, B., Soto, R., Torres-López, S., 2013. Magnetic fabrics in the Jurassic-Cretaceous continental basins of the northern part of the Central High Atlas (Morocco): Geodynamic implications. J. African Earth Sci. 87, 13-32. doi:10.1016/j.jafrearsci.2013.07.001

Moussaid, B., Casas, A.M., El Ouardi, H., Villalaín, J.J., Torres, S., 2014. Paleomagnetic and AMS study of the Tagelft inverted basin. Evidences of early compressional events in the High Atlas belt (North Africa), in: 14th Castle Meeting, New Trends on Paleo, Rock and Environmental Magnetism. Évora (Portugal).

Moussaid, B., Villalaín, J.J., Casas-Sainz, A., El Ouardi, H., Oliva-Urcia, B., Soto, R., Román-Berdiel, T., Torres-López, S., 2015. Primary vs. secondary curved fold axes: Deciphering the origin of the Aït Attab syncline (Moroccan High Atlas) using paleomagnetic data. J. Struct. Geol. 70, 65-77. doi:10.1016/j.jsg.2014.11.004

Muñoz, J.A., Beamud, E., Fernández, O., Arbués, P., Dinarès-Turell, J., Poblet, J., 2013. The Ainsa Fold and thrust oblique zone of the central Pyrenees: Kinematics of a curved contractional system from paleomagnetic and structural data. Tectonics 32, 1142-1175. doi:10.1002/tect.20070

Muxworthy, A.R., Evans, M.E., 2013. Micromagnetics and magnetomineralogy of ultrafine magnetite inclusions in the Modipe Gabbro. Geochemistry, Geophys. Geosystems 14, 921-928. doi:10.1029/2012GC004445

Muxworthy, A.R., Evans, M.E., Scourfield, S.J., King, J.G., 2013. Paleointensity results from the lateArchaean Modipe Gabbro of Botswana. Geochemistry, Geophys. Geosystems 14, 2198-2205. doi:10.1002/ggge.20142

Nagata, T., 1961. Rock magnetism, 2nd editio. ed. Maruzen, Tokyo.

Néel, L., 1950. Théorie du traînage magnétique des substances massives dans le domaine de Rayleigh. J. Phys. le Radium 11, 49-61. doi:10.1051/jphysrad:0195000110204900

Nemkin, S.R., Fitz-Diaz, E., van der Pluijm, B., Van der Voo, R., 2015. Dating synfolding remagnetization: Approach and field application (central Sierra Madre Oriental, Mexico). Geosphere 11, 1617-1628. doi:10.1130/GES01187.1 
Neres, M., Font, E., Miranda, J.M., Camps, P., Terrinha, P., Mirão, J., 2012. Reconciling Cretaceous paleomagnetic and marine magnetic data for Iberia: New Iberian paleomagnetic poles. J. Geophys. Res. 117, B06102. doi:10.1029/2011JB009067

Nomade, S., Knight, K.B., Beutel, E., Renne, P.R., Verati, C., Féraud, G., Marzoli, A., Youbi, N., Bertrand, H., 2007. Chronology of the Central Atlantic Magmatic Province: Implications for the Central Atlantic rifting processes and the Triassic-Jurassic biotic crisis. Palaeogeogr. Palaeoclimatol. Palaeoecol. 244, 326-344. doi:10.1016/j.palaeo.2006.06.034

Norris, D.K., Black, R.F., 1961. Application of Palæomagnetism to Thrust Mechanics. Nature 192, 933-935. doi:10.1038/192933a0

O’Driscoll, B., Stevenson, C.T.E., Troll, V.R., 2008. Mineral lamination development in layered gabbros of the British palaeogene igneous province: A combined anisotropy of magnetic susceptibility, quantitative textural and mineral chemistry study. J. Petrol. 49, 1187-1221. doi:10.1093/petrology/egn022

Oliva-Urcia, B., Larrasoaña, J.C., Pueyo, E.L., Gil, a., Mata, P., Parés, J.M., Schleicher, A.M., Pueyo, O., 2009. Disentangling magnetic subfabrics and their link to deformation processes in cleaved sedimentary rocks from the Internal Sierras (west central Pyrenees, Spain). J. Struct. Geol. 31, 163176. doi:10.1016/j.jsg.2008.11.002

Oliva-Urcia, B., Casas, A.M., Soto, R., Villalaín, J.J., Kodama, K., 2011. A transtensional basin model for the Organyà basin (central southern Pyrenees) based on magnetic fabric and brittle structures. Geophys. J. Int. 184, 111-130. doi:10.1111/j.1365-246X.2010.04865.x

Oliva-Urcia, B., Casas, A.M., Pueyo, E.L., Pocovi-Juan, A., 2012. paleomagnetic evidence for non-rotational kinematics of the South Pyrenean Frontal Thrust at the western termination of the External Sierras (southwestern central. Geol. Acta 10, 125-144. doi:10.1344/105.000001704

Oliva-Urcia, B., Casas, A. M., Ramón, M.J., Leiss, B., Mariani, E., Román-Berdiel, T., 2012. On the reliability of AMS in ilmenite-type granites: An insight from the Marimanha pluton, central Pyrenees. Geophys. J. Int. 189, 187-203. doi:10.1111/j.1365-246X.2011.05355.x

Oliva-Urcia, B., Román-Berdiel, T., Casas, A.M., Bógalo, M.F., Osácar, M.C., García-Lasanta, C., 2013. Transition from extensional to compressional magnetic fabrics in the Cretaceous Cabuérniga basin (North Spain). J. Struct. Geol. 46, 220-234. doi:10.1016/j.jsg.2012.09.001

Oliva-Urcia, B., Casas, A.M., Moussaid, B., Villalaín, J.J., El Ouardi, H., Soto, R., Torres-López, S., RománBerdiel, T., 2016. Tectonic fabrics vs. mineralogical artifacts in AMS analysis: A case study of the Western Morocco extensional Triassic basins. J. Geodyn. 94-95, 13-33. doi:10.1016/j.jog.2016.01.004

Oliva-Urcia, B., Beamud, E., Garcés, M., Arenas, C., Soto, R., Pueyo, E.L., Pardo, G., 2016. New magnetostratigraphic dating of the Palaeogene syntectonic sediments of the west-central Pyrenees: tectonostratigraphic implications. Geol. Soc. London, Spec. Publ. 425, 107-128. doi:10.1144/SP425.5

Oliva-Urcia, B., Gil-Peña, I., Soto, R., Samsó, J.M., Antolín, B., Pueyo, E.L., 2018. New insights into asymmetric folding by means of the anisotropy of magnetic susceptibility, Variscan and Pyrenean folds (SW Pyrenees). Stud. Geophys. Geod. 62. doi:10.1007/s11200-017-0143-6

Osete, M.L., Rey, D., Villalaín, J.J., Juárez, M.T., 1997. The Late Carboniferous to Late Triassic segment of the apparent polar wander path of Iberia. Geol. en Mijnb. (Geology Mining) 76, 105-119. doi:10.1023/A:1003197500052

Ovtracht, A., 1980. Tectonique salidère de l'Atlas (Maroc), in: 26th Congr. Géol. Internat. Paris, p. 370. 
Özdemir, Ö., Dunlop, D.J., Moskowitz, B.M., 1993. The effect of oxidation on the Verwey transition in magnetite. Geophys. Res. Lett. 20, 1671-1674. doi:10.1029/93GL01483

Parés, J.M., 2004. How deformed are weakly deformed mudrocks? Insights from magnetic anisotropy. Geol. Soc. London, Spec. Publ. 238, 191-203. doi:10.1144/GSL.SP.2004.238.01.13

Parés, J.M., 2015. Sixty years of anisotropy of magnetic susceptibility in deformed sedimentary rocks. Front. Earth Sci. 3, 1-13. doi:10.3389/feart.2015.00004

Parés, J.M., van der Pluijm, B.A., Dinarès-Turell, J., 1999. Evolution of magnetic fabrics during incipient deformation of mudrocks (Pyrenees, northern Spain). Tectonophysics 307, 1-14. doi:10.1016/S00401951(99)00115-8

Parés, J.M., van der Pluijm, B.A., 2002. Phyllosilicate fabric characterization by Low-Temperature Anisotropy of Magnetic Susceptibility (LT-AMS). Geophys. Res. Lett. 29, 68-1-68-4. doi:10.1029/2002GL015459

Parés, J.M., van der Pluijm, B. A., 2014. Low-temperature AMS and the quantification of subfabrics in deformed rocks. Tectonophysics 629, 55-62. doi:10.1016/j.tecto.2014.03.005

Pariso, J.E., Kelso, P., Richter, C., 1996. Paleomagnetism and Rock Magnetic Properties of Gabbro from Hole 894G, Hess Deep, in: Proceedings of the Ocean Drilling Program, 147 Scientific Results. Ocean Drilling Program. doi:10.2973/odp.proc.sr.147.023.1996

Pastor-Galán, D., Mulchrone, K.F., Koymans, M.R., van Hinsbergen, D.J.J., Langereis, C.G., 2017. Bootstrapped total least squares orocline test: A robust method to quantify vertical-axis rotation patterns in orogens, with examples from the Cantabrian and Aegean oroclines. Lithosphere 9, 499-511. doi:10.1130/L547.1

Pevear, D.R., 1999. Illite and hydrocarbon exploration. Proc. Natl. Acad. Sci. U. S. A. 96, 3440-6. doi:10.1073/pnas.96.7.3440

Piqué, A., Laville, E., 1996. The Central Atlantic rifting: Reactivation of palaeozoic structures? J. Geodyn. 21, 235-255. doi:10.1016/0264-3707(95)00022-4

Poisson, A., Hadri, M., Milhi, A., Julien, M., Andrieux, J., 1998. The Central High-Atlas (Morocco). Lithoand chrono-stratigraphic correlations during Jurassic times between Tinjdad and Tounfite. Origin of Subsidence, in: Crasquin-Soleau, S., Barrier, E. (Eds.), Peri-Tethys Memoir 4: Epicratonic Basins of Peri-Tethyan Platforms. Mémoires du Muséum National d’Histoire Naturelle, Paris, pp. 237-256.

Potter, D.K., 2004. A comparison of anisotropy of magnetic remanence methods - a user's guide for application to palaeomagnetism and magnetic fabric studies, in: Martin-Hernández, F., Lüneburg, C.M., Aubourg, C., Jackson, M. (Eds.), Magnetic Fabric: Methods and Applications, Geological Society Special Publications. The Geological Society of London, London, pp. 21-36. doi:10.1144/GSL.SP.2004.238.01.03

Potter, D.K., Stephenson, A., 1988. Single-domain particles in rocks and magnetic fabric analysis. Geophys. Res. Lett. 15, 1097-1100. doi:10.1029/GL015i010p01097

Pueyo Anchuela, Ó., Gil Imaz, A., Pocoví Juan, A., 2010. Significance of AMS in multilayer systems in foldand-thrust belts. A case study from the Eocene turbidites in the Southern Pyrenees (Spain). Geol. J. 45, 544-561. doi:10.1002/gj.1194 
Pueyo Anchuela, Ó., María Casas-Sainz, A., Pocoví Juan, A., Gil Imaz, A., 2011. Lithology-dependent reliability of AMS analysis: A case study of the Eocene turbidities in the southern Pyrenees (Aragón, Spain). Comptes Rendus Geosci. 343, 11-19. doi:10.1016/j.crte.2010.11.003

Pueyo Anchuela, O., Gil Imaz, A., Gil-Peña, I., Maestro, A., Galindo-Zaldivar, J., López-Martínez, J., Rey, J., Soto, R., Oliva-Urcia, B., 2014. Application of AMS for reconstruction of the geological evolution of recent volcanic systems: Case of Deception Island (South Shetland Islands, Antarctica). Tectonophysics 626, 69-85. doi:10.1016/j.tecto.2014.03.032

Pueyo, E.L., Parés, J.., Millán, H., Pocoví, A., 2003. Conical folds and apparent rotations in paleomagnetism (a case study in the Southern Pyrenees). Tectonophysics 362, 345-366. doi:10.1016/S00401951(02)00645-5

Pueyo, E.L., Pocoví, A., Millán, H., Sussman, A.J., 2004. Map-view models for correcting and calculating shortening estimates in rotated thrust fronts using paleomagnetic data. Geol. Soc. ... 383, 1-15. doi:10.1130/0-8137-2383-3(2004)383[57:MMFCAC]2.0.CO;2

Pueyo, E.L., Sussman, A.J., Oliva-Urcia, B., Cifelli, F., 2016. Palaeomagnetism in fold and thrust belts: use with caution. Geol. Soc. London, Spec. Publ. 425, 259-276. doi:10.1144/SP425.14

Radhakrishnamurty, C., Likhite, S.D., 1993. Frequency dependence of low-temperature susceptibility peak in some titanomagnetites. Phys. Earth Planet. Inter. 76, 131-135.

Ramón, M.J., 2013. Flexural unfolding of complex geometries in fold and thrust belts using paleomagnetic vectors. PhD thesis. Universidad de Zaragoza.

Ramón, M.J., Pueyo, E.L., Briz, J.L., Pocoví, A., Ciria, J.C., 2012. Flexural unfolding of horizons using paleomagnetic vectors. J. Struct. Geol. 35, 28-39. doi:10.1016/j.jsg.2011.11.015

Ramón, M., Pueyo, E.L., Rodríguez-Pintó, A., Ros, L.H., Pocoví, A., Briz, J.L., Ciria, J.C., 2013. A computed tomography approach for understanding 3D deformation patterns in complex folds. Tectonophysics 593, 57-72. doi:10.1016/j.tecto.2013.02.027

Ramón, M.J., Pueyo, E.L., Oliva-Urcia, B., Larrasoaña, J.C., 2017. Virtual Directions in Paleomagnetism: A Global and Rapid Approach to Evaluate the NRM Components. Front. Earth Sci. 5, 1-14. doi:10.3389/feart.2017.00008

Ramsay, J.G., Huber, M.I., 1987. The Techniques of Modern Structural Geology. Volume 2: Folds and Fractures. Academic Press, London.

Renne, P.R., Scott, G.R., Glen, J.M.G., Feinberg, J.M., 2002. Oriented inclusions of magnetite in clinopyroxene: Source of stable remanent magnetization in gabbros of the Messum Complex, Namibia. Geochemistry, Geophys. Geosystems 3, 1-11. doi:10.1029/2002GC000319

Richter, C., van der Pluijm, B.A., 1994. Separation of paramagnetic and ferrimagnetic susceptibilities using low temperature magnetic susceptibilities and comparison with high field methods. Phys. Earth Planet. Inter. 82, 113-123. doi:10.1016/0031-9201(94)90084-1

Roberts, A.P., Tauxe, L., Heslop, D., Zhao, X., Jiang, Z., 2018. A Critical Appraisal of the “Day” Diagram. J. Geophys. Res. Solid Earth 123, 2618-2644. doi:10.1002/2017JB015247

Roca, E., Beamud, E., Rubinat, M., Soto, R., Ferrer, O., 2013. Paleomagnetic and inner diapiric structural constraints on the kinematic evolution of a salt-wall: The Bicorb-Quesa and northern Navarrés salt-wall segments case (Prebetic Zone, SE Iberia). J. Struct. Geol. 52, 80-95. doi:10.1016/j.jsg.2013.04.003 
Rochette, P., Vialon, P., 1984. Development of planar and linear fabrics in Dauphinois shales and slates (French Alps) studied by magnetic anisotropy and its mineralogical control. J. Struct. Geol. 6, 33-38.

Rochette, P., Fillion, G., 1988. Identification of multicomponent anisotropies in rocks using various field and temperature values in a cryogenic magnetometer. Phys. Earth Planet. Inter. 51, 379-386. doi:10.1016/0031-9201(88)90079-9

Rochette, P., Jackson, M.J., Aubourg, C., 1992. Rock magnetism and the interpretation of anisotropy of magnetic susceptibility. Rev. Geophys. 30, 209-226. doi:10.1029/92RG00733

Rodriguez-Pintó, A., Pueyo, E., Barnolas, A., Pocoví, A., Oliva-Urcia, B., Ramón, M.J., 2013. Overlapped paleomagnetic vectors and fold geometry: A case study in the Balzes anticline (Southern Pyrenees). Phys. Earth Planet. Inter. 215, 43-57. doi:10.1016/j.pepi.2012.10.005

Rodríguez-Pintó, A., Pueyo, E.L., Calvín, P., Sánchez, E., Ramajo, J., Casas, A.M., Ramón, M.J., Pocoví, A., Barnolas, A., Román, T., 2016. Rotational kinematics of a curved fold: The Balzes anticline (Southern Pyrenees). Tectonophysics 677-678, 171-189. doi:10.1016/j.tecto.2016.02.049

Román-Berdiel, T., 1999. Geometry of granite emplacement in the upper crust: contributions of analogue modelling. Geol. Soc. London, Spec. Publ. 168, 77-94. doi:10.1144/GSL.SP.1999.168.01.06

Roman-Berdiel, T., Gapais, D., Brun, J.P., 1995. Analogue models of laccolith formation. J. Struct. Geol. 17, 1337-1346. doi:10.1016/0191-8141(95)00012-3

Román-Berdiel, T., Gapais, D., Brun, J.P., 1997. Granite intrusion along strike-slip zones in experiment and nature. Am. J. Sci. 297, 651-678. doi:10.2475/ajs.297.6.651

Román-Berdiel, T., Casas, A.M., Oliva-Urcia, B., Pueyo, E.L., Rillo, C., 2004. The main Variscan deformation event in the Pyrenees: new data from the structural study of the Bielsa granite. J. Struct. Geol. 26, 659-677. doi:10.1016/j.jsg.2003.09.001

Román-Berdiel, T., Casas, A.M., Oliva-Urcia, B., Pueyo, E.L., Liesa, C., Soto, R., 2006. The Variscan Millares granite (central Pyrenees): Pluton emplacement in a T fracture of a dextral shear zone. Geodin. Acta 19, 197-211. doi:10.3166/ga.19.197-211

Rouvier, H., Henry, B., Le Goff, M., 2012. Mise en evidence par le paleomagnetisme de rotations regionales dans la virgation des Corbieres (France). Bull. la Soc. Geol. Fr. 183, 409-424.

Saddiqi, O., El Haimer, F.-Z., Michard, A., Barbarand, J., Ruiz, G.M.H., Mansour, E.M., Leturmy, P., Frizon de Lamotte, D., 2009. Apatite fission-track analyses on basement granites from south-western Meseta, Morocco: Paleogeographic implications and interpretation of AFT age discrepancies. Tectonophysics 475, 29-37. doi:10.1016/j.tecto.2009.01.007

Sagnotti, L., Speranza, F., Winkler, A., Mattei, M., Funiciello, R., 1998. Magnetic fabric of clay sediments from the external northern Apennines (Italy). Phys. Earth Planet. Inter. 105, 73-93.

Salas, R., Casas, A., 1993. Mesozoic extensional tectonics, stratigraphy and crustal evolution during the Alpine cycle of the eastern Iberian basin. Tectonophysics 228, 33-55. doi:10.1016/00401951(93)90213-4

Santolaria, P., Casas, A.M., Soto, R., 2015. Anisotropy of magnetic susceptibility as a proxy to assess internal deformation in diapirs: case study of the Naval salt wall (Southern Pyrenees). Geophys. J. Int. 202, 1207-1222. doi:10.1093/gji/ggv231 
Santolaria, P., Vendeville, B.C., Graveleau, F., Soto, R., Casas-Sainz, A., 2015. Double evaporitic décollements: Influence of pinch-out overlapping in experimental thrust wedges. J. Struct. Geol. 76, 35-51. doi:10.1016/j.jsg.2015.04.002

Saura, E., Vergés, J., Martín-Martín, J.D., Messager, G., Moragas, M., Razin, P., Grélaud, C., Joussiaume, R., Malaval, M., Homke, S., Hunt, D.W., 2014. Syn- to post-rift diapirism and minibasins of the Central High Atlas (Morocco): the changing face of a mountain belt. J. Geol. Soc. London. 171, 97-105. doi:10.1144/jgs2013-079

Schaer, J.P., 1987. Evolution and structure of the High Atlas of Morocco, in: Schaer, J.P., Rodgers, J. (Eds.), The Anatomy of Mountain Ranges. Princeton University Press, pp. 107-128.

Schaer, J.J., Persoz, F., 1976. Aspects structuraux et pétrographiques du Haut Atlas calcaire de Midelr (Maroc). Bull. La Soc. Geol. Fr. 7, 1239-1250.

Schmidt, V., Hirt, A.M., Rosselli, P., Martín-Hernández, F., 2007. Separation of diamagnetic and paramagnetic anisotropy by high-field, low-temperature torque measurements. Geophys. J. Int. 168, 40-47. doi:10.1111/j.1365-246X.2006.03202.x

Schmidt, V., Hirt, A.M., Leiss, B., Burlini, L., Walter, J.M., 2009. Quantitative correlation of texture and magnetic anisotropy of compacted calcite-muscovite aggregates. J. Struct. Geol. 31, 1062-1073. doi:10.1016/j.jsg.2008.11.012

Schöbel, S., De Wall, H., 2014. AMS-NRM interferences in the Deccan basalts: Toward an improved understanding of magnetic fabrics in flood basalts. J. Geophys. Res. Solid Earth 119, 2651-2678. doi:10.1002/2013JB010660

Schofield, N., Alsop, I., Warren, J., Underhill, J.R.R., Lehné, R., Beer, W., Lukas, V., Lehne, R., Beer, W., Lukas, V., 2014. Mobilizing salt: Magma-salt interactions. Geology 42, 599-602. doi:10.1130/G35406.1

Schöpa, A., Floess, D., Saint Blanquat, M.D., Annen, C., Launeau, P., 2015. The relation between magnetite and silicate fabric in granitoids of the Adamello Batholith. Tectonophysics 642, 1-15. doi:10.1016/j.tecto.2014.11.022

Schott, J.J., Peres, A., 1987. Paleomagnetism of the Lower Cretaceous redbeds from northern Spain: evidence for a multistage acquisition of magnetization. Tectonophysics 139, 239-253. doi:10.1016/0040-1951(87)90099-0

Seber, D., Barazangi, M., Tadili, B.A., Ramdani, M., Ibenbrahim, A., Ben Sari, D., 1996. Three-dimensional upper mantle structure beneath the intraplate Atlas and interplate Rif mountains of Morocco. J. Geophys. Res. Solid Earth 101, 3125-3138. doi:10.1029/95JB03112

Séguret, M., 1972. Etude tectonique des nappes et series decollées de la partie centrale du versant sud des Pyrenées. Caractére sedymentaire, rôle de la compression et de la gravité. Université des Sciences et Techniques du Languedoc (Montpellier II).

Shipunov, S.V., 1997. Synfolding magnetization: detection, testing and geological applications. Geophys. J. Int. 130, 405-410. doi:10.1111/j.1365-246X.1997.tb05656.x

Simón, J.L., 2004. Superposed buckle folding in the eastern Iberian Chain, Spain. J. Struct. Geol. 26, 14471464. doi:10.1016/j.jsg.2003.11.026

Smith, B., Derder, M.E.M., Henry, B., Bayou, B., Yelles, A. K., Djellit, H., Amenna, M., Garces, M., Beamud, E., Callot, J.P., Eschard, R., Chambers, A., Aifa, T., Ait Ouali, R., Gandriche, H., 2006. 
Relative importance of the Hercynian and post-Jurassic tectonic phases in the Saharan platform: a palaeomagnetic study of Jurassic sills in the Reggane Basin (Algeria). Geophys. J. Int. 167, 380-396. doi:10.1111/j.1365-246X.2006.03105.X

Soto, R., Casas-Sainz, A.M., Villalain, J.J., 2011. Widespread Cretaceous inversion event in northern Spain: evidence from subsurface and palaeomagnetic data. J. Geol. Soc. London. 168, 899-912. doi:10.1144/0016-76492010-072

Soto, R., Casas-Sainz, A.M., Pueyo, E.L., 2006. Along-strike variation of orogenic wedges associated with vertical axis rotations. J. Geophys. Res. 111, B10402. doi:10.1029/2005JB004201

Soto, R., Casas-Sainz, A.M., Villalaín, J.J., Gil-Imaz, A., Fernandez-Gonzalez, G., Del Rio, P., Calvo, M., Mochales, T., 2008. Characterizing the Mesozoic extension direction in the northern Iberian plate margin by anisotropy of magnetic susceptibility (AMS). J. Geol. Soc. London. 165, 1007-1018. doi:10.1144/0016-76492007-163

Soto, R., Villalaín, J.J., Casas-Sainz, A.M., 2008. Remagnetizations as a tool to analyze the tectonic history of inverted sedimentary basins: A case study from the Basque-Cantabrian basin (north Spain). Tectonics 27, n/a-n/a. doi:10.1029/2007TC002208

Soto, R., Larrasoaña, J.C., Arlegui, L.E., Beamud, E., Oliva-Urcia, B., Simón, J.L., 2009. Reliability of magnetic fabric of weakly deformed mudrocks as a palaeostress indicator in compressive settings. J. Struct. Geol. 31, 512-522. doi:10.1016/j.jsg.2009.03.006

Soto, R., Kullberg, J.C., Oliva-Urcia, B., Casas-Sainz, A.M., Villalaín, J.J., 2012. Switch of Mesozoic extensional tectonic style in the Lusitanian basin (Portugal): Insights from magnetic fabrics. Tectonophysics 536-537, 122-135. doi:10.1016/j.tecto.2012.03.010

Soto, R., Beamud, E., Roca, E., Carola, E., Almar, Y., 2017. Distinguishing the effect of diapir growth on magnetic fabrics of syn-diapiric overburden rocks: Basque-Cantabrian basin, Northern Spain. Terra Nov. 38, 42-49. doi:10.1111/ter.12262

Spera, F., 1980. Thermal evolution of plutons: a parameterized approach. Science 207, 299-301. doi:10.1126/science.207.4428.299

Stamatakos, J., Kodama, K.P., 1991. Flexural flow folding and the paleomagnetic fold test: An example of strain reorientation of remanence in the Mauch Chunk Formation. Tectonics 10, 807-819. doi:10.1029/91TC00366

Stampfli, G.M., Hochard, C., Vérard, C., Wilhem, C., vonRaumer, J., 2013. The formation of Pangea. Tectonophysics 593, 1-19. doi:10.1016/j.tecto.2013.02.037

Steiner, M.B., 1973. Late Paleozoic Partial Remagnetization of Ordovician Rocks from Southern Oklahoma. Geol. Soc. Am. Bull. 84, 341. doi:10.1130/0016-7606(1973)84<341:LPPROO>2.0.CO;2

Stephenson, A., 1994. Distribution anisotropy: two simple models for magnetic lineation and foliation. Phys. Earth Planet. Inter. 82, 49-53. doi:10.1016/0031-9201(94)90101-5

Stephenson, A., Sadikun, S., Potter, D.K., 1986. A theoretical and experimental comparison of the anisotropies of magnetic susceptibility and remanence in rocks and minerals. Geophys. J. Int. 84, 185200. doi:10.1111/j.1365-246X.1986.tb04351.x

Strauss, B.E., Strehlau, J.H., Lascu, I., Dorale, J.A., Penn, R.L., Feinberg, J.M., 2013. The origin of magnetic remanence in stalagmites: Observations from electron microscopy and rock magnetism. Geochemistry, Geophys. Geosystems 14, 5006-5025. doi:10.1002/2013GC004950 
Strehlau, J.H., Hegner, L. A., Strauss, B.E., Feinberg, J.M., Penn, R.L., 2014. Simple and Efficient Separation of Magnetic Minerals From Speleothems and Other Carbonates. J. Sediment. Res. 84, 10961106. doi:10.2110/jsr.2014.89

Studer, M., Dresnay, R.D., 1980. Déformations synsédimentaires en compression pendant le Lias supérieur et le Dogger, au Tizi n’Irhil (Haut Atlas central de Midelt, Maroc). Bull. la Soc. Geol. Fr. 7, 391-397.

Sugiura, N., 1979. ARM, TRM and magnetic interactions: Concentration dependence. Earth Planet. Sci. Lett. 42, 451-455. doi:10.1016/0012-821X(79)90054-2

Suk, D., Peacor, D.R., Van Der Voo, R., 1990. Replacement of pyrite framboids by magnetite in limestone and implications for palaeomagnetism. Nature 345, 611-613.

Suk, D., Van der Voo, R., Peacor, D.R., 1993. Origin of magnetite responsible for remagnetization of early Paleozoic limestones of New York State. J. Geophys. Res. B Solid Earth 98, 419-434.

Sun, W., Jackson, M., Craddock, J.P., 1993. Relationship between remagnetization, magnetic fabric and deformation in Paleozoic carbonates. Tectonophysics 221, 361-366. doi:10.1016/0040-1951(93)90167I

Sun, W., Jackson, M.J., 1994. Scanning electron microscopy and rock magnetic studies of magnetic carriers in remagnetized Early Paleozoic carbonates from Missouri. J. Geophys. Res. B Solid Earth 99, 29352942.

Suppe, J., 1983. Geometry and kinematics of fault-bend folding. Am. J. Sci. 283, 684-721. doi:10.2475/ajs.283.7.684

Surmont, J., Sandulescu, M., Bordea, S., 1990. Mise en évidence dúne réaimantation fini crétacée des séries mésozoïques de l'unité de Bihor (Monts Apuseni, Roumanie) et de sa rotation horarie ultériore. Comptes Rendus L Acad. Des Sci. Paris 310, 213-219.

Tarling, D.H., Hrouda, F., 1993. The Magnetic Anisotropy of Rocks. Chapman \& Hall, London.

Tauxe, L., 2010. Essentials of Paleomagnetism. University of California Press Ltd, Berkeley.

Tauxe, L., Kylstra, N., Constable, C., 1991. Boostrap Statistics for Palcomagnetic Data. J. Geophys. Res. 96, 723-740.

Tauxe, L., Watson, G.S., 1994. The fold test: an eigen analysis approach. Earth Planet. Sci. Lett. 122, 331341. doi:10.1016/0012-821X(94)90006-X

Tauxe, L., Mullender, T.A.T., Pick, T., 1996. Potbellies, wasp-waists, and superparamagnetism in magnetic hysteresis. J. Geophys. Res. Solid Earth 101, 571-583. doi:10.1029/95JB03041

Tauxe, L., Shaar, R., Jonestrask, L., Swanson-Hysell, N.L., Minnett, R., Koppers, A.A.P., Constable, C.G., Jarboe, N., Gaastra, K., Fairchild, L., 2016. PmagPy: Software package for paleomagnetic data analysis and a bridge to the Magnetics Information Consortium (MagIC) Database. Geochemistry, Geophys. Geosystems 17, 2450-2463. doi:10.1002/2016GC006307

Teixell, A., Arboleya, M.L., Julivert, M., Charroud, M., 2003. Tectonic shortening and topography in the central High Atlas (Morocco). Tectonics 22, 1051. doi:10.1029/2002TC001460

Teixell, A., Ayarza, P., Zeyen, H., Fernandez, M., Arboleya, M.-L., 2005. Effects of mantle upwelling in a compressional setting: the Atlas Mountains of Morocco. Terra Nov. 17, 456-461. doi:10.1111/j.13653121.2005.00633.x 
Teixell, A., Ayarza, P., Tesón, E., Babault, J., Alvarez-Lobato, F., Charroud, M., Julivert, M., Barbero, L., Amrhar, M., Arboleya, M.L., 2007. Geodinámica de las cordilleras del Alto y Medio Atlas: Síntesis de los conocimientos actuales. Rev. la Soc. Geológica España 20, 119-135.

Teixell, A., Barnolas, A., Rosales, I., Arboleya, M.-L., 2017. Structural and facies architecture of a diapirrelated carbonate minibasin (lower and middle Jurassic, High Atlas, Morocco). Mar. Pet. Geol. 81, 334-360. doi:10.1016/j.marpetgeo.2017.01.003

Tesón, E., Teixell, A., 2008. Sequence of thrusting and syntectonic sedimentation in the eastern Sub-Atlas thrust belt (Dadès and Mgoun valleys, Morocco). Int. J. Earth Sci. 97, 103-113. doi:10.1007/s00531006-0151-1

Thellier, E., Thellier, O., 1959. Sur l'intensite du champ magnetique terrestre dans le pass historique et geologique. Ann. Geophys. 15, 285-376.

Tohver, E., Weil, A.B., Solum, J.G., Hall, C.M., 2008. Direct dating of carbonate remagnetization by 40Ar/39Ar analysis of the smectite-illite transformation. Earth Planet. Sci. Lett. 274, 524-530. doi:10.1016/j.epsl.2008.08.002

Torres-López, S., Villalaín, J.J., Casas-Sainz, A.M., El Ouardi, H., 2012. Cretaceous widespread remagnetization in Mesozoic sediments of the High Atlas (Morocco). Magnetic properties constrained by paleo-basin geometry, in: Contributions to Geophysics and Geodesy 42. pp. 117-118.

Torres-López, S., Villalaín, J.J., Casas, A.M., EL Ouardi, H., Moussaid, B., Ruiz-Martínez, V.C., 2014. Widespread Cretaceous secondary magnetization in the High Atlas (Morocco). A common origin for the Cretaceous remagnetizations in the western Tethys? J. Geol. Soc. London. 171, 673-687. doi:10.1144/jgs2013-107

Torres-López, S., Villalaín, J.J., Casas, A.M., El Ouardi, H., Moussaid, B., Ruiz-Martínez, V.C., 2015. Sobre la extensión de la remagnetización cretácica en el Alto Atlas (Marruecos). On the extension of the Cretaceous remagnetization in the High Atlas (Morocco). Geogaceta 57, 23-26.

Torres-López, S., Casas, A.M., Villalaín, J.J., El Ouardi, H., Moussaid, B., 2016. Pre-Cenomanian vs. Cenozoic folding in the High Atlas revealed by palaeomagnetic data. Terra Nov. 28, 110-119. doi:10.1111/ter.12197

Torsvik, T.H., Van der Voo, R., Preeden, U., Mac Niocaill, C., Steinberger, B., Doubrovine, P. V., van Hinsbergen, D.J.J., Domeier, M., Gaina, C., Tohver, E., Meert, J.G., McCausland, P.J.A., Cocks, L.R.M., 2012. Phanerozoic polar wander, palaeogeography and dynamics. Earth-Science Rev. 114, 325-368. doi:10.1016/j.earscirev.2012.06.007

Usui, Y., Nakamura, N., Yoshida, T., 2006. Magnetite microexsolutions in silicate and magmatic flow fabric of the Goyozan granitoid (NE Japan): Significance of partial remanence anisotropy. J. Geophys. Res. 111, B11101. doi:10.1029/2005JB004183

Usui, Y., Yamazaki, S., 2010. Salvaging primary remanence from hydrothermally altered oceanic gabbros in the Oman ophiolite: A selective destructive demagnetization approach. Phys. Earth Planet. Inter. 181, 1-11. doi:10.1016/j.pepi.2010.04.008

Usui, Y., Shibuya, T., Sawaki, Y., Komiya, T., 2015. Rock magnetism of tiny exsolved magnetite in plagioclase from a Paleoarchean granitoid in the Pilbara craton. Geochemistry, Geophys. Geosystems 16, 112-125. doi:10.1002/2014GC005508

van der Pluijm, B.A., 1987. Grain-scale deformation and the fold test - evaluation of syn-folding remagnetization. Geophys. Res. Lett. 14, 155-157. doi:10.1029/GL014i002p00155 
Van der Voo, R., 1979. Age of the Alleghenian folding in the Central Appalachians. Geology 7, 297. doi:10.1130/0091-7613(1979)7<297:AOTAFI>2.0.CO;2

Van der Voo, R., 1967. The rotation of Spain: Palaeomagnetic evidence from the Spanish meseta. Palaeogeogr. Palaeoclimatol. Palaeoecol. 3, 393-416. doi:10.1016/0031-0182(67)90027-2

Van der Voo, R., 1969. Paleomagnetic evidence for the rotation of the Iberian Peninsula. Tectonophysics 7 , 5-56. doi:10.1016/0040-1951(69)90063-8

Van der Voo, R., French, R.B., 1977. Paleomagnetism of the late Ordivician Juniata Formation and the remagnetization hypothesis. J. Geophys. Res. 82, 5796-5802.

Van der Voo, R., Torsvik, T.H., 2012. The history of remagnetization of sedimentary rocks: deceptions, developments and discoveries. Geol. Soc. London, Spec. Publ. 23-53. doi:10.1144/SP371.2

van Hinsbergen, D.J.J., Lippert, P.C., Li, S., Huang, W., Advokaat, E.L., Spakman, W., 2018. Reconstructing Greater India: Paleogeographic, kinematic, and geodynamic perspectives. Tectonophysics 0-1. doi:10.1016/j.tecto.2018.04.006

Vendeville, B.C., Jackson, M.P.A., 1992. The rise of diapirs during thin-skinned extension $\backslash r S p e c i a l$ issue; salt tectonics. Mar. Pet. Geol. 9, 331-353. doi:10.1016/0264-8172(92)90047-I

Vera, J.A., 2004. Geología de España. SGE-IGME, Madrid.

Verati, C., Rapaille, C., Féraud, G., Marzoli, A., Bertrand, H., Youbi, N., 2007. 40Ar/39Ar ages and duration of the Central Atlantic Magmatic Province volcanism in Morocco and Portugal and its relation to the Triassic-Jurassic boundary. Palaeogeogr. Palaeoclimatol. Palaeoecol. 244, 308-325. doi:10.1016/j.palaeo.2006.06.033

Vergés, J., Moragas, M., Martín-Martín, J.D., Saura, E., Casciello, E., Razin, P., Grelaud, C., Malaval, M., Joussiame, R., Messager, G., Sharp, I., Hunt, D.W., 2017. Salt Tectonics in the Atlas Mountains of Morocco. Permo-Triassic Salt Prov. Eur. North Africa Atl. Margins 563-579. doi:10.1016/B978-0-12809417-4.00027-6

Verwey, E.J., 1939. Electronic Conduction of Magnetite (Fe3O4) and its Transition Point at Low Temperatures. Nature 144, 327-328. doi:10.1038/144327b0

Villalaín, J.J., Osete, M.L., Vegas, R., García-Dueñas, V., 1992. Evidencia de una reimanación terciaria en la Béticas Occidentales. Implicaciones tectónicas. Física la Tierra 4, 165-184.

Villalaín, J.J., Osete, M.L., Vegas, R., García-Duenas, V., Heller, F., 1994. Widespread Neogene remagnetization in Jurassic limestones of the Southern-Iberian palaeomargin (Western Betics, Gibraltar Arc). Phys. Earth Planet. Inter. 85, 15-33.

Villalaín, J.J., Fernández-González, G., Casas, A.M., Gil-Imaz, A., 2003. Evidence of a Cretaceous remagnetization in the Cameros Basin (North Spain): implications for basin geometry. Tectonophysics 377, 101-117. doi:10.1016/j.tecto.2003.08.024

Villalaín, J.J., Soto, R., Casas, A., Mata, P., Bógalo, M.F., Fernández-González, G., 2006. Cretaceous remagnetizations in North Iberian Basin: Contribution to extensional basin evolution - Paleomagnetism and rock magnetism. Trav. Géophysiques XXVII, 121.

Villalaín, J.J., Casas, A.M., Aurell, M., Palencia, A., 2008. Aplicación del estudio de reimanaciones a la datación de las brechas de la base del Jurásico en la Cordillera Ibérica. Geotemas 10, 1215-1218. 
Villalaín, J.J., Casas, A.M., Bógalo, M.F., Rossi, C., Liesa, C., Greca, I.M., 2014. New paleomagnetic records of the cretaceous remagnetizations in eastern Iberia (Maestrat Basin), in: 14th Castle Meeting, New Trends on Paleo, Rock and Environmental Magnetism. Évora (Portugal).

Villalaín, J.J., Casas-Sainz, A.M., Soto, R., 2016. Reconstruction of inverted sedimentary basins from syntectonic remagnetizations. A methodological proposal. Geol. Soc. London, Spec. Publ. 425, 233-246. doi:10.1144/SP425.10

Villalaín, J.J., Ruiz, V.C., Torres-López, S., Casas-Sainz, A., Moussaid, B., Calvín, P., 2016. Estudio paleomagnético preliminar de diques mesozoicos del Alto Atlas. Control térmico en la generación de pirrotina en calizas remagnetizadas con magnetita, Geotemas 16, 901-904.

Waldhör, M., 1999. The small-circle reconstruction in palaeomagnetism and its application to palaeomagnetic data from the pamirs. PhD thesis. Tübingen University.

Waldhör, M., Appel, E., Frisch, W., Patzelt, A., 2001. Palaeomagnetic investigation in the Pamirs and its tectonic implications. J. Asian Earth Sci. 19, 429-451. doi:10.1016/S1367-9120(00)00030-4

Waldhör, M., Appel, E., 2006. Intersections of remanence small circles: new tools to improve data processing and interpretation in palaeomagnetism. Geophys. J. Int. 166, 33-45. doi:10.1111/j.1365246X.2006.02898.x

Walz, F., 2002. The Verwey transition - a topical review. J. Phys. Condens. Matter 14, R285-R340. doi:10.1088/0953-8984/14/12/203

Watson, G.S., Enkin, R.J., 1993. The fold test in paleomagnetism as a parameter estimation problem. Geophys. Res. Lett. 20, 2135-2137. doi:10.1029/93GL01901

Weil, A., Gutierrez-alonso, G., Conan, J., 2010. New time constraints on lithospheric-scale oroclinal bending of the Ibero-Armorican Arc: a palaeomagnetic study of earliest Permian rocks from Iberia. J. Geol. Soc. London. 167, 127-143. doi:10.1144/0016-76492009-002

Weil, A.B., Van der Voo, R., van der Pluijm, B.A., 2001. Oroclinal bending and evidence against the Pangea megashear: The Cantabria-Asturias arc (northern Spain). Geology 29, 991. doi:10.1130/00917613(2001)029<0991:OBAEAT>2.0.CO;2

Weill, A., Sussman, A., 2004. Classifying curved orogens based on timing relationships between structural development and vertical-axis rotations. Geol. Soc. Am. Spec. Pap. 383, 1-15. doi:10.1130/0-81372383-3(2004)383[1:ССОВOT]2.0.CO;2

Weinberger, R., Agnon, A., Ron, H., 1997. Paleomagnetic reconstruction of a diapir emplacement: a case study from Sedom diapir, the Dead Sea Rift. J. Geophys. Res. 102, 5173-5192.

Wenk, H.R., Chen, K., Smith, R., 2011. Morphology and microstructure of magnetite and ilmenite inclusions in plagioclase from Adirondack anorthositic gneiss. Am. Mineral. 96, 1316-1324. doi:10.2138/am.2011.3760

Williams, P.F., 1985. Multiply deformed terrains-problems of correlation. J. Struct. Geol. 7, 269-280. doi:10.1016/0191-8141(85)90035-5

Winklhofer, M., Fabian, K., Heider, F., 1997. Magnetic blocking temperatures of magnetite calculated with a three-dimensional micromagnetic model. J. Geophys. Res. 102, 22695-22709. doi:10.1029/97JB01730

Worm, H.U., 1998. On the superparamagnetic-stable single domain transition for magnetite, and frequency dependence of susceptibility. Geophys. J. Int. 133, 201-206. 
Worm, H.-U., Jackson, M., 1999. The superparamagnetism of Yucca Mountain Tuff. J. Geophys. Res. Solid Earth 104, 25415-25425. doi:10.1029/1999JB900285

Zayane, R., Essaifi, A., Maury, R.C., Piqué, A., Laville, E., Bouabdelli, M., 2002. Cristallisation fractionnée et contamination crustale dans la série magmatique jurassique transitionnelle du Haut Atlas central (Maroc). Comptes Rendus Geosci. 334, 97-104. doi:10.1016/S1631-0713(02)01716-9

Zeyen, H., Ayarza, P., Fernàndez, M., Rimi, A., 2005. Lithospheric structure under the western AfricanEuropean plate boundary: A transect across the Atlas Mountains and the Gulf of Cadiz. Tectonics 24, doi:10.1029/2004TC001639

Zhao, X., Liu, Q., 2010. Effects of the grain size distribution on the temperature-dependent magnetic susceptibility of magnetite nanoparticles. Sci. China Earth Sci. 53, 1071-1078. doi:10.1007/s11430010-4015-y

Ziegler, P.A., Stampfli, G.M., 2001. Late Palaeozoic-Early Mesozoic plate boundary reorganization: collapse of the Variscan orogen and opening of Neotethys. Nat. Brescia. 25, 17-34. 

